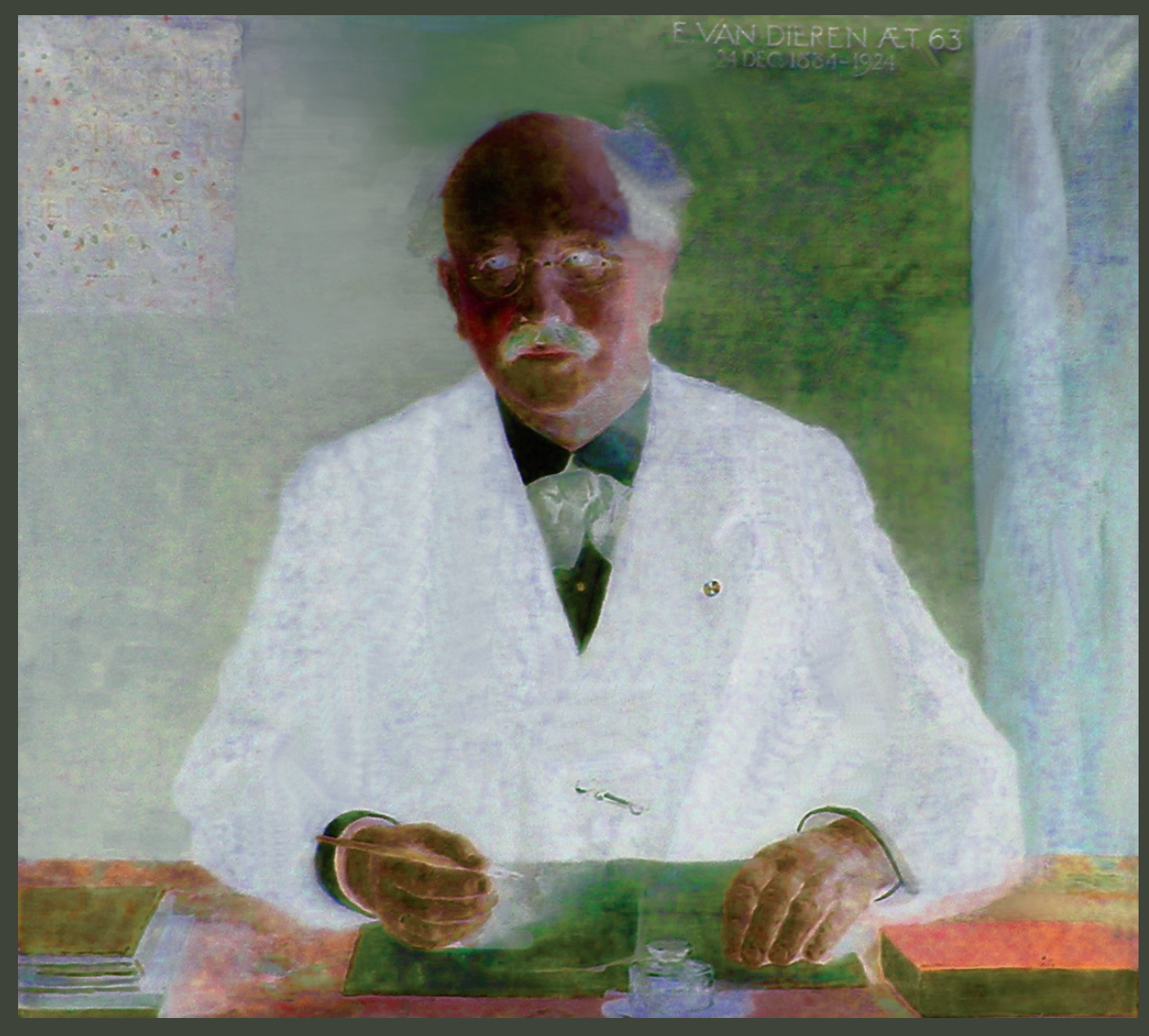

\title{
Evart van
}

Dieren een kroniek

van het falen

$$
\text { JAAP BOS }
$$


Evart van Dieren 



\title{
Evart van Dieren een kroniek van het falen
}

\author{
Jaap Bos
}


Dit boek kwam tot stand met financiële steun van de Stichting Historia Medicinae en de Historische Vereniging Zutphen

Omslagillustratie: foto Evart van Dieren

Ontwerp omslag: Geert de Koning, Kampen

Lay-out: Paul Boyer, Amsterdam

$$
\begin{gathered}
\text { ISBN } 9789089640048 \\
\text { NUR } 680 / 764
\end{gathered}
$$

(C) Amsterdam University Press, 2008

Alle rechten voorbehouden. Niets uit deze uitgave mag worden verveelvoudigd, opgeslagen in een geautomatiseerd gegevensbestand, of openbaar gemaakt, in enige vorm of op enige wijze, hetzij elektronisch, mechanisch, door fotokopieën, opnamen of enige andere manier, zonder voorafgaande schriftelijke toestemming van de uitgever.

Voorzover het maken van kopieën uit deze uitgave is toegestaan op grond van artikel г6B Auteurswet I9 I2 $\mathrm{j}^{\circ}$ het Besluit van 20 juni I974,

Stb. 35 I, zoals gewijzigd bij het Besluit van 23 augustus I985,

Stb. 47I en artikel I7 Auteurswet I9I2,

dient men de daarvoor wettelijk verschuldigde vergoedingen te voldoen aan

de Stichting Reprorecht (Postbus 305 I, 2 I30 кв Hoofddorp).

Voor het overnemen van gedeelte(n) uit deze uitgave in bloemlezingen, readers en andere compilatiewerken (artikel I6 Auteurswet I9I 2) dient men zich tot de uitgever te wenden. 


\section{Inhoud}

$\begin{array}{ll}\text { Voorwoord } & 7\end{array}$

1 De geboorte van een mislukking 12

2 Kiemen van een polemisch leven $\quad 27$

3 Ik heb altijd gelijk $\quad 71$

4 De geboorte van een idee-fixe 91

5 Een prachtige vijandschap 109

6 Een briefwisseling 123

7 Een onderaards bestaan 139

8 De schrijver en het woord 174

9 Eén tegen allen, allen tegen één 191

10 Onder vijanden en figuranten 227

11 Slotbeschouwing. Over marginaliteit als bestaanswijze 248

Overzicht publicaties van Van Dieren 259

Overzicht publicaties over Van Dieren 264

Geraadpleegde archieven $\quad 267$

Fotoverantwoording $\quad 267$

Noten 268

$\begin{array}{ll}\text { Register } & 288\end{array}$ 
selbst der Untergang war ihm

nur ein Vorwand, zu sein: seine letzte Geburt

Rainer Maria Rilke

Un homme seul est toujours en mauvais compagnie Paul Valérie

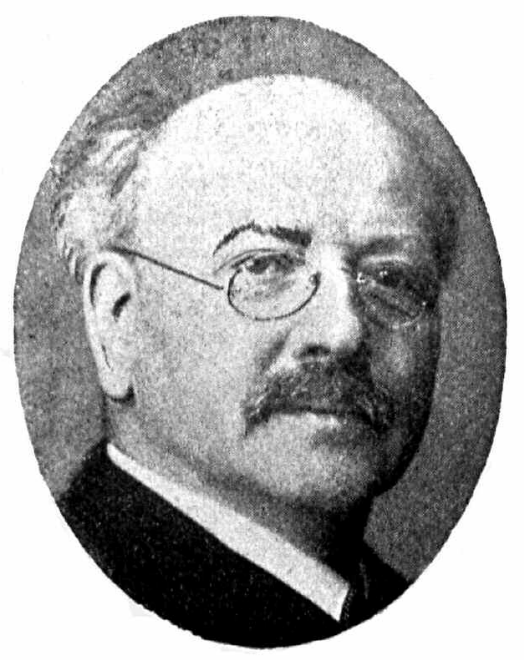

Dr. E. van Dieren. 


\section{Voorwoord}

Mijn eerste Van Dieren kwam ik jaren geleden tegen in een Utrechts antiquariaat, waar mijn oog viel op de onweerstaanbare titel Prof. Freud en het door velen onderschatte perverse gevaar. Ik kocht het, hoewel ik eigenlijk vond dat er te veel voor werd gevraagd, de verzekering van de boekhandelaar ten spijt dat het een titel was die je zelden tegenkwam en dat er mensen waren die deze schrijver verzamelen.

Het boek was nog nooit gelezen; het was zelfs nog nooit opengesneden. Ik deed dus waar de vorige eigenaar van af had gezien: ik nam een mes en sneed het pagina voor pagina open - en verminderde zo de antiquarische waarde. In die ontwijdende handeling, waarmee lezers zich langgeleden een boek toe-eigenden, opende zich een bijna intieme wereld. Wankelend, als koorddansers, stevenen lezer en schrijver op elkaar af over het smalle pad van het geschreven woord dat hen in tijd en ruimte van elkaar scheidt en toch verbindt. De deur van de werkkamer zwaait open en daar ontwaren we de auteur, lezend, verzamelend, schiftend, overdenkend, schrijvend en drukproef corrigerend. Zuchtend kijkt hij op van zijn werk, de lezer volgt zijn blik en merkt een motto op dat aan de muur van de werkkamer prijkt: The only real failure is to give up trying, maar hij weet niet wie hier wordt aangespoord nooit op te geven: lezer of schrijver?

$\mathrm{Nu}$ de lezer die werkkamer is binnengestapt kan hij er al bijna niet meer uit. Vanaf de eerste pagina dwarrelden ronkende zinnen over elkaar als confetti tijdens carnaval; er viel geen touw aan vast te knopen. Zo'n bizar boek was ik niet eerder tegengekomen. Het nam de schrijver voor me in. Toch ben ik hem pas later gaan lezen, min of meer bij toeval. Ik hield een vrolijke voordracht over 'marginale kritiek op de psychoanalyse' waarin ik ook naar dit boek verwees. Een redacteur van een historisch tijdschrift vroeg of ik dat verhaal over die gekke Hollander niet wilde omwerken tot een artikel, en in een onbewaakt ogenblik zei ik niet nee. Bij het uitwerken ervan vroeg ik, brave wetenschapper die ik nu eenmaal ben, de beschikbare literatuur op die in de bibliotheek voorhanden is. En zo, terwijl de ene vreemdsoortige titel na de andere binnendruppelde, raakte ik langzaamaan gefascineerd door het buitenissige werk en een nog merkwaardiger 
leven. Als ik de historicus Richard Holmes mag geloven gaat het meestal zo.

Nog ben ik verbaasd over de overstelpende hoeveelheid sporen die levens blijken achter te laten, ook gewone levens, en dat uit al die op zichzelf betekenisloze aanwijzingen zich levende geesten laten reconstrueren. Want het zijn niet de geschiedenissen die liggen opgesloten in de geboorte- en sterfakten, in de door de jaren heen op met kroontjespen bijgehouden archiefkaarten, en in de met zorg bijgehouden knipselmappen, maar de levens zelf, die langgeleden tot zwijgen zijn gebracht en nu hun kans schoon zien zich te richten tot hen van wie ze geen weet hadden.

Ik heb lang gedacht dat die kakofonie aan opgesloten stemmen mij enkel van mijn werk zou houden, totdat ik bedacht dat geschiedenis niet in stilte wordt geschreven, maar integendeel, dat geschiedenis zelf niets anders dan dialoog is, en dat ik met andere woorden een gesprek met de ghost of history moest aangaan. Om kort te gaan, nadat dat artikel verschenen was besloot ik ook nog een boek over Van Dieren te schrijven. Een besluit dat te lichtvaardig was genomen, want terwijl ik dieper en dieper in een querulanteske ruimte verdwaald raakte sloeg de twijfel toe.

Waar ben je mee bezig? Ik formuleer de vraag in de tweede persoon, omdat de twijfel van buiten leek te komen. Laat ik het wat preciezer zeggen. De mensen met wie ik sprak over mijn plan zeiden allemaal 'niet doen' - de een wat onomwondener dan de ander, maar toch. Niettemin heb ik, geheel in overeenstemming met het onderwerp zelf, dat advies in de wind geslagen, en zo is dit boek er dan toch gekomen, wat niet wil zeggen dat mijn vrienden ongelijk hadden.

Een korte opmerking over de manier waarop ik hier te werk ben gegaan. Ik aarzel om aan dit boek het predicaat 'biografie' mee te geven. Waarom? Is dit boek dan geen biografie? Gaat het niet van A tot Z over Van Dieren? Niet in de strikte zin van het woord. Daar waar de biograaf de hoofdpersoon tot leven wil wekken om hem (of haar) in al zijn glorie en met al zijn zwakheden aan het publiek te tonen als een min of meer verklaarbaar figuur wiens leven om de een of andere reden verteld moet worden, het liefst binnen een samenhangend verhaal met aan het eind een logische conclusie die de raadsels oplost die aan het begin zijn gesteld, daar zie ik af van de gedacht dat het leven dat hier centraal staat verteld moet worden als verhaal op zichzelf.

Het is waar, ik heb het historische handwerk niet geschuwd, en ik heb langer in bibliotheken en archieven doorgebracht dan ik voor wen- 
selijk hield, maar ik heb bij het verzamelen van mijn materiaal niet de vraag gesteld: wie is Van Dieren? En ook nu, nu het boek is geschreven, kan ik het antwoord op die vraag niet met zekerheid geven. Ik heb dit boek de ondertitel 'kroniek van het mislukken' meegegeven, niet 'kroniek van een mislukkeling'. Het gaat mij niet om de persoon Van Dieren. Ik heb in de meest letterlijke zin van het woord een non-entity als onderwerp van studie gekozen; niet echter in de betekenis die Sam Dresden eraan gaf, namelijk van een 'alledaagse persoon', dus een onbelangrijk iemand, maar iemand die in zekere zin de alledaagse persoon vertegenwoordigt. ${ }^{1}$

'Ik ken ook een Van Dieren' zeiden mensen als ik over mijn protagonist vertelde. Van Dieren staat voor de niet eens onsympathieke dwarsligger die gedoemd is in de marge van het leven te verdwijnen, en daar hoort een ander verhaal bij dan bij een held of een schurk. Hij is plat als een schaduw, maar onlosmakelijk verbonden met het leven. Liever dus dan mij te laten leiden door de vraag wie Van Dieren is, vraag ik mij af voor wie of wat hij staat. Zo is dit boek voor alles een verhaal over het falen zelf, waarbij Van Dieren dienst doet als leidsman. Anders gezegd: ik wil de lezer meenemen op expeditie langs de randen van onze wereld, naar een universum dat ons wel bekend voorkomt, maar waar we liever niet te lang vertoeven - de stal van onze geest waar we buiten het zicht van de wet de bastaarden hebben ondergebracht die uit ons zijn geboren en die we, hoewel ze ons verachten, koesteren en die ons zullen overleven.

Omdat dit boek geen biografie in de strikte zin is, volg ik het leven van Van Dieren niet in chronologische volgorde, maar volg ik een thematisch traject. Hoofdstuk I schetst het kader waarbinnen het leven en werk van Van Dieren worden begrepen. Hierbij wordt enerzijds aandacht geschonken aan de (onontkoombare) vraag of de protagonist van deze studie niet 'krankzinnig' was, terwijl ik tegelijkertijd wil laten zien waarom de belangstelling voor deze figuur buiten de dimensies van het psychopathologische moet worden gevonden. Aan de hand van archiefonderzoek geef ik in hoofdstuk 2 een levensschets van Van Dieren, geboren en getogen in Zutphen en opgeleid in Amsterdam. Kernmotief is dat het leven van Van Dieren gesitueerd moet worden rond de constante drang om 'erbij te horen' en de daarbij behorende herhaalde afwijzing.

Zijn werk, waarop in hoofdstuk 3 wordt ingegaan, vormde zowel bron als oorzaak van die mislukkingen. Van Dieren publiceerde meer dan Ioo titels, deels in eigen beheer, deels bij echte uitgevers. Dat werk vormt een unieke werkelijkheid die hoewel 'geconstrueerd' ook reëel is 
in de wijze waarop ze is opgebouwd en reëel in haar consequenties bovendien. De hoofdstukken 4 tot en met 6 gaan in op Van Dierens beriberiwerk, zijn strijd tegen Eijkman en de 'mystificaties' waarmee Van Dieren voor zichzelf een plaats in de geschiedenis probeerde te veroveren. In deze hoofdstukken zoek ik een antwoord op de vraag waar de bron van de idee-fixe ligt. Een ongepubliceerde briefwisseling tussen Eijkman en een bevriend medicus geeft een fascinerend inkijkje in de gedachtewereld van negentiende-eeuwse medische onderzoekers en daarmee een insidersblik op het fenomeen outsider.

Het autobiografische element in het werk van Van Dieren, die wetenschappelijke verklaringen nadrukkelijk rond zijn eigen ervaringen construeerde, komt aan de orde in hoofdstuk 7 , en in de hoofdstukken 8 en 9 gaan aan de hand van zijn discussies met socialisten, letterkundigen en psychoanalytici in op het schrijven en het spreken van Van Dieren: parallelle universums die als het ware langs de buitenkant van de werkelijkheid strijken zonder er ooit mee in contact te komen. 'Familierelaties' in de Van Dierense wereld, zijn verhouding met vrienden, vijanden en andere figuranten, komen in hoofdstuk to aan de orde. Het laatste hoofdstuk neemt tot besluit de dynamiek van het buitenstaanderschap zelf onder de loep en onderzoekt de relevantie van een figuur als Van Dieren in het huidige tijdsgewricht.

Ik heb bij mijn onderzoek gebruikgemaakt van de openbare bronnen die mij ter beschikking stonden, zoals gemeentearchieven, de archieven van universiteitsbibliotheken, reguliere en gedigitaliseerde krantenarchieven ('Historische kranten in beeld', van de Koninklijke Bibliotheek bijvoorbeeld, het webarchief van De Groene Amsterdammer, enz.), en verder onderzoeksarchieven en natuurlijk het wereldwijde web, ontsloten via Google en andere zoekmachines, en ik heb al doende de data verzameld waarop dit boek rust. Ik heb mij willen toeleggen op dat deel van het leven van Van Dieren dat aan de openbaarheid is prijsgegeven; dat is wel niet precies hetzelfde als het publieke bestaan, omdat er zich onder mijn bronnen ook delen uit de persoonlijke correspondentie bevinden, maar wel sluit het die delen van het bestaan uit die niet op enig moment inzet zijn geweest in zijn buitenstaandersstrijd. Ook in dit opzicht is dit boek dus geen biografie, althans niet in de gebruikelijke zin van het woord. Werpt men tegen dat dit verhaal daarmee niet compleet is, dan kan ik dat alleen maar beamen, maar ik zeg ook: dat is nimmer mijn pretentie geweest.

Tot slot: zelfs dit boek had niet geschreven kunnen worden zonder de hulp van vrienden en collega's en niet zonder de medewerkers van verschillende instellingen die mij allen belangeloos ter wille stonden in mijn 
marginale zoektocht en aan wie ik hier graag mijn erkentelijkheid wil uitspreken. Tanny Dobbelaar, Ruud Abma en Joost Overduin, lezers van diverse, soms onleesbare versies van dit boek, en Wijnand Mijnhardt, Christien Brinkgreve en Annet Mooij, adviseurs op afstand die hun onvoorwaardelijke geloof in dit project uitspraken: dank jullie wel! De redacties (en lezers) van, Gewina, De Groene Amsterdammer, JHBS en P\&M (de laatste helaas opgeheven), Jos Gabriëls van het BWN: dank voor het bruikbare commentaar op verschillende hoofdstukken. Prof.dr. E.S. Houwaart ben ik erkentelijk voor een waardevolle tip, en voor toegezonden kopieën, navorsingen en andere hulp dank ik Siebe Thissen, Tim Douma en Harm Kaal. Dank ook, ten slotte, aan C.J.M. Eymael, hoofdarchivist van het Koninklijk huisarchief in Den Haag; L.Y. Mulder van de Koninklijke Bibliotheek in Den Haag, afdeling bijzondere collecties; K. van der Horst, conservator van de handschriften Universiteitsbibliotheek Utrecht; Klaas van der Hoek, conservator handschriften Universiteitsbibliotheek Amsterdam (UvA); Jan de Ruiter van het stadsarchief in Zutphen, Wouter van Dieren voor een foto van het gehavende portret van zijn voorvader, Hille van Dieren voor enkele andere foto's uit het familiearchief, en een anonieme medewerkster van Amnesty International, afdeling Amsterdam, die op een doordeweekse namiddag, toen het kantoor eigenlijk gesloten was vanwege een personeelsfeestje, uit de archieven een briefje opdiepte dat mij bereikte als - hoe symbolisch - een papieren vliegtuigje. 


\section{I \\ De geboorte van een mislukking}

Ontmoet Evart van Dieren, Amsterdams schrijver-arts, sociaal-criticus, amateur-filosoof en auteur van een groot maar inmiddels vergeten oeuvre. Hij gleed als een schim langs de geschiedenis en werd wie hij niet had moeten zijn: een marginale figuur die ondanks verwoede pogingen om voet aan de grond te krijgen in de wereld van de gevestigde orde door zijn tijdgenoten bespot en opzij is gezet en uiteindelijk vrijwel helemaal is genegeerd; een aartsmislukkeling dus.

Stel het leven voor als een film; op de voorgrond, in het centrum van de aandacht, spelen de verwikkelingen en intriges zich af, waarop de toeschouwer gefascineerd zijn blik richt. Als de handelingen van de hoofdpersonen en de bijfiguren, ja het hele decor, zo zijn ingericht dat het lijkt of er een consistent verhaal ontstaat, hoeveel toeschouwers zullen dan die ene persoon opmerken die op de achtergrond consequent van het script afwijkt? Niet velen, wijst waarnemingsonderzoek in de psychologie uit, al blijkt wel dat het afwijkende als een onbewust spoor, bijna als een gevoel van onbehagen, in de herinnering van de toeschouwer achterblijft. ${ }^{1}$ Draai de blikrichting om en vraag: hoe weten de acteurs hoe ze zich moeten gedragen? Hoe moeten ze weten wie hoofdpersoon en wie figurant is?

Het eerste deel van die dubbele vraagstelling staat in dit hoofdstuk centraal: hoe moeten we de buitenstaander begrijpen; welk perspectief kunnen we daarbij innemen? Het tweede deel van de vraagstelling, die op de werkelijkheidsbeleving van de buitenstaander zelf betrekking heeft, stel ik uit tot het laatste hoofdstuk.

\section{De vernuftige huisarts uit Amsterdam}

Het werk van Van Dieren is omvangrijk, het omvat een indrukwekkende verzameling boeken en brochures over de meest uiteenlopende medische, politieke en sociale vraagstukken en een veelvoud aan artikelen en ingezonden stukken. En toch is dat alles tegelijkertijd onbedui- 
dend. Zijn oeuvre gaat over alles en niets en stelt uiteindelijk alleen dat werk zelf centraal. In het middelpunt ervan schittert de schrijver als een maniak die zich gehaat weet maar niet gevreesd, een uitzinnige luis die er niet in slaagt zelfs maar het kleinste gaatje in de pels van de bestaande orde te knagen. Van Dieren was een onvermoeibare maar hulpeloze schrijver, die zich tegen de opkomende culturele en wetenschappelijke opvattingen van zijn tijd verzette met een onvoorstelbare energie, maar keer op keer op het 'nee' van de ander stuitte en nooit erkenning zou krijgen voor zíjn opvattingen.

Door zijn niet-aflatende strijd tegen onrecht en misverstand dat alleen hij zag en niemand anders werd hem het etiket 'Don Quichotte' opgeplakt, een eretitel waar hij trots op was. ${ }^{2}$ En net zoals de ridder van de droevige figuur hoongelach en slaag incasseerde, maar daar toch nooit door werd afgeschrikt, omdat de uiteindelijke overwinning immers bij voorbaat vast stond, zo ook liep Van Dieren vol goede moed zijn ondergang tegemoet, in de rotsvaste overtuiging dat zijn heldendaden eens zouden worden geboekstaafd door een historicus.

\section{De lachende geestdrijver}

Als de naam Van Dieren wordt genoemd, schreef een redacteur op een keer, dan wordt er gegrinnikt. ${ }^{3}$ Andere recensenten hadden het zelfs over het 'schaterlachen' waarmee het lezen van de lectuur gepaard ging. Ja, leedvermaak moet een belangrijke impuls zijn geweest in de relatie tussen de lezer en deze schrijver. Een echt 'dieren-boek' werd er in de pers geschreven, en dat betekende zoveel als: 'kostelijk', 'amusant', 'geestig' - minder vanwege de inhoud als vanwege de ontspoorde polemieken die op de lachspieren werkten. Wie een avondje wil gniffelen schaffe zich Het socialistisch gevaar aan of Futuristische behandeling van zielszieken (ondertitel: 'Freudsche psychoanalyse, zoogenààmde zielsontleding'). Ook daarvan was hij zich bewust. 'De schrijver brengt ons telkens weer in het goede humeur door zijn malle uitvallen', citeerde Van Dieren een recensent, alsof hij daarmee het imago van de dwaze dolende ridder van zich af kon schudden: als er wat te lachen valt, dan wil ik graag meelachen. ${ }^{4}$

Toch kon niet iedereen om hem lachen. Zo kwalificeerde een opponent Van Dieren eens als een 'Hercules op stelten' vanwege de verbale krachtpatserij waarmee hij zijn polemieken en ruzies uitvocht, en bedacht hij elders de titel 'listige figurant'. ${ }^{5}$ Kwalificaties die zo uit een schelmenroman konden zijn genomen, maar die ook op een gevoel van wrevel lijken te duiden. $\mathrm{Nu}$, bij sommige lezers was er sprake van wel 


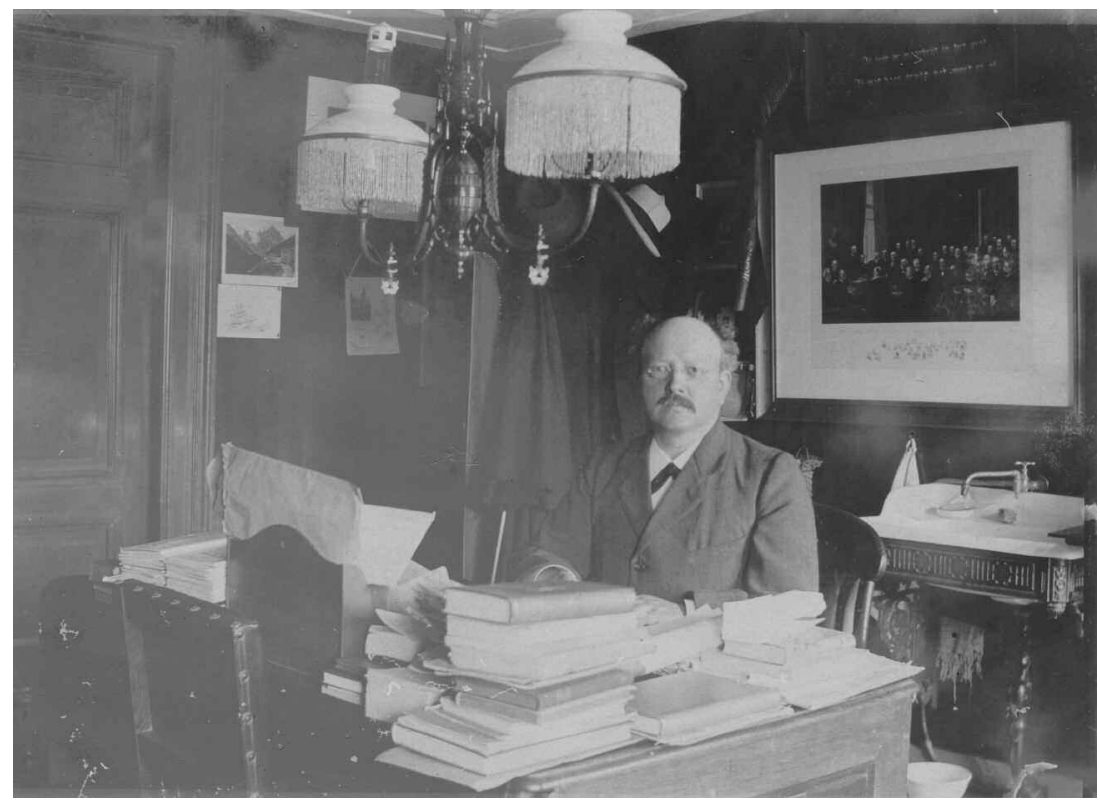

Zuchtend kijkt de schrijver op van zijn werk.

meer dan wat wrevel. Van Dieren zelf schrijft dat hij wekelijks, soms zelfs dagelijks briefkaartjes ontving van mensen die hem de huid volscholden en bedreigden - soms waren die poststukken zo erg dat ze alleen 'onder couvert' konden worden bezorgd. ${ }^{6}$ Omgekeerd mocht hij zelf ook graag een potje schelden en stond hij bij krantenredacties bekend als 't kwaaie kreng', of zelfs als 'het ploertje'.

Het hoeft dus niet te verwonderen dat we de lezer halverwege leedvermaak en verontwaardiging aantreffen, niet in staat te kiezen tussen de twee emoties. Hij zoekt naar een manier om grip te krijgen op dat wonderlijke werk dat als een anomalie, als een unieke, onverklaarbare tegenstrijdigheid boven al dat andere obscure werk van inmiddels al lang in de vergetelheid weggezakte schrijvers uitsteekt en hem tart: verklaar mij!

Aan pogingen om dat werk te verklaren en aan de besluiteloosheid van de lezer een eind te maken heeft het natuurlijk niet ontbroken. Daarbij is dankbaar geput uit het arsenaal van de psychiatrie die haar diagnostiek sinds jaar en dag belangeloos ter beschikking stelt aan eenieder die verlegen zit om een definitie waarmee het pathologische van het normale kan worden gescheiden. Ik bespreek de belangrijkste categorieën die tegen Van Dieren zijn ingezet en die ons als zodanig mis- 
schien kunnen helpen antwoord te geven op de vraag langs welke lijnen we het object van studie moeten situeren.

De eerste poging tot duiding bestaat erin vorm en inhoud te herleiden tot een bepaald type schrijver, te weten de 'querulant'. De kwalificatie querulant staat voor de persoon die sterk op zijn rechten staat, en na een vermeende krenking van zijn rechten zich tot de autoriteiten wendt en daarbij situaties schept waarin hij iedere keer opnieuw zijn neus moet stoten tegen een muur van onbegrip. Een krankzinnige ruziemaker dus, legde Van Dieren zelf behulpzaam uit. ${ }^{8}$ En misschien wel een met een masochistisch verlangen door de vader te worden geslagen, opperde Freud, die de hersenschimmen van de querulant dicht bij de paranoïde grootheidswaan plaatste. ${ }^{9}$ Bij dat alles blijft de waan zelf echter volkomen logisch en zitten de ideeën goed in elkaar, merkte de psychiater $\mathrm{M}$. Zeegers op - het komt alleen niet overeen met de realiteit van de rest van de wereld..$^{10}$ Voor de psychiater is de querulant iemand dus die aan een psychische aandoening lijdt, een 'waan'.

Als zodanig is de 'querulantenwaan' een typisch negentiende-eeuws begrip waarin een mengeling van morele diskwalificatie en psychiatrische diagnostiek samenkomen. Zo schrijft de Duitse psychiater Heinrich Schüle in zijn Handbuch der Geisteskrankheiten: 'Zeer vaak, zelfs in de regel, is een organisch zedelijk defect de oorzaak van deze ziekte, een stuk moral insanity, die de drager ervan altijd weer een eigenaardige rechtswereld doet scheppen: een cultus van onbegrensd egoïsme met overeenkomend gereduceerd rechtsgevoel voor anderen, en daarnaast een door duister zelfgevoel gedragen geestelijke onttakeling die al haar kracht zet in het opstellen van rechtvaardigende schijngronden voor het zelfzuchtige rechtsstreven. [De querulant] laat meestal een arglistig en strijdzuchtig karakter zien, [hij is] een nietsnut die het van kinds af aan altijd beter [heeft] willen weten en het ene na het andere opvoedingsinstituut of leerinrichting verlaat, omdat hij overal ruzie krijgt en iedere tegenspraak brutaal afwijst als een infame inbreuk op zijn rechtsgevoel. ${ }^{11}$

In de beschrijving van Henri van der Hoeven, psychiater te Utrecht en een tijdgenoot van Van Dieren, ligt de nadruk op het tragische van de querulantenwaan. De zieke is buitengewoon welbespraakt, schreef hij, en terwijl de querulant het doet voorkomen alsof alles met zijn vooropgezette mening overeenkomt, en het dus lijkt alsof hij de zaak bedriegt, handelt hij in werkelijkheid toch te goeder trouw, want 'hij beheerscht niet zijn mening, maar deze beheerscht hem'. Om zijn gelijk te halen versmaadt de querulant geen middel en geen gelegenheid; zijn toon wordt al brutaler, al luider, zijn geschriften al onbeschofter, maar 
een genezing, in de strikte zin van het woord, lijkt uitgesloten; een reden te meer om medelijden met hem te hebben. ${ }^{12}$

Zelfzuchtig, arglistig, brutaal, onbeschoft, meelijwekkend: de diagnostische meerwaarde van de term ligt in haar retorische gebruik. Het begrip querulant is in discussies met Van Dieren gebruikt in de betekenis van: 'U bent niet goed wijs', maar ook: 'U hoort er niet bij', en zelfs: 'Wij trekken ons niets van uw kritiek aan.' Voor de gewone lezer, die zich zonder veel vragen te stellen heeft aangepast aan de maatschappelijke orde, representeert de querulant een onaangename verstoring van de natuurlijke loop der dingen - een mug in de nacht die zich niet uit de slaapkamer laat verjagen en die je wakker houdt met zijn tergende gezoem.

De tweede poging om het werk van Van Dieren te duiden bestaat eruit het tot een bepaalde activiteit terug te brengen, waarvoor de term 'geestdrijverij' is gereserveerd. Geestdrijverij lijkt de substantivering van dat wat de querulant in de praktijk brengt. Het staat in strikte zin voor fanatieke geloofsijver, maar de term wordt meestal in een wat bredere toepassing gebruikt en heeft een lange geschiedenis die terugvoert tot een opstel van de filosoof David Hume over vormen van 'vals geloof'. Geestdrijverij (enthusiasm in het Engels) is ook bij Hume een 'pathologische toestand', een ziekelijke vorm van geloof namelijk, waarbij de zieke zich 'in zijn eigen verbeelding verlustigt'. ${ }^{13}$ Volgens Hume zijn de bronnen van geestdrijverij echter niet een zieke geest, maar hoop, trots, verwaandheid, een teveel aan verbeelding en een overmaat aan naïviteit. In een commentaar van Peter van Rooden op Hume heet het dat de geestdrijver 'iedere willekeurige inval vol vertrouwen beschouwt als een onmiddellijke inspiratie door de godheid. Al snel koestert hij voor de menselijke rede en zedelijkheid slechts minachting en beschouwt hen als onbetrouwbaar. ${ }^{14}$

Dat tezamen - trotse verbeelding en hovaardig gebrek aan respect voor autoriteiten - levert een gevaarlijk mengsel op voor de maatschappij. Geestdrijverij lijkt op een explosie of liever: een hevig onweer, want het is boven alles een kracht die het gezag ondermijnt en juist daarom bijdraagt aan het streven van de mens naar onafhankelijkheid, zo meende Hume. We komen de kwalificatie geestdrijverij niet heel vaak tegen in het debat met Van Dieren, maar het is vaak geïmpliceerd, als stond zijn naam ermee synoniem, en sprak men, om Van Dieren zelf niet te hoeven noemen, liever in het algemeen over de manier waarop sommige lieden zich medezeggenschap toe-eigenen op terreinen waar zij niets van af weten, maar dat zij met het ondeskundig oordeel dreigen te verstoren. 
Geestdrijverij als begrip is voor ons interessant, omdat het behalve kritiek ook een zekere waardering inhoudt voor het verzet tegen de autoriteiten. Want bij alles wat men tegen Van Dieren zou inbrengen ontbrak het zelden aan enige bijval voor zijn 'eigenzinnige geest' het 'unieke' in hem. In boekbesprekingen werd vaak gezegd dat Van Dieren weliswaar ongelijk had, maar dat men toch moest toegeven dat hij ook wel 'harde waarheden' wist te zeggen, waarmee tegelijk het ingebeelde karakter van Van Dierens werk alsook het autoriteitsondermijnende ervan werd onderkend.

Tegenwoordig worden de begrippen querulantisme en geestdrijverij niet meer gebruikt - de psychiatrie heeft ze leren vermijden, omdat ze worden gezien als normatief beladen, te veel belast met onbewijsbare veronderstellingen. De klinische psychologie wil classificeren, niet moraliseren, zo houdt het diagnostisch-statistische handboek (DSM) ons thans voor. Ik denk dat het geval Van Dieren nu als een 'bipolaire stoornis met manische episodes' zou worden geclassificeerd, misschien in combinatie met een 'obsessieve persoonlijkheidsstoornis'. De klinische beschrijving van een bipolaire stoornis meldt: langdurig en aanhoudend opgewonden toestand bij de patiënt, disproportionele zelfwaardering, verminderde behoefte aan slaap en een ononderbroken stroom aan ideeën. Stuk voor stuk criteria die, zoals we nog zullen zien, Van Dieren karakteriseerden. Daarnaast rept het handboek van 'deelname aan activiteiten die een verhoogd risico hebben op een schadelijke afloop'. Als voorbeeld wordt genoemd 'domme of onrendabele investeringen'. Wanneer we de wetenschappelijke arbeid van Van Dieren als een 'investering' opvatten en bedenken dat die niet alleen een enorme hoeveelheid geld kostte, maar vooral ook veel tijd en energie vergde die bovendien niets opbracht, omdat de opvattingen van de auteur nooit voet aan wal hebben gekregen binnen de academische wereld, dan is duidelijk dat ook dit criterium zonder meer van toepassing mag worden geacht.

De diagnose 'bipolaire stoornis' doet overigens vermoeden dat Van Dieren behalve manische perioden ook perioden van depressie moet hebben gekend, omdat het een volgens het diagnostisch handboek niet zonder het ander optreedt. Met zekerheid kan dit vermoeden niet worden bevestigd. Wel weten we dat hij als student een crisis doormaakte en later, rond de eeuwwisseling, aan een 'ernstige aandoening' heeft geleden en een jaar lang niet productief was. Uitgesloten is het niet dat hij toen depressief was, maar nadere mededelingen over de aard van de crisis en aandoening ontbreken, en daarbij is van uitgesproken zwaarmoedige stemmingen of suïcidale gedachten in het werk 
van Van Dieren geen sprake. Zou Van Dieren manisch zijn geweest zonder aan depressies te hebben geleden, dan zou de diagnose van unipolaire manie kunnen worden overwogen - een aandoening die volgens het handboek echter zo zelden voorkomt dat ze eigenlijk niet gesteld kan worden en daarom als categorie ontbreekt.

Kort samengevat duiden de klinische termen zoals hierboven besproken dus in eerste instantie wel een abnormale geestestoestand aan, een 'pathologisch gestel', maar slaagt de diagnostiek, ook de huidige, er niet in de figuur Van Dieren in absolute zin van het lijf te houden. De diagnostiek zelf is niet vrij van normatieve elementen, dat wil zeggen, kan niet zonder een zekere hoeveelheid verwondering. De waan van de ander blijft vanuit klinisch oogpunt even raadselachtig als vanuit intermenselijk oogpunt fascinerend. En zo duiden al die kwalificaties als querulantisme, geestdrijverij en ook manische waan in tweede instantie op een complex sentiment, een gevoel, waarmee niet de afstand maar de nabijheid, de relatie tussen schrijver en lezer tot uitdrukking komt: afkeer, antipathie en verachting maar ook tegelijk verholen afgunst en misschien zelfs bewondering. Wanneer in het vervolg aan psychiatrische diagnostiek wordt gerefereerd, dan is het niet om de afstand, maar integendeel, om de verwantschap onder woorden te brengen.

\section{Fugit, partes adversae!}

Iedere diagnose is een ideaaltype, maar sommige patiënten slagen er beter in dan andere om zich naar dat ideaal te schikken. Vanuit een klinisch perspectief zou Van Dieren zich vrijwel volledig voegen naar de definities van geestdrijverij en querulantisme (behalve dat hij niet opgroeide in een internaat, maar in een gewoon ambachtsliedengezin en geenszins een nietsnut was). Inderdaad waren alle ondernemingen waarin hij zich ooit heeft gestort doortrokken van een even ondoorgrondelijke als vijandige geldingsdrang die van meet af aan wel op zelfdestructie moest uitlopen. Steeds maar weer betrok hij bij voorbaat de underdogpositie, en steeds ook weer moest hij het onderspit delven; een situatie die hem zowel verbitterde als waarvan hij tegelijkertijd leek te genieten. Bij zijn dood althans merkte iemand op dat hij in zijn leven veel spot en hoon had moeten oogsten, maar ook dat hij goede spot had weten te waarderen. ${ }^{15}$

Onbeschroomd en vol vertrouwen wendde hij zich heel zijn leven tot de autoriteiten, groot en klein, en sommeerde ze zonder aanzien des persoons zijn gelijk te erkennen. Onderzoekers, schrijvers, minister- 


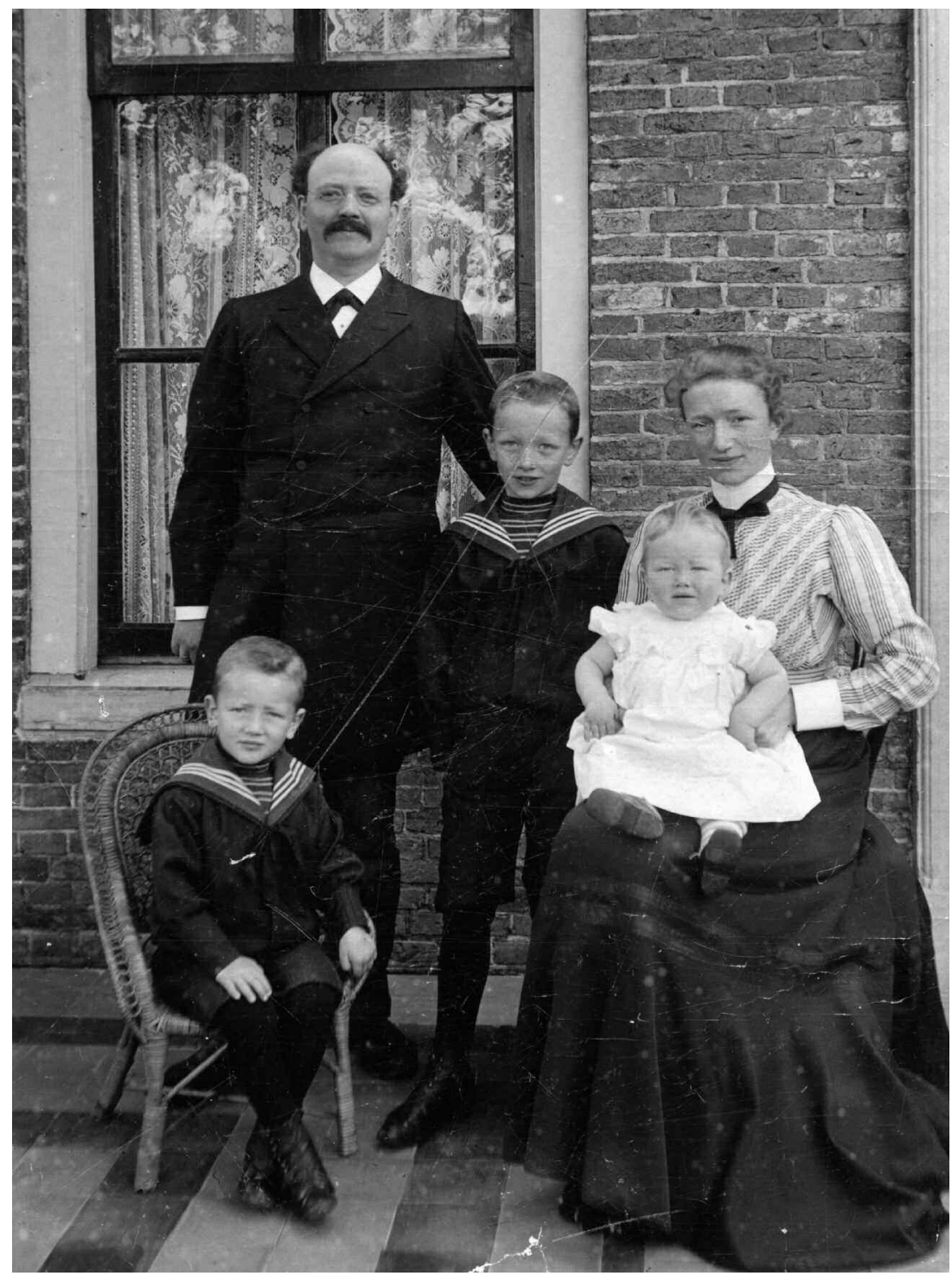

Evart en Catharina van Dieren en drie van bun kinderen op Terschelling, ca. 1904. Een plus een plus een plus een plus een blijft altijd alleen maar een.

president Colijn, de gouverneur-generaal van Nederlands-Indië, de rector van de universiteit, bestuurders, redacties van kranten, en zelfs de koningin: hij beschouwde het als niets minder dan zijn 'heilige taak' aan hen zijn brandschriften te richten. ${ }^{16}$ Soms in de vorm van brieven, 
vaak in de vorm van een publicatie en slechts bij hoge uitzondering in de vorm van een gesprek, want het geschreven woord genoot zijn voorkeur. En toch, ondanks het 'pathologische' van al dat geschrijf, ligt op de bodem daarvan een verlangen, niet alleen naar zelfstandigheid, maar ook en misschien wel vooral naar erkenning.

Er is in het werk van Van Dieren een zo sterke hang naar eigen oordeelsvorming dat men er onwillekeurig soms van onder de indruk raakt. Als voorbeeld noem ik zijn aanval op de Duitse onderzoeker Robert Koch in de jaren negentig van de negentiende eeuw. Koch (I 843 I9I0) had in I 882 wereldfaam vergaard met de ontdekking van de tbcbacil. Op grond van zijn werk werd het mogelijk om specifieke microorganismen op te sporen die verantwoordelijk zijn voor bepaalde ziekten, wat eerder niet mogelijk was. Zijn werk wordt om die reden tot een van de grote omwentelingen in de medische wetenschappen beschouwd (hij ontving daarvoor de Nobelprijs in 1905). Toen Koch in I 890 tuberculine ontwikkelde, een vaccin waarmee hij tuberculose hoopte te bestrijden, werd het door velen dan ook ontvangen als een wondermiddel. Zo niet door Van Dieren, die datzelfde jaar nog een brochure deed verschijnen waarvan de titel al voldoende zegt: Indien ik aan tuberculose leed, liet ik mij niet inspuiten met het middel van Koch. De brochure werd vertaald in het Duits en kreeg nog een vervolg, een jaar later, ditmaal getiteld Het middel van Koch veroorzaakt tuberculosis in plaats van deze te genezen. Dwars tegen de stroom in, op eigen gezag en zonder enige bijval: Van Dieren wist zeker dat hij geen ongelijk kon hebben.

En wat bleek? Het middel van Koch voldeed niet aan de hooggespannen verwachtingen. Sterker nog: het middel veroorzaakte daadwerkelijk tuberculose. Had de kleine Van Dieren dus gelijk en de grote Koch niet? Zo eenvoudig zal die vraag niet te beantwoorden zijn, al lijkt het op het eerste gezicht van wel.

Het middel tuberculine was, zoals Van Dieren terecht vermoedde, niets anders dan (een verdunde versie van) de tuberculose zelf (Koch hield de receptuur van het middel aanvankelijk geheim). Het bestrijden van de kwaal met de ziekte zelf leek Van Dieren een perverse omkering van de logica waaruit niets goeds kon voortkomen, dus eiste hij onmiddellijke stopzetting van het experiment. Zoals vaak nam hij radicaal stelling tegen de voorstanders van vernieuwing en de bedenkers van gewaagde vindingen, maar steeds leidde dat ertoe dat zijn eigen standpuntbepaling ondergeschikt werd aan het bestrijden van de ander. Zo ook in dit geval. Tuberculine wees hij af als een volslagen mislukking, omdat het op een contra-intuitieve of liever gezegd contranatuurlijke 
logica was gebaseerd. Maar juist die contra-intuïtieve logica zorgde steeds voor vooruitgang. Het tuberculineonderzoek zou wel degelijk tot verdere ontwikkeling in de medische wetenschap leiden, ook al voldeed het middel zelf niet. En op die manier bleek ook in het zeldzame geval waarin Van Dieren het gelijk wel aan zijn kant leek te hebben zijn verzet nog steeds onvruchtbaar.

Blijft over de contrapositie tegenover autoriteiten als een 'verdienste' op zichzelf, zoals vastgelegd in talloze geschriften. Moet men op grond daarvan Van Dieren lof toezwaaien, al was het alleen maar voor zijn consequent volgehouden, onmodieuze opstelling?

\section{De erfenis}

Onmodieuze gedachten hebben, paradoxaal genoeg, eigenlijk alleen betekenis in het tijdsgewricht waarin ze worden geformuleerd. Daarna worden ze al snel irrelevant, behalve wanneer ze op den duur zelf modieus worden. De erfenis van een 'onmodieuze' is gedoemd in de vergetelheid te raken, en dat is wat er met het gedachtegoed van Van

Dieren is gebeurd. Hij werd een voetnoot bij een voetnoot - een eigen geschiedenis niet waardig geacht: uit de kronieken verdreven, een schrijver voor wie de term 'vergeten' bij uitstek lijkt te zijn uitgevonden.

Als zodanig, als vergeten rariteit, is Van Dieren na zijn dood verschillende malen herontdekt. Onafhankelijk van elkaar schreven binnen een tijdspanne van dertien jaar Martin van Amerongen, daarna Max Pam en Christien Brinkgreve en tenslotte Boudewijn Büch een paginagroot artikel over 'het geval Van Dieren' waarin op besmuikte toon de geschiedenis van de 'wonderlijke wonderdokter' uit de doeken wordt gedaan. Vermeend antisemitisme, zijn fiets van 340 gulden, de dolgedraaide polemieken, zijn strijd tegen Freud, Marx en de letterkundigen: het komt, daar er van een karikatuur immers geen karikatuur kan worden gemaakt, bij de auteurs onder aanhaling van zijn eigen geschriften allemaal voorbij in zeldzaam uniforme bewoordingen. ${ }^{17}$

'De echo van zijn woorden', schreef Van Amerongen, 'zou tot in onze dagen nagalmen boven de ontbijtborden, mariakaakjes en stamtafels.' De meeste van zijn boeken en brochures en slechts enkele fragmenten van zijn dilettantencorrespondenties zijn bewaard gebleven en liggen her en der verspreid in universiteitsbibliotheken en historische archieven, als aangespoeld wrakhout van de Nederlandse cultuurgeschiedenis. 
DE AVERECHTSCHE GEESTESR I C H T ING DER ZOOGENAAMDE "N I E U W L I C H T E R S" OP ALLERLEI GEBIED; IN HET BIZONDER DIE DER K O L L E W IJ N E R S EN HUN VERDERFELIJKE INVLOED OP O N D R W IJ S, TAA L E $N$ V O L K E. VAN DIEREN, ARTS, LID VAN DE AMSTERDAMSCHE SCHOOLCOMMISSIE.

VOOR REKENING VAN DEN SCHRLJVER UITGEGEVEN DOOR SWETS \& ZEITLINGER - HEERENGRACHT 496 - AMSTERDAM

Als slot kregen wij even nog weer de Kollewijnsche spelling op 't tapijt, maar onze dokter moest geen Van Dieren heten om dit op zich te laten zitten en trok natuurlijk maar weer onvermoeid van leer.

Daar vormen ze een ondergrondse wereld, een microkosmos, waarin we een leven aantreffen dat zich aan het voorstellingsvermogen lijkt te onttrekken. Een obscuur en genegeerd leven, maar ook een 
leven dat zo gezegd nog steeds van het eigen gelijk is overtuigd. Het verschilt van dat van de huis-, tuin- en keukengek, de 'morosoof', om die mooie term van Van Boxel te gebruiken, omdat Van Dieren er nooit in berustte dat zijn denkbeelden wel nooit begrepen zouden worden. ${ }^{18}$ Integendeel: kenmerkend voor de querulant/geestdrijver is dat hij de aan zijn adres gestelde publieke schimpscheuten en de hem toegestuurde afwijzende brieven niet anders kan opvatten dan als aansporingen om zijn werk voort te zetten, zegt het psychiatrisch handboek.

En inderdaad, Van Dieren schuwde niet hele voor hem nadelige correspondenties op te nemen in zijn geschriften, waarmee hij onbedoeld de psychologie van de querulant blootlegt, die daadwerkelijk verwant lijkt aan de paranoïde grootheidswaan. 'Uw werk is het geraaskal van een maniak', beet de socialist Henri Polak hem een keer toe, en prompt drukte Van Dieren het hem toegestuurde briefje af in zijn volgende boek, alsof hij wilde bewijzen dat de schrijver ervan gelijk had. ${ }^{19}$

Gelijk en ongelijk vloeien in elkaar over en worden een samenhangend geheel, een bron die nooit opdroogt. In die bodemloze put ligt een nalatenschap van werk op ons te wachten dat nog steeds hardnekkig volhardt in haar eigen falen.

\section{Het falen als carrière}

Toch is het niet het persistente falen op zichzelf dat interesseert, maar het falen van de buitenstaander als manier om carrière te maken, ja, zelfs aanzien te vergaren. Dit is waarin hij groots kan zijn. In het falen kan een buitenstaander zich zijns ondanks verheffen en uitstijgen boven het niveau van de gewone mislukkeling. Hij is noch held noch schurk, verricht geen buitengewoon heldhaftige handelingen en is niet bovengemiddeld intelligent; hij vindt niets uit en zou nooit in de geschiedenisboeken terecht zijn gekomen als hij niet zo overtuigend zou hebben gefaald. Erkenning krijgen: niet voor wat hij heeft gedaan, maar voor wat hem is ontzegd - het is een begin van een interesse.

Als miskende buitenstaander bleek Van Dieren buitengewoon getalenteerd. Want niet alleen slaagde hij erin enorm veel weerstand op te roepen, ook wist hij zich keer op keer verzekerd van een aanzienlijke belangstelling voor zijn publicaties. Hij zag steeds opnieuw zijn boeken en brochures in kranten en vakbladen besproken, en iedere keer weer haalde hij zich de vijandschap op de hals van een keur aan bekende en minder bekende schrijvers, wetenschappers, politici en andere figuren uit zijn tijd die op dat moment om de een of andere reden in de publieke 
belangstelling stonden. 'Van Dieren' werd een handelsmerk, zijn werk een manier van leven. ${ }^{20}$

De retorische stijlfiguur die Van Dieren gebruikte om zijn buitenstaandersstrijd uit te vechten was de polemiek. Kenmerk van de polemiek is dat het op de persoon is gericht, geestig moet zijn verwoord en op een losse, associatieve manier gestructureerd is. Dit gold in meer of mindere mate voor bijna alles wat Van Dieren ooit schreef. Tegenwoordig is het middel in onbruik geraakt in wetenschappelijke en literaire kringen (W.F. Hermans was een der laatste grote polemisten), maar voor de lezers en schrijvers uit de tijd van Van Dieren was het gebruik van de polemiek bijna even vanzelfsprekend als dat van de brief - met Ter Braak, een van Van Dierens laatste tegenstanders, als bekendste proponent ervan. Vrijwel alle opponenten van Van Dieren hebben op enig moment in hun carrière van de polemiek gebruikgemaakt en vaak met succes. En zo kan de keuze van Van Dieren voor dit middel dus in zekere zin als opportuun worden aangemerkt: geboren niet uit nood maar gekopieerd van zijn vijanden beleed Van Dieren de polemiek als een 'echte schrijver', al was zijn gebruik ervan onmatig en kan een vergelijking met Ter Braak alleen maar in zijn nadeel uitvallen.

De vorm die de polemiek aannam was Van Dieren trouwens om het even. Alle schermutselingen met zijn tegenstanders buitte hij uit door er publiciteit aan te geven, ongeacht of zijn eigen reputatie daar onder zou leiden, neen, juister gezegd: vooral als zijn reputatie daar onder zou leiden. Zo kon het gebeuren dat er van een van zijn bekendste boeken, $D e$ waanzinnige waereld, een als een 'zielkundige ontleding' vermomde afrekening met Troelstra cum sui, zomaar I 5.000 exemplaren binnen een jaar aan de man konden worden gebracht, juist omdat het zulke heftige reacties onder de Nederlandse socialisten teweegbracht. 'De schrijver zal er wel 't een en ander over te hooren krijgen in de roode pers, maar daar is hij aan gewend', meende een recensent van De Standaard. De auteur behoort immers tot het type schrijvers dat geen blad voor de mond neemt, maar heel duidelijk zijn mening zegt. 'Als ge met een bewering aankomt - en onze tijd is vol van beweringen - houdt dr. van Dieren u even staande, ontleedt haarfijn wat ge vertelt en toont er de waarde of waardeloosheid van aan.' Kortom, een eigentijds boek van een eigentijdse Socrates dat gelezen diende te worden, aldus de krant. ${ }^{21}$ En het wérd gelezen.

Voor zijn anti-Freud-boeken gold hetzelfde. Een recensent schreef dat het niemand hoefde te verwonderen dat zijn geschriften veel werden gelezen: 'hij schrijft wat velen denken maar liever voor zich houden' - een twijfelachtig compliment dat een eeuw later aan rechtse 
populisten werd gegeven om onder woorden te brengen dat wat hen drijft niet zozeer eerlijkheid als wel gebrek aan fatsoen is. ${ }^{22}$

Natuurlijk werden de pamfletten van Van Dieren nauwelijks serieus genomen in de vakbladen, maar het leverde hem wel landelijke bekendheid op als 'socialistenvreter', 'psychoanalysten-doder-bij-uitnemendheid', enz. ${ }^{23}$ Een jaar na publicatie van het bovengenoemde anti-socialistenboek kon de schrijver tevreden terugzien op zijn 'debat' met de sociaal-democraten, dat gemeten naar de invloed van zijn werk op de publieke opinie als een mislukking moet worden begrepen, maar gemeten naar de hoeveelheid aandacht voor het werk zelf als een succesvolle mislukking.

Van dit soort boeken en pamfletten schreef Van Dieren er twee dozijn: opgewonden, rancuneuze, ruzie zoekende werken die één ding gemeen hebben, namelijk dat ze de bijl aan de wortel leggen van het werk van een ander.

\section{Nabeelden van een mislukking}

Hoe kan een wereldbeeld dat is gegrondvest in een grandioos echec, namelijk de volslagen ontkenning van iedere overeengekomen of gedeelde opvatting over wat is en niet is, over wat had kunnen of moeten zijn en niet zijn, aan de basis staan van of in elk geval samengaan met succes?

Daarmee kom ik op een tweede motief om aandacht aan deze figuur te besteden: de gedachte dat het succes van het werk van een buitenstaander misschien begrepen kan worden als we het zien als een soort cultureel nabeeld.

Een nabeeld is de voorstelling die men ziet wanneer men intensief naar iets heeft gekeken en dan de ogen sluit: op het netvlies licht een negatieve afspiegeling van het origineel op. Zou niet dit begrip in overdrachtelijke zin op het werk van Van Dieren kunnen worden toegepast? Als metafoor voor de relatie tussen de ideeën die zich aandienden in het publieke domein en de bijna onwillekeurige reacties van verzet die die voorstellingen vaak opriepen? Kenmerkend voor een nabeeld is immers dat het niet alleen de oorspronkelijke voorstelling negatief weergeeft, maar ook dat de voorstelling zich als een geïsoleerde verschijning aan ons voordoet, dus het object uit zijn context licht en als een opzichzelfstaand fenomeen presenteert. Dat laatste aspect is, zoals we nog zullen zien, niet minder belangrijk dan het eerste.

Zo lijkt het vooral de schok van ontzetting te zijn geweest die zich van de buitenstaander meester maakte en in schrijfdrift deed uitbar- 
sten. Zijn publicaties zijn afspiegelingen van de oorspronkelijke voorstellingen, nadat die in de publieke ruimte zijn geprojecteerd, en als zodanig is het werk van de buitenstaander een reflectie van de berichten die nieuwe wetenschappelijke, culturele en politieke posities aankondigen die hij niet begrijpt, omdat ze een logica veronderstellen die hem vreemd is: noem het een oerconservatieve wereld waaruit die boeken ontsproten - wat het zeker was -, maar dan mis je de essentie: dat het primair om betekenisgeving gaat. Deze idee is verwant, maar niet helemaal identiek aan de beroemde formulering van Marx, als commentaar op Hegel, dat de geschiedenis zich herhaalt, de tweede keer als 'farce', wanneer in tijden van revolutionaire crisis angstig de geest van het verleden wordt opgeroepen 'om in deze oude eerwaardige vermomming en in deze geleende taal het nieuwe bedrijf van de wereldgeschiedenis op te voeren'. ${ }^{24}$

De buitenstaander wijst het nieuwe af niet bij wijze van parodie, omdat hij het ermee oneens is, maar als een manier om er grip op te krijgen. Zijn tragiek is dat hij over geen andere instrumenten beschikt. De waanzinnige waereld verschijnt een halfjaar na Troelstra's aankondiging van de socialistische revolutie ('De arbeidersmassa grijpt thans de politieke macht!'); Futuristische behandeling van zielszieken, zijn eerste boek tegen Freud, komt uit, nadat er door psychiaters in de landelijke pers waarderend over Freud werd geschreven ('meesterlijke stijl'), en Darwinisme en ongeloof niet lang nadat Darwin door wetenschappers publiekelijk geëerd werd als belangwekkend onderzoeker. De beelden flitsen op en flakkeren na op het netvlies: weg met Troelstra, die elitaire nepsocialist! Weg met Freud, die pornografische zedenbederver! Weg met Darwin, die aapachtige schurk!

De buitenstaander die zich uit alle macht tegen het nieuwe verzet en juist daarin betekenis vindt, biedt een unieke gelegenheid de maatschappij te bezien vanaf de buitenkant, door ogen en oren van de burgerman, de 'man op straat', de krantenlezer, die zich door de loop van de geschiedenis overvallen voelt, en daarom stug, om niet te zeggen tegen beter weten in alles waarmee hij wordt geconfronteerd en waaraan hij geen deel kan nemen probeert te begrijpen door er 'nee' tegen te zeggen.

Dit is het verhaal van een 'gewone man' die verzeild raakte in de omwenteling van de negentiende naar twintigste eeuw, toen technologische vooruitgang en een grenzeloos optimisme, maar ook enorme sociale, politieke en maatschappelijke onrust de levens van allen voorgoed hebben veranderd - die van de hoofdrolspeler niet meer dan die van de figurant. 


\section{Kiemen van een polemisch leven}

Zutphen, tweede helft negentiende eeuw. Een welvarende, cultureel hoogontwikkelde voormalige Hanzestad aan de IJssel. Een goed beschermde maar wat krap toebemeten vooruitgeschoven post van de voormalige Republiek ook, ingeklemd tussen haar eigen vestingmuren die de omtrek van de stad al driehonderd jaar hebben bepaald en eigenlijk aan niet meer dan vijfduizend inwoners plaats biedt, maar waarbinnen rond 1850 bijna vijftienduizend mensen wonen. Op elkaar gepropt treft men er op slechts 40 hectare grond verscheidene kerken en kloosters, een synagoge, talloze monumentale zestiende- en zeventiende-eeuwse koopmanshuizen, vijftiende-eeuwse pakhuizen en tientallen nog uit de Middeleeuwen stammende woningen aan, maar ook hofjes, pleintjes, markten, steegjes, winkelstraten, een galgenveldje, een Latijnse school, een krankzinnigengesticht, een arrondissementsrechtbank, een schouwburg, verschillende sociëteiten, een ziekenhuis, een gemeentehuis, en ook, sinds I 864, de hogere burgerschool (hbs), 't visitekaartje van het burgerdom.

Het is alles bij elkaar een miniatuurstad dus, ter grootte van een stadswijk, maar met de pretenties van een universiteitsstad als Utrecht. Daadwerkelijk ontwikkelde Zutphen zich in de negentiende eeuw tot een lokaal kenniscentrum dat zich overgaf aan wetenschap, onderwijs, literatuur en kunsten, zij het dan ook op B-niveau, en zijn bewoners even in de waan moet hebben laten verkeren zich te hebben kunnen meten met steden als Delft of Leiden, net als zij klein, maar fijnbesnaard. Een schilderij van W. Verschuur toont de stad halverwege de negentiende eeuw als een in het licht van de Verlichting badend eiland te midden van een onontwikkeld platteland, met in het midden van de aandacht de Wijnhuistoren, niet eens een echte kerk, en ter rechterzijde daarvan de toren van de majestueuze St. Walburgskerk die zich dapper opheft naar een dreigende Hollandse hemel. Ja, Zutphen was wel bijna deftig te noemen; zelfs de tongval van de Zutphenaren had iets gedistingeerds en was zeker niet zo grof en boers als het achterhoeks, maar 
netter, gekuister, al bleef Zutphen natuurlijk een omhooggevallen dorp, ver verwijderd van de culturele elite, hoewel weinigen zich daarvan bewust leken te zijn. ${ }^{1}$

De waan duurde zolang Zutphen opgesloten bleef liggen in het achterland. In I 864 kwam aan haar isolement een einde door de aanleg van de spoorlijn, tien jaar later kreeg Zutphen toestemming haar vestingmuren af te breken en kon de uit haar voegen gebarsten stad opgelucht ademhalen en verder groeien (naar ruim achttienduizend inwoners in I900). Toch zou die opstoot in de vaart der volkeren haar eigen verval inluiden. De industrialisatie die in de rest van Holland zijn beslag kreeg ging aan Zutphen goeddeels voorbij, zodat in de tweede helft van de negentiende eeuw daar wel de moderne tijd maar niet de daarbij behorende psychologische constellatie van vooruitgangsoptimisme werd binnengehaald, maar eerder een knagend onbehagen postvatte onder haar bewoners, een sluimerende angst voor verval. En feitelijk was aan het eind van de negentiende eeuw Zutphen ook alweer teruggezakt naar de periferie, en geworden wat de stad niet had willen zijn maar altijd was geweest: een provincieplaats.

\section{Op de bodem van het bestaan}

De familiekroniek van het geslacht Van Dieren speelt zich in hoofdzaak af binnen die begrensde sociale en economische ruimte en is goeddeels geconcentreerd rond deze stad en haar directe omgeving. Het geslacht Van Dieren komt zeker vanaf het midden van de achttiende eeuw voor in Zutphen. Het is een geslacht van kleine zelfstandigen en opeenvolgende generaties van schilders. Jacobus Wouterus van Dieren (I79II 836), de grootvader van Evart van Dieren, heet verver van beroep te zijn geweest. Twee van zijn zoons zetten het schildersambacht voort: Derk-Johan van Dieren, de vader van Evart, was huis- en rijtuigschilder en had een onderneming aan de smalle maar prominente Turfstraat, een winkelstraat in het oudste deel van de stad; een jongere broer van hem was eveneens huis- en rijtuigschilder en gevestigd aan de verderop gelegen en wat bredere Schopstoel. Hij liet in het Zutphensche adresboekje opnemen dat hij tevens beschikt over een speciale inrichting tot het lakken van haarden en kachels, waaruit misschien mag worden afgeleid dat hij zijn zaakjes iets beter voor elkaar had. ${ }^{2}$

Derk-Johan van Dieren (geb. I822) trouwde in I846 op vierentwintigjarige leeftijd zijn ruim een jaar oudere bruid, Jentien Uiterwijk (geb. I 820), een schippersdochter. Uit dat huwelijk kwamen negen kinderen voort: vijf meisjes en vier jongens. ${ }^{3}$ Alleen de oudste zoon Jacobus 
Wouterus, het vierde kind van Derk-Johan en Jentien, vernoemd naar de grootvader, zou de volwassen leeftijd niet bereiken; hij stierf in I 866 op veertienjarige leeftijd. Minder dramatisch maar niettemin een bron van zorg moet het huwelijk van dochter Assiena zijn geweest met een Arnhemse winkelier. Het liep na drie jaar spaak, zij keerde terug naar Zutphen en bestierde enige tijd een winkel in garen en band, maar aan de man zou ze niet meer komen. Voor het overige kwamen de broers en zussen van Van Dieren echter allemaal goed terecht; de meisjes trouwden binnen hun eigen sociale klasse, met leraren, winkeliers en commiezen, de jongens werden rijkstelegrafist of koopman.

Geen van de kinderen koos ervoor het familiebedrijf voort te zetten, misschien omdat het economische tij in de jaren tachtig van de negentiende eeuw al zo ver was gekeerd dat er in Zutphen geen plaats meer was voor twee families die van hetzelfde beroep moesten leven. Aan de andere kant was er in het gezin Van Dieren van armoede nooit sprake. Er werd sober geleefd, zo lezen we ergens bij Van Dieren, maar dat was vanwege de financiën niet altijd noodzakelijk. ${ }^{4}$ Derk-Johan van Dieren stierf op 2I januari I 890, acht dagen na zijn achtenzestigste verjaardag en kort voordat ook de laatste dochter zou trouwen en hij, vanuit functioneel perspectief gezien althans, zijn taak als pater familias had vervuld. Jentien verhuisde kort daarna naar een kleinere woning aan de Beukerstraat, waar ze samen met haar gescheiden dochter tot kort voor de eeuwwisseling bleef wonen. Daarna vertrok ze alsnog naar Apeldoorn om op 83-jarige leeftijd nog één keer te verhuizen en wel naar Arnhem, om er op 22 november 1903 in de nabijheid van haar oudste dochter, Maria Elisabeth, te sterven.

Aan die familiegeschiedenis is weinig opvallends, de enige uitzondering vormt nummer zeven uit de rij van kinderen, Evart van Dieren, geboren op I 5 januari I 86I, klokslag twaalf uur in de middag. Over de vroege jeugd van Evart die in de beschermde omgeving van dat betrekkelijk eenvoudige protestantse ambachtsliedengezin opgroeide is mij helaas weinig bekend, een idealiserende opmerking van hemzelf daargelaten over de 'schone en indrukwekkende geluiden van de klokken van de St. Walburgskerk te Zutphen', of een notitie over hoe hij 'als kind speelde als kind', waarin we een verwijzing naar een brief van de apostel Paulus herkennen. ${ }^{5}$ Alle twee de notities bevatten, zoals de overige spaarzame opmerkingen die op zijn jeugd betrekking hebben, niet toevallig toespelingen op het geloof; Zutphen vervulde in de negentiende eeuw een lokale spilfunctie in het kerkelijk leven. Maar om op grond daarvan te concluderen dat zijn ouders streng religieus waren en dat de kleine Evart zich nooit uit die beklemmende greep heeft los 
kunnen maken, of dat andersom, de christelijke bekeringsdrang die het latere werk van Van Dieren kenmerkt, met terugwerkende kracht op zijn jeugd werd geprojecteerd, lijkt mij niet goed mogelijk. Als we toch moesten kiezen zou ik voor het laatste, niet het eerste, opteren, omdat het geloof voor hem steeds belangrijker werd naarmate het in de loop van de twintigste eeuw steeds vaker onder vuur kwam te liggen.

Een andere aanwijzing over de betekenis van het geloof staat in een brief van Van Dieren uit I9I9 aan een bevriend letterkundige waarin hij schrijft dat hij er geen probleem mee heeft dat er verschillende godsdiensten naast elkaar bestaan zolang de belijders elkaar maar respecteren. Maar juist dat, beweerde hij, was onmogelijk: 'het zijn maar ménschen!' Daaruit trok hij de conclusie dat mensen naar iets te streven moeten hebben wat zij niet kunnen bereiken; zouden ze het wel bereiken, dan 'dommelen we weer in, verslappen we, dan zakken we door'. ${ }^{6}$

Op de bodem van het geloof rust dus geen vertrouwen in het kunnen van de mens, maar integendeel, de geruststelling dat iedere vooruitgang gedoemd is te mislukken. 'Welvaart is er, en behagen, en komt ten koste van een ongelooflijke misère!' schreef hij in een andere brief (zijn cursiveringen). ${ }^{7}$ Misschien is het niet toevallig dat het werk van Van Dieren gekenmerkt wordt door een alom aanwezige verbazing over de grote dingen waartoe de menselijke geest in staat blijkt te zijn, vooral op wetenschappelijk gebied, en een onmiddellijk daaropvolgende waarschuwing dat daarvoor een faustiaanse prijs moet worden betaald: aardse genietingen leiden tot verlies aan geloof. ${ }^{8}$

Vanuit die bijna fatalistische geloofsopvatting is de voor ons meest relevante herinnering uit zijn prille jeugd er een die betrekking heeft op een vreemd ongeval. Ik vertel het kort na. Er was eens een schipperszoon, De Jonge geheten, die als hardrijder enige malen een eerste prijs won, maar kort na een overwinning bloed opgaf en plotseling stierf, misschien als gevolg van uitputting. 'Och, och, voor een paar honderd gulden en een beetje vergankelijke roem! Hoe kan een mens zo dom wezen!' moet de vader van Van Dieren daarop hebben gezegd. Het geval maakte op de zoon een 'geweldige indruk', al was het maar, omdat hij naar eigen zeggen voor alles wat met de geneeskunde samenhing toen al een grote belangstelling toonde. Uit het verhaal trok Van Dieren de conclusie dat zijn vader 'er een veel beter kijk op had dan alle huidige sportartsen bij elkaar."

Hoewel hij met die autobiografische anekdote zijn belangstelling voor de medische wetenschappen dus al in zijn jeugd wilde situeren, kan ook hiervan worden gezegd dat het om een achteraf geconstrueerde herinnering of misschien zelfs pseudo-herinnering gaat. Het is per 
slot voor veel mensen verleidelijk om achteraf een lijn te ontdekken in hun leven die hen gevoerd heeft naar het punt waarop ze zich nu bevinden, ongeacht of die lijn of zelfs dat punt er is. Interessanter evenwel, hoewel niet per se authentieker, is de aan de vader gebonden antiautoritaire houding: hoe een leek een betere kijk op het geval kan hebben als alle sportartsen bij elkaar. Het is een grondhouding die hier onder woorden wordt gebracht: dat iemand met een gezond-verstandmentaliteit openstaat voor eenvoudige waarheden en het daarom beter kan weten dan de artsen die ervoor gestudeerd hebben. Simplex veri sigillum: eenvoud is het kenmerk van de waarheid, zei Van Dieren Boerhaave vaak na als iemand hem ervan beschuldigde iets niet te begrijpen..$^{10}$ Maar is de waarheid niet altijd eenvoudig voor wie er van de buitenkant tegenaan kijkt?

\section{Onder professoren}

Evart doorliep, voor zover dat valt na te gaan, zonder problemen de hbs. Daarmee zou hij geen toegang tot de universiteit hebben verkregen ware het niet dat de Wet op het Hoger Openbaar Onderwijs sinds I 876 in de mogelijkheid voorzag dat hbs'ers tot het academisch onderwijs werden toegelaten. Het enige, zij het ook niet onbelangrijke, voorbehoud bestond erin dat de student niet het recht had te promoveren. Onder die beperkende conditie dus kwam Van Dieren in 1879 op zeventienjarige leeftijd in Amsterdam terecht, als een van de circa 300 studenten aan de medische faculteit. Van al zijn broers en zussen was hij de enige die ging studeren. Bescheiden middelen dwongen hem zich in te schrijven als 'pil', een militair student wiens opleiding door de staat werd betaald, in ruil waarvoor hij na afloop enige jaren in rijksdienst zou treden. De 'pillen' kregen aanvankelijk les aan de militaire academie, maar omdat die na enige tijd werd samengevoegd met de universiteit, belandde Van Dieren in de collegebankjes tussen de reguliere corpsstudenten, die die inbreuk van de lagere sociale regionen in hun tot dan toe tamelijk elitaire wereldje niet in dank afnamen. ${ }^{11}$

Ingeklemd tussen een rots en een steen, in een wereld waarin hij als eenvoudige 'pil' van lagere komaf steeds op een achterstandspositie werd gezet, begon Van Dieren aan zijn studie medicijnen en merkte hij al spoedig dat hij niet overal werd geaccepteerd. Jaren later schreef hij in een brief dat hij door elitaire corpsstudenten 'beroerd' werd behandeld, al gold dit vooral de eerste maanden van zijn studie; later zou hij tamelijk 'getapt' zijn geworden, vond hij. Toen op zeker moment tijdens zijn studie sprake was van een studentenopvoering van een toneelstuk 


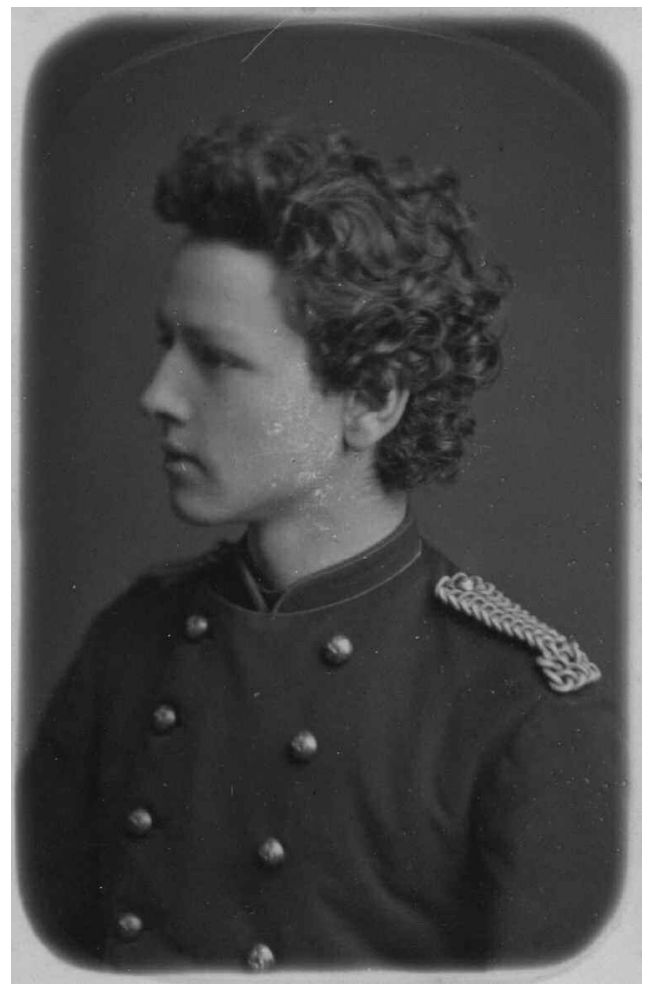

Evart van Dieren als officier van gezondheid.

kreeg Van Dieren daarin dan ook een rol toebedeeld, wat wijst op een zekere aanvaarding van de buitenstaander. ${ }^{12}$

Op 24 december I 884 slaagde hij voor zijn artsexamen en trad daarmee een wereldje binnen dat dan wel niet direct klein genoemd kan worden (op een inwonertal van ruim vier miljoen waren er in Nederland in totaal iets minder dan 2000 geneeskundigen), maar het was wel een overzichtelijke wereld. Aan de top stonden medisch specialisten. Hun aantal bedroeg in I $8843 \mathrm{I}$; tien jaar later was dat nog steeds maar 63. Onder de specialisten stonden de medisch professoren en onderzoekers; hun aantal was navenant klein. Daaronder ten slotte de reguliere artsen. Ruim de helft van hen was lid van de Koninklijke Nederlandsche Maatschappij tot bevordering der Geneeskunst, en velen zaten ook weer in plaatselijke verenigingen, zoals de Amsterdamsche Geneeskundige Kring. Nagenoeg allen waren geabonneerd op het 'Tijdschrift' (Nederlandsch Tijdschrift voor Geneeskunde), dat niet alleen voor het grootste deel werd volgeschreven door dezelfde mensen die ook zitting 
hadden in of voorzitter waren van geneeskundige gezelschappen, maar die zich bovendien vaak ook roerden in andere geneeskundige bladen, zoals het Medisch Weekblad, of de wat populairdere Geneeskundige Courant, en soms ook een medische column hadden in een van de landelijke dagbladen (de 'medische kroniek' van Pijnappel in het Algemeen Handelsblad is daarvan een bekend voorbeeld, waarmee we verderop nog kennis zullen maken). Kortom, het werd Van Dieren al spoedig duidelijk dat de medische wereld, gelijk alle andere, een strenge hiërarchie kende en ook aan 'kliekvorming' onderworpen was.

Onder de studie- en generatiegenoten die rond dezelfde periode tot arts werden bevorderd treffen we H. Pinkhof aan, die een week voor Van Dieren promoveerde, en verder C. Delprat, en M. Straub, die in respectievelijk I 88 I en I 882 promoveerden. Alle drie zouden ze later toetreden tot de redactie van het gezaghebbende 'Tijdschrift'. Van hen zou alleen Pinkhof het daarin weleens voor Van Dieren opnemen (maar hem werd dan ook verweten zelf 'een soort v. Dieren' te zijn). ${ }^{13}$ Met Delprat en vooral Straub bevond hij zich later bijna steeds op voet van oorlog. Verder behoorde G. Jelgersma, de latere hoogleraar psychiatrie met wie hij in de jaren twintig in conflict zou treden, tot zijn studiegenoten (Jelgersma was twee jaar ouder en werd in 1885 tot arts bevorderd). Met veel van die figuren en met praktisch alle door hen volgeschreven tijdschriften en door hen bestuurde gezelschappen zou Van Dieren het aan de stok krijgen, of preciezer gezegd: al die figuren, bladen en verenigingen zouden met hem te maken krijgen.

Voorlopig echter had hij conform zijn contract eerst nog als officier van gezondheid in het leger te dienen. Hij werd aanvankelijk ondergebracht bij de roemruchte 'gele rijders' (de mobile brigade), bij Arnhem. Dan, vanaf de winter I886-I887, bij het korps bij het Remonte-depôt te Millingen op de Veluwe en tenslotte werd Van Dieren gedetacheerd naar het 8ste regiment der infanterie opnieuw nabij Arnhem, niet al te ver van zijn ouderlijk huis.

In deze van God verlaten streken had hij weinig te doen. Misschien was het louter uit verveling dat hij zich als publiek figuur begon te ontwikkelen. In elk geval zou hij in deze periode door het aanschrijven van autoriteiten en het bespelen van de media naar eigen zeggen tal van misstanden aan de kaak hebben gesteld en een hoop ellende hebben voorkomen. In een enkel jaar (I 885) zou hij in een brief aan de minister van Oorlog hebben gewezen op antihygiënische toestanden bij fort Hellevoetsluis, via een stuk in het Nederlandsch Militair Geneeskundig Archief het probleem van de zonnesteek die zich bij lange militaire marsen voordeed aan de orde hebben gesteld, en door middel van een 
ingezonden brief in de Arnhemsche Courant de 'ingedommelde regenten' van het Rijksopvoedingsgesticht De Kruisberg te Doetinchem (strafgevangenis voor jongens) hebben geattendeerd op Sodom en Gomorraachtige toestanden aldaar. Dat laatste zou zelfs tot Kamervragen hebben geleid. ${ }^{14}$

Van al die protesten heb ik geen spoor terug kunnen vinden, wat niet wil zeggen dat het verhaal dat hij daarover vertelde niet waar is. In een Kamerdebat van september I 886 over 'wijziging van de gestichtenwet', bijvoorbeeld, komt De Kruisberg wel ter sprake, en noemt een Kamerlid het 'verkeerd' wanneer veroordeelde meisjes in het gezelschap van vrouwen zouden worden geplaatst die 'zeer verdorven kunnen zijn', doch blijven bijbelse kwalificaties in het verslag achterwege, evenals iedere verwijzing naar de Arnhemse officier van gezondheid Van Dieren. ${ }^{15}$ De enige conclusie die op grond daarvan kan worden getrokken is dat de impact van die publieke protesten blijkbaar toch nog wel tegenviel. Of anders gezegd, vinden we in die claim de grondvorm terug van wat later in vele variaties door Van Dieren wordt uitgewerkt, namelijk de gedachte dat het loutere feit dat een bewering die in de publieke ruimte wordt geuit, vooral als het een schriftelijke mededeling betreft, ook moet betekenen dat ernaar wordt geluisterd en $d u s$ effect heeft op de publieke opinie. We zullen deze overschatting van de relatie tussen uiting en effect nog vaak in dit boek tegenkomen, vooral in de 'historiserende vorm', waarin een later gevolg zonder meer tot een eerder gedane bewering wordt teruggevoerd.

In september I 887 nam Van Dieren deel aan een vergadering van de Koninklijke Nederlandsche Maatschappij tot bevordering der Geneeskunst, afdeling Arnhem, waar hij twee gevallen presenteerde - zijn eerste publieke optreden in de medische wereld voor zover mij bekend. ${ }^{16}$ Begin I 888 verbleef hij een korte periode in Paramaribo, waar hij verbonden was aan het militair hospitaal. Het zou zijn enige koloniale ervaring worden. Hoe lang hij in deze contreien heeft vertoefd is onduidelijk, maar langer dan ongeveer een halfjaar kan het niet zijn geweest, want medio herfst I 888 was hij weer in Nederland. Uit die hele episode is ons slechts één detail bekend, namelijk hoe hij in dat jaar als jong officier eens een bunzing had doodgetrapt. Het heldhaftige verhaal ('ik stond vooraan en liep niet weg zooals de anderen') vatte hij later op als een metafoor voor zijn levenshouding; hoe hij met één welgemikte trap een einde maakt aan allerlei verderfelijke praktijken die een ander uit lafheid liever de rug toekeert. ${ }^{17}$

Eenmaal terug op vaderlandse bodem begon hij zich spoedig steeds grotere vrijheden te veroorloven. We vernemen hoe hij in I 888 lezingen 
begon te geven, opnieuw in Arnhem, tegen het gebruik van alcohol bij en ter voorkoming van allerlei ziekten te velde, waar het publiek naar zijn zeggen 'misnoegt' naar zat te luisteren. ${ }^{18}$ Men liet zich ook toen de geneugten des levens blijkbaar niet graag ontzeggen, vooral niet door een jonge en onervaren dokter. Ten slotte zwaaide hij in I 888 af en meteen daarna stichtte hij zijn allereerste persoonlijke ruzietje. Tijdens een werkbezoek aan het Rothschild-Spital in Wenen confronteerde hij de ervaren professor Oeser met zijn eigen opvatting over de behandeling van tyfuspatiënten. Direct, schreef hij, had hij het bij hem verbruid, omdat hij het waagde te zeggen dat hij zich niet kon verenigen met diens koudwater-behandeling 'aangezien hierdoor wel een nuttig reactiemiddel bestreden werd maar niet de ziekte-oorzaak'. ${ }^{19}$ Noodzakelijke aanvaring of moedwillige confrontatie - de kiem voor een polemisch leven was gelegd.

\section{Goede smaak behoeft geen krans}

$\mathrm{Na}$ het vervullen van zijn dienstplicht keerde Van Dieren terug naar Amsterdam, waar hij tot I 889 als semi-arts (min of meer vergelijkbaar met het huidige co-assistentschap) in het Nederlandsch-Israelisch Ziekenhuis aan de Nieuwe Keizersgracht de nodige praktijkervaring opdeed. Datzelfde jaar assisteerde hij de hoogleraar heelkunde J.A. Korteweg (I85I-I930), een van de weinige autoriteiten die hij zou erkennen. Bij diens dood verscheen in het alternatieve medische blad Vox Medicorum een anoniem 'In memoriam' van een van zijn oud-leerlingen, waarin Korteweg's bescheidenheid en zelfkritiek werden geroemd welke zouden hebben belemmerd dat hij 'de grote plaats in de wetenschappelijke wereld kon innemen waarop hij krachtens zijn verdiensten recht had'. Een man van hoge wetenschappelijkheid, aldus de schrijver, die zijn leerlingen op ieder schijnbaar nog zo onbelangrijk detail leerde te letten alvorens een diagnose te maken. ${ }^{20}$

Het behoorde niet tot de gewoonte van Van Dieren om stukken ongetekend te doen verschijnen, maar het is niettemin denkbaar dat hij de auteur was van deze necrologie. Wat er voor spreekt is het feit dat hij zitting had in de redactie van Vox Medicorum, bovendien een oudleerling van Korteweg was, en de sterke nadruk die de auteur op de miskenning van de overledene legt, hetgeen ook een Leidmotif in het denken van Van Dieren was. Wat er tegen spreekt is dat de naam Van Dieren nergens wordt opgevoerd.

Behalve bij Korteweg was Van Dieren in I 889 ook nog korte tijd assistent bij A.W.C. Berns (I838-I9II), aan het Burgerziekenhuis aan 
de Keizersgracht, waar de meer gegoede burgerij werd bediend, totdat hij zich ten slotte in september I 890 vestigde als zelfstandig huisarts aan de Schippersgracht. Hij kreeg volgens eigen opgave al heel spoedig een zeer drukke praktijk met patiënten uit in hoofdzaak de hogere en middenklasse. ${ }^{21}$ Dat berustte zeer waarschijnlijk niet op overdrijving, want Van Dieren boerde al heel gauw goed.

Waar kwamen die vandaan, die rijke patiënten? Wat trok hen in Van Dieren aan om uitgerekend hem, die toch overduidelijk niet uit dezelfde klasse afkomstig was, tot hun huisarts te nemen? Had hij zich tijdens zijn stage in het Burgerziekenhuis de mores van de hogere klasse weten aan te meten, of was er iets anders wat de afstand kon overbruggen? In verschillende van zijn boeken voert Van Dieren gesprekken met patiënten op; als die maatgevend zijn voor zijn rapport met zijn cliëntèle, kunnen we ons misschien indenken waaraan hij zijn succes had te danken.

Van Dieren was wars van allerhande vormen van bijgeloof en profileerde zich graag als een no-nonsense-arts met een uitgesproken afkeer van modieuze middeltjes en een onbegrensd vertrouwen in eigen kunnen. Hij nam de tijd voor zijn patiënten, leek overal verstand van te hebben en twijfelde nooit. Zijn raadgevingen beperkten zich zelden tot het zuiver medische en waren in de regel ook van ethische en soms ook van politieke aard. Zijn werkwijze kwam neer op wat we tegenwoordig waarschijnlijk 'integrale geneeskunde' zouden noemen: een holistische benadering gericht op lichaam en geest met een sterk moraliserende ondertoon. Van Dieren was, kortom, veeleer raadsman-geneesheer dan simpelweg huisarts, en dat zal althans een deel van het ontwikkelde publiek hebben aangesproken, een publiek dat op de drempel van de moderne tijd stond en zich losgeweekt wist van de negentiende eeuw, maar tegenover het huidige tijdsgewricht geen houding wist aan te nemen. (Later, in de jaren twintig, zou dezelfde houding zich tegen hem keren, en weigerden de kinderen van zijn patiënten zich door hem te laten behandelen, juist omdat ze geen behoefte hadden aan die bevoogdende praatjes van Van Dieren.)

Als praktiserend huisarts zou Van Dieren dus een bloeiende praktijk opbouwen en doorstoten tot de gegoede Amsterdamse burgerij en op die manier zijn eenvoudige komaf ontgroeien - maar niet helemaal. In zijn levenslange afkeer van alles wat naar intellectualisme zweemt, cultiveerde hij van meet af aan een recht-voor-zijn-raap, ik-zeg-'tzoals-'t-er-voorstaat-mentaliteit - een mentaliteit die hij in auteurs als De Genestet en Bredero herkende en bewonderde. Schrijvers die net als hij niet door de goegemeente werden geaccepteerd. Van Bredero adapteerde hij als lijfspreuk de gevleugelde woorden 't Kan verkeeren', en 
van De Genestet mocht hij graag rijmpjes citeren als deze: 'Overal stuit g'op verband; overal mijn vrinden! 't Is de vraag maar wie het al, wie het niet kan vinden.' Het is niet bepaald het summum van fijngevoeligheid, gaf hij toe, maar geaffecteerd, dat was hij beslist niet. ${ }^{22}$

Maar meer nog dan tot Bredero of De Genestet voelde hij zich aangetrokken tot Klikspaans 'studententypen', vooral tot de breedsprakige, grofgebekte maar goedhartige hoofdpersoon Flanor; een belangstelling die hij, tussen haakjes, deelde met zijn latere rivaal Frederik van Eeden, die in zijn studententijd samen met Franc van der Goes een literair Flanorgezelschap oprichtte (waaruit later De Nieuwe Gids ontstond). Van Eeden deed in I 885 artsexamen in Amsterdam, een jaar na Van Dieren. Ze moeten elkaar gekend hebben, ten minste van gezicht. Zou Van Dieren aansluiting hebben gezocht bij het Flanorgezelschap? Dat lijkt me eigenlijk niet waarschijnlijk - in elk geval zijn er geen bronnen bekend die dat bevestigen..$^{23}$

Het werk van Klikspaan (een pseudoniem van de schrijver Johannes Kneppelhout) is doordesemd van kritiek op de academische wereld, en de auteur die zelf nooit was afgestudeerd, wordt vaak gezien als de verpersoonlijking van ontevredenheid. Flanor is de Asterix onder de negentiende-eeuwse romanfiguren. Hij is van het type ruwe bolster blanke pit; een antiheld die als een populaire man des volks wordt neergezet. Kneppelhout liet Flanor promoveren en schilderde daarbij een vrolijke heidense scène: als een Gallisch opperhoofd wordt de held op een schild door het kroeggebouw gedragen, terwijl het Io Vivat schalt: 'Io vivat! Io vivat Floranis sanitas!'24

In Flanor vond Van Dieren zijn alter-ego. Maar anders dan Flanor zou híj nooit promoveren en het applaus dat Flanor ten deel viel zou hij nooit oogsten. Slechts eenmaal, op 24 december I909, ter gelegenheid van zijn zilveren artsjubileum, kwam hij in de buurt. Nadat iedereen had gesproken en de aanwezigen in optocht langs hem hadden gedefileerd zette de fanfare het beroemde studentenlied in.

Io vivat! io vivat!

Nostrorum sanistas!

Hoc est amoris poculum!

Doloris est antidotum!

(Hoezee! Leve!

De goede smaak van onze leden!

Dit is de beker der liefde!

Een tegengif voor het verdriet! ${ }^{25}$ ) 


\section{De kliek}

Het lijkt erop dat het verzet waarin Van Dieren zijn hele verdere leven is blijven volharden alleen maar bedoeld was om er uit alle macht bij te horen. Tegen de filosoof Gerardus Bolland (I854-I922), met wie hij op afstand bevriend was en in wie hij een medestander dacht te herkennen, klaagde hij over de slechte behandeling die hem ten deel viel in het medische wereldje, waar niemand meer in God geloofde en iedereen een materialist was geworden. En als hij dat eens aan de orde stelde werd er achter zijn rug om kwaad over hem gesproken, zo schreef hij eens aan Bolland. ${ }^{26}$

Achter die klacht stak een treurige geschiedenis. Op 27 januari I920 was Van Dieren, negenenvijftig jaar oud, tot voorzitter van de Amsterdamse Geneeskundige Kring gekozen. Om dat heugelijke feit te vieren stak hij voor het gezelschap een voordracht af tegen het hand over hand toenemende materialisme. Dat bleek tegen het zere been van de socialistische artsen binnen de vereniging; zij vonden dat de voorzitter geen godsdienstige en politieke kwesties diende te behandelen binnen een neutraal genootschap als het hunne en bereidden een motie van afkeuring voor. Tot debat en stemming kwam het niet, Van Dieren was tevoren van de couppoging op de hoogte gesteld en hield de eer aan zichzelf. Op de meivergadering, nog geen half jaar na zijn aantreden, zag Van Dieren zich gedwongen af te treden. 'Van Dieren is geen voorzitter meer!,' moet hij hebben geroepen, waarna hij de voorzittershamer neerwierp en de bijeenkomst verliet, zo meldde de NRC. ${ }^{27}$ In een voetnoot bij Historisch-idealisme of historisch-materialisme waarin Van Dieren op zijn smadelijke afgang ingaat, staat bovendien te lezen dat hij de aanwezigen bij het weggaan nog zou hebben toegevoegd: 'Ik kan mijn geestkracht elders nuttiger aanwenden dan hier. In het isolement làg en ligt mijn kracht! ${ }^{28}$ Aan zijn vriend, de chirurg Otto Lanz, een generatiegenoot, schreef hij later verbitterd: 'De kliek is vanouds goed georganiseerd en gedisciplineerd. Wie wat wil worden moet de kliek, de kliekelingen, prijzen en bewonderen.'

Onmogelijk. De kliek was tegen hem. 'Als je hoog wilt stijgen op de maatschappelijke ladder, dan moet je tegen Van Dieren schrijven, allen die dat gedaan hebben werden beloond', luidde zijn analyse in een toespraakje dat hij in de jaren tien voor studenten hield. Veel van de generatiegenoten met wie hij zich identificeerde waren hem toen al gepasseerd en waren al lang en breed professor, hoofdambtenaar of curator geworden, of ten minste tot ridder in de orde van de Nederlandse 
Leeuw benoemd (voor zijn aartsrivaal Christiaan Eijkman gold dat hij dat vrijwel allemaal was geworden). ${ }^{29}$

Zo ook vriend Lanz (I865-I935), Zwitser van geboorte, als persoon nogal autoritair en in de omgang tamelijk ongemakkelijk, maar als professor in de chirurgie, later rector van de Universiteit Amsterdam, een 'hooggeplaatste'. 'Waarom helpt u mij niet?' smeekte Van Dieren op een keer. ${ }^{30}$ Lanz was zo gek nog niet of hij keek wel uit. Het enige waartoe hij bereid bleek was hem een plekje in zijn rectorale rede te gunnen, en in navolging van Van Dieren van een 'psychische epidemie' te spreken met betrekking tot de toen almaar voortwoekerende sportwoede. Maar zelfs die verwijzing werd bij nader inzien ingetrokken tijdens het uitspreken van de rede, zo klaagde Van Dieren. ${ }^{31}$ In de gedrukte versie zoals die in het Jaarboek van de Universiteit van Amsterdam verscheen, ontbreekt inderdaad iedere verwijzing naar hem. Lanz wist de kracht van de kliek misschien beter op waarde te schatten, maar bleef toch oprecht in Van Dieren geïnteresseerd en onderhield langere tijd een vriendschappelijke briefwisseling met hem en nam als een wat verlate publieke steunbetuiging zitting in het comité ter voorbereiding van zijn veertigjarig artsjubileum, in 1924.

De kliek ... ezels, 'geboefte', onbereikbaar ver weg en toch zo nabij. Tot zijn cliëntèle behoorde vanaf de jaren negentig van de negentiende eeuw het gezin van componist-dirigent en generatiegenoot Alphons Diepenbrock. Diepenbrock (I862-I92I) was een selfmade man die een heel onkarakteristiek spoor had gevolgd. Hij had op aandringen van zijn vader klassieke talen gestudeerd, alhoewel hij eigenlijk dirigent had willen worden, was dan in I 888 gepromoveerd op een proefschrift over Seneca en vervolgens leraar geworden aan het stedelijk gymnasium in 's-Hertogenbosch, maar in I 894 teruggekeerd naar Amsterdam om zich alsnog aan het componeren te wijden. Om in zijn levensonderhoud te voorzien gaf hij privéles in klassieke talen. Met een in I 896 geschreven compositie verwierf hij tenslotte landelijke bekendheid (hoewel opvoering ervan pas in 1916 zou plaatsvinden).

Als musicus was Diepenbrock een autodidact - een 'geleerde dilettant' is hij wel genoemd. Hij had net als Van Dieren uitgesproken meningen en publiceerde graag over de meest uiteenlopende onderwerpen, zoals politiek, filosofie, religie, cultuurgeschiedenis en andere culturele onderwerpen. Met Van Dieren deelde hij bovendien een grote bewondering voor klassieke Duitse auteurs als Goethe, maar anders dan Van Dieren liet hij zich ook inspireren door moderne Duitse auteurs, zoals Nietzsche (voor wie Van Dieren een diepe verachting koesterde). Hij was bevriend met beroemdheden als Gustav Mahler en 
Willem Mengelberg (door Van Dieren eveneens veracht) en had een uitgebreide vriendenkring onder de Tachtigers (door Van Dieren gezien als dégénérés). ${ }^{32}$

Dat was er dus nog eens één die hoog op de maatschappelijke ladder stond. Via de Diepenbrocks zou Van Dieren de culturele elite gadeslaan, maar er geen deel van uitmaken. Er waren zijdelingse contacten met W.G. Hondius van der Broeck, Willem Verkade, Jan Toorop, de salonsocialist Herman Gorter en anderen die bij de Diepenbrocks over de vloer kwamen, ja, er zelfs een vriendenclubje op na hielden, een 'kliekje' - maar zonder 'VD', zoals hij in de gepubliceerde documenten van de Diepenbrock-familie werd aangeduid. Er waren wel korte, vruchteloze briefwisselingen met Frederik Van Eeden, Albert Verwey en Henriëtte Roland Holst, maar er was niets dat beklijfde in die contacten. Hij bleef een buitenbeentje om wie de 'socies' ten huize Diepenbrock grijnsden als zijn naam viel. ${ }^{33}$ Een omhooggevallen provinciaal: 'daar komt van Dieren met zijn HBS-argumenten. ${ }^{34}$ Toch bleef ook Diepenbrock hem de hand boven het hoofd houden, misschien omdat hij als autodidact een beetje een Van Dieren in zichzelf herkende. $\mathrm{Nu}$ goed, hij betreurde diens zelfoverschatting, zo zei hij eens, maar toch gunde hij hem graag een lintje..$^{35}$

Onder de patiënten van Van Dieren treffen we verder curieus genoeg de latere sociaal-anarchist Ferdinand Domela Nieuwenhuis aan. ${ }^{36}$ Maar ook, ter rechterzijde van het politieke spectrum, Pierre Henri Ritter, remonstrants predikant, hoogleraar in de wijsbegeerte, en later hoofdredacteur van het Amsterdamse dagblad Het Nieuws van den Dag. Met zijn zoon, de schrijver-journalist P.H. Ritter junior, raakte Van Dieren in de jaren dertig ook in contact toen deze redacteur werd bij Vox Medicorum. Vox was het enige blad dat zich onvoorwaardelijk achter Van Dieren schaarde, jaar in jaar uit. Het accepteerde al zijn stukken die elders geweigerd waren. Uit dank trad Van Dieren zelf tot de redactie toe, al betwijfel ik het dat zijn redactionele bemoeienis verder ging dan het schrijven van nog meer stukken voor dat blad.

Via vrienden als Ritter en anderen zocht Van Dieren toegang tot het publieke domein, de wereld van het gedrukte woord, en via vrienden als Diepenbrock en professor Lanz toegang tot de academische wereld, de ideeënwereld (om een platoons onderscheid te hanteren), maar in beide gevallen met opmerkelijk weinig succes. Op eigen terrein echter zou hij het, net als Diepenbrock, ver schoppen. Zijn huisartsenpraktijk bloeide in de jaren negentig onder invloed van de gestaag groeiende cliëntèle van welgestelde middenstanders en regenten. En omdat zijn klantenkring 
doorgaans in goeden doen was, ging het met hem spoedig ook goed. Hij kon zich na enige tijd een rijwiel veroorloven, op enig moment ook een koetsje en later zelfs een gemotoriseerd rijtuigje met chauffeur. ${ }^{37}$ Hij was ook, om nog iets noemen, een van de eerste Nederlanders met een telefoonaansluiting. En hij was een van de eersten die regelmatig op vakantie naar het buitenland ging. Tekenen van voorspoed.

Een ander blijk van zijn succes vinden we in de opgaven van de donaties aan het armen- en wezenfonds van de Koninklijke Nederlandsche Maatschappij tot bevordering der Geneeskunst, waarvan iedere zichzelf respecterende arts lid was. Niemand was verplicht om aan dat fonds te geven, maar wie dat wel deed kreeg een vermelding in het Nederlandsch Tijdschrift voor Geneeskunde; een lichte vorm van sociale controle dus, hetgeen zal verklaren waarom zo velen aan het fonds doneerden. De meeste leden gaven een rijksdaalder per jaar, een enkeling vijf gulden, wie het armer had gaf een gulden. Zo niet Van Dieren. Hij doneerde vanaf I896 ieder jaar vijftien gulden. Dat was zonder twijfel veel en veel te veel. Niemand, met uitzondering van een enkele gepensioneerde professor gaf zo'n buitensporig groot bedrag aan het fonds. Het moet op anderen zijn overgekomen als snoeverige pronkzucht: Kijk eens hoe goed het mij gaat! Maar toch is het nog maar de vraag of die mateloze gift een vertoon van bezit moest aanduiden. Het is misschien alleen maar een onvermogen om zich binnen de grenzen van het betamelijke te gedragen. Smaak is per slot niet te koop, het is een teken van onderscheid.

Tegen het einde van zijn carrière schreef Van Dieren een herinnering op aan zijn beginperiode als assistent onder professor Korteweg. In reactie op een bewering van een collega, gedaan in het Nederlandsch Tijdschrift voor Geneeskunde, dat advertenties van zogenaamde patiënten in werkelijkheid vaak alleen maar verkapte vormen van reclame waren, wierp Van Dieren tegen dat in I 883 een voormalig patiënt van hem eens in het Algemeen Handelsblad de volgende advertentie had laten plaatsen: 'Hartelijk dank aan de doktors Korteweg en Van Dieren, aan wie ik naast God en het verdere personeel, het herstel mijner gezondheid te danken heb.' Hony soit qui mal y pense! schreef Van Dieren onder zijn opstel, niet voor het eerst en niet voor het laatst. ${ }^{38}$

Schande over hem die er kwaad van denkt. Toch kan men die onbedoeld komische zin, waarin God en het verdere personeel worden bedankt, moeilijk lezen zonder een glimlach te onderdrukken. Van Dieren schreef de anekdote op in I926, op vijfenzestigjarige leeftijd, meer dan vier decennia na dato. De ingezonden annonce moet, als het hele 
verhaal niet op fantasie of overdrijving van zijn kant berust, de eerste vermelding van zijn naam in de krant zijn geweest. Maar zelfs als het verhaal waar is, dan ligt het belang ervan niet in de inhoud, maar in de vorm, in de publieke erkenning namelijk van Korteweg en Van Dieren die door de vermelding in dezelfde zin met titel 'dokters' op gelijke hoogte waren gebracht. Om die erkenning als een serieus te nemen dokter, als het even kon in publiek, liefst in een krant en het allerliefst een groot dagblad, zou Van Dieren later nog talloze malen smeken, maar van een zo openlijk blijk van erkentelijkheid als toen zou het nooit meer komen.

\section{Kwesties}

Nog een indicatie van zijn maatschappelijk succes: in I 894 verhuisde Van Dieren van de Schippersgracht naar de Amstel. In datzelfde jaar trouwde hij Catharina Bakker en stichtte met haar een gezin. Een kleine twintig jaar later betrokken zij een pijpenla van vijf verdiepingen aan de sjieke Keizersgracht ter hoogte van de Vijzelstraat, waar de gracht op z'n breedst is. Een kleine sprong binnen de grachtengordel, maar een aanzienlijke sprong in het maatschappelijk verkeer. De Van Dierens bleven er wonen tot kort voor zijn dood, pas in I 939 verhuisde het gezin naar de Noorderamstellaan (thans Churchilllaan), alwaar Van Dieren in het voorjaar van I940 overleed.

Op het pand aan de Keizersgracht herinnert een kleine in juni 1999 aangebrachte gedenkplaat er aan dat 'Evert van Dieren, initiatiefnemer en eerste voorzitter van het Amsterdams Geneeskundig Genootschap', daar heeft gewoond (we zullen het degenen die de plaat hebben aangebracht niet kwalijk nemen dat zijn voornaam verkeerd is gespeld, zelf schreef hij haar nooit voluit). Is die plaquette op zichzelf al een teken dat zijn sociale kapitaal aanzienlijk moet zijn geweest; daarnaast kunnen we constateren dat hij ook in tal van commissies en gezelschappen zat, en allerlei functies bekleedde die zijn maatschappelijk aanzien fors bekrachtigden. ${ }^{39}$ Ook nog oefende Van Dieren naast zijn eigen praktijk de eerste 27 jaar van zijn carrière een verloskundige praktijk uit en heeft hij naar eigen zeggen in die hoedanigheid meer dan I 600 bevallingen bijgewoond. Dat zijn gemiddeld bijna zestig bevallingen per jaar, ofwel iedere week wel één. ${ }^{40}$ En dan was hij ook nog jarenlang stadsgeneesheer en vanaf i 895 geneesheer aan de Kweekschool voor de Zeevaart. Er zullen in Amsterdam weinig verenigingen of genootschappen zijn geweest die het woord 'geneeskunde' voerden waarvan Van Dieren geen lid is geweest. 
Hoewel gelieerd aan allerhande genootschappen en sterk geïnteresseerd in politiek liet Van Dieren zich er lange tijd op voorstaan niet lid te zijn van een politieke partij, waarschijnlijk omdat er geen enkele partij was waarvan hij alle principes kon onderschrijven. Door de socialisten werd hij niettemin beschouwd als een partijganger van Abraham Kuyper en feitelijk kwamen zijn opvattingen ook het meest in de buurt van wat die partij voorstond, maar ook met Kuyper kon Van Dieren het hartgrondig oneens zijn (bijvoorbeeld over de vaccinatiedwang) en dus werd hij geen lid van de ARP.

Twee keer echter kon hij de verleiding niet weerstaan aan het politieke bedrijf deel te nemen, zij het ook in de marge ervan. De eerste keer in het eerste decennium van de twintigste eeuw, toen hij zich naar eigen zeggen liet overtuigen zich kandidaat te stellen voor de Tweede Kamer, 'omdat het zo goed zou zijn een dokter af te vaardigen'. Spijtig genoeg vertelde hij er niet bij voor welke partij dat was; zeker is het wel dat er van een Kamerzetel niets is gekomen. ${ }^{41}$ De tweede keer dat hij zich kortstondig met partijpolitiek inliet was begin jaren twintig, toen Van Dieren als voorzitter van de Amsterdamse afdeling op de lijst van de Nederlandse bond van belastingbetalers stond, een splinterpartijtje dat zich sterk maakte voor een terughoudende overheid en aan actieve bestrijding van het socialisme deed, twee standpunten die ook Van Dieren onverkort voorstond. Het secretariaat van de partij was gevestigd aan de Keizersgracht in Amsterdam, op loopafstand van zijn huisadres. De partij gaf het blad De Belastingbetaler uit, waarvoor van Dieren tenminste één artikel schreef, en afficheerde zichzelf geheel in stijl als de 'dokter van 's lands grootste gekkenhuis' (de overheid). Ze deed slechts eenmaal mee aan de Tweede Kamerverkiezingen, won geen enkele zetel, en ontsloeg zo Van Dieren definitief van de verplichting serieuze politiek te hoeven beoefenen.

Liever bestookte hij de maatschappij met ongevraagde adviezen over politiek getinte problemen waarover hij zich met omgekeerd onevenredige verbetenheid opwond: hoe kleiner het probleem, hoe groter zijn bemoeizucht. Hieronder behandel ik enkele van die incidenten, niet in chronologische volgorde maar in orde van grootte, te beginnen bij de kleinst mogelijke, de affaire die toepasselijk genoeg als het 'pantoffelincident' de geschiedenis zou ingaan, zijn eerste officiële confrontatie met de socialisten.

Eind oktober van het jaar 1902 adviseerde de Schoolcommissie aan de gemeenteraad van Amsterdam om aan arme schoolgaande kinderen pantoffels te verstrekken, daar deze kinderen meestal op kousenvoeten 
naar school gaan en 's winters dus koude voeten krijgen als gevolg waarvan zij ziek worden en school moeten verzuimen. ${ }^{42}$

Van Dieren vond dat maar een onzinnig voorstel: pantoffels over natte kousen leidt tot niets. De kinderen wier ouders geen schoenen kunnen kopen moeten maar klompen dragen. Vinnig verzette hij zich in een groot artikel op I november 1902 in De Telegraaf tegen het advies van de commissie waarvan hij echter zelf lid was. Dat leidde tot grote interne commotie. De voorzitter van de commissie, de sociaaldemocraat A.H. Gerhard, zag zich gedwongen steunbetuigingen te verzamelen voor zijn standpunt en daarvan werden er dan daags daarop een twintigtal in dezelfde krant gepubliceerd. Saillant detail: een van die steunbetuigingen was afkomstig van Cornelis Winkler, die we nog vaker zullen tegenkomen in dit verhaal - hij loopt als een running gag door het leven van Van Dieren. Winkler schreef dat hij desgevraagd niet met zekerheid wist welke invloed natte koude voeten hebben. 'Het volksgeloof zegt dat men er ziek van wordt, maar streng in medische zin bewezen is deze stelling allerminst.' Wel geloofde hij dat, als kinderen in plaats van koude natte voeten warme voeten hebben, ze een zeker welbehagen voelen, en dat dat vast wel helpt de aandacht vast te houden, beter in elk geval dan wanneer ze de onaangename sensatie van koude voeten hebben. ${ }^{43}$

Of de pantoffels er nu wel of niet zijn gekomen vertelt het verhaal niet en is hier ook niet van belang; de geschiedenis is illustratief voor het soort incidenten waarmee Van Dieren zichzelf geassocieerd zag, incidenten waarin een miniscuul detail als het ware de rol van betekenaar vervult: de pin van het moment waaraan de wereld wordt opgehangen. ${ }^{44}$

Een decennium eerder was door de gemeenteraad in Amsterdam een politieverordening inzake de vleeskeuring afgevaardigd om de groeiende import van vlees en de daarmee samenhangende risico's voor de volksgezondheid in goede banen te leiden. Vlees moet in het gemeenteabattoir zijn gekeurd en er mogen geen kleinere stukken dan halve dieren ter keuring worden aangeboden. Vooral die laatste bepaling leidde tot protest, omdat kleinere slagers zich daardoor benadeeld voelden. Van Dieren deed als medicus in I89 I een duit in het zakje in de discussie rond de vleeskeuring via een open brief aan de gemeenteraad, waarin hij bezwaar maakte tegen het feit dat het hem als ingezetene van Amsterdam 'niet geheel vrij staat te Amsterdam vleesch te eten, geleverd door een slager bijvoorbeeld uit Baarn; dat hem zulks bemoeilijkt wordt door een artikel eener verordening, vastgesteld door gemeenteraadsleden, die 's zomers bijvoorbeeld te Baarn verblijf hou- 
den, daar hetzelfde vleesch nuttigen zonder er eenig bezwaar tegen te opperen. ${ }^{45}$

Of die ad-hominemargumentatie veel indruk maakte betwijfelde Van Dieren zelf ook, want hij verwachtte niet dat de verordening op korte termijn zou verdwijnen. Feitelijk moest de overheidsbemoeienis met de volksgezondheid onder druk van een groeiende populatie en een toenemende welvaart natuurlijk ook alleen maar toenemen in plaats van afnemen, en daarbij speelde, zeer tot ergernis van Van Dieren, het opkomende socialisme bovendien een steeds belangrijkere rol, daar zij aan het hygiënevraagstuk de grotere kwestie van de verheffing van de arbeidersstand had verbonden en in de vleeskeuring een bruikbaar instrument in haar strijd zag.

Zeventien jaar later, in de zomer van I908, treffen we Van Dieren in hevige strijd verwikkeld, nu met de Amsterdamse Geneeskundige Kring, tegen het besluit van de algemene ledenvergadering om leden van de 'Ancient Order of Foresters' (een soort vrijmetselaarsvereniging die ook nu nog bestaat) van behandeling uit te sluiten, en iedere arts die desondanks bereid was een Forester te behandelen uit de Kring te zetten. Van Dieren vond dat onethisch, onwettig, ja 'onmenselijk'. Hij dreigde op te stappen, hield een militante speech voor de kring, en begon, toen dat alles niets had uitgehaald, een ingezonden brievencampagne in de hoop medestanders voor zijn standpunt te winnen en het besluit terug te doen draaien. ${ }^{46}$ Ook dat leverde niet het gewenste resultaat op (slechts I 5 van de 90 kringleden kozen zijn zijde), maar het ontlokte wel een stekelige reactie over 'het terrorisme van Van Dieren' aan een van die I 5 'medestanders' die het, na zich over het probleem te hebben gebogen, duidelijk was geworden dat Van Dieren de zaak volledig verkeerd had voorgesteld.

Van Dieren moet en zal zijn zin hebben, tegen alle beter in, tegenover alle overtuigende redeneeringen van anderen in, de Kring zal op zijn besluit terugkomen. En om dat doel te bereiken zullen alle middelen gebezigd worden, de andere afdelingen der Maatschappij zullen in beroering worden gebracht, de dagbladpers zal er zich druk mede bemoeien en niet ver ligt de tijd dat het publiek de Amsterdamsche doctoren zal beschouwen als een troep onmenschen die zulke arme zieke Foresters niet behandelen willen. De mooie rol speelt van Dieren, opkomend voor den typhuslijder in extremis, de algemeene sympathie zal naar hem toegaan. $\mathrm{O}$, die typhuslijder! Ja, van Dieren, dat was nu het reinste melodrama dat er maar vertoond kon worden... ${ }^{47}$ 
De werkelijkheid is, schreef de tot inzicht gekomen voormalige medestander, dat de Foresters voor hun leden een eigen ziekenfonds ingericht hebben en via dat ziekenfonds invloed uitoefenen op de keuze van behandelend geneesheer, dus een vorm van oneerlijke concurrentie ten gunste van een bevoorrechte klasse artsen in de hand werken. ${ }^{48}$ Van Dieren werd er zelfs van verdacht daar zelf van te hebben willen profiteren, zo bleek althans uit een opmerking van een van de kringleden, die met voetgetrappel door de vergadering werd onthaald, een verdachtmaking die Van Dieren natuurlijk verontwaardigd van zich wierp. $^{49}$

Van dergelijke kwesties zijn er ontelbaar vele geweest. Of het nu ging om het probleem van de vivisectie (I 898), het bestrijden van de mazelen (1903), de organisatie van de gemeentelijke geneeskundige dienst (in de jaren tien), of het bestrijden van de mond- en klauwzeerepidemie (I9I6): steeds richtte Van Dieren zich via krantenartikelen, brochures of brieven tot de betrokkenen en probeerde hij in het publieke domein sympathie voor zijn standpunt te genereren. ${ }^{50}$ Meestal 46 ging hij openlijk te werk, maar een enkele keer gunde hij zichzelf het genoegen zijn protesten of kritieken anoniem te versturen, zoals bijvoorbeeld in het geval van de GGD-kwestie, waarbij een open brief aan de raadsleden ondertekend werd met: 'een gewezen stadsheelkundige'. Titel en stijl van de brief verraden de hand van de meester. ${ }^{51}$

Later nam zijn belangstelling meer megalomane proporties aan en wees hij in jaren rond de eeuwwisseling met een stelligheid die niet de minste tegenspraak duldt de landelijke invoering van schoolartsen af. Laat de opvoeding maar aan de moeders over, betoogde hij. Als schoolartsen zich daarmee gaan bemoeien, halen ze de hoeksteen onder de samenleving vandaan, te weten het gezin. Voor de gelegenheid liet hij een pamfletje drukken met 'hygiënische raadgevingen voor het huisgezin' dat desgewenst aan iedereen die het interesseerde kon worden toegestuurd. De 'hygiënische raadgevingen' balden in luttele bladzijden het totaal aan praktische medische kennis samen dat nodig was om een gezin de opvoeding van zijn kinderen ter hand te kunnen laten nemen en maakten, zo gezegd, de schoolarts overbodig. De openingszinnen rollen als retorische golven de huiskamer binnen: 'Onreinheid bevordert ziekten! Houd uw huis zindelijk, verfrischt uw lijfgoed en uw beddegoed, klop uw kleeren uit, lucht uwe kamer, vooral de slaapkamer en doe dat nog meer als er een zieke in ligt - onverschillig aan welke ziekte - ook 's nachts, want z.g. slaaplucht of menschenlucht is bedorven lucht [...].' Het leverde hem een polemiek met de sociaal-democraat Van Det op, die met die magere brochure vol met gratuite raadgevingen 
en platitudes geen genoegen nam en betoogde dat de schoolarts in tegenstelling tot wat Van Dieren dacht juist wel zou bijdragen aan de ondersteuning van het gezin. ${ }^{52}$

In de jaren tien keerde hij zich tegen de plannen voor een nieuwe watervoorziening voor Amsterdam, en een paar jaar later ook tegen de drooglegging van de Zuiderzee. Vooral dat laatste plan was zijns inziens 'jammerlijk' en kon tot niets anders dan financiële rampspoed leiden. Hij voorzag instortende dijken, een dichtslibbende Waddenzee, het verdrinken van 250.000 mensen; het was, kortom, een 'roekeloze onderneming,.$^{53}$

Hij stond in zijn protest niet alleen. De Zuiderzeekwestie hield vanaf het allereerste plan, dat al uit I 886 stamde, tot en met het feitelijke begin van de drooglegging, in I924, de gemoederen flink bezig. Raadpleeg de Handelingen en zie: het onderwerp 'Zuiderzee' krijgt een eigen trefwoord bij de afdeling ingezonden brieven aan de Tweede Kamer. Ook deze kwestie doorsneed allerlei politieke belangen. De grootsheid van de plannen sprak sommigen wel aan, maar anderen vreesden net als Van Dieren het financiële risico en weer anderen meenden, eveneens als Van Dieren, dat de dijken niet sterk genoeg zouden zijn om een stormvloed te keren, terwijl de socialisten graag zagen dat degenen die bij een drooglegging het meeste baat zouden hebben het meest aan verwezenlijking ervan zouden bijdragen.

In maart I9I 8 werd in de Tweede Kamer de knoop doorgehakt: de Zuiderzee zou definitief worden drooggelegd, maar niet nadat twee moties waren aangenomen; één ter geruststelling van de angstigen onder de Kamerleden, waarbij de garantie werd afgegeven dat de polderdijken van zodanige afmetingen zouden zijn dat ze een stormvloed konden keren, ook 'wanneer de afsluitdijk gedurende geruimen tijd over groote lengte eventueel is doorgebroken of de sluizen het begeven', en één waarbij de regering zou laten onderzoeken of niet toch de provinciën rondom de Zuiderzee en individuen, 'voor zoover hun ten gevolge van afsluiting en droogmaking der Zuiderzee geldelijke voordeelen te beurt vallen' vorderingen konden worden opgelegd, ter paaiing van de socialisten.

Kortom, het poldermodel werkte ook in I9I 8 al uitstekend, en de minister van Waterstaat, ir. Cornelis Lely (niet toevallig ook de ontwerper van het plan), werd op de dag dat het plan eindelijk was aangenomen door zijn collega-Kamerleden van allerwegen hartelijk gefeliciteerd met het 'moedige besluit'. ${ }^{54}$ Zo werd dus zonder dat naar de ernstige waarschuwingen van de zwartkijkers was geluisterd tot het Zuiderzeeproject besloten dat vanwege de crisis overigens eerst pas in 
de jaren dertig kon worden voltooid. Nog net op tijd voor Van Dieren om er commentaar op te kunnen geven. Als een ware onheilsprofeet die de voorspelde dag des oordeels voorbij ziet gaan, zonder dat het einde der tijden is aangebroken, maar zich daardoor juist gesterkt voelt in zijn geloof in plaats van verzwakt, riep Van Dieren in I93 I uit dat zijn waarschuwingen volkomen terecht waren geweest: 'Als men nù nog beginnen moest, zou er vast en zeker niets van komen. ${ }^{, 55}$

Ook op lokaal niveau probeerde Van Dieren vaak het openbaar bestuur op andere gedachten te brengen inzake niet-medisch kwesties. In 1926 beklaagde hij zich bij de burgermeester van Amsterdam, Willem de Vlugt, over opvoering van het toneelstuk De gevangene van Eduard Bourdet door het Vereenigd Tooneel. Het stuk gaat over een homoseksuele vrouw die tracht zich door middel van een huwelijk aan haar tegennatuurlijke gevoelens te ontworstelen, maar daaraan toch niet weet te ontsnappen. Volgens Van Dieren was het stuk nog erger dan Gevallen engelen van Noel Coward, een toneelstuk dat kort daarvoor in Den Haag al als 'niet netjes genoeg' was beoordeeld en daarom niet was opgevoerd, en in Amsterdam al na enkele uitvoeringen werd gestaakt. Van Dieren hoopte hetzelfde gedaan te krijgen voor $D e$ gevangene en hij vroeg De Vlugt de opvoering te verbieden. $U$ zult door de 'modernelingen' natuurlijk wel weer voor 'duisterling' worden uitgemaakt, schreef hij aan De Vlugt, maar dat geeft niet, hij zelf vond het een 'eer' als ze zo over hem spraken. ${ }^{56}$

$\mathrm{Nu}$ is Gevallen engelen wel een voor haar tijd tamelijk gewaagde komedie over twee verveelde vrouwen uit de high society die langzaam dronken worden en zich 'onwelvoegelijk' beginnen te gedragen, maar anders dan De gevangene gaat het stuk niet over homoseksualiteit, al was de auteur dat zelf openlijk wel. In die zin was De gevangene dus inderdaad 'nog erger' dan het stuk van Coward; wat voor Van Dieren tenslotte de doorslag gaf om zich te beijveren voor een verbod was het feit dat het stuk ermee eindigt dat de vrouw toch weer aan de 'opgewekte verlanges' toegeeft. Het gevolg van zijn protest was dat De Vlugt de tekst van De gevangene opvroeg bij de directeur van het Verenigd Tooneel, maar tot het verbieden ervan zou hij niet overgaan, wat ook wel begrijpelijk is als men bedenkt dat Gevallen engelen ook niet van hogerhand werd gestaakt, maar wegens gebrek aan succes. Op zondag 24 oktober 1926 ging De gevangene in première en werd door pers en bezoekers unaniem enthousiast ontvangen; volgens een recensent had de auteur 'het bewijs geleverd dat het toneel zich elke vermetelheid kan veroorloven, op voorwaarde dat die niet verbloemd wordt door den schijn, maar behandeld wordt met de oprechtheid der analyse'. ${ }^{57}$ 
Dat die uiting van 'vermetelheid'- het bespreekbaar maken van homoseksualiteit - niet meer vanzelfsprekend op heftige verontwaardiging kon rekenen, maar integendeel op begrip, en niet alleen van de 'modernelingen', had Van Dieren trouwens vier jaar eerder al gemerkt, zoals we verderop nog zullen zien, toen hij in het $N T v G$ pleitte voor harde maatregelen tegen zulke 'bevorderaars van ontucht' en onder collega-medici geen enkele steun vond.

Zo bleven veel van zijn protesten zonder enig gevolg. Wel dreef zijn onophoudelijke uitvallen tegen allerlei vormen van nieuwlichterij, in het bijzonder die der socialisten, de Amsterdamse stadsbestuurders geleidelijk tot vertwijfeling. Polak en Wibaut moesten het daarbij het vaakst ontgelden. De naam Van Dieren werd synoniem voor bemoeizucht, en onder de socialisten gold de 'dierenarts' als een 'farizeeër'. Maar ja, schreef een vriend eens in een loftuiting aan zijn adres: 'zijn karakter brengt nu eenmaal mee dat hij geen blad voor de mond neemt, doch meermalen ongezouten uit den hoek komt'. ${ }^{59}$ Zelf zag hij dat anders: wie uit lafheid meedoet aan het gekoketteer van de 'karakterloze afwijkelingen' (de socialisten) is evengoed schuldig aan zijn eigen verval. ${ }^{60}$

Daarom schrok Van Dieren er ook niet voor terug anderen voor zijn karretje te spannen als het er om ging de socialisten te bestrijden. Zo, bijvoorbeeld in de zomer van I9I9, toen hij C.J. Hoogendijk tegen het lijf liep, een oud-patiënt van hem die zojuist na een langdurig verblijf te Rusland in Nederland was teruggekeerd. Onbekend is met welk doel Hoogendijk in Rusland vertoefde, of zelfs maar waar precies, maar het loutere feit dat hij zich daar toen bevond makkte hem, zo realiseerde Van Dieren zich, tot unieke ooggetuige van een historische gebeurtenis toen in volle gang: de Russische revolutie.

Nog geen twee maanden eerder had hij krachtig uitgehaald naar de wantoestanden in Rusland in het antisocialistische pamflet De waanzinnige waereld en bevond hij zich kortstondig in het centrum van de aandacht. In wat Hoogendijk hem over Rusland vertelde moet hij een buitenkansje hebben geroken om het vuurtje nog wat verder op te stoken. In elk geval slaagde hij erin de ander te verleiden tot het houden van een 'causerie' - een lezing, in dit geval, over 'wat de bolsjewiki willen en wat zij bereikt hebben'. De voordracht vond anderhalve week na hun ontmoeting plaats, op 4 juli r9 99 in de Nutszaal in Amsterdam, en werd bijgewoond door journalisten van zowel de conservatieve NRC als het socialistische Het Volk. Blijkens een verslag in de NRC was de zaal tot de nok gevuld; volgens Het Volk met merendeels vertegenwoordigers der bourgeoisie, hoewel her en der ook enkele tientallen communisten vertegenwoordigd waren. 
Van Dieren leidde de lezing in en verklaarde dat de spreker een ontnuchterende boodschap had voor de lezers van mevrouw Roland Holst die in haar geschriften een wel erg rooskleurig beeld had geschetst van de Russische revolutie. Daarop sprak Hoogendijk over de hongersnood in Rusland en andere misstanden, die volgens de sociaal-democratische journalist schromelijk overdreven werden. De NRC herkende in het met schrille kleuren geschetste betoog weinig nieuws, maar meende desondanks dat het 'sombere verhaal over de honger, de wanorde, de arbeidsschuwheid boeiend genoeg' was. ${ }^{61}$ Boeiend of niet, de spreker werd al na een kwartier onderbroken toen de eerste communistische interrupties door de zaal knetterden. Hij kon zijn verhaal ternauwernood afmaken en werd tot slot toch beloond met langdurig applaus. Vervolgens gaf Van Dieren gelegenheid tot het stellen van vragen. Daarbij deelde hij de vragenstellers bij voorbaat in twee groepen op: zij die wel in Rusland waren geweest, en zij voor wie dat niet gold. Een merkwaardige strategie voor iemand die zelf ook niet in Rusland was geweest, maar desalniettemin grote kritiek op het Sovjetregime had. Het droeg in elk geval niet bij aan een ordelijk verloop van de discussies. Er was bijval voor de spreker, maar vooral de 'propagandisten van het communisme' roerden zich al rumoeriger in het debat en richtten zich daarbij nauwelijks op Hoogendijk, maar des te meer op de socialistenvreter Van Dieren die er al minder in slaagde de rust te bewaren. Ten slotte ontstond er zo veel ophef dat de politie moest worden gewaarschuwd en er aan de bijeenkomst van hogerhand een einde werd gemaakt. Enkele communisten deden nog een poging de Internationale in te zetten, maar werden door de agenten de zaal uitgejaagd. Op straat, aldus het verslag in Het Volk, bleef het nog even druk van napratende groepjes, die ten slotte door de politie verspreid werden. ${ }^{62}$

Wat een explosieve bijeenkomst! Dichter bij een handgemeen was Van Dieren nog niet eerder gekomen. Hoe zou hij die avond hebben ervaren? Een indirect antwoord op die vraag vinden we in een toneelstuk van zijn hand dat een jaar later werd gepubliceerd en waaraan ik de volgende scène ontleen.

Studenten en sommige anderen applaudisseren en roepen: "Bravo!" De rest fluit, gilt of schreeuwt: "Smoelhouwen!" “'t Is een schande!" Een paar heethoofden vliegen naar den tribune, anderen naar het spreekgestoelte, bedreigen den dokter en schreeuwen: "Ben jij een dokter?" "Hemeldragonder hadt je moeten worden" "Een beschermer van de brandkast ben je" "Een volksverdommer ben je!" "Je heult met de dominees en priesters!" "Je bent bang voor je bróódje!" 
De studenten raken slaags met de buren. Politieagenten beveiligen den dokter. De inspecteur [van politie] vliegt op den tribune en roept: "Ik gelast $\mathrm{u}$ allen oogenblikkelijk de zaal te verlaten en anders zullen we gebruik maken van de wapenstok.

Geroep: Foezel! Smeris! Politieagenten drijven het publiek de zaal uit. Iemand heft den socialistenmarsch aan, de meesten beginnen mee te zingen, daardoor komt er meer gang in de massa, zoodat de zaal spoedig ontruimd is. Buiten hoort men het lied langzaam wegsterven. ${ }^{63}$

Als de rust uiteindelijk is weergekeerd, pakt de hoofdpersoon van het drama zijn boeken en papieren van de katheder, stopt ze in zijn tas, trekt zijn jas aan en verlaat hoofdschuddend maar uiterlijk onaangedaan, ja kalmpjes het toneel. - Vanuit het oog van de orkaan lijkt het alsof de ganse wereld dol is geworden en in een krankzinnige rondedans tierend om hem heen wervelt, maar de aanstichter van heel die chaos lijkt zich van van al die drukte nauwelijks bewust.

\section{Hanengevecht}

Al dat gepolemiseer en geagiteer leverde Van Dieren op den duur bekendheid en uiteindelijk zelfs maatschappelijk aanzien op - alsof zijn strijdbaarheid op zich al een verdienste was. Dat blijkt bijvoorbeeld uit de groots gevierde jubilea rond zijn vijfentwintigjarig en zijn veertigjarig artsjubileum. Bij die laatste gelegenheid, op 24 december I924, kreeg Van Dieren de koninklijke onderscheiding waarnaar Diepenbrock eerder had gevist. Niet een unieke maar wel een memorabele gebeurtenis.

De feestelijkheden vonden plaats in het statige hotel Bellevue, waar de jubilaris en zijn familie op de tonen van Valerius 'danklied' werden ontvangen. Het organiserende comité moet het zeventiende-eeuwse geuzenlied wel bijzonder toepasselijk hebben gevonden, omdat het de bloedige strijd van het dappere, kleine Holland tegen het machtige Spanje bezingt. Dees' fellen slag' / Met groot gewag / Men heugen mag, heet het in de tekst. Dat de jubilaris daarbij geen geus onder de Hollandse edelen maar een Jan Klaassen in de vaderlandse poppenkast was, kon die dag geen afbreuk doen aan het feest. ${ }^{64}$

S.H. Solkes, collega-huisarts, sprak die middag de jubilaris toe. Hij maakte gewag van dr. Van Dierens strijdvaardigheid. In woord en geschrift, aldus de spreker, viel deze de 'averechtse geestesrichting' in onze 'waanzinnige wereld' aan - toespelingen op twee van zijn bekendste boeken. Hij noemde hem een 'sieraad van de medische stand' (applaus), 
terwijl omgekeerd de dokter zelf wel de belichaming van welvaart leek, want, zo sprak hij 'als we u daar nu zoo zien staan, als 'n voorbeeld van gezondheid en levenslust en we bedenken wat $\mathrm{u}$ in die 40 jaren gewerkt en volbracht hebt, dan mogen we met 't volste recht zeggen "sana mens in corpere sano". ${ }^{65}$ Daarna werden telegrafische gelukwensen voorgelezen, onder meer van de burgemeester. Als klapstuk: een levensgroot geschilderd portret door Georg Rüter, vermaard schilder van voorname portretten, aangeboden door zijn dankbare patiënten.

E. VAn Dieren, Æ.T 63, 24 DEC. I 884-I924. Op de enige ons bekende afbeelding in kleur kijkt Van Dieren ons blozend aan van achter zijn schrijftafel, kroontjespen in de aanslag. Zijn ogen zijn van een onbestemde kleur, vaal groen misschien. De diagnose van Solkes blijkt correct: hij ziet er patent uit, gezond. Achter hem ontwaren we op een geborduurd vaandel de wapenspreuk van de schrijvende arts: 'De pen is machtiger dan het zwaard.' Op tafel ligt schuin voor de geportretteerde een oranjerood boek dat de verder weinig contrastrijke compositie een beetje uit haar evenwicht brengt. Aan de ander kant van de tafel ligt een stapeltje brochures en in het midden staat een halfvolle inktpot, het vel papier daarachter is nog leeg maar zal spoedig worden beschreven: zo wilde Van Dieren de eeuwigheid in gaan.

Vergelijk het portret met dat van zijn politieke opponent, de Amsterdamse wethouder Wibaut, door Jan Sluijters, geschilderd in 1933. Een oudere man, hand in de jaszak, aktetas onder de andere arm, treedt de toeschouwer statig en tegelijk onderzoekend tegemoet onder een Hollandse hemel waar de lucht grijs is en de wolken wit zijn; de wind blaast door de lange zilveren lokken van Wibaut. Hij heeft de stad de rug toegekeerd en loopt de toekomst tegemoet.

En Van Dieren? Van Dieren heeft zich in de Gouden Eeuw verschanst als het koekoeksjong onder de patriciërs. Buiten de kaders van het portret stromen de eeuwen in marsmanesk tempo door het laagland; daarbinnen, verstard, een gedaante die zich in de koplampen van de geschiedenis roerloos houdt. Maar het portret heeft de tand des tijds niet goed doorstaan; de vernis is aangetast en een winkelhaak heeft het voorhoofd opengescheurd en toont ons onbarmhartig de rafels van het platte linnen waarin de illusie van leven oplost. ${ }^{66}$

Van het feest in Bellevue, waar het jubileum werd gevierd, is een foto genomen. Van Dieren zit midden op het podium zichtbaar te glunderen, zijn vrouw gaat verscholen achter een door een van de kinderen gemaakte versiering die twee kemphanen moet voorstellen. In het oog van de ene kemphaan is een fotootje van Christiaan Eijkman gemonteerd, zijn levenslange rivaal die we nog vaker tegen zullen komen. In 
het oog van de andere haan een fotootje van de jubilaris zelf. Het onderschrift luidt, met een verwijzing naar Eijkmans kippenproeven die door Van Dieren werden bestreden: 'Een hanengevecht om een kippenproef.'

Haan - kip - ei, een prioriteitsstrijd op leven en dood. Moge de vijanden te gronde gericht worden! ${ }^{67}$

Verder op de foto bespeuren we links en rechts van Van Dieren waarschijnlijk zijn kinderen en hun aanhang. Een spreker staat links op het podium en leest voor van een papier - het zal vermoedelijk Solkes zijn. Het portret van Rüter staat op de achtergrond en toont ons de jubilaris in al zijn glorie. De voorgrond toont nog juist voldoende hoofden om de indruk te wekken dat de zaal afgeladen moet zijn geweest. 'Zijn veertigjarig artsjubileum was grootsch', meldt een krant. ${ }^{68}$

In diezelfde periode moet ook zijn optreden voor het Tweede Christelijke Congres voor Intellectuelen worden gesitueerd, dat in oktober I92I in Amsterdam plaatsvond. Van Dieren bevond zich als spreker in het gezelschap van echte schriftgeleerden zoals professor G. Ch. Aalders, die 'het gezag van de Schrift en de historische kritiek' behandelde, de theoloog J.G. Geelkerken, die over 'de betekenis van de kunst voor Christenen van deze tijd' sprak, en de predikant-filosoof A.H. de Hartog, die het had over de 'toetsing der bezwaren tegen de persoonlijke onsterfelijkheid'. Van Dieren sprak over 'idealisme contra materialisme' en viel daarmee qua onderwerpkeuze althans wel nauwelijks uit de toon, hoewel zijn referaat duidelijk meer politiek getint zal zijn geweest dan dat van zijn collega's. Een verslag van zijn optreden verscheen de volgende dag in de NRC, waarin nu eens niet met ironie of dedain maar met gepaste eerbied over zijn opvattingen werd geschreven, bijna alsof de spreker een echte geleerde was. ${ }^{69}$

Dit waren onmiskenbaar glorieuze momenten voor Van Dieren. Een overwinning of in ieder geval een revanche van de outsider op het burgerdom. Maar er was een schaduwzijde. Het maatschappelijk aanzien lijkt te zijn betaald met persoonlijk ongeluk. Tussen I 895 en I909 werden acht kinderen geboren waarvan er slechts vier de volwassen leeftijd bereikten. Kort na elkaar stierven aan het begin van de nieuwe eeuw Jan, Cornelis en Catharina. Geen van hen was ouder dan vijf jaar geworden. Maar het was de dood van Derk-Johan, de zoon die de naam van vaders vader droeg, en die in augustus I9I 6 op zeventienjarige leeftijd aan een ongeneeslijke ziekte stierf, die hem het meest aangreep. Het verhaal van zijn tragische dood duikt op in een voetnoot in een van Van Dierens boeken: 'Twee dagen vóór zijn dood nam hij van ons allen afscheid; tegen mij zeide hij: "Vader ik had wel graag willen 
blijven leven en dat spreekt ook wel vanzelf voor een jongen op mijn leeftijd; ik voel ook nog zooveel energie in me en die had ik zo graag nuttig willen aanwenden, maar als God het beter vindt dat ik wegga, dan vind ik het ook goed; wat Hij doet, dat is welgedaan." "70

Tussen Evart, de oudste zoon, en Jacobus Wouterus, de eerstvolgende nog levende, was een gat geslagen van zeven jaar. Samen met Gerhard en Gustaaf maakten de jongens nu deel uit van een gezin van nog slechts vier kinderen. Hoe bitter om acht kinderen ter wereld te brengen en toch een gezin te hebben van niet meer dan vier, en uiteindelijk zelfs maar drie (Jacobus Wouterus stierf in I935). Eén plus één plus één plus één plus één plus één plus één plus één blijft altijd alleen maar één: een optelsom van enkelvoudige levens in een tijdloos universum waar geboorte en dood als onverklaarbare grootheden noch als baten, noch als lasten op de balans kunnen worden weggeschreven.

\section{De tranen}

Het lijkt een weinig gelukkig en misschien ook wel tragisch maar in elk geval weerspannig leven dat in het verschiet ligt. Maar opzienbarend is het met dat al nog niet. Naam maakte Van Dieren vooral als schotschriftschrijver inzake de beriberikwestie, een medisch vraagstuk dat aan het begin van zijn carrière als arts de onderzoekers bezighield, maar pas aan het eind van zijn leven werd opgelost, en waarmee ook Van Dieren zich intensief zou bemoeien.

Zijn allereerste strijdschriften dateren uit de jaren tachtig, toen hij nog als officier van gezondheid in het leger diende, en gaan allemaal over het 'grote misverstand' onder de geleerden in zake de beriberikwestie. De daaropvolgende vijftig jaar zou hij er steeds weer op terugkomen. Aanvankelijk bestreed Van Dieren vooral de gangbare opvattingen, spoedig echter zou hij ook een eigen hypothese gaan verkondigen die met die van de officiële onderzoekers moest rivaliseren. In de loop van de jaren verdween de inhoud meer en meer naar de achtergrond en ten slotte ging het er enkel nog om dát hij zich in het debat wist te mengen. Maar dat lukte hem dan ook steeds beter.

Zijn kritiek werd van meet af aan weggehoond - achteraf misschien niet helemaal terecht, maar wel begrijpelijk, omdat zijn opvattingen noch op eigen onderzoek noch op eigen ervaring met de beriberi, maar louter op grond van vergelijkende studie berustten. Dat werd hem dan ook steeds in niet mis te verstane bewoordingen duidelijk gemaakt. Maar karakteristiek genoeg vatte Van Dieren die afkeur helemaal niet op als een ontmoediging, maar juist als een stimulans 
om zijn veldtocht voort te zetten. En hoe vaker hij ten strijde trok, des te vaker werd hij afgewezen, hetgeen hij steeds vaker begreep als een bewijs van zijn gelijk. Op die manier werd de strijd tegen de 'beriberimisvatting' van lieverlee zijn levensvervulling. Zijn pijlen richtte hij in de jaren daarop steeds vaker op Christiaan Eijkman, die in Nederland als beriberionderzoeker zoetjesaan bekendheid begon te krijgen, maar zich nooit iets aan de kritiek van zijn Amsterdamse collega gelegen liet liggen. Van Dieren nam hem dat kwalijk, zeer kwalijk, en putte zich uit in beledigende schimpscheuten aan diens adres. Eenmaal verweet hij Eijkman zelfs dat 'een zee van ellende sedert vele jaren gedempt had kunnen zijn' als hij maar naar hem had willen luisteren. Slechts drie woorden had Eijkman hoeven spreken: 'Ik heb gedwaald. ${ }^{71}$ Een gotspe.

Die groteske aantijging leidde in 1897 tot een heuse affaire waarbij Eijkman zich gedwongen zag in een reeks artikelen af te rekenen met zijn tegenstander, de 'kannieverstaan' die hij verweet geen helder begrip te hebben van de betekenis van hypothesen bij wetenschappelijk onderzoek en wiens rijstvergifthypothese volgens hem 'eigenlijk alleen belangwekkend is uit een psychologisch oogpunt, als een merkwaardig staaltje namelijk van autosuggestie'. Vanzelfsprekend, zo schreef Eijkman, had hij zich door het geschrijf van Van Dieren 'niet in het minst laten influenceren; ik vond daarin te weinig onvervalschte en oorspronkelijke wetenschap'. ${ }^{72}$

Talloze malen heeft Van Dieren die zinnen herhaald en ze in het gezicht van Eijkman teruggesmeten om iedere keer tot dezelfde conclusie te komen: 'Mijne critiek bevestigd door het fiasco der desinfectie.' Maar het verdere zwijgen van Eijkman kon hij daarmee niet doorbreken.

\section{Een proefschrift dat geen proefschrift mocht zijn}

Van Dieren zou zijn polemiek tegen Eijkman ook na die 'affaire' voortzetten. In 1907 verscheen van zijn hand een kolossaal boek, Meelvergiftigingen: beri-beri, pellagra, kriebelziekte, erwtenziekte, enz., geheten, waarin hij het andermaal op zijn 'tegenstribbelende medestander' had voorzien. Het boek lijkt uiterlijk op een echt academisch werkstuk, compleet met stellingen, aanhangsels, talloze voetnoten en verklarende tabellen en draagt toepasselijk genoeg als ondertitel 'Eene proeve van vergelijkende ziektekunde'. Er zijn lange hoofdstuktitels die meerdere regels beslaan, en de omvang van het boek zelf is ook al enorm: ruim 460 pagina's. Het werd opgedragen aan zijn vrouw en voorafgegaan door een motto: 'Gedachte, eenmaal opgewekt, slaapt 
niet weder in, groeit in mensch na mensch, in geslacht na geslacht, totdat haar volle wasdom bereikt is. ${ }^{73}$ Het zou een proefschriftwaardig motto kunnen zijn.

Maar behalve in vorm lijkt het boek in niets op een proefschrift. Het is één enorme fantasmagorie aan zelfvervullende wensdromen en 'bewijzen' dat hij het altijd bij het rechte eind heeft gehad en ieder ander niet. Als een slagschip op volle kracht stoomt de auteur in een keur aan lettertypen door het door hem verzamelde materiaal. Een oceaan aan statistieken, publicaties, krantenknipsels, observaties, ziektegeschiedenissen en zijdelingse mededelingen van dezen en genen wordt omgewoeld om te komen tot deze ene grondstelling: beriberi wordt veroorzaakt door ondeugdelijke rijst.

Niet dat Van Dieren geen oog had voor tegenwerpingen van anderen. Integendeel. Het grootste deel van zijn boek is gereserveerd voor ontkrachtingen van bedenkingen tegen zijn werk. Van de zeer fundamentele vraag van Eijkman die uitvoerig documenteert hoe beriberi ook daar voorkomt waar voldoende nevenvoeding wordt genuttigd en zich afvraagt 'wat er na dat alles overblijft van v. Dieren's bewering' [dat de ziekte enkel met voeding te maken heeft] en enthousiast begroet wordt met de uitroep 'Alles, alles, alles! - luidt mijn antwoord', tot het miniemste detail over de bodemgesteldheid, het 'opbewaren van rijst' in gevangenissen of de toestand aan boord van marinevaartuigen; alles, maar dan ook letterlijk alles wordt bestreden aan de hand van 'leerrijke voorbeelden'. ${ }^{74}$

Van een rustige, objectieve beschouwing is geen sprake, schreef een recensent; in plaats daarvan treffen we het geringschatten van de motieven van een ander en het breed uitmeten van zijn eigen motieven aan. ${ }^{75}$ 'Een meesterstuk', zo meende de schrijver zelf, dat in al haar eenvoud eens als een waarheid zal moeten worden erkend: 'zelf vind haar daar nu reeds eenvoudig genoeg voor. ${ }^{976}$

Twaalf jaar later kwam de aap uit de mouw. In De waanzinnige waereld vertelde hij hoe hij werd gepest met het feit dat hij maar een gewone huis-tuin-en-keukendokter was, 'zonder c'; geen doctor dus dat wil zeggen: niet gepromoveerd. De regels stonden het niet toe dat een hbs'er zou promoveren. Toen die bepaling eenmaal was geschrapt (de Wet Limburg uit I9I7 voorzag in de mogelijkheid dat ook hbs'ers voortaan zouden mogen promoveren) hoefde het niet meer voor hem en daarbij: hij had toch nu al genoeg 'proefschriften' afgeleverd. ${ }^{77}$

Toch zou hij zich eeuwig achtergesteld blijven voelen. In 1922 citeerde Van Dieren een opmerking van een collega die beweerde dat het hoogtepunt van de carrière van de 'plantlandicus' en de 'stedeling- 
arts' in het behalen van het artsexamen zou liggen. De eenvoudige huisarts ontwikkelt zich immers niet verder, daar al zijn tijd in beslag wordt genomen door geldelijke zorgen en zorgen voor het gezin. Dat is niet erg, aldus de schrijver, maar de wetenschap heeft niets meer aan hem. Dit geldt niet de onderzoeker, de goed bezoldigde rijksambtenaar, waarin de wetenschap haar vertrouwen wel mag steken. Hém ontbreekt het immers niet aan het heilige vuur. Dit nu, zo voelde Van Dieren, was gewoonweg tegen hem persoonlijk gericht, schrijver van vele dikke boeken die het had moeten opnemen tegen de goed bezoldigde Rijksambtenarij. ${ }^{78}$ Een schandelijk onrecht, temeer daar die goedbetaalde onderzoekers het nu al zo lang bij het verkeerde eind hadden - en hij.... bij het rechte.

\title{
Het einde van een vendetta
}

Met Meelvergiftigingen had Van Dieren dan misschien voorgoed afgerekend met het academische, maar niet met de academici, vooral niet met Eijkman, de haan die hij nooit wist te verschalken. Veel onaardigheden heeft hij over hem geschreven, zoals we nog zullen zien, maar altijd in de veronderstelling dat de ander eens het licht zou zien. Nog in I9I 3 trachtte hij Eijkman tevergeefs in een brief voor zijn standpunt te winnen. Schoon schip wilde hij maken, zijn vroegere vijand recht in de ogen kijken en voor eens en voor al een streep zetten onder alles wat er was gebeurd. Maar dan moest Eijkman wel op zestien nader genoemde punten ingaan, alsmede op een voetnoot in een van zijn boeken. ${ }^{79}$ Dat Eijkman daartoe bereid zou zijn, daaraan twijfelde hij geen moment.

Eijkman bleef beleefd.

\author{
Utrecht, 20 mei I9I3 \\ WelEdelZeerGeleerde Heer, \\ in antwoord op uw schrijven van I8 dezer deel ik u mede, dat ik het \\ onvruchtbaar acht op de inhoud daarvan nader in te gaan. Uw boek, \\ waarin ik de door u aangewezen noot op blz. I I 8-i I9 gelezen heb, zend \\ ik tegelijk hiermede in dank terug. \\ Met verschuldigde achting. \\ Uw dw. C. Eijkman. ${ }^{80}$
}

Aan het eind van de jaren twintig vond de definitieve ontsluiering van het beriberiraadsel plaats toen Jansen en Donath erin slaagden vitamine B synthetisch af te scheiden. Het pleit was daarmee definitief beslecht in het nadeel van Van Dieren. 
Niet overtuigd van de leer der vitaminen zou Van Dieren nog tot in de jaren dertig over de beriberi blijven schrijven en polemiseren. Pogingen om anderen bij zijn strijd te betrekken liepen nu echter steeds spaak. Zo kreeg hij van de hoogleraar interne geneeskunde K.F. Wenckebach, die hij per brief had uitgedaagd een veertig jaar eerder ingenomen standpunt over de beriberi te herzien, als antwoord te horen: 'Als ge mij een klein boekje zendt, waarin gij haarfijn de aethiologie der beri-beri uiteenzet, niet volgens uw fantasie alleen maar met zuivere critiek en steekhoudende bewijzen, ja dan kunnen wij er over spreken en zullen wij $\mathrm{U}$ dankbaar zijn allemaal. ${ }^{, 11}$ De medicus S. Postmus heeft in die tijd met Van Dieren gesproken en gemerkt dat hij zich nog altijd niet gewonnen wilde geven. 'Van Dieren was niet bereid, of er geestelijk niet toe in staat, de strijdbijl te begraven. [...] Hij bleef doorhameren op het feit dat nooit direct bewezen was dat de zilvervlies-extracten van Jansen en Donath direct actief waren bij beri-beri. ${ }^{92}$ Van Dieren had te veel in de beriberistrijd geïnvesteerd om er zich nog uit terug te kunnen trekken.

\section{Nieuwe uitdagingen}

Maar ook al zou de beriberi zich in zijn blijvende belangstelling mogen verheugen, toch was het zo dat zijn aandacht al voor de eeuwwisseling steeds vaker afdwaalde in de richting van politieke, sociaal-hygiënische en maatschappelijk-culturele vraagstukken, waarbij hij zich allengs steeds meer richtte tegen de modernismen van zijn tijd en haar vertegenwoordigers.

De drie grootste kwaden daaronder waren voor hem achtereenvolgens: het darwinisme, het socialisme en de psychoanalyse waarmee hij zich ook in die volgorde heeft beziggehouden.

Tegen het darwinisme bracht hij in redevoeringen die hij voor verschillende gezelschappen afstak geregeld het nodige in. Hij opende zijn betoog met de 'ontegenzeggelijke waarheid' dat geen wetenschapper, hoe begaafd of geleerd ook, zijn eigen vakgebied geheel kan overzien. Daaruit vloeit voort dat dat dus ook voor Darwin geldt. Vervolgens moet worden opgemerkt dat uit diens autobiografie zonneklaar blijkt dat zijn karakter 'morele schade' heeft opgelopen (als gevolg van zijn twijfel aan God). En tenslotte blijkt de mutatieleer helemaal niet Darwins uitvinding (maar al veel ouder want reeds bekend bij Linnaeus), en bovendien al lang en breed achterhaald! Maar zelfs al zou het allemaal wel waar zijn, en al zouden de soorten door middel van mutatie en selectie daadwerkelijk evolueren, dan nog moet worden toegegeven dat dat alleen kan als daaraan een Groter Plan ten grondslag ligt, een 
doel, of, om Abraham Kuyper te citeren, een Zweck (hetzelfde argument gaat tegenwoordig onder de noemer 'intelligent design' door het leven). ${ }^{83}$

Van Dieren koos de hoogleraren Hugo de Vries (I848-I935) en Ambrosius Hubrecht (I853-I9I 5) uit als zijn antagonisten, omdat zij beiden hadden deelgenomen aan de Darwin-huldiging op 24 november I909. Van Dieren was daarvan getuige geweest en vond het een grof schandaal dat er aan zo'n 'doelverwerper' als Darwin zo veel aandacht werd besteed en nog wel door wetenschappers ook.

Van de twee onderzoekers was de eerste het beroemdst. In binnenen buitenland bekend om zijn erfelijkheidsonderzoek gold De Vries als een belangrijke verdediger van Darwins opvattingen (die ook door Darwin zelf op verschillende plekken in zijn werk is geciteerd), en nu nog is hij bekend als een van de herontdekkers van de wetten van Mendel. Hubrecht zou vooral de maatschappelijke acceptatie van de evolutieleer bespoedigen en correspondeerde korte tijd met Darwin.

Voor Van Dieren was het een uitgemaakte zaak dat deze twee wetenschappers een achterhoedegevecht leverden. Toch konden ze niet vaak genoeg worden bestreden, omdat in het verlengde van hun goddeloos materialisme immers het verderfelijke marxisme ligt. ${ }^{84}$ En zo opende zijn brochure tegen het darwinisme de weg naar het antisocialisme, waarover hij ongeveer tezelfdertijd begon te spreken.

De lezingen van Van Dieren moeten worden geplaatst tegen een achtergrond van in snel tempo oprukkende secularisatie, waaraan, ironisch genoeg, de medische wetenschappen misschien wel de belangrijkste bijdrage leverden, daar de kennis waarmee ziekte, epidemie en verval op afstand konden worden gehouden, ook de hand van God, die naar willekeur over leven en dood leek te beschikken, uit het bestaan wiste. Een stroom van in bovenzaaltjes en voor allerhande verenigingen gehouden voordrachten, veelal door beginselvaste dominees of paters, tegen het darwinisme was het gevolg. Ik noem twee van zulke optredens uit die tijd ter illustratie, vooral omdat ze een bijna identieke argumentatie laten zien. Op I 6 december I 909 sprak de jezuïtische pater $\mathrm{H}$. Bolsius over 'het Darwinisme in de huidige tijd'. Darwin was niet geheel wetenschappelijk, beweerde de spreker, fantasie was hem niet vreemd, en daarbij was hij 'geen kritische geest'. Tegen professor Hubrecht bracht hij in dat zijn denken een en al tegenspraak was. De 'rake lezing' werd beloond met 'langdurig applaus', aldus een verslag in een krant. ${ }^{85}$ Een paar maanden later trad kapelaan Van Golkom aan om de vraag te onderzoeken of het darwinisme invloed op wetenschappelijk en godsdienstig gebied 
uitoefende. De invloed op wijsgerig gebied was ronduit beroerd, gaf de spreker toe. Darwin was verantwoordelijk voor een hoop dwaalbegrippen en verwarring, maar van een eigen leer kon gelukkig niet worden gesproken. Helaas was de invloed op godsdienstig gebied nog erger, want velen begonnen aan het bestaan van God te twijfelen, nu gebleken zou zijn dat de mens van de aap afstamt. Onzin natuurlijk. Daarom sloot de spreker zijn voordracht af met een speciaal aan professor De Vries gericht woordje: 'In den beginne schiep God de aarde.' Zo staat het immers in de Bijbel. ${ }^{86}$

Van Dieren past naadloos in die traditie, al geldt hier net als bij zijn beriberibemoeienis dat hij een liefhebberende amateur op het betreffende vakgebied was, geen echte predikant. De verschillende voordrachten die hij her en der hield bundelde hij in een boekje van bijna Ioo pagina's dat hij Darwinisme en ongeloof. Een bijdrage tot de kennis der schijnwetenschap noemde en dat in I9I 3 verscheen. Een al te bescheiden titel voor een referaat dat veel weg had van een donderpreek. In de $N R C$, dat van zo veel stichtelijke praatjes niet was gediend, werd het honend weggezet onder aanhaling van een citaat uit de inleiding: 'gelooft niets van wat ik u zal mededelen, controleert alles en houdt de waarheid vast.' De redactie vond dat 'een voortreffelijke raad, en tevens de verstandigste uitlating die in het boek te vinden is' ${ }^{87}$ Maar zelfs van de redactie van het katholieke Lectuur-Repertorium kreeg het boekje de code 'IV P' mee, wat zo veel betekende als: lectuur voorbehouden aan volwassenen, hoewel verder wel van protestantse strekking. Alle andere in het repertorium opgenomen publicaties van Van Dieren kregen het predicaat 'III' mee: wegens bepaalde passages of grondgedachten niet voor alle volwassenen geschikt; de op twee na strengste kwalificatie (na 'verboden lectuur' en 'streng voorbehouden lectuur'). ${ }^{88}$ Stichtelijke lectuur vormt zijn oeuvre dus niet direct, al wordt er nog zo gescholden op Darwin.

De volgende grote strijd werd geleverd tegen het socialisme, met wier aanhangers hij afrekende in vele artikelen en twee boeken. Het eerste was getiteld Het socialistische gevaar (1909), dat als een voordracht voor de Amsterdamse schoolcommissie begon, maar bij de uitwerking ervan in artikelvorm van lieverlee tot een heel boek uitgroeide, waarover in de rechtse pers verbazend lovend werd geschreven: een 'goed opgezet boek', oordeelde een recensent, omdat er op 'duidelijke wijze wordt uiteengezet hoe het streven der sociaal-democraten vooral in de school tot eene besmettelijke zielsziekte geworden is' ${ }^{89}$ Rondom dat boek schreef Van Dieren ook nog polemische stukken die hij in De Telegraaf geplaatst wist te krijgen, waarmee hij de nodige aandacht op 
zich wist te vestigen. In Het Volk werden het boek en de stukken in De Telegraaf gekraakt, zoals was te verwachten, maar ook dat was aandacht. Een decennium later herhaalde Van Dieren het trucje met het al eerdergenoemde De waanzinnige waereld (I919), waarin hij bekende socialisten als Troelstra, Heijermans, Polak, Henriëtte Roland Holst, Gorter en anderen op de hak nam. En opnieuw wist hij daarmee flink wat consternatie teweeg te brengen. Elders in dit boek ga ik uitvoeriger in op deze discussie, zodat ik me hier tot de belangrijkste wapenfeiten kan beperken.

Tegen de psychoanalyse kwam Van Dieren aan het eind van de jaren twintig in het geweer, ook weer in twee geschriften: Futuristische behandeling van zielszieken (1927), en Prof. Freud en het perverse gevaar (I932). Met zijn schotschriften tegen Freud slaagde hij erin een debat los te weken met Van Ophuijsen, Keuchenius, Van der Hoeven, Giltay, Westerman Holstijn, Querido en anderen, dat twee zomers lang de kolommen van Het Vaderland vulde. Ook hier komen we later uitvoeriger op terug.

De keuze om in die kranten over juist deze onderwerpen te publiceren was strategisch ingegeven: binnen het sterk verzuilde bestel representeerde De Telegraaf ook toen het conservatieve gedachtegoed en vormde het dus een uitstekend podium om tegen de socialisten te ageren, terwijl Het Vaderland het meer liberale en intellectuele tegenwicht daartegen vertegenwoordigde en goed was om er een 'discussie op niveau' in te voeren, zoals over de psychoanalyse. Het socialistische dagblad Het Volk was het lijfblad van de vijand en vormde een even noodzakelijke als welkome bron van ergernis waaruit altijd naar believen kon worden geput. Hun kritische besprekingen van zijn werk verschafte hem zowel excuus als gelegenheid om van zich te doen horen, en een enkele keer slaagde hij erin zelfs in hun dagblad door te dringen, en mocht hij op een kritisch stuk reageren met een oeverloze tegenkritiek waarop de krant dan wijselijk geen commentaar gaf.

Maar al publiceerden al deze kranten ingezonden stukken van Van Dieren, de schrijver voelde zich daardoor tot niets verplicht en dreef even vrolijk campagne tegen al die bladen als hij er in probeerde te schrijven, soms zelfs tegelijkertijd. De krant vormde dus zowel object van als instrument in de polemiek. Dat gold voor de landelijke kranten zo goed als de lokale bladen en weekbladen en zelfs de vaktijdschriften, zoals het Nederlandsch Tijdschrift voor Geneeskunde, waarmee hij zijn hele leven lang op voet van oorlog verkeerde. De enige uitzondering daarop was De Standaard, het huisorgaan van de Anti-Revolutionaire Partij van Abraham Kuyper. In wat De Standaard schreef vond 
Van Dieren nimmer aanleiding tot debat of dispuut. En al was hij het lang niet altijd eens met hun beleid, en al werden enkele van zijn boeken erin doorgaans betrekkelijk welwillend besproken, toch achtte hij de lezers van dit blad niet het juiste publiek om zich tot te richten. Waarom niet? Misschien vond hij het niet nodig om voor eigen parochie te preken, daar de lezers van De Standaard hem na stonden en hij in hen bondgenoten zag, maar het omgekeerde kan ook: al te grote nabijheid sloot hen juist uit.

De polemieken tegen Freud, Darwin, Marx en hun Hollandse aanhangers leidden herhaaldelijk tot kleine en grotere 'affaires', en leverde vele ingezonden stukken op en nog veel meer boze brieven. Van Dieren verzamelde al dat materiaal en gaf het allemaal een plek in volgende publicaties hetgeen hem definitief de naam van querulant opleverde, of ook wel als variant daarop, 'brochuromaan'. ${ }^{90}$

Het tempo waarin zijn brochures en boeken verschenen, en de snelheid waarmee ze werden geschreven, droegen bij aan dat imago. Tijd voor bezinning was er nooit, en dat werd hem door lezers en recensen62 ten dan ook vaak verweten. Toen de schrijver Johan Been, met wie Van Dieren in contact trachtte te komen, hem kalmte en bezadigdheid toewenste, kreeg hij een brief terug waarboven in een vierkant kadertje stond: 'Deze brief werd haastig geschreven, en telkens werd ik gestoord. Als U goed oplet, zult U bemerken dat mijn boeken op dezelfde wijze geschreven zijn. Mijn beroep brengt mede dat ik haast nooit rustig werken kan. Gelukkig werkt de motor uitstekend, hij staat dadelijk stil en slaat direct weer aan. ${ }^{91}$ Het verhaal gaat dat in zijn dokterskoetsje altijd een stapel drukwerk lag van onbehoorlijke lengte en breedte, zodat hij zelfs als hij onderweg was naar een patiënt nog even een paar correcties kon doorvoeren of een stukje kon schrijven. ${ }^{92}$

In de loop der jaren zou de haast alleen maar toenemen en de aanvallen steeds buitensporiger vormen aannemen. Er vond in die tijd een door de student Arie Querido bijgewoonde openbare discussie plaats tussen Van Dieren en 'de bekende magistraat-met-het-slappe-hoedje' F.M. Wibaut (I859-I936), die door de eerste tot blauw aangelopen sprakeloze woede zou zijn gebracht. ${ }^{93}$ Het is zeer waarschijnlijk hetzelfde debat als dat waarvan een registratie bewaard is gebleven in de krant, en waarover ook een kort verslagje van Van Dieren bekend is.

Op 20 januari 1920 sprak Wibaut voor een Amsterdamse studentenvereniging over 'socialisatie van bedrijven.' Een bedrijf dat socialiseert, aldus Wibaut, gaat over tot het socialisme; het geeft de arbeider deel in de leiding en het beheer van het bedrijf. Het gesocialiseerde bedrijf buit niet langer uit, maar vergroot de productiviteit en dus ook 
de economische kracht. ${ }^{94}$ Een win-winsituatie zouden we dat tegenwoordig noemen.

Van Dieren was aanwezig in de zaal en maakte gebruik van de gelegenheid tot debat. Hij begon met het voorlezen van een groot aantal citaten van socialistische voormannen om te eindigen met de suggestie dat Wibaut voor de houthandel een uitzondering wilde maken, daar hij er zelf belang bij had. Naar eigen zeggen had Wibaut op zijn vragen 'niets terug' en was hij dus de morele winnaar. ${ }^{95}$ In het debat zoals dat door Het Volk werd opgetekend, zegevierde Wibaut echter en trok Van Dieren aan het kortste eind.

Wibaut: Ik heb tot den heer van Dieren weinig te zeggen, ik ga op zijn citaten, waarbij er zijn van zeer oude datum, niet in.

Dr. v. DieRen: Dat is makkelijk.

Wibaut: Dat is het, maar deze methode is mij te minderwaardig (luid, langdurig applaus).

DR. v. Dieren: Ik ga weg.

Wibaut: Gij zult blijven. Gij zult mijn antwoord op uwe insinuaties horen.

DR. v. Dieren: Ik ga weg!

Verschillende aanwezigen: Ploert, lafaard! Eererover!

Dr. v. Dieren: Ben ik laf? Ik durf tegen jullie allemaal wel op. Ik blijf!

Wibaut: Gij hebt te verstaan gegeven dat ik de socialisatie van den houthandel niet wil, omdat ik bij dien handel belang zou hebben.

Dr. v. Dieren: Dat heb ik niet gezegd.

Wibaut: Neen, gij hebt het te verstaan gegeven. En dat is nog veel erger dan het duidelijk te zeggen. (Daverend applaus). ${ }^{96}$

De verschillende versies van dezelfde bijeenkomst van respectievelijk Querido (woede), Van Dieren (afgetroefd) en de krant (applaus) komen interessant genoeg in niets met elkaar overeen, behalve misschien op één punt: de debatten met Van Dieren waren tot mislukken gedoemd.

Een analoge confrontatie uit I9I9 tussen Van Dieren en David Wijnkoop (I876-I94I), de welbespraakte en nogal radicale voormalige propagandist van de SDAP die een jaar eerder de communistische partij had opgericht, geeft een vrijwel identiek beeld. Wijnkoop sprak op een bijeenkomst voor studenten van de landbouwhogeschool Wageningen over socialisatie. Gewapend met een knipselmapje met uitspraken van Wijnkoop was Van Dieren naar Wageningen afgereisd om de voordracht bij te wonen. Toen de gelegenheid tot debat was aangebroken stond hij op. 
De Heer Wijnkoop heeft zich eens in een Vergadering van Arbeiders uitgelaten over den landbouw; die Voordracht is in druk verschenen; er blijkt uit, dat de Heer Wijnkoop slecht te spreken is over het Landbouwonderwijs en ook dat er zijns inziens genoeg hapert aan de mest. Wàt er aan beide hapert, heeft hij echter niet meegedeeld! En nu had ik zoo vurig gehoopt, dat hij in dit landbouwkundig milieu - er bevinden zich zelfs Professoren onder zijn gehoor - die beide onderwerpen uitvoerig behandeld zou hebben; maar dat heeft hij verzuimd; en ik verwacht derhalve dat hij zoo aanstonds dit verzuim goed zal maken.

Helaas, Wijnkoop zag zich niet genoopt om aan die 'uitdaging' gehoor te geven. Tot hilariteit van de aanwezigen merkte hij daarentegen op dat Dokter van Dieren erom bekend staat de kunst van het uit hun verband rukken van citaten uitstekend te beheersen. ${ }^{97}$

Als gesprekspartner werd Van Dieren nauwelijks nog serieus genomen. Zijn boeken daarentegen waren een begrip geworden; lachwekkende, bizarre ontsporingen, zo over the top dat ze weer leuk werden. 64 Onwillekeurig vraagt men zich af of Van Dieren met dat Don Quichotteske imago niet een beetje heeft gekoketteerd, bijvoorbeeld in de keuze van titels voor zijn boeken, zoals het idiote De averechtse geestesrichting der zoogenaamde "nieuwlichters" op allerlei gebied; in het bijzonder die der Kollewijners en hun verderfelijke invloed op onderwijs, taal en volk uit I9I7, waarvan taalkundigen moesten 'rillen'.98

Het was voor de recensent ook niet altijd even duidelijk of de auteur niet een loopje met zijn lezers nam. Eén schreef ironisch dat hij (Van Dieren) wel een zeer zwak moment moest hebben gehad toen hij beweerde dat hij zélf tot dwalen in staat was, zo rotsvast waren immers zijn overtuigingen. Daaruit vloeide dan de vraag voort of Van Dieren wel de aangewezen persoon was om twijfelaars te beïnvloeden. ${ }^{99}$

Voor journalisten van Het Volk was het natuurlijk geen vraag wat er met die rotsvaste overtuigingen moest worden gedaan. Koos Vorrink, de latere voorzitter van de SDAP, noemde Van Dieren een man met een 'steenkolenziel' tegen wiens benedenvloerse beschuldigingen hij niet eens wenste te protesteren: 't zou teveel eer zijn. ${ }^{100}$ Desalniettemin verschenen er in Het Volk en De Notenkraker, het zondagse bijblad, met enige regelmaat satirische stukjes over Van Dieren. Zo drukte die krant bijvoorbeeld in I909 een spotprent af naar aanleiding van zijn eerste grote antisocialistenboek (Het socialistisch gevaar). De titel luidt: 'het amusante boek'. We zien een mannetje onderuitgezakt in een strandstoel, in zijn hand houdt hij een enorm dik boek, hij kijkt er een beetje mismoedig naar. Het onderschrift bij de prent: 'Er wordt zoo dikwijls 
geklaagd dat onze hedendaagsche lectuur zoo zwaar op de hand is. Maar zoo iets lachwekkends als dat boek van dr. Van Dieren heb ik toch in lang niet gelezen!' ${ }^{101}$

Toen Van Dieren dat zag wierp hij tegen dat de socialisten zichzelf natuurlijk weer tegenspraken: Het heertje zag er helemaal niet vrolijk uit, zei hij, 'Zijn gezicht stond zo bedrukt mogelijk; de teekenaar had hem zelfs met een diepe, pijnlijke plooi bedacht. ${ }^{102}$

Op wie van de twee leek Van Dieren? Op de vrolijke pestkop of op de zwaarmoedige geest? De man die ons op de her en der gepubliceerde foto's ankijkt toont een zeldzaam uniforme gelaatsuitdrukking. We zien een expressie die in de loop der jaren bijna niet verandert, maar hooguit wat weker wordt. Het is niet de spottende, ironische of in ieder geval uitdagende oogopslag die men zou vermoeden bij een twistziek iemand als hij, maar een blik die halverwege het poseren lijkt bevroren: zijn lichaamshouding en de onderste helft van zijn gezicht, zijn mond en kaak en de verzorgde, halfronde druipsnor lijken een fiere, misschien zelfs wel autoritaire pose aan te willen nemen, maar de ogen kijken steeds onzeker, ja, bijna bang in de wereld. Van Dieren lijkt op een man die voor zichzelf terugdeinst.

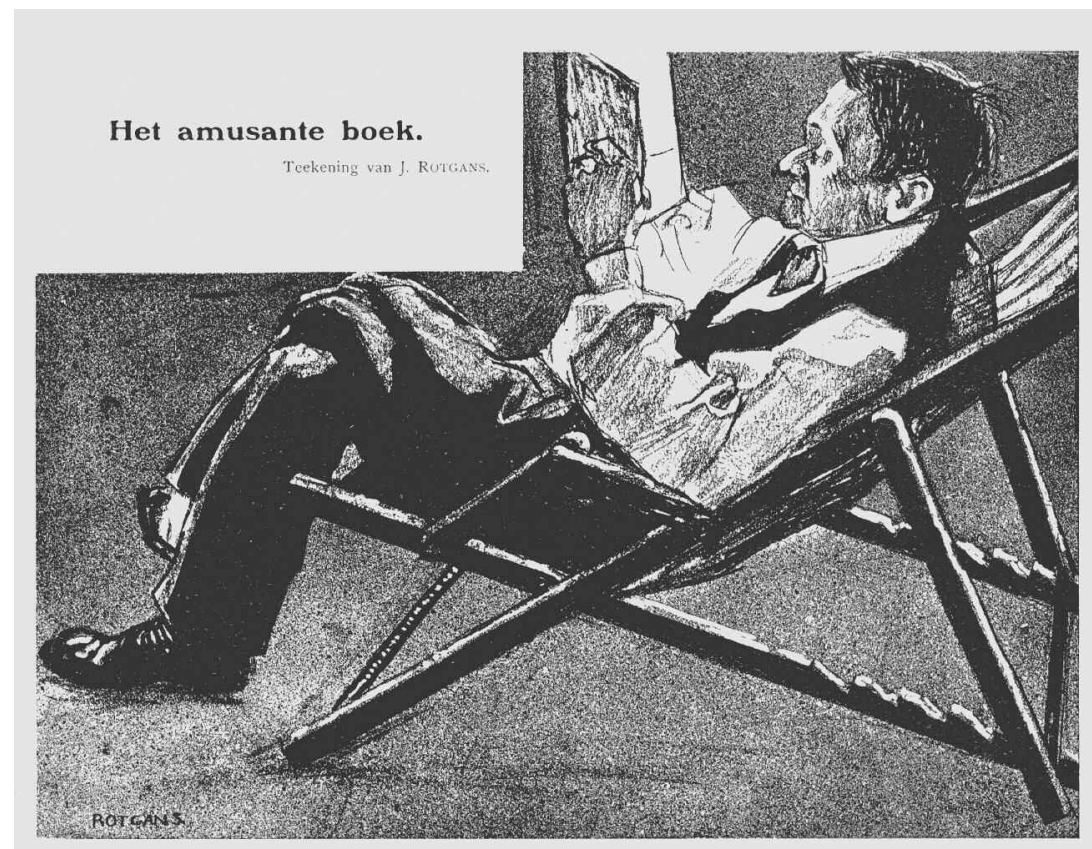

"Er wordt zoo dikwijls geklaagd, dat onze hedendaagsche lectuur zoo zwaar=op=de=hand is. Maar zoo lets lachwekkends als dat boek van dr. Van Dieren heb ik toch in lang niet gelezen !" 


\section{Het lachen}

Zelfspot lijkt niet een van Van Dierens sterkste kanten te zijn geweest. Omgekeerd echter kwam zijn gebrek aan humor vaak onbedoeld komisch over, en soms is het gewoonweg niet mogelijk om te zeggen wie een loopje neemt met wie.

In oktober I920 schreef Van Rijnberk, hoofdredacteur van het gerenommeerde medische vakblad Nederlands Tijdschrift voor Geneeskunde, een artikeltje over het publicatiebeleid van zijn tijdschrift. Aanleiding ertoe zou zijn geweest een klacht dat het $N T v G$ zulke strenge censuur toepaste dat men tot 'de vriendjes' moest behoren wilde men een stuk geplaatst krijgen. Van Rijnberk liet zien dat over het afgelopen jaar van de I8I oorspronkelijke stukken er slechts 6 waren geweigerd, en dat van de 3 Io ingezonden stukken er 16 niet waren geplaatst: een plaatsingspercentage van 97 respectievelijk 94 procent. ${ }^{103}$ Van censuur kan dus geen sprake zijn, concludeerde de hoofdredacteur terecht.

66 In het volgende nummer van het $N T \nu G$ stond een stuk van Van Dieren afgedrukt onder de titel 'Salon des refusés'. Goed, schreef Van Dieren, deze onthulling is 'niet vleiend voor alle "vriendjes", maar dit feit verergert wel de weigering die de "zes", waaronder $i k$ behoor, te beurt viel', waarmee hij half leek te zeggen dat hij degene was die zich tot Van Rijnberk had gewend met voornoemde klacht. Maar toch, vervolgde hij, zijn de 'door u meegedeelde eischen o zoo licht, veel te licht zelfs; en toch heb ik tot dusver zoo goed als nooit er aan kunnen voldoen!' Kortom, zelfs heel lichte criteria zijn nog unfair vanuit het standpunt van degene die wordt afgewezen.

Dat is een vreemde redenering, zeker voor een zelfverklaard tegenstander van de vrijheid van drukpers. ${ }^{104}$ Want hoewel het niet leuk is om te worden afgewezen, kan dat op zichzelf niet het argument vormen om het beleid van een tijdschrift te bekritiseren, omdat dan immers het enige juiste beleid kan zijn alles maar te accepteren. Toch was dat precies wat Van Dieren voorstelde. Stel van tijd tot tijd een deel van de beschikbare ruimte ter beschikking aan hen die zich - zoals hij - miskend voelen, schreef hij. 'Laat boven hun artikelen drukken: "wij hebben bezwaar tegen de opneming, het artikel voldoet niet aan de eischen, die wij menen te mogen stellen, maar wij willen voorkomen dat er gezegd zal worden dat wij artikelen van sommigen weren omdat zij niet tot onze vriendjes behooren".' Een rubriek dus waarin de door de redactie geweigerde artikelen worden afgedrukt onder de mededeling dat de betreffende artikelen zijn geweigerd? Dat kan toch wel 
moeilijk anders worden opgevat dan als zelfspot, met als achterliggende gedachte de lezer te confronteren met diens minachting jegens hem?

Voor de volledigheid zet ik naast het staatje van Van Rijnberk een staatje waaruit kan worden opgemaakt hoeveel stukken van of over Van Dieren wel zijn geplaatst. Een computersearch op de i-pagina van het NTvG levert 4I treffers op met de zoekterm Van Dieren voor de periode I888-I940. Daaronder 2 berichten over voordrachten van hem, 4 oorspronkelijke stukken van Van Dieren, I 4 ingezonden berichten van zijn hand en maar liefst $2 \mathrm{I}$ besprekingen van boeken van hem. (Ik laat buiten beschouwing het aantal stukken dat werd geschreven in reactie op of naar aanleiding van artikelen van hem.) Zelfs als we aannemen dat een even groot aantal artikelen van hem geweigerd zou zijn, dan nog is de indruk die hij zelf graag wilde vestigen van een volledig buitengesloten auteur eenvoudig onwaar. Sterker nog, de vijandige houding van de media tegenover zijn standpunten blijkt een door hem zelf geconstrueerde werkelijkheid te zijn. Hij was een auteur die volledig werd gemarginaliseerd. Dat hij zelf de belangrijkste bijdrage heeft geleverd aan die marginalisatie is daarbij ook waar.

\section{Het einde}

In oktober 1935 overleed op 33-jarige leeftijd zijn zoon Wouter, een veelbelovende bioloog die nog maar kort tevoren was gepromoveerd op een proefschrift over het duinlandschap op Terschelling, de besloten paradijselijke geboortegrond van zijn moeder. Wouter van Dieren was als zijn vader een gedreven persoon, 'schier onuitputtelijk in zijn energie', een man van de wetenschappen bovendien, maar dan wel een die zich wist te voegen in de academische wereld. De tijdens het promotiediner gehouden 'donderrede' (een geestige kritiek) wist hij op passende wijze te pareren. Het proefschrift zelf (waarop hij cum laude was gepromoveerd) werd beschouwd als 'belangrijk' en lijkt in niets op het polemische werk van zijn vader. Alleen in de grondstelling horen we misschien een echo terug van de vader die zich zijn leven lang tegen de machtige kliek zou verzetten in de veronderstelling dat hij op den duur gelijk zou krijgen. Duinvorming, zo luidt de te verdedigen stelling van het proefschrift, is niet het werk van de grote krachten wind en zee, maar juist van de kleine krachten: de levende plantenmassa's die zand opvangen en zo geleidelijk duinen opbouwen die de machtige golven het hoofd kunnen bieden. Een betere metafoor voor het werk van zijn vader is bijna niet denkbaar. 
Zijn dood als gevolg van een jarenlang slepende nierziekte was een dreun voor het gezin dat al vier kinderen had verloren. Maar voor Van Dieren leek het ook de bevrijding van zijn eeuwigdurende verontwaardiging te hebben betekend. De stroom artikelen nam in ras tempo af en halverwege de jaren dertig droogde de bron waaruit heel zijn polemisch talent putte even plotseling op als ze vijftig jaar eerder was begonnen over te lopen.

Er brak een periode van volslagen stilzwijgen aan, er zijn mij althans geen tekenen van leven bekend van na die periode. Het leven, of wat er van over was, raasde in een moordend tempo langs hem heen, maar hij kon of wilde er zich niet langer tegen verzetten. De ontdekking van de bacteriedodende schimmel penicilline; de muiterij op de Zeven Provincien in 1933, het Jordaanoproer van I934-allemaal zaken die hem in hevige verontwaardiging hadden moeten brengen, maar niets beroerde hem nog. Zelfs zijn 50-jarig artsjubileum, op 24 december I934, liet hij in stilte voorbijgaan. Hij vertoefde in het buitenland en onttrok zich zo aan de huldeblijken, stond er in de krant, hoewel 'talloos velen met belangstelling van dit bijzondere jubileum kennis zullen nemen'. ${ }^{105}$ Waarom? Misschien was hij moegestreden en wilde hij zijn laatste dagen in rust doorbrengen. Of misschien was het simpelweg zoals de psychiaters het stelden, namelijk dat met de ouderdom of de dood een einde aan de strijd van de querulant komt. ${ }^{106}$

Nog één keer verhuisde Van Dieren, in april I939. Hij had intussen zijn praktijk ingekrompen maar nog niet helemaal opgegeven. En zo, terwijl de wereld zich voorbereidde op het einde van de beschaving, bereidde Van Dieren zich voor op de dood. Op ro mei I940 vielen de Duitsers ons land binnen; 4 dagen later had Nederland gecapituleerd. Ook Van Dieren gaf zich over. Op I 5 mei marcheerden de Duitse troepen door Amsterdam. Van Dieren moet de oorlogsberichten en wellicht ook nog de intocht van de bezetter vanaf zijn ziekbed hebben vernomen - we kunnen slechts gissen naar wat er in zijn geest omging. Hij wachtte op het einde. Dat kwam, drie dagen later, op I 8 mei 1940. Capitulatie en bevrijding ineen.

Herdacht werd Van Dieren in vrijwel alle landelijke kranten. Ze brachten collectief zijn eenzame pioniersarbeid betreffende de beriberi in herinnering en spraken bewonderend van zijn tomeloze energie. Ook in het Nederlandsch Tijdschrift voor Geneeskunde verscheen een in momoriam waarin een bevriend medicus zijn strijdvaardigheid roemde, maar het bij alle aardige dingen die hij wist op te schrijven, toch niet kon nalaten zich af te vragen of deze man, die alles zo intens aanvoelde, wel één nacht rustig had geslapen. ${ }^{107}$ 
Vier dagen later, op woensdag 22 mei, werd hij begraven. Het was een stralende lenteochtend. De oorlog die over Nederland had getrokken was uitgeraasd en het normale leven nam weer zijn beloop. Rotterdam, zo stond in de krant, stak zijn handen uit de mouwen en begon aan de wederopbouw. In overleg met de bezetter was afgesproken dat het voetballen zo spoedig mogelijk hervat zou worden, en ook de gemeenten verkondigden dat alle grote werken voortgezet zouden worden. Bedrijven lieten in advertenties weten de jongste gebeurtenissen ten spijt gewoon weer zaken te zullen doen. Men zou bijna vergeten dat er elders in de wereld nog gevochten werd.

Honderden patiënten en oud-patiënten en collega-artsen verzamelden zich op de Nieuwe Oosterbegraafplaats om de dokter naar zijn laatste rustplaats te brengen. Een aantal vrouwen, aldus Het Vaderland, kwam bij de vele bloemstukken die de baar bedekten een tuiltje bloemen neerleggen, als laatste blijk van dankbaarheid voor wat hij als geneesheer voor hen en hun gezinnen was geweest. De kweekschool voor de zeevaart, waaraan Van Dieren zo lang verbonden was geweest, had een grote krans doen bezorgen.

Aan het graf sprak zijn oudste zoon, ir. Evart van Dieren. Zijn vader, zei hij, was door weinigen geheel, door velen gedeeltelijk en door nog meer geheel verkeerd begrepen. Een variatie op Abraham Lincoln, van wie het gezegde bekend is dat iedereen gedeeltelijk, een deel van de mensen vaak, maar niemand altijd gelijk kan hebben. In de uitspraak van ir. Van Dieren wordt aan de vader door iedereen het gelijk onthouden, waarop echter volgens het gezegde niemand recht zou hebben. Met die paradox gaf de zoon ervan blijk de positie van zijn vader beter dan wie dan ook begrepen te hebben. ${ }^{108}$

'En waar is nu Marx? Waar Einstein? Waar Kollewijn?' vervolgde ir. Van Dieren zijn grafrede. De retorische vragen zullen hebben moeten onderstrepen dat de strijd van zijn vader gerechtvaardigd was en niet tevergeefs, want waren de spellingvereenvoudigers, socialisten en relativisten immers niet voorgoed verslagen? Niemand zal het daar, die dag, hebben durven ontkennen. Maar ongewild vestigde de zoon ook de aandacht op het feit dat er aan het graf van zijn vader geen vertegenwoordigers van de wetenschap stonden. Alleen de universiteitsarts C. Bellaar Spruyt, die hem had behandeld, en zijn vriend Nico Knapper waren vertegenwoordigd als wetenschappers. De onmogelijkheid van autorijden in die eerste dagen van de bezetting lag daaraan ongetwijfeld ten schuld, schreef een vriend vergoelijkend, hoewel de meesten van hen natuurlijk in Amsterdam woonden. ${ }^{109}$ Neen, de reden dat zij ontbraken is eenvoudiger: al zijn rivalen, al zijn broedervijanden met 
wie hij zijn leven lang in een onmogelijke symbiose had verkeerd, waren dood. Vriend Lanz was vijf jaar eerder gestorven, Wibaut vier en Eijkman en Troelstra tien jaar eerder. Bolland was al achttien jaar dood en Diepenbrock al weer een kleine twintig jaar. Freud was dood, Gorter ook, evenals Van Eeden, Treub, Straub, Hugo de Vries, Grijns en heel de medische kliek met wie hij overhoop had gelegen. De waarheid was, er was niemand meer over om hem postuum gelijk te geven.

\section{Epiloog}

Met de dood van Evart van Dieren zat de taak van Catharina erop. Ze verhuisde in augustus I940 terug naar haar geboortegrond, Terschelling. Althans een deel van de bibliotheek van Van Dieren bleef achter in het appartement aan de Noorderamstellaan en werd in het voorjaar van I94I opgeruimd. Het aanwinstenjournaal van de Universiteitsbibliotheek van Amsterdam geeft tussen maart en mei I94I de ontvangst van een groot aantal boeken uit zijn nalatenschap op (zijn privéarchief echter bevond zich daar niet onder). En daarmee loste ook het laatste restje buitenstaanderschap op. 


\section{3 \\ Ik heb altijd gelijk}

Het aantal publicaties dat Van Dieren in zijn leven deed uitkomen is ronduit indrukwekkend te noemen. Ik kwam op I 6 boeken, I 8 brochures, ten minste 30 artikelen en minstens 25 ingezonden brieven, 2 toneelstukken en nog enkele andere stukken zoals een wetsvoorstel; in totaal zo'n honderd titels, maar de lijst is lang niet compleet, vermoed ik (een literatuuropgave bevindt zich achter in dit boek). ${ }^{1}$

Heel dat oeuvre vormt een in zichzelf besloten, consistent en men is geneigd te zeggen volmaakt geheel - met als enige tekortkoming dat het volledig buiten de realiteit staat. Alle claims op waarheid, geldigheid en relevantie lijken alleen binnen dat oeuvre zelf op te gaan.

\section{Nog een zo'n boek en ik word niet meer gelezen}

Uit een uitgeversoverzicht blijkt dat de meeste van zijn boeken nogal aan de prijzige kant waren: van circa drie kwartjes tot anderhalve gulden voor de eenvoudige brochures, tot $f \mathrm{I}, 90$ voor de ingenaaide editie van Besmettelijke zielsziekten ( $f$ 2,50 voor de gebonden uitgave), $f 3,90$ voor Averechtse geestesrichting, $f$,- voor Meelvergiftigingen, tot zelfs $f 7,50$ voor het tweedelige Historisch-idealisme of historisch-materialisme, gepubliceerd in 1922 en alleen in gebonden uitgave te verkrijgen. ${ }^{2}$

Ter vergelijking: in de jaren twintig van de twintigste eeuw verdiende een landarbeider misschien Io of I 5 gulden per week ofwel zo'n 500 tot 800 gulden op jaarbasis, een bootwerker minder dan Ioo० gulden en een fabrieksarbeider net iets meer. Voor alle drie ging daarvan bovendien het grootste deel op aan vaste lasten, zodat zelfs voor de kleinste extra uitgaven gespaard moest worden. Een onderwijzer verdiende 1000 tot $\mathrm{I} 200$ gulden plus toeslag, een schoolhoofd ongeveer I 800 gulden, en een directeur van een kleine fabriek niet meer dan 2000 gulden; een verzekeringsinspecteur ongeveer 3000 . Een geneesheer in dienst van een sanatorium werd in I9I9 een beloning van 3000 
tot maximaal 5000 gulden in het vooruitzicht gesteld en was daarmee een hele meneer. Aan de bovenkant van de markt daarentegen werd makkelijk het vijfvoudige gehaald. Hendrik Colijn, de latere ministerpresident, toucheerde in I9I4, nadat hij als minister van marine was afgetreden, al een jaarsalaris van 25.000 gulden als bestuurder van de Betaafsche Petroleum Maatschappij.

Wat zou Van Dieren, die een vrij beroep beoefende, hebben verdiend? We kunnen er alleen maar een slag naar slaan. Stellig was het niet zo veel als Colijn, maar anderzijds waarschijnlijk wel veel meer dan zijn directe rivalen, zoals de wat verarmde schrijverarts Van Eeden, de gymnasiumleraar (later privaatdocent) Gorter of zelfs de hoogleraren Verwey, Lanz en Eijkman die van een jaarwedde van tussen de 7000 en de 8000 gulden moesten rondkomen, en zeker ook meer dan de politici Wibaut en Troelstra, die als rijksambtenaar met misschien 4000 of 5000 gulden genoegen moesten nemen.

Van Dieren werd als huisarts nog door vrijwel geen regelgeving beperkingen opgelegd en kon zo veel of zo weinig vragen als hij wilde, en omdat hij alleen particulier verzekerden behandelde en, als gezegd, hoofdzakelijk onder welgestelden praktiseerde, moet hij op een ruim inkomen hebben kunnen rekenen, ruim genoeg in ieder geval om zich

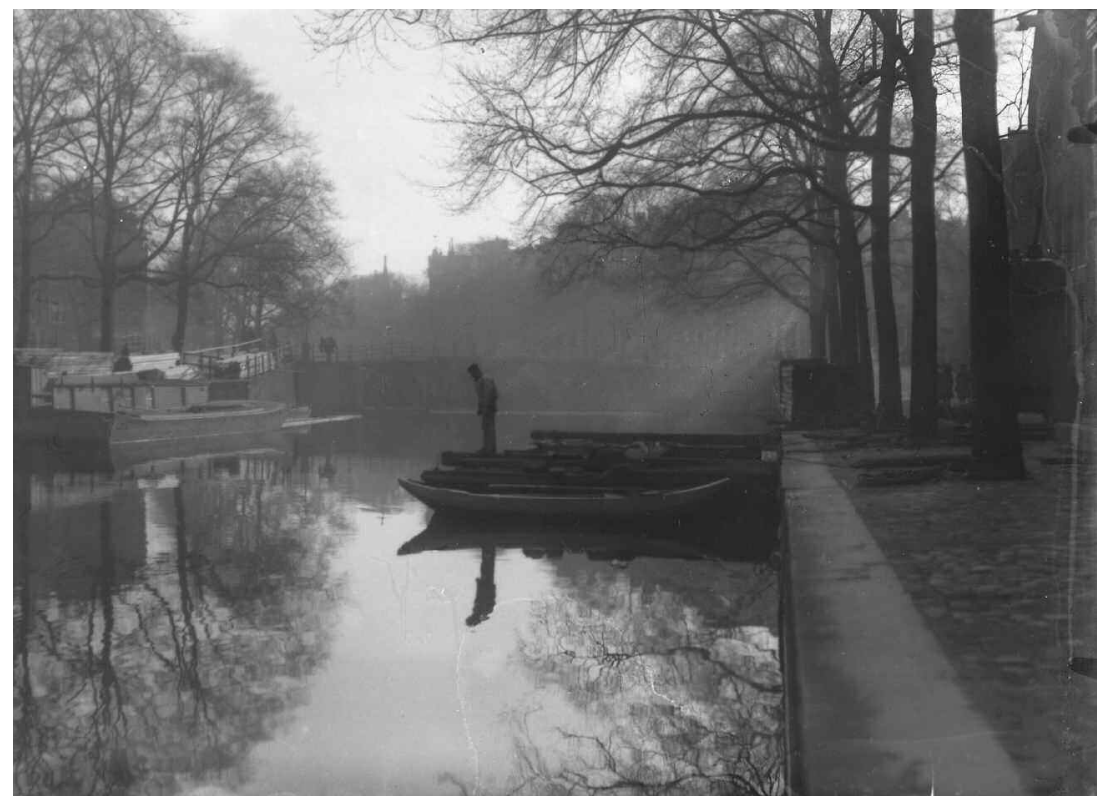

De Keizersgracht ter hoogte van nr. 7oo. Van Dieren woonde op nr. 622. Foto: Bernard Eilers. () Stadsarchief Amsterdam 
er een huis aan de Keizersgracht en bijkomend personeel van te kunnen veroorloven, plus een geldverslindende verslaving aan drukwerk.

Met het doen drukken en binden van een boek was aan het begin van de twintigste eeuw, afhankelijk van de omvang en oplage natuurlijk, al snel zo'n 500 gulden gemoeid (oftewel een heel jaarsalaris van een eenvoudige landarbeider), en als men bedenkt dat Van Dieren wel bijna ieder jaar een boek of brochure voor eigen rekening deed verschijnen, dan kan men zich wel een voorstelling maken van hoe zwaar het schrijven van boeken alleen in financieel opzicht al woog op het artsenbestaan. Veel van zijn boeken bleven bovendien onverkocht op de plank liggen - vooral de beriberiwerken en de meer filosofisch getinte boeken. Dat gold evenwel niet voor al zijn publicaties; sommige verkochten zelfs boven verwachting goed. Van zijn eerste antisocialistenboek uit I909 $(f \mathrm{I}, 90)$ zijn ten minste twee drukgangen verschenen en van zijn brochure over de vermeende pro-Engelse opstelling van $D e$ Telegraaf tijdens de Eerste Wereldoorlog zeker vier, plus een Duitse vertaling. Futuristische behandeling van zielszieken, uit 1927, verkocht volgens opgave van de auteur alleen al in de eerste drie maanden 2500 exemplaren. ${ }^{3}$ Aan twee niet nader genoemde werken verdiende Van Dieren naar eigen zeggen 250 respectievelijk 600 gulden; van dat laatste boek zouden I0.000 exemplaren zijn gedrukt. Van De waanzinnige waereld, zijn tweede antisocialistenboek uit I9I9, zijn in de goedkope volksuitgave zelfs I 5.000 exemplaren verschenen, maar daarop leed hij weer verlies, omdat hij ze onder kostprijs à $f \circ, 5 \circ$ per stuk verkocht dan wel gratis weggaf. ${ }^{4}$

Daarmee moest Van Dieren al met al dus fors toeleggen op zijn schrijverij, en eigenlijk kon hij die activiteit alleen uitoefenen, omdat af en toe 'bemiddelde medestanders' (rijke patiënten) bereid waren het risico van de uitgever over te nemen. ${ }^{5}$ Vaak vond de verspreiding ervan zelfs alleen plaats vanaf zijn huisadres dat in een grote vette letter voorin stond afgedrukt: E. van Dieren, Keizersgracht 622. Maar juist omdat veel van zijn publicaties voor eigen rekening verschenen wist hij zich tot amateur-schrijver gereduceerd. Zijn schrijverschap kon allesbehalve professioneel genoemd worden, hetgeen ook de belastinginspecteur haarfijn wist duidelijk te maken toen Van Dieren eens probeerde zijn verliezen op de belastingen te verhalen. 'O neen! - zei de inspecteur - u bent geneesheer en u schrijft boeken voor liefhebberij; dat is precies hetzelfde als een ander dure sigaren rookt.' ${ }^{6}$

Om zijn boeken onder de aandacht van zijn lezers te brengen liet hij geregeld advertenties opnemen in de landelijke dagbladen, waarin keurig onder elkaar gedrukte loftuitingen en schimpscheuten aan zijn 
adres stonden. Zo vinden we bijvoorbeeld bij het verschijnen van $D e$ waanzinnige waereld in een advertentie broederlijk naast elkaar gedrukt uitspraken terug van Henri Polak ('Geraaskal van een stumperige maniak'), professor Bolland ('Een voortreffelijk boek. Van Dieren's gevoelswijze is deugdelijk, zijn verstand helder') en Abraham Kuyper ('Dr. Van Dieren verstond steeds uitstekend de kunst, om het psychologische vraagstuk dat hier op den voorgrond treedt zoo alzijdig mogelijk toe te lichten') - als waren het allemaal bijzondere aanbevelingen voor zijn boek door de uitgever verzameld uit de diverse recensies. In werkelijkheid echter waren het uit zijn persoonlijke correspondentie geplukte zinnetjes, maar Van Dieren maakte dat weinig uit, voor hem waren alle uitspraken, publiek of privé, allemaal van dezelfde orde van grootte.

Verder had hij de gewoonte zijn talrijke opponenten en zijn wat minder talrijke medestanders te trakteren op een gratis 'presentexemplaar': Kuyper, Bolland, Polak, De Savornin Lohman, Troelstra, Wibaut, Winkler, L. Bouman, Lanz, Henriëtte Roland Holst, Van Eeden, Colijn, diverse ministers, de koningin en vele vele anderen kregen zijn drukwerk ongevraagd toegestuurd, niet zelden als 'luxe editie', op oudHollands papier gedrukt. Ook universiteitsbibliotheken, kranten, tijdschriften, overheidsorganen en al wie zich ook maar enigszins geïnteresseerd toonde of om andere redenen op zijn verzendlijst stond stuurde hij zijn pennenvruchten toe, waarbij hij in de exemplaren voor de bibliotheken soms de bepaling liet opnemen dat het werk wel mocht worden ingezien maar niet uitgeleend. Hij wilde niet graag het risico lopen dat toekomstige generaties lezers van zijn boeken verstoken zouden kunnen blijven.

Ook dat onmatige uitdelen en adverteren drukte op de balans. Maar het was hem toch niet om de verdiensten te doen. Als het aan hem lag werden zijn dure sigaren tegen lage prijzen of zelfs voor niets verspreid, het liefst onder de 'niet bemiddelde recruten van het intellect' (studenten), die per slot nog het meest ontvankelijk waren voor zijn werk. ${ }^{7}$ Want bij alles wat hij deed dienden de boeken maar één doel, en dat was het in de markt zetten van de schrijver zelf.

Het opwekken van ruzie of tenminste wrevel was daarin een belangrijk middel. Hoe groter de tegenwerking die hij ondervond, des te sterker werd zijn positie, zo moet hij hebben gemerkt. 'Kort en goed', schreef hij in 1908 in een terugblik op wat hij tot dan toe had bereikt in het beribericonflict, 'ik ben geboycot; en al is dat lastig, tòch heb ik alle reden mij er door gevleid te voelen."

En inderdaad: het is een niet geringe prestatie om zo lang zo veel tegenstand op te brengen als hij deed. Een opsomming van alle misère 


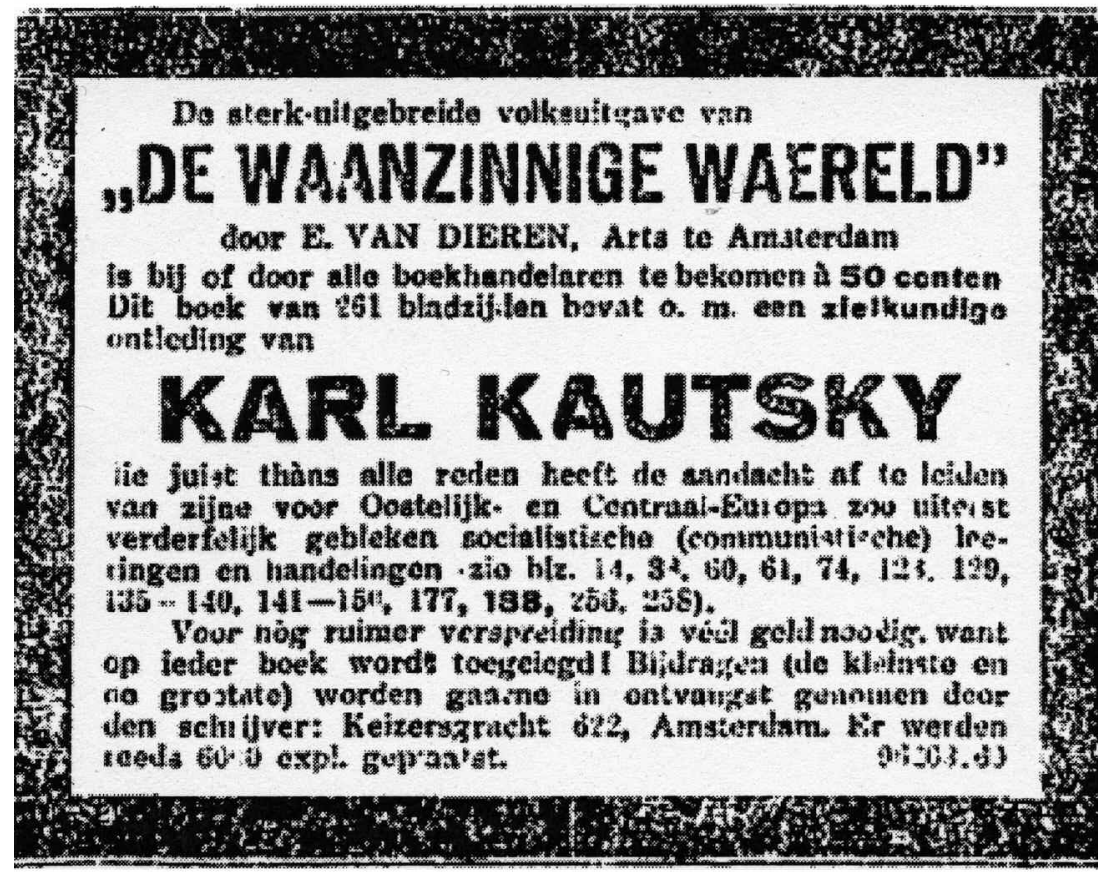

Reclame voor 'De waanzinnige waereld', Van Dierens meest succesvolle boek, waarvan binnen een jaar I5.00o exemplaren aan de man werden gebracht, maar waarop de auteur desalniettemin verlies leed.

die over hem was uitgestort in de loop der jaren, samengeperst in nog geen dertig pagina's, vindt men in een van zijn laatste brochures: Het Beri-beri en vitamine-treurspel. Ongeloofelijke bizonderheden uit mijn 40-jarige strijd tegen laboratoriumgeleerdheid-op-haar-smalst, enz., enz., waarmee hij als lezing door het land trok. We treffen een heel leven aan van tegengewerkt worden, van verkeerd begrepen zijn, van onbeantwoorde brieven schrijven, kortom van uitgesloten worden. Difficile est non satyram scribere concludeerde hij. De balans opmaken en toe te moeten geven dat je de weddenschap hebt verloren die je bijna een halve eeuw eerder met het leven bent aangegaan: wie kan daar zonder bitterheid over schrijven?

In 65 paragraafjes wordt met behulp van citaten uit het werk van andere auteurs gedemonstreerd dat zijn naam jarenlang door het slijk is gehaald, en dat nog wel zonder enige aanleiding, en zonder dat hij er iets aan kon doen. 'Had men de Beri-Beri willen bestrijden en zich daarbij baseeren op de leer van Van Dieren, dan had men die strijd ons zeker 
oneindig veel teleurstelling gebracht zonder dat wij misschien achter de waarheid waren gekomen, ${ }^{9}$ citeerde hij een criticus, om even later te zeggen: 'Op den duur ben ik in alle opzichten in het gelijk gesteld. ${ }^{10}$ Alle gevechten verloren en toch de oorlog gewonnen? 't Kan verkeren.

\section{De ontlanding}

Overal ruzie krijgen en toch door niemand serieus worden genomen; alle tegenspraak afwijzen als een infame inbreuk op je rechtsgevoel en je altijd maar opnieuw vastbijten in een schijnwereld: dat is het lot van iemand die aan zichzelf is overgeleverd en door niets en niemand wordt geremd. Het is een leven als in een schelmenroman, permanent in staat van hevige opwinding. Maar de uitbarstingen brengen nooit de bevrijdende ontlading waarop de lezer wacht.

\section{Het pijnlijke gelijk}

Van Dieren bevond zich op het snijvlak van twee tijdperken: de langzame premoderne tijd van zijn jeugd, waarnaar hij steeds heviger terugverlangde naarmate hij er verder van verwijderd raakte, en de snelle, moderne twintigste eeuw, die hij niet begreep, maar die hem leek te overkomen en waartegen hij zich steeds heviger zou verzetten. Naarmate de jaren verstreken slaagde hij er steeds minder in die twee werelden te verenigen, en dwaalde hij steeds vaker van de ene in de andere tijd, zonder ergens houvast te vinden, als een slaapwandelaar, op zoek naar prikkels die hem eraan herinnerden dat hij niet droomde. Het beeld doemt op van een man die zich erin vergenoegt door anderen te worden tegengewerkt om tenminste nog iets van contact met de realiteit te ervaren.

Kom op v. d. Scheer!

Gij wildet mij op den rechterwang slaan; ik keer u thans de linker toe, ja, ik stel mijn gansche lichaam aan u bloot en... mijn ziel erbij.

Doe wat Gij moet!

SLA...of...GA! ${ }^{11}$

Zo ging dat steeds. 'Begrijp mij wèl, Meneer de Redacteur, ik verlang niet... gespaard te worden; men geve mij de volle laag, als... ik het er naar gemaakt heb', smeekte hij een andere keer. ${ }^{12}$ Nog in I93 I klaagde hij dat al zijn geesteskinderen werden 'mishandeld' en wentelde hij zich in de fantasie door SDAP'ers in het aangezicht te worden getrapt. ${ }^{13}$ 
Omgekeerd schiep hij er een genoegen in de ander verbaal eens flink af te rossen, misschien om dezelfde reden: om zich ervan te vergewissen dat zijn woorden zouden aankomen.

Vooral voor de psychoanalyse putte hij zich uit in welluidende beledigingen die de lezer al op de omslag van het boek worden aangekondigd: 'psychopaat', 'sadistisch mishandelaar van zielszieken', 'bevorderaar van de perverse ontucht', 'duivelwèkker'. ${ }^{14}$ Het lijkt wel of het in zijn werk erom ging de ander werkelijk pijn te doen, fysieke, lichamelijke pijn, als zocht hij naar woorden die diep zouden doordringen in de huid van de ander en daar een schrijnende wond zouden achterlaten. In debat had Van Dieren nooit met opponenten te maken, maar altijd met bestrijders, die hij niet zocht te overtuigen maar te vernietigen.

\section{Het publieke gelijk}

De strijd werd het liefst in publiek gevoerd, maar dan wel schriftelijk, niet mondeling, want, zoals hij Eijkman ter verduidelijking eens schreef, 'daarbij wint dikwijls alleen de gevatste'. En gevat was Van Dieren eigenlijk niet, ondanks de vele pogingen de lachers op zijn hand te krijgen. ${ }^{15}$ Als zijn toespraken al als 'komisch' werden opgevat, dan was dat vaak het onbedoelde effect van de gedateerde, veel te plechtige toon die werd gebezigd, wat weer het gevolg was van het feit dat Van Dieren iedere strijd, hoe futiel ook, in het publiek trachtte uit te vechten met behulp van uitgeschreven redevoeringen. De dokter sprak niet, hij las voor.

Bijna al zijn boeken zijn geënt op zulke uitgeschreven redevoeringen en beginnen met de woorden 'Geachte toehoorder' en sluiten vaak ook af met de aan de academische colleges ontleende formule 'Ik heb gezegd', als waren al zijn praatjes inaugurale redes. Dat gold zelfs het ruim 560 pagina's tellende tweedelige Historisch-idealisme of historisch-materialisme dat, als het in die vorm zou zijn voorgelezen wel ongeveer als een moordaanslag op zijn toehoorders zou moeten worden opgevat. De boeken ontstonden eerst na afloop van de voordracht, als Van Dieren zijn praatjes verder uitwerkte en de speeches bijna 'als vanzelf' uitgroeiden tot kolossale werken, daar zich iedere keer 'de geest van hem waardig maakte'. Geschreven en gesproken tekst blijven daarom bij Van Dieren nauw samenhangen, als zijn het synoniemen voor elkaar, of liever: als zou iedere gesproken tekst zich uiteindelijk naar de geschreven hebben te voegen. De uitgeschreven rede, niet het debat, vormde zijn belangrijkste wapen in de talloze krachtmetingen die hij met zijn tegenstanders zocht. 
Op het hoogtepunt van zo'n krachtmeting schreef een criticus eens: 'De vijanden van den heer Van Dieren zijn verslagen en teneergeveld. Hij heeft hen in zijn laatste boek in tal van lettersoorten en met vele leestekens bestookt en overwonnen, en in eene apotheose van louter kapitale letters staan aan het slot zijn medestanders op het slagveld, met al de verslagenen zieltogend om hen heen. Wie zich later nog eens op durfde richten [...] zou gevaar loopen met nog een andere eigenschap van den heer Van Dieren, dan alleen met zijn taalgevoel in conflict te raken. ${ }^{16}$

Of het ooit weleens tot een handgemeen is gekomen durf ik niet te zeggen, maar het moet menigmaal zeker zo hebben aangevoeld. Geen wonder dat die polemieken onveranderlijk uitmondden in de getergde weigering van de ander zich nog verder in te laten met Van Dieren. Debatteren met hem was niet alleen onaangenaam, het was ook gevaarlijk. Voor je het wist werd je erin meegesleurd. Hoe vaak stond er in een aan Van Dieren gerichte brief niet een zinnetje als de volgende: 'Ik beeld mij geen oogenblik in dat mijn geschrijf ook maar den geringsten indruk op u zal maken, maar hoop dat ook gij zult inzien dat het verder hoegenaamd geen nut kan hebben nog verder te schrijven. ${ }^{17}$ Of, wat minder beleefd maar minstens even beslist: 'Tenslotte moet ik u zeggen, dat de onzakelijke beleedigende wijze waarop $\mathrm{u}$ in uw boek spreekt over menschen die ik hoog acht, mij een reden is u te verzoeken verder geen contact meer met mij te zoeken, daar ik u niet verder antwoorden zal. ${ }^{18}$ Of zelfs: 'Ps. Iedere eventuele poging uwerzijds met mij verder te corresponderen is nutteloos. Uw brieven worden ongeopend vernietigd. ${ }^{19}$

Ten slotte werd er helemaal niet meer gereageerd op zijn uitdagingen, brieven en artikelen, zodat het einde van het liedje steeds was dat er een pijnlijk stilzwijgen over de relatie tussen hem en zijn tegenstander kwam te hangen, en Van Dieren op zoek moest gaan naar nieuwe prikkels.

\section{Het postume gelijk}

'Pijnlijk' hangt als het zwaard van Damocles boven de briefwisselingen van Van Dieren, en niet alleen boven zijn briefwisselingen, maar boven al zijn menselijke contacten. 'Wat gij meent te kunnen doen, doe dat haastiglijk! Neem positie tegenover hem, die zich - meer dan enig ander - beijverde de rijstvoeding voor beri-beri aansprakelijk te stellen' gebood hij eens een tegenstander in kapitale letters. ${ }^{20}$ In de marge stond voor alle duidelijkheid gedrukt: 'Eene uitdaging.' 
Het verzet, zo realiseerde hij zich al vroeg, moest zijn grondhouding zijn. En tegen wie kan men zich beter verzetten dan tegen een autoriteit: onbereikbaar, gehaat, geliefd, veracht. 'Geachte Professor', schreef hij terugblikkend op zijn leven aan zijn vriend Lanz, ' $U$ gaf me vanmorgen een welgemeende raad. Ik moet mij wenden tot Colijn of een ander hooggeplaatste. Van 1889 af deed $i k$ dat. ${ }^{21}$ De cursivering is van Van Dieren. Altijd weer deed hij een beroep op dergelijke lieden, en enige malen had hij er succes mee, zei hij. Maar jammer genoeg was dat gelijk 'postuum', dat wil zeggen: nog niet toegekend. Het gelijk bleef in het verschiet liggen, op steenworp afstand verwijderd, maar zou pas achteraf worden toegekend, nooit op het moment zelf.

Vroeg, al heel vroeg, heeft hij erop ingezet postuum gelijk te krijgen, in de stiekeme hoop dat het gelijk misschien toch wel wat eerder zou komen dan pas na zijn dood. 'Ik zal mij weten te troosten met de zekerheid dat op den duur de waarheid altijd triomfeert', schreef hij vaak, en soms voegde hij daaraan toe dat hij verwachtte dat men dat wel bijtijds zou inzien en dan met hangende pootjes bij hem om vergiffenis zou komen vragen: ' $K$ verwacht, dat Ge zulks te eeniger tijd nog eens zult inzien en mij excuses zult aanbieden. ${ }^{22}$

Maar ook dat is hem niet vergund geweest, het postume gelijk. Aan zijn graf sprak zijn zoon ir. Evart van Dieren, op wie de duistere banvloek van het querulantisme misschien was overgegaan: 'Altijd heeft Dr. Van Dieren bestreden dat de beriberi een vitamineziekte zou zijn, hij hield vast aan zijn opvatting dat zij een vergiftiging is, ontstaan door onvoldoende voeding. Duizenden zijn aan deze verschrikkelijke ziekte gestorven; hun dood was te voorkomen geweest. Het wachten is op een jongen geneeskundige die den strijd van mijn vader zal voortzetten. ${ }^{23}$

Tijdens zijn leven heeft hij het gelijk-achteraf evenmin mogen beleven, en het moet hem hebben verbitterd dat de weinige blijken van waardering geen eenduidige erkenning inhielden, maar steeds gepaard gingen met wat we tegenwoordig een disclaimer noemen: een bewering die zichzelf opheft doordat ze als het ware meteen weer wordt teruggetrokken. Zoals bijvoorbeeld in de zeldzame gevallen waarin waardering voor Van Dierens bekommernis om het lot der beriberilijders werd geuit, die echter altijd eindigden met de constatering dat zijn toon het wel onmogelijk maakte dat men hem ernstig zou nemen. En zo bleef het netto-effect dus nul. In een voordracht uit I9I 5 van P.K. Pel voor de Nederlandse Maatschappij tot bevordering der Geneeskunst overheerste bijval nog het sterkst, al was ook hier de twijfel over de juistheid van de aangeslagen toon niet afwezig. 
Ware zijn [Van Dierens] telkens weer met aandrang herhaalde raad om toch vooral deugdelijke rijst te gebruiken eerder opgevolgd, dan had de beri-beri nooit het aantal slachtoffers gemaakt dat in de laatste 30 jaren in Ned.- Indië is gevallen. Voorzeker zou ons medelid grooter voldoening van zijn ijverig en belangeloos streven hebben gemaakt, indien hij minder heftig en agressief ware geweest in de bestrijding van anderen en meer waardeering had getoond voor de zoo beteekenisvol gebleken wetenschappelijke onderzoekingen van zijn tegenstanders. ${ }^{24}$

Van Dieren hield nauwkeurig bij wie wat over hem schreef en op gezette tijden maakte hij de balans op. Die viel altijd in zijn voordeel uit. Dat men niet bereid was het eigen ongelijk en zijn gelijk eerlijk te erkennen, maar integendeel deed alsof $z i j$ altijd al gelijk hadden gehad en $h i j$ van begin af niet, tekende, vond hij, de bekrompen en zelfzuchtige houding van zijn tijdgenoten, de kliekelingen, die elkaar de hand boven het hoofd hielden, maar bevestigden natuurlijk wel dat hij het bij het rechte eind had. Zo werd de waarheid dus al vroeg een artikel waarop Van Dieren weliswaar het exclusieve recht leek te bezitten, maar dat hij om de een of andere reden toch niet kon opeisen. In I 922 liet hij zichzelf in een tweespraak met een bevriend collega zeggen: 'In I 887 schreef en bewees ik, dat Beri-Beri veroorzaakt wordt door ondeugdelijke rijst en dat zij bevorderd wordt door ontoereikende nevenvoeding, en eerst 20 jaren later zijn met schitterend succes de maatregelen genomen, die ik noodig achtte. Welnu, precies zoo is het gegaan met alles wat ik ten beste gaf; altijd stuitte ik op krachtig verzet, op onwil zelfs; en gelijk kreeg ik nooit, al bleek het later nog zoo duidelijk, dat ik het had. ${ }^{25}$

\section{Het achteloze gelijk}

Hoewel hij door niemand werd erkend en inderdaad nooit gelijk heeft gekregen (daarover zouden zijn tegenstanders en hij het eens zijn), heeft Van Dieren vaak beweerd dat men zijn ideeën zonder bronvermelding overnam. Grotendeels waren die claims gebaseerd op 'mystificaties': het herschrijven van de geschiedenis, zodanig dat de eigen rol er veel voordeliger in uitkomt (ik kom er later nog op terug). Voor zijn aandeel in de oplossing van het beriberivraagstuk gold dat zeker, zoals we in het volgende hoofdstuk zullen zien. Maar gold dat voor al zijn claims op prioriteit? Wie een schot hagel afvuurt raakt immers toch ook wel eens iets?

Op verschillende plaatsen in zijn werk liet Van Dieren een briefje van de Weense psychiater Julius von Wagner-Jauregg (I857-I940) 
afdrukken dat hem zou zijn toegestuurd in het voorjaar van I9I5: 'Zeer geachte collega, ik vind uw suggestie om paralyse met behulp van malaria te bestrijden zeer interessant. Ik zou de proef ook zelf uitproberen, maar ben voorlopig nog bezig met de door mij ontwikkelde methode (tuberculine, staphylococcen); anderzijds is malaria een ziekte die zo weinig voorkomt dat het niet makkelijk is om entmateriaal te krijgen. ${ }^{26}$ Enige jaren later, schreef Van Dieren achteloos, las hij dat Wagner-Jauregg de behandeling met succes had toegepast.

Wat hier zo tussen neus en lippen door wordt verteld is niets minder dan een kolossale ontdekking. In de zomer van I9I7 zou WagnerJauregg een doorbraak bereiken met de 'malariakuur': het opwekken van malariakoorts (door toediening van malaria) bij neurosyfilitische patiënten leek een genezende werking op deze psychische ziekte te hebben. En hoewel aan de koortskuur ook grote nadelen verbonden waren, en het bovendien niet het verwachtte panacee bleek te zijn dat men er enige tijd voor hield, toch zou Wagner-Jauregg in 1927 de Nobelprijs voor dit werk ontvangen - het leek waarachtig wel een echo van het Kochse tuberculine-avontuur uit I 890 .

Wat een vrij onbetekenende ontdekking lijkt, duidt in feite een keerpunt in de geschiedenis van de psychiatrie aan, schrijft Edward Shorter in Een geschiedenis van de psychiatrie, omdat Wagner-Jauregg als een van de eerste onderzoekers erkende dat er een organische oorzaak aan psychische problemen ten grondslag kan liggen. ${ }^{27}$ Zelfs als we Shorters wat eenzijdige benadering van de psychiatrie niet onverkort overnemen, moet toch worden toegegeven dat de malariakuur van Wagner-Jauregg een onmiddellijke impact had op de medische wetenschappen, en een kentering in het denken betekende.

$\mathrm{Nu}$ eiste Van Dieren wel niet direct de hele ontdekking voor zichzelf op, omdat hij in een toelichting toegaf dat hij Wagner-Jauregg de malariasuggestie aan de hand had gedaan, nadat hij had gelezen dat deze met koortsverwekkende middelen dementia paralytica probeerde te bestrijden. Maar wel beweerde hij dat het hem was opgevallen dat in tropische landen malaria vaak, en dementia paralytica weinig voorkwam, en zo zou die Nobelprijswaardige vondst dus eigenlijk op een briljante ingeving van Van Dieren teruggaan - of niet?

Wagner-Jauregg noemde in zijn Nobelprijsrede Van Dieren niet; hij zei in plaats daarvan dat hij in I 887 al aan malaria had gedacht als 'natuurlijk middel om koorts op te wekken'. In feite sluit het briefje aan Van Dieren dat ook niet uit. 'Ik zou de proef ook zelf uitproberen' (Ich würde den Versuch auch selbst machen in het origineel): dat kan men lezen als het willen opvolgen van een raad, maar evengoed als het 
voortzetten van werk dat hoe dan ook al wordt verricht. En in werkelijkheid ging Wagner-Jauregg als experimenteel onderzoeker eenvoudig de verschillende mogelijkheden af, en belandde daarbij vanzelf bij malaria - met of zonder Van Dieren. Als men vervolgens bedenkt dat Van Dieren voor het eerst in 1927, het jaar waarin Wagner-Jauregg de Nobelprijs ontving, gewag maakte van dat briefje, dan begrijpt men eerst hoe het proces van 'mystificatie' in zijn werk gaat. Pas als blijkt dat het doel is geraakt eist de schutter met terugwerkende kracht het schot op. Het is een variant van de gedachte dat al zijn beweringen een effect moeten hebben louter, omdat hij ze heeft geuit.

\section{Het beslissende gelijk}

Sarajevo, 28 juni I9I4, aartshertog Franz Ferdinand, de OostenrijkHongaarse troonpretendent, en zijn vrouw komen bij een moordaanslag om het leven. Een maand later verklaart Oostenrijk-Hongarije Servië de oorlog; een kettingreactie van in werking tredende onderlinge verdragen sleurt heel Europa mee.

Wordt die moordaanslag algemeen als het startschot van de Eerste Wereldoorlog gezien, zo niet door Van Dieren, die de ophitsende antiOostenrijkse propaganda in de Engelse kranten de schuld gaf. Ongelijk had hij niet, althans in zoverre het politieke klimaat door maandenlange mediacompagnes in Europa grondig op een oorlog was voorbereid. Zelden zal er met minder twijfel aan een oorlog zijn begonnen als toen: iedere partij, iedere natie, ja, vrijwel iedere afzonderlijke burger was vervuld van een gevoel van verongelijktheid en de gedachte de ander eens duchtig een lesje te leren deed in heel Europa de soldaten zingend naar het front marcheren.

In héél Europa? Nee, een kleine natie hield zich afzijdig. Nederland mobiliseerde, ving een enorme stroom Belgische vluchtelingen op in armoeiige barakken, leed ongemak, maar wist zich gewiekst uit het conflict te houden. Maar de oorlog bracht de gemoederen in het neutrale Nederland niet minder in beweging. De verschillende sympathieën sneden dwars door de klassieke tegenstellingen van links en rechts, confessioneel en niet-confessioneel heen (zie bijvoorbeeld het boek Buiten Schot van Paul Moeyen). ${ }^{28}$ Ook de vriendenkring van Van Dieren was verdeeld: Alphons Diepenbrock was zeer anti-Duits, maar Otto Lanz juist weer pro (hij vocht in de oorlog aan Oostenrijkse zijde). Bolland was voor Duitsland; Duitsland was de oorlog opgedrongen, vond hij. Dat was ook het standpunt van Van Dieren, die het vrijwel onverdraaglijk vond dat anderen er anders over dachten. Aan die situatie van 
verdeeldheid binnen zijn eigen kring probeerde hij op zijn eigen bekende wijze een einde te maken.

Als steeds zocht en vond hij zijn cause célèbre in een afgeleide zaak. In de zomer van I9I 5 bond hij de strijd aan met De Telegraaf die in zijn ogen te zeer pro-Engels was. Hij had daarin trouwens geen ongelijk; de krant was werkelijk niet op de hand van de Duitsers en deed weinig moeite dat te verbergen. De aanleiding om van leer te trekken vormde een futiliteit: een aan de Duitse keizer toegeschreven uitspraak in een piepklein artikeltje, overgenomen uit een Franse krant. Daarin stond te lezen dat keizer Wilhelm tegen zijn troepen zou hebben gezegd: 'Ik ben het werktuig des Allerhoogsten. Ongeluk en dood aan allen, die niet in mij geloven. ${ }^{29}$

Van Dieren meende dat een dergelijke blasfemie nooit van de Duitse keizer afkomstig kon zijn en vermoedde een soort canard. Het was oorlog, de Fransen hadden er baat bij de Duitse keizer belachelijk te maken en De Telegraaf liet zich ziende blind voor dat karretje spannen. Hij schreef een lange kritiek die door de krant werd geweigerd (ze eiste sterke besnoeiing van het stuk, maar daar wilde de schrijver niet van horen). Er volgden enige telefonische gesprekken met de chef van de redactie en een correspondentie met de hoofdredacteur, H. Holdert, wat echter niet tot opname van het stuk leidde. Ook zijn poging om via de advertentierubriek zijn standpunt gepubliceerd te krijgen mislukte. Daarop besloot Van Dieren er 'een zaak' van te maken. Hij schreef een brochure van meer dan honderd pagina's waarin opgenomen zijn correspondentie met de redactie, verschillende geweigerde artikelen en een uitgebreide documentatie van de pro-Engelse houding van $\mathrm{De}$ Telegraaf, de Nederlandse regering en veel Nederlanders in het algemeen, alsmede een veelheid aan polemische beschouwingen over de oorzaak van de oorlog. Een J'accuse van jewelste dus. Maar bij dat alles was de toon van het boek, althans in de ogen van Van Dieren zelf, 'mild en vergoelijkend' gebleven, eigenschappen die volgens de schrijver 'héél goed samengaan met scherp polemiseren'. ${ }^{30}$

De brochure verscheen op I 8 augustus I9I 5 . In een voorwoord voert hij een dialoog op met een 'welmenende vriend': 'Wat hoor ik? Ben je bezig een boek over den oorlog te schrijven? Dat is toch, hoop ik, niet waar?' 't Is wèl waar, antwoordde Van Dieren; nu Professor Treub, Prof. Lanz, Prof. Saltet, Prof. Sleeswijk en dr. van Zadelhoff erover hebben geschreven, nu mag ik niet langer zwijgen. Jij mag je met schaken of musiceren bezighouden, maar ik heb nog werk te verzetten.'

Of hij met de 'welmenende vriend' een specifieke kennis op het oog had, bijvoorbeeld Alphons Diepenbrock, of er eigenlijk heel de kliek 


\section{Contra ys'accuse". Is ibe Tológraalt cen ... En- golsoho kraniz. - Wlo ver- oorzaken den oorlog ? - Van welken kant dreigt voor No- derland het meeste gevaar? - Wat is de taak on de plicht van tederen Nederiander? - Is de sohrijuer van al'ac." cusen ceii uaarheịdslie- vend Duitscher of ean ... minderwaardigheids type ? Ba zoo voorts 1 \\ door E. VAK DIEREH, Arts to A'dam.' Prlls sioohts 80 ets. Uitg. W. TEN HAVE, A'dam. In elken Boekb. verkrijgbaar of rechtstreeks v. d. Uitgever,}

Reclame voor Is de Telegraaf een...Engelsche krant?

'Na deze brochure kunnen wij niet meer vriendschappelijk omgaan en moet ik zeer tot mijn leedwezen naar een anderen arts omzien.'

van rivalen mee bedoelde, is niet met zekerheid vast te stellen. De verwijzing naar het 'musiceren' van de ander lijkt in de richting van de eerste veronderstelling te wijzen. We weten ook dat Van Dieren met Diepenbrock in de zomer van I9I4 een 'onaangenaam gesprek' had over de oorlog, waarbij Van Dieren zich volgens de ander liet kennen als 'een halve Duitser' die geheel doortrokken was van Duitse vooroordelen, te weten 'dat Duitsland de beschaving, de moraal, de vooruitgang representeert, en Frankrijk bedorven is etc.'. Inderdaad was Van Dieren ervan overtuigd dat het Franse volk gedegenereerd was, en dat de algehele zenuwuitputting van de Fransen weleens teruggevoerd kon worden tot een medische oorzaak: het eten van ondoelmatige voeding, in het bijzonder witbrood. Nee, dan de Duitsers, en hun degelijke Schwarzbrod! $!^{31}$ 
Toen Diepenbrock korte tijd daarna een stuk schreef in De Groene Amsterdammer over de oorlog en tegen de Duitsers, stuurde Van Dieren hem een 'lange en ontstemde brief', waarin hij de 'grondstemming' van Diepenbrock bekritiseerde. ${ }^{32}$ Een verwijdering leek nog slechts een kwestie van tijd. Een jaar later was het zover; met De Telegraafbrochure had Van Dieren zich in één moeite door met de heren professoren op één lijn gesteld én zich op hen gerevancheerd.

Maar hij stuurde het boekje niet op aan zijn welmenende vriend. Dat alleen al was een betekenisvolle geste, zoals Diepenbrock zich realiseerde, en hij was Van Dieren daar overigens 'dankbaar' voor. Toch kon dat niet voorkomen dat het tot een breuk zou komen. Op ro september I9I 5, drie weken nadat Is de Telegraaf ...een Engelsche krant enz. was verschenen, schreef Diepenbrock aan zijn huisarts een brief die het hele drama ontvouwt van een relatie die is geworteld in een onmogelijke verhouding.

Beste van Dieren.

$\mathrm{Na}$ deze brochure die je over de oorlog geschreven hebt, kunnen wij niet meer vriendschappelijk omgaan en moet ik zeer tot mijn leedwezen naar een anderen arts omzien. Spaar mij de noodzakelijkheid dit toe te lichten. Het kan niet anders dan pijnlijk voor ons beiden zijn. Waar 2 menschen in zaken die zoo het diepst van de ziel raken, lijnrecht tegenover elkaar staan, houdt de mogelijkheid van dergelijke betrekkingen zooals wij jaren hebben gehad op. Wat baat het mij of ik met mijn verstand je vrij wil spreken wanneer mijn gemoed tot in zijn diepste schuilhoeken geschokt en gekrenkt is. Ik apprecieer het dat je me de brochure niet gestuurd hebt. Laten wij als mannen en als vrienden uit elkaar gaan, zonder ruzie, zonder gekijf en verwijten. Jouw verleden, physisch en psychisch, preadisponeert en preadestineert je om aldus die eene kant van de zaak te zien en geen andere. - Dit veroorzaakt een breuk en een houding die mij tot op het bloed grieft, als een persoonlijke krenking en waarover ik geen woord verder wil zeggen. Het is al bitter genoeg je deze brief te moeten schrijven en voor jou om hem te lezen. Ik dank je voor alles wat je in de loop der jaren als arts en vriend voor mij en de mijnen geweest bent. Laat mij daaraan een goede herinnering bewaren en laat ik je hiermede een weemoedig vaarwel toeroepen. Het beste zou zijn als je hier niets op antwoordde. Het ga je goed. A.D. ${ }^{33}$

Zo hielp de Telegraaf-brochure dus gewild of ongewild bij het scheiden der wateren. (De breuk met Diepenbrock zou overigens aan het einde van de oorlog, in I9I 8, worden hersteld, zodat we de melodramatische 
toon wel met een korreltje zout moeten nemen.) Het stuk hielp trouwens in nog een opzicht de bokken van de schapen te scheiden. Van Dierens sympathie met de Duitsers was de Duitse gezant in Den Haag, Von Kühlmann, niet ontgaan. Deze schreef op 28 mei I9I 6 aan de Rijkskanselier in Berlijn een geheime notitie over de mogelijkheden om het Duitse standpunt meer voet aan de grond te doen krijgen in Nederland, in eerste instantie binnen de politiek en universiteitskringen, maar liefst ook daarbuiten, bijvoorbeeld binnen de wereld van de artsen, waarna tussen haakjes de namen van enkele medici volgden op wie de 'belangstelling' van de Duitsers was gericht. Daaronder die van Van Dieren. ${ }^{34}$ Zijn pro-Duitse houding en wellicht deze geheime correspondentie hebben onder historici het vermoeden doen postvatten dat Van Dieren bij de Duitsers op de loonlijst heeft gestaan. ${ }^{35}$ Daarvoor zijn geen bewijzen, maar wel lijkt het me goed mogelijk dat de Duitse vertaling van zijn brochure, die niet veel later verscheen, door hen is bekostigd. ${ }^{36}$

\section{Het foute gelijk}

En dan is er nog een goed-foutkwestie waarvan Van Dierens positiebepaling bekend is: die rond het antisemitisme. Ook deze kwestie sneed dwars door de gelederen. Van Eeden was er niet geheel verschoond van; Abraham Kuyper enige tijd ook niet. Onder katholieken was de fabel wijdverbreid dat de dood van Jezus aan de Joden moest worden geweten, maar ook de protestanten hechtten daaraan soms geloof. Dit is niet de plek om op de geschiedenis van het antisemitisme in te gaan, maar met de constatering dat de Joden voor de oorlog een herkenbare en misschien ook wel vrij gesloten gemeenschap vormden, aan wie door leken en wetenschappers zonder veel plichtplegingen 'raseigen' psychologische en fysiologische kenmerken werden toegeschreven, lijkt niet al te veel gezegd. Of het antisemitisme daaraan ten grondslag ligt, dan wel ervan in het verlengde ligt is moeilijk te zeggen; feit is dat het, net als het rassenonderscheid zelf, breed gedragen werd.

Van sommige van de relaties van Van Dieren weten we hoe ze hierin stonden. Diepenbrock, om nog een keer dat ijkpunt in het Van Dierense universum te noemen, was sterk antisemitisch. De filosoof Gerardus Bolland, dat andere ijkpunt, eveneens. Met beiden heeft Van Dieren het er vaker over gehad en met beiden was hij het niet geheel eens.

'Een tere kwestie' heet het hoofdstuk in De waanzinnige waereld dat handelt over het 'joodse vraagstuk', meer in het bijzonder over de 
vraag waarom het speciaal Joden zijn die gevoeliger zijn voor psychische besmettingen zoals het socialisme. Er zijn een hoop Joden onder de socialisten, constateerde Van Dieren (Marx, om te beginnen, natuurlijk), maar ook onder de intellectuelen, dus hoe zit dat eigenlijk: is het een 'gedegenereerd ras' of niet?

Zijn analyse ging als volgt: het joodse volk is 'hypernerveus', ten eerste vanwege inteelt en ten tweede vanwege de vervolgingen. Aan dat laatste kunnen ze niks doen. Komt nog bij dat het een volk is van 'uitersten': men treft er de mooisten en de lelijksten onder de mensen, de slimsten en de domsten, de conservatiefsten en de vooruitstrevendsten. Die uitersten houden elkaar wel min of meer in evenwicht, leek Van Dieren te zeggen. Maar juist ook omdat er zulke grote contrasten bestonden, zorgen ze samen voor wat leven in de brouwerij. Tegen Diepenbrock zei hij dat het 'de rol der Joden is het oude op te ruimen en het nieuwe te brengen', wat zijn vriend 'geniaal geformuleerd' vond, hoewel hij er wel bij aantekende dat het erop aankomt 'met welke verstande' dat opruimen in z'n werk zou gaan. ${ }^{37}$ Kortom, beweerde Van Dieren, zolang de Joden zich niet aan socialisme te buiten gaan is er niet zo veel aan de hand. 'Men denke zich alle Joden weg, wat zou er van Europa worden? Een duffe boel!' ${ }^{38}$

Huiveringwekkende zinnen voor een post-Auschwitz-lezer, maar anno I920 niet zo bijzonder of onredelijk. Integendeel, voor die stellingname zou hij enige erkenning krijgen. In een artikel in Het Vaderland met het Van Dierense opschrift 'Het Joodsche Gevaar' wordt de schuld voor het antisemitisme niet bij het semitische volk als zodanig gezocht, 'doch bij de vele gedegenereerden die het telt (lees dr. van Dieren) en men wijte het ook voor een deel aan de wrok, dien zij [de joden] koesteren tegen de volkeren, onder wie zij steeds woonden als vreemdelingen'. ${ }^{39}$

Rancune en verval: kernwoorden in het lexicon van Van Dieren.

Dat was dus zijn positie in I920. In datzelfde jaar schreef hij aan Bolland dat, als Spinoza in deze tijd had geleefd, hij beslist een bolsjewiek zou geweest zijn: 'hij heeft dezelfde manier van schrijven als Marx, Kautsky, Trotsky, Radek, Wijnkoop en andere gedegenereerde Joden en... niet Joden. ${ }^{40}$ Twee jaar later echter zou hij zijn standpunt in zoverre bijstellen dat hij het de joden nu toch vooral ook zélf aanrekende dat ze werden vervolgd. Over zijn gesprek met Bolland, dat in I9I9 moet hebben plaatsgevonden, zou hij toen zeggen dat ze het over allerlei kwesties 'volmaakt met elkaar eens waren', zoals bijvoorbeeld de jodenkwestie, en hij verwees daarbij naar diens zwanenzang $D e$ Teekenen des Tijds. ${ }^{41}$ Maar voor de conclusie uit dat betoog, dat ont- 
wrichting van de Europese samenleving op conto van het internationale jodendom moet worden geschreven, tekende hij niet, noch voor de consequentie die door anderen daaruit werd getrokken: dat er maar één geneesmiddel is, en dat is de vernietiging van het jodendom. ${ }^{42} \mathrm{Had}$ Bolland het nou gelaten bij zijn gefulmineer tegen de vermolmde, oppervlakkige en verkankerde beschaving die ten onder dreigde te gaan aan zedenverwildering en aan haar gepeupelregering, ja, dan had hij nog wel wat langer aan de voeten van de meester willen blijven zitten. ${ }^{43}$ Maar om de Joden overal de schuld van te geven? Dat ging ook Van Dieren toch te ver.

'Weet u wat uw ongeluk is?', vroeg een Joodse man op een keer aan Van Dieren. 'Nog niet', antwoordde hij, alsof hij een Joodse grap verwachtte, een Witz. 'Uw ongeluk is dat u alles veel te vroeg zegt. ${ }^{34} \mathrm{Te}$ vroeg - te laat - wat is een slecht getimede grap anders dan een belediging?

Halverwege de jaren twintig vond het antisemitisme bij Van Dieren zijn uiteindelijke beslag in de vorm van de redenering dat de Joden overal een 'rassenzaak' van maken door zich ten onrechte te beklagen over antisemitisme waar gerechtvaardigde kritiek op hun de christelijke moraal vijandige opvattingen op zijn plaats is. Voorbeeld: de 'spleetkijker' Freud, die meent dat kritiek op zijn 'zwijnerij' aan antisemitische drijfveren mag worden toegeschreven. 'Listige waanzin', noemde Van Dieren dat, en dat heeft niets te maken met het feit dat Freud een Jood is..$^{45}$

Het zou interessant zijn geweest om te weten hoe Van Dieren in de jaren dertig het oprukkende fascisme heeft beoordeeld, dat per slot enerzijds de 'hoge Duitse waarden' vertegenwoordigde, maar anderzijds ook het vulgaire antisemitisme, waarmee hij zich niet of in elk geval niet geheel kon verenigen, maar een duidelijk oordeel kunnen we ons niet vormen bij gebrek aan bronnen. $\mathrm{Nu}$ ja, een handvol aanwijzingen zijn er wel. In Besmettelijke zielsziekten noemt Van Dieren het fascistische weekblad De Bezem een tijdschrift dat 'de waarheid durft te zeggen', al had die opmerking maar een heel beperkte reikwijdte (namelijk betreffende het voetbal). Ook betoonde hij zich daar een ijverig lezer van de antidemocratische priester Wouter Lutkie (I 887-I968), van wie hij instemmend de uitspraak citeerde dat 'miskenning de hoogste onderscheiding is welke een mensch te beurt kan vallen'. ${ }^{46}$ Een handgeschreven opmerking van Van Dieren in de marge van een brochure, gericht aan de ontvanger, geeft een volgende indicatie: 'Help toch... want wij vergaan. ${ }^{{ }^{47}}$ Ter verduidelijking voegde hij eraan toe: “'Wij vergaan” is de titel van een mooi boek van Arnold Meijer.' 
Dat 'mooie boek' van Arnold Meijer (1905-1965), de latere leider van Zwart Front, bestond uit een 300 pagina's lange aan Bollands DeTeekenen des Tijds herinnerende tirade tegen het 'verrottingsproces' en het geestelijk verval in Europa, vooral het verlies aan godsdienstzin. Zowel Lutkie als Meijer was een uitgesproken bewonderaar van de Italiaanse fascist Mussolini en ze waren dat vanuit een diep gevoelde religieuze basis. Dat gold ook voor Van Dieren die op verschillende plaatsen in het latere werk hunkerde naar 'een kerel met knuisten', 'een "Mussolini"', die aan het 'slappe gepraatvaar' wel een einde zal maken. ${ }^{48}$ 'O, was ik maar zo machtig als Mussolini in Italië', verzuchtte hij meer dan eens, 'ik zou aan heel de flessentrekkerij in Holland een einde maken.' Boudewijn Büch leidde uit die laatste opmerking af dat Van Dieren een 'protofascist' zou zijn geweest, een aantijging die, denk $\mathrm{ik}$, alleen in zoverre juist is dat Van Dieren met zijn interesse voor $D e$ Bezem, het werk van Arnold Meijer en Lutkie en vooral Mussolini zich in de vroege jaren dertig een aanhanger van de Italiaanse variant van het fascisme betoonde, maar niet direct van het Duitse nationaalsocialisme. Of hij zich in de late jaren dertig met de NSB-politiek heeft kunnen verenigen weten wij niet, Van Dieren had het geluk dat hij juist op tijd is gestopt met schrijven. ${ }^{49}$

\section{Het geconstrueerde gelijk}

Denk aan een zaadje dat ontkiemt, en zich tegen de zwaartekracht in opricht. Het leven in het zaadje heeft stengel, stam en takken hemelwaarts, perst de sappen onder sterke druk omhoog. Maar een worm knaagt aan de stam, een bliksemstraal slaat in de boom, een houthakker velt de woudreus, een lekke gasleiding vergiftigt de grond - en de plant sterft.

De beeldspraak en het bijpassende taalgebruik is afkomstig van Felix Ortt, collega-querulant. ${ }^{50}$ Het sluit naadloos bij het Van Dierense gedachtegoed aan. Ook hij zou vaak spreken over zijn 'zaden' die op 'rotsachtige bodem' waren uitgestrooid en tot wasdom zouden komen. Hij moet daarbij gedacht hebben aan de bijbelse gelijkenis van het mosterdzaadje, het kleinste van alle zaden dat als het opkomt groter wordt dan alle andere planten: het wordt een boom, zodat de vogels in zijn takken komen nestelen. ${ }^{51}$ Toch zou geen enkele gedachte van hem ooit vruchtbaar zijn, en geen boek ooit gedachten dragen die door een navolger zou worden uitgedragen. Waarom niet?

De wereld waarover Van Dieren zijn zaden uitstrooide is letterlijk een 'geconstrueerde werkelijkheid' - een waanzinnige wereld, om zijn 
eigen titel te parafraseren. En toch is die wereld behalve waanzinnig ook reëel: reëel in de wijze waarop die is opgebouwd, reëel in haar consequenties bovendien. Wie het werk van Van Dieren leest raakt verzeild in een schemerwereld die met de echte wereld dit gemeen heeft: dat ze niet zonder meer bestaat, maar alleen in reactie op het spreken, schrijven, denken en doen (en niet doen en niet schrijven) van anderen kan ontstaan. Het is een schaduwwereld waarin alles vlakker, donkerder is als in het echt. En desondanks wijkt de wereld waarin Van Dieren zichzelf situeert niet eens zo heel veel af van de realiteit zoals wij die kennen. Ze loopt er in feite parallel aan, volgt al haar bewegingen, maar raakt haar toch nooit aan. Een zaadje dat ontkiemt en zich steeds verder de grond inboort, in de rotsvaste overtuiging dat niet hij, maar de wereld op z'n kop staat. “'O zaaier zaai en lijd maar voort.” Als het zaad op rotsachtige bodem valt, dan kan het geen vrucht voortbrengen. Kan ik het helpen dat mijn landgenooten niet naar mij luisteren. I $k$ ga vrijuit. Mijn landgenooten niet. ${ }^{92}$ 


\section{4 \\ De geboorte van een idee-fixe}

De ontdekking van de oorzaak van beriberi vormt een fascinerend hoofdstuk in de geschiedenis van de medische wetenschappen. Het heeft een mensenleven geduurd voordat duidelijk werd wat beriberi was en wat haar oorzaak (gebrek aan vitamine B). De periode waarin dat werd onderzocht valt volledig samen met de werkzame levens van Christiaan Eijkman, die een kleine tien jaar onderzoek naar beriberi heeft verricht en uiteindelijk de hoogste wetenschappelijke onderscheiding zou krijgen die er bestaat voor zijn bijdrage aan de ontdekking van de vitaminen, en Van Dieren, die als 'leunstoelonderzoeker' een levenslange vete uitvocht met Eijkman en hem tevergeefs de ontdekking van de oorzaak van beriberi trachtte te ontzeggen.

Parallel aan die broederstrijd, die steeds duidelijker in het voordeel van Eijkman uit kwam te vallen naarmate de geschiedenis zich ontvouwde, loopt een lijn in tegengestelde richting die ons steeds verder in de geschiedenis terugvoert. Dat is de zoektocht naar de oorsprong of bron van het dilettantisme. De twee lijnen komen samen in het beriberiwerk van Van Dieren, dat we dus kunnen lezen als een onderzoek naar de oorsprong van een idee-fixe. Hier volg ik beide lijnen, met als gevolg dat ik mij in twee richtingen door de geschiedenis zal begeven: vooruit en achteruit tegelijk.

\section{Beriberi}

Het is een van de meeste raadselachtige tropische ziekten die de aarde heeft geteisterd: de beriberi pakt haar slachtoffer onaangekondigd op en ontneemt hem sluipenderwijs of heel plotseling al zijn krachten. Of de patiënt het zou overleven kon niemand zeggen (de mortaliteit liep op tot tien of twintig procent, soms nog veel hoger, al naar gelang het seizoen en de plaats).

Van deze aandoening, waaraan sinds de zeventiende eeuw, toen ze voor het eerst werd beschreven, vele tienduizenden, misschien wel 
honderdduizenden, stierven, wist men tot ver in de negentiende eeuw eigenlijk helemaal niets af. Jacob Bontius, die er zelf aan had geleden, schreef in 1769: 'Een uiterst moeilijke aandoening, die de inlanders "Beriberi" (dat wil zeggen schaap) noemen, tast hier de menschen aan. [...] Het is een soort van verlamming, beter nog van beven: want zij doet de beweging en het gevoel der handen en der voeten, en soms zelfs van het geheelen lichaam veranderen en laat beven. [...] Dikwijl wordt ook de stem aangetast, waardoor de zieke bijna niet articuleren kan wat mij zelf overkomen is, toen de klank van mijn stem, terwijl ik aan die ziekte leed, gedurende een geheele maand zoo zwak was, dat zelfs wie dicht bij mij zat, mij nauwelijks verstaan kon.'

De etymologische afleiding van de term beriberi is niet correct (het voert terug tot het Singaleese woord voor zwakte), maar dat laat onverlet dat Bontius het referentiepunt vormt voor iedereen die over de beriberi schrijft, vele malen ontdekt en herontdekt. Dan komt er een hele tijd niets en dan het onderzoek van Christiaan Eijkman uit de jaren negentig van de negentiende eeuw, dat de aanzet gaf tot de uiteindelijke oplossing van het raadsel. Daartussen ligt een jammerlijk mislukte expeditie van Pekelharing en Winkler, uit I886-I887, die meestal alleen wordt genoemd als opstapje voor een verdere beschrijving van Eijkmans werk. Voor ons vormt dat korte moment, het jaar van Pekelharing en Winkler, het uitgangspunt van waaruit we de geschiedenis in zullen stappen.

Het verhaal begint op het moment dat de Nederlandse regering besluit om een expeditie uit te rusten wier taak het zou moeten zijn de oorzaak van de beriberi te achterhalen. De directe aanleiding vormt het almaar oplopende aantal slachtoffers dat aan deze ziekte ten prooi viel onder de Nederlandse militairen die in het kader van de Atjeh-oorlog naar Nederlands-Indië werden verscheept.

Als hoofd van de expeditie werd de patholoog Cornelis Pekelharing (I 848-I922) aangesteld, gesecondeerd door Cornelis Winkler (I855I94I), neuroloog. Misschien waren juist zij gevraagd de expeditie op te zetten, omdat zij als nog jonge enthousiaste onderzoekers een rotsvast vertrouwen hadden in de bacteriologie, de door Koch ontgonnen veelbelovende wetenschap die hele nieuwe perspectieven had geopend in het medische landschap welke Neerlands niet aflatende expansiedrift wel eens goed van pas kon komen in het Verre Oosten, waar de inheemse zowel als de eigen soldaten massaal ten prooi vielen aan de beriberi (op dat moment onder medici nog als een epidemische ziekte gezien). 'Medicine followed trade and flag', schrijft Roy Porter in Boold \& Guts. ${ }^{2}$ 
Pekelharing en Winkler legden voorafgaand aan hun expeditie een kort studiebezoek af bij Robert Koch in Berlijn, en de door Eijkman zelf met smaak vertelde legende wil dat hij daar, in café Bauer, als een nog piepjonge en veelbelovende onderzoeker Cornelis Winkler tegen het lijf zou zijn gelopen, en dat hij, toen hij over het doel van de expeditie was ingelicht, zou hebben geroepen 'Kan 'k mee?'. 'Ter plekke zou zijn besloten dat Eijkman deel zou worden van de expeditie toen bleek dat hij het 'infectionisme' was toegedaan en bovendien al ervaring had in de tropen. 'Gezegend toeval...' merkte Eijkman later op. ${ }^{4}$ Volgens anderen is het anders gegaan en werd Eijkman op voorspraak van Koch meegenomen. Een laatste opvatting wil dat Winkler en Pekelharing Eijkman hebben verzocht om aan de expeditie te worden toegevoegd. Mij lijkt een combinatie van alle drie de opvattingen waarschijnlijk. De medische wereld was niet zo groot dat Pekelharing niet allang van het werk van Eijkman op de hoogte moet zijn geweest, terwijl omgekeerd Eijkman van de op handen zijnde expeditie op de hoogte moet zijn geweest en mogelijkerwijs daarvoor zijn belangstelling kenbaar had gemaakt; een aanbeveling van Koch kan daarbij alleen maar tot zijn voordeel hebben gestrekt - niettemin kan de ontmoeting in dat café toevallig zijn geweest. Hoe het ook zij: hij werd zonder mankeren als assistent aan de expeditie toegevoegd. ${ }^{5}$

De onderneming duurde een klein jaar, van november I 886 tot augustus I887. In de zomer meende Pekelharing een beriberibacil in het bloed van de beriberilijder te hebben ontdekt, of liever gezegd, zes varianten daarvan, 'de cocci Pekelharingii' gedoopt. Of nog liever gezegd: zes varianten die vaak voorkomen in het bloed van beriberipatiënten. En nog preciezer: die vaak voorkomen in het bloed van beriberipatiënten, maar ook in het bloed van niet-beriberipatiënten.

Daarmee voldeed de Pekelharingse bacil wel helemaal niet aan de 'postulaten van Koch', de onderscheidende criteria waaraan je een bacterie kunt herkennen, maar daar stond tegenover dat Pekelharing van een van die bacillen meende een zuivere 'micrococcus-cultuur' te hebben gekweekt, en zo leek het er dan toch weer sterk op dat de beriberi een infectieziekte zou zijn, zoals bij voorbaat al gehoopt was. Dat bleek later toch niet te kloppen, maar, werd er in de biografie van Pekelharing op ietwat apologetische toon geschreven, op dat moment in de geschiedenis kon ook helemaal niet van hem verlangd worden dat hij de oplossing van het beriberiraadsel zou vinden. ${ }^{6}$

Er werd een provisioneel rapport opgesteld, er werden voorlopige aanbevelingen gedaan (grondige desinfectie van de lokalen waar beriberi wordt aangetroffen), en de expeditie kon huiswaarts keren. Eijkman 


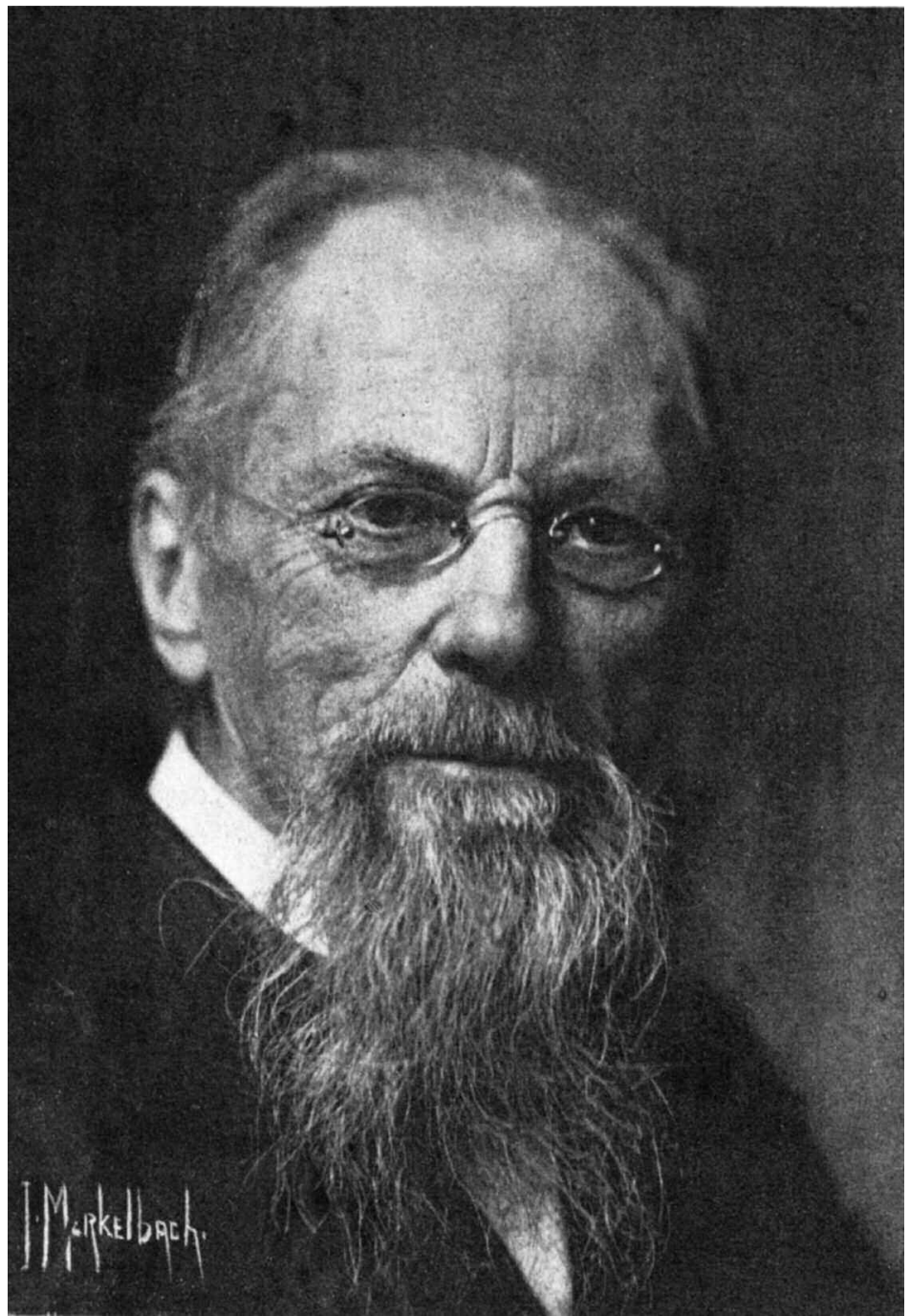

Cornelis Pekelharing en de beriberi-expeditie: nieuwe perspectieven in het medische landschap welke Neerlands niet aflatende expansiedrift wel eens goed van pas kon komen in het Verre Oosten.

echter bleef achter in Batavia; hij werd op voorspraak van Pekelharing aangesteld als directeur van het nieuw op te richten 'Laboratorium voor onderzoekingen op het gebied der pathologische anatomie en bacteriologie' in Weltevreden, met als doel het beriberiprobleem definitief op te lossen. Het 'laboratorium met de lange naam' bestond uit een 
paar kamertjes, praktisch zonder voorzieningen. De omstandigheden waaronder gewerkt moest worden waren beroerd. 'Een nachtmerrie', zou Eijkman later zeggen, die acht jaar zou duren. Op Eijkman komen we later terug; we vervolgen eerst de loop van de geschiedenis.

\section{De entree}

Het einde van de expeditie Pekelharing vormt het punt waarop Van Dieren zijn entree in de geschiedenis van de beriberi maakte. Van Dieren vormde op zijn eentje een schaduwonderzoeksteam. Want weliswaar bleef hij thuis en zou hij nooit voet op Indische bodem zetten, stil zat hij niet. Driftig verzamelde hij al het materiaal dat door Pekelharing en de zijnen werd afgescheiden, wachtend op het juiste ogenblik om toe te slaan. Dat kwam luttele maanden nadat Pekelharing zijn ontdekking via de pers prijsgaf: beriberibacterie ontdekt; grootscheeps desinfecterende maatregelen aangekondigd.

Voor Van Dieren vormde die media-aandacht aanleiding om met een eigen brochure naar buiten te treden, brutaalweg getiteld Critiek op de beweringen van Prof. Pekelharing omtrent de Beri-Beri. Zijn kleine I 8 pagina's tellende opstel is feitelijk niet meer dan een voetnoot bij het onderzoek van Pekelharing dat op dat moment nog niet eens was verschenen. Een vooruit snellende voetnoot dus, maar wat voor een voetnoot. Zonder enige plichtpleging valt de schrijver met de deur in huis.

Het is mijn doel een critiek te leveren op het door den heer Prof. Pekelharing omtrent de beri-beri beweerde [...]. Ik stel mij in de eerste plaats voor aan te tonen, dat Prof. Pekelharing eenzijdig te werk ging, toen hij de oorzaak der beri-beri meende te moeten zoeken in een bacterie, en tweedens zal ik trachten duidelijk te maken, dat de proeven, welke door hem werden genomen en die dit moesten bewijzen, geen steek houden. Welnu dan. ${ }^{7}$

Welnu dan, een aanloopje, een sprong, en de schrijver bevindt zich in de ruimte van het geschreven woord. Zij die gaan schrijven groeten $\mathrm{u}$.

\section{De heer Van Dieren}

De schrijver stuurde recensie-exemplaren van zijn brochure op aan alle kranten en medische tijdschriften die hij kende, en overigens ook aan Pekelharing en Winkler zelf, en hij slaagde erin op die manier flink wat 
respons los te weken. Enkele krantenrecensies waren gematigd positief, of in elk geval neutraal. Maar de vakbladen bleken aanmerkelijk minder te spreken over de jonge (want net zesentwintig jaar oude) volslagen onbekende officier van gezondheid die het had bestaan een gerespecteerde onderzoeker publiekelijk de les te lezen.

Delprat sabelde het opstel neer voor het gerenommeerde Nederlands Tijdschrift voor Geneeskunde: 'Deze brochure werd door den schrijver aan de Redactie van ons Tijdschrift toegezonden. Wij zouden wellicht de aankondiging daarvan achterwege hebben gelaten, indien niet de inhoud deze brochure door eenige nieuwsbladen in ruimer kring verspreid was. Getuigt reeds de titel van weinig waardeering van den arbeid van Prof. Pekelharing, de inhoud draagt hiervan doorloopend het kenmerk en kan op den naam van critiek nauwelijks aanspraak maken."

Van der Burg deed hetzelfde voor het Nederlandsch Militair Geneeskundig Archief, waar hij zijn ergernis uitsprak over het 'hoge standpunt dat de heer Van Dieren in zijne brochure aanneemt, van waaruit hij Prof. Pekelharing met ongevraagde adviezen overstroomt'. Zijn conclusie luidde dat de kritiek van Van Dieren voorbarig was, getuigde van 'onvoldoende voorafgaande studiën' en bovendien was geschreven in een toon 'die het vermoeden wekt dat de schrijver niet onverschillig zou blijven als zijn naam onder de meer dan tweehonderd schrijvers over beri-beri ook eene plaats kreeg'. De brochure droeg volgens Van der Burg niets bij tot de kennis van beriberi en deed ook geen afbreuk aan het werk van Pekelharing en Winkler, 'die door zulk een schrijven wel niet in hunnen rustigen arbeid gestoord zullen worden'.'

Van de heren onderzoekers zelf zou alleen Winkler van zich laten horen. In een voordracht die hij een paar weken na de publicatie van de brochure hield dacht hij de bezwaren van Van Dieren af te kunnen doen door zich te beroepen op de 'gunstige resultaten' van de desinfecterende maatregelen in de tropen.

Dat was een weinig bemoedigend begin, maar zo gemakkelijk liet Van Dieren zich niet afschepen. In een nieuwe brochure, getiteld Nogmaals: De Beri-Beri-Kwestie, kregen alle critici er duchtig van langs. Delprat had hem verweten zijn kritiek op niet één feit te hebben gebaseerd, maar slechts op gissingen. Niks gissingen, blafte Van Dieren: de kritiek berust op tal van feiten. Zo is het een niet te ontkennen feit dat er tussen beriberi en de kriebelziekte overeenkomsten bestaan, schreef hij. ${ }^{10}$ Winkler durfde te juichen over de goede resultaten der desinfectie? Dat werd hem zwaar aangerekend. 'Wat is nu gebleken? De desinfectie heeft, helaas! niet geholpen.' Integendeel. Krantenberichten doen 
vermoeden dat ze niets uithalen, schreef Van Dieren. Zo stond in de Javabode van II februari I 888 te lezen dat alleen al in de maand januari meer dan I 300 mensen door beriberi waren aangetast: op dergelijke cijfers valt niet te roemen. ${ }^{11}$ En tot slot dan dr. Van der Burg die, zo meende Van Dieren, hem niet op grond van argumenten probeerde te verslaan, maar in plaats daarvan 'heeft getracht mij op grond van eenige woorden het recht te critiseren te ontzeggen' ${ }^{12}$ Welnu, woorden bleek Van Dieren opnieuw tot zijn beschikking te hebben. Genoeg om er 85 pagina's mee te vullen en een nieuwe brochure het licht te doen zien.

Ook deze brochure zou zijn rondgang langs de media maken, en ook nu weer zou Van Dieren het nodige stof doen opwaaien. Dezelfde recensenten schreven in dezelfde kranten en tijdschriften dezelfde soort besprekingen. Ongunstiger weliswaar, maar ook daarop zou hij weer reageren. Aldus verschafte Van Dieren zichzelf een middel waarmee hij zijn polemiek kon voortzetten en waarmee hij voortdurend de aandacht wist te trekken. Al met al een vliegende start, een entree die een onuitwisbare indruk wist te maken. Dit zou weleens het begin kunnen zijn van een bloeiende vete.

Is het dus met de brochure Critiek op Prof. Pekelharing allemaal begonnen? Is dit de oorsprong van de waan, de bron van dat altijd maar overlopende gemoed waaruit Van Dieren steeds weer zou putten?

\section{Een alternatief}

Voordat we die vraag kunnen beantwoorden doen we er verstandig aan te onderzoeken wat Van Dieren nog meer te zeggen had. De Critiek bevat namelijk niet alleen een rechtstreekse aanval op Pekelharing, in een tweede gedeelte wordt ook een alternatieve verklaring voor het ontstaan van beriberi gezocht: het is geen infectieziekte maar een vergiftiging, veroorzaakt doordat de rijst te lang wordt bewaard, gaat rotten en tijdens het rotten een vergift produceert. 'De aard der ziekte laat [toe] een vergift als oorzaak aan te nemen', schreef Van Dieren. Zenuwontaarding, zoals bij beriberi wordt gevonden, kan ook veroorzaakt worden door vergiftiging, zoals door lood, arsenik, alkohol en door bestanddelen van moederkoren..$^{13}$

Op deze plek in zijn betoog aangekomen ontvouwde Van Dieren een historische parallel. In de veertiende eeuw was er een soortgelijke ziekte als de beriberi die eveneens een epidemisch voorkomen had en die bovendien precies dezelfde symptomen kende. Dit was de kriebelziekte, veroorzaakt door 'moederkoren'; een giftige zwam die zich in 
het gewas (maïs) ophoudt en sluipenderwijs degene die er van eet doodt. Zet je die twee ziekten naast elkaar, dan valt uit de vergelijking een 'alternatieve veronderstelling' af te leiden, schreef Van Dieren, namelijk dat de aard en verspreiding van de beriberi evengoed op een vergiftiging kan duiden als op de veronderstelling van Pekelharing dat het een infectie is. ${ }^{14}$

Langzaam komt de machine op gang: een historische parallel - kritiek op de gevestigde orde - een alternatieve verklaring - die evengoed naast de veronderstelling van anderen mag staan. Hij bedacht er de term 'critisch-historische methode' voor en ontsloeg zich daarmee van de verplichting zelf op onderzoek uit te hoeven gaan. Bovendien verschafte hij zichzelf zo een alibi om alles wat zijn tegenstanders zeiden of schreven tegen het licht te houden en van een andere betekenis te voorzien.

In de 'critisch-historische methode' zijn 'feiten' aan elkaar verbonden met behulp van inductieve hypothesen. Van Dieren vatte bijvoorbeeld de klinische observatie dat bij moederkoren bepaalde symptomen horen op als een 'feit', net zoals hij het een 'feit' vond dat bij beriberi dezelfde symptomen horen. Uit die 'feiten' volgde de hypothese dat de twee ziekten door hetzelfde principe moesten worden veroorzaakt, en wel: vergiftiging als gevolg van rottingsprocessen in het gewas. Door nu maar genoeg 'feiten' te verzamelen wordt de hypothese uiteindelijk 'bewezen', redeneerde Van Dieren, en hij putte zich dan ook uit in overzichtjes waarin naast elkaar de ziekten en hun bijbehorende symptomen werden gezet, als onweerlegbaar bewijs van zijn stelling.

Tegenover deze benadering moet de experimentele methode worden geplaatst, door onderzoekers als Pekelharing, Eijkman en anderen gehanteerd, die min of meer de omgekeerde weg volgt. De vergiftigingshypothese van Van Dieren is daarin pas interessant als in een experimentele opzet duidelijk gemaakt kan worden dat alleen vergiftiging tot deze ziekte leidt, en niets anders. 'Feiten' zijn in deze benadering blind: ze krijgen pas betekenis als blijkt dat ze ertoe doen. Voor Van Dieren geldt nu juist dat er tussen 'feit' en 'theorie' geen principieel verschil bestaat: ze brengen elkaar voort en ze versterken elkaar.

Behalve dat er een methodische scheidslijn liep tussen het streng wetenschappelijke denken van de specialist Eijkman, die kennis vergaarde door middel van experimentele toetsing van hypothesen, en het inductieve denken van de generalist Van Dieren die op basis van observaties de werkelijkheid benaderde, liep er ook een inhoudelijke scheidslijn tussen de twee over de status van kennis over de werkelijkheid. 'Kennis' betekende voor hen beiden iets wezenlijk anders. Voor Van 
Dieren bestond kennis uit de totaliteit van indrukken en de logische verbanden die daartussen kunnen worden gevonden, en was het resultaat een zekerheid waarop je moest vertrouwen. Voor Eijkman bestond er in de strikte zin van het woord geen 'kennis': er waren alleen hypothesen die na onderzoek (voorlopig) werden vastgesteld of niet, maar vooropstond altijd onzekerheid, scepsis, misschien zelfs wantrouwen ten aanzien van de werkelijkheid. Ja, als er iets is dat het werk van Eijkman kenmerkt, dan is het wel de fundamentele twijfel die hij zelfs niet wilde opgeven toen anderen al lang waren overtuigd van de ontdekkingen die hij had gedaan, maar waaraan hij nog steeds geen definitieve status durfde toe te kennen.

Het is misschien wat te makkelijk om de opvattingen van Van Dieren als typische lekenopvattingen te kwalificeren, en die van Eijkman als een expertbenadering, maar feit is dat Van Dieren het experiment nooit heeft willen erkennen als een legitieme manier om te komen tot kennis, en misschien zelfs wel nooit het fundamentele verschil tussen die benadering en zijn eigen benadering heeft ingezien. Hij is zijn leven lang onvoorwaardelijk in de kritisch-historische methode blijven geloven, en als er iets onwetenschappelijk in zijn benadering genoemd kan worden is het misschien juist wel dat gebrek aan kritische reflectie.

In de jaren tachtig, een stuk of wat artikelen verder inmiddels, was de historische parallel met het moederkoren al uitgegroeid tot een vergelijking met ergotisme, pellagra, acrodynie en pelade. Allemaal vergiftigingsziekten die lijken op de beriberi en dus ook allemaal 'bewijzen' voor het ongelijk van Pekelharing vormen. In zijn meelvergiftigingenboek uit 1907 komen daar ook nog psychische vergiftigingsziekten bij (het socialisme) en in de jaren dertig bereikt de parallel het natuurlijke eindpunt van de querulantenwaan wanneer alles met alles blijkt samen te hangen, en dus ook met de beriberi.

Maar terwijl de bewijslast voor zijn beriberihypothese zich in de loop der jaren ophoopt als oud roest op een autokerkhof, zal het moment waarop de oorspronkelijke vergelijking tussen beriberi en een vergiftigingsziekte postvatte steeds verder de geschiedenis in worden geschoven.

Van Dieren zelf zal het exacte begin van zijn obsessie met de beriberi in I9I 5 , in een van zijn latere geschriften dus, geschreven dertig jaar na dato, situeren op een middag in de maand februari van het jaar I 885, dus nog twee jaar voor zijn aanval op Pekelharing. Hij liep toen juist als assistent-chirurg in het Nederlands Israëlitisch Ziekenhuis wacht, toen er een uit Indië afkomstige patiënt werd binnengebracht die leed aan de 'Indische spruw'. 
Op studie had ik nog nooit van Indische spruw gehoord, en ik begreep derhalve in dat oogenblik nog beter dan te voren, dat er nog wel het een en ander aan mijn medische vorming ontbrak. Hoe daarin te voorzien? In het hospitaal bevond zich een bibliotheek, grootendeels afkomstig van de vroegere Utrechtsche school tot opleiding van militair geneeskundigen; daarin hoopte ik opheldering te vinden. Ik zocht dus en vond... een boek van August Hirsch over de "historisch-geografische pathologie”. Reeds de titel alléén was voor mij een openbaring. Ja, dáár moest het van komen - dacht ik -; ervaringen uit alle tijden en van alle plaatsen moeten bijeengevoegd, gecontroleerd, vergeleken en beredeneerd worden; zóó doende zullen we op menig gebied de waarheid op het spoor komen.

'K had vier en twintig uren de wacht, en derhalve tijd genoeg om te lezen; maar 'k làs niet, ik verslond het boek. In het hoofdstuk, handelend over de intoxinatie-ziekten vond ik niet alleen de door ondeugdelijk koren veroorzaakte Ergotismus uitvoerig beschreven, maar ook de aan ondeugdelijke maïs toegeschreven Pellagra en Pelada, en tevens de daarmede weleens vergeleken Acrodynie, die in de twintiger en dertiger jaren in Belgie en Frankrijk heerschte en door de geneesheeren toegeschreven werd aan het gebruik van ondeugdelijk graan.Vervolgens viel mijn oog op de beri-beri. Ook van dèze ziekte was mij alléén de náám bekend, en wel uit de eentonige krantenberichten [...]. Onder het lezen werd ik getroffen door de groote overeenkomst met Ergotismus, Pellagra en Acrodynie; ook hierbij was het zenuwstelsel ziek, wat bleek uit de bewegings-, gevoels- en voedingsstoornissen [...]. [Hoe] verder ik in het onderwerp doordrong, des te duidelijker werd mij dat verband; máár... des te schichtiger werd ik óók! Ik had nl. in die dagen nog een véél te hogen dunk van mijn medemenschen; het wilde er maar bij mij niet in, dat al die mannen, en daaronder vele met klinkende titels en anderen, die dikke boeken geschreven hadden, zulk een eenvoudige waarheid over het hoofd zouden gezien hebben; en telkens kwam de verlammende gedachte bij mij op, dat ik het wel mis moest hebben, dat mij op dien grooten afstand wel iets ontgaan zou zijn, wat al die geleerden, die er immers met hunne neuzen vlak boven op lagen, al lang moesten hebben opgemerkt. ${ }^{15}$

Deze geschiedenis is, vind $\mathrm{ik}$, de moeite waard om wat uitvoeriger te citeren, omdat het immers niets minder lijkt dan een getuigenverslag uit de eerste hand van de bevalling van een idee-fixe, en in ieder geval in toon authentiek aandoet. De ontdekking dat al die geleerde mannen met hun klinkende titels met hun neus boven op de eenvoudige waar- 
heid zaten, maar ze niet zagen, herinnert ons aan de passage over zijn vader 'die er een veel betere kijk op had dan alle sportartsen bij elkaar'. Maar ook aan de historische juistheid van het eerste deel van de anekdote kan wel nauwelijks worden getwijfeld, al was het maar omdat de naam Hirsch ons nog voor verrassingen zal doen staan.

Het boek waar Van Dieren in het bovenstaande citaat naar verwijst, is het grote overzichtswerk Handbuch der historisch-geographischen Pathologie dat oorspronkelijk in twee delen tussen I860-I864 was verschenen en de verspreiding van alle mogelijke chronische infectie- en vergiftigingsziekten behandelt vanuit een historisch perspectief. Van Dieren gebruikte de tweede, vermeerderde editie, waarvan de eerste twee delen juist waren gepubliceerd en het derde deel nog moest verschijnen.

De Berlijnse hoogleraar en medisch-historicus August Hirsch (I8I7-I894) wordt tot de 'voor-bacteriologen' gerekend, omdat het leeuwendeel van zijn werk, waaronder de eerste editie van zijn Handbuch, verscheen voor de ontdekking van de tbc-bacil in I882. Maar de tweede editie van het handboek verscheen kort nadat Koch zijn ontdekking had gedaan, en de impact ervan is in de tweede editie van dat werk al naspeurbaar. Hirsch was nog niet bereid de traditionele opvattingen op te geven ten gunste van de nieuwe bacteriologie, maar realiseerde zich terdege de claims die de nieuwe discipline op het vakgebied legde, zoals blijkt uit het hoofdstuk 'chronische voedingsziekten', waarin we de beriberi terugvinden. Hirsch bespreekt daarin eerst uitgebreid de geschiedenis en geografische verspreiding van beriberi en de verschillende mogelijke factoren in haar etiologie, zoals de invloed van de luchtvochtigheid, de bodemgesteldheid, de levenswijze en conditie van de zieke. Onder verwijzing naar studies van Overbeek de Meyer en Van Leemt, die later door Van Dieren als zijn voorlopers zouden worden opgeëist, gaat Hirsch dan in op de mogelijke invloed van (onvoldoende) voeding, met name een gebrek aan eiwitten en vetstoffen. Hirsch wijst die hypothese niet af, maar noemt ook de mogelijkheid dat niet gebrekkige voeding maar een of andere gifstof in de voeding een rol kan spelen. Hij schrijft: 'het vermoeden dat een bepaalde, door de omgeving gedetermineerde specifieke schadelijke factor in de voeding deze ziekte veroorzaakt ligt voor de hand, en hypothesen in die richting zijn dan ook niet uitgebleven. Eerder werd de vraag opgeworpen of misschien niet een giftige toestand in de (bedorven) rijstkorrel de etiologische factor uitmaakt. ${ }^{16}$ Aan het eind van het hoofdstuk wijst Hirsch er ten slotte op dat het vooralsnog niemand gelukt is de oorzaak van beriberi in het nosologisch systeem onder te brengen, maar dat het 
'onverstandig' zou zijn de ziekte onder de infectieziekten te scharen, en dat het nog onverstandiger zou zijn om het etiologisch onderzoek zonder meer aan de moderne bacterierage toe te vertrouwen. ${ }^{17}$

Uit deze discussie kan moeilijk iets anders worden geconcludeerd dan dat Hirsch' handboek al alles bevat wat Van Dieren in zijn polemiek tegen Pekelharing zou inbrengen, en eigenlijk ook alles wat hij er daarna nog over zou zeggen. Constateren we vervolgens ook nog dat onder het hoofdje 'vergiftigingen' bij Hirsch Ergotismus, Pellagra, Acrodynie en Pelade in exact dezelfde volgorde die Van Dieren later zou geven worden behandeld, inclusief de interessante geschiedenissen, dan ligt het voor de hand te concluderen dat Van Dieren Hirsch heeft overgeschreven. Als dat wat onaardig klinkt, zou ook kunnen worden gezegd dat hij niets anders heeft gedaan dan zich diens standpunt eigen te maken en het keer op keer onder de aandacht te brengen, aanvankelijk zonder bronvermelding, later met verwijzing naar dat handboek en ten slotte in uitgebreide citaten daaruit, met in vette letters in de marge: 'een waarschuwing van August Hirsch. ${ }^{18}$ Uiteindelijk identificeerde Van Dieren zichzelf zodanig met Hirsch dat hij zijn beriberiboeken er uiterlijk net zo liet uitzien: als grote dikke folianten die alleen al daardoor in gewicht zouden moeten winnen.

Mogen we hieruit concluderen dat in dat handboek van Hirsch de bron van Van Dierens idee-fixe ligt, of moeten we nog verder terug de geschiedenis in om de bron van de waan op te sporen? Het antwoord op beide vragen luidt nee. Dat moment ligt niet verder terug de geschiedenis in: het ligt buiten hem. En het heeft een naam: Eijkman.

\section{Eijkman}

Het levensverhaal van Christiaan Eijkman lijkt op dat van Van Dieren, met dit grote verschil dat hij wel werd wie hij moest zijn. Geboren te Nijkerk in 1858 , en daarmee slechts drie jaar ouder dan Van Dieren, was Eijkman eveneens afkomstig uit een niet al te bemiddeld gezin (zijn vader was kostschoolhouder) en zou hij een vergelijkbaar traject afleggen. Ook hij had de hbs doorlopen en ook hij kwam, net als Van Dieren, de universiteit binnen als 'pil' en ook hij zou dus na zijn studie als officier van gezondheid in het leger hebben te dienen. ${ }^{19}$

Anders dan Van Dieren echter excelleerde Eijkman al tijdens zijn studie (hij studeerde in I 88 I cum laude af) en hij kreeg na het afleggen van aanvullende examens toegang tot het doen van onderzoek. In I 883 resulteerde dat in een promotie, opnieuw cum laude, bij T. Place, een leermeester die op hem 'diep heeft ingewerkt'. Nu was gebleken dat hij 
de mogelijkheden tot 'belangrijker werk dan dat van een officier van gezondheid in zich had', zou men hem niet aan de letter van de overeenkomst houden en werd Eijkman in de gelegenheid gesteld verder wetenschappelijk onderzoek te verrichten. ${ }^{20}$

Dat Eijkman wel en Van Dieren niet promoveerde zou voor de laatste in de loop der jaren een steeds belangrijker teken van onderscheid worden. Eijkman zou uiteindelijk professor worden en in I929, een jaar voor zijn dood, de Nobelprijs ontvangen voor zijn werk. Van Dieren bleef de rest van zijn leven huisarts. Zijn grootste verdienste bestond eruit door iedereen genegeerd te worden. Zou er een Nobelprijs voor miskenning hebben bestaan, Van Dieren zou hem zeker hebben ontvangen.

Eijkman werd in I 883 uitgezonden als onderzoeker naar Nederlands-Indië, kwam echter in I 885 met ziekteverlof terug nadat hij malaria had opgelopen. Eenmaal in Nederland besloot hij zich te verdiepen in het dan nog gloednieuwe vakgebied van de bacteriologie en bracht hij enige tijd door in het laboratorium van Robert Koch. Nog datzelfde jaar werd Eijkman samen met Winkler door Pekelharing aangezocht als lid van de eerdergenoemde onderzoekscommissie. ${ }^{21}$

Toen de expeditie na een klein jaar huiswaarts keerde bleef Eijkman, zoals gezegd, achter op Batavia om op voorspraak van Pekelharing te worden aangesteld als directeur van het zojuist opgerichte onderzoekslaboratorium met de bedoeling het beriberivraagstuk verder te bestuderen. Hij zou er de komende acht jaar ploeteren op de beriberi zonder veel vooruitgang te boeken. Een experimentele studie, gepubliceerd in 1890 , deed verslag van een op beriberi gelijkende ziekte bij twee van zijn zes proefkippen. Eijkman dacht aan een infectie, maar besefte dat voeding ook een rol van belang moest hebben gespeeld. Vervolgonderzoek leverde niets op. In I 894 was hij nog even ver als vier jaar eerder, maar hij had nu wel bereikt dat de rol van infectie in ieder geval op geen enkele manier kon worden bewezen.

In 1896 keerde Eijkman andermaal terug naar Nederland en ditmaal voorgoed. In hetzelfde jaar verscheen zijn artikel 'Polyneuritis bij hoenders', waarin hij liet zien hoe aan beriberi verwante verlammingsverschijnselen experimenteel kunnen worden opgewekt met behulp van een bepaald eenzijdig dieet, te weten witte rijst, en dat omgekeerd, in het beschermende vlies rond de kern van de korrel een bestanddeel moest zitten dat stoffen bevat 'die voor het behoud van het leven en de gezondheid onmisbaar zijn'. Het is met dit artikel dat hij de basis legde voor de uiteindelijke oplossing van het beriberivraagstuk, namelijk de ontdekking van vitaminen, en hoewel dat nog drie decennia op 
zich liet wachten zou Eijkman er wel nog net op tijd voor worden onderscheiden.

\section{Read my lips}

Het is ook met dit artikel uit I 896 dat Eijkman zich de woede van Van Dieren op de hals haalde. Immers, zei Van Dieren, was het hem in I 887 al opgevallen dat beriberi vooral daar voorkomt waar witte (gepelde) rijst wordt gegeten. Tegenover de infectiehypothese van Pekelharing cum sui stelde hij toen de gedachte dat beriberi door verrotting van de rijst wordt veroorzaakt en pleitte hij voor een verandering in het dieet: minder gepelde rijst, meer nevenvoeding. Eijkman had zich daar toen niet in kunnen vinden en was de infectietheorie blijven onderzoeken. Daarvan had hij nu blijkbaar afstand gedaan. Maar terwijl het erop leek dat er dan eindelijk een omslag zou plaatsvinden in het beriberionderzoek, moest Van Dieren tot zijn ontzetting bespeuren dat de onderzoeker het wéér niet wilde begrijpen. Zijn bijna tien jaar eerder gelanceerde vergiftigingshypothese werd opnieuw afgewezen, ditmaal ten gunste van de gedachte dat iets in de rijst beriberi voorkómt in plaats van veroorzaakt. 'God betere het', kreunde Van Dieren, 'door twee kippen liet Dr. Eijkman zich verleiden, den rechten weg, dien ik hem 9 jaren lang gewezen had, te vermijden en een verkeerd zijpad in te slaan. ${ }^{22}$

In hedendaagse terminologie uitgedrukt zou het heten dat Eijkman volgens Van Dieren aan een 'tunnelvisie' leed. Maar dat verwijt keert zich, zoals bekend, makkelijk tegen de aanklager zelf, en inderdaad kan het Van Dieren niet ontzegd worden behept te zijn geweest met een minstens even hardnekkige starheid van opvattingen die grensde aan een complottheorie. Zo wierp hij bijvoorbeeld een hypothese op die moest verklaren waarom zo veel indische artsen een ander inzicht in de kwestie waren toegedaan dan hij: ze bevonden zich zélf in het eerste stadium van de meelvergiftigingsziekte. En omdat dat een ziekte is die lijkt op een verslaving, kan worden gezegd dat zijn tegenstanders 'verslaafd' waren aan de infectietheorie. Net zo min als een verslaafde ertoe te brengen is zijn alcoholconsumptie te stoppen, zo min zijn beriberionderzoekers ervan af te brengen de infectiehypothese op te geven, stelde hij; 'zo iemand laat zich niet gemakkelijk overtuigen van de gevaren die er aan verbonden zijn. ${ }^{23}$

In een door het Nederlandsch Tijdschrift voor Geneeskunde geweigerd en daarop als aparte brochure gepubliceerd artikel brulde hij zijn tegenstander in kapitale letter het volgende toe. 
Een zee van ellende had sedert vele jaren gedempt kunnen zijn! Dat het niet geschiedde...is grootendeels te wijten aan den officiëelen raadgever der Regeering, den man die in I 887 geroepen werd om het werk voort te zetten, dat hij met de H.H. Pekelharing en Winkler begonnen was. Het zou hem [Eijkman] slechts drie woorden gekost hebben en duizenden gouvernements-kostgangers in Nederlandsch-Indië zouden, evenals hun Engelsch-Indische en Japaneesche makkers voor een verschrikkelijk lijden gespaard zijn gebleven... slechts drie woorden:... IK HEB GEDWAALD. Meer zal ik er niet aan toevoegen, uit vrees dat ik mijn ingetoomde pen niet meer zou kunnen bedwingen. ${ }^{24}$

Met die beschuldiging tilde Van Dieren een tweede beriberidebat van de grond, en ditmaal met meer succes. Van alle kanten mengden medici en journalisten zich in de discussie, ook Eijkman zelf, die alle zeilen moest bijzetten om zich zijn opponent van het lijf te houden (daarover zo dadelijk meer).

Een jaar na dato werd Eijkman benoemd tot hoogleraar in Utrecht, als opvolger van zijn leermeester Pekelharing. Het beriberi-onderzoek, waarover hij nog wel regelmatig zou publiceren, werd nu door anderen voortgezet, zoals Gerrit Grijns, D.J. Hulshoff-Pol en later Casimir Funk, die de term 'vitamine' zou munten, het 'levensbestanddeel' zonder hetwelk het lichaam blijkbaar beriberi ontwikkelt. ${ }^{25}$ Deze onderzoekers zouden overigens tot ongenoegen van Eijkman steeds meer afstand nemen van de infectiehypothese ten faveure van de deficiëntietheorie (die de ziekte wijt aan gebrekkige voeding), en dat leidde in de jaren tien tot een confrontatie tussen Eijkman en Grijns.

Niet alleen Van Dieren maar ook anderen hebben Eijkman in deze kwestie weleens een al te obstinate of in ieder geval al te aarzelende houding verweten, maar, zo schreef historicus Kamminga terecht, dat heeft minder te maken met diens vermeende conservatisme als wel met zijn verzet tegen een specifieke interpretatie van zijn werk door zijn tijdgenoten. ${ }^{26}$ Zou Van Dieren daarin een rol hebben gespeeld? Hijzelf dacht van wel. Eijkman zou volhouden van niet.

\section{Anti-beriberi}

In 1926 lukte het de onderzoekers Jansen en Donath eindelijk het antiberiberivitamine te isoleren, waarna Eijkman zijn laatste reserves ten aanzien van de vitaminehypothese liet varen. Twee jaar later gaf hij zijn afscheidscollege, het jaar daarop, in I929, volgde de Nobelprijs als bewijs van erkenning van het feit dat hij aan de wieg had gestaan van 
de ontdekking van de vitamine. Hij moest de eer overigens delen met Frederick Hopkins, die dezelfde verdienste werd toegeschreven.

In zijn Nobelprijsrede vertelde Eijkman hoe die ontdekking tot stand kwam. Die geschiedenis is de moeite waard om kort na te vertellen. In de zomer van I 889 merkte Eijkman dat enkele van zijn zes kippen in de ren plotseling ziek werden. Ze konden niet meer rechtop zitten, ademden moeilijk, hadden een verlaagde lichaamstemperatuur en vertoonden kortom alle kenmerken van beriberi. Hij dacht aanvankelijk met een infectieziekte van te doen hebben, maar slaagde er niet in, ondanks vele proefnemingen, de gezonde dieren te infecteren. Na twee maanden hield de ziekte even plotseling op als ze was gekomen en werden de nog levende dieren beter. Hoe was dat mogelijk? Dit is wat Eijkman daarover schreef.

Het laboratorium was nog altijd provisorisch ingericht en op een zeer erbarmelijke wijze in het militair hospitaal ondergebracht, hoewel het organisatorisch gesproken onder civiel bestuur viel. De laboratoriumassistent betrok uit zuinigheid witte rijst uit de hospitaalkeuken nu om de kippen te voeren, naar ik later pas begreep. Toen de kok overgeplaatst werd weigerde diens opvolger ten behoeve van de civiele kippen [Zivilen Hühner] militaire rijst af te geven. En zo gebeurde het dat de kippen van Io juni tot 20 november met witte rijst werden gevoederd. De epizoötie begon echter op Io juli en duurde tot de laatste dagen van november. ${ }^{27}$

Door toeval dus - een wisseling van de wacht der koks, zei Eijkman later, misschien met iets te veel nadruk - kwam hij erachter dat zijn kippen ziek werden als gevolg van een verandering in de voeding, waarna hij overging tot het systematisch variëren van het dieet. Hij merkte al spoedig dat voeding met gepelde rijst wel, en met ongepelde rijst (zilvervliesrijst) geen 'polyneuritis' tot gevolg had. Aan die ontdekking ligt de definitieve ontsluiering van het beriberiraadsel ten grondslag, want juist in de buitenste schil van de rijst blijkt zich de grootste concentratie vitamine B te bevinden. Het vraagstuk was eerst door een toevallige ontdekking en dan na zuiver experimentele toetsing opgelost; Van Dieren had er hoegenaamd geen rol in gespeeld.

\section{Van Dieren versus Eijkman}

Tot zo ver de geschiedenis van de ontdekking van vitamine B die ook de geschiedenis van Eijkman was. Van Dieren heeft daarin tevergeefs een plaatsje voor zichzelf trachten te reserveren. Er ligt een dubbele ironie 
verscholen in de geschiedenis van deze twee gelijkvormige maar ongelijksoortige levenslopen die elkaar zo vaak hebben gekruist. In de eerste plaats was Van Dierens advies om het dieet aan te passen achteraf gezien volkomen juist, maar om geheel andere redenen dan hij dacht: de oorzaak van beriberi zat niet in wat zich in de rijst bevindt maar in wat er zich niet in bevindt. Dat verschil werd later door hem weliswaar gemakshalve gebagatelliseerd als was het slechts een onbetekenend 'academisch' detail, maar dat voeding inderdaad een cruciale rol speelde, zoals hij steeds had volgehouden, kon moeilijk worden ontkend. In de tweede plaats werd het werk van Eijkman gezien als onmisbaar in de ontdekking van vitaminen, omdat het tot het juiste theoretische inzicht zou leiden, maar de latere Nobelprijswinnaar zelf kon maar moeilijk afstand doen van het achteraf onjuist gebleken inzicht dat een gebrek aan een of andere stof vermoedelijk een bijkomende factor was in het ontstaan van de beriberi, een die de infectieoverdracht alleen maar bespoedigde maar niet veroorzaakte.

De twee ironieën stonden toe dat Van Dieren in Eijkman zijn gastheer zou vinden waarop hij zich met al zijn retorische vernuft onlosmakelijk zou vastklemmen, en naar wiens werk hij zich voor altijd zou richten. Eijkman werd zijn antileermeester, zijn bête noir, zijn betere broer; zijn alles wat hij niet was en wel had moeten zijn. Van Dieren zou leren nee te zeggen op alles wat Eijkman deed en ja op alles wat hij niet deed. Als Eijkman schreef: 'Eenvoud is niet het kenmerk van het ware', hoefde Van Dieren alleen maar het woordje 'niet' te verwijderen om te weten wat het ware is. ${ }^{28}$ Werd het beriberivraagstuk een ingewikkeld vraagstuk genoemd, dan was het een 'axioma' van Van Dieren dat de kwestie 'een zéér eenvoudige is'. De proeven die Pekelharing, Eijkman en andere hielden waren in al hun eenvoud echter juist weer te eenzijdig, en hielden dus ook geen stand. Kortom, de heren onderzoekers hadden het steevast bij het verkeerde eind, de Amsterdamse huisarts onveranderlijk bij het rechte.

Die formule bleek overdraagbaar op andere terreinen. Meenden de socialisten dat de marxistische meerwaardetheorie gecompliceerd is, dan rekende Van Dieren voor dat Marx I 20 woorden gebruikte en drie formules om te zeggen wat hij zelf in I 5 woorden kon uitdrukken. ${ }^{29}$ Waren er wiskundigen die vonden dat Einsteins relativiteitstheorie moeilijk was, dan had Van Dieren er een simpel antwoord op: 'krom gezwam in de ruimte over de ruimte. ${ }^{30}$ Een paar hbs-opgaven volstonden om te laten zien dat hij gelijk had.

Maar hoewel Van Dieren het dus steeds beter wist, ontkwam hij er niet aan dat zijn alternatieve scenario's altijd in reactie op de ander 
moesten worden geformuleerd, en bleef hij dus, in zekere zin, van hen afhankelijk, zoals een parasiet niet zonder het lichaam van zijn gastheer kan. Het kan bijna niet anders of de gastheer begon daarvan op den duur hinder te ondervinden. In zijn inaugurale rede noemde Eijkman de parasiet het organisme dat afdaalt tot een eenvoudigere organisatie. Is het al te ver gezocht om in de parasiet Van Dieren te herkennen, zijn levenlangs kwelgeest? De parasiet, zei Eijkman, kenmerkt zich door 'eener eenzijdige specialiseering', en men herinnert hoe hij de opvattingen van zijn opponent 'eenzijdig, op het pathologische af', had genoemd. ${ }^{31}$

$\mathrm{Al}$ zijn bewegingen zou Van Dieren volgen; geen publicatie of lezing ontging hem. Stap voor stap sloop hij Eijkman naderbij en steeds dichter drong hij zich aan hem op. Het duurde jaren, maar Van Dieren had de tijd, hij overleefde Eijkman meer dan tien jaar. 


\section{5 \\ Een prachtige vijandschap}

In zijn relatie met Eijkman ligt het hele querulantistische mechaniek besloten waarop Van Dieren zijn polemische bestaan zou bouwen. Niet de beriberi maar Eijkman vormde zijn doel. Op deze plek ga ik die innige vijandschap na en zullen we de geschiedenis van de beriberi opnieuw doorlopen, maar nu gezien vanuit een nieuw gezichtspunt: dat van de elkaar bestrijdende tegenpolen.

\section{Eijkman dus}

Voor het eerst bekroop Van Dieren Eijkman in september I 894, in een artikel voor het Medisch Weekblad. De oorzaak van de beriberi was bij lange na nog niet gevonden. Pogingen om de bacteriecultuur van Pekelharing te kweken waren mislukt. De door Pekelharing voorgestelde desinfecterende maatregelen hadden niet het beoogde resultaat opgeleverd en waren al weer stopgezet. Koch zelf was in I 892 vanuit Berlijn naar het verre Nederlands-Indië gehaald om de beriberibacterie op te sporen, maar ook hij was onverrichter zake teruggekeerd. Kortom, voor de buitenwacht leek het onderzoek van Eijkman zich op een dood spoor te bevinden.

Zonder dat iemand het kon verklaren kon het dus gebeuren dat in I 894 het aantal met beriberi geïnfecteerden juist weer licht begon te stijgen, terwijl in de jaren daarvoor de statistieken een daling hadden laten zien. Misschien greep Van Dieren die gebeurtenis aan om van zich te laten horen, of misschien had hij alleen maar gewacht totdat persoonlijke omstandigheden het toelieten (in mei van dat jaar was hij getrouwd), feit is in elk geval dat hij in de zomer van I 894 de tijd rijp achtte om toe te slaan.

'Open brief aan zijne Excellentie den Minister van Koloniën' heet het stuk van Van Dieren waarin hij Eijkman belaagde. Een onschuldige titel - een schijnbeweging. 'Excellentie, sedert September I887 heb ik mij beijverd in twee brochures en tal van tijdschrift- en krantartikelen 
aan te toonen: $\mathrm{I}^{\mathrm{e}}$ dat Prof. Pekelharing's onderzoekingen omtrent de oorzaak en bestrijding der beri-beri niet deugen, en $2^{\mathrm{e}}$ dat in de laatste jaren te weinig rekening werd gehouden met de meening, dat de oorzaak dezer ziekte in de voeding gelegen zou zijn.'

$\mathrm{Na}$ die opluchtende introductie vervolgde Van Dieren zijn brief met het verzoek nog een paar waarnemingen te mogen mededelen. Die mededeling bestond uit wat feitjes en vergelijkingen, een paar jaartallen en enkele beriberistatistieken ter verfraaiing van het geheel. Daarna volgde het piece de resistance.

Wij bezitten thans in Indië een officiëelen B.B. onderzoeker, den directeur van het laboratorium te Weltevreden, Dr. C. Eykman. Hij assisteerde Prof. Pekelharing bij diens arbeid doch kon later, zelfstandig werkend, omtrent diens resultaten, betreffende de oorzaak der ziekte, niets bevestigend vinden, wat hem er niet van weerhield toch nog quasi-vleiend te spreken van de "positieve" resultaten van Pekelharing. ${ }^{2}$

Doel getroffen. $\mathrm{Nu}$ was het zaak het schip te doen zinken, en daartoe werden alle argumenten uit de kast gehaald die er voorradig waren.

De officiëele B.B.-onderzoeker negeert, wat de ondervinding bij land- en zeemacht leerde; negeert, wat omtrent de koelieschepen wordt medegedeeld; negeert wat Dr. Hogg schreef omtrent de Britsche marine in Japansche wateren, waar de B.B. zeer verminderde toen de voeding met rijst vervangen werd door eene welke meer stikstofhoudend was; negeerde de meening van Wernich uit Japan $[. . .]^{3}$

Zo ging het verbale bombardement nog even door. Dr. Eijkman negeert gewoonweg alles, althans alles wat hijzelf ter berde had gebracht. Daarom achtte Van Dieren het zijn heilige plicht zijne excellentie de minister van Koloniën daarvan op de hoogte te brengen, ' $U$ die het waarschijnlijk ook niet weten kondt'. ${ }^{4}$

Of de minister reageerde weten wij niet, maar Eijkman reageerde in ieder geval niet. Negeerde ook dit. Maar dat hinderde Van Dieren niet in het minst; hij had zijn tanden in zijn tegenstander gezet en zou van nu af aan niet meer loslaten. Er gingen twee jaar voorbij. Eijkman was ziek (vermoedelijk leed hij opnieuw aan malaria), en hij zou de komende tijd niet over de etiologie van beriberi publiceren; zijn experimenten leverden geen eenduidig resultaat op. Toen kwam de zomer van I 896; Eijkman stond op het punt huiswaarts te keren en publiceerde een artikel waarin hij tot de conclusie was gekomen dat iets in het zil- 


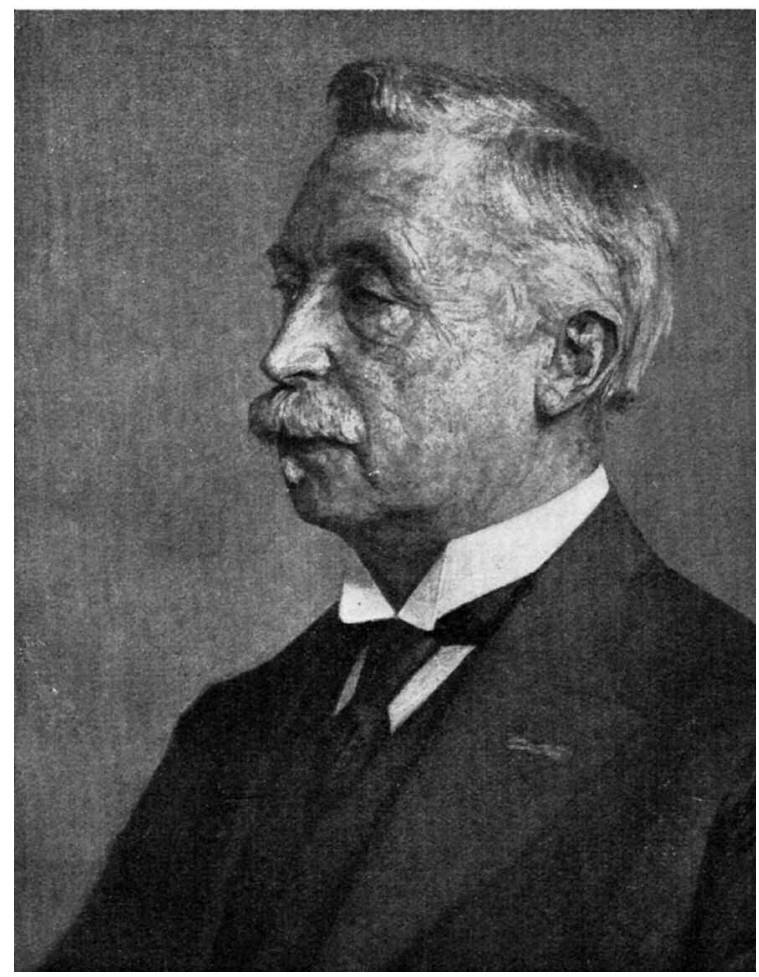

Christiaan Eijkman, de haan die Van Dieren nooit wist te verschalken.

vervlies verantwoordelijk moest zijn voor 'het behoud van leven'. Wat dat was wist hij nog niet, maar men moest aan een blijkbaar beschermende factor denken.

Tussen I 889, toen die toevallige omstandigheid zich had voorgedaan bij zijn proefkippen waardoor hij het belang van voeding was gaan inzien, en I 896, toen hij experimenteel de rol van zilvervlies als beschermende factor had aangetoond, had het denken van Eijkman een ontwikkeling doorgemaakt, maar was de uitkomst nog onbeslist. Aan de ene kant had hij de infectiehypothese nog niet opgegeven - hij dacht nog aan factoren die de besmetting 'faciliteerden'-, maar aan de andere kant was hij inmiddels wel voorbij het punt waar Van Dieren zich nog bevond, namelijk het standpunt dat iets in de rijst de ziekte veroorzaakt; er moest volgens Eijkman iets zijn in de rijst wat beschermt tegen de ziekte.

Eijkman hinkte in I 896 dus op twee gedachten die hij niet met elkaar wist te verenigen. Een gesprek, die zomer, met zijn vriend Adolphe 
Vorderman (I844-I902) inspecteur van gezondheid in NederlandsIndië, zou zijn vermoedens verder richting geven. Vorderman had Eijkman verteld dat het hem was opgevallen dat in gevangenissen waar hoofdzakelijk witte rijst werd geserveerd veel vaker beriberi voorkwam dan in gevangenissen waar dit niet het hoofdvoedsel was. Vorderman leek via een andere weg tot dezelfde conclusie als Eijkman te zijn gekomen. Ook Vorderman dacht aan infectiebevorderende factoren, maar zag eveneens het belang van voeding in. Op aandringen van Eijkman werd Vorderman door de lokale autoriteiten opgedragen een onderzoek in te stellen naar het voorkomen van beriberi bij zo'n honderd gevangenissen. De uitkomst van dat onderzoek leek vervolgens in de richting van een verband met het dieet te wijzen. Meer dan dertig jaar later was voor Eijkman de bevrijdende verbazing nog steeds niet verdwenen: 'n Treffende overeenkomst! Gepolijste rijst toegediend: de beriberi verschijnt; grove rijst? Ze blijft weg; 'n Middelmatig [gepolijste rijstsoort], de ziekte ook middelmatig..."s

Door een reeks van toevalligheden dus, en door toewijding, kwam I 2 Eijkman steeds dichter bij de waarheid, zo moest het lijken, al was voorlopig nog niet duidelijk waaruit die waarheid precies bestond. Voor Eijkman was dat overigens geenszins een probleem: de waarheid stond nooit helemaal vast. Maar voor Van Dieren was dat mooie, klassieke verhaal over het doen van wetenschappelijke ontdekkingen, waarin Eijkman het onbevooroordeelde instrument van de empirie vormde en zo de waarheid aan het licht bracht, in al haar objectivistische eenvoud onacceptabel. Eijkman stelt het voor, schreef Van Dieren, als zou hij de waarheid geheel alleen ontdekt hebben met behulp van zijn kippen. Maar wat Eijkman had gevonden door middel van experiment wist Van Dieren al lang op grond van eenvoudige observatie, namelijk dat beriberi iets met voeding te maken moest hebben! En nu zou Eijkman tot dezelfde conclusie komen zonder naar hem te hebben geluisterd? Onmogelijk!

Nog eens: wie was er eerst? De onderzoeker of de geestdrijver? Anders gezegd: had Eijkman zonder Van Dieren tot zijn bevindingen kunnen komen, of was Van Dieren niets anders dan een parasiet die zich op de huid van zijn gastheer heeft vastgezogen en diens bloed drinkt, maar geen bijdrage aan het organisme levert? 'Een parasiet', verklaarde Eijkman tijdens zijn inaugurele college, 'veronderstelt een gastheer, kan derhalve nimmer de eersteling op het gebied van het leven zijn geweest'. ${ }^{6}$ Met andere woorden: als het niet de vraag is of Eijkman zonder de speculaties van Van Dieren tot de oplossing van het probleem had kunnen komen, maar dat het eerder omgekeerd het geval is, 
namelijk dat Van Dieren alleen tot zijn kritiek had kunnen komen dankzij Eijkmans werk, dan moet het werk van Van Dieren de ontwikkeling van Eijkman volgen, in plaats van omgekeerd. Of dat zo is zullen we hieronder onderzoeken.

\section{Erkenning!}

De volgende brochure waarin Van Dieren op Eijkman reageerde is getiteld Beri-Beri eene rijstvergiftiging. Het is een radicale ontkenning van het werk van Eijkman en een frontale aanval op zijn wetenschappelijke en persoonlijke integriteit, een halfjaar later gevolgd door nog een brochure, nu ook althans in titel tegen Eijkmans medestanders gericht: Kantteekeningen op Dr. Vordermans rapport en nog iets, hoewel uit het voorwoord duidelijk wordt dat Van Dieren zich ook hierin maar tot één lezer richtte: 'een machthebbende, een hooggeplaatste, een man van de daad.' Dat was niemand anders dan Eijkman, aan wie Van Dieren bijna bovennatuurlijke vermogens toeschreef, en in elk geval het vermogen aan hem de erkenning te doen toekomen waarop hij recht had.

Op onbarmhartige wijze wordt in de twee brochures afgerekend met zijn aartsrivaal, en verder met alle onderzoekers die weleens iets onaardigs over hem hadden geschreven en de infectiehypothese in bescherming hadden genomen. 'Erken de verdiensten uwer vele voorgangers!', jammerde Van Dieren aan het slot ervan in kleinkapitaal.'

Erken mij, betekende het.

Aan de meeste tegenwerpingen in die brochures kunnen we voorbijgaan, behalve aan één: dat de statistische gegevens van Vorderman waren gemanipuleerd. Op het eerste gezicht lijkt Van Dieren aannemelijk te kunnen maken dat er opzettelijk dan wel uit dommigheid fouten in de statistische berekeningen waren geslopen waardoor er een onrealistisch optimistisch beeld was ontstaan ten gunste van de infectiehypothese. ${ }^{8}$ Vorderman wierp in een verweerschrift tegen dat de kritiek van Van Dieren op het door elkaar halen van verschillende typen kansberekening berustte. ${ }^{9}$ Maar Van Dieren had voorlopig de schijn mee en de overtuiging dat Vorderman in zijn berekening een lapsus van enorme omvang had begaan, werd door de meeste beoordelaars van het rapport onderschreven, met uitzondering van Eijkman, die een lovende bespreking over Vordermans onderzoek schreef en zijn eigen positie aldus nog hechter verbond met die van de auteur. ${ }^{10}$ En met succes: de geschiedschrijving zou later 'de experimenten van Eijkman op gevangenen in Java' in herinnering brengen als eerste stap op weg naar de ontraadseling van het beriberivraagstuk. ${ }^{11}$ 
Met Beri-beri eene rijstvergiftiging en de Kanttekeningen begon de controverse de proporties van een heuse affaire aan te nemen, zeker toen er ook nog eens ruim aandacht in de vakbladen en in de landelijke pers aan werd besteed. In het $N T v G$ verscheen al in februari I 897 een vroege recensie door dezelfde C.L. van der Burg die een decennium eerder Van Dieren nog in het Militair Geneeskundig Archief de oren had gewassen, maar nu in opmerkelijk neutrale termen de brochure besprak. Als pleidooi voor het toedienen van goede voeding vond hij het een overtuigend stuk; als bewijs voor het bestaan van een rijstvergif niet - vooral niet omdat de auteur weigerde de aard van het vergif nader te bepalen -, maar 'de redeneering, door de schrijver gevolgd, is helder en klemmend genoeg om een proefneming [naar de rijstvergiftigingshypothese] geheel als verantwoord te beschouwen. ${ }^{12}$ Een anonieme bespreking in de Indische Gids van mei van dat jaar was ook tamelijk welwillend, al was het maar, aldus de recensent, omdat het stuk aandacht vroeg voor onderzoek uit Japan, waarvoor betrekkelijk weinig belangstelling bestond in Nederland. De brochure werd een I 4 'belangrijke bijdrage aan de beriberi-literatuur' genoemd, en de schrijver beval lezing ervan ten zeerste aan aan alle autoriteiten in Indië en Nederland. ${ }^{13}$ In het Medisch Weekblad ging de recensent heel wat verder en heette het dat het de machthebbers niet aangaat 'jaarlijks honderden soldaten en duizenden veroordeelden willens en wetens te vermoorden, want weten kunnen ze het, nu Van Dieren in een voor ieder verstaanbare taal heeft aangetoond, dat slechte rijst, door rijkwordende chineese aannemers aangeleverd, de oorzaak der beri-beri is'. De recensent aarzelde zelfs niet de schrijver met Multatuli op een lijn te zetten, daar zij beiden immers voor de verdrukten in het geweer kwamen. ${ }^{14}$ Het Geneeskundig Tijdschrift voor Nederlandsch-Indië echter gaf ruimte aan verschillende tegenstanders van Van Dieren. De Duitse onderzoeker O.C. Gelpke, aan wie Van Dieren zijn brochure had toegestuurd, noemde de schrijver 'ein Prophet, ohne prophezieren zu können', een man die het onderscheid tussen bedorven en vergiftigde rijst niet goed begreep. En passant werd het onderzoek van Eijkman van tafel geveegd: zijn kippenproeven hadden ofwel niets met beriberi van doen, ofwel bevatten ze grote fouten (het eerste leek Gelpke waarschijnlijker dan het tweede). H.J. Kessler, geneesheer van het protestantse weeshuis te Samarang, bekritiseerde de eenzijdigheid in de benadering van Van Dieren, en nam het nu juist weer op voor Eijkman. Gelpke werd van repliek gediend door Van Dieren in een 'verweerschrift' dat in hetzelfde tijdschrift verscheen. Een samenvatting van die discussie werd in augustus I 897 besproken in het Algemeen Handelsblad. ${ }^{15}$ 
In de Indische Gids werd de schrijver verder in een lange sarcastische bespreking grondig gekraakt door W.J. van Gorkom (I 868-I9 I 5), die in een minutieuze analyse de vaak subtiele manipulaties die Van Dieren in zijn betoog gebruikte blootlegde, en eindigde met de niet ongeestige diskwalificatie van de auteur in kwestie.

Arme Hercules, die u met wapenen van dit allooi moest behelpen! Hadt gij uw kracht anders willen besteden, hoe hechte steun had zij der infectie-theorie kunnen worden. Als een reus op stelten hebt gij zo verspild, vermorst aan het doel, u op uw hooge voetstukken staande te houden en al uw spitsvondigheid te hulp moeten roepen om de onzekerheid uwer beweringen aan de aandacht van het ongeruste publiek te onttrekken. Het heeft niet mogen baten. In stede van een forschen strijder kan de oplettende toeschouwer in u niets anders bespeuren dan een listigen figurant. ${ }^{16}$

Maar dat was allemaal slechts olie op het vuur voor Van Dieren; een aanmoediging op de ingeslagen weg verder te gaan. En dat deed hij ook. In een poging meer aandacht voor zijn publicaties te wekken stuurde hij de koningin een exemplaar van beide boekjes toe. Niet in de veronderstelling, schreef hij, dat Hare Majesteit als scherprechter in het conflict met Eijkman zou optreden, maar wel in de hoop dat zij haar macht zou aanwenden om een dieetverandering te doen invoeren, waarmee niet langer gedraald mocht worden. ${ }^{17}$

Ook benaderde hij twee oude vijanden: Winkler en Pekelharing. Op het toesturen van Beri-Beri eene rijstvergiftiging kreeg hij zowaar respons, zij het niet een die hem beviel: ze scheepten hem af met het 'gemakzuchtige antwoord' dat de kwestie alleen experimenteel kon worden opgelost (Winkler) en dat de door hem beoefende kritisch-historische methode 'als zijnde te "eenzijdig", in deze van geen nut kon zijn' (Pekelharing)..$^{18}$

Al met al had de mediacampagne van Van Dieren dus wel degelijk succes. Er was aandacht, kritiek maar ook bijval. En er kwam nog meer steun voor zijn kritiek, en wel uit onverwachte hoek: dezelfde W.J. van Gorkom die Van Dieren zo duchtig de les had gelezen in de Indische Gids, schreef een halfjaar later een kritisch referaat over het rapport van Vorderman dat in het Geneeskundig Tijdschrift voor NederlandschIndië verscheen. Vorderman heeft slecht werk afgeleverd, beriberi is geen bacteriologische besmetting en het werk van Eijkman staat 'geïsoleerd'.

Een curieuze koerswijziging. Curieus is ook dat Van Gorkom tegelijkertijd Van Dieren in een persoonlijk schrijven feliciteerde met zijn 
'harde waarheden', zelfs meende dat hij de 'cardinale fout van het rapport nog te licht had gesteld'. Ook nam hij in een brief zijn kritiek aan het adres van Van Dieren half terug: '[ik zou] in mijn Indische Gids opstel (dat ook wat heftig is uitgevallen) aan het slot niet getuigd hebben, dat "de belangen van de gouvernements-kostgangers met gerustheid aan de zorgen van Dr. Vorderman konden worden toevertrouwd" (ofzoo), indien ik zijn rapport voor het schrijven van die verhandeling had kunnen lezen. ${ }^{19}$

Van Dieren stond paf. 'Ik vertrouwde mijn oogen niet, toen ik het las: "de verkrachter der waarheid" was geworden een "zegger van een aantal harde waarheden". ${ }^{20}$ Dat was levensgevaarlijk dom geweest van Van Gorkom, omdat hij had kunnen weten dat zijn brief vroeg of laat tegen hem zou worden gebruikt. En dat gebeurde ook, zes jaar later, toen in een discussie in de Amsterdamse Geneeskundige Kring uitlekte dat hij Van Dieren had gesteund, en Van Gorkom er alsnog onderuit probeerde te komen door te beweren dat het toch alleen maar om een 'beleefdheidsschrijven' ging van een collega tot een andere, in vertrouwen geschreven I 6 bovendien, met niet meer dan wat 'oppervlakkige meningen'. Dan had hij, zo bleek, duidelijk buiten de waard gerekend. Van Dieren deed een open brief uitgaan naar alle leden van de Kring (400 in getal) waarin heel de geschiedenis in geuren en kleuren uiteen werd gezet en als klap op de vuurpijl de bewuste brief was opgenomen, op fotomechanische wijze gereproduceerd, zodat hij niet van 'citaatverminking' beschuldigd kon worden. En inderdaad: bij lezing van de bewuste brief blijkt dat Van Gorkom wel erg aardig was geweest tegenover van Dieren.

Maar hoe zoet die wraak in 1903 ook mocht hebben gesmaakt, Van Dieren wenste toch niet zo lang te wachten en stapte al in de zomer van I 887 naar de hoofdredacteur van de Indische Gids om hem op de hoogte te brengen van zijn briefwisseling met Van Gorkom. De hoofdredacteur vertrouwde het niet, en zo, schrijft Van Dieren triomfantelijk, trof hij op een avond thuiskomende de heer Van Sandick in zijn spreekkamer aan, gebogen over de bewuste brief. 'Hij las hem, terwijl ik er bij zat, nog eenige malen door en eindigde te zeggen; "ik begrijp zo'n man niet". ${ }^{21}$ Natuurlijk was de Indische Gids daarna gedwongen om een stuk van hem op de nemen, en dus verscheen daarin even later ' $t$ Kan verkeeren' van een in zijn vuistje lachende Van Dieren die zich gerehabiliteerd wist - voor eventjes dan. 'De heer Van Gorkom heeft bewezen dat hij zijn ongelijk bekennen kan [...] och, dat allen anderen het even gemakkelijk viel. ${ }^{22}$

Was Van Gorkom als een blad aan de boom omgedraaid, zoals Van Dieren de lezer wilde doen geloven? Neen. In werkelijkheid had Van 
Gorkom in zijn bespreking van het rapport van Vorderman geen woord van zijn kritiek op Van Dieren teruggenomen: hij deelde slechts de mening van Van Dieren dat het rapport niet deugde, en de eerste stelling van zijn artikel luidde onverkort: de rijstvergiftigingshypothese is onhoudbaar gebleken.

Maar de verwarring was gesticht. Was voor Van Dieren de opstelling van Van Gorkom al moeilijk te begrijpen, ook Eijkman had de aanval op Vorderman en zichzelf niet zien aankomen en betreurde in een open brief aan Van Gorkom diens 'hyperkritische' houding. 'Door al te groote twijfelzucht - défault d'une qualité - loopt men gevaar de kern van waarheid, die ergens in mocht schuilen, te verstikken', schreef hij. ${ }^{23}$ Vooral de 'beoordelaars aprés-coup' (degenen die met de wijsheid van nu een zaak achteraf beoordelen) wees hij af, omdat zij niet in staat zijn zich een billijk en barmhartig oordeel over iets te vormen. En in een toevoeging die moeilijk anders dan als een verwijzing naar Van Dieren kan worden opgevat sneerde Eijkman: ' $\mathrm{Zij}$ [de beoordelaars aprés-coup] vervallen verder te licht in de fout om, waar een bewijsvoering hun gebrekkig toeschijnt, er nu juist het tegendeel uit te willen afleiden.'

Dit was de eerste inmenging van Eijkman in het debat. Hij had zich tot dan toe buiten de strijd proberen te houden, maar dat was, zo realiseerde hij zich nu, niet langer meer mogelijk. Vooral niet toen er nog een tweede gunstige bespreking van de 'Kantteekeningen' verscheen, ditmaal in het Nederlandsch Tijdschrift voor Geneeskunde, geschreven door vaste recensent A.P. Fokker (I840-I906). Delprat schreef later over deze auteur: 'Zijn critische en ietwat sarcastische geest wierp zich bij voorkeur op nog niet geheel opgeloste vraagpunten, die dan voor hem uitgangspunt waren voor polemisch gestelde referaten tegen de zich meer en meer baanbrekende bacteriologie. ${ }^{24}$ Zo ook, waarschijnlijk, in dit geval. Van Dieren werd door Fokker een 'onvermoeibare strijder' genoemd die de 'groote verdienste [toekomt] een der eersten geweest te zijn, die den invloed der rijstvoeding heeft begrepen', en die terecht kritiek uitoefende op Eijkmans werk. Immers, veel verder dan de constatering dat beriberi geen infectieziekte is zijn we tot nu toe niet gekomen, zei Fokker. Daarop volgde de uitsmijter waarmee Eijkman het kon doen: 'Of zich na het pellen in de rijst een vergif vormt (van Dieren), dan wel of dat daarin praeëxisteert (Eijkman) is niet met zekerheid gebleken. ${ }^{25}$

Op gelijke hoogte gebracht met Eijkman! Dichter bij een publieke erkenning voor zijn standpunt door een vakman dan in deze zin zou Van Dieren nooit meer komen. Bij het verschijnen van het $N T v G$ van I I november I 897 moet ten huize Van Dieren een klein vreugdedansje 
zijn uitgevoerd. ${ }^{26}$ Eijkman reageerde per kerende post. In het volgende nummer van het $N T v G$ verscheen een ingezonden brief van hem waar de ingehouden woede van afdroop. Allereerst wilde hij de geachte recensent opmerkzaam maken op het feit dat de bewering als zou vergif in de rijst preaëxistent zijn de zijne niet was, zo begon Eijkman. 'Mijn proeven bewezen wel de schadelijkheid van de rijstvoeding, maar ik leidde er niet uit af, dat de rijst een vergift bevat.' Van een theorie van hem was trouwens helemaal geen sprake, 'tenzij men met dien titel zou willen vereeren een terloops gemaakte opmerking, dat er ook m.i. veel pleit voor de opvatting, dat beri-beri een infectieziekte is, waarbij de voeding op eenigerlei wijze een voorname rol speelt'. En ten aanzien van de etiologie van de hoenderziekte had hij enkel vermoedens geopperd die als 'werkhypothesen' dienst konden zijn, als richtsnoer voor verder onderzoek. En wat die Van Dieren betreft: 'die verdient in het minst geen vertrouwen. ${ }^{27}$ Dat sloeg op het feit dat Van Dieren uitvoerig uit zijn werk had geciteerd, maar daarbij naar willekeur woordjes en zinnen had weggelaten en zodoende citaten uit het verband had gerukt.

Van de hele kwestie werd door een anonieme verslaggever in het Algemeen Handelsblad kort melding gemaakt: 'De heer Van Dieren gaf zonder omwegen en zonder aanzien des persoons zijn meening te kennen, maar de heer Eykman windt er ook geen doekje om "Wat van Dieren van mijn geschriften en mijn werk zegt, verdient in het minst geen vertrouwen", zegt hij en hij licht dit met een paar voorbeelden toe. ${ }^{28}$ Die verslaggever bleek, zoals we nog zullen zien, de medicus Pijnappel te zijn, die partij voor Eijkman koos.

Voor Van Dieren waren er gouden tijden aangebroken, zijn finest hour als querulant had geslagen. Hij liet nu letterlijk geen gelegenheid onbenut om van zich te doen horen en dus waren de ingezonden brieven en antikritieken niet van de lucht. ${ }^{29}$ In een voor hem kenmerkende mengeling van zelfbeklag en hoogmoed probeerde hij in het NTvG de 'allerheftigste beschuldigingen' als zou hij onjuist hebben geciteerd te weerleggen met het argument dat hij om stilistische redenen Eijkmans betoog wat had geherformuleerd. Eijkman had hem verweten dat hij het woordje 'spontaan' in de uitdrukking 'spontane infectieziekte' had weggelaten, maar: 'infectie-ziekten ontstaan niet "van zelf", "vrijwillig”, "uit eigen beweging", nooit ontstaan zij vanzelf. Dat woord was een lapsus en meer dan overbodig', aldus Van Dieren.

Neen, antwoordde Eijkman: 'spontaan' duidt nu juist het verschil aan met andere infectieziekten; weglating daarvan tast het fundament van het betoog aan. 
Vroeg men nu, waar kwam de infectie dan vandaan, zo kan het antwoord luiden: dat moeten wij in 't midden laten. Om deze gevolgtrekking weer te geven sprak ik van spontane infectieziekte. [...] Het pleidooi van Van Dieren voor de overbodigheid van "spontaan” is eenvoudig onzinnig. Niets komt "vanzelf” en men zou dus wel het woord spontaan uit alle woordenboeken kunnen schrappen. Ik heb het woord gebruikt in de zin van: zonder nader bekende oorzaak. ${ }^{30}$

Dat was voor Van Dieren een onmogelijk standpunt: iets is eenvoudig zo of niet zo. Er tussenin bevindt zich niets, zeker geen twijfel. De waarheid is eenvoudig, kenbaar en staat bij voorbaat vast. Daar tegenover lijkt de twijfel van Eijkman kwetsbaar, en dat wist hij ook. Met behulp van een vergelijking trachtte Eijkman zijn standpunt daarom nog wat meer kracht bij te zetten. 'Van Dieren wil ook maar niet toegeven dat correct citeren niet bestaat in het corrigeren (zoogenaamd) van citaten. Als eerste eisch van betrouwbaarheid mag, dunkt mij, gesteld worden, dat men letterlijk citeert zonder iets weg te laten, zoodra men van aanhalingstekens gebruik maakt. Zijn wijze van doen doet mij denken aan Benjamin Franklin's verhaal van den eerzame hoedemaker, U zeker wel bekend. Deze had op zijn uithangbord laten schilderen: "Mr. Schripps (de naam kan ook een andere zijn, dat herinner ik mij niet) maakt en verkoopt alle soorten hoeden." Al spoedig kwam er een "taalgevoelige" klant opdagen, die dat "alle soorten" totaal overbodig vond. Toegestemd, die woorden worden weggelaten. Doch al spoedig kwam er een tweede klant met de snuggere opmerking dat wie hoeden maakt ze natuurlijk ook wil verkoopen. De woorden en verkoopt kwamen dus als totaal overbodig te vervallen. En zoo ging het door tot onze vriend, die nog wel zoo in zijn nopjes was over het taalgevoel zijner klanten, ten slotte met schrik bespeurde dat er helemaal niets meer op zijn uithangbord stond. ${ }^{31}$

Benjamin Franklin bedacht de parabel van de hoedenmaker in I776, tijdens de onderhandelingen over de Amerikaanse onafhankelijkheidsverklaring, naar verluidt ter verzachting van de gekwetste trots van Thomas Jefferson, die moest toezien hoe het congres zijn kladversie van de verklaring, die hij zelf als volmaakt beschouwde, voorturend veranderde en 'verbeterde'. Het verhaal is een ironisch commentaar daarop; het eindigt ermee dat het lege uithangbord op aanraden van een andere klant wordt voorzien van een tekst die precies gelijk is aan die er oorspronkelijk op stond. ${ }^{32}$ Als zodanig illustreert het voor Eijkman de futiliteit van Van Dierens 'verbetering'. Maar tegelijk levert het commentaar op de moeilijkheid die hij ondervond om met behulp 
van argumenten vat te krijgen op het denken van Van Dieren. Zoals de woorden spontaan van het uithangbord lijken af te vallen, zo lijkt Eijkman te vrezen dat heel zijn betoog geen enkele indruk zal maken op zijn tegenstander, ja, zelfs zijn medestanders onbetuigd zal laten. Zo bezien is het verhaal van de hoedenmaker misschien bovenal een metafoor voor Eijkman zelf, de eeuwig twijfelende onderzoeker wiens onafhankelijkheid door het commentaar van de nimmer twijfelende Van Dieren inderdaad dreigde te worden aangetast.

De discussie tussen Van Dieren en Eijkman waarover in december I 897 in het Algemeen Handelsblad al was bericht, vormde ten slotte aanleiding voor Pijnappel om er op 9 januari I 898 een medische kroniek van een halve pagina aan te wijden, waarin op vernietigende wijze met de 'razende querulant' werd afgerekend en hem aan het slot werd gemaand te zwijgen: 'waarlijk, er moet een grens zijn aan alle dingen, ook aan hetgeen men meent te mogen zeggen, en niet iedere toon is geoorloofd'. Hierop bracht Van Dieren in een ingezonden stuk van ongeveer dezelfde lengte zijn geschut in stelling, waaronder, tot verbijstering van Eijkman en Pijnappel, particuliere correspondentie met de vermaarde medicus B.J. Stokvis, die kort tevoren nog nietsvermoedend aan Van Dieren had geschreven: 'Vraagt men te avond of te morgen mijn advies in de beri-beri-questie, ik zal niet aarzelen mijn meening te geven $[. .$.$] en te erkennen, dat door u het allereerst met$ grooter klem dan ooit te voren op de rijstvergiftiging als een der oorzaken van B.B. geweezen is. ${ }^{33}$ Dat die dag waarop naar zijn advies zou worden gevraagd spoedig zou aanbreken kon Stokvis toen niet bevroeden.

Eijkman bereidde ondertussen een artikel voor dat hij eerst vanwege de lengte ( 70 pagina's) als brochure wilde laten verschijnen, maar dat na enig onderhandelen toch onderdak kreeg in het $N T v G$, waar het in drie afleveringen verscheen onder de titel 'Beri-beri en voeding' en waarvan de pesterige ondertitel luidde 'een kritisch historische studie', wat een rechtstreekse verwijzing was naar Van Dierens 'critisch-historische methode'. De eerste twee delen bestonden uit een uitvoerige weergave van allerhande onderzoek waaruit niets anders bleek dan dat er met geen mogelijkheid een eenduidige uitspraak over de oorzaak van beriberi kan worden gezegd. In het derde deel ten slotte revancheerde Eijkman zich op zijn Amsterdamse opponent.

Niet alleen zou hij, Eijkman, ongemerkt van standpunt zijn veranderd, ook zou hij 
als "officiëel beri-beri-onderzoeker" - als een soort van Directeur van beri-beri'sche zaken, die het maar voor het zeggen had - van geen hervormingen in zake de voeding hebben willen weten, omdat dit gelijk zou staan met ongelijk bekennen. "Het zou (mij) slechts drie woorden gekost hebben, en duizenden gouvernementskostgangers in Nederlandsch-Indië zouden, evenals hun Engelsch-Indische en Japaneesche makkers voor een verschrikkelijk lijden gespaard zijn gebleven... slechts drie woorden:... IK HEB GEDWAALD”. Deze door niets gemotiveerde beschuldiging getuigt van een te grote naïviteit om haar ernstig op te nemen, of er hem, die haar blijkbaar in een onbewaakt ogenblik uitsprak, hard over te vallen. ${ }^{34}$

Waarop een filippica volgde tegen die 'onbetrouwbare en gevaarlijke gids', bij wie de 'neiging bestaat alsof hij alles reeds in I 887-88 gezegd had en ik eigenlijk eerst in het laatst van I 896 kwam mee te spreken', en die verder ook geen 'helder begrip heeft van de betekenis van hypothesen bij wetenschappelijk onderzoek', en van wie bovendien gezegd kan worden dat hij zijn hypothesen 'niet toetst aan de verschijnselen maar juist omgekeerd te werk gaat'; wiens rijstvergifthypothese, tot slot, 'eigenlijk alleen belangwekkend is uit een psychologisch oogpunt, als een merkwaardig staaltje namelijk van autosuggestie'.

Met die 'kannieverstaan' hield Eijkman zich bijna dertig pagina's lang bezig, maar hij beloofde dat hij daarna nooit meer met Van Dieren in debat zou treden. 'Ik gun hem gaarne het laatste woord, waarop hij steeds zoo gesteld blijkt te zijn en den goedkoopen triomf zijn pleit te winnen bij hen, die altijd den laatste spreker gelijk geven', schreef Eijkman.

Ja, Eijkman was gekwetst. Als zelfstandig onderzoeker was hij van aanvang af geheel zijn eigen weg gegaan en had hij zich niet in het minst laten beïnloeden door het geschrijf van Van Dieren; hij vond daarin steeds 'te weinig onvervalschte en oorspronkelijke wetenschap om [zich] er lang mede op te houden'. Dat hij die suggestie zelfs maar moest tegenspreken was eigenlijk al onverteerbaar.

\section{Wraak}

Van Dieren kon na die artikelenreeks natuurlijk nog maar aan één ding denken: wraak. Hij eiste van het $N T v G$ recht op weerwoord, maar de redactie schreef terug: 'Dat recht is maar zoo zoo' en weigerde plaatsing van het stuk; ruimte voor een ander artikel werd hem wel geboden, maar 'een stuk te schrijven, zoo dat ik het opnemen kan, ligt buiten uw temperament', dacht de redacteur. ${ }^{35}$ 
Dat weerhield Van Dieren er uiteraard niet van zijn gram op te schrijven en naar de drukker te brengen, en zo verscheen in december I 898 een op eigen kosten gedrukte brochure waarin Van Dieren de vermoorde onschuld speelde. Niettegenstaande de laffe methoden van zijn vileine tegenstander legde hij zélf een bewonderenswaardige waardigheid aan de dag, zo meende Van Dieren: 'K laat mij niet afschrikken door de behandeling, die mij aangedaan werd in het officiëele orgaan van eene vereniging van duizenden Nederlandsche artsen. U... schijnt enigszins onthutst Mijnheer de redacteur', sneerde hij. ${ }^{36}$ De hoofdredacteur van het $N T v G$, Manuel Straub, degene die hier door Van Dieren werd aangesproken, was zo hoffelijk hem toe te staan de brochure met het decembernummer van het $N T v G$ mee te laten sturen, maar inhoudelijk werd er geen woord meer aan vuil gemaakt. ${ }^{37}$

Van Dieren heeft in de jaren daarna nog vaak, maar zonder succes, getracht de controverse nieuw leven in te blazen met behulp van vele voordrachten en de publicatie van het kolossale boek Meelvergiftigingen. Het boek werd in het NTvG door Van der Scheer besproken die een I22 zakelijke toon wist te bewaren, maar er niettemin weinig van heel liet. Het behoeft nauwelijks te worden betwijfeld of andersdenkenden, onder wie tal van schrijvers over tropische ziekten, zullen door de deductieve literarische beschouwingen van Van Dieren niet worden bekeerd, aldus de recensent, die verder observeerde hoe bij de auteur 'een juiste appreciatie van de door zijn tegenstanders aangevoerde motieven geleden heeft tengevolge van gebrek aan persoonlijke bekendheid met de werkelijke toestanden en omstandigheden, waaronder beri-beri optreedt [...]. ${ }^{38}$ En weer probeerde Van Dieren uit die 'verdachtmakingen' munt te slaan met een tegenkritiek die wel bijna vanzelfsprekend moest worden geweigerd, al was het maar vanwege de omvang van het stuk (25 pagina's in druk), en derhalve als brochure het leven zag. De titel is reeds veelzeggend genoeg: Geboycot en vogelvrij verklaard?

In de jaren tien liet hij het onderwerp beriberi rusten om zich op andere zaken te concentreren, maar vanaf het midden van de jaren twintig sloop de beriberi weer binnen in zijn redevoeringen, meestal voor studentgezelschappen gehouden, en gaf hij lezingen waarin hij zijn eigen opvattingen bleef bepleiten, alhoewel er, zo gaf hij zelf toe, 'alweer niet, helaas, naar de buitenstaander werd geluisterd' ${ }^{39}$ Een van zijn laatste publicaties is getiteld 'Het Beri-Beri- en Vitamine-Treurspel. Ongelooflijke bizonderheden uit mijn 40-jarigen strijd tegen Laboratoriumgeleerdheid-op-haar-smalst, enz., enz.', tevens de titel van een lezing waarmee Van Dieren tussen I929 en I933 door het land trok. De beriberi-oorlog was een strijd die niet meer eindigen kon. 


\section{6 \\ Een briefwisseling}

Van Dierens polemische werk gaf aanleiding tot een 'verwarrende en achteraf eigenlijk wel vermakelijke vechtpartij tussen nagenoeg alle betrokkenen', oordeelde Eijkmans biograaf Jansen later over de beribericontroverse. ${ }^{1}$ Een deel van die vechtpartij laat zich reconstrueren, omdat we kunnen beschikken over een ongepubliceerde briefwisseling uit deze periode tussen Eijkman en M.W. Pijnappel, scribent van een medische kroniek voor het Algemeen Handelsblad, waaruit blijkt dat Van Dieren zijn opponent niet alleen tot grote woede maar ook tot diepgewortelde vertwijfeling kon drijven. ${ }^{2}$ In vrijwel iedere brief klinken aanklachten tegen Van Dieren op, maar ook pogingen hem te begrijpen. Soms, schreef Eijkman een keer aan Pijnappel in een poging zijn opponent te doorgronden, zijn de publicaties van Van Dieren 'zoo verbluffend dat men onwillekeurig aan een mystificatie denkt'. ${ }^{3}$

Met die analyse had Eijkman de spijker op de kop geslagen. Het succes van Van Dieren werd grotendeels bepaald door de manier waarop hij erin slaagde de geschiedenis te herschrijven, en wel zodanig dat zijn eigen rol erin veel gunstiger naar voren kwam. Mystificaties zijn verrassend moeilijk te beantwoorden, laat staan recht te zetten. De briefwisseling tussen Eijkman en Pijnappel werpt een interessant licht op de strategieën die achter de schermen werden ontwikkeld om de querulant buiten de deur te houden.

\section{De zaak Van Dieren}

Het was eind I 897 toen de kritiek van Van Dieren op Vorderman en Eijkman door A.P. Fokker in het NTvG werd ondersteund, en de zaak de proporties van een affaire begon aan te nemen. Van Dieren was, zoals we eerder gezien hebben, verbazend behendig in het bespelen van de pers. De getroffen opponent zag zich steeds geconfronteerd met het paradoxale gegeven dat het kortweg negeren van de querulant op den duur in diens voordeel werkt en hij dus wel gedwongen wordt publie- 
kelijk de strijd met hem aan te binden, hetgeen echter precies is wat de ander wil.

In die verlies-verliessituatie bevond Eijkman zich toen hij een brief kreeg van Marie Willem Pijnappel (I854-I92I), net als Van Dieren huisarts te Amsterdam en auteur van werken op medisch-hygiënisch gebied en daarnaast, als gezegd, schrijver van een medische kroniek. Pijnappel was een weinig op de voorgrond tredende maar actieve bestuurder in de Maatschappij tot bevordering der Geneeskunde die in I 898 zitting had in de raad van toezicht. Als mens is hij gekenschetst als een bescheiden persoon die niet graag de aandacht op zich vestigde en dat is ook de reden waarom er betrekkelijk weinig over hem bekend is. ${ }^{4}$ Waarom hij zich voor 'de zaak-Van Dieren' interesseerde kan ook niet goed worden vastgesteld; de brieven van Pijnappel zelf zijn niet bewaard gebleven. Het is mogelijk dat hij handelde uit hoofde van zijn functie als toezichthouder, of op instigatie van de krant, maar hij kan zich ook uit eigen beweging, uit nieuwsgierigheid tot Eijkman hebben gewend. Uit het antwoord, gedateerd 6 december I 897, kunnen we in I24 elk geval opmaken dat Eijkman zich ter dege bewust was van de kans die hem hier geboden werd om zijn kant van de zaak te bepleiten.

Het is dan een kleine maand geleden dat Fokker zich in gunstige zin over Van Dieren heeft uitgelaten en ongeveer drie weken nadat Eijkman zelf zich voor het eerst in de beriberistrijd had geworpen. Uit de aanhef van de brief blijkt dat Eijkman reageert op een verzoek van Pijnappel om nadere informatie, met name over de beschuldiging van Eijkman als zou Van Dieren onzorgvuldig hebben geciteerd, een verwijt dat Van Dieren keer op keer heeft getroffen. Voor Eijkman moet de brief van Pijnappel een geschenk uit de hemel zijn geweest. Onder het mom van het informeren van een 'onpartijdige' stuurde hij Pijnappel de nodige informatie toe, terwijl hij hem tegelijk in de loop van zijn brief voor zich trachtte te winnen.

Omtrent mijn aandeel in de beri-beri kwestie ontstaat door Van Dierens toedoen zoo zoetjes aan een legende en hetzelfde geldt voor zijn eigen aandeel. Hij heeft alles al in I887-88 voorspeld, bij mij dateert alles wat op de rijstvoeding betrekking heeft uit den jongsten tijd. Ik wees er reeds op, dat ik van I 889 af het recht heb om in de rijstkwestie als zelfstandig onderzoeker mede te praten, en dat ik mij nimmer en nergens een voorstander van de rijstvergifthypothese heb betoond. ${ }^{5}$

Aan het slot van zijn brief verklaarde Eijkman onomwonden: 'Ik geloof dat ik u met het bovenstaande overtuigd heb niet te veel gezegd te heb- 
ben toen ik Van Dieren van onbetrouwbaarheid beschuldigde. Als u niet anders deed dan dit openlijk verklaren op grond van de door u ter vergelijking ingeziene stukken, zou mij dit reeds veel waard zijn. U kunt overigens voor dit mijn schrijven gebruik maken, zooveel u nodig dunkt. ${ }^{9}$ En met nog wat meer pathos verklaarde hij in een brief van drie weken later zelfs openlijk: '[Er] moet niet getalmd worden om Van Dieren slag op slag te brengen', waarmee hij zichzelf maar vooral ook de adressant hoopte aan te sporen de strijd tegen van Dieren te intensiveren. ${ }^{7}$

Maar toch leek Eijkman niet alleen of zelfs misschien niet primair geïnteresseerd te zijn geweest in het beïnvloeden van het grote publiek: 'Ik zou ook op zijn [Van Dierens] beschuldigingen te mijnent het stilzwijgen bewaard hebben, aangezien ik hem zijn goedkope triomfen bij een leekenpubliek gaarne gun, als mij niet gebleken was uit Prof. Fokkers aankondiging dat die [...] onder de suggestie van Van Dieren geraakt was en mij dingen toeschreef, lijnrecht in strijd met hetgeen ik gezegd had'.

Eijkman zag dus in dat een gunstige pers in de eerste plaats functioneel was binnen het medische veld zelf, en dat hij via deze omweg Fokker c.s. misschien wel beter kon bereiken dan door hem in het $N T \nu G$ te attaqueren. Hij haastte zich dan ook Pijnappel uitvoerig zijn eigen positie te schetsen, uitvoeriger dan nodig is voor een eenvoudig eenkoloms krantenartikeltje: 'In verband met mijn bewering, dat wie Van Dieren controleert, hem telkens op scheeve voorstellingen en onjuiste of halve citaten zal betrappen, ben ik ook gaarne bereid U van mijn zijde zooveel mogelijk in de gelegenheid te stellen die controle uit te oefenen. Ik zend U dus de tot dat doel noodige litteratuur [...].'

Wat volgt is een brief van niet minder dan twintig dicht beschreven velletjes die van lieverlee tot een half artikel uitgroeide. Feitelijk blijkt bij vergelijking met het enkele maanden later gepubliceerde anti-Van Dieren artikel in het NTvG dat hele passages overeenkomen met wat hij aan Pijnappel schreef. Eijkman leek te oefenen op een repliek en daarbij Pijnappel als publiek te gebruiken.

We volgen Eijkman enige momenten in zijn worsteling om Van Dieren te weerleggen en merken op dat de schrijver nooit het overzicht op het hele debat uit het oog verliest, maar zich tegelijkertijd ook steeds bewust is van de moeilijkheden en subtiliteiten daarin. De afkorting 'P.h.' die Eijkman in zijn brief gebruikt staat voor polyneuritis bij hoenders, de op beriberi gelijkende ziekte waardoor zijn kippen werden aangetast en waarover hij in zijn in het Geneeskundig Tijdschrift voor Nederlandsch-Indië gepubliceerde jaarverslagen had geschreven. 
$\mathrm{Nu}$ komt het gegoochel van Van Dieren met mijn beschouwingen van 'onderzoek der omgeving' enz. U zult zich kunnen overtuigen dat ik er niet te veel van gezegd heb (zie ook Kantteekeningen op Vordermans rapport, p. 6I-62). In mijn Jaarverslag over I 889 [staat] niets van belang over beri-beri (p. 250), doch 't eerste stuk over P.h. (p. 295). Ik concludeer alleen met zekerheid dat de hoenderziekte door voeding met gekookte rijst geprovoceerd wordt (p. 33I). Ik vermoedde wel een vergift, maar geen dat reeds in de rijst voorhanden was op 't oogenblik dat zij gegeten werd. Hier hadden alle hypothesen vrij spel en ik zei dan ook kortelings: Van Dieren kon er feiten aan ontleenen, die voor zijn opvatting pleitten, hoewel die ook anders konden worden uitgelegd (NTvG, 2e dl., p. 898) - over verband P.h. en beri-beri zie later. In [het] Jaarverslag over I 890 weerleg ik de opvatting dat de oorzaak der ziekte in 't water zou schuilen, zooals Fiebig beweerde (p. 8 en verder). In [het] Jaarverslag [over] I 89I, voor de path. anatomie van P.h. hier verder van geen belang. In die van I 892 tot en met I 894 evenmin iets bizonders, dan alleen dat het volgend jaar (I 895 ) een mededeeling over P.h. tegemoet te zien, benevens een zeer voorzichtig gesteld bericht over de toepassing bij beri-beri (Jaarverslag I 894, p. I4). Dan komt de 2e mededeling over P.h. die U bekend is. Als ik naar het voorbeeld van Fokker mijn meening omtrent de aethiologie in extract wilde weergeven, zou die kunnen luiden: Een autoinfectie die door het direct intermediair van het zetmeelhoudend voedsel tot intoxinatie leidt. Ik heb echter om niet te prejudiceeren het woord autoinfectie niet gebruikt, maar alleen gesproken van giftproductie uit het voedsel onder inwerking van mikro-organismen. Ik bezig het nu alleen wegens de tegenstelling tegenover spontane infectie. Mijn bedoeling met spontaan was de volgende. Ik voorzag de tegenwerping (die later ook inderdaad gemaakt is, onder andere door Kessler en Vorderman), dat mijn kippen onder invloed van onvoldoende voeding meer vatbaar geworden zouden zijn voor de ziekte en dat [zij] dus eenvoudig haar oorsprong dankt aan de omgeving waarin de dieren verkeerden, met andere woorden, de dieren waren in een omgeving waar beri-beri voorkwam en ze hebben nu eenvoudig beri-beri gekregen, de voeding was niets anders dan een predispioneerend moment. Vroeg men nu, waar kwam de infectie dan vandaan, zo kan het antwoord luiden: dat moeten wij in 't midden laten. Om deze gevolgtrekking weer te geven sprak ik van spontane infectieziekte. Ik wilde daar niet aan, voornamelijk met het oog op de waarneming dat de hoenders met aardappelmeel gevoederd in die zg. geïnfecteerde omgeving niet ziek werden. Deze werden dan toch enigszins gebrekkig gevoed. Van den anderen kant zag ik de ziekte bij goede voeding (vleesch en indische zetmeelsoorten) toch 
optreden. Een infectieve ziekte, dat wil zeggen, een waarbij het infectioneerend agens van het zieke dier uit ging, wilde ik ook niet aannemen, omdat ik de ziekte evengoed verwekken kan als ik mijn kippen met rijst, dago, enz. voederde in een omgeving waar nog geen ziek dier geweest was. 'Spontaan' omvatte dus de overblijvende mogelijkheid, nadat die van autoinfectie en van infectie van dier op dier. ${ }^{8}$

Pijnappel koos hierna zonder omhaal partij voor Eijkman. In een berichtje dat twee dagen later in het Algemeen Handelsblad verscheen herhaalde Pijnappel het 'infectie-argument' van Eijkman en merkte hij met gevoel voor understatement op dat 'ons althans de heer Van Dieren nog niet geheel overtuigd [heeft]'. ${ }^{9}$ Minder dan een week later schreef Eijkman opnieuw een lange brief aan Pijnappel om zijn standpunt verder uiteen te zetten, en in één moeite door kondigde hij aan aan een eigen repliek tegen Van Dieren te werken: 'Laat men toch vooral niet te veel denken dat ik alles al wil verklaren, integendeel de zaak is nog niet uitgemaakt, wij zoeken nog naar een goede verklaring. Bij ons handelen moeten wij ons aan de feiten houden, daar heeft van Dieren gelijk aan, hoewel hij het zelf niet altijd betracht en bovendien zijn feiten gelijk ik zal aantoonen - niet alijd feiten zijn. ${ }^{10}$

Pijnappel was ondertussen op zoek gegaan naar medestanders die het standpunt van Eijkman nog wat meer kracht bij zouden kunnen zetten en zocht om die reden contact met de Apeldoornse medicus dr. J.A. Voorthuis die ruim tien jaar op Deli had gepraktiseerd, dus uit eigen ervaring kon putten, en bovendien onlangs een artikel over beriberi voor het $N T v G$ had geschreven waarin hij de ziekte voor 'miasmatisch' (tot een vervuild element in de bodem of lucht terugvoerende ziekte) hield, en vooral nadrukkelijk niet aan een verband met de rijstvoeding dacht. Maar in zijn privécorrespondentie met Pijnappel bleek Voorthuis heel wat minder eenduidig. De beriberi was naar het inzicht van Voorthuis ook geen bacteriële infectie, maar waarschijnlijk een 'organische vergifting', wat weer dichter in de buurt van Van Dierens standpunt lag. Eijkmans proeven hield hij bovendien voor 'onbetekenend'. ${ }^{11}$ Ten slotte verklaarde hij te weinig in de beriberiliteratuur ingevoerd te zijn om een polemiek met Van Dieren aan te willen gaan, en overigens ook niet met Eijkman.

Van Dieren van zijn kant wilde dat maar al te graag, misschien omdat hij beter dan Pijnappel vermoedde dat er nog wel wat ruimte in het standpunt van Voorthuis zat, en hij schreef hem daarom op 8 januari I 898 een brief waarin hij trachtte de ander over te halen om op het praktische vlak althans zijn kant te kiezen; dus om zich uit te spreken 
over de vraag 'waar hij zich bijna uitsluitend mee bezig had gehouden', namelijk: 'wat moet er gedaan worden om de ziekte te beteugelen.' 12 Voorthuis schreef al de volgende dag een beleefd briefje terug waarin hij liet weten op dat verzoek niet in te zullen gaan. Wel lichtte hij zijn eigen standpunt wat nader toe en en passant zwaaide hij de ander een klein beetje al te achteloos lof toe vanwege de aandacht die hij op de beriberi had weten te vestigen.

Ik houd de ziekte voor een van miasmatische oorsprong, en heb getracht de miasmen op te sporen, of mij dat gelukt is zal de tijd moeten leeren. Intusschen, wat wij nooit gedaan zouden krijgen hebt gij met uw geschriften bewerkt. De tijd lijkt mij niet ver meer dat de beri-beri zal worden [...] uitgeplozen. Gij hebt de kwestie tot een publieke, tot een brandende gemaakt. Alleen met dat resultaat zoudt gij reeds tevreden kunnen zijn. [...] Dat zich in rijst die lang bewaard is vergif bevindt acht ik mogelijk doch niet waarschijnlijk.

[...] Beri-beri is (m.i.) een bloedziekte waarbij een vergift wordt gevormd dat in staat is gangliëncellen te verlammen; of dit vergif in het bloed gevormd wordt door ingedrongen organismen, of dat het in het bloed gebracht wordt door bedorven voedsel blijft uit te maken. Dat dit spoedig gebeure wensch ik van harte, en zoover gaan wij hand aan hand.

Gegroet

Voorthuis $^{13}$

En al hield die brief dan ook geen onomwonden bijval in, voor Van Dieren was hij wel al ruimschoots genoeg en hij aarzelde dan ook niet om in een groot artikel dat in het Algemeen Handelsblad verscheen uit zijn correspondentie met van Voorthuis triomfantelijk zinnen te citeren die zijn gelijk zouden bewijzen. Wel valt bij vergelijking op dat de citaten nogal afwijken van de briefversie waarover wij kunnen beschikken. 'Dat zich in rijst een vergif kan bevinden is niet apriori uit te sluiten', citeerde Van Dieren Voorthuis bijvoorbeeld, niet alleen de toevoeging 'doch niet waarschijnlijk' negerend, maar ook het woord 'bevindt' veranderend in het nu juist weer conditionele 'kan bevinden'. Ook citeerde hij: 'Beri-beri is een bloedziekte waarbij een vergift circuleert' in plaats van 'wordt gevormd', een belangrijk accentverschil wanneer men geïnteresseerd is in de vraag wie of wat het gif produceert. ${ }^{14}$

Op wiens conto die verschillen moeten worden geschreven staat niet bij voorbaat vast, omdat we alleen over een door Voorthuis zelf afgeschreven kopie van zijn brief aan Van Dieren kunnen beschikken, 


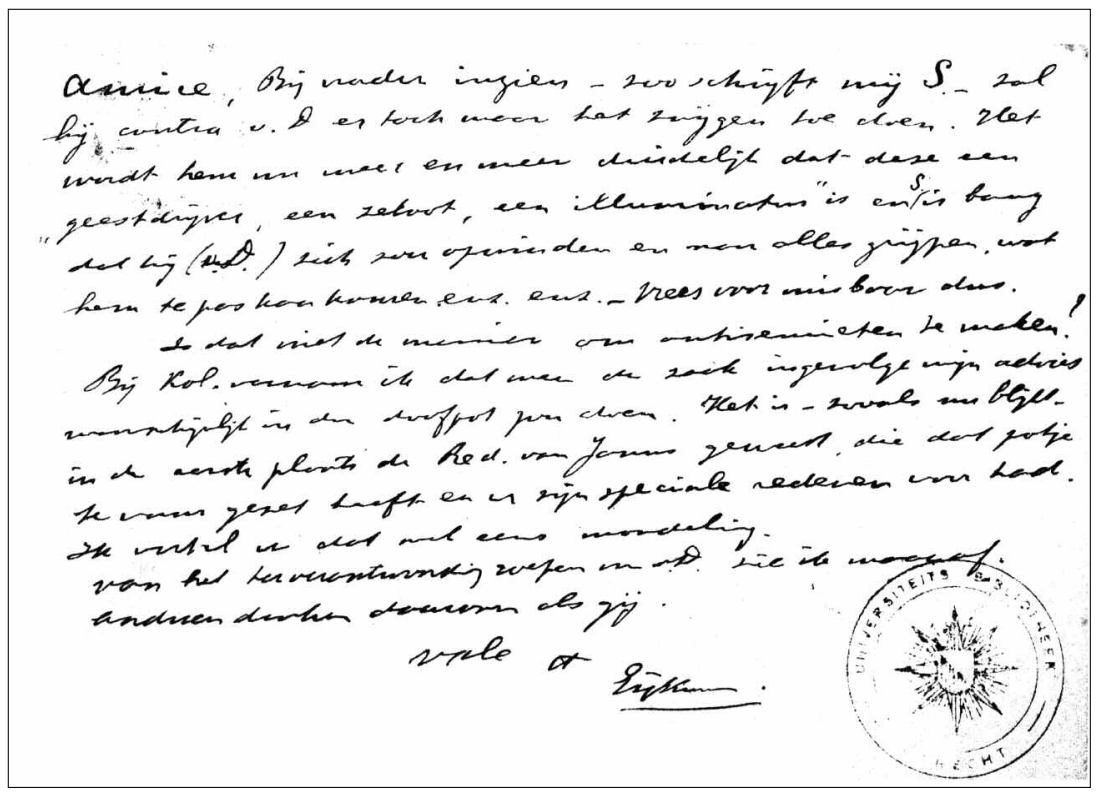

Briefkaartje van Eijkman aan Pijnappel: 'Het wordt nu meer en meer duidelijk dat Van Dieren een geestdrijver, een zeloot is.'

niet over het origineel. Voorthuis stuurde Pijnappel namelijk een kopie van zijn antwoord aan Van Dieren en schreef verontschuldigend dat hij, hoewel hij eigenlijk wel had verwacht dat Van Dieren van zijn brief gebruik zou maken, toch vond dat zijn standpunt niet verkeerd was weergegeven. Maar niet veel later kreeg hij berouw en schreef hij: 'Wat een vervelend individu is die Van Dieren. [...] Het spijt mij dat ik met die vent gecorrespondeerd heb. Hij heeft uit mijn brief gehaald wat hij gebruiken kon, terwijl de bedoelding geheel anders was. ${ }^{15}$ Voorthuis was daarna natuurlijk als medestander niet meer zo bruikbaar.

Het tandem Eijkman-Pijnappel deed er vervolgens alles aan om het mediaoffensief tegen Van Dieren verder zo goed mogelijk te orkestreren. Ze probeerde bijvoorbeeld de sympathie van C.L. van der Burg te winnen, schrijver van het overzichtswerk De geneesheer in Nederlandsch-Indië, en vooral: opponent van Van Dieren uit de jaren tachtig. Van der Burg bleek wel bereid voor Eijkman in het geweer te treden, maar vond het $N T v G$ en de NRC niet bereid een artikeltje van zijn hand te plaatsen, en stuurde het daarom maar op aan Pijnappel met de mededeling dat deze er naar eigen goeddunken gebruik van mocht maken. ${ }^{16}$ 
Met die wat matige oogst toog Pijnappel aan het werk. Op 9 januari I 898 liet hij een stukje over 'Beri-beri in Deli' in het Algemeen Handelsblad opnemen waarin het artikel van Voorthuis uit het $N T v G$ nog eens kort werd samengevat, en waarin hij Voorthuis liet zeggen dat de rijstvergiftigingshypothese naar zijn mening hoegenaamd geen waarde had. Op dezelfde dag verscheen ook de eerdergenoemde paginagrote 'medische kroniek' van Pijnappel die geheel gewijd was aan 'de zaak-Van Dieren.' Niet de wetenschappelijke vraag naar de oorzaak van de beriberi, hoe belangrijk ook, had hem aangezet tot het schrijven van de kroniek, verklaarde Pijnappel, maar louter de wijze waarop door Van Dieren de strijd wordt gevoerd: 'een zaak van eminent publiek belang, juist omdat den heer Van Dieren strijdt ten aanschouwe van het groote publiek, en omdat in dien strijd mannen genoemd zijn van groote beteekenis, omtrent wier goede trouw en bekwaamheid het Nederlansche publiek niet in twijfel mag verkeeren.' Op sarcastische toon werd de lezer gewaarschuwd dat 'wie zich nu nog eens durfde op richten tegen Van Dieren gevaar zou loopen nog I30 met een andere eigenschap van den heer Van Dieren, dan alleen met zijn taalgevoel in conflict te raken'. Dat Pijnappel voor zijn stuk uit zijn correspondentie met Eijkman had geput blijkt uit diverse formuleringen, zoals die waarin wordt gesteld dat de geschriften van Van Dieren 'niet in het minst invloed' op Eijkman hebben uitgeoefend, of de opmerking dat het onderzoek van Eijkman niet van hypothesen maar van 'werkhypothesen' uitgaat. Van experimenteel onderzoek heeft de heer Van Dieren geen kaas gegeten, maar Eijkman wel. Ja, het laboratorium voor Pathologische Anatomie en Bacteriologie te Weltevreden is een instelling 'waar wij trotsch en zeer trotsch op mogen zijn', concludeerde de medische correspondent van het Algemeen Handelsblad. ${ }^{17}$

Eijkman, die er met spanning naar had uitgezien, kwam het stuk pas tien dagen later onder ogen, maar toen hij het had gelezen, vond hij zijn geduld beloond en feliciteerde hij de ander en zichzelf ermee: 'Uw toon is van het begin tot het eind waardig en toch worden de puntjes op de i gezet.' Het zou de velen die door Van Dieren 'gehypnotiseerd' waren wel eindelijk wakker schudden en doen begrijpen dat hij 'een gevaarlijk en onbetrouwbare gids is', meende Eijkman hoopvol. ${ }^{18}$ Pijnappel moest zijn spotzucht bekopen met een vermoeiende polemiek met Van Dieren die de hele maand februari voortsudderde. Stukjes in de krant onder de titel 'het beri-beri debat' volgden elkaar in hoog tempo op, maar de argumenten spitsten zich al meer toe op details en de hele polemiek werd tot slot voor de argeloze lezer volkomen 


\begin{tabular}{|c|c|c|c|c|c|c|c|}
\hline & Brochure & $\mathrm{NTvG}^{*}$ & $\begin{array}{l}\text { Handels- } \\
\text { blad }\end{array}$ & GTvNI** & $\begin{array}{l}\text { Medisch } \\
\text { Weekblad }\end{array}$ & $\begin{array}{l}\text { Indische } \\
\text { Gids }\end{array}$ & $\begin{array}{l}\text { Brief- } \\
\text { wisseling }\end{array}$ \\
\hline Van Dieren & $\begin{array}{l}{[\mathrm{A}] \text { Beri-beri eene }} \\
\text { rijstvergiftiging } \\
\text { ( } 897) \\
{[\mathrm{B}] \text { Kantteekenin- }} \\
\text { gen op Vorderman } \\
\text { (I897) } \\
{[\mathrm{C}] \text { Begripsver- }} \\
\text { warring of erger? } \\
\text { ( } 898)\end{array}$ & $\begin{array}{l}\text { Ingezonden } \\
\text { brief }\end{array}$ & $\begin{array}{l}\text { Polemiek met } \\
\text { Pijnappel }\end{array}$ & $\begin{array}{l}\text { 'Verweer- } \\
\text { schrift tegen } \\
\text { Gelpke' }\end{array}$ & $\begin{array}{l}\text { 'De bestrij- } \\
\text { ding der } \\
\text { beri-beri' }\end{array}$ & $\begin{array}{l}\text { 't kan } \\
\text { verkeeren' }\end{array}$ & $\begin{array}{l}\text { Pijnappel } \\
\text { v. Gorkom } \\
\text { Voorthuis }\end{array}$ \\
\hline Eijkman & & $\begin{array}{l}\text { [Ingezonden } \\
\text { brief }(2) \\
N T v G] \\
\text { Bespreking D } \\
\text { 'Beri-Beri en } \\
\text { voeding' }\end{array}$ & $\begin{array}{l}\text { [Verslag } \\
\text { bijdragen] }\end{array}$ & & & $\begin{array}{l}\text { [Verslag rede } \\
\text { voor KNAW] } \\
\text { v. Gorkom }\end{array}$ & $\begin{array}{l}\text { Pijnappel } \\
\text { Voorthuis }\end{array}$ \\
\hline Pijnappel & & & $\begin{array}{l}\text { 'Medische } \\
\text { kroniek' } \\
\text { Polemiek met } \\
\text { Van Dieren }\end{array}$ & & & & $\begin{array}{l}\text { Eijkman } \\
\text { v. Dieren } \\
\text { Voorthuis } \\
\text { v/d Burg }\end{array}$ \\
\hline Fokker & & $\begin{array}{l}\text { Bespreking B } \\
\text { Bespreking D } \\
\text { Ingezonden } \\
\text { brief (2) }\end{array}$ & & & & & \\
\hline Vorderman & $\begin{array}{l}{[\mathrm{D}] \text { Onderzoek }} \\
\text { naar het verband } \\
\text { tusschen rijstvoe- } \\
\text { ding en beri-beri } \\
\text { onder geïnterneer- } \\
\text { den }(\mathrm{I} 897)\end{array}$ & & $\begin{array}{l}\text { 'Toelichting } \\
\text { op mijn } \\
\text { beri-beri } \\
\text { verslag' }\end{array}$ & & & & \\
\hline Gelpke & & & $\begin{array}{l}\text { [Verslag } \\
\text { discussie } \\
\text { Gelpke - } \\
\text { Van Dieren] }\end{array}$ & $\begin{array}{l}\text { 'Über die } \\
\text { aethiologie } \\
\text { der beri-beri.' }\end{array}$ & & & \\
\hline Kessler & & & $\begin{array}{l}\text { [Verslag } \\
\text { discussie } \\
\text { Kessler - } \\
\text { Van Dieren] }\end{array}$ & $\begin{array}{l}\text { 'Beri-beri } \\
\text { geen rijst- } \\
\text { vergiftiging' }\end{array}$ & & & \\
\hline Voorthuis & & $\begin{array}{l}\text { 'Mededeeling } \\
\text { over Beri-Beri' }\end{array}$ & $\begin{array}{l}\text { [bespreking } \\
\text { van zijn } \\
N T \nu G \text {-artikel] }\end{array}$ & & & & $\begin{array}{l}\text { Pijnappel } \\
\text { Eijkman } \\
\text { v. Dieren }\end{array}$ \\
\hline Van der Burg & & Bespreking A & & & & & Pijnappel \\
\hline Van Gorkom & & & & Bespreking D & & $\begin{array}{l}\text { 'De Beri-Beri } \\
\text { Questie' }\end{array}$ & $\begin{array}{l}\text { v. Dieren } \\
\text { Eijkman }\end{array}$ \\
\hline $\begin{array}{l}\text { Anoniem/ } \\
\text { overig }\end{array}$ & & & & Bespreking B & Bespreking A & Bespreking A & \\
\hline
\end{tabular}

Figuur I. Overzicht van de belangrijkste wapenfeiten in de beriberischermutselingen (I897-I898)

* $\mathrm{NTvG}=$ Nederlandsch Tijdschrift voor Geneeskunde

** GTvNI = Geneeskundig Tijdschrift voor Nederlandsch-Indië 
onbegrijpelijk, zoals ook Pijnappel zich realiseerde toen hij zich op zeker moment gedwongen zag uit te leggen wat zijn opponent eigenlijk bedoeld had en hij korzelig uitriep: 'Met zoo iemand is werkelijk niet te redeneeren.' Daarna vond de redactie het wel welletjes en sloot zij het debat. ${ }^{19}$

Het verbond tussen Eijkman en Pijnappel was Van Dieren zo pijnlijk dat hij er I 5 jaar later nog wraakfantasieën over koesterde. Het liefst, schreef hij een keer, zou hij zien dat hij Eijkman nader kwam te staan en dat... Pijnappel ertussenuit werd gedrukt. ${ }^{20}$

Ook Eijkman leek de vertwijfeling nabij. Op 27 januari, kort voor publicatie van zijn eerste artikel tegen Van Dieren in het $N T \nu G$, schreef hij aan Pijnappel: 't Is toch bar dat zo'n man zich aan de spits waant en nog indruk maakt, zelfs op wetenschappelijke mensen. 't Pleit niet voor de hoogte van de medische wetenschap in ons land. Mij dunkt, het gezond verstand moet toch ieder dadelijk doen inzien dat iemand die zo doldriftig en zo onbezadigd optreedt, onmogelijk een voorganger in de wetenschap kan zijn. [...]'t Wordt dunkt me, tijd dat zich einI32 delijk eens een krachtige algemene afkeuring tegen zijn drijven uitspreekt.'

\section{Meer van zulke critici}

De afkeuring bleef, zoals we eerder zagen, niet uit. Tegelijk met Eijkman werkte ook Vorderman aan een repliek die in april in het Geneeskundig Tijdschrift voor Nederlandsch-Indië zou verschijnen en waarvan Eijkman al in maart I898 de drukproeven inzag en doorstuurde aan Pijnappel. Maar toen dat stuk uitkwam was het uitgerekend Fokker die er in het $N T v G$ een boekaankondiging aan wijdde (een overdruk van het stuk verscheen ook als aparte brochure). En opnieuw was Fokker pesterig vriendelijk tegenover Van Dieren, wiens verdiensten hij graag onderstreepte, evenals diens 'intuïtief verkregen vaste overtuigingen' die hij wel geschikt achtte 'om de aandacht van onderzoekers en autoriteiten gaande te maken en levendig te houden'. Dat Van Dieren zelf geen onderzoeker was vond Fokker een bijkomend voordeel, daar deze immers 'de rol op zich genomen [heeft] van kriticus, en waar hij die rol, een rol die den onderzoeker wel onaangenaam moet zijn, vervult, kan zijn medewerking aan de zaak slechts ten goede komen. Het zou wenschelijker zijn, dat er meer zulke critici opstonden. ${ }^{21}$ In een woedende brief schreef Eijkman aan Pijnappel: 
Amice

Wat zegt ge van Fokkers jongste stukje? Mij lijkt het een wanhopige poging om Van Dieren, ridder van de droevige figuur, nog op den been te houden.

Welk een tegenspraak met zichzelf telkens en dan - is het niet alsof mijn stuk niet de minste herinnering bij den hooggeleerden heeft achtergelaten? "Van Dieren is geen onderzoeker en toch heeft hij zijn meening met meer kracht dan anderen verdedigd." Met krachtige argumenten? Neen, "grootendeels door intuïtieve overtuiging”. Wat heeft een ander daaraan? Er zijn waarschijnlijk honderden menschen, die er intuïtieve overtuigingen op na houden, maar verstandig genoeg zijn die voor zich te houden, zoolang zij daar geen zwaarder weegend bewijsmateriaal aan hebben toe te voegen. En omdat Van Dieren zulks niet gedaan heeft, maar integendeel hoogst eenzijdig er maar op los beweert en zijn bekende zucht om te kritiseeren op ieder en alles behalve op zich zelf botgevierd heeft, zou hij verdienste hebben! [...]

"Het zou wenschelijk zijn dat er meer zulke critici opstonden". De hemel beware ons ervoor! [...]

Is de wetenschap er mede gediend dat men zulk gebazel aanmoedigt door iemands naam te vereeuwigen? Ik heb grooten lust een scherp stukje in den trant van bovenstaande tegen Fokker te schrijven en dan te eindigen met: Excuseer mijn temperament, Hooggeleerd!

Wat denkt u er van?

Met collegiale groet

Uw

Eijkman $^{22}$

Daadwerkelijk verscheen op 23 april I 898 een ingezonden brief in het $N T v G$ waarin Eijkman zich in vrijwel gelijkluidende bewoordingen tegen Fokker keerde en eindigde met de iets getemperde verzuchting: 'Dit moge niet hoffelijk klinken, doch dat doet er tegenwoordig minder toe, men excuseert zich maar met mijn "temperament". ${ }^{23}$ Met gespeelde verbazing antwoordde Fokker dat hij niet begreep hoe Eijkman zich zo boos had kunnen maken. 'Religie en politiek komt er niet bij te pas en toch een maximale verbittering van beide zijden! Unde irae? [vanwaar de woede].' Ja, geenszins had hij zich willen voordoen als partijganger van Van Dieren, veel liever had hij zich geschaard onder de volgelingen van Eijkman, 'ware het niet dat diens denkbeelden mij tamelijk onbepaald overkomen'. ${ }^{24}$

Daar nam Eijkman dan maar genoegen mee: 'Ja, Fokker draait er zich aardig uit en ik heb daar volkomen vrede mee, zoodat ik het erbij 
laat. Maar meer dan uitdraaien is het dan ook niet, de hoofdpunten raakt hij nauwelijks aan. ${ }^{25}$

\section{Een misoogst}

Terugkijkend op de affaire schreef Eijkman aan Pijnappel op 2 mei I 898: 't Kan soms eigenaardig loopen; met dit kleine stukje [bedoeld is zijn ingezonden brief tegen Fokker] heb ik uiterlijk nog meer succes dan met het groote [driedelige beriberi-artikel], waar ik zoo over heb moeten ploeteren. Enfin, zonder dit was het andere ook niet mogelijk geweest' (cursief toegevoegd). Met andere woorden: de polemiek had het hem mogelijk gemaakt zijn standpunt te verduidelijken. En ook al had hij Fokker dan niet weten te overtuigen, feitelijk mag hij hem wel dankbaar zijn, zo schreef Eijkman, omdat 'hij mij gelegenheid gegeven heeft de punten nog eens op de i te zetten, vooral met het oog daarop dat mijn grooter stuk voor het gros der lezers rijkelijk lang was'. ${ }^{26}$

I34 Dat voorjaar waande Eijkman zich de morele overwinnaar in de beriberistrijd en zichtbaar opgelucht begon hij erover te denken zijn succes te incasseren: 'Ik geloof dat er termen voor mij bestaan hem [Van Dieren] wegens laster voor den rechter te brengen of wegens eerroof, doch denk daar natuurlijk niet aan. Het zou, dunkt me, een zaak zijn voor een ärztliches Ehrengericht [medisch tuchtcollege], als men hier iets dergelijks ten onzent had. Ik vind dat er grond genoeg is hem uit den medischen Kring te bannen, als hij zich niet verantwoordt. Maar misschien oordeel ik partijdig en daardoor te hard. ${ }^{27}$

Men herinnert zich dat Pijnappel toezichthouder was bij de Koninklijke Maatschappij tot Bevordering der Geneeskunst, en misschien moet deze passage als een verkennende poging van Eijkman worden gelezen om te onderzoeken of er genoeg steun zou zijn om Van Dieren werkelijk aan te klagen en uit de vereniging te laten zetten. De slotconclusie van zin betoog luidde dat, sinds hij twee jaar eerder Indië had verlaten, zijn onderzoek niet veel verder was gekomen, en daarvoor stelde Eijkman 'voor een niet gering deel Van Dieren c.s.' aansprakelijk. 'Dat alles weet men hier zoo niet en het gaat moeilijk met zulke grieven openlijk voor den dag te komen, men kan er hoogstens, zooals ik deed, in algemene termen op zinspelen. ${ }^{28}$ Gelukkig was tenminste dat dan rechtgezet!

Maar toen bleek in juni van dat jaar hoezeer hij zich had vergist. De minister van Koloniën was van plan een internationaal beribericongres te organiseren en vroeg Eijkman en Stokvis om advies. Stokvis, die zich 
in een privéschrijven aan Van Dieren al lovend over hem had uitgelaten, stelde tijdens een bijeenkomst met Eijkman tot diens ontzetting voor om zowel Van Dieren als Fokker uit te nodigen voor dat congres.

Vooral tegen de keuze van Van Dieren heb ik mij sterk verzet, zonder baat echter. Bij die gelegenheid heb ik ook gemerkt, hoe weinig Stokvis op de hoogte is. Dat Overbeek de Meyer een der eerste en verdienstelijkste schrijvers over beri-beri is, was hem onbekend. Mijn stuk over beriberi en voeding had hij niet behoorlijk gelezen. [...] [Ook] van uw heele polemiek met Van Dieren [in het Algemeen Handelsblad] was Stokvis onkundig! Stokvis schreef mij dienaangaande: "Waar heeft Van Dieren dien passus uit den brief gepubliceerd, die niet voor openbaarmaking bestemd was, en dien ik hem schreef, juist omdat ik de inmenging van anderen weinig vruchtbaar en verkeerd vond, toen hij met alle kracht bij mij aanhield om in het openbaar vóór hem te getuigen. ${ }^{29}$

En zo moest Eijkman constateren dat het effect van zijn mediacampagne tegen Van Dieren niet alleen niets had uitgehaald, erger, het keerde zich als een boemerang tegen hem.

Het blijkt meer en meer, welke heillooze verwarring zulke lieden stichten. Zijn appèl aan het gezond verstand der leeken, iets wat altijd in goede aarde valt, heeft zulk een wantrouwen gewekt bij de autoriteiten tegen het juiste inzicht der Indische medici, speciaal ook tegen Vorderman en het Laboratorium, dat men heel veel buiten hen om doet. Zoo is het Departement van Oorlog in Indië op eigen houtje begonnen met een proef met versch gepelde rijst zonder zilvervlies. Ik ben ook in niets gekend, noch vanuit Indië, noch van wege het Departement van Koloniën. Zelfs ontving ik geen exemplaar van Vorderman's rapport (officiële uitgave), Van Dieren wel. [Minister] Ruygrok is nooit bij mij geweest, de voorbereiding van een eventueel beri-beri-congres gaat of ging geheel buiten mij om. En mij opdringen ligt nu eenmaal niet in mijn aard..$^{30}$

Het hele beribericongres zou geen doorgang vinden. Het werd, ingevolge het advies van Eijkman 'in de doofpot gestopt', en Eijkman zag er nu ook maar van af Van Dieren ter verantwoording te roepen. De bedoeling daarvan was hoe dan ook geweest, zoals hij aan Pijnappel schreef, 'het doen afnemen van diens aanhang, niet bij wijze van strafoefening'. ${ }^{31}$ 


\section{De bittere waarheid}

Toch was de polemiek niet zonder gevolgen gebleven, zo begreep Eijkman. Ten eerste bleek nu dat Van Dieren definitief naam gemaakt als iemand die blijkbaar op intuïtieve wijze tot ongeveer dezelfde conclusie was gekomen als hijzelf, en omgekeerd zou bij het publiek de opvatting postvatten als zou hij een voorstander van de rijstvergifthypothese zijn geweest, en die twee proposities zouden ten slotte samensmelten in de gedachte dat Van Dieren en Eijkman hetzelfde doel nagestreefd hebben..$^{32}$ In een boek over Gezondheidsleer voor Nederlandsch-Indië van de arts E.H. Hermans, heet het bijvoorbeeld dat Van Dieren als een der eersten op het verband tussen beriberi en voeding heeft gewezen, en dat juist zijn 'buitengewone manier van schrijven [...] de tegenstander [Eijkman] wel moest prikkelen [waardoor] het vraagstuk van het ontstaan en het wezen der beriberi des te eerder tot oplossing [werd gebracht].'

Twee decennia later, in mei I929, het jaar waarin aan Eijkman de Nobelprijs werd verleend, verscheen een paginagroot artikel in het I36 Algemeen Handelsblad over de ontdekking van vitaminen waarin Eijkman en Van Dieren naast elkaar werden neergezet als grootheden van ongeveer gelijke omvang. De anonieme schrijver besprak de 'allergeweldigste strijd' tussen de twee en schreef aan Van Dieren de 'grootse verdienste' toe 'het hoofd koel te hebben gehouden toen zelfs de bekwaamste bacteriologen beri-beri-bacteriën zochten'. Dat Van Dieren gelijk had gehad met zijn vergiftigingshypothese wilde de schrijver niet beweren, maar 'de meeningen van Eykman en van Dieren stonden niet tegenover elkaar; integendeel, zij vullen elkander aan. Laat ons zeggen dat ieder een deel van het vraagstuk opgelost heeft en dat nog een deel op te lossen blijft'. ${ }^{33}$ Drie weken eerder had in een artikeltje in de NRC zelfs gestaan hoe eens, langgeleden, 'Pekelharing en zijn medewerkers uit Indië terugkwamen met een beriberibacil en spoedig grondig door van Dieren en Eykman werden afgemaakt. ${ }^{34}$

Ja werkelijk, de publieke opinie bleek niet ongevoelig voor de pogingen van Van Dieren om de geschiedenis naar zijn hand te zetten en aan hem verdiensten toe te schrijven op het gebied van de beriberibestrijding. Verschillende ingezonden brieven kwam ik tegen, steeds wanneer de geschiedenis van de beriberi aan de orde werd gesteld, waarin de redacties van kranten aan de 'vergeten pionier' Van Dieren werden herinnerd die immers 'onverstoord te midden zijner drukke bezigheden te Amsterdam de meelvergiftigings- en rijstvergiftigingshypothese staande had weten te houden', terwijl om hem heen de wetenschappelijke inzichten langzaamaan veranderden..$^{35}$ 
Zo genereus als de geschiedenis leek voor Van Dieren, zo onbarmhartig was ze bijna dertig jaar lang voor Eijkman, de voormalige medewerker van Pekelharing die zijn leermeester samen met Van Dieren zou hebben 'afgemaakt' en pas na verloop van tijd zou hebben ontdekt wat Van Dieren intuïtief allang wist. Wat een gruwelijke verminking van de waarheid, en wat een onrechtvaardige misvatting! De toekenning van de Nobelprijs moet niet alleen als een erkenning maar ook als een bevrijding hebben aangevoeld.

$\mathrm{Nu}$ was Eijkman zich wel bewust van de hardnekkigheid waarmee mystificaties zich in de geschiedschrijving kunnen nestelen, maar ook begreep hij goed dat iedere poging haar recht te zetten wel het tegenovergestelde moest bereiken. De verbittering daarover klonk nog door toen hij in een voordracht het beriberivraagstuk behandelde en klaagde over het onbegrip dat hij steeds maar weer moest bestrijden. ${ }^{36}$ De ironie wil dat dat de bijeenkomst was waarop Van Dieren 'schoon schip' hoopte te maken - maar waartoe hem de toegang werd ontzegd.

Begrijpelijkerwijs had Eijkman zich voorgenomen de naam van zijn opponent nooit meer te zullen noemen, en hij hield zich daaraan. Ook toen hij in I9I 3 in zijn rede 'Simplex non veri sigillum' (eenvoud is niet het kenmerk van de waarheid) waarschuwde tegen geestdrijvers: lieden met vooropgevatte meningen en al te eenvoudige waarheden, die zich in de medische praktijk het recht van meespreken willen toe-eigenen. 'Wat van hun gading is, wordt gretig en zonder oordeel des onderscheids aanvaard, en, al wordt het nog zoo afdoende en bij herhaling weerlegd, telkens weder als hoogste waarheid verkondigd, de argumenten der wederpartij daarentegen aan een overdreven en spitsvondige kritiek onderworpen of doodgezwegen. ${ }^{37}$ Men mag zonder mankeren in die 'geestdrijver' Van Dieren herkennen.

In de Nobelprijsvoordracht is ook de toespeling op Van Dieren vrijwel helemaal verdwenen en wordt de rijstvergiftigingshypothese in één zin afgeserveerd. Alleen de laatste vier woorden herinneren ons aan die bittere en nutteloze strijd: 'Het feitelijke bewijs van een in de rijst preexisterend gif is niet geleverd of zelfs maar gezocht. ${ }^{38}$

\section{Mystificatie}

Omgekeerd lijkt het moeilijk om die uitdrijving van Van Dieren uit de wetenschappelijke gemeenschap in letterlijke en figuurlijke zin anders te begrijpen dan als het bewijs van diens dwaling, of liever gezegd als zijn definitieve echec als wetenschapper. 'Wetenschappers moeten met elkaar wedijveren opdat hun ideeën kunnen evolueren', schrijft Michael 
White in zijn boek over wetenschappelijke rivalen. ${ }^{39}$ En juist daarin slaagde Van Dieren niet: een concurrent te zijn. Zijn rijstvergiftigingshypothese stond wel tegenover de infectieopvatting van Eijkman en was strikt genomen zelfs even onjuist, maar heeft toch geen invloed op de oplossing van het beriberivraagstuk uitgeoefend. Het beriberionderzoek heeft zich voortgezet zonder zich iets aan de oppositie van Van Dieren gelegen te hebben laten liggen, zo heeft Eijkman steeds volgehouden, en hij had daarin gelijk.

Toch was Van Dieren er bijna in geslaagd door te dringen tot de geschiedschrijving, zoals we gezien hebben. We gebruiken voor die poging om met terugwerkende kracht een plek op te eisen in de loop van de geschiedenis door aan de eigen geschriften achteraf een voorspellende waarde toe te kennen de aan Eijkmans commentaar ontleende term 'mystificatie'. Letterlijk betekent mystificatie het verspreiden van onware informatie met als doel het verdoezelen van de waarheid. In de geschiedschrijving zijn mystificaties vaak verhalen die de machthebbers in omloop brengen om hun machtspositie te versteI 8 vigen, maar bij Eijkman wordt het omgekeerde bedoeld: verhalen die de geautoriseerde of althans ware geschiedschrijving ondermijnen.

Die mystificerende geschiedschrijving heeft op de korte termijn effect gehad, maar op de lange duur niet; de naam Van Dieren is uiteindelijk uit de geschiedenisboekjes verdwenen. In de biografie van Eijkman figureert Van Dieren als een 'vermakelijk uitstapje'; in de geschiedenis van de beriberi is hij een onbelangrijke voetnoot, in de geschiedenis van de geneeskunde komt hij niet voor.

En terecht, zegt de wetenschapshistoricus, en ik spreek hem niet tegen. Toch denk ik niet dat hieruit volgt dat die mystificerende strategieën terzijde moeten worden geschoven als verwarring stichtende onzin. Ze hebben een zekere waarde of betekenis, althans wanneer we ze lichten uit het objectivistische kader waarbinnen ze doorgaans liggen opgesloten en ze plaatsen in het perspectief dat in dit boek vooropstaat: dat van de buitenstander die probeert betekenis te geven aan de loop van de geschiedenis waarin hij verwikkeld is zonder er deel aan te kunnen nemen. Als zodanig vormen de mystificaties instrumenten van betekenisgeving en geven ze ons inzicht in de manier waarop de buitenstaander grip tracht te krijgen op die ontwikkelingen, juist door voor zichzelf daarin een plekje te reserveren..$^{40}$ Het succes van die strategieën ligt daarom paradoxaal genoeg in het falen ervan: hoe meer weerstand de buitenstander weet op te wekken in zijn mystificaties, des te meer 'betekenis' hij daarmee voortbrengt, en al is het uiteindelijke resultaat een volkomen 'mislukking', dan nog is het in die mislukking dat de buitenstaander zich erkend weet. 


\section{7 \\ Een onderaards bestaan}

In I9I 2 schreef Van Dieren een toneelstuk dat hij $O p$ dwaalwegen noemde en dat als ondertitel 'Spel van den woeligen tijd' meekreeg. Geschreven als een eigentijds en tegelijk stichtelijk drama gaat het stuk over een wat al te goedgelovige domineesdochter die door een laffe sociaal-democratische student zwanger wordt geschopt, tot abortus wordt gedwongen en vervolgens door hem in de steek wordt gelaten. Redder in de nood is de scherpzinnige dr. Mol, door de auteur omschreven als een Amsterdamse geneesheer van ongeveer vijftig jaar met snor en toegepunte baard, die op de schedel kaal begint te worden, drager van een gouden bril. Een dokter die zich in een koetsje laat verplaatsen. ${ }^{1}$

Ruimte voor vergissing is er niet. In dr. Mol moeten we per se de dan 5 I jarige Amsterdamse geneesheer Van Dieren zelf herkennen, die niet alleen exact met de uiterlijkheden van dr. Mol overeenkomt, maar die zich voor het overige ook gedraagt als de dokter in het toneelstuk, namelijk als een gelijkhebberig en praatziek figuur, die gemakkelijk drie of vier bladzijden tekst per beurt voor zich opeist, en met wie iedereen het oneens is, hoewel hij aan het eind natuurlijk gelijk krijgt.

\section{Scenarioschrijver of figurant?}

Op dwaalwegen schetst een intiem kijkje in het huishouden van de Van Dierens, waar de ramen en deuren weliswaar altijd openstaan, maar waar het desalniettemin toch altijd benauwd lijkt. Het doek gaat op. Het toneel toont ons een oerburgerlijke huiskamer waarin we een schoorsteenmantel met pendule en een rekje Goudse pijpen ontwaren, een piano en een zwaar buffet. Aan de muur hangen enige christelijke platen en een onbestemd damesportret. Verderop werpt een gaskroon haar eeuwig licht in de duisternis.

Een dienstmeisje dribbelt door de kamer met de thee, de mevrouw des huizes stopt een sok; meneer, een dominee, leunt achterover in zijn 
fauteuil en leest de krant. De bel gaat, het dienstmeisje doet open. De dokter komt binnen. Omstandige begroeting. Al pratend loopt de dokter op de dochter des huizes toe, zij heeft verhoging. Hij neemt haar pols op en steekt ondertussen een politiek-theologisch traktaat af tegenover haar verloofde. Die werpt schuchter tegen een andere mening te zijn toegedaan en wordt bediend met een belerende repliek. Wrevelig commentaar van de jongeman leidt tot nog meer vertoog van de kant van de dokter. Het dienstmeisje sluipt de kamer uit, de dominee slaat geërgerd zijn krant dicht. Langzaam slaat de trage zondagse loomheid om in een sfeer van geagiteerdheid. Waar de dokter komt, komt ruzie. $^{2}$

Op verschillende plaatsen in zijn werk heeft Van Dieren naar dat nooit opgevoerde toneelstuk verwezen, bijvoorbeeld in de tweede druk van De waanzinnige waereld, in het deel waarin hij zijn eigen verdiensten opsomde. Aangekomen bij zijn 'literaire werk' verklaarde hij dat hij het toneelstuk had geschreven met een bepaald doel, namelijk iets te scheppen wat 'schoon, waar en goed is', en wat de geesten 'verkwikt, I 40 verrijkt, verheft en veredelt door te ontroeren of te verheugen.' Vergelijk dat eens met het werk van Heijermans, vond Van Dieren, die immers precies het tegenovergestelde beoogd heeft: zou dan niet hij op den duur oneindig veel meer bereiken? Of denk eens aan Van Eeden, die met zijn onchristelijke stukken een enorm bereik heeft, maar de mensen een rad voor ogen draait, zo meende hij.

Generatiegenoot Van Eeden had zich inderdaad al vroeg als een kritische, spottende geest ontpopt. $\mathrm{Al}$ in $\mathrm{I} 885$ had hij onder het veelzeggende pseudoniem Cornelis Paradijs een parodie op de stichtelijke gevoelens van het godvrezende deel der natie gepubliceerd met de dichtbundel Grassprietjes, waarin bijvoorbeeld de lof op de Heer in het gedicht 'Bij een geschenk' (ondertitel: 'Twaalf geborduurde zakdoeken'), zo uit Van Dierens stuk had kunnen zijn geknipt, maar dan zonder de ironische ondertoon: 'Want bedenk bij wát ge doet / Wij zijn nietig stof / God alleen geeft alle goed / Hem zij alle lof!'

Zou die bundel nog als een jeugdzonde kunnen worden afgedaan, zo niet de latere toneelstukken, waarin het geloof steeds opnieuw mikpunt van spot en twijfel wordt, zeer tot ergernis van Van Dieren, die het aandurfde dat aan Van Eeden zelf te schrijven: 'Toe, v. Eeden, denk nog eens goed over àlles na, en schrijf dan mij nog veel waarderender over het Christendom dan gij er $n u$ reeds over spreekt. Misschien kunt gij er dan zelfs toe komen een model-Christen uit te beelden als wèlgelukten tegenhanger van den mislukten Heintje-Wil-wèl uit het Beloofde Land 
(Bij de première heb $i k$ gefloten na het tweede bedrijf en ben heengegaan). ${ }^{3}$

Het door Van Dieren uitgefloten stuk was De idealisten, of het beloofde land, een komedie uit 1909 over Van Eedens eigen ervaringen met Walden, de mislukte utopische kolonie te Bussum die in 1907 op de fles was gegaan, tot groot leedvermaak van de burgerlijke en zelfs de socialistische pers. Een spotprent van Albert Hahn in Het Volk van 26 januari I 907 toont een bedrukte Van Eeden naast een hoop kale stenen, waarboven een verdort takje uitsteekt. Het onderschrift luidt: 'Hoe ik mijn boompje ook besproei, het wil maar niet groeien' - het had een commentaar op Van Dierens 'op rotsachtige bodem uitgestrooide zaden'-filosofie kunnen zijn.

'Het is niet alles in de bedompte sfeer van een vijandig vaderland te moeten leven', noteerde de auteur van De idealisten in het voorwoord bij zijn autobiografische toneelstuk. Mislukking en vijandigheid: thema's die Van Eeden en Van Dieren gemeen hadden. Ook Van Eeden is van harte uitgelachen. Maar anders dan de Amsterdamse schrijver-arts gebruikte de Haarlemse psychiater-schrijver die ervaring om de mensen een spiegel voor te houden. In het toneelstuk IJsbrand bijvoorbeeld, dat uit dezelfde tijd stamt, laat hij een gesjeesde profeet opdraven om de benepen burgermansmoraal aan de kaak te stellen.

IJsbrand was een van de succesvollere producties van Van Eeden, door sommigen als 'gevaarlijk' beschouwd vanwege het vele gevloek erin. Onchristelijk was het zeker, maar subversief was het stuk om nog een geheel andere reden. Dat wordt eerst duidelijk wanneer we kennismaken met IJsbrand', de hoofdpersoon, die zich aldus bij het publiek introduceert.

\footnotetext{
Waarom moet ik nutteloos tot het eind jammeren?

Hoe kan God met zijn ijdelen jammer gediend zijn?

$\mathrm{Al}$ wat ik zeg is toch immers machteloos?

De ijspegels smelten niet voor mijn heten adem -

$\mathrm{Al}$ schrei ik vuur, geen enkele verweekt

Vreselijk is het leven van den onbegrepene. ${ }^{4}$
}

Het droge commentaar van omstanders daarop luidt: 'Nou, stapel, hoor!'

IJsbrand was natuurlijk Van Eeden zelf, die met zijn hooggestemde idealen alleen maar hoongelach opwekte bij de benepen burgerman. Aan het slot laat Van Eeden, zelf psychiater, IJsbrand een klinisch onderzoek ondergaan. 'Arme man', zegt de arts meevoelend tegen IJsbrand, 
'voor sommigen onder ons is het leven schrikkelijk wreed'. 'Kun je me zeggen waarom?', vraagt IJsbrand, maar de ander moet het antwoord schuldig blijven. 'Voel je je wel eens ver boven alle andere menschen verheven?', wil de psychiater weten, waarop IJsbrand in zijn onschuld antwoordt: 'Oneindig meer.' De psychiater noteert: 'Oneindig meer... ja! ja!' 'Ook is er vreugde in woede', vervolgt IJsbrand zijn betoog. 'Ja, maar dan toch een kortstondig en gevaarlijk geluk', zegt de psychiater. 'Neen!', zegt IJsbrand, '... want er volgde zegening.' 'Openbaren de goden zich aan je', wil de psychiater tot slot weten, om er zeker van te zijn met een gek te maken te hebben. IJsbrand, naïef als altijd, zegt: 'Wat ander werk hebben we op aarde te doen, als hun openbaringen geduldig te ontcijferen?'

De psychiater weet genoeg, hij laat IJsbrand opnemen in een inrichting. Te laat realiseert deze wat de bedoeling van het gesprek was; jammerend laat hij zich wegvoeren: 'Oooh!... Erbarmen! Mijn God! (Hij werpt zich snikkend op den grond voor den professor.) Oooh!... Oooh!... genade!... listig maar machtig monster... ik erken het... je I42 bent machtiger geweest dan ik... je hebt gewonnen!... je hebt gewonnen!... neem mijne vernedering!'

In IJsbrand blijven de wereld van de krankzinnige en die van de gewone burger keurig gescheiden, en is het de taak van de gek om commentaar op de wereld te geven. Bij Van Dieren kunnen die werelden niet gescheiden zijn en kan hij in IJsbrand en al die andere onbegrepen karakters van Van Eeden niets anders dan zichzelf herkennen. Dit was een voorstelling die hij als verlamd van begin tot eind heeft uitgezeten, onmachtig eraan te ontsnappen. Dat een 'gewone krankzinnige' als IJsbrand met zo veel egards werd behandeld vond hij een uitgesproken onhebbelijkheid, en als Van Eeden zijn held tot slot laat uitroepen 'In Uwe handen, God, in Uwe handen mijn geest' (bij Van Dieren: Vader, in uwe handen beveel ik mijn geest), dan was dat niet alleen een godslastering van de ergste soort, maar vooral een belediging van de onbegrepen grote mannen. ${ }^{5}$ Immers, het mag dan waar zijn dat sommige grote mannen als krankzinnigen of misdadigers zijn behandeld door hun tijdgenoten die hen niet begrepen ('nog niet begrijpen konden'), maar daaruit volgt niet dat men het recht heeft om de waarheid om te keren, en te doen alsof krankzinnigen grote mannen zijn, zo wierp Van Dieren tegen. Waaruit dan weer de onweerlegbare conclusie volgde dat als krankzinnigen geen grote mannen zijn, grote mannen niet als krankzinnigen mogen worden behandeld, enkel omdat ze nog door niemand worden geloofd. QED. 
Woedend haalde Van Dieren uit naar de auteur van Het beloofde land, omdat hij vond dat de schrijver zich onvoldoende in zijn standpunt had verdiept: 'Ik ben er zeker van dat ge bij nader onderzoek ook anders zult leeren oordeelen over het werk der zendelingen dan ge in uw laatsten tooneelwerk getoond hebt te doen!' ${ }^{\prime}$ Maar het tegendeel was waar: Van Eeden had zich juist gevaarlijk goed in de wereld van de outcast ingeleefd; zo goed zelfs dat Van Dieren niets anders kon doen dat zijn eigen stuk daar tegenover zetten.

Van Eeden en Heijermans zijn dus de Eijkmannen van de literatuur aan wie Van Dieren zich nimmer gewonnen zou geven. Op hen entte hij zijn eigen stuk. Zelfs Antje, de dienstbode in IJsbrand, liet hij daartoe in zijn eigen stuk opdraven; hij mat haar zelfs dezelfde Amsterdamse straatmentaliteit aan. Heijermans en Van Eeden vormden dus zijn publiek; zij waren het die moesten worden overtuigd, of liever gezegd: aan wie hij zijn leven opvoerde.

Had de figurant zich tot scenarioschrijver ontpopt? Was hij erin geslaagd zijn leven te transformeren en het lot in eigen hand te nemen? Neen. Hij had zich slechts de tekst toegeëigend die bij zijn rol hoorde. Duidelijk wordt dat in het derde bedrijf, dat ongeveer de helft van het stuk in beslag neemt en waaruit blijkt dat het hele abortusdrama dat eraan voorafging niet meer is dan een even hinderlijke als noodzakelijke aanleiding om te komen tot de kern: de dokter aan het woord te laten.

\section{De mol graaft zich autobio}

De plaats van handeling heeft zich verplaatst van de huiskamer van het domineesgezin naar een socialistische vergaderruimte waar de student zojuist een betoog heeft gehouden waarvan de strekking moet zijn geweest dat geloof en wetenschap niet met elkaar kunnen samengaan. Het betoog zelf heeft de schrijver maar achterwege gelaten, we vallen binnen als een instemmend applaus de student ten deel valt. Nadat het rumoer is verstomd eist dr. Mol het woord en begint hij aan een lange rede tegen het darwinisme. Hele stukken eruit zijn rechtstreeks ontleend aan Van Dierens eigen boeken, soms woord voor woord.

'Je schreef brochures en zelfs een toneelstuk dat levende drama's waren die maar één gebrek hadden', schreef een vriend eens mild spottend: 'ze waren net als sommige worsten, haringkoppen en eindjes sigaar volgestopt met citaten." De scène in het vergaderhol beslaat ruim vijftig pagina's en zou het uiterste van de toeschouwer-luisteraar hebben gevergd, omdat de enige onderbrekingen in het betoog van dr. Mol worden gevormd door schutterige tegenwerpingen van de 


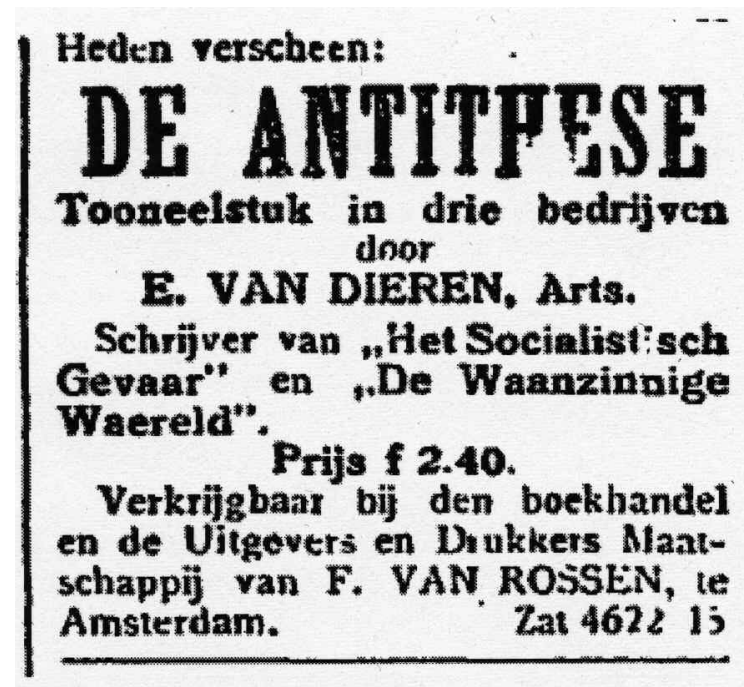

De antithese, mislukt als eigentijds drama maar niet als autobiografie.

student die onverbiddelijk worden afgestraft met moraliserende terechtwijzingen. Aan het slot volgen komisch bedoelde interrupties van het figurerende publiek, waarmee Van Dieren de dramatische kwaliteiten van het stuk hoopte te verhogen. 'Aanpakke, ouwe jongen! Ga maar naar huis toe! Bravo-geroep. Gelach. Voorzitter hamert."

Een Kneppelhout-waardig tafereeltje, ontleend aan zijn eigen ervaringen met de socialisten, maar het was verspilde moeite. Als toneelstuk was $\mathrm{O} p$ dwaalwegen bijzonder onsuccesvol. Het werd wel gepubliceerd maar nooit opgevoerd, zelfs niet nadat Van Dieren de door hem benaderde theaterdirecteuren de onwaarschijnlijk hoge waarborgsom van duizend gulden in het vooruitzicht had gesteld 'met het oog op een mogelijke mislukking'. ${ }^{9}$ Zelfs een sterke besnoeiing van het stuk dat meer dan honderd pagina's in druk besloeg mocht niet baten, want ook de herschreven versie uit I 920 , nu als De antithese gepresenteerd, naar het toen gangbare onderscheid tussen links en rechts (soms ook: confessionelen en niet-confessionelen) in de politiek, vond geen genade in de ogen van de cultuurkliek. En dus bleef het drama in de kast liggen, terwijl de schrijver niets anders kon doen dan hopen dat 'een of ander dilettantengezelschap' zich erover zou ontfermen. ${ }^{10}$

Ik vond welgeteld één recensie, in het Nederlandsch Tijdschrift voor Geneeskunde nota bene. De recensent was Pinkhof, een studiegenoot 
van Van Dieren, die de bespreking rechtvaardigde door te verklaren dat het besproken probleem, abortus provocatus, 'een maatschappelijk verschijnsel is dat ons artsen maar al te zeer aangaat'. Maar juist daarom vond hij het verkeerd dat dokter Mol ten overstaan van een verzwakte en door verdriet gekwelde vrouw een boom van zes pagina's opzet om te bewijzen dat Hugo de Vries het darwinisme de doodsteek geeft. 'Dàt moet men een patiënte niet aandoen, zelfs niet als inleiding tot een gestreng maar moedig en reddend woord, gelijk een geneesheer soms heeft uit te spreken.' ${ }^{11}$

\section{Getrouwd}

Mislukt als eigentijds drama maar niet als autobiografie: de dwaalwegen-antithese-voorstelling doet verslag van het ondergrondse leven van Van Dieren, de mol die ziende blind was.

'Het decor verandert, de mensen komen de kamer binnen, en gaan weer naar buiten, maar verder gebeurt er niets. ${ }^{12}$ Het is pas achteraf dat we in de opeenvolgingen van gebeurtenissen, waaraan we dachten niet te kunnen ontsnappen, regelmatig herhalende patronen zien die zich steeds opnieuw aan ons hebben voorgedaan. Van Dieren dacht dat zijn leven een drama was, maar het bleek een klucht, een toneelstuk in een toneelstuk over een figurant die denkt dat hij de hoofdrol speelt.

Hij trouwde op I7 mei I 894 met een meisje van vijfentwintig, een schippersdochter uit een bekend Terschellings geslacht. Toeval of niet, maar we herinneren ons dat ook Evarts moeder schippersdochter was. De vader van zijn vrouw, Cornelis Anes Bakker (I84I-I9IO), had fortuin gemaakt bij de maatschappij Nederland. ${ }^{13}$ 'Kapitein Bakker' was, blijkens een brief van Van Dieren uit I9I9, vrijmetselaar. Hij werd op het eiland beschouwd als 'rijk' alhoewel niet bekend is hoe rijk 'rijk' inhield, maar het is denkbaar dat Cornelis Bakker zijn schoonzoon financieel heeft bijgestaan toen deze zich vestigde als huisarts in Amsterdam. Feit is dat de Van Dierens nog in het jaar van hun huwelijk (I 894) een woning aan de Schippersgracht betrokken.

Over Catharina Bakker (I 868-I955) is weinig bekend. Zij was het tweede kind uit een reeks van zeven (vijf meisjes en twee jongens). Nooit schreef Van Dieren over haar, maar in Op dwaalwegen gebruikte hij de ongelovige student om dr. Mol iets op te laten biechten.

Lang geleden was ik net als u onder den invloed van diezelfde schijnwetenschap ( hij smijt het opgenomen boek [van Darwin] op tafel) op datzelfde goddelooze, glibberige pad verdwaald geraakt; tot ik den afgrond 
zag, vlak voor mijn voeten. En toen was het een vrouw... mijn vrouw, die me de reddende hand toestak; ze... wist toen niet, wien ze de hand toestak, want... dan had ze 't misschien niet gedaan. En met en door haar heb ik 't geloof, dat me als kind was ingeprent door een lieve moeder, teruggekregen; ... toen is er rust in me gekomen, en hoe langer en hoe meer heb ik me opgericht... ik heb me weer mensch voelen worden, ja... eindelijk kon er zelfs kracht van me uitgaan... tot nut van anderen. ${ }^{14}$

Van Dieren zou dus het darwinisme enige tijd zijn toegedaan, of in ieder geval als fellow traveller op de wagen ervan hebben meegelift, waarna zich een diepe identiteitscrisis zou hebben voorgedaan. Van zijn dwalingen teruggekeerd zal hij Darwin te vuur en te zwaard bestrijden en in zijn trouw aan 'de zaak', allen overtreffen, want hij weet: voor een renegaat is er geen weg meer terug.

Als die scène inderdaad autobiografisch van aard is, dan moeten we de episode aan het begin van de jaren negentig plaatsen - dat wil zeggen praktisch op hetzelfde moment dat Eijkman in zijn leven komt. I46 Op het moment dus dat hij zijn bestemming lijkt te hebben gevonden als querulant en daarover misschien wel in hevige verwarring verkeert, dient zich de toekomstige mevrouw Van Dieren aan, die hem met haar strenge geloof zal verleiden en hem aan haar zal binden. Hij zwicht zowel voor Eijkman als voor haar.

Er is een foto van het gezin Van Dieren bekend die omstreeks 1904 moet zijn genomen, voor het huis van haar ouders op Terschelling. Catharina zit op de voorgrond, in lange rok en gesteven hemd met stijve boord. Ze kijkt zelfverzekerd en met een hele flauwe glimlach in de camera - niet iemand, vermoedt de kijker, met wie valt te spotten. Haar man staat op een pas afstand, evenwicht lichtjes op het linkerbeen, borst vooruit. Hij is 43 en bovenop de schedel al helemaal kaal. Een onopvallende, tamelijk slanke man in een donker kostuum met strikdas, kort van stuk, met een vol gezicht waarin een ovale bril boven een volle snor. Hij kijkt zoals een schoonzoon naar zijn schoonouders kijkt, een beetje ongemakkelijk, maar niet zonder trots.

Tussen hen in staat Evart junior, een jongen van een jaar of tien. In een kinderstoeltje rechts naast zijn vader zit Derk-Johan, een kleuter van vijf. Beide jongens zijn in een matrozenpakje gestoken, kleine schippers op een onbestuurbare boot. Op de schoot van zijn moeder zit een peutertje van nog geen twee. Het is hun jongste zoon, Wouter. Afwezig zijn Cornelis en Jan, de nummers twee en vier - gestorven in I90I en I902 - en Catharina, het enige meisje uit het gezin; ze is nog een baby en ze zal een jaar later sterven. ${ }^{15}$ 
De kinderen lijken op haar, niet op hem. Dezelfde mond, hetzelfde haar, dezelfde blik. Hollandse koppen, echte eilanders ook, voor wie Terschelling een tweede thuis werd, een lost paradise. Jan, die maar een halfjaar geleefd heeft, was er geboren; Wouter, de vroeg gestorven bioloog die zijn hart aan het eiland had verpand en als een van hen werd beschouwd, hoewel hij er formeel niet heeft gewoond, werd er begraven. De oudste zoon, ir. Evart van Dieren vluchtte er in september 1944 naartoe in de hoop zich voor de wraak van de Hollandse burgers te kunnen verschuilen. Tevergeefs. $\mathrm{Na}$ de oorlog werd hij gearresteerd en veroordeeld wegens openlijk hulp aan de vijand (hij had als NSB'er voor de bezetter gewerkt). Voor de jongste zoon ten slotte, Gustaaf van Dieren (I909-I974), werd Terschelling een laatste toevluchtsoord. $\mathrm{Na}$ een mislukte studie medicijnen en een afgebroken carrière in het jeugdherbergwezen vestigde hij zich in 1938 op Terschelling als fruitteler. Onder de Duitse bezetting fungeerde hij als wethouder en waarnemend burgemeester op het eiland, maar moest uit die functie ontslagen worden na een hoog opgelopen ruzie met de burgemeester. Na de oorlog kocht hij een molen op Terschelling en werd toepasselijk genoeg voor iemand die de weg kwijt lijkt te zijn geraakt windwijzermaker. ${ }^{16}$

Als kinderen kwamen de Van Dierens in de zomervakantie al vaak op het eiland, maar zonder hun vader. Misschien had hij het te druk, misschien had hij geen zin of misschien was hij niet zo op de vrijmetselarij van zijn schoonouders gesteld, want over een van de zusters van zijn vrouw schreef hij eens: 'zij bekijkt de wereld door een spleetje.' Terschelling, de familie Bakker, Catharina, ze blijven nadrukkelijk buiten beschouwing in het werk van Van Dieren dat voor het overige overloopt van autobiografische elementen.

MeVrouw Warners: En waar blifft uw vrouw dokter? Waarom hebt $u$ die thuis gelaten?

DR. Mol: Vanmiddag is ze naar bed gegaan, omdat ze d'r gewone migraine-aanval kreeg. En nou moeten jullie niet denken: Wat een onhartelijke man, om niet thuis te blijven; want ze heeft zelf verlangd, dat ik hier heen zou gaan. [...] "Voluntas uxoris suprema lex" - zooals wij latinisten zeggen. ${ }^{17}$

'Wij latinisten.' De zichzelf opwaarderende oud-hbs-leerling smokkelde een beetje met de waarheid om de aandacht af te leiden van wat uit de nog niet zo heel langgeleden gepubliceerde brieven en dagboekaantekeningen van de Diepenbrocks over Van Dieren blijkt. Sinds I 894 huisarts van de familie en nadien stilletjes aan huisvriend geworden, 


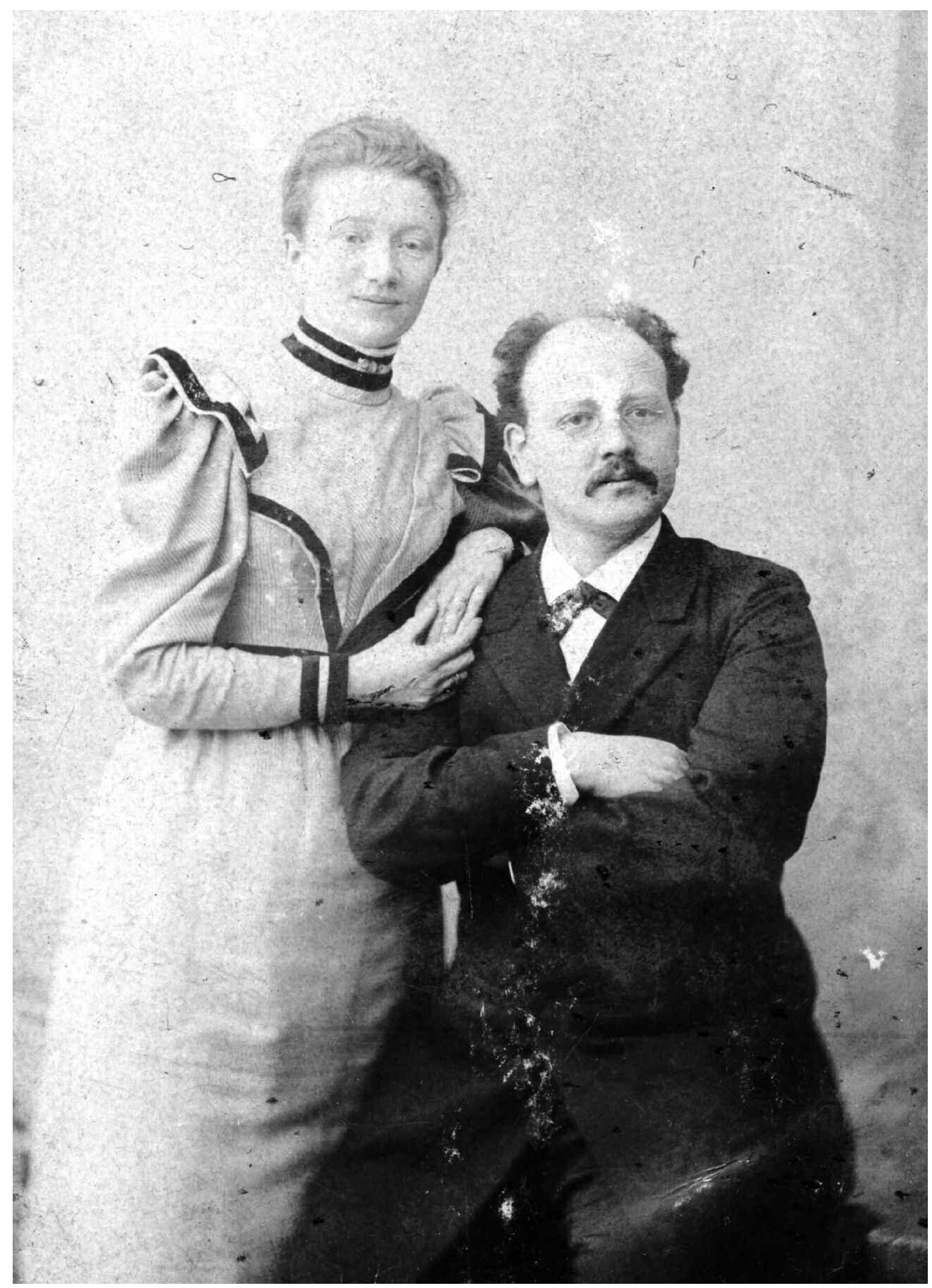

Evart en Catharina van Dieren, datum onbekend.

komt Van Dieren als een tamelijk eenzaam man naar voren. '3 Augustus at Dr. Van Dieren hier, heel prettig', schrijft Elisabeth Diepenbrock in haar dagboek. ${ }^{18}$ En wat later: 'Verkade en zijn vrouw en Toorop kwamen hier eens aan 's avonds, juist toen Dr. Van Dieren bij ons gegeten 
had. Dat was een heel gezellige avond. ${ }^{19}$ Er zijn discussies, over politiek met name, en over het jodenvraagstuk, waarover Van Dieren en Alphons niet hetzelfde dachten. Opvallend aan die aantekeningen over al die gezellige avondjes is echter maar één ding: altijd is Van Dieren alleen, nooit zal zijn vrouw meekomen of zelfs maar genoemd worden. Wie de brieven en dagboeken van de Diepenbrocks leest en niet beter weet zal denken dat hun huisdokter vrijgezel is.

In het toneelstuk laat hij een van zijn personages uit de afwezigheid van zijn vrouw de conclusie trekken dat de dokter blijkbaar thuis onder de plak zit. Maar dat is een betreurenswaardig misverstand, aldus dr. Mol: 'ik word thuis net zo behandeld zooals ik het zelf altijd verlangd heb. [...] Mijn vrouw houdt boek, stuurt rekeningen en quitanties weg, beheert de gulden, geeft me zakgeld als ik er om vraag, maant de kwade betalers aan...' Kortom, raadt de ander, '... zij is je tot hulp en steun in alles waar jij geen plezier in hebt, en de rest doe je zelf.' Zo is het maar net, verklaart de dokter, die aldus het verstek van zijn vrouw als een blijk van volmaakte samenwerking, of in ieder geval van een overeengekomen taakverdeling wilde laten doorgaan. Maar zouden we, zonder dat relaas in twijfel te trekken, niet ook de redenering mogen omkeren, en kunnen concluderen dat Catharina van Dieren haar afwezigheid nadrukkelijk zelf heeft geregisseerd? Dus dat ze met evenveel liefde en uit eigen beweging uit het publieke leven van haar man is weggebleven? - Van elkaar gescheiden door dat eeuwige schrijven stellen we ons de doktervrouw thuis voor, in dat halflege huis, terwijl Evart boven aan zijn brochures werkte. 'Mijn leven is druk', schreef hij aan Bolland, 'den geheelen dag op, meestal 's avond ook nog en soms 's nachts praktijk, in de weinige vrije uren wetenschappelijke arbeid. ${ }^{20}$ En elders: 'Ik slaap gemiddeld 8 uur, maar soms maar 3 à 4 , als ik bezig ben met iets dat af moet. ${ }^{21}$

Zijn verminderde behoefte aan slaap herinnert ons aan de klinische diagnose bipolaire stoornis die immers gepaard gaat met periodes van insomnia. Maar of Van Dieren nu aan manische wanen leed of niet, zijn energie was ongeëvenaard. Hij was een man met een missie die door niets of niemand van zijn doel kon worden afgebracht, en alleen een vastbeslotenheid die even fenomenaal moet zijn geweest kan daar tegenover hebben gestaan en heeft Catharina in staat gesteld om dat moeilijke, strijdbare leven te weerstaan. $\mathrm{Zij}$ overleefde haar man vijftien jaar. Ze stierf op 4 april 1955 te Etten-Leur en werd in Amsterdam begraven, in hetzelfde graf als haar man, maar haar naam werd nooit op de steen gebeiteld. Ook in de dood zou ze geen deel uitmaken van zijn publieke bestaan. 


\section{De opgewekte gedachte...}

Hoeveel rusteloze, slapeloze nachten kostte het niet om de geest uit de fles te houden? Het gebeurde vaak dat Van Dieren zich beklaagde over dat nachtelijke werk dat hij zich zelf en zijn gezin aandeed, maar hij wist ook: 'Ik kòn niet anders! Ik mòcht niet anders!' En hij deed niet anders. ${ }^{22}$

Ongemerkt knaagde de tijd aan het bestaan, en zo ging het leven voorbij. Er stierven vier van zijn kinderen, terwijl hij aan dat enorme oeuvre werkte. Tegenslagen? Jazeker, maar geen die hem van zijn pad hebben kunnen afbrengen. Alleen toen hij rond de eeuwwisseling zelf ernstig ziek werd en op sterven na dood was, verscheen er geen boek van zijn hand. Maar verder heeft hij zonder een moment van twijfel gewerkt alsof zijn leven ervan af hing - misschien hing het leven er ook wel van af.

Zo in elk geval in г916. In de Amsterdamse schoolcommissie werd over de kollewijnse spellingvereenvoudiging gesproken en dadelijk schoot het gemoed van Van Dieren vol: hij begon terstond 'strijdmateriaal' te verzamelen. Hij wachtte al zo lang op een kans om dit misverstand aan de kaak te stellen. Maar halverwege moest hij zijn voorbereidingen staken, omdat een van zijn kinderen (de I7-jarige Derk-Johan) door een dodelijke ziekte werd aangetast. Hij schreef aan de voorzitter dat hij niet op de vergadering aanwezig kon zijn, en verzocht hem het door hem uitgelokte debat te willen uitstellen tot de eerste najaarsbijeenkomst. ${ }^{23}$ Hieraan werd voldaan, en dus werd Van Dieren op de vergadering van 2 oktober I9I6, anderhalve maand na de begrafenis van zijn zoon, in de gelegenheid gesteld om het onderwerp toe te lichten, en ging hij in een 'uitvoerige met tal van voorbeelden gestaafde rede op soms geestige dan weer sarcastische wijze de Kollewijnspelling te lijf', volgens een bericht in de krant. ${ }^{24}$

Een kort oponthoud, en de dokter hervat het rusteloze schrijven. Hij heeft geen richting en geen doel, enkel een drive, en die drive is zo machtig dat in de hele tuin van de Nederlandse cultuur geen veldje onaangetast is gebleven. Onder de knollen de citroenen van de Nederlandse letterkunde groef hij een tunnel die reikte van de Tachtigers tot aan de spellingvernieuwers. Op het geschoren gras van de medici liet Van Dieren zijn vele hoopjes achter; ze ontsierden het landschap, maar genegeerd konden ze bijna niet worden. Diep in de tuin van de darwinisten groef hij een hol dat jammer genoeg niet groot genoeg was om de structuur van de bodem aan te tasten, maar iedereen die de tuin op die plek betrad zakte er door en verzwikte zijn enkel. Evenzo verging 
het de socialisten, de marxisten, de einsteinianen, de nietzschianen, de spinozisten, de relativisten, de leninisten, de trotskisten, Trostsky zelf, Freud, Graaf Hermann Keyserling, Paul Lafargue, Wibaut, W.A. Bonger. Evenzovele vijanden die evenzoveel misdaden op hun geweten hadden, en enkel Van Dieren die er tegen streed.

Een vermoeiend bestaan.

\section{Een ongelukje}

Diep dook Van Dieren onder in zijn eigen werk. Eén keer dook hij op. Dat was op 5 augustus I 920, voorpaginanieuws in de krant van de volgende dag: 'Dr van Dieren aangereden en gewond. ${ }^{25}$ Die donderdag werd hij op de Johannes Verhulststraat, ter hoogte van de Banstraat, om elf uur 's ochtends door een automobilist aangereden. De dader was een 34-jarige machinefabrikant die zijn voertuig over de weg had gejaagd met wat werd beschouwd 'grote snelheid'. Hij moest uitwijken voor een kar met kinderen, zei hij (getuigen konden het niet bevestigen), en zodoende vloog hij zonder te remmen op Van Dieren in. Een motorrijder die achter de beklaagde reed dacht dat hij met een snelheid van 27 à 30 kilometer per uur reed, zelf dacht de automobilist dat hij hooguit 20 tot $25 \mathrm{~km} / \mathrm{u}$. had gereden.

Het ongeval kwam op een moment dat het verkeer in Nederland explosief begon te groeien en autobezit niet meer tot de allerhoogste klassen beperkt bleef. Het ongeluk was niet uniek en in feite slechts één uit een groeiende reeks van meldingen van grotere en kleinere incidenten in het verkeer. Anderhalve week later verscheen er bijvoorbeeld een stuk in Het Vaderland over het hand over hand toenemende wangedrag van verkeersgebruikers, getiteld 'Gevaren op den weg'. De journalist tekende uit de mond van een zekere mr. Lamberts Hurrelbrinck de volgende aanklacht op: 'Voerlieden en rijtuigbestuurders houden rechts of links, al naar het hun goeddunkt; uit zijwegen komen fietsers aanhollen zonder zich te vergewissen of niet een motorvoertuig nadert, terwijl voetgangers de trottoirs verlaten en straten of pleinen oversteken zonder ook maar een oogenblik de moeite te nemen om eens om zich heen de zien of de weg vrij is.' Een ander observeerde hoe kinderen van de Potgieterschool dwars over de weg haasje-over speelden, terwijl daags tevoren nog een jongetje van negen was doodgereden op het Frederik Henderikplantsoen. Toen de verslaggever enige onderwijzeressen die dat alles kalmpjes gadesloegen daarover aansprak kreeg hij, als was hij Van Dieren zelf, ten antwoord: 'Och meneer, ik discussieer niet met $\mathrm{u}$ hierover, maar wilt u soms het hoofd spreken??26 
En zo representeerde het ongeluk van Van Dieren in zekere zin de hardhandige wijze waarop de modernisering zich opdrong aan de twintigste eeuw. Een jaar eerder nog maar had Van Dieren in de schoolcommissie geklaagd over het baldadige gedrag van de kwajongens op Kattenburg die zijn auto onder handen namen: kon iemand met ferme hand die rakkers niet eens mores leren, vroeg hij. En nu was hij dus zelf slachtoffer geworden. ${ }^{27}$ Was het toeval dat Van Dieren juist moest worden aangereden door een representant van de vooruitgang, een jonge industrieel?

In een eerste krantenbericht werd geschreven dat Van Dieren door de klap uit zijn eigen voertuig was geslingerd. ${ }^{28}$ Later bleek dat hij niet in zijn driewielig voertuig had gezeten, maar op het trottoir had gestaan voor een winkelruit, terwijl zijn chauffeur op hem wachtte in het voertuig. Hij raakte bekneld tussen spatbord en winkelpui; verwondingen aan het linkeronderbeen, bloeduitstortingen aan de borstkas, een ontvelling van de rechterhand, een longembolie en trombose aan de aderen die zich uitbreidde tot aan de negende rib toe waren het

I 52 gevolg. De 59-jarige geneesheer was ernstig gewond. In een advertentie in de krant liet hij weten zijn praktijk voorlopig niet uit te kunnen oefenen, en wees hij zijn plaatsvervanger aan. ${ }^{29}$ Het zou maanden duren eer hij weer aan het werk kon.

Maart I92 I vond de rechtszaak tegen de machinefabrikant plaats. Het is hier dat we voor het eerst en voor het laatst kennismaken met het subject buiten de context van zijn eigen werk. Van Dieren zelf werd opgeroepen als getuige-deskundige. Moeizaam hinkte hij de rechtszaal in. Toen hij de eed wilde afleggen tekende de advocaat van de gedaagde bezwaar aan: Meneer is van plan om een civiele zaak aan te spannen tegen mijn cliënt en is dus belanghebbende in de zaak. Jawel, wierp Van Dieren tegen, maar ik ben onbevangen genoeg om als deskundige verklaringen te kunnen afleggen. Daarmee nam de rechtbank genoegen, en nam hem de eed af.

Hij vertelde hoe hij die dag, komende uit de Banstraat, aan zijn chauffeur de opdracht gaf even te stoppen opdat hij een vreemd gebouwd motorvoertuig kon bekijken dat in een winkelkast was uitgestald. Hij stapte uit terwijl zijn chauffeur de auto de Johannes Verhulststraat indraaide. En toen, terwijl hij voor de winkelramen stond te kijken, vloog eensklaps de auto van de gedaagde de stoep op doordat de chauffeur een verkeerde manoeuvre maakte en zijn draai niet kort genoeg kon nemen, en het ongeluk had al plaatsgevonden. Hij was het slachtoffer geworden van een toevallige samenloop van omstandigheden, legde hij uit, waartussen geen oorzakelijk verband bestond. 
Immers, de betrokkenen kennen elkander niet. Hier geschiedde dus bij toeval een ongeluk. En zoals altijd wanneer toeval in het spel is, was ook nu het resultaat: chaos, wanorde, tegenspoed.

Hij werd na het ongeluk opgenomen in de Boerhaavekliniek, verpleegd, en na vijf dagen ontslagen. Thuisgekomen deden zich complicaties voor en ontwikkelde zich een trombose. Hij verkeerde in levensgevaar. Hij vreesde dat hij nooit meer de oude zou worden. Vroeger wist hij van vermoeidheid niet af, nu was hij snel moe. Maar vooral deed het hem leed dat de beklaagde voor hem niet de minste belangstelling had getoond...

Tot zo ver het verslag van Van Dierens getuigenis voor de rechtbank, zoals die vrijwel woordelijk in de krant is verschenen. ${ }^{30} \mathrm{De}$ beklaagde werd veroordeeld tot zes maanden hechtenis (in hoger beroep teruggebracht tot een maand): hij was de hoofdschuldige en enig schuldige - toeval of niet. Het verslag eindigde met de volgende analyse: 'De auto is een zeer nuttig vervoermiddel in handen van zich verantwoordelijk gevoelende bestuurders maar in handen van bestuurders die zich gedragen als slagersjongens is het een allergevaarlijkst vervoermiddel. Om niet een paar seconden te laat te komen, wilde beklaagde de auto van dr. Van Dieren passeren en daardoor heeft hij het leven van dr. Van Dieren geknakt.'

We weten niet aan wie we die woorden moeten toeschrijven: aan de aanklager, de rechter of misschien Van Dieren zelf? Het enige dat wij weten is dat voor één keer het leven zich heeft aangepast aan de wereld van Van Dieren, die het nu eindelijk is toegestaan triomf te vieren in zijn glorieuze slachtofferrol.

\section{Niemand tevredenstellen}

'De schrijver wordt genegeerd en het geschrevene wordt gebruikt', klaagde Van Dieren in een brief aan de schrijver Been. ${ }^{31}$ Hij bedoelde: er wordt maar naar hartelust uit mijn werk geplagieerd, maar erkend word ik niet. Maar hij had ongelijk, het was precies omgekeerd: het geschrevene werd genegeerd en de schrijver werd gebruikt.

In een feestrede in 1927 ter gelegenheid van de 8oste verjaardag van $\mathrm{H}$. Klinkert, voorzitter van het Klinisch Genootschap, liet een spreker de naam Van Dieren terloops passeren op de volgende manier: 'Natuurlijk kunnen wij van onze voorzitter niet zeggen: qui peut contenter tout le monde et van Dieren' - wie kan iedereen en Van Dieren tevredenstellen. ${ }^{32}$ Een onschuldig grapje op kosten van de bekende bemoeizieke Van Dieren. De rede haalde de NRC en kwam onder ogen 
van het slachtoffer van de grap, aan wiens blik hoe dan ook niets ontging als het hemzelf betrof. ${ }^{33}$ Van Dieren zag er de aardigheid niet van in en schreef een stuk terug. Dat verscheen niet in de NRC (dat het vermoedelijk had geweigerd), maar in Vox Medicorum, en eindigde met de klaagzang dat hij zich voelde als Cyrano de Bergerac uit de gelijknamige film die hij kort daarvoor had gezien. Dodelijk gewond roept Cyrano daarin uit: 'Ik heb gevochten tegen domheid, oppervlakkigheid, halfheid, karakterloosheid en gebrek aan ridderlijkheid', en evenzo was het hem vergaan, schreef Van Dieren. ${ }^{34}$

Cyrano gaat over een man die zich niet durft te vertonen aan de vrouw op wie hij verliefd is, en haar daarom brieven schrijft onder de naam van zijn rivaal. $\mathrm{Zij}$ wordt ook verliefd, maar niet op hem, maar op de rivaal, omdat hij zo mooi kan schrijven. Pas aan het slot komt alles uit - maar het is te laat, Cyrano sterft. En daarmee is Cyrano inderdaad een metafoor voor Van Dieren, die het moet afleggen tegen zijn rivaal - en het is nog zijn eigen schuld ook. Had hij die boeken maar niet moeten schrijven.

I 54 Zo waarde Van Dieren als een fantoom door zijn eigen boeken zonder ooit werkelijk aanwezig te zijn. Hij was als auteur van een oeuvre dat niet bestond, een voetnoot bij zijn eigen leven geworden; overtroffen door zijn rivalen die het publiek hadden verleid met boeken die door hem hadden moeten zijn geschreven, ja, die goed beschouwd door hem geschreven waren.

\section{Ondergrondse gangen}

In zijn werk liet Van Dieren een hele onderwereld na in de vorm van talloze voetnoten die zijn persoonlijke leven documenteren, sommige zo groot dat ze vele bladzijden beslaan en bovenaan de pagina nog slechts ruimte laten voor een dun laagje tekst. Rondom al zijn boeken loopt een slotgracht, een loopgraaf eigenlijk, gevuld met autobiografisch water. Hij waande zich er veilig.

De voetnotenwereld is een wereld op zich. Het is het autobiografische verslag van iemand die in volle vaart achteruitholt. Misschien hadden zijn boeken op de kop moeten worden gedrukt, de voetnoten boven, de hoofdtekst daaronder. Of misschien had de hoofdtekst wel helemaal achterwege kunnen blijven? 'Nog iets! Van sommigen vernam ik, dat zij door de nooten onder aan de bladzijden al te veel afgeleid werden; wie daar last van heeft, die zal, dunkt me, verstandig doen met ze over te slaan en ze eerst te lezen nadat hij met den tekst gereed is', aldus de schrijver zelf. ${ }^{35}$ Maar het is eenvoudig onmogelijk 
om die tekst te lezen zonder de voetnoten te raadplegen: ze vormen de enige vorm van continuiteit in het betoog. Want alles wat hem in het leven overkwam werd in een voetnoot gedocumenteerd en vormde de leidraad voor de beoordeling van wat hem later nog overkwam. De voetnoten verwijzen dus zowel vooruit als achteruit. Zijn boeken staan vol met persoonlijke ontboezemingen, en iedere nieuwe ontboezeming opent de deur naar een volgende. Op de internetsite van een antiquariaat wordt een van zijn boeken als volgt aangeprezen: 'een heerlijk boek vol persoonlijke voetnoten.' Daaraan is geen woord gelogen. Het is de dynamiek tussen tekst en voetnoot die zijn boeken zo bijzonder maakt.

Het leven in die voetnoten bouwt op zichzelf voort; iedere gebeurtenis vormt een steen in een steeds hogere stapel, maar de stapel is maar één steen breed, en al na een paar stenen begint de stapel te wankelen; de schrijver moet alles op alles zetten om het bouwwerk voor omvallen te behoeden. Dat is de reden waarom de voetnoten steeds omvangrijker werden en een steeds belangrijkere plek gingen opeisen in zijn betoog. Ze grepen al maar verder terug, vouwden het leven uit van het heden terug de toekomst in die ooit in het verschiet lag; een oneindige achterwaarts gerichte keten die geen begin heeft en geen eind, een warboel van associaties, waarin maar één continuüm te vinden is: de eeuwige terugkeer tot het zelf.

Op I april 1922 verscheen in het Nederlandsch Tijdschrift voor Geneeskunde een stuk van Van Dieren over homoseksualiteit. De aanleiding vormde een artikel waarin de stelling werd geponeerd dat homoseksuelen geen gevaar voor de maatschappij zouden opleveren. Daarop vroeg Van Dieren zich hardop af of dat wel waar is. Dit zou een van zijn meest pijnlijke publicaties worden, waarover nog in de jaren vijftig met afschuw werd geschreven in Vriendschap, het blad van de homo-emancipatievereniging COC. ${ }^{36}$

De meeste homoseksuelen hebben een grote voorliefde voor knapen, schreef Van Dieren, en in navolging van Bolland riep hij uit: 'een volk dat knapenschenders duldt, gaat te gronde. ${ }^{37}$ Observaties over het proces tegen Oscar Wilde, dat meer dan dertig jaar eerder had plaatsgevonden, een tirade tegen een in Amsterdam woonachtige bestuurder van de padvinderij die door Van Dierens toedoen uit zijn functie was ontheven en opmerkingen over Jacob Israël de Haans Pijpelijntjes (dat ook alweer bijna twintig jaar eerder voor ophef had gezorgd) dienden als afschrikwekkende onderbouwing voor een vreselijk argument dat aan het slot van het artikel wordt ontvouwd. 
Van mijn acht kinderen heb ik er vier moeten verliezen, maar ik zou de overigen liever hebben laten opgroeien en des doods zien sterven in een sanatorium voor tuberculeuzen; ja zelfs in een leprakolonie, dan dat ik hen ook slechts korten tijd zou hebben toevertrouwd aan de vriendelijke verzorging en toewijding van een of anderen Pijpelijner. ${ }^{38}$

De schrijver van Pijpelijntjes, merkte Van Dieren bijna terloops op, zou, verwijzend naar Leviticus 20:I3, volgens de Bijbel gedood moeten worden ('Een man die gemeenschap heeft met een man heeft een gruwel begaan en zal zeker ter dood gebracht worden'). In I927 nam Van Dieren het hele stuk uit het $N T v G$ en de bijbehorende argumentatie over in zijn Prof. Freud-boek, maar hij voegde er een voetnoot aan toe waarin hij tussen neus en lippen door liet weten: Jacob Israel de Haan is inmiddels vermoord. ${ }^{39}$

Hij lokte met zijn homofobe stuk zowaar nog een polemiekje uit in het $N T v G$ ook, zijn eerste sinds lange tijd. Een van de opponenten maakte bezwaar tegen de gedachte dat homoseksuelen moreel op een I 56 lager niveau zouden staan dan heteroseksuelen, en pleitte voor een wat genuanceerder opvatting waarbij onderscheid gemaakt wordt tussen 'knapenschenders' en gewone homoseksuelen. Een ander bracht tegen de 'verleidingstheorie' van Van Dieren in dat veel jongeren aan het eind van de puberteit blootstaan aan homoseksuele invloeden, maar dat nog nooit iemand door verleiding homoseksueel werd.

Uit het debat wordt duidelijk dat voor het in een religieuze ethiek verankerde denken van Van Dieren, waarin homoseksualiteit wordt begrepen als een 'ontaarding' van de normale seksualiteit, door ontucht teweeggebracht, geen plaats meer is. De gedachte dat homoseksualiteit door de natuur gedetermineerd is en als een 'spontane afwijking' van de gewone seksuele voorkeur moet worden begrepen, heeft dan al lang postgevat binnen medische kringen, en ook daarbuiten, zoals blijkt uit de ontvangst van het toneelstuk De gevangene, waar het thema van geslachtsinversie tot 'prachtige lijdens-hoogte' voert, niet tot protest (zoals we in hoofdstuk 2 zagen). ${ }^{40}$

Omgekeerd wordt ook duidelijk dat al die argumenten en pleidooien voor nuancering aan Van Dieren niet waren besteed. Zijn standpunt stond van begin af aan vast en was immuun voor iedere vorm van debat. Daarom misschien nam de discussie al snel een andere wending, en begonnen de verschillende opponenten elkaar te bekritiseren. Spoedig ontspon zich bijvoorbeeld naar aanleiding van een reactie van psychoanalyticus Westerman Holstijn een discussie over de freudiaanse interpretatie van 'het derde geslacht'. Gaandeweg verdween de 
naam Van Dieren uit de kolommen van het tijdschrift en was op het eind van zijn inbreng niets meer te herkennen. De aanstichter bleef alleen achter met zijn morele verontwaardiging.

Toch was het niet helemaal voor niets geweest, zo bleek, want toen hij later de hele affaire nog eens aanhaalde, schreef hij dat hij naar aanleiding van zijn artikel een waarderend schrijven van de psychiater K.H. Bouman had mogen ontvangen, die hij daarop onmiddellijk opzocht. Bouman zou het van harte met hem eens zijn geweest en hem allerlei sterke staaltjes van homoseksuele verleiding hebben opgedist, maar op het verzoek van Van Dieren om het voor hem publiekelijk op te nemen wilde hij niet ingaan..$^{41}$ Daaraan vastknopend haalde Van Dieren een briefje aan dat hem eens was toegestuurd door een jongeman die, ondanks zijn ernstige waarschuwing dat niet te doen, zich op zijn homoseksualiteit had laten voorstaan en toen naar het buitenland had moeten vluchten onder druk van de gemeenschap. Maar ook hier was een dankbetuiging zijn deel geworden, schreef Van Dieren, want in het vervolg zou de jongeman zijn raad niet meer in de wind slaan. Waarmee hij dus alsnog het gelijk aan zijn zijde had gekregen. ${ }^{42}$

In de beleving van Van Dieren vormden zijn beschouwingen zowel de noodzakelijke input in ieder debat als ook de finale conclusies ervan, en werd dat eerste door anderen weliswaar in publiek ontkend maar het tweede stilzwijgend geaccepteerd.

\section{Een oerervaring}

Op de hbs leerde van Dieren van een leraar dat evenwijdige lijnen elkaar nooit kunnen snijden, maar van een andere leraar dat ze elkaar op oneindig grote afstand wel snijden. Hij sneed de kwestie thuis aan. Zijn jongste broer zei: 'Als dat waar is, dan zouden twee mensen, die naast elkaar loopen, uiteindelijk door elkaar heen moeten lopen.' Van Dieren kon het nog sterker vertellen: Er zou niets van hen overblijven. Denk maar eens aan een kubus. Voor mij blijft het een kubus, al wordt hij in het oneindige verplaatst; de moderne wiskundigen beweren echter dat de evenwijdige zijden dan in elkaar zullen overlopen. Hadden zij gelijk, dan zou er dus van de kubus niets overblijven, want een punt is iets denkbeeldigs. ${ }^{43}$ De anekdote vormde de voetnootopmaat voor een beschouwing tegen Einstein en de relativistische wiskundigen.

Gefascineerd door de logische tegenspraak zag Van Dieren het punt opdoemen waarin hij een bestaansreden zou vinden: de tegenstelling. En net als zijn overige motieven werd ook dit motief terug de geschiedenis in geplaatst, als had hij zich daar en toen, in dat gesprek met zijn broer, 
voorgenomen dat zijn leven voortaan één enorme consequentie zou zijn, als zou hij zichzelf nimmer meer in iets nog tegenspreken: altijd consequent zou zijn levensdoel worden, onwrikbaar zijn standpunten.

Jonkheer A.F. de Savornin Lohman (I837-I924), temperamentvol politicus, antirevolutionair uit overtuiging en oprichter van de CHU uit onbuigzaamheid (zoals het ergens treffend heet), was een 'hooggeplaatste' (zij het geen generatiegenoot) die eens het bijzondere genoegen mocht smaken om met de Van Dierense rechtlijnigheid in aanvaring te komen.

Rond 1903 kwam er in de Tweede Kamer een discussie op gang over de verplichte inenting van kinderen (tegen de pokken), en daarmee raakte de politiek rechtstreeks in Van Dierens vaarwater. Deze had zich juist op dat moment als rapporteur van de commissie herziening epidemiewet in de materie verdiept en was tot de conclusie gekomen dat het inenten een nuttig, ja, noodzakelijk middel vormde in de bestrijding van besmettelijke ziekten. In een poging de politieke discussie te beïnvloeden stuurde hij in 1905 een brochure de wereld in getiteld VaccinaI 58 tie en hare bestrijders. We hoeven geen rekening te houden met de 'ziekelijke weekheid van christelijk-orthodoxen' (lees: gereformeerden), schreef Van Dieren, daar de medische praktijk evengoed als een poging Gods kan worden beschouwd de mensen te onderrichten 'hoe te handelen ten einde zich de liefsten die zij bezitten te behoeden voor ziekte'. ${ }^{44}$

Dat is wel een opmerkelijk liberaal standpunt, maar niet in strijd met zijn Nederlands-hervormde geloofsovertuiging, die, zoals Van Dieren niet genoeg kon benadrukken, het toeval afwijst en een doel vooropstelt. God schiep de aarde, redeneerde Van Dieren; we weten niet hoe Hij dat deed, we weten alleen dat Hij er een bedoeling mee moet hebben gehad, dus dat er een met rede begaafde oorzaak ten grondslag ligt aan de schepping. Het doorgronden van die bedoeling is het doel van de wetenschap, en hoe geruststellend moet het voor de buitenstaander zijn dat de wetenschapper daarbij wel steeds moet falen! Vandaar dat Van Dieren zich met graagte tegen de mutatieleer van de darwinisten verzette, die immers zelf moesten toegeven dat de 'sprongetjes' waarmee de evolutie zich lijkt voort te bewegen met 'een geheimzinnig bijsmaakje' omgeven zijn. Zouden de darwinisten er niet eerlijker aan doen toe te geven dat zij daar op een wonderlijke kracht zijn gestuit 'die uit het lager georganiseerde het hooger georganiseerde doet geboren worden'? ${ }^{45}$ Zoals alles rijst ook God op uit eenvoudige waarnemingen.

Dit was de eerste en enige keer dat Van Dieren zich uitsprak als voorstander van iets, zij het ook dat moet worden aangemerkt dat de 
propositie in dit geval natuurlijk niets anders dan de omkering van het contrastandpunt vormt, dat toen onder sommige politici nog gangbaar was. Dit was de eerste en enige keer ook dat we Van Dieren zonder mankeren gelijk kunnen geven. Het verwijt aan zijn tegenstanders dat zij zich van stemmingmakerij bedienden en onterecht deden voorkomen alsof de kuur (vaccinatie) erger was dan de kwaal, was volkomen juist. De enige kanttekening die we misschien kunnen plaatsen is dat Van Dieren een achterhoedegevecht voerde - weerstand tegen vaccinatie bestond eigenlijk alleen nog maar onder de 'christelijk-orthodoxen', de rest had zich op een pragmatisch standpunt gesteld en principiële en ethische bezwaren al eerder laten varen. Dat blijkt bijvoorbeeld uit wat de onderzoeker G. Overbeek de Meyer, die Van Dieren nog uit zijn beriberitijd kende en die hij nu voor zijn karretje trachtte te spannen, hem desgevraagd schreef: 'De menschen, die wegens eerlijk gemeende gemoeds- of andere bezwaren, ook wel opgezweept door geestdrijvers, tegen die koepokinenting zijn, zijn dus mijns inziens zeer te beklagen, maar zijn ten stelligste ook gevaarlijk voor de Volksgezondheid. De Volksvertegenwoordiging heeft daarom te beslissen of zij die menschen zal dwingen die inenting en herinenting te ondergaan, dan wel op welke andere wijze zij het groote meerendeel der ingezetenen tegen die gevaarlijkheid zal beschermen. ${ }^{36}$

Onder die volksvertegenwoordigers bevonden zich echter twee twijfelaars, Abraham Kuyper en A.F. de Savornin Lohman (hier nog op één lijn; de 'lintjesaffaire', waarover later meer, zou hen uit elkaar drijven). $\mathrm{Zij}$ behoorden tot de bijzondere doelgroep van de schrijver van de vaccinatiebrochure. Kuyper, ten tijde van het wetsvoorstel minister van Binnenlandse Zaken en politiek leider van de ARP; De Savornin Lohman als lid van de Kamercommissie die het vaccinatiewetje moest voorbereiden, was fractievoorzitter van CHU.

Zowel Kuyper als De Savornin Lohman leunde op een achterban die voor een flink deel uit zulke orthodoxe christenen bestond en zij konden dus wat minder makkelijk over die bezwaren heen stappen. Toen Van Dieren hen zijn boekje opstuurde kon hij nauwelijks verwacht hebben antwoord te krijgen. Toch schreef De Savornin Lohman een vriendelijk briefje terug: 'Gaarne erken ik, dat Gij een ernstig onderzoek van den questie gemaakt hebt en indien uwe redeneeringen juist zijn, kan uw boekje bijdragen tot bevordering der inenting. Nimmer heb ik mij tegen inenting verklaard of het nut der inenting bestreden. ${ }^{47}$

Daar zou hij nog spijt van krijgen. Van Dieren begon te wroeten in het verleden. Een standpunt van De Savornin Lohman uit I 892 werd boven water gehaald. 'Bestrijdt niet alleen de vaccinedwang, doch 


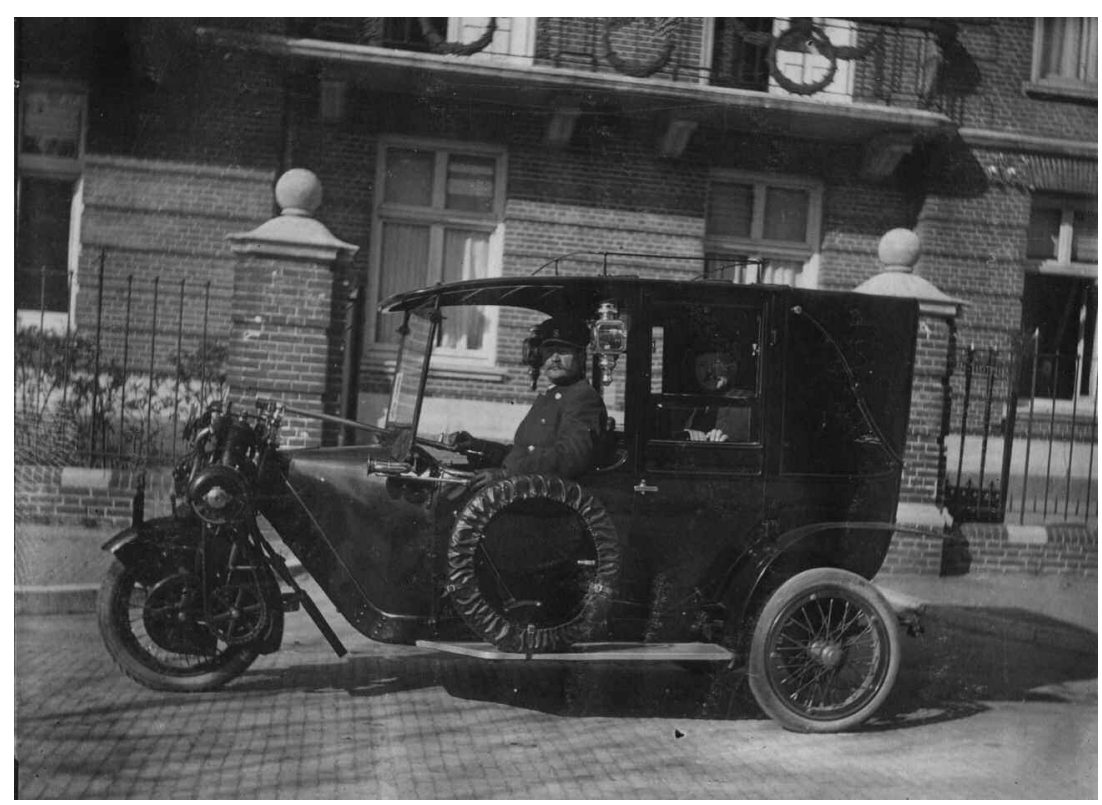

Het verhaal gaat dat in zijn dokterskoetsje altijd een stapel drukwerk lag zodat hij, zelfs als hij onderweg was, nog even een paar correcties kon doorvoeren of een stukje kon schrijven.

bestrijdt vooral de vaccine-vereering', had deze geschreven. Dat was al vast één tegenspraak. Daarna bleef het enige tijd stil, maar het dossier van Van Dieren was geduldig, en toen De Savornin Lohman in I9I I opnieuw in de Kamer over de kwestie kwam te spreken en nu de risico's van inenting onderstreepte die 'door de heren medici, ook een soort clerus, worden doodgezwegen', en toen hij daarbij ook nog eens de naam van Van Dieren, arts te Amsterdam, liet vallen, zag Van Dieren zijn kans schoon en opende hij de aanval op de politicus met behulp van een reeks artikelen in het tijdschrift Moleschott.

Het werd een woeste aanval op de draaikonterij van de heer Lohman, die hij trouwens voor het overige onder de beste Kamerleden rangschikte. Dat hij ditmaal de heer S.L. 'zéér onaangenaam moest bejegenen' had het object van studie echter geheel aan zichzelf te danken en lag geenszins in de bedoeling van de schrijver. ${ }^{48}$ Een omslachtige manier om te zeggen dat hij zich beledigd voelde, maar ook om te zeggen dat hij hoopte dat zijn opponent zou reageren. En om aan ieder misverstand een eind te maken stuurde Van Dieren aan het slot van zijn artikelenreeks een briefje aan De Savornin Lohman, waarin hij schreef 
te verwachten niet genegeerd te zullen worden: 'Thans verwacht ik dat $\mathrm{U}$ ongelijk zult bekennen of zult willen aantoonen dat mijne gegevens, berekeningen of "redeneeringen" foutief zijn. Mocht dat laatste onverhoopt en ongedacht - in uwe bedoeling liggen, dan verzoek ik U zulks spoedig te willen doen. ${ }^{49}$

De Savornin Lohman beging nóg een vergissing: hij liet het er inderdaad niet bij zitten en schreef een brochure van bijna 50 pagina's terug, getiteld Een vaccine-aanbidder. De inhoud van zijn brochure kan worden samengevat met behulp van vijf aanklachten die De Savornin Lohman aan het adres van zijn tegenstander richtte: 'Ie De Heer van Dieren maakt zich voortdurend schuldig aan onjuist citeren; 2e De Heer Van Dieren rukt woorden en feiten uit hun verband; 3e De Heer Van Dieren beschuldigt zonder grond het Kamerverslag [Handelingen van de Tweede Kamer] van partijdige mededeeling en feiten; 4e De Heer Van Dieren zoekt zijn kracht in bespotting, minachting, en verdachtmaking van de personen die hij bestrijdt, en 5 e De Heer Van Dieren munt niet uit door logische redeneering en schijnt zich geen juist begrip te maken van datgene waar het hier om gaat. ${ }^{50}$

Dat alles was natuurlijk koren op de molen van Van Dieren. Als het de bedoeling van De Savornin Lohman was geweest de rel tot groter proporties op te blazen, dan was hij daarin uitstekend geslaagd. Van Dieren aarzelde geen moment en smeet de hele verzameling vaccinatiaria in een brochure ter grootte van zo'n 200 pagina's. Het stuk behoort tot een van de minst gestructureerde producten die Van Dieren ooit heeft gepubliceerd. Een overlappende reeks teksten, citaten, fragmenten en beweringen werd over het hoofd van De Savornin Lohman uitgestort, zonder dat het betoog ook maar één moment ergens heen lijkt te gaan. $\mathrm{Na}$ lezing blijft de lezer achter met de vraag waarvan deze politicus eigenlijk wordt beschuldigd, behalve dan van het feit dat hij in een onbewaakt ogenblik een briefje aan de schrijver had gestuurd om hem te bedanken voor een toegestuurde brochure. Dat vroeg het onderwerp van die vreemde aanval zich trouwens ook af: 'veel erger is dat hij tegen mij persoonlijk zoo goed als niets aanvoert [...] en de Heer Van Dieren, zijn aanvallen richtend tegen een groep van 5 personen, had het recht niet al de slagen, gesteld zij waren raak, op mijn arm hoofd te doen neerdalen. ${ }^{51}$

Toch oordeelde een recensent in het Nederlandsch Tijdschrift voor Geneeskunde dat de heer De Savornin Lohman het aan de geneeskundige stand wel verdiend had dat hem eens naar aanleiding van zijn uitlatingen 'onomwonden de waarheid wordt gezegd'. ${ }^{52}$ De medische stand was duidelijk niet gediend van inmenging in haar zaken door 
buitenstaanders, en al helemaal niet van gratuite beschuldigingen als zouden medici zaken die hen niet te pas komen eenvoudig doodzwijgen. 'De heeren medici vormen ook een soort clerus, waaraan wij ons te onderwerpen hebben', had de politicus gezegd. ${ }^{53}$ Welnu, wanneer hij als straf daarvoor Van Dieren op zijn dak kreeg, dan was dat zijn verdiende loon.

$\mathrm{Na}$ die afrekening met De Savornin Lohman zou Van Dieren nog talloze malen op de kwestie terugkomen. Nog in de jaren dertig lezen we in een voetnoot: 'Dit werd door mij bewezen in een boek getiteld Het kamerlid Jhr. De Savornin Lohman..$^{54}$ De Savornin Lohman zelf was toen al lang dood.

\section{Het voetnotenapparaat kraakt uit zijn voegen}

Naarmate de jaren verstreken begonnen de noten steeds vaker naar elkaar terug te verwijzen. Opeens bleek dat de beriberibestrijding samenhing met de Kollewijnse spellingvernieuwing en dat de psychoI62 analyse en het socialisme feitelijk op een en dezelfde gedachtekronkel waren gebaseerd. Freud - Marx - Heijermans - Van Eeden - Verwey Adama van Scheltema - Bonger - Polak - Roland Holst... is er een verschil? De namen verschenen vaak in een rijtje, alsof het leden waren van een en dezelfde bende.

Maar het aardige is natuurlijk dat er inderdaad wel een overeenkomst tussen al die figuren uit de culturele elite kan worden gevonden. Het is bijvoorbeeld waar dat er tussen de verschillende kliekjes veel kruisbestuiving bestond. Van Eeden was als schrijver bevriend met Henriëtte Roland Holst en Albert Verwey, in wiens tijdschrift hij publiceerde, en als arts met Freud en Jelgersma; Gorter en Roland Holst waren als literaten weer diep in socialistische kringen geworteld en op die manier bevriend met politici als Polak, Troelstra en anderen; Emants en Van Eeden waren als schrijvers betrokken bij de spellingvereenvoudiging en van daaruit geïnteresseerd in het werk van Kollewijn, De Vooys, en anderen. Verschillende periodieken die bij de respectievelijke bewegingen hoorden deden verslag van elkaars werk en gaven ruimte aan elkaars auteurs en versterkten daarmee de indruk van een min of meer samenhangend geheel. Veel van die zijdelingse sporen kwamen bovendien bijeen bij Diepenbrock, waar schilders, dichters, politici en schrijvers zoals Verwey, Ritter, Toorop, Gorter en vele anderen over de vloer kwamen. En Van Dieren, het buitenbeentje...

Dat er onderling ook een hoop kinnesinne en afgunst bestond wordt pas duidelijk uit de biografieën over en autobiografieën van de 
diverse kopstukken. Een paar voorbeelden. Nadat in I9I2, respectievelijk I9 I3, Adler, Stekel en Jung uit de beweging waren getreden (dan wel eruitgezet), was de psychoanalytische gemeenschap verdeeld geraakt in 'orthodoxen' en 'afvalligen', hetgeen ook hier te lande zijn beslag kreeg. Analytici die door Stekel en Jung waren getraind werden bijvoorbeeld niet erkend en moesten opnieuw in analyse, iets wat Van Dieren natuurlijk niet kon weten, en wat de meeste krantenlezers ook niet wisten, zodat nog tot ver in de jaren dertig Freud, Stekel en Jung in één adem werden genoemd wanneer de psychoanalyse werd bekritiseerd, alsof ze nog steeds lid waren van één en dezelfde bende. Ook onder de beriberi-onderzoekers kwam het tot onenigheid en wel tussen het kamp van Eijkman c.s. en dat van zijn vroegere medewerker Grijns, toen de laatste in de jaren tien afstand deed van de infectiehypothese waartoe de eerste (nog) niet bereid bleek. Onder de socialisten geraakte Troelstra na het mislukken van de novemberrevolutie van I9I 8 enige tijd uit de gratie; de partij wreef hem eigengereid optreden aan. Troelstra op zijn beurt wreef Henriëtte Roland Holst een gebrek aan loyaliteit aan en Gorter brak met haar toen zij niet met hem meeging. Onder de literaten ergerde Heijermans zich aan het 'hol platzakkig literairekliekje' waartoe hij Verwey rekende, terwijl Verwey het aan de stok kreeg met Van Deyssel over de koers van hun Tweemaandelijksch Tijdschrift dat als tegenhanger van De Nieuwe Gids was bedoeld. ${ }^{55}$ En zo kunnen we nog wel even doorgaan.

Van dat 'narcisme van de kleine verschillen', om met Freud te spreken, merkte een buitenstaander als Van Dieren natuurlijk niet veel; hij had immers geen toegang tot de intiemere kring. Alleen op afstand maakte hij daarvan wat mee als een meningsverschil in de publieke ruimte terechtkwam, zoals de scheuring binnen de SDAP, in de jaren I909-I9I0, waarbij Wijnkoop c.s. de radicale tak vertegenwoordigden en Troelstra de gematigde.

Van Dieren had die scheuring via krantenberichten gevolgd en deed op opgewonden toon verslag van Troelstra's 'loochening' van Gorter in Het socialistisch gevaar, dat nog in datzelfde jaar uitkwam. De socialisten hebben God ingeruild voor hun organisatie, concludeerde Van Dieren, 'maar waar is de trouw?' ${ }^{66}$ Alsof hun gebrek aan eendracht op zijn schouders woog. Want ondanks dat interne gekrakeel bleef het front voor hem gesloten, en daarin zag hij een nieuw bewijs voor een alomvattende samenzwering tegen hem.

Er zijn aparte brochuretjes verschenen waarin die verbanden moesten worden aangetoond, zoals die tussen Freud en Marx. In zijn analyse heet het dat Freud in I926 door het 'Marxistische Gemeente- 
bestuur van Wenen' tot ereburger werd verheven, en dat dat 'alleszins begrijpelijk' is, omdat Freud immers tot de sociaal-democraten behoort, en men hem geen onrecht doet door hem een Bolsjewiek te noemen. ${ }^{57}$ In Einstein zag Van Dieren een kabbalist, in Darwin en zijn volgelingen nietzscheaanse godloochenaars, terwijl hij bijna al zijn tegenstanders spinozisme verweet, wat in zijn denken neerkwam op moreel verval. Spinoza was een 'autotheist' die zich verafgode. ${ }^{58} \mathrm{Zijn}$ analyses lijken op een populaire karikatuur uit die tijd, waarin Einstein, Freud en Steinach (bekend van de naar hem genoemde, omstreden operatie aan de geslachtsklier) naast elkaar zijn neergezet: 'bij leven onsterfelijk, maar wat roept men in koor? Waarom dringen de Joden steeds voor? 59

Bij al dat complotdenken moet men Van Dieren evenwel één ding nageven, en dat is dat een aanzienlijk deel van de culturele elite in Nederland in die tijd haar inspiratie inderdaad vaak bij Spinoza en Nietzsche zocht. Opnieuw kunnen we hier de naam Diepenbrock bij zetten, lezer van Nietzsche van het eerste uur en enthousiast bewondeI64 raar van Spinoza, zoals Van Dieren niet kan zijn ontgaan. Maar ook Gorter, Verwey, Henriëtte Roland Holst en Van Suchtelen voelden zich tot Spinoza aangetrokken, misschien wel omdat zijn systeem openstond voor velerlei interpretaties - van mysticisme tot materialisme en toch een vorm van zekerheid wist te bieden. ${ }^{60}$ Een onweerstaanbare combinatie die Van Dieren tot een woede-uitbarsting bracht, omdat openheid en zekerheid in zijn denken immers niet samen kunnen gaan, en heel zijn historisch-filosofische analyse was er dan ook op gericht die twee weer uit elkaar te drijven.

Maar ook nu is er sprake van een vorm van 'mystificatie': met het blootleggen van de 'bronnen' van het socialisme, de 'filosofie' in de poëzie van de Tachtigers, of ook 'ethiek' in de psychologische theorieën van Freud en zijn volgelingen lijkt het alsof Van Dieren een geheime onderliggende structuur heeft ontdekt, terwijl hij in werkelijk niets anders heeft gedaan dan de geschiedschrijving voor zich op te eisen. In al die verbanden vormt hij zelf het middelpunt, de onfeilbare observator, voor wie alles in toenemende mate duidelijk is.

Geleidelijk begon de voetnoot druk uit te oefenen op de hoofdtekst. De hoofdtekst gaf toe. Wat in het ene boek nog in een voetnoot stond keerde in het volgende terug in de hoofdtekst en baarde op haar beurt haar eigen voetnoot. Een briefje van Polak, waarin Van Dieren voor 'een stumperige maniak' werd uitgemaakt verscheen in I9r9 in een discussie over het socialisme en dook elders op toen het ging over de beriberi en daarna in een discussie over de onrechtvaardige behandeling die 
hem steeds maar weer ten deel viel. ${ }^{61}$ Een enkele zin uit een briefje van De Savornin Lohman aan hem werd al op de omslag van het boek tegen deze politicus aangekondigd en keerde in een steeds iets andere context almaar terug. Het zinnetje bleek halverwege het boek de kern van het hele betoog te vormen. Een losse opmerking over Freud in Het socialistisch gevaar groeide uit tot een boek toen bleek dat iemand weleens iets aardigs over Freud had geschreven, hetgeen nodig aan de kaak moest worden gesteld. Omgekeerd werden hele paragrafen uit dat antisocialistenboek dan weer voetnoot in het anti-Freud-boek.

Zo was er ook veel overlap. Maar dat was noodzakelijk, want anders was het verband niet te begrijpen. Het is alleen wat moeilijk de betoogtrant te volgen, want er is op die manier geen chronologische opbouw mogelijk. Steeds moeten er verbanden worden gelegd naar eerdere zaken, en van daaruit weer naar volgende. Eigenlijk is er maar één manier waarop je Van Dierens werk kan lezen en dat is door alles in één keer te lezen. Dat zou je een bijkomend voordeel kunnen noemen. Bijkomend nadeel is dat dat wel wat te veel gevraagd was van een gewone lezer, en er is dan ook niemand die dat ooit heeft gedaan.

Zelfs één enkel boek was voor de meeste recensenten al te veel gevraagd. Opgave van titel en inhoud vond men vaak ruim voldoende om het boek te karakteriseren. Een enkeling deed een poging wat verder door te dringen in het werk. Pinkhof, een Van Dieren welwillende predikant-geneesheer, gevraagd door het Nederlandsch Tijdschrift voor Geneeskunde om het populaire De waanzinnige waereld te beoordelen, zwaaide de schrijver lof toe vanwege de ontzaglijk grote hoeveelheid boeken en geschriften die hij had gelezen. Maar had hij gelijk? Dat bleek de recensent onmogelijk te kunnen beoordelen, en ook niet te willen trouwens. ${ }^{62}$ De recensent van De Amsterdammer die Historisch-idealisme of historisch-materialisme besprak kwam niet verder dan het roze inlegvel waarop reclame voor het boek werd gemaakt. 'Geen beter kerstgeschenk (vooral voor ontwikkelde jongelieden)!' stond erop. Sarcastisch verklaarde de recensent dat hem persoonlijk, als ontwikkeld jongmens, aangenamere kerstgeschenken voor de geest gezweefd hebben. ${ }^{63}$

\section{De boeken die er niet waren}

Langzaam vloeiden leven, schrijven en strijden steeds meer in elkaar over. De boeken richtten zich al minder op een centraal thema, lieten zich almaar meer leiden door de waan van de dag. De onderwerpkeuze van Van Dieren laat zich lezen als een kroniek van de belangrijkste 
publieke discussies tussen I 890 en I930: de bestrijding van de tbc, het socialisme, de vaccinatieplicht, de opkomst van de moderne kunst, de sportbeoefening, de psychoanalyse, Einstein, homoseksualiteit, de drooglegging van de Zuiderzee, de lekwaterplannen, de spellinghervorming, de stellingname van de Nederlandse pers in de Eerste Wereldoor$\log$. De enige anomalie in dit rijtje vormt het vrouwenkiesrecht, waarover Van Dieren zweeg als het graf. Een onverklaarbare lacune als men bedenkt dat Aletta Jacobs (I854-I9I2) een tijdgenote van hem was, zich als huisarts vestigde in Amsterdam op het moment dat hij daar ging studeren en zich net als hij voor allerlei sociaal-hygiënische vraagstukken interesseerde. In de jaren na de Eerste Wereldoorlog beleefden beiden hun apotheose; Jacobs in I9I7, toen het passief kiesrecht voor vrouwen werd ingevoerd (twee jaar later gevolgd door het actief kiesrecht), en Van Dieren in I9I9, met zijn De waanzinnige waereld, die mateloze veldtocht tegen alles wat naar vernieuwing riekt. Toch komt haar naam in zijn werk niet voor, zijn er geen brieven van hem aan haar bekend en vormt het feminisme geen trefwoord in het lexicon van Van I66 Dieren, en heeft hij, omgekeerd, in haar Herinneringen geen spoor achtergelaten, hoewel het haar aan tegenwerking van conservatieve kant toch echt niet heeft ontbroken. Zouden hun wegen elkaar nooit hebben gekruist? Of zou hij haar behoedzaam uit de weg zijn gegaan?

Voor die laatste hypothese spreekt een voetnoot, begraven in een werk van hem over de 'invloed van zonlicht en sport op lichaam en geest'. Kinderloze feministen (Aletta Jacobs had haar enig kind op eenjarige leeftijd verloren en was dus technisch kinderloos) moesten het hem nageven, zo zei hij: gestudeerde vrouwen zijn minder vruchtbaar. In overeenstemming met de Bijbel moet daarom worden opgemerkt 'dat de vrouw den man gegeven is tot "hulpe en steun", dus niet als... concurrente!'64

Waar hij zijn vrouwelijke concurrenten liever uit de weg ging trad hij zijn mannelijke medestrevers met open vizier tegemoet. Tegenover hen verklaarde hij zich met uitzondering van de vaccinatieplicht van alles een tegenstander. En het merkwaardige is, schreef een redacteur van de Vox Medicorum die al die kwesties ter gelegenheid van zijn gouden artsjubileum in I934 de revue nog eens liet passeren, 'dat hij uiteindelijk vaak gelijk kreeg, hoezeer hij ook tegenspraak en tegenwerking ondervond' ${ }^{65}$

$\mathrm{Ja}$, dat is wel bijna een wonder te noemen, en dubbel zo merkwaardig is het dat het gelijk alleen maar lijkt toe leek te nemen naarmate er meer claims op werden gelegd. Daarom misschien ook reikten de verbanden steeds dieper terug in de tijd. Wie wist er bijvoorbeeld dat 
Winkler in 1878 cum laude gepromoveerd was op een proefschrift over de tuberculose, en dat hij daarin schreef dat deze ziekte geen virale aandoening is, maar een vergiftiging? Hoogst opmerkelijk voor iemand die zich later tegen de vergiftigingshypothese zou keren, vond Van Dieren. Wel doet het leed een overigens verdienstelijk man in het publiek daaraan te moeten herinneren, schreef hij: maar ook een professor kan zich weleens vergissen, en een gewone dokter kan het weleens bij het juiste eind hebben!

En toch, hoewel in de loop der jaren de bewijzen zich opstapelden, werkte de tijd uiteindelijk ook in het nadeel van Van Dieren. Hoe dieper de verbanden terugreikten, des te minder bleef ervan over. Neem Besmettelijke zielsziekten uit I93 I, een van zijn laatste grote boeken, verworden tot één enorme associatieve keten, volkomen onleesbaar voor wie niet leven en werk van Van Dieren van haver tot gort kent. Men kan op iedere willekeurige bladzijde binnenvallen en na een paar bladzijden weet men al evenveel als wanneer men het hele boek zou lezen. Van Dieren was er zelf ook verbaasd over. 'En zoo zijn we dan vàn de Naaktlooperij en het Socialisme en Bolsjewisme (Heijermans en Pieck) over de Godsdienstbestrijding, de achterlijke cultuur en de opzettelijke onzindelijkheid héén, weer ongemerkt terecht gekomen bij de Sport! Zonder toelichting zou het haast een al te gekke overgang lijken, maar als we ons dan herinneren dat Jan Feith schreef... [enz.]. ${ }^{96}$ En dan zijn we pas op pagina 43 en hebben we er nog meer dan honderd voor de boeg, waarin het zal gaan over de Duitse keizer, Napoleon, een gedicht van Jan Engelman, en nog veel meer, en ook, af en toe, over de sportbeoefening, waarover het boek eigenlijk had moeten gaan. De schrijver is de gekte nabij, oordeelde Boudewijn Büch in een krantenartikeltje een halve eeuw later. ${ }^{67}$

Krantenartikeltjes: het alfa en omega in Van Dierens universum. Uitgangspunt voor Besmettelijke zielsziekten vormde een in 1930 in de Haagsche Post gepubliceerd artikeltje waarin en passant het standpunt van een 'bekend Amsterdamsch geneesheer' inzake de openbare sportbeoefening ter sprake kwam. Van Dieren begreep wel dat daarmee niemand anders dan hij bedoeld kon zijn en greep de verwijzing dankbaar aan om zijn in de loop van een heel leven verzamelde inzichten nog eens samen te vatten, aanschouwelijk gemaakt aan de hand van een opgevangen gesprek op het achterbalkon van de tram, een conversatie met dokter X, een dialoog met een hogere ambtenaar op het hoofdbureau van politie of een andere toevallige ontmoeting. Elk treffen met een ander mens werd door Van Dieren gebruikt om nog eens even kort voor te rekenen hoe de vork in de steel zit, met de bedoeling zijn 
gesprekspartner met een mond vol tanden achter te laten. Of om laatste rekeningen te vereffenen. Een I 6 pagina's lange tirade aan het slot van het boek richt zich tegen prof. Isidore Snapper (I889-1973), de enig overgebleven hoogwaardigheidsbekleder binnen de academische wereld waarmee hij nog op vriendschappelijke voet stond (Snapper had in 1924 zitting gehad in het comité ter voorbereiding van het 40jarig jubileum van Van Dieren). Snapper, zelf een liefhebber van de voetbalsport (hij trad op als scheidsrechter), had Van Dieren een overdrukje toegezonden van zijn artikel over het 'sporthart' en kreeg als dank een stroom verwijten naar zijn hoofd geslingerd en aan het slot de raad zijn kinderachtige hobby ('scheidsrechtertje spelen') op te geven.

En zo is dat boek een opeenstapeling van bezwaren tegen alles en iedereen waarmee Van Dieren weleens in aanraking was geweest, een finale afrekening; een afscheid. Van een of andere samenhang kan niet worden gesproken in het boek, maar wel keert als een soort mantra een weinig controversiële stelling steeds terug: overdadige sportbeoefening is slecht voor de gezondheid. Wedstrijdschaatsers die zomaar dood I68 neervallen en hardlopers die zich onmatig uitputten, kinderen die niet meer spelen maar overal een wedstrijd van maken: de hand over hand toenemende het lichaam afbeulende sport corrumpeert het volk. Toegegeven, het is niet moeilijk om je over zo'n boek vrolijk te maken, ja, het was wel bijna onvermijdelijk dat dat in boekbesprekingen, zoals in het Amsterdamse studentenblad Propria Cures, ook werd gedaan. Daar roemde een onder het pseudoniem van dr. Marbuse schrijvende recensent sarcastisch 'de heerlijk populaire markttoon, de weergaloze doorhollerij en het dikwerf machtelooze geschetter als van een portier van een bioscoopje achter aan de Nieuwendijk'. Tegelijk moest hij toegeven dat onder de bast van onzin, verwarring en eigen verheerlijking een 'zuivere kern' schuilging die niet van waarheid was ontbloot. ${ }^{68}$ Waaruit die waarheid bestond wordt niet geheel duidelijk, behalve dat dr. Marbuse het door Van Dieren gekraakte gedicht van Jan Engelman ook wel 'erg bar' vond.

Louis Heijermans (I873-1938), SDAP'er en 'sociaal-geneeskundige' die zich sterk maakte voor de arbeiders en armen, en als directeur van de Amsterdamse Gezondheidsdienst uit hoofde van zijn positie en opvattingen zo ongeveer de natuurlijke tegenpool van Van Dieren, bracht een gelijkluidend bezwaar tegen het boek naar voren in zijn 'hygiënische kroniek' voor Het Volk. Het geschrijf van Van Dieren heeft iets onrustigs, iets multatuliaans, merkte hij op; het verliest veel aan betoogtrant doordat de auteur zijn stokpaardjes te pas en te onpas berijdt. 'Het kost moeite de boeken van v. Dieren objectief te lezen, de 
kern eruit te diepen en los te pellen uit de franje van zelfingenomenheid, van het pralerige: heb ik het ze nou niet eens lekker gezegd?' Niettemin zou hij 'des poedels kern' van Van Dieren kunnen aanvaarden, ware het niet dat de door de schrijver bereide pil vanwege de verzuurde stekelige schil onverteerbaar was geworden. ${ }^{69}$

Opnieuw blijft de vraag waaruit die kern dan wel zou bestaan onbesproken. Maar ik denk dat het er ook helemaal niet om ging een kern van waarheid bloot te leggen, voor zover daar op de een of andere manier al sprake van kan zijn geweest, en dat de waarheid eigenlijk alleen maar heeft afgeleid van waar het in dit boek om ging. Besmettelijke zielsziekten was in zekere zin het eerlijkste van al zijn boeken. Het voert ons dwars door zijn strijdziek leven; het is een getuigenis van dat leven, een autobiografie zoals er nog nooit een is geschreven. In krap I 50 pagina's marcheert als in een zelfgeregisseerde aflevering van This is your life een bonte stoet van bekende en minder bekende figuren uit het leven van Van Dieren voorbij: zijn ouders, de marxisten, I75.000 negers uit New York, Jan Sluijters, L. Heijermans van Het Volk zelf, Prof. Freud, Guus Wansleven (een jeugdvriend uit Zutphen), Mr. Kan, lid van de Raad van State (noblesse oblige!), dr. Enklaar, Prof. Buitendijk, een van de zoons (die op een woonboot woont), de heer Helder uit Harderwijk, Prof Lanz... ieder doet zijn zegje. Er wordt gelachen, de glazen klinken, men is in een opperbest humeur. De camera zoemt in op het gelaat van Van Dieren in wiens ogen een tevreden, bijna voldane schittering is te zien. 'Weg met de zich zelf telkens weer hoger salariërende en pensionerende corruptieve bende!', roept hij duidelijk hoorbaar boven het geroezemoes uit.

Tegen het einde van de aflevering neemt het gedrang in de coulissen toe, niet iedereen kan meer aan bod komen; van sommige gasten vangen we slechts een glimp op, anderen blijven daarentegen weer een beetje te lang hangen (de regie heeft moeite om ze van het toneel te krijgen), maar het hindert niet, Van Dieren verkeert in een roes. 'Poets uw gebit enige malen per dag. Gebruik tandenstokers, de Italianen doen dat ook, maar ze doen het al te opvallend. Eet roggebrood, het bevat fluoor. Geef uw kinderen vast voedsel, laat ze kauwen, maak er geen "melkmuilen" van' - het is feest vandaag!

Waarom ik zulke goede boeken schrijf? - zou men met Nietzsche kunnen vragen - Omdat ze door niemand worden gelezen - zou het overeenkomstige antwoord kunnen luiden. Besmettelijke Zielsziekten voorheen en thans, de Danszucht, de Naaktlooperij, de Geeselaarsvertooningen en de hand-over-hand-toenemende SPORT-EPIDEMIE en hare bevorderaars (SPORTARTSEN enz) met een Naschrift gericht 
tegen een artikel van Prof. Snapper over "Het Sporthart", door E. van Dieren, arts te Amsterdam, zoals de volledige titel luidt, sluit een levenslange outsidercarrière af. De titel vat niet alleen in de eerst twee woorden de kernthema's van heel het werk van Van Dieren samen, maar verwijst in de lange ondertitel terug naar waar zijn belangstelling voor de medische wetenschappen ooit was begonnen: bij een voorval in zijn vroege jeugd, de dood van schipperszoon De Jonge die zichzelf had doodgereden voor een beetje geld en wat vergankelijke roem. 'Hoe kan een mens zoo dom wezen', had zijn vader gezegd, en de zoon wist van toen af aan dat de buitenstaander het allemaal 'veel beter weet dan alle huidige sportartsen bij elkaar'.

Een 'oneigentijds' boek dus, niet vanwege een teveel maar juist door een gebrek aan inhoud. Het werd genegeerd, op besmuikt gegrijns onthaald of met een woedende kreet in een hoek geworpen (als naar gelang het karakter van de lezer), maar vreemd genoeg niet gelezen als dat wat het in essentie was, zowel in vorm (in een stroom aan nauwkeurig gedateerde aantekeningen), als in inhoud (van louter persoonI70 lijke ontboezemingen), namelijk als een kroniek van het falen zelf. Was het plaatsvervangende gêne die de lezer instinctief deed huiveren voor de schrijver die zich zo liet kennen?

De sociaal-democratische socioloog Willem Bonger (I876-I940) die in dat boek een veeg uit de pan had gekregen, omdat hij het voor de homoseksuelen had durven opnemen, kreeg een op oud-Hollands kwaliteitspapier gedrukte luxe-editie van het geschrift als presentexemplaar toegestuurd. De ontvanger stuurde het cadeautje terug.

Zeer geleerde heer

Hierbij retourneer ik $\mathrm{U}$ het mij ongevraagd toegezonden drukwerk, ik stel op het bezit geen prijs. Reeds vroeger nam ik kennis van één uwer geschriften en kwam tot de conclusie, dat gij als publicist niet ernstig te nemen zijt. Deze conclusie werd mij bevestigd door de lezing van de tegen mij gerichte pagina's. Gij kunt niet eens behoorlijk lezen en iemand's betoog weergeven en breekt maar den staf over een ander en beleedigt hem ernstig. Als object van medische wetenschap is uwe figuur niet on-interessant, als subject niet de moeite waard zich ermee te occupeeren.

Met verschuldigde gevoelens, W.A. Bonger.

PS. Iedere eventuele poging Uwerzijds met mij verder te corresponderen is nutteloos; $\mathrm{Uw}$ brieven worden ongeopend vernietigd. ${ }^{70}$ 
Het is een pijnlijk, om niet te zeggen vernederend briefje. De schrijver neemt nu eens geen blad voor de mond en lijkt vastbesloten zijn opponent in één klap van tafel te vegen. Maar Bonger was dan ook een 'uitgesproken persoonlijkheid', die, zoals eens is gezegd, een 'geweldig vermogen bezat verontwaardigd te zijn'. ${ }^{71}$ Van Dieren citeerde het niettemin zonder enige aarzeling, ja zelfs met enige trots. Alsof het enige bewijs dat eruit volgt is dat hij, een bekend Amsterdamsch geneesheer immers, als persoon bij zijn vijanden in aanzien staat, want: een 'niet on-interessant object'. Ja, zijn naam als buitenstaander, lastpak, loner, lijkt te zijn gemaakt; zijn plek in de geschiedenis verzekerd.

Vergelijkbaar in opzet, aanpak, uitwerking en ontvangst was Prof. Freud en het perverse gevaar dat slechts een maand later het levenslicht zag; zijn tweede grote anti-Freud-boek - ik bespreek het verderop wat uitvoeriger. Ook dit boek was natuurlijk alleen maar een manier om zijn leven gestalte te geven; een after-party bij Besmettelijke zielsziekten. Maar er was een Ter Braak voor nodig om dat in te zien: 'Het komt erop neer dat waarheid en gevaar voor van Dieren synoniem zijn, al meent hij in ontwapenend oprechte duel-manie het tegenovergestelde', schreef Ter Braak over het Prof. Freud-boek. ${ }^{72}$

Besmettelijke zielsziekten en Prof. Freud zijn twee voorbeelden van het latere werk van Van Dieren, waarin de schrijver nog een laatste poging doet om door middel van het geschreven woord tekst en context met elkaar te verweven en zich zelf in lange voetnoten of ook in de hoofdtekst een centrale plaats te geven in zijn eigen universum. Maar het bolwerk brokkelde af nog voor het er goed en wel stond, en tenslotte was alles daarin voetnoot geworden: hoofdtekst, bijtekst, voetnoot, bijlage, inleiding, uitleiding, het hele gangenstelsel was opgelost, ingestort, en er restten enkel nog flarden van wat eens op een betoog heeft geleken. De boeken hebben geen begin meer en geen einde. Letterlijk. Het bleek Van Dieren onmogelijk nog iets af te ronden, want net als hij ergens een punt achter had gezet, bleek iemand ergens iets te hebben gezegd waar ook weer op gereageerd moest worden, in een voetnoot, een nawoord, een aanhangsel, of als het moest nog een nawoord. Allemaal keurig gedateerd, en altijd ondertekend met: E. van Dieren, arts - de identiteit die hem tot op zijn grafsteen zekerheid verschafte. Zijn laatste zekerheid in een wereld die hem in toenemende mate ontglipte.

De afbrokkeling is in al zijn werken zichtbaar, maar neemt pas pathologische proporties aan in De waanzinnige waereld. Het boek opent met een woord vooraf (I mei I9I9), nog een woord vooraf bij de tweede druk (28 juni I9I9), waarna het eigenlijke boek begint, dat al 
op pagina I 84 eindigt. Daarna volgen nog een kleine honderd pagina's met aantekeningen, een lang citaat uit een werkje waarop hij pas op I 2 juni attent werd gemaakt, maar dat hij niet onbesproken kon laten. Dan nog een brief aan de arbeiders van Nederland, gedateerd 28 september I9I9 en tot slot een 'onherroepelijk laatste naschrift' gedateerd 6 oktober I9I9, waarin nog even kort moet worden gereageerd op een lezing die Van Dieren de dag ervoor had bijgewoond. De enige reden dat er niet nog meer naschriften volgden is dat dat woordje 'onherroepelijk' erboven staat. - Het boek vervluchtigt waar de lezer bij staat.

Voor Besmettelijke zielsziekten gold hetzelfde in het kwadraat. Nog in de zomer van I93 I, vlak voor publicatie, werden steeds weer nieuwe stukken toegevoegd, terwijl het boek zelf, zoals we eerder zagen, voornamelijk bestaat uit precies gedateerde observaties die zich uitstrekken van zijn jeugd en hbs-tijd, tot de jongste gebeurtenissen, zoals de Olympiade van I928, en tezamen een geschrift vormen waarover de auteur zelf opmerkt dat hij vroeger had gedacht dat het beter zou zijn iets dergelijks maar niet in de openbaarheid te brengen. ${ }^{73}$

In Prof Freud, het laatste boek dat als een paukenslag op Besmettelijke zielsziekten volgde, is de onttakeling volkomen. Het enige dat met zekerheid kan worden gezegd is dat Van Dieren op I2 april I93 I aan het schrijven ervan was begonnen en dat het begin I 932 werd gepubliceerd. Wat zich tussen die datum en de dag waarop het werd gezet en gedrukt afspeelde is moeilijk te reconstrueren. Een eerste versie van zijn stuk, toen nog een artikel, werd al direct naar de drukker gebracht, maar blijkbaar werden steeds nieuwe stukken ingelast, zodat het uiteindelijke resultaat een bricolage is van driehonderd doorlopend genummerde paragrafen.

Van interne consistentie is nu hoegenaamd geen sprake meer. Het boek begint met een haastig 'woord achteraf' en raast dan als een wervelwind door haar eigen voorgeschiedenis heen, ruim driehonderd pagina's lang, tot aan het eind, zonder dat het boek ooit begint. Anders gezegd: dat hele boek gaat alleen maar over het boek zelf, beginnend bij de aanleiding ertoe, waarna een weergave volgt van alles wat Van Dieren eerder over Freud had gezegd, plus een opsomming van alle tegenwerking die hij heeft mogen ervaren, en eindigend in een oproep om nu eindelijk eens iets tegen de 'vieze bedenkseltjes' van de 'maximaal pornografische' verspreider van walgelijke, zedenbedervende onwetenschappelijke onzin te ondernemen.

Als we op tweederde van het boek zijn vallen we midden in een briefwisseling met Paul Scholten, de rector van de Universiteit van Amsterdam die door Van Dieren verantwoordelijk werd gehouden 
voor de eerdergenoemde sarcastische bespreking van Besmettelijk zielsziekten in Propria Cures. Van Dieren schreef aan Scholten: 'Binnenkort verschijnt mijn boek, getiteld: Prof. Freud (de uitvinder van de zoogenaamde "Diepte-zielkunde") en het door velen onderschatte gevaar. In dit boek worden ongelooflijke vuiligheden aan het licht gebracht, die, helaas, bijna alle Psychiaters ontgaan schijnen te zijn. Ook de [recensiekwestie] zal ik daarin behandelen, met de bedoeling goed te doen uitkomen, hoe noodig het is in de studentenwereld de lucht te zuiveren door alle ramen en deuren wijd open te zetten! Ik betreur het, in verband hiermede uw naam niet te kunnen weglaten! ${ }^{74}$

Een gevoel van vervreemding overvalt de lezer: hij realiseert zich dat de inhoud van het boek op dat moment wordt geschreven, in die correspondentie over datzelfde boek. Maar waar is dat boek dan?

\section{Eén met het werk}

'Beheersching der stof - ze ontbreekt den schrijver zoo goed als geheel', werd er in een bespreking tegen een eerder boek van Van Dieren ingebracht. ${ }^{75}$ En inderdaad, het onvermogen om een bezwaar op een coherente manier te verwoorden was ontegenzeggelijk de grootste zwakte van Van Dieren - maar ook zijn kracht. Het dwingt de lezer om het betoog letter voor letter na te gaan. 'De wijze waarop Van Dieren alles dooreenhaspelt, maakt het bijna niet mogelijk hem bij de weerlegging op de voet te volgen', klaagde Eijkman eens tegen Pijnappel. ${ }^{76}$ En later nog eens: 'Ge zegt, als men Van Dieren bestrijdt, moet er geen speld tusschen kunnen. Ik maak me de illusie niet, dat men hem ooit zoo zou kunnen bestrijden. 't Is even vruchteloos als dat men een warhoofd met logica zou willen aan boord komen. Eerlijke wapens hebben eenvoudig geen vat op hem, zet hem nog zoo vast, hij geeft toch geen krimp. Hij zal overal een speld tusschen krijgen, ook al is er niet het minste hiaat in het betoog. ${ }^{37}$

Het werk was een levend organisme geworden; het groeide en groeide en groeide, en Van Dieren had nu eindelijk bereikt waarnaar hij zijn hele leven had gestreefd: hij was volledig één geworden met zijn schrijfsels. Begraven onder zijn eigen werk, die torenhoge instabiele stapel drukwerk. Het lijkt het natuurlijke lot van de querulant. Maar ook begraven in zijn eigen werk. Dat maakt dat het schrijven van Van Dieren behalve iets geweldig komisch ook iets enorm tragisch heeft de schrijver is als een gestrande schipbreukeling die ziet hoe de vloed zijn fles steeds opnieuw terugwerpt op het strand, hoe vaak hij hem ook de zee insmijt. 


\section{8 \\ De schrijver en het woord}

We stellen ons Van Dieren voor in zijn werkkamer aan zijn bureau gezeten. Het licht van zijn leeslamp valt scherp op de daarop verzamelde papieren. De schrijver zit gebogen over een geschrift van een van zijn tegenstanders, zijn vingers glijden langs een passage, terwijl hij een zin onderstreept.

Hij staat op, pakt een schaar en begint te knippen. Behoedzaam als een chirurg snijdt hij geïnfecteerde delen uit het betoog van de ander

I74 weg, plakt de knipsels op een vel papier en voegt er zijn eigen betoog aan toe. Als hij daarmee klaar is naait hij de verhandeling dicht, en is er weer een brochure voltooid.

Voor Van Dieren was het schrijven zuiver klinisch werk. Hij zag het als zijn taak als schrijver-arts om de rotte delen in een tekst op te sporen en ze van de gezonde te scheiden. Het schrijven vatte hij op als een medisch college. Denk aan de voorstelling van Rembrandt, waarop dr. Nicolaes Tulp met een tang in zijn hand een bundel pezen bijeenhoudt, terwijl hij boven het bleke lijk van Aris Kindt staat te doceren. In de grond van de zaak draait het in het schilderij niet om dr. Tulp, schrijft Simon Schama in De ogen van Rembrandt, maar om het goddelijke vernuft van de Schepper: het schilderij toont ons een 'moment van waarheid'. ${ }^{1}$ Een licht verbeterde versie van de waarheid, mogen we eraan toevoegen. Want de rechterhand van Kindt, een geëxecuteerde misdadiger, was jaren eerder al eens bij wijze van straf afgehakt. Rembrandt had er de hand van een ander voor in de plaats geschilderd. Met die stilzwijgende correctie op de werkelijkheid ging hij Van Dieren vooraf, die, zoals we gezien hebben, de feiten uit didactische overwegingen ook graag in een eigen keurslijf perste. Zet dr. Van Dieren in de plaats van dr. Tulp en plak op de hoofden van de omstanders de fotootjes van Eijkman, Gorter, Van Eeden, Diepenbrock, en nog zo wat figuren die als leerling dienst kunnen doen, en de voorstelling is compleet. De schrijver waant zich een autoriteit, eigenlijk alleen maar omdat hij de pen ter hand heeft genomen. 


\section{De waanzinnige waarheid}

Van Dieren was gesteld op de voorstelling van Rembrandt, misschien wel omdat dr. Tulp net als hij ook maar een gewone huisarts was en ook aan de Keizersgracht heeft gewoond. In december I 909, ter gelegenheid van zijn vijfentwintigjarig artsjubileum kreeg hij een replica van het schilderij op tegeltableau aangeboden. ${ }^{2}$ In datzelfde jaar verscheen zijn analyse van het 'socialistische gevaar' als een bijdrage tot de kennis der besmettelijke zielsziekten en tevens waarschuwing aan autoriteiten, ouders en onderwijzers. Zo graag, schreef hij in het voorwoord, wilde hij de socialisten uit hun woorden en geschriften leren kennen dat hij speciaal voor hen een brochure had geschreven. Ach, hij hield ervan zijn tegenstanders te ontleden als ze stil en onhoorbaar op zijn schrijftafel lagen, hun dode vellen overgeleverd aan zijn wil, terwijl hij in alle rust de waarheid uit ze kon peuren.

Het socialistisch gevaar verscheen in april 1909 bij de uitgeversmaatschappij Vivat in Amsterdam, dezelfde uitgever die ook Kritiek der zuivere rede van Kant uitbracht, en werken van Willem Paap, Jules Verne, Alexandre Dumas en anderen; kortom een respectabele uitgever. Het moest niet als een politiek geschrift worden gelezen, maar als een serieuze 'bijdrage tot de kennis der besmettelijke zielsziekten' aldus de ondertitel. Nog datzelfde jaar verscheen een tweede druk, wat wijst op een zeker verkoopsucces. Dat het boek niet alleen goed verkocht maar ook ernstig werd gelezen blijkt uit het aan die tweede druk toegevoegde hoofdstuk 'Hoe mijn boek geprezen en veroordeeld werd', waarin Van Dieren niet minder dan 2I verschillende kranten en tijdschriften citeerde die het boek hadden gerecenseerd, of er althans aandacht aan hadden besteed. Dat die kranten zonder uitzondering zijn werk als een politiek geschrift hadden opgevat en niet als een medische studie doet weinig af aan het succes, evenmin als het feit dat het merendeel der besprekingen weinig lovend was. Sapientis et stulto sat est, zo besloot de auteur zijn boek in eigengereid Latijn: een wijze en een dwaas hebben genoeg aan één woord. Een pakkend motto voor iemand die uit die twee vormen van weten nooit wist te kiezen en er ten slotte een soort epistemologische eenheid uit smeedde; een dwaasheid die zich als wijsheid vermomt.

Tien jaar later was het op handen zijnde reveil waarvan hij aan het slot van Het socialistisch gevaar kond deed nog niet tot het nuchtere Hollandse volkje doorgedrongen, maar dreigde integendeel de socialistische epidemie van de pratende klasse over te slaan op de arbeidende klasse. De tijd van waarschuwen was voorbij. In een tweede, niets- 


\title{
Besmettelijke Zielsziekten voorheen en thans
}

de Danszucht, de Naaktlooperij, de Geeselaarsvertooningen en de handover-hand-toenemende SPORTEPIDEMIE en hare bevorderaars (SPORTARTSEN enz.) met een Naschrift gericht tegen een artikel van Prof. Snapper over „HET SPORTHART"

\author{
DOOR E. VAN DIEREN \\ Arts te Amsterdam
}

\begin{abstract}
Met mijn vriend van Dieren moet ik bekennen, "dat mij de sport van heden wil vóórkomen als "een psychische epidemie, als een degeneratie"verschijnsel". - „Wisten de sport-aanbidders ",maar, welke de gevolgen zijn voor den lateren "leeftijd. Als chirurg ben ik steeds bang een "sportsman te moeten opereeren; het sporthart "verdraagt de narcose bijzonder slecht, zooals het "ook tegenover infectieziekten weinig weerstand "heeft".

(Prof. Lanz in zijn rectorale rede 1925).
\end{abstract}

In dit boek worden ook eenige onderwerpen behandeld, waarvan ik vroeger zou gezegd hebben: het is beter om er in het openbaar over te zwijgen. Thans is het echter, helaas, noodzakelijk zèlfs de jonge lieden er vroegtijdig mee in kennis te stellen.

E. van Dieren, Arts.

UITGEGEVEN DOOR DE N. V. HOLLANDIA-DRUKKERIJ TE BAARN

Zijn laatste boek was in zekere zin het eerlijkste van al zijn boeken.

ontziende zielkundige ontleding van de socialisten en hun voorgangers probeerde Van Dieren de Nederlandse arbeider voorgoed afkerig te maken van de 'dwaasheden en gevaarlijkheden der volksmisleiders', 
want: de toekomst ziet er duister uit indien de socialisten nog meer invloed krijgen. Met die strijdkreet in de mond smeet Van Dieren in I9I9 De waanzinnige waereld de wereld in, en ditmaal zelfs met aanmerkelijk succes.

'En nu komt Herman Gorter aan de beurt,' opende Van Dieren zijn aanval op de socialistische dichter-ziener en kunstbroeder van Roland Holst. Ook deze man blijkt ondanks zijn studiën op economisch gebied nog geen ál te heldere kijk te hebben op de toekomstige maatschappij die hij met behulp van de handarbeiders denkt te kunnen opbouwen, aldus Van Dieren. Gorter spoort de arbeiders aan de bourgeoisie en haar handlangers, de geleerden en de priesters, ten onder te brengen en hun eigen klasse tot de heersende te maken. ${ }^{3}$ Dat was een onverdraaglijke gedachte voor Van Dieren, die zelf niet tot de bourgeoisie mocht behoren. Tegen die gedachte moest hij wel in opstand komen, uit lijfsbehoud.

Hij was een antisocialist uit overtuiging, maar net als bij zijn antifreudianisme en antidarwinisme werd zijn afkeer van de socialisten niet gedragen door een ideaal maar door een allesoverheersende angst. Als waarheid en gevaar synoniem zijn voor Van Dieren, zoals Ter Braak zei over het antifreudianisme van Van Dieren, dan gold dat voor zijn antisocialisme niet minder. De waarheid was dat Gorter, net als Eijkman, tot zijn eigen generatie behoorde (geboren in I864), succesvol was (ook Gorter promoveerde) en boven zichzelf was uitgegroeid door zijn steun aan de socialistische zaak en bovendien als een uit de kring van Diepenbrock angstig dichtbij Van Dieren in de buurt kwam.

Gorter moest worden opgenomen in het repertorium van vijandbroeder, net als zuster-vijand Henriëtte Roland Holst. 'O zeker, deze dame is een virtuoze op de wipplank; of ze rechts of links zal gaan zitten, dat laat ze afhangen van de omstandigheden; als woordkunstenares weet ze altijd wel een paar woorden te vinden om de plaatsverandering aannemelijk te maken voor de "bewuste" stommelingen die haar als een "hoog begaafde" dichteres en leidsvrouw vereeren. ${ }^{4}$

De waarheid was: hij wilde haar plaats innemen. Toen zij op 29 januari r9I9 voor een Amsterdamse studentenvereniging een voordracht hield over de proletarische revolutie en het intellect, zat Van Dieren in de zaal. $\mathrm{Na}$ afloop was er gelegenheid tot het stellen van vragen, maar Van Dieren had daaraan geen behoefte. Hij wist al precies wat hij weten wilde. ${ }^{5}$ Thuis zette hij zich aanstonds aan het schrijven. Hij eiste van de vereniging dat hij onmiddellijk óók een voordracht mocht houden en wel over 'de proletarische revolutie en het onverstand'. 
Tot zijn eigen verbazing ging het bestuur daarmee akkoord. En zo trad hij op 26 februari I9I9 aan om een lezing te geven die drie uur zou duren, en al die tijd was zijn merendeels bolsjewistische gehoor muisstil, schreef Van Dieren. Dat lijkt gegeven zijn eerdere ervaringen met de socialisten tamelijk ongeloofwaardig, maar feit is wel dat een maand later het uitgewerkte, nu bijna tweehonderd pagina's tellende typoscript al bij de drukker lag als De waanzinnige waereld. Een zielkundige ontleding van de huidige socialisten en hunnen voorgangers. De titel was, zoals Van Dieren niet kon nalaten te verduidelijken, een toespeling op De betoverde waereld uit I69 Ivan de predikant Balthasar Bekker, een klassieker in de bestrijding van bijgeloof en heksenwaan. ${ }^{6}$

Het werd het tweede boek dat hij zou opdragen aan zijn vrouw, zijn geschenk aan haar ter gelegenheid van hun zilveren huwelijksjubileum. Als motto liet hij drukken: Spreuken 3 I: Iо-I 3. ${ }^{7}$ Daar lezen we: Een degelijke huisvrouw, wie zal haar vinden? Zij doet hem goed al de dagen van haar leven. Haar man is bekend in de poorten, als hij neer-

I78 zit te midden van de oudsten des lands. Duidelijk is het dat de eerste twee zinnen uit dat bijbelcitaat niet meer zijn dan een excuus om te komen tot de laatste, waarin verhaald wordt van een man die 'overal bekend' is en 'te midden van de oudsten' neerzit. En daarmee is De waanzinnige waereld dus vooral een poging om op gelijke hoogte te komen met zijn tegenstanders.

\section{De revolutionaire waarheid}

Het boek werd een hit. De eerste oplage was binnen anderhalve week uitverkocht en werd vanaf juni I9I9, nu in een goedkopere volksuitgave, steeds opnieuw herdrukt. ${ }^{8}$ Het is een krankzinnig boek, zeker, maar wel een vrolijk krankzinnig boek, en dat zal een deel van het succes verklaren. Neem bijvoorbeeld de bestrijding van Troelstra's 'allerdomste bewering' dat de voortgebrachte rijkdommen ten goede zouden moeten komen aan de massa. Onzin! Men behoeft echt geen college over staatshuishoudkunde te hebben gevolgd om dat te kunnen begrijpen, schreef Van Dieren. De maag van een bourgeois is heus niet groter dan die van een arbeider; zijn klerenkast geen pakhuis, zijn woning bevat zelden meer dan zes of zeven vertrekken (personeel meegerekend): hoe groot - neen, hoe klein - zou dan ieders portie zijn? ${ }^{9}$ Het gezonde verstand op z'n scherpst: wie heeft ooit durven beweren dat de heren professoren en doctoren het beter begrijpen dan een eenvoudige hbs'er? 
Een in het boek opgetekende dialoog in een café tussen de schrijver en een bootwerker over de mogelijkheid om de werkdag tot vier uur terug te brengen mondde uit in de conclusie dat in hun 'egocentrische beschouwing' de bootwerkers het belang van de gemeenschap volledig uit het oog waren verloren: 'ze hadden de maatschappij enkel met het oog op hun eigen belangetjes bekeken', schreef Van Dieren. Het deed de recensent van Het Volk in een schaterlach uitbarsten: 'De heer E. van Dieren, arts, doet aan inwendige zending. Hij schijnt inrichtingen te frequenteren, die hij aanduidt met een verzachtende term als "Volkskoffiehuis" en daar ontmoet en beleert hij "socialistische" bootwerkers, die 4 uur, zelfs 2 uur werken genoeg vinden. Wat den heer E. van Dieren, arts, gelegenheid geeft om zijn ekonomische ontzaglijkheid te bewijzen $[\ldots] .{ }^{10}$

We volgen Van Dieren op het moment dat hij in het volkskoffiehuis het stel bootwerkers tegen elkaar hoort zeggen dat vier uur werken lang genoeg is en hij in hun gesprek inbreekt met de opmerking dat hij als dokter een véél langere werkdag heeft, maar zich daar volstrekt niet over beklaagt.

BOOTWERKER: Dat maakt een groot verschil meneer; daar zijn immers bootwerkers genoeg.

VAN DiEREn: En als er nog mèèr bootwerkers bij komen, wat wilt ge dan? Bootwerker: Heel eenvoudig, meneer, dan zullen we maar 2 uren behoeven te werken.

VAN DiEREn: En dan zult ge toch zeker hetzelfde weekloon willen verdienen?

Bootwerker: Natùùrlijk, want dat kan er best af; nou gaan de Directeuren en de aandeelhouders er immers mee strijken.

VAN DIEREN: Bij sommige maatschappijen wordt er in buitengewone tijden weleens zè̀r veel geld verdiend; maar ik heb ook andere tijden gekend; als datgene wat gemiddeld te vè̀l verdiend werd, niet bij een maar bij alle maatschappijen, onder de werklieden verdeeld werd, dan zou het $\mathrm{u}$ niet meevallen; en dan zou het ook billijk zijn om u te laten mee betalen, dus minder te laten verdienen in slechte tijden. Maar dat kunt ge u moeilijk indenken, en daarom vraag ik u het volgende: àls er zich in uw buurt telkens weer nieuwe dokters, apothekers, schoenmakers, kruideniers, slagers enz. komen vestigen, bent $\mathrm{u}$ dan van plan het busgeld te verdubbelen, en naar verhouding meer te betalen voor schoenreparaties, rijst, gort, boonen, erwten, suiker, vleesch, enz. teneinde àl die mensen een behoorlijk en vast bestaan te verzekeren zooals ge dat zèlf durft eischen? ${ }^{11}$ 
Dat in Het Volk hartelijk werd gelachen om de wat pedanterige toon van de huisarts die die arme bootwerkers in een hoekje drijft kan men wel begrijpen. Maar achter het komieke gaat in die bootwerkersdialoog een commentaar schuil dat appelleert aan een in die tijd sterk gevoeld verlangen naar een rechtvaardiger maatschappij en een meer serieuze behandeling behoeft.

Ik schreef al dat het boek verscheen niet lang na de aangekondigde revolutie. 'En thans neemt de arbeidersklasse de macht over', riep Troelstra uit in navolging van Lenin. De Russische revolutie vormde in ieder geval het model waarnaar ook de Nederlandse revolutie zich diende te voegen, en dat werd dan ook door de voormannen en -vrouwen hier te lande uitgedragen, zoals bijvoorbeeld leidsvrouwe $\mathrm{H}$. Roland Holst. 'Diep bewogen door de revoluties, eerst in Rusland, dan in Duitsland en Hongarije, met massa-akties in Italië en andere landen, was Henriëtte Roland Holst uiterst aktief met spreekbeurten en met haar pen', herinnerde Dirk Struik zich later. ${ }^{12}$ Een van die redevoeringen van Roland Holst, gehouden voor de Amsterdamse studentenvereniging, vormde, zoals we eerder zagen, het acute voorwendsel voor Van Dieren om zich ten tweede male met het socialisme bezig te houden.

Toch was zij slechts een der velen die de groeiende roep om de maatschappelijke verhoudingen radicaal te hervormen onder woorden trachtte te brengen. Het algemeen kiesrecht en het recht op een pensioen vormden belangrijke inzetten in de strijd der sociaal-democraten, maar ook de eis om de duur van de werkdag aan banden te leggen. In zijn Gedenkschriften schrijft Troelstra over die periode: 'Met cijfers over den heerschenden arbeidsduur toonde ik aan, hoe noodig een aktie voor beperking was en ik vervolgde: "Als wij zien arbeidsdagen van I I, I 2, I3 en I 4 uur en langer en daarbij rekenen den tijd van gaan en komen naar en van de fabriek, dan zeggen wij: voor het gezin, de ontwikkeling, het staatsburgerschap blijft zoo goed als niets over. In de arbeidersklasse is doordrongen het fiere besef: wij zijn wat anders dan een werkmachine van onzen meester, wij willen zijn mensch [...]". ${ }^{13}$

De discussie in De waanzinnige waereld over het bekorten van de werkdag tot vier uur is in feite een parodie op die eis, een commentaar op dat vooroorlogse, wereldwijd gedragen emancipatieverlangen der socialisten dat volgens Van Dieren wel moest uitmonden in het verval van de maatschappij indien men er gehoor aan gaf. Hij was niet de enige die daar kritiek op had. In Aldous Huxley's Brave New World, de in 1932 verschenen satirische kritiek op de socialistische heilstaat, keert die eis terug en merkwaardig of toevallig genoeg ook in de vorm 
van een vierurige werkdag. En ook daarin wordt dat idee met kracht verworpen, alhoewel arbeidstijdverkorting technisch een koud kunstje blijkt te zijn in de toekomst. 'En waarom voeren we die niet uit? Omwille van de arbeiders; het zou domweg wreed zijn hen te belasten met een overmaat aan vrije tijd', laat Huxley De Chef zeggen op een toon die Van Dieren niet had misstaan. ${ }^{14}$ Een overmaat aan vrije tijd leidt tot onrust, en dat is niet in het belang van iedereen. Doch de utopie van gemeenschappelijkheid mondt, zoals iedere utopie, ook bij Huxley uit in een nachtmerrie van terreur en onderdrukking.

In de ridiculisering van het verlangen naar een vierurige werkdag ligt een merkwaardig en niet alleen oppervlakkig maar ook inhoudelijk verband tussen de heerlijke nieuwe wereld van Huxley en de goede oude tijd waarnaar Van Dieren terugverlangde, maar die nooit bestaan heeft. Dat is de gedachte dat de manier waarop de wereld is ingericht zinvol is, ja, zinvol moet zijn. In de utopie van Huxley zijn de verschillen tussen mensen 'functioneel', legt De Chef uit, en vormt elke verandering een bedreiging van de stabiliteit. Ook Van Dieren legt aan zijn lezers geduldig uit dat het goed is dat er klassenverschillen bestaan: zonder de mensen die het beter hebben dan anderen loont het immers niet om iets nieuws te maken dat voor veel geld kan worden verkocht, zodat het later, en goedkoper, anderen ook ter beschikking kan komen. Een elementaire les in het nut van een standenmaatschappij, geillustreerd aan het rijwiel van dr. Van Dieren, dat in I 895 was gekocht voor het formidabele bedrag van 340 gulden, terwijl het bezit ervan thans (dat wil zeggen in I9I9) binnen eenieders bereik ligt. ${ }^{15}$

Wat de onverwachtse parallel tussen Huxley en Van Dieren nog interessanter maakt is dat in de socialistische utopie zo goed als in de wereld van Van Dieren de wetenschap de rol van vijand vervult: elke wetenschappelijke ontdekking is potentieel ontwrichtend, zegt De Chef. Bij Van Dieren is de wetenschap zelfs per definitie bedreigend, want gebaseerd op een benepen soort 'laboratoriumgeleerdheid' die a priori in tegenspraak is met de intuïtieve logica van de eerlijke waarnemer die openstaat voor eenvoudige waarheden.

In beide universums diende de wetenschap daarom kort te worden gehouden door een bovenschikkend principe: een 'geloof'. Conclusie: Huxley wijst het socialisme af, omdat het zich als een godsdienst gedraagt; Van Dieren omdat het zich als een rivaliserende godsdienst gedraagt.

Maar er is nog een parallel te vinden tussen het betoog van Van Dieren en dat van Huxley. In zowel Brave New World als in De waanzinnige waereld is het het naar eigenheid strevende individu dat zich 
tegen het hoogste gezag verzet en door het systeem vemorzeld dreigt te worden, ja, is het loutere bestaan voor zowel Huxley als Van Dieren al een uiting van verzet. Beiden zien dan ook de uiteindelijke consequentie daarvan haarscherp in: wie zich niet conformeert wordt genadeloos uit de gemeenschap gesloten.

\section{Van Dieren blijft desondanks Van Dieren}

Om althans de schijn op te houden dat hij als medicus het recht had zich met een sociaal vraagstuk als het socialisme bezig te houden probeerde Van Dieren het socialisme als een 'psychische epidemie' te karakteriseren, dus als een ziekte en interessant genoeg een infectieziekte - de gedachte aan de beriberi was nooit ver weg. Hij trok vergelijkingen met de danswoede uit de Middeleeuwen, de convulsie-epidemie bij meisjes in de achttiende eeuw, en de kinderkruistochten, die bewezen 'welk een onweerstaanbare macht een of ander denkbeeld kan uitoefenen op de massa. ${ }^{16}$

I 82 Van Dieren gebruikte het begrip 'psychische epidemie' om te verklaren waarom zo veel mensen konden geloven in wat objectief gezien immers pure waanzin was, namelijk het socialisme. Vooral labiele karakters zouden vatbaarder zijn voor massahysterische verschijnselen, redeneerde hij. Spiegel ze de gedachte voor dat iedere aardbewoner recht heeft op een gelijke portie, overgiet het idee met 'quasi-geleerd gezwam over materialisme en de veranderlijkheid van moraal', en een waanidee als het marxisme kan epidemische vormen aannemen, vooral onder de lager opgeleide gremia in de maatschappij, wanneer er van hogerhand niet tegen wordt opgetreden. ${ }^{17}$

De enige medische autoriteit die Van Dieren opvoerde ter ondersteuning van de hypothese dat zieke denkbeelden overgedragen kunnen worden op anderen was D.W. Yandell (bij Van Dieren vernederlandst tot Jandel) die in I88 I een studie over epidemic convulsions had gepubliceerd in het tijdschrift Brain. Toen het boek al af was kwam hij bovendien tot de ontdekking dat hij een voorganger had gehad die zowaar nog verder terug de geschiedenis invoer: Carl Theodor Groddeck, een Berlijnse arts die in I 849, een jaar na de revolutie dus, op De morbo democratcio, nova insaniae forma was gepromoveerd. Van zijn proefschrift verscheen in I 850 de Duitse vertaling als Die demokratische Krankheit eine neue Wahnsinnsform. Het proefschrift behandelt het socialisme vanuit het perspectief van een medicus, als een vorm van psychische besmetting. Het werkje staat verder bol van de waarschuwingen tegen allerhande vormen van zedelijk verval en de auteur her- 
innert de lezer er aan dat God de mens met rede heeft begiftigd, maar dat de mens er vaak een potje van maakt.

Via een omweg belandde dat geschrift zeventig jaar later op het bureau van Van Dieren; op dinsdag 24 juni I9I9 gaf prof. Ariëns Kappers het hem te leen, vier dagen later had hij het uit. Wat een merkwaardig, hoopvol stemmend boekje, vond hij. Enthousiast deelde Van Dieren zijn lezers in zijn ontdekking en citeerde hij anderhalve pagina daaruit in wat we niet anders kunnen noemen dan een wel bijzonder vrije vertaling, die hij aan het slot van De waanzinnige waereld toevoegde. Dat weekend ging de tweede druk van zijn eigen boek naar de drukker.

Dat die twee autoriteiten zijn boek een solide medische basis verleenden kan niet direct worden beweerd. Van een systematische bespreking van beide stukken is geen sprake. Hij putte eruit om gevallen van psychische besmetting uit vroegere tijden te kunnen citeren die de lezer de suggestie aan de hand moesten doen dat het socialisme inderdaad een soort godsdienstwaan is, zoiets als de danswoede uit de Middeleeuwen, maar van een of andere vorm van verklaring hield hij zich verre, afgezien dan van de veronderstelling dat het blijkbaar zwakken van geest waren die vatbaarder voor zieke ideeën zijn dan de sterkere geesten onder ons.

Toch begaf Van Dieren zich met zijn politiek-psychologische opvattingen niet geheel buiten het domein van de medische wetenschappen, zoals het boekje Beitrag zur Lehre von den psychischen Epidemien van de Würzberger psychiater Wilhelm Weygandt bewijst, dat slechts vier jaar eerder was verschenen. Aan de hand van klinische gevalsstudies onderscheidde Weygandt vier verschillende typen van 'psychische besmetting', waaronder die van een waanzinnige op psychisch labiele personen. ${ }^{18}$ Maar juist dit boekje werd niet door Van Dieren geciteerd.

Ondanks de suggestie dat zijn werk als een klinische studie moest worden begrepen heeft het begrip 'psychische epidemie' dus eigenlijk alleen een overdrachtelijke of op z'n best een sociologische betekenis bij Van Dieren (zijn opvatting roept associaties op met het werk van Le Bon). De grondvorm van De waanzinnige waereld is zodoende afgeleid uit het beriberistrijdwerk: een historische parallel die dient als vertrekpunt van waaruit naar believen verschijnselen onder één noemer kunnen worden gebracht, waarna een 'kritisch deel' volgt; het neersabelen van een misvatting, het opblazen van een domheid, het belachelijk maken van een vijand - in één woord: het ondermijnen van het establishment. En dat alles vervat in een achteraf geconstrueerde geschiedenis van voorgangers. 
In de korte tijd tussen 29 januari, de datum waarop Henriëtte Roland Holst haar voordracht hield, en de dag waarop De waanzinnige waereld verschijnt, uitgerekend I mei, de socialistische dag van de arbeid, was Van Dieren erin geslaagd om een trommeltje vol bewijsmateriaal te verzamelen waarmee hij zijn tegenspeelster van de troon dacht te stoten. Kritiek op enkele brochures en artikelen van Kautsky en Bebel (de theoretici van het socialisme), en een uitstapje naar het werk van Jean-Jacques Rousseau ('een beroemd geworden warhoofd' voor wie de socialisten ten onrechte bewondering koesterden ${ }^{19}$ ) vormden de onderbouw voor het hoofdbestanddeel van de analyse: de ontleding van mevrouw Roland Holst zelf, en haar kunstbroeder-volksophitser Herman Gorter, nevens de 'demagoog Henri Polak' en de 'profeet Wibaut' die 'niet leeft naar zijn eigen leer'. Het was de vriendenkring van Roland Holst dus waartegen hij zich richtte; haar 'kliekje'.

De strategie is nu bekend: Van Dieren wrijft zich tegen zijn tegenstander aan, klemt zich met alle macht aan hem (of haar) vast, als een soort schrijvende sumoworstelaar, en probeert de tegenstander dan met I 84 al zijn poëtische en dichterlijke gewicht op te tillen en uit de ring te smijten. Dat ging zo: 'Uit één en ander blijkt overtuigend, dat de taktiek van Herman Gorter evenals die van alle socialisten hierop neerkomt, het nu eens zus en dan weer zòò te beweren; de ééne keer tracht hij de arbeiders in het gevlei te komen door hun te vertellen, dat ze ò zoo knap zijn, dat er voor hèn geen raadselen bestaan (zooals voor de bourgeois!), dat er niets is in natuur of maatschappij wat $z i j$ niet kunnen begrijpen; de andere keer maakt hij hen giftig door te beweren, dat bij de groote massa van geestelijke ontwikkeling geen sprake is, en dat zulks geweten moet worden aan staat en kerk. ${ }^{20}$

Bij Henriëtte Roland Holst zelf ging hij nog wat verder. $\mathrm{Na}$ het lezen van haar dichtbundel Verzonken grenzen waarin zij over de dood van haar moeder schrijft (in I9I4 overleden) kwam Van Dieren tot de conclusie dat ze 'niet meer achter het dualisme stof en geest staat'. Uit de bundel haalde hij de volgende strofe aan: 'Wij weten niet wat van de zielen wordt / wij weten niet het wezen van den dood / omdat wij 't wezen van de ziel niet kennen'. ${ }^{21}$ Daaruit concludeerde hij dat 'Mevr. R.H. tegenwoordig over dood en ziel alles behalve materialistisch denkt'. Was ze soms teruggekomen op de materialistische wereldbeschouwing? Had ze misschien haar geloof in de massa verloren? Hij besloot haar een briefje te schrijven waarin hij eiste dat zij de inhoud van haar gedichten in eenvoudige taal zou mededelen aan de arbeiders, liefst in een goedkoop boekje uit te geven en te verspreiden door de brochurehandel van haar partij. ${ }^{22}$ 
Het antwoord op die brief werd ons door Van Dieren niet meegedeeld. Men kan zich indenken dat ze er in het geheel niet op heeft geantwoord. Een beschouwing van haar hand over het wezen van de ziel vanuit marxistisch oogpunt, uitgelegd aan arbeiders en gepubliceerd door de SDAP, verscheen in ieder geval niet. Wel een stuk van een kennis van haar, Jan van Breemen, die in het Medisch Weekblad de verzekering gaf 'dat mevrouw Roland Holst nog steeds een hoge dunk van de massa bezit en allerminst teleurgesteld is'. ${ }^{23}$ En dat zou dan dat kunnen zijn geweest, ware het niet dat zijn naam toch een spoortje in haar werk blijkt te hebben achtergelaten: het miniemste, kleinste spoortje

\section{Prof. FREUD \\ DE UITVINDER VAN DE Z. G. PSYCHO. \\ ANALYSE OF TE WEL „DIEPTE”-ZIELKLINDE \\ EN HET \\ PERVERSE GEVAAR}

\section{DOOR E. VAN DIEREN}

Arts te Amsterdam

Inhoudsopgave: Freud als stylist en pornograaf; als Godsdienst-verachter en bolsjewiek; als psychopat en sadistisch mishandelaar van zielszieken; als bevorderaar van de perverse ontucht èn als "advocaat van den duivel" en "duivelwèkker" (zoo noemde hij zich zèlf!)

De zenuwdokter A. Querido schreef in het Ned. Tijdschr. v. Geneesk. van 7 Maart f.l, $₹$,Het werl
van Frend steekt ver uit boven dat van zijn tijdgenooten".

Prof. Winkler schreef in 1927 aan dokter van Dieeen naar aanleiding van diens eerste boek contran Dieren naar aanleiding van diens eerste boek contra Freud het waarlijk gevaarlijke systeem van Freud is drin. gend noodig.... Ik acht het stelsel verderfelitk ... Het doet mij genoegen, dat ilk - afgezien van mijn waardeering voor den persoon (1) van Freud - gehee! aan uwe zijde sta in de bestrijding van zijn stelsel". Prof. Aengenent - thans Bisschop van Haarlem schreef in 1927; "Het is mijns inziens meer dan tijd, dat openlijk en met kracht tegen de theoriez̃n van Preud en hare practische aanwending op zenuw tieken worde opgetreden zooals onlangs gedaan van veel studie en groote belerenheld en gat gezond oordeel".

Dit is geen boek voor fut- en karakterlooze, zelfgenoegzame nfatsoenlijke Hallemannetjes", die liefst zoo lang mogelijk hwn oogen dicht knijpen voor de gevaren, Dit is een boek voor.... " nkêrels"! Hoeveel zijn er nog in Nederland? B. van Dieren, Arts.

UTTGBGBVEN DOOR DE N. V. HOLLANDIA-DRUKKERIJ TE BAARN

Ook dit boek was natuurlijk alleen maar een manier om zijn leven gestalte te geven. 
dat men zich kan indenken, maar een spoortje niettemin. In haar Levensherinneringen zal zij in een bijzin dr. Van Dieren afdoen als iemand die had 'bewezen niets te begrijpen van de groote omwentelingen die zich op maatschappelijk gebied voorbereidde'. ${ }^{24}$ Van Dieren heeft die zin niet meer kunnen lezen, natuurlijk, maar had hij het wel kunnen doen dan zou hij ongetwijfeld tevreden hebben uitgeroepen: 'De afgod waarvan mevr. Henriëtte Roland Holst de priesteres is neemt alles en geeft niets terug. ${ }^{25}$

Zijn succes bij Henri Polak (I868-I943) was groter, hoewel hij aan hem slechts een paar voetnoten had besteed. Net als de 'zeer rijke mevr. Roland Holst' woonde Polak in een te dure woning naar de smaak van Van Dieren, en dat is onverenigbaar met zijn socialistische principes. Als de revolutie eenmaal is uitgebroken, schreef Van Dieren, dan verwachtte hij dat dit 'vreemdsoortige, onbetrouwbaar gebleken heerschap' wel weer een baantje zal weten te vinden bij de leiding, en er wel voor zal weten te zorgen dat hij zelf niets tekortkomt; 'dat zijn "landhuisje" niet in beslag genomen wordt door een proletariërgezin'. ${ }^{26}$ Pure kinnesinne, zou men I 86 denken, maar het tegendeel is waar: het was zijn manier om uitdrukking te geven aan verwantschap, want de zaken die hij Polak aanrekende (drang naar status en bezit) kenmerkten hem niet minder dan Polak.

Aan Polak, die dus een 'welverdiende beurt' had gekregen in het boek, stuurde Van Dieren een presentexemplaar van De waanzinnige waereld. Hij kreeg het teruggestuurd met het volgende kattebelletje.

Laren, N.H. I 8 juni I9I9

Daar het geraaskal van een ontoerekenbare mij, als het geschreven is, even weinig belang inboezemt als wanneer het gesproken wordt, zelfs wanneer de dwaas een arts is, zend ik de stumperige maniak hierbij het product van hetgeen hij zijn geest noemt terug.

HENRI POLAK ${ }^{27}$

Van Dieren was zo ingenomen met dat briefje, misschien wel het hoogtepunt in zijn omvangrijke correspondentie-oeuvre, dat hij het in verschillende van zijn volgende boeken liet afdrukken en het bovendien als advertentie in Het Volk, De Telegraaf, het Algemeen Handelsblad, Het Nieuws van den Dag, Het Vaderland en de Nieuwe Rotterdamsche Courant liet opnemen. Als bijzondere aanbeveling voor zijn boek, moet men aannemen. Maar het is dan ook een briefje 'dat boekdeelen spreekt', schreef hij. ${ }^{28}$ Nog bij zijn overlijden keerde het zinnetje over de 'stumperige maniak' terug, als illustratie van de 'persoonlijkheid' die Van Dieren was geweest. ${ }^{29}$ 
Ook die advertentie stuurde hij op aan Polak, en ook daarop kreeg hij antwoord. 'Zelfs als er niet zulke aan mijn persoon en werk gerichte grofheden in het boek hadden gestaan', schreef Polak, 'dan nog zou mijn oordeel erover niet essentieel anders hebben geluid. ${ }^{30}$ Met dat antwoord was Van Dieren dan weer veel minder ingenomen, en hij probeerde Polak nog eens te verleiden tot een nieuwe aanval, het liefst een waarbij hij zelf in persoon werd genoemd. Hij schreef zijn opponent zelfs voor wat deze van hem diende te denken: 'Kort en goed, Henri Polak blijft bij de door hem gestelde diagnose: dr. Van Dieren is een stumperige maniak, en ontoerekenbare, een dwaas, een raaskaller! ${ }^{31}$

Van Polak zou hij geen woord meer horen. Wel van de christensocialist, antimilitarist en vrijdenker Bart de Ligt (I883-I938). Die hield in februari I92 I in een lezing over twee controversiële schrijvers ter linker- en rechterzijde van het politieke spectrum, namelijk Dokter van Dieren en Upton Sinclair. De precieze inhoud ervan is niet bekend, maar de voordracht eindigde met de stelling dat arbeiders die kanonnen en geweren produceren gelijkstaan met prostituees, waarna de redenering werd doorgetrokken naar degenen die het 'verderfelijke boek van Van Dieren' (De waanzinnige waereld) hadden gezet en gedrukt. De schrijver-souteneur zelf zat als te doen gebruikelijk in de zaal en ging het debat aan, al weten we jammer genoeg niet hoe dat verlopen is. ${ }^{32}$

In De waanzinnige waereld komt heel het universum samen. Als een orkaan draait Van Dieren rond zijn as. In het oog is het windstil en doet het bijna vredig aan - bezadigd, zou Van Dieren zeggen - maar daar omheen kolkt het onstuimig. Alles wat op zijn weg ligt zuigt hij op, alles wat de mens moeizaam heeft opgericht, wankele strohutten zo goed als machtige kerken; achteloos rukt hij de bouwsels van hun fundament en slingert het resterende puin in het rond, een spoor van vernieling achterlatend.

De onder het pseudoniem Melis Stoke publicerende journalist Herman Salomonson vatte de kruistocht van Van Dieren tegen het socialisme treffend samen in een commentaar waarvan de conclusie precies overeenkwam met dewelke Van Dieren Polak liet trekken, alleen dan wat geestiger geformuleerd: '[dr. Van Dieren staat] bij de hooiwagen en tracht met volle vorken het overvloedige hooi op te laden. Hij tiert en raast en vloek en roept soms zeer juiste dingen... maar er is te veel... hij kan het niet omvatten en omvademen, de heele lading hooi valt hem van de vork en over het paars-rood-opgewonden hoofd. Er is werkelijk geen actuele questie of hij heeft er zijn oordeel over, geen uitspraak van staatsman, dichter, econoom of filosoof of hij heeft er zijn commentaar 
op... hij is van alle tijden, van alle culturen, van alle markten thuis, en van alle rassen... maar blijft desondanks dr. van Dieren, schrijver van "Beri-beri eene rijstvergiftiging". ${ }^{33}$

\section{Gerepresenteerde afwezigheid}

Van Dieren was de grote afwezige in ieder vraagstuk, degene die niet werd aangesproken, uitgenodigd of geraadpleegd. Zijn lot was het om onbegrepen en miskend te blijven door degenen die het voor het zeggen hadden, maar ook om dat onrecht aan de kaak te stellen. Dat levert een spanning op: de buitenstaander eist van de ander erkenning, ten minste voor het feit dat hij door hem wordt buitengesloten, maar in feite ook voor zijn positie als zodanig. Hij verlangt, zo gezegd, dat zijn afwezigheid wordt gerepresenteerd in het vertoog van de ander.

Die gerepresenteerde afwezigheid zocht Van Dieren op plekken in het betoog van de ander waar hij aanwezig had moeten zijn, bijvoorbeeld in vondsten of ontdekkingen die niet zonder zijn werk hadden I 88 kunnen worden gedaan, of in passages waarin zijn invloed 'indirect' naspeurbaar is, of in standpunten die hij zelf reeds langgeleden had voorgestaan en nu door de ander 'heimelijk zijn binnengesmokkeld'. Kortom, zijn methode bestond eruit in het werk van de ander zichzelf een plaats toe te kennen en de 'gecorrigeerde' versie vervolgens de wereld weer in te sturen.

Het citaat is daarom Van Dierens meest belangrijke 'empirische instrument', zijn enige toegang tot de wereld van de ander. De methode Van Dieren is even simpel als doeltreffend. De schrijver werpt zijn drijfnetten uit in de bronnen van een ander en haalt in één ruk de vangst naar boven. Zonder nog een of andere vorm van schifting toe te passen smijt hij de inhoud neer in zijn boek en begint hij aan de verkoop ervan: Ja, geachte toehoorder, 't staat er heus... !'t Is misleidend, gevaarlijk, duivels. Ik vraag u: kan het erger? Ja, soms moet 't eens ongezouten gezegd worden.' Enzovoorts. Waarop lange aanhalingen volgen van wat deze of gene ergens heeft gezegd, geschreven of beweerd.

Aan de vrouw van de socialist Wibaut, Mathilde Berdenis van Berlekom (voorzitster van de Bond van Sociaal-Democratische Vrouwenclubs en zelf ook auteur) schreef hij een keer: 'Wilt u zoo goed zijn tevoren de tegen mij uit te spelen voorbeelden op te geven, dan zal ik mijn overtuigingsmateriaal meebrengen. Het resultaat van de bespreking kan dan vervolgens gepubliceerd worden.' Het antwoord luidde: 'Mij dunkt, dat het aan de lezers uwer werken kan worden overgelaten 


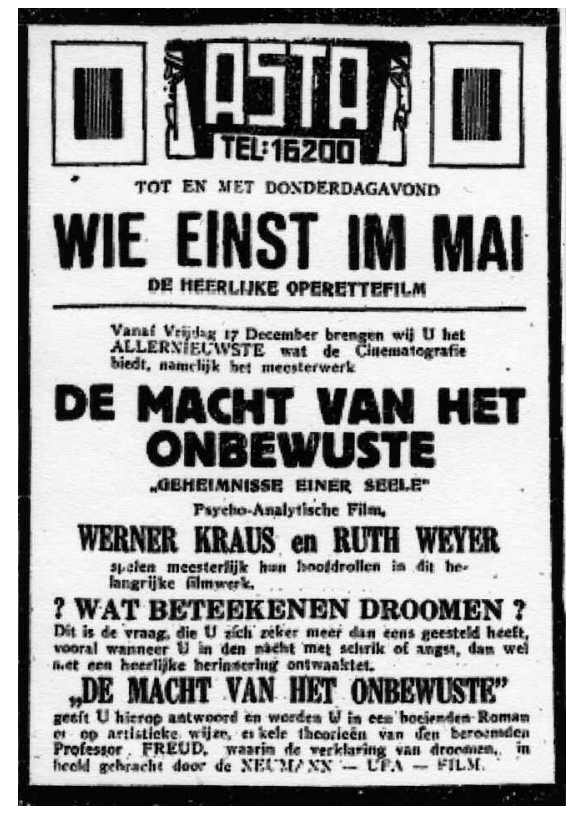

'Ik kèn de film, en de geschriften van Freud en zijn medestanders beb ik grondig bestudeerd, vandaar dat ik weet dat deze film niet weergeeft wat in die geschriften te lezen staat.'

om te beoordelen of ik gelijk heb of niet. In geen geval gevoel ik mij geroepen hier verder op in te gaan. ${ }^{34}$ En ook dat antwoord werd vanzelfsprekend afgedrukt.

Hij gebruikte het citaat zoals een houthakker de bijl: overvloedig en niet al te nauwkeurig. Zou men alle citaten uit het oeuvre van Van Dieren verwijderen, zijn boeken en brochures zouden slinken tot minder dan de helft van de oorspronkelijke omvang. Dat komt ook omdat Van Dieren niet bang was voor herhaling - in vrijwel al zijn boeken zijn er veel aanhalingen uit zijn eigen werk te vinden, meestal voorafgegaan door een opmerking in de trant van: 'Reeds in I92I schreef ik...' en afgesloten met een verzuchting in de trant van: 'Ja, geachte toehoorder, zoo schreef ik reeds in 1921... ${ }^{35}$ Ook losse argumenten herhaalde hij graag. Zo wordt bijvoorbeeld het feit dat Freud in I 926 tot ereburger van de stad Wenen was uitgeroepen in Prof. Freud steeds maar weer opgedist, soms tot tweemaal op dezelfde pagina aan toe, als een bijna niet te vatten staaltje van vriendjespolitiek. En soms, wanneer hij lange aanhalingen aanhaalt waarin opnieuw lange aanhalingen staan, is bijna niet meer mogelijk om te onderscheiden wie er over wie of wat aan het woord is of waarom. De stemmen van Van Dieren en zijn tegenstanders versmelten, worden door de feedback een soort dreunende brom die de lege glazen op tafel doet rinkelen. 
Sommige van de citaten bij Van Dieren zijn zo lang dat ze vele pagina's in beslag nemen, maar de meeste zijn eigenlijk ondermaats, te klein, hebben kop noch staart. En omdat boektitels en paginanummers zelden bij de citaten vermeld staan is het opzoeken en navorsen ervan bijna onbegonnen werk. Wie dat toch doet komt voor verrassingen te staan. Niet zelden blijken de citaten danig gemanipuleerd te zijn. Er is eens een woordje weggelaten hier - niet zo belangrijk vindt Van Dieren - of een aantal bijzinnetjes geschrapt daar - ook niet zo belangrijk (we herinneren ons de discussie met Eijkman over het woord 'spontaan'). Dat stuit, zoals we al eerder hebben gezien, op verzet bij degenen uit wiens vijver weleens een visje was gestolen. 'Dat citeren, Mijnheer Van Dieren! schijnt bij u ook al niet zoo heel nauwkeurig te gaan. ${ }^{36}$

Het verwijt dat hij zijn tegenstanders niet correct heeft weergegeven trof hem iedere keer opnieuw, en iedere keer veinsde hij verbazing. Dat moet men dan maar bewijzen, schreef hij. Met citaten, moeten we aannemen, zodat, als de opponent daarop inging, deze hem vanzelf meer ammunitie verschafte. Verschillende keren loofde Van Dieren een prijsvraag uit om zijn tegenstanders te dwingen de beschuldiging van citaatverminking waar te maken. In geval van zijn ongelijk maakte Van Dieren graag vijftig of honderd gulden over op de rekening van een goed doel naar keuze, schreef hij, in een poging de ander te verleiden tot weerwoord.

Nooit zou hij geld hoeven overmaken naar het goede doel. Wel werd zo de discussie gerekt. Maar daardoor trad er ook een enorme vertraging op in het dispuut dat steeds verder van de hoofdvraag afleidde. Dat gaf echter niet, want in de hoofdvraag was Van Dieren eigenlijk helemaal niet geïnteresseerd. Hem was het te doen om het debat op zich. Dat wil zeggen: het doen voortduren ervan.

Met het citaat strijkt Van Dieren langs de buitenkant van de wereld. Het geeft hem het gevoel dat hij ergens iets kan raken - maar wat? In geen van al zijn honderden citaten zou hij ooit de kern vatten van wat iemand had gedacht of gezegd. Altijd bleef hij in zijn citaten tegen de buitenkant aankijken als ging het om een machtig, ondoordringbaar bolwerk. 


\section{9 \\ Eén tegen allen, allen tegen één}

Parallel aan het schrijven ontwikkelde Van Dieren een praktijk die wel niet precies als 'spreken' mag worden opgevat, maar wel als een afgeleide vorm daarvan: het debatteren. Het debatteren was voor hem wat aan het schrijven voorafging, maar er ook in doorklonk en misschien nog wel het beste begrepen kan worden als een poging de taal zelf op te eisen. In dit hoofdstuk nemen we zijn belangrijkste non-beriberidiscussies onder de loep: die met de socialisten, psychoanalytici en de spellingvereenvoudigers (buiten beschouwing blijft de polemiek tegen een ander kwaad van zijn tijd, het darwinisme, dat niet de vorm van een discussie aannam).

\section{Het Volk versus Van Dieren}

De meeste van zijn confrontaties met de socialisten vonden plaats in de Amsterdamse schoolcommissie, waarin Van Dieren zelf zitting had. Van verschillende van dergelijke confrontaties zijn getuigenverslagen bewaard gebleven, zij het niet uit onpartijdige bron, want in hoofdzaak opgetekend door verslaggevers van Het Volk, het sociaal-democratische dagblad voor de arbeiderspartij. Daarin duiken in de rubriek 'Amsterdams nieuws' met regelmaat berichtjes op over de verrichtingen van de commissie en Van Dieren dient in die berichtjes vaak als kop van jut. Honend wordt zijn standpunt weggezet: ' $\mathrm{Nu}$ is het dr. v. Dieren maar die het zegt en daarom nemen wij het niet zo ernstig.'

In de beschrijving van zijn optreden ligt het accent vaak op zijn ongewild komische verschijning: 'Hij had nieuwe grappen op zijn repertoire waarmede hij 't gezelschap zou vermaken. De foliovellen kwamen te voorschijn, de bril werd rechtgezet en de dokter sprak. [...] En telkens keek hij zegevierend zijn publiek aan, afwachtend het applaus dat maar niet wou komen.'

Dat was wel onaardig gezegd, maar Van Dieren stemde dan natuurlijk ook steevast tegen socialistische plannen. Zo was hij tegen 
het invoeren van medezeggenschapsrecht voor onderwijzers op school, waar door de socialisten op werd aangedrongen, en bepleitte hij juist weer het afschaffen van de financiering van bijzonder onderwijs (behalve als het een protestantse instelling betrof), omdat de socialisten daar baat bij zouden kunnen hebben. Volgens Het Volk maakte het echter allemaal weinig uit en had zijn stemgedrag hoegenaamd geen invloed op de besluitvorming. Van Dieren zelf echter wekte graag de indruk dat hij vrijwel altijd aan het langste eind trok, al duurde het soms geruime tijd voor men tot het juiste inzicht kwam. Staan die verschillende getuigenissen lijnrecht tegenover elkaar, op één punt stemmen ze volkomen overeen: in de schermutselingen tussen de Amsterdamse huisarts en zijn tegenstanders van meestal socialistische snit (Van der Waerden, Sleef, Polak) botsten niet enkel standpunten maar hele werelden op elkaar.

\section{Zuiveringspogingen}

I92 Om te beginnen de polemiek met de socialist J. van Eizenga in De Telegraaf van oktober 1908 - de opmaat voor zijn eerste antisocialisten boek, Het socialistisch gevaar, dat een jaar na het debat zal verschijnen. De discussie is een voorafschaduwing van de grote debatten over de psychoanalyse die Van Dieren eind jaren twintig, begin jaren dertig zou voeren, waarin hij nog één keer al zijn polemische gaven zou inzetten om gehoor te doen vinden.

De aanleiding was, zoals steeds, triviaal. De polemiek opende met een aanval van Van Dieren in de krant op de plannen van de sociaaldemocratische onderwijzersvereniging (SDOV), zoals gepubliceerd in de brochure Het klassenkarakter der Volksschool. De SDOV stond een 'nieuwe pedagogiek' voor, omdat die der kapitalisten enkel is gericht op het in stand houden van de bovenlaag van de bevolking; de socialistische onderwijzer daarentegen 'haalt naar boven wat des kinds is' dat wil zeggen dat het ook het intelligente arbeiderskind een kans wil geven. 'De strijd is voor meer en beter onderwijs, voor een gezonde opvoeding, een deel van den grooten strijd tusschen arbeid en kapitaal. $^{33}$

In de samenvatting van Van Dieren heette het dat de SDOV voorstelde om de arbeiderskinderen via het onderwijs voor te bereiden op de maatschappij, dat wil zeggen op de ongunstige maatschappelijke en economische positie die zij daarin zullen innemen. Dit betekent feitelijk, schreef Van Dieren, dat de socialisten het erop aanleggen de kinderziel 'omlaag te drukken, te bezoedelen met hun ontevredenheid, 
haat en afgunst'. De socialisten praten de fut uit de kinderen en dat zien ze zelf niet eens in, zo meende hij. ${ }^{4}$

De SDOV reageerde bij monde van haar voorzitter Van Eizenga, die zich in een ingezonden brief geschokt betoonde over deze onheuse beschuldigingen. Eizenga wist uit ondervinding dat er van dergelijke lasterpraatjes altijd wat blijft hangen, en wilde er daarom ten ernstigste tegen opkomen. 'Laat dr. van Dieren maar op onderzoek uitgaan om feiten van schending der neutraliteit te ontdekken; hij zal de eerste niet zijn die zijn vingers brandt!'s

Op die uitnodiging om 'de feiten zelf te onderzoeken' had Van Dieren natuurlijk zitten wachten. Drie dagen na de ingezonden brief van Van Eizenga verscheen al het eerste deel van een groot artikel dat geheel gewijd was aan een bespreking van de SDOV-brochure, na een week gevolgd door het tweede deel. Triomfantelijk haalde hij zinsneden aan die zijn gelijk moesten bewijzen, zoals die waarin het arbeiderskind wordt gemaand 'geduldig, gehoorzaam en tevreden te zijn en te blijven, ook onder de tergendste uitzuigerij'. Dát zijn dus de deugden die het kind volgens de socialist op school moeten worden aangeleerd, aldus Van Dieren. ${ }^{6}$ Conclusie: de socialisten brengen precies het tegenovergestelde in de praktijk van wat ze voorstaan, en niemand die dat beter kan bewijzen dan zijzelf!

Het geïncrimineerde citaat blijkt bij nadere bestudering op pagina 24 van de brochure terug te vinden. Daar bespreekt de schrijver dat het in de bedoeling van de socialistische schoolwet ligt om het kind op te leiden in alle christelijke deugden. Wat wordt daaronder verstaan? Volgt het citaat waarin geduldigheid, gehoorzaamheid en tevredenheid voorkomen - als karakterisering van die 'christelijke deugden', wel te vertaan. Een bladzijde verder wordt echter duidelijk dat het geenszins de bedoeling van de socialistische onderwijzer is het arbeiderskinderen op te voeden tot een 'onderdanige, gluiperig-vriendelijke dienaars van den kapitalist', maar wel tot 'flinke, fiere, zelfbewuste, op eigenkracht steunende mannen en vrouwen'.

Hoe kan Van Dieren daar overheen hebben gelezen? Mystificaties... Als enige toelichting schrijft hij: 'Commentaar is geheel overbodig; ook de eenvoudigsten van geest kunnen met behulp van dat citaat uitmaken of ik de bedoeling der brochure zuiver weergaf, ja dan neen. Ik ben er gerust op!' Maar de lezer, eenvoudig van geest of niet, kan maar moeilijk uitmaken of Van Dieren het wel ernst is met zijn kritiek: ironie en verontwaardiging ondergraven elkaar in het lange stuk waarin de schrijver als een ware polemist om zijn tegenstander heen zwiert, terwijl hij links en rechts flarden uit het betoog 
van de ander citeert en triomfantelijk uitroept: ben ik nu gek!

Een jaar later herhaalde Van Dieren de formule op een ander probleem dat de geschiedenis in zou gaan als de zogenaamde 'lintjeskwestie'. Deze zaak, die tot een heuse affaire zou uitgroeien, ontstond in de zomer van 1909, toen de antirevolutionair Abraham Kuyper ervan werd beschuldigd drie jaar eerder, als minister-president, de koopman R. Lehmann een ridderorde te hebben doen toekomen in ruil waarvoor deze aanzienlijke sommen in de partijkas zou hebben gestort, terwijl aan andere personen, onder wie een zekere mejuffrouw Mathilde Westmeijer, een 'avontuurlijke dame van niet geheel onbesproken gedrag', en de advocaat Mr. Tideman, weer geld zou zijn betaald. Jan de Bruijn schreef er een vermakelijk boek over, waarin heel die geschiedenis vol van chantage, opportunisme, politiek gekonkel en kleinburgerlijk gedraai uit de doeken wordt gedaan. ${ }^{7}$

De lintjeskwestie werd een politieke zaak, door Het Volk en Troelstra maandenlang smeulende gehouden, doordat steeds weer nieuwe compromitterende documenten boven water kwamen waarmee Kuyper I94 tenslotte in grote verlegenheid werd gebracht. Hij verloor er zijn respect bij velen door, waaronder dat van De Savornin Lohman. Troelstra trachtte in december 1909 munt uit de zaak te slaan door in de Kamer op een parlementair onderzoek aan te sturen en zo het gezag van Kuyper verder te ondermijnen.

Van Dieren probeerde zich in de kwestie te mengen in de winter van I909-1910 via drie artikelen waarvoor hij opnieuw De Telegraaf wist te strikken. Ze verschenen praktisch gelijktijdig met de viering van zijn zilveren artsjubileum. Een, mag men zeggen, toevallige samenloop van omstandigheden?

Voor Van Dieren, die geen partijganger van Kuyper was, maar wel een gloeiende hekel aan de socialisten had, vormde de kwestie in de eerste plaats een uitstekende gelegenheid om Troelstra dwars te kunnen zitten en Het socialistisch gevaar, dat eerder die zomer was verschenen, nog eens voor het voetlicht te brengen. Wat een brutaliteit van Troelstra, schreef hij, om een parlementaire enquête te eisen voor een kwestie die het sop de kool niet waard is, en wat een praatjesmaker is hij dat hij dr. Kuyper zulke dingen durft te verwijten: 'men behoeft nu juist geen diepe studie van de psychologie gemaakt te hebben, om te kunnen begrijpen, dat menschen die gewichtige dingen aan hun hoofd hebben, wel eens kleinigheden vergeten kunnen. ${ }^{8}$ Iemand die nu juist wel een diepe studie van de psychologie gemaakt had, zoals hij, kon dan ook met een gerust hart beweren dat het 'spraakvermogen van Troelstra beter ontwikkeld was als diens denkvermogen'. ${ }^{9}$ Troelstra kon dat alles 
nog eens op zijn gemak nalezen in het presentexemplaar van Het socialistisch gevaar - een bijdrage tot de kennis van besmettelijke zielsziekten - dat de auteur hem had toegestuurd.

Allicht verwaardigde Troelstra zich niet met Van Dieren in debat te treden. In De Telegraaf echter slaagde hij er wel in de discussie los te weken, en wel met mr. Tideman zelf, die de hele zaak aan het rollen had gebracht, maar tegenover Van Dieren in een open brief zijn eigen betrokkenheid bij de zaak zo veel mogelijk trachtte weg te moffelen. 'Flauwe uitvluchtjes', oordeelde Van Dieren. Ook een dr. Wiedeman uit Harderwijk reageerde. Hij beklaagde zich over de 'kleinheid' in de aanval van Van Dieren en veroorloofde zich een grapje: hij vergeleek Van Dieren met een smid wiens hersenen 25 jaar lang aan te hoge temperaturen zijn blootgesteld. Een 'guitigheid', wist Van Dieren, die met zijn zilveren artsjubileum in verband stond, waarover immers uitvoerig in de krant was bericht.

In de socialistische pers werd op zijn uitdagingen gereageerd met kleine plaagstootjes, maar tot een discussie liet men het niet komen. Het Volk schreef bijvoorbeeld op 2 I december I 909 over zijn artikelen in De Telegraaf dat het ene geheel uit gemopper op de persoon van mr. Tideman bestond, het ander een slap afkooksel van Kuypers Kamerrede was, en het derde tenslotte een hoop scheve voorstellingen omtrent de staking van I903. 'Conclusie, de heer v. Dieren is bereid Dr. Kuyper alles te vergeven, omdat hij een reactionair, antisocialistisch geweldmensch was. Jammer dat dr. Kuyper geen kans meer heeft om ooit minister te worden; dr. v. Dieren kreeg anders ook bepaald... een lintje. ${ }^{10}$ Het is duidelijk: voor althans sommigen was het verband tussen het lintje van Kuyper en het jubileum van Van Dieren niet zo toevallig - men vermoedde afgunst (Van Dieren zou zijn lintje krijgen, maar moest er nog 15 jaar op wachten).

Zijn stukjes in de krant, de brieven van Tideman en Wiedeman en zijn antwoorden daarop, plus een 'naschrift waarmede volgens schrijver's oordeel alle Kuyper-vervolgers het doen kunnen' werden in een veertig pagina's tellende brochure gebundeld en in januari I9Io gepubliceerd onder de titel Kleine Nederlanders! Hiermede heeft de kwestie eindelijk afgedaan, verklaarde Van Dieren zelfverzekerd. En als Troelstra er nog weer eens over beginnen wil, moet men hem maar de mond snoeren door hem op zijn eigen gebreken te wijzen. Het is tijd geworden voor de heren in Den Haag maar weer aan het werk te gaan - er valt immers nog zo ontzettend veel te verbeteren in het land, aldus de schrijver. ${ }^{11}$

Maar de lintjeskwestie had, Van Dierens verzekering van het tegenovergestelde ten spijt, nog lang niet afgedaan en bleef doorsudderen tot 
in de zomer van I9Io. Pas in augustus van dat jaar kwam er een eind aan toen Kuyper door de commissie van onderzoek officieel van corruptie werd vrijgepleit. Van allen die over de zaak publiceerden was Van Dieren wel degene die de minste invloed uitoefende op het debat (hij komt in het boek van Jan de Bruijn met nog geen voetnoot voor). Maar de kwestie was dan ook bijzonder schimmig en omgeven met geheimzinnigheid, voor een insider al moeilijk te doorgronden, laat staan dat een buitenstaander er veel van kon begrijpen. Van Dierens roep om nu maar eens een einde aan de zaak te maken, kan dan ook wel moeilijk anders worden geïnterpreteerd dan als een eis om niets in de openbaarheid te brengen wat buiten zijn bevattingsvermogen ligt. De brochure werd in de pers begrijpelijk genoeg niet erg serieus genomen. Het Volk wijdde er welgeteld één zin aan: 'door blinde socialisten-haat ingegeven brabbelpraatjes.' Ook de NRC maakte er slechts kort melding van: 'Een verplettering, ongeveer', oordeelde ze ironisch. Alleen Het Centrum citeerde er een langere passage uit, maar liet commentaar achterwege. ${ }^{12}$

I96 De discussies die Van Dieren in De Telegraaf probeerde aan te zwengelen over de socialistische onderwijzersmentaliteit en de lintjeskwestie zijn dan ook niet interessant als standpuntbepalingen, maar wel als vormen van gezichtsbedrog. Ze vertonen behalve een thematische vooral ook een retorische gelijkenis. In beide gevallen smeedde Van Dieren zijn eigen opvattingen en die van zijn tegenstanders aaneen tot een merkwaardig coherent geheel, bijna alsof er tussen de twee in feite geen tegenspraak bestond, of liever gezegd, alsof wat de ander beweerde alleen maar een opstapje kon vormen voor een door hem te ontwikkelen conclusie. Alsof de hele discussie dus deel uitmaakt van een in zichzelf besloten 'dialoog interieur' - een door een en dezelfde persoon gevoerde innerlijke dialoog die het voorkomen van een echt debat heeft.

\section{Op wie z'n kop?}

Nog zo'n confrontatie tussen Van Dieren en een half-imaginaire tegenstander vinden we in zijn bespreking van de Kollewijnse spellingvereenvoudiging, die in 1909 eens ter loops ter sprake kwam in de schoolcommissie en in de winter van I9I6-I9I7 tot een heus treffen zou leiden.

Taalhervormers pleitten sinds de jaren negentig van de negentiende eeuw in navolging van de schrijver Roeland Kollewijn voor afschaffing van de naamvallen en geslachtsaanduidingen, en voor sterke vereen- 
voudiging van de spelling. Hoewel veel van die voorstellen pas na de Tweede Wereldoorlog zouden worden ingevoerd, begonnen voorstanders bij wijze van 'eksperiment' al vroeg hun stukken in het 'Kollewijns' te schrijven, wat niet onopgemerkt was gebleven, zeker niet binnen de schoolcommissie, die per slot de vinger aan de pols diende te houden in zaken die het openbaar onderwijs aangingen. Voor Van Dieren hield de spellingvereenvoudiging behalve een bedreiging van het openbaar onderwijs, dat er zijns inziens door de spellingvereenvoudiging alleen maar moeilijker op zou worden, ook een belediging van zijn taalgevoel in, waardoor de kwestie iets persoonlijks kreeg.

$\mathrm{Na}$ lang aandringen werd Van Dieren in het voorjaar van I9I6, terwijl de rest van de wereld zich in een onmenselijke oorlog had gestort, door de schoolcommissie in staat gesteld zijn bezwaren tegen de spellinghervormers naar voren brengen. Opgewekt toog hij aan de slag om 'bewijzen' te verzamelen. Eerst wendde hij zich tot de pedel van de Amsterdamse universiteit met het verzoek om inzage in de tot dan toe in het Kollewijns geschreven proefschriften. Het bleken er drie te zijn, en tot genoegen van Van Dieren bleken de promovendi allerminst zuiver in de leer. $\mathrm{Al}$ op de eerste pagina trof hij geslachtsaanduidingen aan, maar 'desniettegenstaande durven de Kollewijnsche hoofdmannen zich op deze en dergelijke geschriften te beroepen om de goed-geloovigen in den waan te brengen dat men "Kollewijnsch" kan schrijven zonder dat de stijl behoeft te ontaarden', concludeerde hij in overcorrect Nederlands.

Vervolgens nam Van Dieren de proef op de som en vertaalde hij enkele lukraak gekozen fragmenten uit een boek over het wijsgerig economisch stelsel van Marx van de politicus Marie Treub, in die dagen juist als minister van Financiën verantwoordelijk voor de financiële en economische politiek van Nederland. Van Dieren voorzag het resultaat van commentaar. Een voorbeeld ter adstructie. In het origineel stond: 'Daardoor werd Hegels dialectiek, die volgens Engels op haar hoofd stond, weder op haar voeten gezet.' Daarvan maakte Van Dieren na toepassing van de regel dat de geslachtsaanduiding steeds mannelijk wordt: 'Daardoor werd de dialectiek van Hegel, die volgens Engels op z'n hoofd stond, weer op z'n voeten gezet.' Het commentaar van Van Dieren luidde: 'Op wie $z$ 'n hoofd, op wie $z$ 'n voeten stond de dialectiek? Of stond Hegel op $z$ 'n hoofd - zal een Kollewijner allicht vragen.' De spellingvereenvoudiging zal, zo luidde zijn argument, tot verwarring leiden en de zaak er in het geheel niet eenvoudiger op maken. ${ }^{13}$

$\mathrm{Na}$ deze exercitie legde Van Dieren zijn toepassingen 'ter controle' per brief voor aan enkele voorstanders van de spellingvereenvoudiging, 
onder wie prof. C.G.N. de Vooys, en de schrijvers Marcellus Emants (tevens voorzitter van de spellingvereenvoudigingsbond) en Frans Netscher, schrijver in de vereenvoudigde spelling, en natuurlijk Kollewijn zelf.

De Vooys, nam de moeite op een paar van zijn vragen in te gaan, hoewel hij al gauw begreep dat in de verbeelding van Van Dieren 'de "Kollewijners" een soort fanatieke sekte vormen, die een onverzoenlijke haat gezworen hebben tegen alle buigingsvormen en niets liever willen dan die alle verdelgen', waardoor een gedachtewisseling met hem 'zeer bezwaarlijk' werd. ${ }^{14}$ In een artikel in De Nieuwe Taalgids kwam hij echter op de kwestie terug en behandelde enkele 'moeielikheden' die in de 'Kollwijnse voornaamwoordelike aanduiding der abstrakta' besloten lagen. De Vooys, ging in het bijzonder in op de 'polemiese vraag van een heftig tegenstander' waarin we zonder twijfel Van Dieren mogen herkennen. Het omzetten van de aanduidingen 'zij' en 'haar' in de tekst van een bekende schrijver door 'hij' en 'hem' om te laten zien dat de geslachtsaanduidingen wel degelijk nodig zijn berust I98 op de foutieve redenering dat de stijlvormen die wij nodig hebben voor onze kinderen en nakomelingen tot in de lengte der dagen ook onmisbaar zullen zijn, aldus De Vooys. Iemand die van jongs af aan de sekseonderscheiding ontwend is kan putten uit de grote rijkdom en fijne nuancering van de gesproken taal. ${ }^{15}$

Frans Netscher wees ieder contact bij voorbaat af en schreef op een briefkaartje: 'U moet 't in uw medische praktijk wel wonderlik stil hebben om uw tijd aan dergelijke beuzelarijen te kunnen besteden. Maar het is een onschuldige liefhebberij en houdt de beoefenaars zoet en thuis. Dus veel succes er mee. ${ }^{16}$

Kollewijn, tot slot, gaf helemaal geen antwoord. Dat wil zeggen: niet direct. Maar Van Dieren wist de hand te leggen op een door Kollewijn onder pseudoniem geschreven klucht, getiteld 'De spreektaalveredelingsbond', waarin een zekere predikant Eibergens op komische wijze in een redevoering over 'grammaties-juist spreken in betrekking tòt en in verband mèt de grondslagen ener morele en ideale levensopvatting' de spellingvereenvoudiging op de korrel neemt: 'De welsprekende redenaar noemt de geschrevene taal het veredelde voertuig des mensen gedachte; de gesproken taal nu hebben te streven gelijken tred steeds te houden met de sierlijker en volkomener beweging des gemelden volmaakteren voertuigs. ${ }^{17}$

Van Dieren liet doorschemeren dat hij het was die in de karikatuur van ds. Eibergens op de hak werd genomen, maar dat is onwaarschijnlijk omdat het toneelstuk al uit I900 dateert. Maar toch had Kollewijn 
een gevoelige snaar geraakt. Het verzet van Van Dieren was gegrondvest in de idee dat de gesproken taal zich naar de geschreven tal diende te voegen, niet omgekeerd. Voor de taalkundige zijn de gesproken en geschreven taal twee praktijken met ieder een eigen productiewijze, maar voor de leek vormen de twee elkaars spiegelbeeld. Aantasting van de geschreven taal houdt aantasting van de gesproken taal in, juist omdat het verschil tussen de twee voor de leek klein is: hij neemt immers niet deel aan de professionele praktijk, maar is een amateurschrijver.

Dat gold ook voor Van Dieren, die zich opmaakte om in mei van dat jaar de spellingvereenvoudigers de genadeslag toe te brengen, maar voorlopig van het plan moet afzien, omdat een van zijn zoons door een dodelijke ziekte werd getroffen. Die zomer zou het gezin Van Dieren zijn vierde kind verliezen: Derk-Johan stierf op I 8 augustus I9I6.

Anderhalve maand later, op 2 oktober I9I6, hield Van Dieren zijn lezing alsnog. Hij maakte daarin uitvoerig gebruik van zijn bewijsmateriaal door overvloedig uit zijn correspondenties met De Vooys, te citeren. Het Volk besprak de rede kort en opmerkelijk neutraal; ze betreurde het alleen dat 'de man bij 't bespreken van zelfs deze zaak zich niet vrij wist te houden van de laag bij grondsche uitdrukkingen, zooals wij die van hem in de loop der jaren gewend zijn geworden', waarmee ongetwijfeld zijn talrijke uitvallen naar de socialisten bedoeld waren. $^{18}$

Pas op de vergadering van januari I9I 7 kwam het tot discussie. De Vooys, die blijkbaar ter ore was gekomen dat zijn correspondentie met Van Dieren tegen hem was gebruikt, deed wat na hem Westerman Holstijn zou doen en voor hem vele anderen al hadden gedaan: hij stuurde de secretaris van de commissie een briefje met het verzoek de hele correspondentie te doen voorlezen opdat eventuele scheve voorstellingen zouden worden weggenomen. G. Leffertstra, een medestander van Kollewijn, vertrouwde op een strategie die voor hem Eijkman en De Savornin Lohman al hadden beproefd: hij schreef in de gauwigheid een hele brochure tegen Van Dieren en stuurde die op aan de leden van de commissie.

Dat alles had voor Van Dieren dan toch niet het gewenste effect, want de spellingkwestie kwam blijkens een verslag in Het Volk in de eerstvolgende vergadering slechts kort ter sprake: 'Als slot kregen wij even nog weer de Kollewijnsche spelling op 't tapijt, naar aanleiding van een schriftelijk protest van prof. De Vooys, tegen dr. Van Dieren. Maar onze dokter moest geen Van Dieren heeten om dit op zich te laten zitten en trok natuurlijk maar weer onvermoeid van leer. ${ }^{19}$ 
Inderdaad liet van Dieren zijn hele verzameling anti-Kollewijnstukken drukken in een boek waarin uit wraak voor miskenning ook zijn correspondenties met de Kollewijners ongevraagd werd afdrukt. Zo verscheen in mei I9I7 De averechtse geestesrichting, 309 pagina's groot, uitgegeven voor eigen rekening bij Swets \& Zeitlinger, als een zwaarlijvige polemiek op foliantformaat, compleet met een eclectisch samengesteld register waarin bijvoorbeeld het trefwoord 'ongelooflijk' verwijst naar de in de kantlijn gedrukte uitroepen van Van Dieren bij het betoog van een ander.

Ongelooflijk was het boek zeker, maar een goede ontvangst was het niet beschoren. I $k$ word genegeerd schreef Van Dieren bitter aan de schrijver Johan Been; erger, ze bestrijden mij zonder mijn werk zelfs maar te kennen. Been schreef vrolijk terug dat hij het ook wel leuk zou vinden als hij zijn bestrijder mocht worden. Ten slotte werd het boek bij verschijning door letterkundigen in een enkele zin weggezet: 'Dit dure en lijvige boek wordt het best beantwoord met een welsprekend stilzwijgen. ${ }^{20}$ Aldus geschiedde.

\section{Roerige wateren}

De psychoanalyse vormde na de beriberi, het socialisme en de spellingvervorming de vierde en laatste grote zaak waarvoor Van Dieren zijn geestdrijverij zou aanwenden. Met zijn anti-Freud-werk zou Van Dieren een bescheiden plaats in de geschiedschrijving voor zich opeisen als de schrijver van "lasterlijke boekjes en artikelen tegen het "Freudianisme", die de 'penetratie natuurlijk niet kon tegenhouden'. ${ }^{21}$ Althans maakten zijn boeken reacties los binnen en buiten psychoanalytische kring. Vanwege zijn relatieve succes als anti-freudiaan schenk ik hier wat meer aandacht aan deze strijd.

De psychoanalyse kwam pas laat in het leven van Van Dieren, namelijk in de jaren twintig, toen de eerste Freud-receptie in Nederland al lang en breed had plaatsgevonden. De studies van Christien Brinkgreve en Ilse Bulhof laten zien dat de psychoanalyse vanaf ongeveer I905 voet aan de grond begon te krijgen in Nederland, althans binnen medische kringen. ${ }^{22}$ Voor die vroege receptie waren in eerste instantie de artsen Van Eeden en Van Renterghem verantwoordelijk, en in tweede instantie de hoogleraar Jelgersma, die in I9I4 in zijn rectorale rede Ongeweten geestesleven de droomduiding als de via regia tot het onbewuste had omarmd.

Het grote publiek zou eerst pas twee jaar later iets van deze nieuwe stroming binnen de psychiatrie merken. In I9I6 verscheen bij de 
Wereldbibliotheek in een vertaling van August Stärcke Psychopathologie van het alledaagse leven van Freud. Dit als een toegankelijke inleiding tot de psychoanalyse geschreven werk bevat tal van aansprekende illustraties uit de klinische praktijk, door de vertaler nog voorzien van eigen voorbeelden, en wist de interesse voor de psychoanalyse bij een breed publiek te wekken. Dezelfde of misschien zelfs een sterkere populariserende functie had ook Uit de diepten der ziel van Nico van Suchtelen, dat een jaar later bij dezelfde uitgever verscheen en volgens Bulhof tot een van de belangrijkste bronnen in de verspreiding van de psychoanalyse in Nederland moet worden gerekend.

Als in het opwekken van de belangstelling van Van Dieren voor de psychoanalyse Uit de diepten der ziel en De psychopathologie van het alledaagse leven al een rol hebben gespeeld, dan alleen een indirecte, want beide boeken werden door hem nooit genoemd. Toch besteed ik hier enige aandacht aan deze twee werken, omdat ze het decor vormen waartegen we de anti-Freud-polemieken van Van Dieren moeten plaatsen.

De sociaal en politiek geëngageerde literator Van Suchtelen (I 878I949) had contact met kringen rond Van Eeden, Gorter, Henriëtte Roland Holst en P.J. Troelstra, en was anderzijds als redactiesecretaris en later als onderdirecteur betrokken bij de Wereldbibliotheek. Zijn persoon vormde daarmee bijna vanzelfsprekend een schakel tussen de culturele voorhoede en het grote publiek, en in die hoedanigheid heeft hij met Uit de diepten der ziel de toon weten zetten waarin door vooren tegenstanders in de eerste jaren in publieke discussies over de psychoanalyse werd gesproken. Dat het uitgerekend een 'leek' moest zijn die daarvoor verantwoordelijk was (Van Suchtelen was van huis uit jurist), is niet toevallig, betoogde een criticus eens: de vakman is immers bevooroordeeld en krijgt geen toegang tot het grote publiek vanwege zijn ondoorgrondelijk jargon, de leek daarentegen kan 'verrassen, verleiden en overbluffen'. ${ }^{23}$

Uit de diepten der ziel draagt als ondertitel Samenspraak over droom en geweten en bestaat inderdaad uit een serie gesprekken tussen een arts en een kunstenaar. In hun avondlijke conversaties worden dromen, associaties en symptoomhandelingen uit de losse pols geanalyseerd. Van een klinisch gesprek is geen sprake: de gesprekken over en weer tussen analysant en analyticus zijn vrij van therapeutische aspecten; 'overdracht' - het belangrijkste analytische instrument volgens Freud - ontbreekt geheel. De gesprekspartners keuvelen er ruim 300 pagina's lang op los zonder dat het tot een 'interventie' leidt. Door dit gebrek aan klinische diepgang lijkt de psychoanalyse meer een bezigheid voor lieden met een hoge opleiding en een hoop vrije tijd - een 
bezwaar dat Freud zelf voorzag toen hij waarschuwde dat de popularisering van zijn leer ertoe zou leiden dat ze tot een soort 'gezelschapsspel' zou verworden.

De inzichten waartoe Uit de diepten der ziel uitnodigen zijn van de orde van grootte dat 'in iedere verworpeling Christus woont, dat elke idioot een wijsgeer herbergt [en] dat elke waanzinnige een dichter is' ${ }^{24}$ Een echo van de IJsbrand van Van Eeden dus, maar dan zonder diens ironie en zelfspot. 'Er is verlossing voor iedereen die heeft verleerd te minachten, te bespotten en te veroordelen', belooft de schrijver.

Tegenover die zalvende woorden van de dichter-analyticus, staat dat het geheel van overpeinzingen en dialogen voorafgegaan wordt door een uitvoerige maar ook nogal 'filosofische' dat wil zeggen speculatieve inleiding over het onbewuste en de droomduiding, waarin behalve aan Freud en zijn volgelingen vooral ook aan Grote Schrijvers wordt gerefereerd, zoals Goethe, Shelley en Dante.

Hoewel het boek een succes bleek en kort na elkaar meerdere herdrukken beleefde, werd het toch door de critici weggezet als 'onwetenschappelijk dilettantisme', zo althans klaagde de schrijver in een voorwoord bij de derde druk. ${ }^{25}$ Wat daarbij een rol kan hebben gespeeld is dat Van Suchtelen zijn analytische inzichten eigenlijk veel minder aan de meester zelf en veel meer aan Wilhelm Stekel had ontleend, tegen wie binnen analytische kringen een soortgelijk bezwaar als tegen Van Suchtelen gold: te veel speculatie en te weinig echte wetenschap. Stekel zelf, het is al eens gememoreerd, was toen al lang uit de orthodoxe kring rond Freud verwijderd.

Over de tweede bron van popularisering, Freuds Psychopathologie van het alledaagse leven, kunnen we opmerken dat het tot een van zijn best verkochte en meest vertaalde werken behoort. Interessant genoeg begon het zijn bestaan, net als Van Dierens anti-Freud-boek, als artikel en nam het in de loop der jaren en met iedere nieuwe druk in omvang toe, tot het ten slotte de grootte van een fors boek had gekregen, dat thans een heel deel van de Gesammelte Werke / Standard Edition in beslag neemt. De meeste toevoegingen bestaan uit beschrijvingen van 'gevallen', vaak door collega-analytici aangeleverd, en ook de Nederlandse vertaler deed een duit in het zakje door eigen analyses en beschrijvingen toe te voegen. Daarmee was het een weliswaar toegankelijk, maar ook een nogal rommelig boek geworden, dat bovendien niet helemaal recht doet aan de psychoanalyse als zodanig. Het theoretisch kader bleef onveranderd, terwijl de toegevoegde praktijkvoorbeelden gebaseerd zijn op inmiddels voortgeschreden inzichten die die historische ontwikkeling wel bekend veronderstellen (en het dus pas 
voor de lezer van de geannoteerde uitgave voor het eerst mogelijk werd het boek als een samenhangend geheel te lezen, doordat de toevoegingen van editie tot editie duidelijk zijn gemarkeerd). In feite kan tegen dit boek hetzelfde bezwaar worden gemaakt als tegen Van Suchtelen of tegen Stekel: het is meer propaganda dan wetenschap. Maar precies om die reden ook was het een succesvol boek. Het ontbreken van al te veel technische en theoretische ballast maakte dat het door brede lagen van de bevolking kon worden gelezen - en werd gelezen.

Het is tegen deze achtergrond niet verwonderlijk dat het in Nederland na publicatie van Psychopathologie van het alledaagse leven en Uit de diepten der ziel snel ging met de verspreiding van de psychoanalyse. In de kranten werd met regelmaat plaats ingeruimd voor artikelen pro en contra Freud. Discussies die voor het eerst in Uit de diepten der ziel of in de 'Psychopathologie' werden gevoerd, zoals over de betekenis van dromen, het pedagogisch effect van het onderdrukken van seksuele behoeften of de vraag welke geheime neigingen er in allerlei cultuuruitingen verborgen zitten, werden onder krantenlezers in korte tijd salonfähig.

Het kan wel bijna niet anders of Van Dieren moet via die discussies in de kranten op de hoogte zijn geraakt van het bestaan van de 'diepte zielkunde'. Feit is in elk geval dat vanaf dat moment de psychoanalyse voor het eerst in het werk van Van Dieren opduikt, en dat zijn kritiek op de psychoanalyse niet alleen als een bewijs van de toenemende belangstelling daarvan kan worden gezien, maar ook, ironisch genoeg, daaraan heeft bijgedragen, zoals Bulhof terecht opmerkte. ${ }^{26}$

De eerste verwijzing naar Freud bij Van Dieren vinden we in $D e$ waanzinnige weareld dat in I9I9 verscheen, dus zo'n twee jaar nadat de psychoanalyse bij het grote publiek was geïntroduceerd. Hierin kondigt de schrijver aan zijn opponenten te zullen 'ontleden', maar dan wel op 'ouderwetse manier', dat wil zeggen, 'niet op de onzinnige "futuristische" manier van Prof. Freud, die zich verbeeldt de zielen te kunnen doorgronden door meerendeels seksueele phantasieen vast te knopen aan de onschuldigste droomen en onbeduidenste feitjes. ${ }^{27}$

Met die verwijzing deed Freud zijn intrede in het Van Dierense rijk - om er nooit meer uit te verdwijnen. Het duurde nog een kleine tien jaar eer hij het tot een zelfstandige aanval zou laten komen, maar in de tussentijd zat hij niet stil. Rustig verzamelde hij zijn strijdmateriaal en wachtte hij het moment af waarop hij naar buiten zou treden.

In de psychoanalyse vond Van Dieren een waardige opvolger van de beriberi en een concurrent van het socialisme. Zo goed echter als in het geval van de antisocialistische polemieken Eizenga niet de meest 


\title{
OP DWAALWEGEN.
}

\author{
SPEL VAN DEN \\ WOELIGEN TIJD.
}

DOOR E. VAN DIEREN, ARTS TE AMSTERDAM.

HET STUK WERD GESCHREVEN EN SPEELT IN HET JAAR I9I 2.

( „Zij was dood en is weder levend geworden, zij was verloren en is gevonden.")

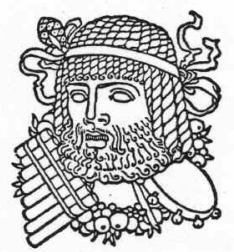

AMSTERDAM,

I9I7.

Redder in de nood is de scherpzinnige dr. Mol, een Amsterdamse geneesheer van ongeveer vijftig jaar met snor en toegepunte baard. Een dokter die zich in een koetsje laat verplaatsen.

voor de hand liggende keuze vormde om tegen op te treden, zo ook koos Van Dieren op het terrein van de psychoanalyse niet de meest vooraanstaande voorstanders uit om mee in debat te gaan, maar juist zij die slechts gematigd positief of zelfs kritisch stonden tegenover Freud. In dit geval: Cornelis Winkler.

Winkler, sinds 1893 hoogleraar in de psychiatrie en neurologie te Utrecht, daarna te Amsterdam, achtte zichzelf geen 'modern psychiater', 
in de zin dat hij geen overtuigd aanhanger van Freud was. ${ }^{28}$ Wel was hij vrij goed op de hoogte van diens werk, en ook was hij aanvankelijk vrij positief over de denkbeelden van Freud, maar later was hij sterker gaan twijfelen en ten slotte stond hij vrij sceptisch tegenover de psychoanalyse (in die zin was hij zijn tijd eigenlijk ver vooruit). Bij zijn afscheid, in I925, noemde hij psychoanalyse 'meer romantisch dan wetenschappelijk' en oordeelde hij dat de leer op 'dwaalwegen' terecht was gekomen 'toen zij zich blind staarde op het seksueele waar de fantasie van een geniaal man (die Freud ontegenzeggelijk was) vrij spel had' ${ }^{29}$ In I9I7 echter, dat cruciale jaar waarin de psychoanalyse doorbrak bij het grote publiek, schreef Winkler een brochure over Freuds leer waarin hij de analyse van kleine Hans besprak en zich nog tamelijk waarderend zij het tegelijk ook al kritisch opstelde. ${ }^{30}$

En juist die kritische bespreking van het geval van kleine Hans riep bij Van Dieren heftige emoties op. Ik licht de gevalsstudie kort toe. Kleine Hans was een jongetje van vijf dat aan nachtmerries leed. Hij werd niet door Freud maar door zijn eigen vader geanalyseerd. Die vader, Max Graf, een volgeling van Freud, had de casus aan Freud doorverteld. De hele casus draait om een droomduiding van Hans' angst voor paarden waarin een oedipuscomplex wordt herkend. Winkler zei daarover: 'Hoe komt nu de psycho-analyse er toe om hier een Oedipusdroom te vinden? Door Hans te laten praten? Allerminst. De vader [van Hans] en Freud zijn ijverig in de weer suggestief vragen te stellen. [...] Wie de zonderlinge paden, die deze psycho-analyse bewandelt, wil leeren kennen, hij leze het origineel. Ik grond mijn oordeel over de psychoanalyse van Hans op de hem gestelde vragen. Ik meen dat de analysanten er op uit waren Hans te laten vertellen want zij verlangden, opdat zijn droom als Oedipus-droom zou kunnen worden aangemerkt. ${ }^{31}$

Het is een inmiddels bekend verwijt aan de psychoanalyse dat hier wordt verwoord, namelijk dat zij alleen vindt wat zij bij voorbaat al zocht. Dat verwijt houdt een serieuze kritiek in en heeft de psychoanalyse van het begin af achtervolgd..$^{32}$ De psychoanalytische therapie wordt gecontamineerd, 'vervuild', door suggestie van de therapeut: de therapeut laat de patiënt zeggen wat hij wil horen en concludeert dan iets gevonden te hebben.

Van Dieren kwam tot een overeenkomstige conclusie na lezing van het geval Dora, zij het in wat minder erudiet filosofisch jargon. Dora is minstens even beroemd (en berucht) als kleine Hans en is binnen de psychoanalyse veelvuldig becommentarieerd. ${ }^{33}$ De analyse van Dora wordt beschouwd als een klassieke 'mislukking'. Ook over 'Dora' een korte opmerking ter toelichting. 
Dora kwam in analyse bij Freud, omdat ze leed aan 'hysterische verschijnselen' (ze voelde zich soms depressief, dreigde met zelfmoord, raakte haar stem weleens kwijt, had last van flauwtes en moeite met slikken). Freud dacht dat die symptomen terugvoerden tot een onbewuste verliefdheid van Dora op een kennis van haar vader, meneer $\mathrm{K}$. Maar in plaats van dat zij verliefd was op meneer K., was meneer K. verliefd op haar, beweerde Dora. Meneer K. had haar zelfs getracht aan te randen. Bovendien had Dora's vader het met de vrouw van meneer $\mathrm{K}$. aangelegd. ${ }^{34}$ Dora was dus niet hysterisch, maar een ruilobject in een ingewikkelde menage à trois, en zag af van verdere behandeling door Freud toen deze haar symptomen psychoanalytisch begon te 'duiden' in termen van onbewuste verlangens van haar kant.

Van Dieren verzette zich vooral tegen de psychoanalytische methode van droominterpretatie, die hij onzedelijk en vergezocht vond. Want ook in het geval van Dora speelt de droomanalyse een belangrijke rol, waarbij een in een droom voorkomende brand en een daarvan te redden juwelenkistje door Freud geïnterpreteerd worden als respectievelijk het uitoefenen van zelfbevrediging en de wens van Dora om met meneer K. naar bed te gaan. Dat vond Van Dieren ongehoord en het bracht hem tot de volgende verontwaardigde uitroep: 'Ziedaar dan, geachte toehoorder, op grond van welke overwegingen Dora voor een hysterica wordt gehouden! Ieder normaal mens zal zeggen: Hoe kan zooveel onzin en vuiligheid uit een stelletje menschenhersenen voortkomen! Welnu, de bezitter daarvan bracht [dat aan het licht] met behulp van zijn onfeilbare "analyse" - beter gezegd, met behulp van zijn onreine fantasie. ${ }^{35}$ Waarna lange citaten uit Freud volgden om aan te tonen hoe vies en voos het er in de hersenen van de Weense psychiater wel niet aan toe ging. Bevreesd dat de lezer niet zou willen geloven dat Freud dat allemaal echt had gezegd nam hij voor de zekerheid van alle geciteerde passages ook de originele Duitse formuleringen op, in de overigens vergeefse hoop dat hij ditmaal in ieder geval niet van citaatverminking zou worden beschuldigd.

Tussen Dora en Hans lopen parallelle paden. Omarmde Van Dieren dus Winkler als zijn wapenbroeder in de strijd tegen de perverse geestesrichting in de psychiatrie? Integendeel. Winkler werd een van zijn belangrijkste doelwitten, want nadat hij diens kritiek had bestudeerd, begreep Van Dieren dat Winkler de psychoanalyse niet in onomwonden bewoordingen veroordeelde en zelfs waardering wist op te brengen voor Freuds stijl. Het ontlokte hem de volgende uitroep: 'Ja warempel, dat schreef Prof. Winkler, en die zelfde Prof. Winkler schreef in hetzèlfde artikel, dat "de uiteenzettingen van Freud over het ontcijferen 
van de beteekenis der symbolen, en over het ontraadselen van de droomgedachten, de stille wenschen, die daarin begraven zijn, tot de beste bladzijden van diens boek over Traumdeutung" behooren! Ziedaar dan geachte toehoorder, welke "zonderlingen paden" door de logica bewandeld worden in de hersenen van Prof. Winkler!" ${ }^{36}$

In plaats van een medestander vormde Winkler een regelrechte bedreiging voor Van Dieren. Er kon maar één anti-freudiaan zijn, en dat was hij. Winkler kon op dezelfde behandeling rekenen als de rest, en dus stuurde Van Dieren hem, nadat hij zijn anti-Freud-boek had gepubliceerd, een presentexemplaar toe, in de verwachting, naar we mogen aannemen, dat de ontvanger het getergd zou terugsturen met een begeleidend briefje vol onheuse bejegeningen waaruit een en andermaal zijn gelijk zou blijken. Maar wat schreef Winkler terug? 'Hartelijk zeg ik u dank voor de toezending van uw boek, dat ik trouwens al gelezen had, en laat ik er bij voegen met genoegen. [...] Bestrijding van het waarlijk gevaarlijke systeem van Freud is inderdaad nodig. [...] het doet mij genoegen, dat ik, afgezien van mijn waardeering voor den persoon van Freud, geheel aan uwe zijde sta in de bestrijding van zijn psychoanalytisch stelsel. ${ }^{37}$

Er zijn er die het een beetje vonden tegenvallen van Winkler om zich zo aardig op te stellen tegenover Van Dieren, maar ik denk dat Winkler het plannetje van Van Dieren doorzag. ${ }^{38}$ Door zich 'geheel aan de zijde van Van Dieren' te plaatsen had hij hem geraakt op zijn zwakste plek: hij maakte het hem onmogelijk om hem verder in het debat mee te sleuren. En zo is dit opmerkelijke briefje, waaruit Van Dieren niet meer dan deze drie zinnetjes durfde te citeren, misschien nog wel dodelijker dan dat van Polak, dat hij keer op keer liet afdrukken.

\section{Afgebroken intermezzo}

$\mathrm{Na}$ Winkler deed zich een nieuwe gelegenheid voor Van Dieren voor om zich tegen de psychoanalyse uit te spreken. Precies op het moment namelijk dat hij de laatste hand legde aan zijn boek tegen Freud werd in Nederland de film Geheimnisse einer Seele in omloop gebracht. Deze Ufa-productie uit 1925 onder regie van G.W. Pabst is de geschiedenis ingegaan als de eerste verfilming van de psychoanalyse en werd hier uitgebracht onder de titel De macht van het onbewuste. Freud zelf had er zijn naam niet aan willen verbinden, maar twee van zijn volgelingen (Karl Abraham en Hans Sachs) hadden er wel aan willen meewerken, en zo kon deze film aan het grote publiek gepresenteerd worden als een min of meer authentieke of in iedere geval 'geautoriseerde' verfilming van de freudiaanse leer. 
In de film staat een gevalsstudie centraal van een impotente man die leidt aan een onbewust en tot zijn kinderjaren terugvoerend rivaliteitcomplex en die nu in een ongelukkig huwelijk terecht is gekomen, althans het huwelijk niet heeft weten te 'consumeren', zoals dat toen heette (het huwelijk was kinderloos gebleven). De psychoanalyse biedt uitkomst. Een lange droomanalyse legt de oorzaak van het probleem uit met behulp van vernieuwende technische middelen en een groot aantal tussentitels waarin een en ander aan de kijker wordt uitgelegd. Tenslotte breekt bij de patiënt het inzicht door, en de film eindigt met een niet mis te vatten scène waarin man en vrouw trots hun pasgeboren baby tonen. En zo was De macht van het onbewuste tegelijk een propagandafilm, een romantisch liefdesdrama en een medisch college. Maar daarin zat ook de zwakte: als drama was het nogal ongeloofwaardig, als verbeelding van de psychoanalyse wel erg optimistisch en als college gewoon te lang. ${ }^{39}$

Toch waren vooral de voorstanders van de psychoanalyse zelf er tamelijk tevreden over. De voorzitter van de Nederlandse psychoanalytische vereniging, Johan van Ophuijsen, had er in maart van dat jaar, nog voordat de film in Nederland in roulatie kwam, een artikel aan gewijd in Het Vaderland, waarin hij het 'welhaast volmaakte spel' van de hoofdrolspeler en de 'met zorg gekozen psychologische inzichten' roemde..$^{40}$

Een besloten vertoning van De macht van het onbewuste vond plaats in december 1926 in het Rembrandt-theater, aan de vooravond van de Nederlandse première. Een select gezelschap van artsen en leden van de pers was uitgenodigd de voorstelling bij te wonen. Onder de genodigden bevond zich Van Dieren.

Dat Van Dieren was uitgenodigd wekt wellicht verbazing, omdat hij een jaar eerder nog in een voordracht de psychoanalyse had vergeleken met 'dadaïstische zwijnerij,' maar het is natuurlijk goed mogelijk dat de organisatoren daarvan niet op de hoogte waren en hem simpelweg hadden uitgenodigd in zijn hoedanigheid van arts, niet beseffende een uitgesproken tegenstander van de psychoanalyse in huis te hebben gehaald. Maar het omgekeerde zou ook het geval kunnen zijn, namelijk dat ze onder het motto dat er niet zoiets bestaat als slechte reclame, hem juist hadden uitgenodigd in de hoop dat hij voor enige opschudding zou zorgen, omdat dat de ruchtbaarheid rond de film alleen maar ten goede zou kunnen komen.

Hoe het ook zij, Van Dieren accepteerde de uitnodiging en toog op de aangegeven datum naar de bioscoop en nam plaats. Het licht werd gedoofd, een spotlight ging aan en een aankondiger verscheen op het toneel die meedeelde dat voorafgaand aan de voorstelling een bekende 
Haagse zenuwarts een inleiding bij de film zou houden. De pers werd verzocht de naam van de inleider geheim te houden. Vervolgens trad 'dokter X' aan en hield een nogal lange inleiding waarin hij duidelijk liet blijken over inside-information over de totstandkoming van de film te beschikken. Aan het slot van zijn inleiding zei de spreker dat hij hoopte dat de aanwezigen, voor zover zij tot de tegenstanders van Freud behoorden, na het zien van de film ertoe zouden kunnen worden gebracht hun tegenstand opzij te zetten.

Wie was dokter X? Het leidt geen twijfel dat dat Van Ophuijsen was, die niet alleen een Hagenees was en de film goed kende, maar die ook tot de intimi rond Freud moest worden gerekend, of in ieder geval met hem daarover in briefcontact stond (toen de film in I933 opnieuw werd vertoond, was hij het die er wederom een inleiding bij gaf).

Van Ophuijsen was nog niet uitgesproken of Van Dieren stond op. 'Meneer Van Ophuijsen, ik ben dokter Van Dieren. Ik kèn de film, en de geschriften van Freud en zijn medestanders heb ik grondig bestudeerd. Vandaar dat ik weet dat deze film niet weergeeft wat in die geschriften te lezen staat. Deze zijn zóó ongelooflijk gemeen, zóó liederlijk vuil, zóó Dadaïstisch vies, dat niemand er òòit toe zal dùrven besluiten ze te verfilmen'. Alle bezwaren zouden de toehoorders goed gedocumenteerd terug kunnen vinden in een binnenkort te verschijnen boek, getiteld--

Boegeroep uit de zaal onderbrak het als een lange verhandeling tegen de psychoanalyse bedoelde betoog dat Van Dieren thuis had voorbereid en dat hij van plan was voor te gaan lezen. Een lid van de directie wendde zich tot het publiek: 'Dokter van Dieren moet begrijpen dat er hier geen gelegenheid kan worden gegeven voor debat en ook dat het hier niet de plaats is om reclame te maken voor zijn boek.' Applaus. De inleider werd bedankt. Opnieuw applaus. Daarop kon de vertoning van de film eindelijk beginnen.

Onbekend is of Van Dieren de opvoering nog heeft uitgezeten of dat hij na het smadelijk afbreken van zijn anti-Freud-betoog de aftocht maar heeft geblazen (hij had per slot de film al gezien). Wel is het duidelijk dat van zijn aanklacht een echo doordrong in de pers. Daags na de besloten opvoering verscheen een recensie van de film in de krant die zich richtte op de vraag hoe men tegen een kunstwerk moet aankijken waarin zo duidelijk een relatie met wetenschappelijke theorieën wordt gelegd. Als kunstwerk is de film heel goed gelukt, meende de journalist, maar daar waar hij propagandadoeleinden probeert te verwezenlijken is de film 'ongelooflijk irritant' - en dat sloeg op zowel de film zelf als op de 'onbenullige inleiding'. Van Dieren moet tevreden hebben 
geglimlacht bij het lezen van die zin: een klein succesje, dat hij graag op zijn conto bijschreef. ${ }^{41}$

\section{Van Dieren contra Freud}

Binnen deze constellatie van gevoeligheden en gelegenheden moet het begin 1927 verschenen Futuristische behandeling van zielszieken, Van Dierens eerste anti-Freud-boek, worden gesitueerd. Het is opgedragen aan de nagedachtenis van Jan Pieter Heije (I809-I 876), Amsterdams schrijver-arts die zich veel om de volksgezondheid en het volksonderwijs had bekommerd; een geneesheer met 'gezond verstand' en een 'vooruitziende blik', aldus Van Dieren, en een voorbeeld aan wie hij zich dus graag mocht spiegelen.

Een inlegvel bij het boek van de uitgever, drukkerij Amicitia te Haarlem, gunt ons een blik in de onderhandelingen achter de schermen die tot publicatie van Futuristische behandeling leidden. Toen de schrijver zich eind 1926 met het manuscript bij de uitgever meldde was deze aanvankelijk helemaal niet geneigd tot uitgave over te gaan, zo bekende ze eerlijk. Doch al lezende en zich in de zaak verdiepende drong het besef door dat met het publiceren van deze studie 'een algemeen belang gediend zou worden' (cursief van de uitgever). Ze zag er een 'heilzaam tegengif' in tegen al die 'ophemelende artikelen' en brochures waarin de loftrompet over Freud werd gestoken, omdat het werk afrekent met de 'geraffineerdste geestelijke en moreele folteringen'. Ja, de uitgever meende dat het boek zelfs voor gematigde bewonderaars nog aan te bevelen was, vooral misschien omdat Prof. Jelgersma, dr. v. Renterghem en vele anderen door de auteur niet worden gespaard. Met vertrouwen bood de uitgever daarom het werk aan het Nederlandse publiek aan. Het is, kortom, niet zo moeilijk om achter al die hooggestemde argumenten opportunistische motieven te raden: de uitgever dacht ongetwijfeld een 'spraakmakend' boek te hebben binnengehaald dat voor ophef zou zorgen en dus goed zou verkopen. En dat had ze goed gezien.

Wat uit dat reclamestuk niet zo duidelijk blijkt is dat Futuristische behandeling een voor Van Dieren ongewoon lange voorgeschiedenis heeft. De onmiddellijke aanleiding lijkt het zilveren ambtsjubileum van Gerbrandus Jelgersma, hoogleraar in de psychiatrie en neurologie te Leiden, te zijn geweest, op 20 september 1924 (dat als toevallige bijkomstigheid slechts drie maanden verwijderd was van het veertigjarig jubileum van Van Dieren). Jelgersma was een der laatsten uit de reeks broedervijanden tot wie Van Dieren zich zou keren. 
Afkomstig uit een predikantengezin kwam Jelgersma (I859-I942) net als Van Dieren via de hbs op de universiteit van Amsterdam terecht, en ook hij ging geneeskunde studeren en leerde er als student Gorter en Van Eeden kennen, en wie weet ook Van Dieren. Hij studeerde in I 885 af, minder dan een jaar na Van Dieren, begon zijn carrière in het krankzinnigengesticht Meerenberg als ontleedkundige, werd in I 894 geneesheer-directeur van de inrichting voor zenuwleiders te Arnhem en kwam in I 899 ten slotte als hoogleraar psychiatrie in Leiden terecht, waar hij de rest van zijn leven zou blijven. Nog als pas afgestudeerd ontleedkun-

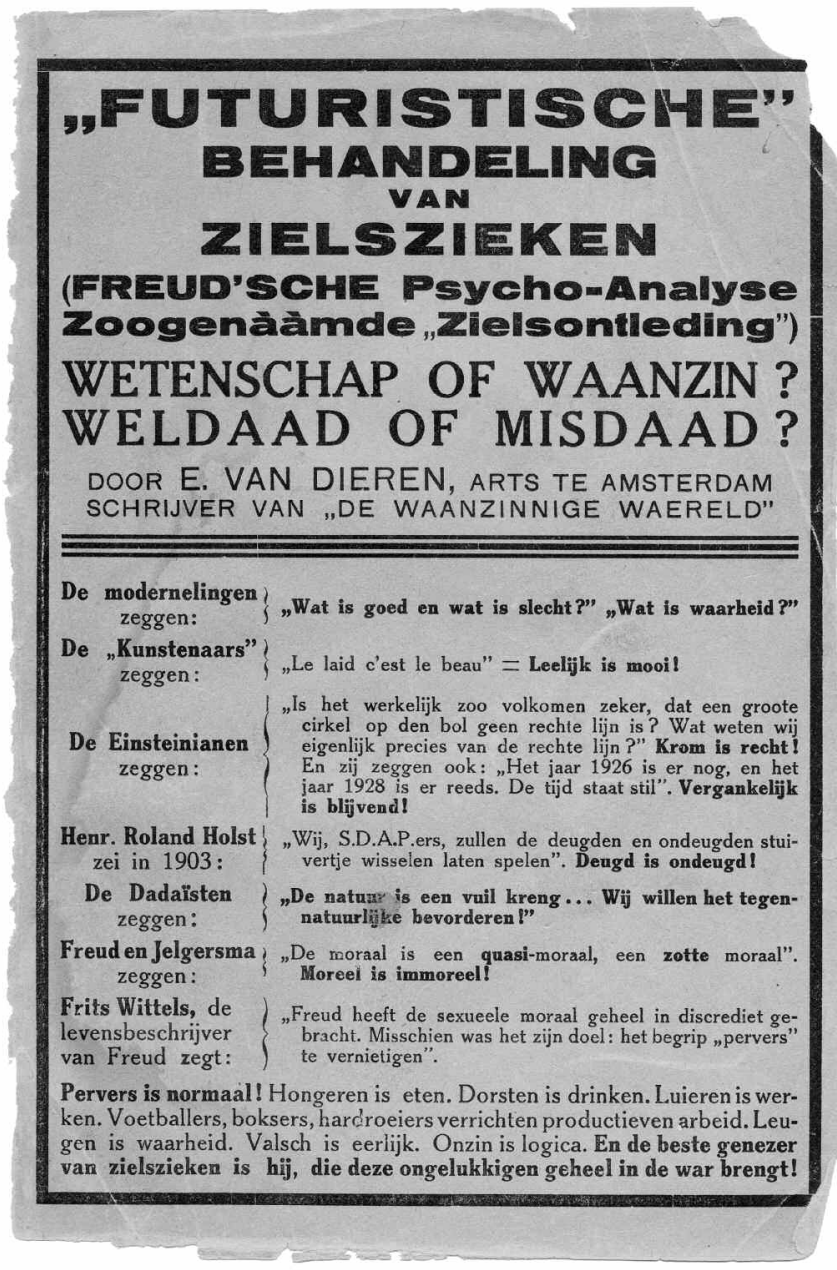

Een heilzaam tegengif tegen al die ophemelende artikelen en brochures waarin de loftrompet over Freud wordt gestoken. 
dige ontwikkelde Jelgersma zich als begaafd hersenonderzoeker, en het grootste deel van zijn werkzaam leven zou hij zich op dat terrein verder bekwamen en zich als een uitgesproken materialist doen kennen. Maar in I9I4 volgde dan de ommekeer in zijn denken waarmee hij ook buiten zijn vakgebied bekendheid verwierf, toen hij de psychoanalyse omarmde. Later zou hij vertellen hoe hij in navolging van de 'grote Winkler' anatoom was geworden, maar gaandeweg zijn vertrouwen in de anatomie was kwijtgeraakt en na lang zoeken Freud had gevonden - 'een openbaring'.

Anders dan Winkler omarmde hij de psychoanalyse dus veel minder voorwaardelijk. In de psychoanalytische methode was hij een zelfverklaard 'auto-didact'; Freud zelf had hij aanvankelijk niet willen ontmoeten: 'eerst zeker zijn van mijzelf', vond hij. Maar na grondige studie van psychoanalytische werken zette hij zijn laatste reserves overboord; zijn rectorale rede uit I9I4 vormde een wat hij later noemde 'aarzelende bekentenis tot Freud' die echter al zo veel bevestiging bevatte dat hij het aandurfde Freud uit te nodigen om in Leiden een 2 I 2 lezing te komen houden. Omgekeerd wekte zijn 'bekering' zo veel enthousiasme bij Freud dat hij de brief van Jelgersma aan verschillende volgelingen rondstuurde (de lezing zou niet doorgaan door het uitbreken van de Eerste Wereldoorlog). 'Onder de hoogleeraren in 't land ben ik de eenige die heel met hem [Freud] meegaat, enkelen zijn hem vriendelijk gezind; andere staan afwijzend', liet hij een verslaggever in I924 trots weten. ${ }^{42}$ Toen in 1920 de psychoanalyse haar zesde internationale congres in Den Haag organiseerde, zou hij Freud ook eindelijk persoonlijk ontmoeten.

Maar het lijkt erop dat het enthousiasme nadien wederzijds toch weer een beetje bekoelde. Een echte 'freudiaan' werd hij nooit; hij bleef 'autonoom', wat voor iemand die per slot slechts drie jaar jonger was dan Freud ook wel makkelijk is te begrijpen. ${ }^{43} \mathrm{Na}$ zijn emeritaat in I930 zegde hij de psychoanalyse helemaal vaarwel en keerde Jelgersma terug tot de hersenanatomie.

Toegegeven, van de finesses rond Jelgersma's relatief autonome toenadering tot de psychoanalyse kan Van Dieren wel nauwelijks op de hoogte zijn geweest. Hij kende Jelgersma, omdat die in de jaren twintig enige stukjes voor De Telegraaf had geschreven over de psychoanalyse. In een daarvan legde hij uit waarom de psychoanalyse op zo veel weerstand stuit: als patiënten aan hun huisarts vragen wat die nieuwe benadering eigenlijk inhoudt, dan heeft deze 'te kiezen tusschen tweeërlei: te zeggen dat hij er geen verstand van heeft of wel luk raak, luk mis een of ander oordeel uit te spreken', want tijd voor studie heeft de huisarts 
niet, en opgeleid in het vak is hij ook niet. Hier is dus een 'conflict van plichten aanwezig waardoor het begrijpelijk wordt, dat een onjuist oordeel tot stand komt', concludeerde Jelgersma. ${ }^{44}$

Als er ooit een combinatie van factoren is geweest die Van Dieren tot het 'heilige moeten' heeft aangezet, dan was het wel deze: de publieke diskwalificatie van de huisarts, omdat die iets niet zou weten. Dat kon Van Dieren moeilijk laten passeren, en toen Jelgersma in I924 een feestbundel kreeg aangeboden met bijdragen van vakgenoten die eveneens de psychoanalyse omarmden, en de jubilaris daarover ten slotte breeduit in de krant werd geïnterviewd, moet voor hem de maat vol zijn geweest. Wellicht in navolging van de grote Bolland die in I 899 Jelgersma al tot openbaar debat had uitgenodigd, trachtte ook hij de Leidse professor te verleiden tot een publieke discussie. ${ }^{45}$ Maar net als bij Bolland ging Jelgersma niet op de uitdaging in, maar liet hij in plaats daarvan in de krant weten een briefje te hebben ontvangen van iemand die de psychoanalyse met 'zwijnerij' op één lijn meende moeten te stellen. Met zo iemand wenste hij dus niet in debat te treden. ${ }^{46}$

Voor Bolland had Jelgersma tenminste nog een 'open brief' gereserveerd waarin hij de toen toch al echt niet meer zo jeugdige filosoof ten antwoord gaf: 'Neen jonge man, gij doorziet niets's7 - Van Dieren moest het doen met die ene anonieme terechtwijzing, maar ook dat was voor hem ruim voldoende. $\mathrm{Na}$ de weigering van Jelgersma met hem te discussiëren besloot Van Dieren een 'debat met een afwezige' te organiseren. Het 'openbaar debat zonder Jelgersma' - in feite natuurlijk een lezing - vond precies een jaar later plaats, op 24 september 1925 binnen het Amsterdams geneeskundig genootschap. De uitwerking van dat praatje tot een boek van bijna 300 pagina's duurde daarna nog een jaar, zodat het werkstuk pas in november 1926 gereed was en eerst begin 1927 verschijnen kon. De volledige titel luidt Futuristische behandeling van zielszieken. Freud' sche psycho-analyse, zoogenààmde "Zielsontleding". Wetenschap of waanzin? Weldaad of Misdaad? En hoewel er bij voortduring aan Jelgersma's opvattingen werd gerefereerd, waren het toch vooral Winklers 'zonderlinge paden der logica' die het moesten ontgelden. 'Daden groeien uit gedachten. Bij de meeste menschen de slechte veel eerder dan de goede', koos hij als motto, als om te benadrukken dat er tussen pro- en contrapositie altijd gekozen moet worden.

De schrijver had bij wijze van uitzondering nu eens geen recensieexemplaar aan het Nederlandsch Tijdschrift voor Geneeskunde toegestuurd, omdat hij er van overtuigd was dat de bespreking toch alleen maar negatief kon uitvallen. Maar de redactie bewandelde eveneens bij 
wijze van uitzondering de omgekeerde weg en schafte het werk zelf aan en vroeg psychoanalyticus Westerman Holstijn om Futuristische behandeling van zielsziekten voor het blad te bespreken.

A.J. Westerman Holstijn (I89I-I980) was een jonge ambitieuze arts die zich vroeg in zijn carrière op de psychoanalyse had toegelegd, assistent was geweest bij Jelgersma, daarna bij Van Renterghem en Van der Chijs, en, hoewel nog niet gepromoveerd (hij zou in I929 promoveren), al wel een behoorlijke publicatielijst op zijn naam had staan. Het hoeft niet te verbazen dat de recensent weinig vleiende woorden voor het boek over had. 'De schrijver meent in dit werk "er in geslaagd te zijn de ziel van Freud zoo haarfijn te ontleden als het tot dusver nog nimmer gelukt is bij wien dan ook". Resultaat is o.a. dat Freud is: de pornograaf der pornografen; een bevorderaar van de ontucht in haar afgrijselijkste vormen en een schandvlek voor de medische stand', opende de bespreking. Was dat eigenlijk al voldoende om te laten zien dat de schrijver zichzelf als criticus had gediskwalificeerd, aldus Westerman Holstijn, wie nu nog twijfelde moest zich maar eens op de 2 I 4 hoogte stellen van de onzorgvuldigheid waarmee Van Dieren uit het werk van Freud geciteerde. ${ }^{48}$ Waarna enkele voorbeelden volgden van dat onzorgvuldig citeren.

Met dat inmiddels al te bekende verwijt toog Van Dieren aan het werk, doch een tegenbespreking werd hem door het $N T \nu G$ geweigerd. Maar ditmaal was het lot hem gunstig gezind, een ingezonden brief in mei van dat jaar in de $N R C$ verschafte hem een nieuwe gelegenheid om in de openbaarheid te treden. De brief opende met de opmerking dat de schrijver het boek van Van Dieren, dat hem door de uitgever was toegestuurd, gaarne schaterend van het lachten terzijde had geschoven als de auteur niet de nagedachtenis van een inmiddels overleden collega (Van der Chijs) erin had bezoedeld: een fijne, nobele figuur die in het aangezicht des doods onverschrokken voortging zich te geven aan zijn patiënten. ${ }^{49}$ De briefschrijver was de psychiater Henri van der Hoeven die Van Dierens werk in een woord als 'zwijnerij' afdeed en zich zodoende mogelijk onbedoeld met zijn opponent op één lijn stelde, daar Van Dieren immers precies dezelfde kwalificatie voor Freud in gedachten had.

Ondersteuning voor Van Dieren volgde echter even later ook. Een anonieme recensent schreef in Het Vaderland dat de psychoanalyse zoals die in populaire vorm bekend is geworden, zeker niet krachtig genoeg bestreden kon worden, al vroeg de schrijver zich wel af of Van Dieren de aangewezen persoon was om dat te doen. ${ }^{50}$ Daarop verscheen bijval van E.A. Keuchenius, zenuwarts en schoolopzichter te 


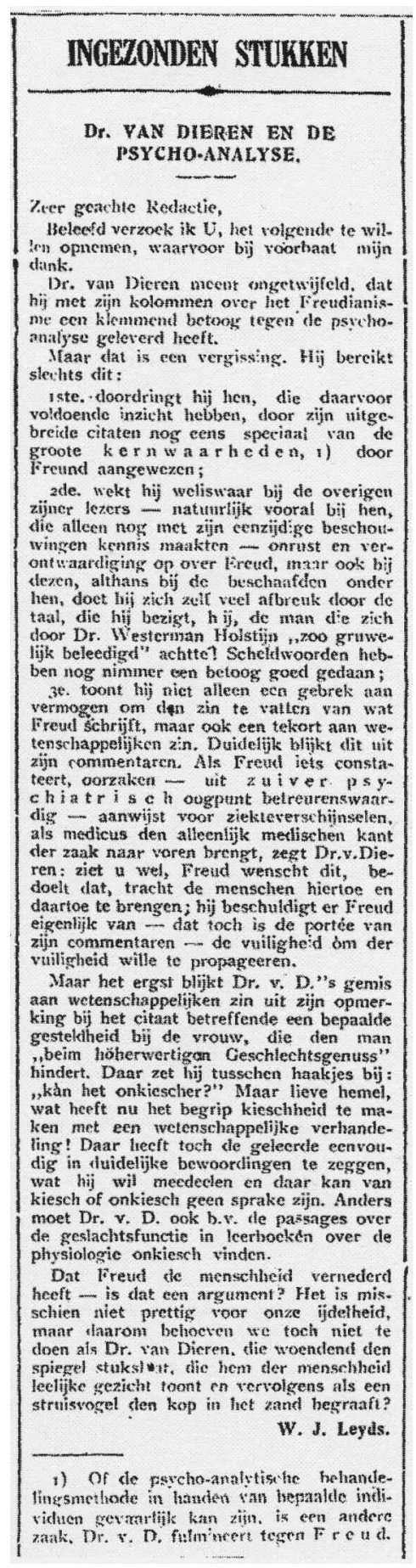

Den Haag, die zich naar aanleiding van het stukje van Van der Hoeven in de NRC graag aansloot bij de bestrijders der psychoanalytici vanwege een gelijkgestemde overtuiging (een paar jaar eerder was van zijn hand De beteekenis van het Christelijke geloof voor het zenuwleven verschenen). Aan de hand van een gevalsbeschrijving van een patiënte van hem liet hij zien tot welke verderfelijke praktijken de psychoanalyse zoal in staat was: ze hadden haar nota bene aangepraat dat ze homoseksueel was, terwijl bij haar 'daar zelfs de schijn niet bij bestond'. Het artikel besloot met de suggestie dat een commissie van wetenschappelijke onderzoekers de psychoanalytische methode maar eens diende te onderzoeken op haar schadelijke gevolgen. In die commissie zou iemand als Jelgersma wel zitting kunnen hebben, vond Keuchenius. ${ }^{51}$

Reacties bleven niet uit. Hendrik Giltay, zelf geen analyticus (maar repetitor), maar wel verklaard voorstander van de psychoanalyse, vond één enkele negatieve ervaring wel wat weinig bewijs om de psychoanalyse in zijn geheel af te wijzen. Ook de suggestie dat Jelgersma in de voorgestelde commissie zitting moest hebben vond hij geen goed idee: laat de psychoanalysten-doder-bij-uitne-

Een lezer van Het Vaderland windt zich op over de anti-freudiaanse artikelen van Van Dieren. 
mendheid, dr. Van Dieren maar zijn plaats innemen, stelde hij sarcastisch voor. ${ }^{52}$ Vervolgens mengde zich ook een echt 'zwaargewicht' in de strijd: Johan van Ophuijsen (I882-I950), voorzitter van de Nederlandse psychoanalytische vereniging. Van Ophuijsen behoorde tot de intimi rond Freud en was geen onbekende van Van Dieren - ze hadden de degens al eens gekruist bij de vertoning van de film De macht van het onbewuste, zoals we hebben gezien. Hij sloot zich aan bij het eerste kritiekpunt van Giltay en beschuldigde Van Dieren nog eens van citaatverminking. ${ }^{53}$

Met al die aandacht kon Van Dieren niet anders dan tevreden zijn geweest. Het dwong bovendien flink wat ruimte af bij de krant. Zijn bijdrage aan het debat verscheen anderhalve week later in drie delen, op 27, 28 en 29 juni 1927. Van Dieren bediende iedereen, vriend en vijand, en ging vanzelfsprekend uitvoerig in op de beschuldiging van citaatverminking. Hij eindigde zijn artikelenreeks met een uithaal naar Winkler, omdat die, zo schreef Van Dieren, het gunstig oordeel over zijn boek blijkbaar alleen voor hèm had bedoeld. Wel nu, verklaarde Van Dieren: hij had er geen ogenblik over gedacht het voor zichzelf te houden. ${ }^{54}$

\section{Schaadt het dan baat het niet}

Lang bleef het niet stil na Van Dierens artikelenreeks. Al de volgende dag verscheen een ingezonden brief van een lezer die vond dat Van Dieren precies het omgekeerde had bereikt van wat hij voorstond: na lezing van zijn driedelig stuk zou eenieder eerder van de 'kernwaarheden' van Freud zijn doordrongen dan van diens ongelijk..$^{55}$ Twee dagen later kwam Giltay in een ingezonden stuk tot het inzicht dat een polemiek met Van Dieren even onvruchtbaar is als een debat met de man die meent de Noordewind te zijn. Met dien verstande dat Van Dieren wel, de Noordewind geen aanhang onder het lekenpubliek verwerft. $\mathrm{Na}$ het gescheld van een gestudeerde dokter op Freuds pornografische, zedenbedervende beschouwingen zal het publiek uitroepen: 'Ja! Ja! Je hebt gelijk. Leve dr. Van Dieren! Weg met Freud!', zo vreesde hij. ${ }^{56}$

Twee ingezonden brieven namen het daarna weer voor Van Dieren op, waarna na twee dagen weer een bijdrage van Van Ophuijsen verscheen. Ook Van Ophuijsen leek, net als Giltay, wel spijt van zijn eerdere bijdrage te hebben. Hij schreef op 7 juli: 'Misschien had ik beter gedaan den raad mijner vrienden en het voorbeeld mijner leermeester Freuds te volgen door niet mijn meening over de reeks van artikelen door Van Dieren onlangs in dit blad gepubliceerd, openlijk uit te spreken.' Zijn stuk spitste zich vooral toe op de vraag wat Freud had 
bedoeld en of Van Dieren die bedoeling juist had weergegeven, en mondde uit in de conclusie dat zijn opponent wel bitter weinig van de theorie van Freud moet hebben begrepen.

Ook dr. Keuchenius, met wiens bijval aan het adres van Van Dieren de hele polemiek per slot was begonnen, of althans een serieus gezicht had gekregen, stuurde nog een stuk in dat op I 3 en I4 juli 1927 verscheen en een grondige kritiek van de psychoanalytische methode bevatte. Keuchenius schaarde zich nu onomwonden achter collega Van Dieren die hij een 'eresaluut' deed toekomen. In de psychoanalyse wordt de eed van Hippocrates geschonden, het principe van 'non nocere' (niet schaden), meende Keuchenius, 'het bij uitnemendheid onmisbare grondbeginsel van elke medische behandeling wordt totaal losgelaten en belachelijk gemaakt'. Maar zijn kritiek bestond uit meer dan morele verontwaardiging alleen en ging ook dieper in op de vraag of het door Freud geclaimde succes logisch gesproken aan de psychoanalytische methode mag worden toegeschreven. Neen, concludeerde hij: uit hetgeen kan zijn mag niet worden afgeleid dat het ook zo is. ${ }^{57}$ Ook dit bezwaar is later in vele toonaarden herhaald, vaak onder aanhaling van de Latijnse naam voor deze specifieke drogreden: post hoc ergo propter hoc, dat wil zeggen uit het feit dat de ene gebeurtenis volgt op de ander kan niet worden afgeleid dat het een het ander veroorzaakt. Specifieker: als een patiënt na een analyse genezen is van zijn kwaal hoeft dat succes niet noodzakelijk aan de analyse te worden toegeschreven. De enige manier om het oorzakelijke verband te achterhalen is, ironisch genoeg, door middel van de door Van Dieren afgewezen methode: experimenteel onderzoek.

$\mathrm{Na}$ de exercitie van Keuchenius werd Van Dieren andermaal in de gelegenheid gesteld het laatste woord te spreken, minder uitgebreid weliswaar als eerst, maar met die beperking ging de schrijver dan morrend akkoord. In een toch nog behoorlijk omvangrijk stuk somde Van Dieren al zijn argumenten en bezwaren nog eens op en liet tussen neus en lippen door weten verbazend veel persoonlijke details te kennen aangaande zijn opponenten. Over Van Ophuijsen wist hij bijvoorbeeld te melden dat deze van boksen hield, wat hij een 'sadistische sport' vond, een psychiater onwaardig, maar voor een volgeling van Freud natuurlijk heel begrijpelijk. ${ }^{58}$ Hoe wist Van Dieren dat Van Ophuijsen van sport hield? Heel eenvoudig: de voorzitter van de Nederlandse psychoanalytische vereniging was ook voorzitter van de Haagsche boksbond en trad op als scheidsrechter, en zag zijn naam daarom onder de afdeling 'sportberichten' geregeld in de krant vermeld. Van Dieren, die immers van al zijn tegenstanders een dossiertje bijhield, moet zulke 
berichtjes hebben uitgeknipt in de zekerheid dat hij ze later nog wel eens zou kunnen gebruiken.

De redactie wilde daarna maar wat graag de discussie besluiten, maar kon het toch niet laten nog een enkele passage uit een brief te citeren van een moeder die zich 'dankbaar' betoonde voor enkele opmerkingen van een ongenoemde psychoanalyticus waar zij haar 'voordeel' mee had kunnen doen.

Misschien was die laatste toevoeging bedoeld als tegenwicht voor een eerder gedane redactionele opmerking bij een ander stuk van Van Dieren waarin werd gesteld dat de schrijver in de betreffende citaten de bedoelingen van Freud naar de mening van de redactie toch wel juist had weergeven. Hoe het ook zij, het hele dispuut beloofde de redactie aan een bekend psychiater te geven die bij wijze van slot zijn oordeel over Freud en de psychoanalyse sine ira et studio (zonder wrok of sympathie) zou geven.

Inderdaad verscheen op 23 juli 1927 een artikel van de hand van de Haagse zenuwarts F.J. Soesman, 'Freud en de psychoanalyse'. Soesman was echter niet geheel de onpartijdige rechter die de redactie had beloofd, hij had eerder een toneelstuk geschreven waarin de draak werd gestoken met de psychoanalyse. ${ }^{59} \mathrm{Zijn}$ stuk begon niettemin neutraal genoeg met een kort overzicht van de geschiedenis van de psychoanalyse waarin de grondlegger ervan als 'een van de grootse neurologen van deze tijd' werd geroemd, maar vervolgde met een bespreking van de psychoanalytische methode die volgens de auteur heel wat minder geslaagd was: soms is al dat gepeur in het onderbewust helemaal niet zo gezond en is het beter dingen niet te weten, meende Soesman. Zijn conclusie was nog ontnuchterender: 'Het Freudisme is onderdeel van de algemene zucht tot analyse en bewustworden, die door de wereld waart en staat als zodanig gelijk met vele andere systemen, waarbij de moderne mensheid haar troost zoekt en het zal op den duur blijken $[\ldots]$ een eendagsvlieg te zijn geweest. ${ }^{60}$

Hoewel die geruststellende oproep om terug te keren tot de orde van de dag Van Dieren uit het hart moet zijn gegrepen, viel zijn naam in het hele stuk niet één keer. En daarmee eindigde ook deze discussie, die eveneens geheel op beriberileest was geschoeid, dan toch nog een beetje onbevredigend voor Neerlands grootste anti-Freudiaan.

\section{U bent nog niet van me af!}

$\mathrm{Nu}$ Het Vaderland zijn kolommen voor hem had gesloten moest Van Dieren zijn heil andermaal elders zoeken, en ook nu weer vond hij de 
Vox Medicorum ('werkelijk een vrije tribune') bereid zijn eindeloze strijd daar voort te zetten. ${ }^{61}$ In een reeks artikelen die hij in de winter van I927-I928 publiceerde zette hij de hele geschiedenis nog weer eens op een rijtje en polemiseerde hij er naar hartelust op los. Daarop zou warempel nog een keer antwoord volgen. Nadat Van Dieren had geciteerd uit zijn correspondentie met Westerman Holstijn over wat Freud zijn vrouwelijke patiënten 'aangeraden' zou hebben, richtte de geciteerde briefschrijver in december 1927 het verzoek aan de redactie dan maar de hele brief te publiceren. Uit de gemanipuleerde fragmenten ontstond namelijk een verkeerde indruk, vond Westerman Holstijn. De bedoelingen die Van Dieren hem, en alle 'ernstige psychoanalytici', aanwreef waren niets minder dan 'belasterend' doordat hij hen het 'Ioo-procentige tegendeel van onze werkelijke meening' toedichtte. Freud had zijn patiënten helemaal niets aangeraden, zeker niet, zoals Van Dieren dacht, het uitoefenen van de vrije liefde voor het huwelijk: 'Ik ben er zeker van dat vrije cohabitatie van jonge meisjes door Freud en alle psycho-analytici zedelijk veroordeeld wordt.'

Een komisch misverstand over die laatste zin rees op toen Van Dieren dacht dat zijn opponent 'redelijk veroordeeld' had geschreven, wat hij slap vond, maar door Westerman Holstijn gecorrigeerd werd: er staat toch echt 'zedelijk veroordeeld', wat natuurlijk wel degelijk een moreel oordeel inhoudt.

In het licht van de biografische informatie die inmiddels over Freud bekend is, zullen huidige lezers geneigd zijn Westerman Holstijn gelijk te geven. De persoonlijke ethiek van Freud was eerder die van een conservatieve negentiende-eeuwse petit bourgeois dan die van een twintigste-eeuwse geëmancipeerde vrijdenker. Maar dat neemt niet weg dat sommigen van zijn minder behoudende volgelingen wel degelijk de conclusie trokken dat de psychoanalyse een vrijbrief inhield voor 'onorthodoxe praktijken' op het gebied van seksualiteit en moraal, en dat echo's van die stemmen doorklonken in het publieke domein. De kritiek van Van Dieren laat zich daarom misschien vooral lezen als een uiting van morele paniek over die afgeleide vormen van psychoanalyse dan over wat Freud zelf zei, al deed Van Dieren alle moeite om die twee als een en dezelfde praktijk voor te stellen.

In zijn (nu door de redactie van Vox Medicorum in zijn geheel) gepubliceerde brief aan Van Dieren slaagde Westerman Holstijn erin een neutrale, om niet te zeggen geduldige toon te bewaren. Pas aan het slot liet hij de beleefdheid varen: 'Ten slotte moet ik u zeggen de onzakelijk beleedigende wijze waarop $\mathrm{u}$ in uw boek spreekt over menschen die ik hoog acht, mij een reden is u te verzoeken verder geen contact 
meer met mij te zoeken, daar ik u verder niet antwoorden zal. ${ }^{92}$ Het aloude refrein op het inmiddels bekende liedje.

Natuurlijk kon Van Dieren het niet laten nog een brief terug te schrijven. 'Ik heb u niet gevraagd waar $U$ zeker van mèǹt te zijn, ik wil weten - want daar is het om begonnen! - wat over dit onderwerp op blz. I9I van [Freuds] 'Sammlung' te lezen staat. Als uw zoon u vraagt om brood en visch, dan moogt gij hem geen steenen en slangen voorzetten! [...] Ik vraag het u nu voor de laatste maal! Als u mij niet antwoordt, bent u nog niet van mij af! Als ik A heb gezegd ga ik zoo nodig door tot $\mathrm{Z}$ toe. ${ }^{63}$

De vergelijking met stenen en slangen is rechtstreeks aan het Nieuwe Testament ontleend, maar het mocht hem niet baten: aan de zich met de Messias identificerende Van Dieren stuurde Westerman Holstijn geen antwoord meer. Wel is er nog een brief bekend van Westerman Holstijn aan de redactie van Het Vaderland, die immers openlijk haar twijfel had uitgesproken over de beschuldiging uit het psychoanalytische kamp dat Van Dieren Freuds bedoelingen verkeerd had weergegeven. De brief werd niet geplaatst daar de redactie de discussie inmiddels had gesloten, maar een kladje van het ingezonden stuk bevindt zich in het Westerman Holstijn-dossier in het Rijksarchief te Utrecht, en geeft ons inzicht in de worstelingen van de tegenstanders van Van Dieren om uit die beklemmende greep van verkeerd citeren en insinueren te komen. Het ontwerp is een lang, aarzelend stuk van meer dan I 200 woorden, vol doorhalingen, verbeteringen, herformuleringen en citaten uit Freud en doet in toon in de verte aan Eijkmans brief aan Pijnappel van december I 898 denken. Het duurt lang voordat de schrijver to the point komt, en dan nog bekent hij dat hij 'eigenlijk het heele artikel van Freud [zou] moeten overschrijven wilde ik aantoonen dat Van Dierens conclusie niet alleen in strijd is met het juiste citaat, maar ook met de geest van het heele artikel'. Kortom, net als Eijkman dreigt ook Westerman Holstijn het af te leggen tegen de citatiemachine Van Dieren.

\section{Van Dieren contra Freud (2)}

Vijf jaar na Futuristische behandeling van zielszieken verscheen het tweede anti-Freud-boek: Prof. Freud en het perverse gevaar (1932). Het is een boek waarover ik eerder opmerkte dat het in eigenlijke zin niet bestaat: het gaat in zijn geheel over hoe het tot stand is gekomen. De geschiedenis van dit boek voert terug tot een krantenartikel van de psycholoog P.A. Dietz, die in 1930 in Het Vaderland had geschreven 
dat de excessieve aandacht voor het abnormale bij de psychoanalyse 'scheve voorstellingen bij de buitenstaander' heeft gewekt en aanleiding gaf tot veel 'ongerechtvaardigde oppositie', waarna een voetnoot volgde: 'Ik wijs bijv. op het boek van E. v. Dieren, "Futuristische behandeling van zielszieken," dat indertijd heel wat opgang maakte. ${ }^{64}$

Dat was een uitdaging die Van Dieren moeilijk kon weerstaan. Een korte brochure over Freud en de bolsjewieken was het eerste gevolg, maar het bleek een valse start. In april I93 I zette hij opnieuw in, ditmaal naar aanleiding van een stuk van Querido, die in het $N T v G$ had geschreven dat het werk van Freud 'ver boven dat van zijn tijdgenoten uitstak'. $\mathrm{Nu}$ vloeide een werk uit zijn pen dat met geen pen valt te beschrijven.

In Prof. Freud overheerst de opgewonden toonzetting en de op de lachspieren werkende manier van citeren en becommentariëren, waarin cursiveringen en uitroeptekens met elkaar wedijveren om de aandacht van de lezer, als nooit tevoren. 't Kwaje kreng' had weer toegeslagen voor 't laatst, zou blijken. ${ }^{65}$ De letterkundige C.P. van Rossem schreef naar aanleiding van het tweede Freud-boek een lange column over Van Dieren in de Haagsche Post waarin op voorspelbare zij het ook geestige wijze de draak werd gestoken met de ongestructureerde polemische inhoud: 'Twee woorden over Freud - druk op den knop! Hier is Dr. van Dieren! Hoort geachte lezers, socialisten, dat is eenvoudig tuig, bezemt ze weg! Pardon ik moet weer terug naar den 'viezerik' van een Freud. Maar luistert eens, Naaktlopers en Wederdoopers, dat is precies hetzelfde. En graaf Keyserling trekt horoscopen.' Enzovoorts.

Van Rossem noemde Van Dieren in de Haagsche Post een 'knallende voetzoeker in onze wetenschappelijke wereld', een man van onbeheerste hartstocht, 'de grote uitsmijter van de bedorven maatschappij en de eeuwige uitgesmetene.' Toch wist hij ook sympathie voor de schrijver op te brengen: de door zijn patiënten aanbeden arts heet 'een pracht exemplaar van het menschensoort', die bijna altijd raak slaat in zijn verontwaardigingen, in zijn aanvallen 'volmaakt gerechtvaardigd' is en daarbij waarheden verkoopt die de moeite waard zijn van het aanhoren. Jammer genoeg verknoeit Van Dieren alles, schreef van Rossem, omdat hij zijn onderwerp maar van één kant kan bekijken, schrijft als een wildeman en hopeloos overdrijft: hij is een man die zijn eigen talent dooddrukt. ${ }^{66}$ Voor het NTvG schreef Valkenburg in dezelfde trant: 'Moge [de auteur] voldoening beleven aan deze andermaal door hem uitgegeven exclamaties van een overkropt gemoed, die - wat men er ook over moge zeggen - het teken dragen van een soort heilige toorn. ${ }^{67}$ 
Ook Menno ter Braak (I902-I940) schonk in een dubbelrecensie voor Forum aandacht aan de Don Quichotte-achtige moralistische uitvallen van Van Dieren, waarvoor hij niet alleen evenals Van Rossem en Valkenburg verbazend veel waardering wist op te brengen, maar die hij, anders dan welke recensent ook, tegelijk merkwaardig serieus nam. Ter Braak, die net als Van Dieren in Amsterdam was gaan studeren om zich aan zijn provinciale afkomst (Eibergen in de Achterhoek) te ontworstelen en, anders dan de schrijver-arts uit Zutphen, tot de intellectuele voorhoede zou gaan behoren, hoewel hij er zich desondanks toch nooit helemaal thuis zou voelen, schreef in die jaren met enige regelmaat besprekingen van psychoanalytische werken waarin hij zich kritisch over Freud uitliet, vooral over diens nogal onkritische volgelingen. Vergeleken bij de freudiaanse epigonen die de meester tot vervelens toe herkauwen vond hij Van Dieren een 'uitermate sympathieke figuur' wiens 'ontwapenende duel-manie' uit een ontroerende overtuigdheid voortkwam. Niet dat zijn burgermans argumenten ook maar iemand zouden overtuigen - nu ja, alleen Sancho Panza - maar, zo 222 vroeg Ter Braak, is niet ieder mens in het diepst van zijn wezen een moralist, daar hij nu eenmaal volgens gecanoniseerde regels leeft en aan die regels een min of meer zwaarwichtig belang hecht?

De kritiek van Van Dieren op de psychoanalyse wordt dus als een ironisch commentaar op de burgermansmoraal opgevat, waarvan Van Dieren overigens zelf een belangrijke exponent was. In die natuurlijk ook ironische beschouwing, waarin de thematiek van het Carnaval der burgers nog duidelijk herkenbaar is, komt Van Dieren er zijns ondanks dus opvallend sympathiek af, maar men moet daarbij bedenken dat Ter Braak, zoals uit de biografie van Léon Hanssen blijkt, zelf ook niet ongevoelig was voor de buitenstaanders dynamiek: veroordeeld om er eeuwig net niet bij te horen, keert iedere kritiek zich rechtstreeks tegen degene die haar uit. Ook voor Ter Braak was de polemiek vooral een manier om zijn leven gestalte te geven. ${ }^{68}$

De analyses van Ter Braak, Valkenburg en Van Rossem moeten Van Dieren al te bekend in de oren hebben geklonken: 'don quichottesk', 'eerlijke woede', 'manische strijdbaarheid', het was allemaal al eens eerder gezegd, zij het dat het misschien nooit eerder zo duidelijk met elkaar in verband gebracht, en niet eerder in de context geplaatst van de wanhopige burger die niet begrijpt wat hem overkomt en daarom tegen beter weten in aan zijn regels vast blijft houden als een dief aan de nacht bij het ochtendgloren.

Met die half als compliment, half als karikatuur en half als serieuze analyse geschreven beschouwingen dreigde de hele geschiedenis zich 
weer te herhalen. In de dagbladen werd het boek opnieuw druk besproken, maar de discussie was inderdaad een herhaling van zetten, en ik laat bespreking ervan om die redenen verder achterwege, met uitzondering van één debat: de laatste mij bekende polemiek van Van Dieren, waarin nog één keer heel het spectrum van misverstand, onbegrip en stemmingmakerij voorbijkomt. ${ }^{69}$

Het was een nog jonge Arie Querido (I90I-I983), net als Winkler geen onvoorwaardelijke voorstander van de psychoanalyse, die in 1932 besloot een duit in het zakje te doen en in een radio-uitzending Freud tegen de kritiek in bescherming te nemen. Zelf was Querido overigens ook door Van Dieren aangevallen, omdat hij zich op een Winkler-achtige manier zowel lovend als tegelijk kritisch had uitgelaten over Freud. Toch ging het grootste deel van zijn radiovoordracht niet daarover, maar over de verdiensten van Freud, en kwam Querido pas een het slot toe aan een bespreking van Van Dieren. Zijn conclusie was dat Van Dieren zijn boek in haat had geschreven. 'Haat deed hem naar citaten delven, naar dingen die er niet instaan; haat deed hem met lachwekkende beschuldigingen om zich werpen; haat deed hem schimpen en schelden. Dit is niet een haat tegen Freud of tegen de psychoanalyse. Het is een haat tegen het nieuw, tegen al het nieuwe. [...] Het is de personificatie van het behoud dat tracht af te breken wat het niet begrijpen kan. ${ }^{70}$

Niet eens die analyse van zijn motieven, maar opnieuw het verwijt van citaatverminking, greep Van Dieren aan: op hoge poten verlangde hij van Querido die beschuldiging hard te maken. In eerste instantie reageerde Querido afwijzend. 'Er schijnt een misverstand te hebben plaatsgevonden', schreef hij koeltjes aan Van Dieren, 'Het was allerminst mijn bedoeling met $u$ te gaan debatteren over uw boeken, en ook niet met $\mathrm{u}$ van gedachten te wisselen over mijn radiovoordracht. Ik ben er te zeer van overtuigd, dat dit verspilde energie zou zijn. ${ }^{71}$ De cursivering is van Querido.

Maar daarmee kon Van Dieren natuurlijk geen genoegen nemen, en hij eiste per ommegaande post genoegdoening: 'Deze beschuldiging [van citaatverminking] hebt gij echter met geen enkel voorbeeld toegelicht! En nu ik van u geëischt heb (meo jure!) dat alsnog te willen probeeren, nu meent gij u - zoo onridderlijk mogelijk! - van deze verplichting te kunnen àfmaken door te gewagen van een "misverstand" en er bij te voegen, dat gij allerminst de bedoeling hebt gehad met mij (het woordje "u" was door u zelf flink onderstreept!) te debatteren over mijn boek, en met mij van gedachten te wisselen over uw Radio-voordracht, aangezien gij er al te zeer van overtuigd zijt, dat gij daarmee uw 
energie... zoudt verspillen! Gij maakt het u dus wederom al te gemakkelijk!'72

Querido gaf toen daadwerkelijk verschillende voorbeelden van door Van Dieren gemanipuleerde citaten uit Freud waarop hij dan zelf weer een paar soms hele subtiele commentaren liet volgen. Een fraai voorbeeld ter illustratie; het heeft betrekking op een door Van Dieren aangehaalde en becommentarieerde uitspraak van Freud die ik onvertaald heb gelaten: "Wer als Mann sein Sexualobjekt energetisch erobert, dem trauen wir ähnliche rücksichtlosen Energie auch in der Verfolgung andere Ziele zu." Daaruit concludeerde Van Dieren: 'De "bruten” zouden dus de aangewezen en uitverkoren wereldverbeteraars zijn! ${ }^{73}$ Hieraan voegde Querido als enig commentaar het slechts vijf woorden tellende, maar daarom des te dodelijker zinnetje tussen haakjes aan toe: 'Dat "dus" is heel goed'. ${ }^{74}$

$\mathrm{Na}$ nog zes van dergelijke voorbeelden wat meer uitvoerig te hebben besproken en becommentarieerd onderbrak Querido zijn dupliek met de woorden: 'Nee, ik houd op. Ik heb geen lust mij verder nog met deze onzin bezig te houden. Ik heb eerlijk getracht Van Dieren au serieux te nemen, maar heus, het gaat niet.' Machteloos liet Van Dieren daarop zijn antwoord volgen dat hij had getiteld: 'Wie kan niet lezen? Wie kan niet denken? Wie interpreteert onjuist? Wie is er verblind? Wie knijpt zijn oogen potdicht voor de Freudiaansche zwijnerij?' Op die aanklacht volgde het stilzwijgen van Querido, die al had afgesloten met de uitroep dat Van Dieren 'wat mij betreft een heele bibliotheek [mag] volschrijven en mij twaalf maal [mag] aanklagen, van mij krijgt hij geen antwoord meer'. ${ }^{75}$

Aanklagen deed Van Dieren natuurlijk wel, zij het niet voor de rechtbank. In een lange reeks van artikelen voor de Vox Medicorum (waarin hij als redactielid zelf zitting had) schreef hij zijn gevoelens van verongelijktheid van zich af. Bovendien liet hij de hele Freud-Queridoaffaire bundelen in een voor eigen rekening gedrukte brochure die verscheen onder de niets verhullende titel 'Verbreiding van Freudiaansche Wetenschap (?) door den Radio-Omroep! Antwoord op de VaraVoordracht van den zenuw-dokter A. Querido (Psychiater bij den gemeentelijken Gezondheidsdienst te Amsterdam) over: "Dokter van Dieren en Professor Freud".' Hierin nam hij zijn hele correspondentie met Querido op, diens radiovoordracht, zijn antwoord daarop, en alle verdere antwoorden van hemzelf op Querido. Het zou zijn laatste brochure worden.

Er stond hem ditmaal echter een teleurstelling te wachten: verspreiding van het boekje werd hem onmogelijk gemaakt doordat de vereni- 
ging tot behartiging van de belangen des boekhandels een handelsverbod afdwong, daar Van Dieren geen bevoegde drukker was. Dat, na veertig jaar lang in eigen beheer uitgegeven brochures te hebben geschreven, moet een bittere pil zijn geweest. ${ }^{76}$

\section{Het verschil}

Kijken we terug op de Van Dierense Freud-oorlogen, dan kunnen we concluderen dat de door hem aangestichte polemieken in Het Vaderland tot de omvangrijkste en misschien ook wel belangrijkste publieke discussies over de psychoanalyse behoorden uit die tijd. Vooraanstaande wetenschappers, analytici en opiniemakers participeerden erin, en, wat belangrijker is, de discussies raakten, misschien nog wel meer dan de beriberidebatten, de kern van de zaak.

Zo men aan het werk van Van Dieren betekenis wil toekennen, dan is het misschien vooral dat het als een bliksemafleider in het publieke domein heeft gefungeerd waarop zich de verschillende emoties richtten en via wie ontlading werd gezocht. Door Van Dieren werd dat echter, zoals steeds, aangezien voor het uitoefenen van invloed: alsof hij de bliksem zelf ook had opgeroepen.

\section{De wereld volgens Van Dieren}

In het geschreven debat was Van Dieren altijd op zijn best. Daarin voelde hij zich thuis als een moer op een bout. Hij had een heilig ontzag voor het gedrukte woord. Het gesproken woord verafschuwde hij, de essentie ontglipte hem gewoonweg. Zelden of nooit was hij in staat om in het gesprek de snedige antwoorden en rappe replieken te geven die hij in zijn werkkamer had uitgedacht; liever vermeed hij discussie helemaal. 'De heer van Dieren weigert mondeling debat', werd er eens opgetekend na afloop van een voordracht. 'Hij wil zijn goede zaak niet blootstellen aan de kans dat hij niet direct op alle vragen en aanmerkingen het gepaste antwoord zou kunnen geven. ${ }^{77} \mathrm{Bij}$ een andere gelegenheid gaf hij zelf toe dat hij na een twee uur durende voordracht zich zo afgemat voelde dat hij op de eerste de beste vraag geen antwoord wist te geven.

Als het toch tot een mondelinge bespreking van zijn kritieken moest komen wapende hij zich vooraf door 'citatenboekjes' te laten drukken en uit te delen waarop hij zich tijdens het debat terugtrok en waarmee hij de oppositie bij voorbaat de mond hoopte te snoeren. Die had, aan de andere kant, lang niet altijd behoefte aan discussie. In I927, om een 
laatste polemiek kort onder de aanacht te brengen, hield hij in Den Bosch een voordracht getiteld 'Domheden, dwaasheden en dwalingen op allerlei gebied, voorheen en thans', waarover in kranten werd bericht als 'een pijnlijk incident'. In de voordracht had Van Dieren collega's Bolk, Lotsky en Hubrecht op de korrel genomen vanwege hun darwinistische en nietzscheaanse sympathieën. $\mathrm{Na}$ afloop werd hij niet zoals te doen gebruikelijk door de voorzitter bedankt en werd er ook geen gelegenheid tot het stellen van vragen gegeven. In plaats daarvan werd onmiddellijk de volgende spreker aangekondigd, die zich bovendien in zijn inleiding beklaagde over het gebrek aan respect bij zijn voorganger. Woedend was Van Dieren toen de zaal uitgebeend 'om goed te doen gevoelen dat hij zijn tijd wel beter kon gebruiken'. $\mathrm{Na}$ afloop schreef hij een open brief aan het bestuur, waarin hij verklaarde zich in de vereniging niet meer op zijn plaats te voelen 'als er zoo weinig waardeering blijkt te bestaan voor mijne opvatting'. ${ }^{78}$

Zo verliepen discussies met Van Dieren steeds. 'U hebt u deze keer net zoo vergaloppeerd als in 1889 , maar u kunt nog terug. Do it now', 226 beet Van Dieren een tegenstander eens toe. ${ }^{79}$ Getergd antwoordde deze: 'Uw oogen zijn zoo astigmatisch dat gij alles om u heen in onjuiste verhouding ziet. Gij verbeeldt $\mathrm{u}$ dat ik mij destijds voor veertig jaren vergaloppeerd heb. Pure verbeelding. ${ }^{80}$

\section{Zwijgend spreken}

Taal is van iedereen, en dat geeft eenieder het recht ermee om te springen zoals het hem of haar goeddunkt. Maar hoewel niemand dat recht kan worden ontzegd, kan toch ook niemand daaraan autoriteit ontlenen. Daarom, misschien, verving het schrijven het spreken in de wereld van Van Dieren. Immers, als, zoals hij in 1922 schreef, tussen woorden en gedachten een zo innig verband bestaat dat de twee eigenlijk als synoniem kunnen worden opgevat, en als het uitdenken van een vraagstuk eist dat de gedachte in de vorm van een betoog uitkristalliseert waartussen geen speld te krijgen is, dan volgt daaruit dat het schrijven niet als een poging moet worden begrepen het denken kracht bij te zetten, maar dat het schrijven de taak van het denken dient over te nemen. ${ }^{81}$ De waarheid van een denkbeeld blijkt uit wat de schrijver opschrijft, niet uit wat hij te zeggen heeft. Nog een stapje verder en ook de schrijvers zijn verdwenen: nu zijn het de teksten zelf die zich tot elkaar richten, als objectieve grootheden, reflecties van zuivere denkbeelden: goed en kwaad. 


\section{IO}

\section{Onder vijanden en figuranten}

Het universum waarin Van Dieren leefde lijkt vaak een wanordelijke boel van tegen- en grootspraak, maar toch is het volgens strenge principes geordend. In die wereld staat niet de vader maar de moeder aan het hoofd, op wier begrip Van Dieren altijd kon rekenen. Onder haar stonden de zonen; zij vertegenwoordigden het betwiste gedeelte van het universum. Vrijwel alle door Van Dieren aangezochte opponenten waren generatiegenoten. Eijkman, bijvoorbeeld, was drie jaar ouder dan hij en Van Eeden was een jaar eerder geboren. Gorter en Verwey waren drie jaar ouder en Roland Holst negen. Een aanzienlijk deel van hen was bovendien medicus en vaak ook nog gepromoveerd. Ligt het dus niet voor de hand om in Van Dierens verzet een uitgebreid familiecomplex te zien, een 'broederoorlog', waarin de rivaliteit met de broer om de gunst van de moeder dominant is?

\section{De moeder der moeders}

'Moeder', aan wie verschillende boeken worden opgedragen, verschijnt in diverse gedaantes. De meest glorieuze daarvan is die van Hare Majesteit de koningin, zij begrijpt alles. $\mathrm{Zij}$ is het aan wie hij zijn leven en werk (vooral dat laatste) toevertrouwt. $\mathrm{Zij}$ is het ook, als enige, tot wie hij zich durft te richten met voor- en achternaam. Evart.

Verschillende brieven schreef hij aan de koningin; de eerste in januari I 897 .

Mevrouw,

Met verschuldigden eerbied neem ik de vrijheid Uwe Majesteit een exemplaar aan te bieden van mijn boekje getiteld: "Beri-Beri; eene rijstvergiftiging, eene critisch-historische bijdrage tot de kennis der meelvergiften." De meening welke sedert jaren, in navolging van anderen, door mij verdedigd werd, begint veld te winnen. Maar zelfs, al zou het blijken, dat die meening foutief was, dan nòg zou men zich in onze Oost-Indische 
Koloniën moeten gedragen overeenkomstig het voorbeeld der Engelsen en Japaneezen, die erin geslaagd zijn de ziekte geheel en blijvend te doen ophouden door dieetverandering. In mijn boek is dat in den breede aangetoond. Op de bladzijden I I 8-I4 I wordt - ook voor hen, die buiten de medische wereld staan - op duidelijke wijze de stand van het Beri-berivraagstuk uiteengezet; en daar het niet enkel een wetenschappelijke kwestie betreft, maar ook het belang van vele onderdaanen er mede gemoeid is, verzoek ik Uwe Majesteit daarvan kennis te willen nemen.

Het ligt niet in mijne bedoeling de oplossing van een wetenschappelijk geschilpunt aan Uwe Majesteit's oordeel te onderwerpen; maar wel om Uwe Majesteit te doen beslissen, of nog langer gedraald mag worden met het invoeren van eene dieetverandering, die afdoende is. In mijn boek zijn tal van voorbeelden aangehaald, die dat laatste onomstootelijk bewijzen. God geve, dat van mijn geschrift zooveel overtuigende kracht uitga, dat mijn wensch spoedig gehoor vinden!

Met grooten eerbied noem ik mij

Uwe Majesteit's onderdaanige dienaar

E. van Dieren

Arts $^{1}$

De brief van Van Dieren werd ingeschreven in het brievenboek van het particulier secretariaat van de koningin onder de afdeling ingekomen post en onder aanhaling van de zin die ook in de kantlijn van de brief van Van Dieren met potlood is aangemerkt: 'Het ligt niet in mijne bedoeling de oplossing van een wetenschappelijk geschilpunt aan Uwe Majesteit's oordeel te onderwerpen...' In datzelfde register staat tevens hoe het antwoord luidde (dd. 28.I.I897): 'Bedankt. Met veel belangstelling werd uwe studie door H.M. ontvangen.'

Meer, zo wist hij wel, mocht een gewone sterveling niet verlangen van een koningin-moeder (Emma). Uit dankbaarheid voor dat begripsvolle antwoord stuurde hij haar tien maanden later nog een boekje toe: Kantteekeningen op Dr. Vorderman's Beri-Beri Rapport, waarin, aldus het begeleidende schrijven, duidelijk uiteengezet staat hoe het hele beriberi-probleem binnen enkele maanden kan worden opgelost. ${ }^{2}$

Daarna wierp hij zijn flessenpost nog driemaal in koninklijke wateren, te weten in 1907, I9I 8 en I93 $1 .^{3}$ Omdat de eerste twee brieven het begin van zijn schrijversloopbaan markeren en de laatste min of meer het einde daarvan, en alle brieven, met uitzondering van de tweede, met vaste tussenpozen van ongeveer tien jaar na elkaar zijn verstuurd, begrijpen we dat de correspondentie als een soort tussentijdse verantwoording moet worden opgevat en ieder toegestuurd boekwerk als een 
bewijs van zijn trouw. Zeker gold dit het in 1907 aan de koningin (Wilhelmina) toegestuurde 'Beriberiproefschrift' waarin hare majesteit zelf werd aangesproken (waarover hieronder meer), maar ook de in een schrijven uit I9I 8 meegestuurde brochure De nadeelige invloed van fel zonlicht en sport op lichaam en geest, gepubliceerd in datzelfde jaar. Het werd ten onrechte door het secretariaat als een 'politiek antiEngelsch geschrift' weggezet. ${ }^{4}$ In werkelijkheid bestaat het uit een reeks populariserende artikelen die, hoewel niet geheel gespeend van polemische uitvallen naar zijn tegenstanders, tezamen toch een tamelijk toegankelijk en zelfs lezenswaardig boekje opleveren, vol met praktische raadgevingen. Reuze handig voor een alleenstaande huisvrouw.

Wat was zijn bedoeling met dit schrijven aan de koningin? Zelf wilde hij er dit over kwijt: dat het ging om een brief waarin de koningin 'de raad werd gegeven onze boeren die zich al te hard toelegden op het planten van in het buitenland o zo duur betaalde kool, te verplichten tot het verbouwen van graan en peulvruchten [...]'. ${ }^{5}$ De brief zelf is niet bewaard gebleven, dus de vraag hoe een en ander zich tot elkaar verhouden kan niet worden beantwoord.

Het stond hem vrij haar zo veel te schrijven als hij nodig achtte antwoorden deed zij natuurlijk slechts bij monde van haar secretaris, maar dat gaf niet, als een ware Cyrano vertrouwde hij erop dat zij hem volkomen begreep: 'Mijn boek zal Uwe Majesteit overtuigen.' 6

Het belangrijkste van die tot het overtuigen der koningin gedrongen boeken was het zo-even genoemde boekwerk getiteld Meelvergiftigingen: Beri-Beri, Pellagra, Ergotismus, Erwtenziekte, Polaranaemie, enz uit 1907. In de inleiding waagt hij het in vetgedrukte letters koningin Wilhelmina persoonlijk drie vragen, eisen eigenlijk, voor te leggen, die op een herhaling neerkomen van zijn tien jaar eerder geschreven brief, maar nu met het expliciete verzoek wél uitspraak te doen in een wetenschappelijk geschil.

I. Vindt Gij het - na kennisneming van het boek van den arts Evart van Dieren - raadzaam om rekening te houden met de sedert I 887 door hem verdedigde stelling dat "de Beri-Beri eene intoxinatie-ziekte is, veroorzaakte door ondeugdelijke rijst"?

II. Is het Uwe meening, dat Wij gerechtigd zijn, den autoriteiten in Nederlandsch-Indie in ernstige overweging te geven, de door hem in verband daarmede aangegeven voorbehoed- en geneesmiddelen toe te passen overal, waar daartoe reden bestaat?

III. Zoo Gij er anders over denkt, welke redenen hebt Gij om Ons zulks te ontraden? 
Ook op dit schrijven is ons geen antwoord bekend, maar omgekeerd weten we wel wat hij over haar dacht. Hij droomde van haar - letterlijk. In een park komt hij haar tegen. Zij draagt een arm in een doek; hij ziet dat zij pijn heeft en dat de vingers blauw van kleur en opgezwollen zijn. Hij biedt haar zijn hulp aan, maar een hofdignitaris die achter de koningin loopt vindt dat niet goed en vraagt op barse toon: "Wie bent u?" - "Dokter van Dieren uit Amsterdam." - "Daar heb ik nog nooit van gehoord." - "Dat jokt u." De koningin mengt zich in het gesprek: "Ik heb wel eens wat van u gelezen." Vol vertrouwen steekt zij hem haar arm toe en laat zich gewillig helpen. Het verband zit te stijf, ziet hij, en de hofdokter is ook nog vergeten de ringen van de vingers te doen! ${ }^{8}$

Wat een merkwaardige droom! De dame met het blauwe bloed valt voor de dokter van wie nog nooit iemand heeft gehoord - behalve zij! Gewillig laat zij hem haar ringen afdoen, waarna ze nog lang en gelukkig leefden. In de wereld van Van Dieren kan het jongetje met zijn moeder trouwen, zelfs nadat hij de boeken van Freud heeft gelezen. Wat een gelukzalige wereld! En wat jammer dat daarin ook nog anderen leven!

\section{De broedergemeenschap}

Met Frederik van Eeden, schrijver-arts en idealist, geboren in I 860 en daarmee slechts een jaar ouder dan Van Dieren, had hij eens een kortstondige briefwisseling over het geloof. De aanleiding was een lezing van Van Eeden over de 'geestelijke ontwikkeling der mensheid'. Daarin had Van Eeden gezegd hoe hij de godsdienst had ervaren als een 'knellende band', en dat hij had gezocht naar een manier om daaraan te ontkomen. De godsdienst, beweerde Van Eeden toen, tracht kunst en wetenschap aan zich ondergeschikt te maken, bang als ze is om door die twee krachten te gronde te worden gericht. Wat men dus moet doen is die twee krachten los van haar maken. Kunst en wetenschap moeten hun religieuze wortels kwijtraken. Ontwortelen en opnieuw beginnen het axioma van iedere revolutionair.

Dat stond lijnrecht tegenover wat Van Dieren had gezegd in een serie voordrachten, later gepubliceerd als Bijgeloof en misbruik op medisch en hygiënisch gebied, waarin hij de stelling verdedigde dat het christelijke geloof voorafgaat aan en als leidraad dient in wetenschappelijk onderzoek. ${ }^{9} \mathrm{Ja}$, het christelijke plichtsbesef was volgens Van Dieren zelfs de enige vorm van beschaving die tot fatsoenlijk onderzoek kan leiden: 'immers van de aanvang af hebben de ware Christenen het als een verplichting beschouwd zieken en afgeleefden te helpen, zelfs met terzijde stelling van eigen belangen. ${ }^{10}$ 


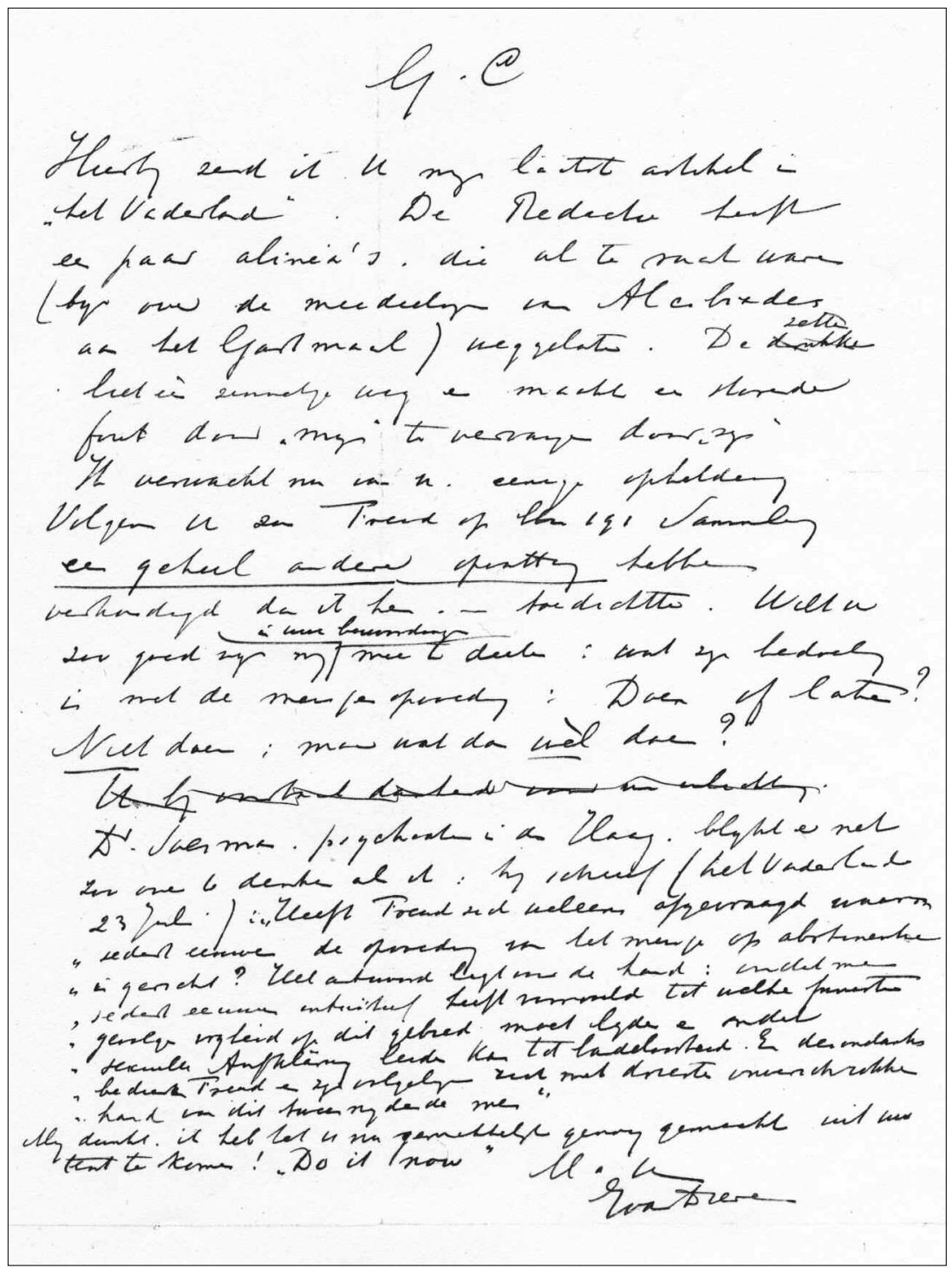

Brief van Van Dieren aan Westerman Holstijn: 'Wilt $u$ zoo goed zijn in uwe bewoordingen mee te deelen: doen of laten? Niet doen: maar wat dan wèl doen?

De bijeenkomst waar Van Eeden die voordracht hield was goed bezocht, hij moest haar zelfs verschillende keren voordragen om iedereen te kunnen bedienen. Van Dieren had zich niet onder zijn gehoor bevonden, maar had een schriftelijk verslag van de lezing in de krant 
aangetroffen, zoals blijkt uit een brief van hem aan Van Eeden uit die tijd waarop in een ander handschrift in de marge de titel van de lezing staat vermeld. Maar al had Van Dieren de woorden niet zelf uit de mond van de meester vernomen, toch voelde hij zich niet minder aangesproken. Typerend is hoe Van Dieren op de voordracht reageerde.

Ik ben het niet met $\mathrm{U}$ eens dat "het Christendom nooit bizonderen nadruk heeft gelegd op het doen, op ijver, op wetenschap en kennis.” Ik zelf heb genoeg moeilijke oogenblikken doorleefd en juist het Christendom heeft me dan aangemoedigd en aangevuurd; ik leerde daaruit: niet te smalen om menselijk oordeel, niet te letten op verdriet, wat me werd aangedaan, want de Voorganger had zooveel meer verdragen; ik "deed" met "ijver" (niemand zal dit ontkennen) wat ik meende te moeten doen, omdat ik "woekeren" moest met het geschonken talent. ${ }^{11}$

Vooral de toon die de briefschrijver zich permitteerde om broeder Van Eeden te adresseren - te bekeren is misschien een beter woord - , meer nog 232 dan de inhoud, is interessant. Het is er een die een te grote familiariteit suggereert. Door zijn eigen ervaringen met die van de ander te verbinden lijkt het alsof ze met elkaar in gesprek zijn, ja, alsof Van Eeden alleen tot hem had gesproken. Dat zou voor de these van het broedercomplex spreken.

Tegelijk echter lijkt het ook om een 'technisch' probleem te gaan het onvermogen zich binnen de grenzen van het betamelijke te gedragen en de juiste aanspreekvorm te vinden die past bij zijn positie. Dat is een probleem waar Van Dieren vaak tegenaan was gelopen en nog zou lopen. We herinneren ons hoe tegen het 'hoge standpunt' bezwaar werd gemaakt van waaruit Van Dieren reeds in zijn allereerste publicatie kritiek op professor Pekelharing had geleverd. Ook in eigen kring permitteerde hij zich ongekende vrijheden die lang niet altijd op prijs werden gesteld. Diepenbrock beklaagde zich erover dat hij zich door zijn huisarts in discussie als een 'jongemensch' behandeld voelde, ${ }^{12}$ en tegen Albert Verwey, met wie hij geen regelmatig verkeer had, sloeg hij een ongepaste, bijna onzedelijke toon aan.

2I Feb. I930

Hooggeachte heer Verwey

Indertijd heeft Flanor (?) de Kliekgaard gehekeld met een samenspraak die o.m. deze woorden bevatte: 'Gatlikabo, gatlikamers. Lik je mij. Ik lik je weer!' Kunt U mij meedeelen waar ik die samenspraak vinden kan ${ }^{13}$ 
Hij wilde van die uitspraak gebruikmaken in een boek, zo schreef Van Dieren. Om de elkaars gat likkende professoren te bekritiseren, zo moet de brieflezer raden. Het vanwege haar vulgaire karakter aanstootgevende rijm in potjeslatijn, dat waarschijnlijk ten onrechte aan Kneppelhout's Flanor wordt toegeschreven, komt op het bordje van Verwey terecht als een quasi-onschuldig verzoek om informatie. In werkelijkheid drukt het briefje een volslagen gebrek aan respect uit. Want of Verwey, geboren in I865, een generatiegenoot dus en sinds I 924 hoogleraar, maar even naar de boekenkast wil lopen om de betreffende informatie op te zoeken ten behoeve van Van Dieren, die over hem weliswaar had geschreven dat hij 'in zijn goede ogenblikken tot onze beste dichters en denkers behoort', maar die hij desalniettemin heftig bestreed vanwege zijn standpunt in spellingvereenvoudingskwestie. ${ }^{14}$

Diezelfde Kneppelhout-geestigheid duikt dat jaar nog een keer op in een brief aan Otto Lanz, ook nu niet alleen om 'de kliek' te hekelen, maar vooral om de briefontvanger zelf eens de les te lezen: 'En vandaag kreeg ik van mijn "vriend" Lanz zelfs te hooren, dat ik het nog altijd verkeerd doe!', waarna Flanor aan het woord komt.

Dat al die vormen van bedekte en minder bedekte kritiek niets uithaalde realiseerde Van Dieren zich waarschijnlijk ook wel, maar hij slaagde er eenvoudig niet in om de weg te vinden naar de ander. Er gaapte, met andere woorden, een gat tussen wat hij iemand zou willen zeggen, en de realiteit waarin hij dat kon doen. Om die leemte althans enigszins op te vullen voegde Van Dieren bij wijze van PS in zijn brief aan Verwey toe: 'Onze zoons zijn met elkaar bevriend uit hun kinderjaren.' Lanz hoopte hij via een stichtelijke aansporing te overtuigen zijn kant te kiezen: 'God zal het U loonen. Ja, dat zal Hij doen!'

In de broedergemeenschap van Van Dieren heerste een zo amicale omgangsvorm dat het lijkt of niemand aan iets enige autoriteit kan ontlenen, en dat er daarom ook van enige distantie geen sprake kon zijn. Iedereen was op ieder moment aanspreekbaar. In die wereld was iedereen vogelvrij, gelijk Spinoza, de 'goddeloze Godszoeker' zoals het bij Jan en Annie Romein heet, die werd vervloekt om zijn volslagen gebrek aan respect voor de autoriteiten en daarmee niet de autoriteiten maar de kleine burger in verwarring bracht. ${ }^{15}$ Iedereen, behalve Van Dieren zelf, die elke vorm van tegenspraak opvatte als een ernstige aantasting van zijn eer. 


\section{Medestanders}

De Oostenrijkse arts Ignaz Semmelweis (I8 8 8-I 865) is in de geschiedenis van de geneeskunde bekend geworden doordat hij in de jaren zestig van de negentiende eeuw de oorzaak van de gevreesde kraamvrouwenkoorts had ontdekt, maar daarvoor geen erkenning had gekregen en was gestorven aan de kwaal die hij zelf had helpen bestrijden (een infectie). Met hem en met zijn lot identificeerde Van Dieren zich graag en hartstochtelijk. 'Telkens trof het mij, dat de wijze, waarop mijne tegenstanders mij bestrijden, geheel dezelfde is als die, waarover Semmelweis zich te beklagen had. ${ }^{16}$ De behandeling die Semmelweis ten deel was gevallen, was in één woord schandalig, schreef Van Dieren. 'Zijn toon deugde niet. En omdat zijn toon niet deugde, daarom lieten ze de moeders doodgaan!" ${ }^{17}$

De toon waarop Van Dieren over Semmelweis schreef, doet vermoeden dat deze nog altijd werd verketterd en dat de medische wetenschap nog altijd geen ontzag voor hem had. Maar dat was niet zo. Sem234 melweis was in de tijd van Van Dieren zo'n beetje de personificatie van de weldoener die de domheid en het vooroordeel van zijn tijd ver vooruit is, en daar zelf het slachtoffer van werd, schrijft Annet Mooij in haar studie over de geschiedenis van de geneeskunde in Amsterdam. ${ }^{18}$ Wel representeerde hij de ideaaltypische outcast voor Van Dieren, de buitenstaander die zich postuum aan zijn lot had weten te ontworstelen, tegen de verdrukking in.

Van Dieren vertelde de geschiedenis van Semmelweis vaak na en schreef dan dat het niet aan pogingen heeft ontbroken om Semmelweis te doen vergeten en alle eer aan Pasteur te doen toekomen, terwijl er in heel Europa maar twee artsen waren die zich door hem hadden laten overtuigen. ${ }^{19}$ Familiegelijkenissen. Semmelweis is Van Dieren, en Pasteur is Eijkman.

Zoals Semmelweis waren er nog enkelen, 'verworpenen der aarde' die zonder het te weten tot medestander van Van Dieren waren uitgeroepen. Jan Pieter Heije was er zo een, maar ook Multatuli, die soms als lichtend voorbeeld werd geciteerd en met wie hij tenminste eenmaal op één lijn was gesteld. Van Dieren had zelfs een eigen lijntje met de schrijver van Max Havelaar, zo blijkt uit een brief: 'Mevrouw Douwes Dekker las mijn boek [De waanzinnige waereld] ook met instemming. Ik vernam het van W. Paap. ${ }^{20}$

'Niets is helemaal waar' citeerde Van Dieren Multatuli instemmend, 'ook dit niet'. ${ }^{21}$ Het is een formulering van de leugenaarsparadox, onoplosbaar vanwege het zelfverwijzende karakter van de zin. 
Maar daarin lag natuurlijk juist de aantrekkingskracht voor Van Dieren: de uitspraak kan eenvoudig niet ontkracht worden, is een onneembaar bolwerk geworden, en iedereen loopt erop stuk, behalve degene die haar heeft geformuleerd. Wat een vondst!

Ook de Zweedse botanicus Carolus Linnaeus (I707-I778) mocht zich verheugen in Van Dierens warme belangstelling. Linnaeus heeft bekendheid verworven met zijn almaar uitdijende Systema Naturae, een poging tot systematische rangschikking van de planten en dieren. Hij schreef zijn werk vanuit de diep religieuze overtuiging dat God de wereld had geschapen, en dat het de taak van de mens was daarin enige ordening aan te brengen. 'God schiep, Linnaeus rangschikte', heet het in zijn biografie. Dat beviel Van Dieren goed. In een tijd dat wetenschappers minder op God en meer op de techniek vertrouwden, verklaarde hij Linnaeus met terugwerkende kracht tot miskend genie, en wenste hij dat zijn werken tot verplichte lesstof aan de studenten medicijnen zouden worden voorgeschreven.

Semmelweis, Linnaeus, Heije en Multatuli werden dus zonder problemen toegelaten tot de wereld van Van Dieren. Maar dat waren dan ook geen rivalen. $\mathrm{Zij}$ waren niet eens mensen van vlees en bloed, maar alleen maar metaforen voor hem zelf, schimmen uit het verleden wiens vooruitgeworpen schaduw hij dacht te zijn.

\section{De leermeester}

Bolland, zelf een halve querulant en eigenlijk ook een marginale persoon, behoorde tot een der weinige professoren met wie Van Dieren bevriend was en met wie hij toch nooit ruzie kreeg. Hij had het geluk dat hij overleed voordat Van Dieren de kans kreeg de meester op zijn fouten te kunnen wijzen. Van Dieren stond sinds I9I4 met hem in briefcontact en had hem al verschillende van zijn werkstukken opgestuurd, zoals de brochure Darwinisme en ongeloof en het anti-marxistische geschrift Het socialistisch gevaar, waarover het oordeel van de filosoof in beide gevallen niet ongunstig luidde. Op z'n Bollands heette het dat

hoewel Uw gebrek aan doorzicht, of liever Uw betrekkelijke onkunde in de zaak van den godsdienst, mijne instemming belet meer dan eene halfheid te zijn, is toch de geest van oprechtheid, de flinkheid en rondborstigheid, die uit Uw schrijftrant spreekt, zoo groot, dat mij de lezing van "het S.G." haast nog meer genoegen heeft gedaan dan die van de brochure over het Darwinisme. Blijkbaar zijt gij een rechtschapen man en 
zoover Uw blik reikt, is die blik ook niet duister. Doch met dat al, hooggeachte heer, staat Gij over het geheel genomen nog niet hoog; ruim is Uw blik nog niet, en zoo blijft dat de helderheid van uwen geest met eene ommezijde behept van donkerheid. Ook de moed der waarheid is in $\mathrm{U}$ vermoedelijk eene halfheid; in allen gevalle bevindt $\mathrm{Gij} \mathrm{u}$, wat het hoogere of liever het ware, dat is het volledige betreft, in eene schemering, die U verhindert, naar alle zijden klaar en helder te zien. [...] Zooals Ge zijt, reeds, zijt Ge mij in allen gevalle niet onsympathiek. ${ }^{22}$

Wie de biografie van Bolland van Willem Otterspeer heeft gelezen weet dat dat laatste geen gering compliment is, en dat de wat schampere aanduiding over de met donkerheid behepte geest van Van Dieren voor Bollands doen eigenlijk vrij gewoon was, al heeft de geadresseerde zich daar wel degelijk aan gestoord - de zinsnede keerde op verschillende plekken waar Bolland ter sprake kwam terug om zich tegen de gebruiker ervan te keren. ${ }^{23}$

Het kwam niet lang na publicatie van De waanzinnige waereld tot een ontmoeting tussen de twee, die drie uur zou hebben geduurd en bij Van Dieren het gevoel deed postvatten dat hij aan de voeten van de meester moest gaan zitten om de wijsheid deelachtig te worden, iets wat hem maar matig beviel, daar hijzelf de wijsheid immers in pacht meende te hebben. Een uitnodiging om de colleges Zuivere Rede bij te wonen sloeg hij af, wat tot wrevel bij de Leidse filosoof leidde, maar Van Dieren was een volgeling van niemand. Toen ze afscheid namen zou Bolland hem een zeldzaam compliment hebben gemaakt door tegen zijn zoon Alfred te zeggen: 'Van dien man houd ik.' ${ }^{24}$

Korte tijd later ontving Bolland een briefkaartje van zijn rechtschapen collega. Die was in Den Haag, zo deelde hij mee, om een boek af te maken voorlopig getiteld Revolutie of Evolutie? Ontbinding of Ontwikkeling? Vernieling of Verbetering? (later gepubliceerd als Historisch-idealisme of historisch materialisme). En terwijl hij daar zo mee bezig was en even een moment vrij had genomen om een kopje koffie te drinken in Café Centraal had hij onderweg een boek opgepikt van Karl Hesse over de vrijmetselarij, waarop hij graag de aandacht van zijn hooggeleerde vriend wilde vestigen, daar hij diens boek over dat onderwerp kende. Conclusie na het lezen van reeds een paar bladzijden: 'Wat een donkere tijd! En toch zie ik het glans van den dageraad. Mijn boek is een psychologische studie. ${ }^{25}$ Was dat de revanche van de met donkerheid behepte dokter?

Maar leermeester en leerling deden nauwelijks voor elkaar onder als het erom ging vanuit de veilige burcht van een eigengereide filosofie 


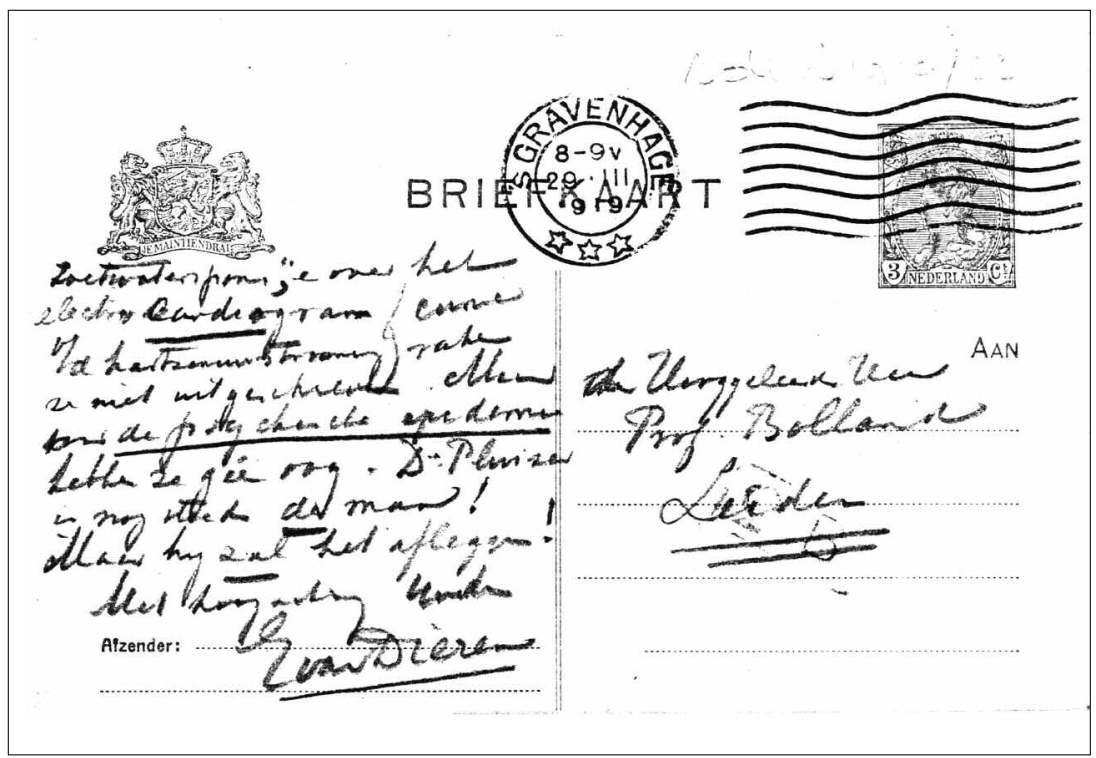

Hopquare teer.

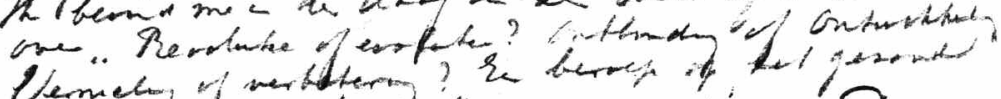

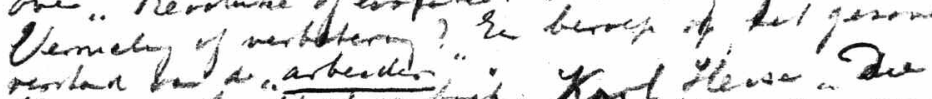

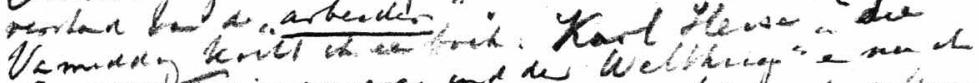

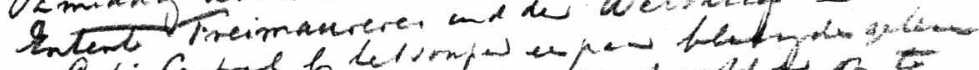

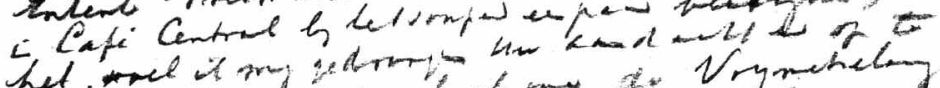

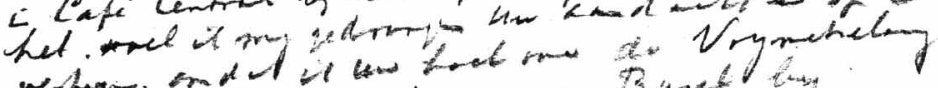

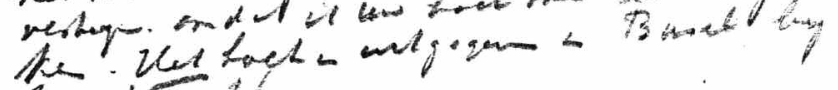
rmot Timez.

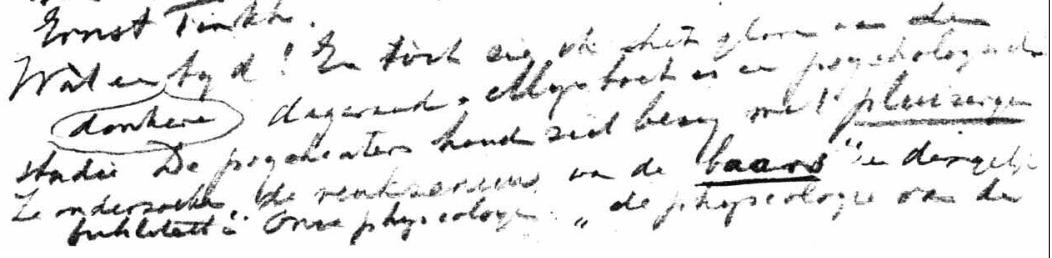

Voor-en achterkant van een briefkaartje van Van Dieren aan Bolland. Had Bolland bet nou gelaten bij zijn gefulmineer tegen de vermolmde, oppervlakkige en verkankerde beschaving die ten onder dreigde te gaan aan zedenverwildering en aan haar gepeupelregering, $j a$, dan had hij nog wel wat langer aan de voeten van de meester willen blijven zitten, maar om de Joden overal de schuld van te geven? Dat ging ook Van Dieren toch te ver. 
ongefundeerde oordelen te vellen over maatschappelijke verschijnselen. Bollands vrijmetselarijstudie werd door A. Klaver, predikant bij de remonstrantse gemeente te Hoorn en in zijn vrije tijd Meester-Vrijmetselaar bij de loge West-Friesland, in een brochure tot de grond toe afgebrand. Niet gehinderd door enige kennis van zaken verwijt deze filosoof de vrijmetselaars een gebrek aan vaderlandsliefde, kinderachtige geheimzinnigdoenerij en natuurlijk een ongodsdienstige levenshouding. En waarop baseert Bolland dit oordeel? Op een lukraak bij elkaar geraapte collectie citaten uit deels verouderde en deels niet-gezaghebbende bronnen, vaak nog onbegrepen bovendien. In plaats van zich naar behoren op de hoogte te stellen heeft hij zijn kennis 'van horen zeggen'. Bakerpraatjes, meneer de filosoof! ${ }^{26}$

Nog weer een jaar later ontving Bolland weer een briefje van Van Dieren waarin tussen neus en lippen door vermeld werd hoe goed $D e$ waanzinnige waereld wel niet verkocht. De I Ide en I 2 de druk, ieder I००० exemplaren groot, zouden binnen een paar dagen verschijnen, schreef Van Dieren opgewekt. Bijgesloten, als om te bewijzen dat hij 238 niet had gebluft, deed hij Bolland een exemplaar van de sterk uitgebreide volksuitgave van het boek toekomen; op pagina I4 en I 22 had hij melding gemaakt van zijn filosofische vriend, zo liet hij weten. ${ }^{27}$ En inderdaad, we treffen daar een citaat van de Leidse professor aan tegen het egalitaristische denken in het marxisme. In de marge had Van Dieren er het wat aanmatigende commentaar 'Bravo Bolland!' naast laten drukken.

We kunnen ons wel een voorstelling maken van hoe Bolland, wiens werken bepaald geen bestsellers waren, gestemd moet zijn geweest over dat eclatante succes van zijn zwakkere wapenbroeder.

Maar dat waren allemaal nog maar inleidende manoeuvres. De definitieve afrekening met Bolland kwam na diens dood, in wat misschien als Van Dierens hoofdwerk was bedoeld, het in 1922 verschenen, ruim 500 pagina's tellende tweedelige Historisch-idealisme of historisch-materialisme. In een apart aan het 'schijnidealisme' gewijd hoofdstuk werd de 'Hegelarij' van Bolland onder de loep genomen. Wat heeft Bolland met zijn zware studie van Hegels redeleer nou helemaal opgestoken, wilde Van Dieren weten. Dat moeizame geploeg door Hegel heeft hem geleerd te orakelen over de 'ware idee', de 'absolute idee', de 'absolute waarheid', en zo meer, maar er is geen zinnig mens die enig idee heeft wat ermee wordt bedoeld, ook Bollands trouwe collegianten niet, die als acteurs de meester napraten zonder te begrijpen wat ze zeggen, aldus Van Dieren. Zelfs Bolland zelf, zo wilde Van Dieren graag kwijt, 'blijkt met die duisterheid te kampen gehad 
te hebben!' ${ }^{28}$ Een beetje gelijk, althans wat betreft die volgelingen van Bolland, mogen we Van Dieren in dezen wel geven.

Tegenover Bolland en Hegel zette Van Dieren zijn 'eenvoudige filosofie'. In werkelijkheid is alles allemaal heel simpel: wijzelf en de dingen om ons heen zijn zo geschapen dat we 'bij elkaar passen'. Mensen zijn zo geschapen dat zij in staat zijn 'in begrijpelijke taal uit te drukken wat hun helder voor de geest staat'. Met betrekkelijk weinig poespas kunnen we uit betrekkelijk weinig feiten afleiden wat goed voor ons is en anderen. ${ }^{29}$ Zo hoefde Van Dieren dus ook maar betrekkelijk weinig van Hegel te lezen om tot de conclusie te kunnen komen dat met dat hele idee van Idee hetzelfde werd bedoeld als God. Ja, daar hoefde hij Hegel zélf niet eens voor te lezen, dat kon hij uit Uren met Hegel ook al afleiden. Exit Bolland.

\section{De krankzinnige}

Nog een randfiguur klopt aan: de bij leven genegeerde en postuum ontdekte schilder Vincent van Gogh - een ware icoon van marginaliteit (geboren in I 853, en daarmee slechts acht jaar ouder dan Van Dieren). Van Gogh had in I 890 op 37-jarige leeftijd een einde aan zijn leven gemaakt nog voordat de erkenning was gekomen. Maar in de jaren na zijn dood groeide zijn faam gestaag. In 1905 vond de eerste retrospectieve tentoonstelling van zijn werk plaats in het Stedelijk Museum in Amsterdam, die als doorbraak in de postume carrière van Van Gogh kan worden beschouwd..$^{30}$

Van Dieren bezocht die tentoonstelling op een zondagmiddag. Hij was er, naar eigen zeggen, afgezien van nog één andere bezoeker, alleen. Een kunstenaar van grote aanleg, oordeelde Van Dieren al snel, maar helaas tot krankzinnigheid vervallen. Nog slechts met moeite kon hij in het broddelwerk van de ongelukkige man hier en daar een spoortje van de geniale aanleg ontdekken, maar verder, nee, niet de moeite. ${ }^{31}$

Voor Van Gogh bestond in het universum van Van Dieren dus ook geen plaats, en misschien was dat ook wel niet te verwachten, daar het de socialisten waren geweest die Van Gogh hadden ontdekt, zo meende Van Dieren althans (in Het Volk was Van Gogh eens geafficheerd als een schilder wiens werk buitengewoon geschikt was om genot te verschaffen aan de proletariërs). Wat daarbij bovendien ook wel een rol zal hebben gespeeld was dat het de door Van Dieren zo verafschuwde 'cultuurkliek' was geweest, misschien nog wel meer dan de socialisten, die de opmars van Van Gogh in Nederland hadden bespoedigd. Roland Holst, Jan Veth en Frederik van Eeden behoorden tot de eersten die 
zich voor zijn werk hadden ingezet, lang voordat van enige erkenning sprake was. Van Eeden schreef al in het jaar van overlijden van de schilder een opstel over hem: 'Het groote publiek lacht hem nu uit, zooals zij elk nieuw en origineel artistiek verschijnsel doen, en de groote schilders, al erkennen zij zijn ernst en genialiteit, halen de schouders op voor zijn werk, als iets ziekelijks, iets geforceerds, iets mislukts. ${ }^{32}$

Erkenning voor een marginale kunstenaar - erkenning die hem werd ontzegd - dat moest wel op hommeles uitdraaien.

Om dezelfde reden werden kunstenaars als Kees van Dongen en Jan Sluijters afgewezen. Natuurlijk, zowel Van Dongen als Sluijters had in de jaren rond de Eerste Wereldoorlog naam gemaakt met brutale, erotische doeken die door Van Dieren werden bekritiseerd als 'naaktvertooningen' met een 'wulpschen en zelfs perversen ondergrond'. ${ }^{33}$ Dat was al erg genoeg, en daarbij verstond Sluijters ook nog de kunst om iedere vrouw als een lichtekooi af te beelden en huldigde hij het principe le laid c'est beau (het lelijke is mooi), zo meende Van Dieren. ${ }^{34}$ Toch lijkt Van Dieren Sluijters en Van Dongen nog iets anders kwalijk te hebben genomen, namelijk hun succes bij de elite. Van Dongen, die naar Frankrijk was verhuisd, had in de jaren twintig veel waardering onder de avant-garde gevonden en Sluijters was in die tijd een veelgevraagd portretschilder van de fine fleur van Nederlandse kunstenaars, politici en zelfs industriëlen, die onder meer Kardinaal van Rossum, Willem Dreesmann en Anton Philips had vereeuwigd, en niet te vergeten: de socialist Wibaut. Beide kunstenaars hadden bereikt wat hem niet was gelukt. Juist door de heersende opvattingen op hun kop te zetten hadden ze niet alleen succes maar ook erkenning, ja, navolging, gekregen; er werd waarderend over hen gesproken en geschreven.

Een beschrijving in Prof. Freud van een dadaïstisch feestje bij de Van Dongens geeft uitdrukking aan zijn afschuw daarover. De gasten zouden, volgens het verslag van Van Dieren (die zich op een krantenartikeltje baseerde), op verzoek in badkledij zijn gekomen, waarna ze zouden hebben gesoupeerd en zich vervolgens in een speciaal daarvoor gebouwde badinrichting hebben teruggetrokken om zich te verfrissen. De kranten hadden hierover bericht op een toon als was het de normaalste zaak van de wereld, zonder één woord van afkeuring, aldus Van Dieren. Welnu, concludeerde de schrijver-moralist, een kunstenaar die niet in staat is zich in te houden moet zich maar uitrazen, maar laat hij dat alsjeblieft in het verborgene doen - dus zo dat niemand het hoeft te weten. ${ }^{35}$ 


\section{De relativist}

Albert Einstein (geboren in 1879 ) was een stuk jonger dan de overige vijanden aan wie Van Dieren zijn vetes opdrong, maar daar stond tegenover dat hij veruit de beroemdste onder hen was. Vanaf het eind van de jaren tien komt hij voor het eerst voor in het werk, maar hij is dan nog niet meer dan een bijfiguur, iemand wiens naam slechts genoemd hoeft te worden om de lezer eraan te herinneren dat de wereld krom en onlogisch in elkaar kan zitten. Daarin komt verandering na I920: in dat jaar werd Einstein gasthoogleraar aan de universiteit van Leiden. Lezingen van hem vonden plaats onder grote belangstelling, in afgeladen zalen en eindigden steevast in langdurig applaus. ${ }^{36}$ Kranten begonnen verslag te doen van zijn 'triomftochten'. Bij zijn bezoek aan New York in maart van het jaar daarop, bijvoorbeeld, was de belangstelling volgens een journalist van de Nieuwe Rotterdamsche Courant groter en spontaner dan enig eminent staatsman zich ten deel had mogen laten vallen de laatste tijd. Een lezing aan het King's College in Londen twee maanden later eindigde zelfs in een stormachtige ovatie. ${ }^{37}$ In november van dat jaar rees zijn ster tot ongekende hoogte toen Einstein de Nobelprijs voor natuurkunde ontving. Een komeetachtig bestaan, vond ook Einstein zelf.

Natuurlijk was er ook kritiek, ook onder fysici, die zich verzetten tegen die revolutionaire omwenteling van perspectieven, en daarin speelden logische en wetenschappelijk argumenten een minder belangrijke rol dan esthetische argumenten. Als er geen dwingende reden is om op een nieuw paradigma over te stappen baseren aanhangers en tegenstanders zich in eerste instantie op hoe aantrekkelijk of afstotelijk een nieuwe theorie is, zegt Thomas Kuhn. Later komen de argumenten wel, en daarmee nieuwe standaarden en methoden om de zaak te beoordelen. ${ }^{38}$ De schoonheid, of, om het minder esthetisch uit te drukken, de overtuigingskracht van een nieuw idee is dus een eerste beoordelingscriterium in een paradigmastrijd.

Geen die dat beter aanvoelde dan Van Dieren, voor wie Einsteins algemene relativiteitstheorie van meet af aan een wanstaltig wetenschappelijk gedrocht voorstelde, vooral vanuit esthetisch gezichtspunt. De combinatie van sterallure, journalistieke aandacht, publieke waardering en, natuurlijk, de toekenning van een Nobelprijs vormde voor hem in de jaren twintig aanleiding om er eens goed voor te gaan zitten. Wat in 1920 nog was begonnen als een lezing voor de Geneeskundige Kring over Teleologie of Teleophobie? Idealisme of Materialisme? mondde twee jaar later uit in het eerder vermelde filosofische traktaat 
Historisch-idealisme of historisch-materialisme, dat speciaal lijkt te zijn ingericht om een einde te maken aan warhoofderij à la Einstein.

Voordat hij de fysicus aanpakte liet hij bij wijze van opmaat een hele verzameling tegenstanders in historische volgorde de revue passeren, te beginnen met de antieken (Plato c.s.), een stuk of wat Middeleeuwse filosofen en enkele verlichtingsdenkers als Descartes en Spinoza, waarna hij geleidelijk uitkwam bij de nieuwe tijd om ten slotte oplopend via Darwin en zijn Nederlandse aanhangers (Hugo de Vries en Ambrosius Hubrecht ), Hegel en zijn aanhangers, Bolland inbegrepen, aan de grande finale te kunnen beginnen: Marx, Nietzsche en Einstein (Freud moest nog worden ontdekt).

De eerste twee godloochenaars werden door Van Dieren in een hoop losse typeringen aan de kant gezet, maar voor Einstein reserveerde hij bijna honderd pagina's. Een deel daarvan ging overigens op aan een kritiek op Einstein-uitleggers, zoals de Groningse hoogleraar Van Rijn, die had beweerd dat Einsteins leer alleen door de ervaring kan worden weerlegd of bevestigd. Van Rijn refereerde daarmee aan 242 de belangrijke eclipsexpeditie van I919, waarmee een van de meest cruciale hypothesen van Einstein werd bevestigd. Voor Van Dieren, die immers altijd op de bewijskracht door zuivere waarneming had gestaan, was dat een moeilijk te accepteren uitkomst. Hij redde zich eruit door de waarneming tot een trivialiteit terug te brengen: 'O zeker, de Einsteiniaansche leer staat of valt met een allerkleinste kleinigheid, met een lengtebepaling, die niet meer bedraagt dan hoogstens eenige milloenste deelen van de golflengte van een lichtstraal.' Des te opmerkelijker, volgens Van Dieren, omdat de einsteinianen willen doen geloven dat de gevolgen van zijn theorie enorm zijn. ${ }^{39}$

Wat dat laatste betreft had Van Dieren natuurlijk gelijk: de consequenties van de relativiteitstheorie waren enorm, alleen waren ze nog moeilijk te overzien. Maar van het hervormen van de wetenschap moest Van Dieren niets hebben. Integendeel. Een lange verhandeling in het Einstein-hoofdstuk is gewijd aan een 'wiskundige bewijsvoering' waaruit moet volgen dat de einsteinianen geen respect hebben voor de 'zuivere logica', en met hun 'gefantaseerde kromme ruimte in hun eigen wereld draaien' ${ }^{40}$ Er volgde een hele reeks formules waarmee de baan van een afgeschoten kanonskogel van roo kg kan worden berekend, en andere opgaven die zo uit een hbs-examen lijken te zijn weggelopen, ten bewijze van de juistheid van de klassieke rekenmethode.

Van Dieren liet die bewijsvoering aan een student wiskunde zien. Deze toonde in enkele bewoordingen wat eraan schortte: hij kon geen 
afstand doen van het idee dat getallen naar iets concreets in de wereld moeten verwijzen. Met andere woorden, het ontbrak Van Dieren aan abstractievermogen. ' $U$ houdt vast aan de ervaring in plaats van de kwestie zuiver-wiskundig te beschouwen', zo werd hem verteld. ${ }^{41}$ De geadresseerde vond dat een onzinnig 'futuristisch' argument en hij bleef erop staan dat getallen te allen tijde 'eenheden' moeten representeren.

We slaan de rest van de polemiek over de getallenleer over en komen aan bij het interessantere deel van de tegenwerping, dat is te vinden in het stuk waarin hij besluit letterlijk in een conversatie van Einstein in te breken. De gedachte om op die manier met de 'oude vijand in een nieuwe wapenuitrusting' af te rekenen werd blijkbaar opgeroepen tijdens het lezen van Alexander Moszkowski's Gespräche mit Einstein. Moszkowski's boek is biografie en uitleg van de leer ineen en niet alleen de ideale maar ook de enige bron waarop Van Dieren zich baseerde.

Ware ik bij die bespreking aanwezig geweest, schreef Van Dieren (die moest toegeven dat dat wel een 'verwaande wens' was, maar zich daardoor niet liet weerhouden die fantasie uit te leven), dan zou ik mij zo bescheiden mogelijk tot professor Einstein hebben gericht. Als beoefenaar van de 'reine Logik', begon hij, was het hem opgevallen dat Einstein het enerzijds heeft over gebeurtenissen die gelijktijdig plaatsvinden, maar anderzijds absolute gelijktijdigheid uitsluit. Een ongerijmdheid! Het woord absoluut sluit relativiteit immers uit, wist Van Dieren, die zich in dezen toch weer graag op Hegel en Bolland verliet. In de rest van het antwoord aan Einstein, dat twee pagina's beslaat, hamerde Van Dieren op het verschil tussen 'uw relatief standpunt' en het 'absolute recht' iets te zeggen, en veroorloofde hij zich nog een paar fraaie vergelijkingen (de bescheidenheid had hij maar laten varen): 'Als gij gelijk hadt, dan zou het in de wetenschap een Janboel, een Poolsche landdag worden', en: '[Nu] ik deze ervaring met u heb opgedaan, dènk ik er ook niet over ùwe "Denkmachine" als "unfehlbar" te beschouwen. ${ }^{42}$

Er zijn talloze van dergelijke gefantaseerde dialogen in het werk van Van Dieren, die net als deze sterk doen denken aan zijn mislukte toneelstuk. Ook daarin beheerste Van Dieren/dr. Mol het gesprek volkomen en slaagde hij er steeds in de tegenstander met achteloos gemak in de val te lokken.

Maar het is dan ook wel nauwelijks een dialoog te noemen wat zich hier afspeelde. Eerder heeft het wat weg van een parodie op het socratische gesprek, waarin een argeloze voorbijganger door de Grote Wijsgeer met behulp van onschuldige vragen in het nauw wordt gedreven 
en gedwongen wordt toe te geven dat de wereld anders in elkaar zit dan hij aanvankelijk dacht. En laat die argeloze voorbijganger nou net het grote genie Einstein zijn!

'Men kent dr. Van Dieren?', vroeg een recensent van Het Vaderland die Historisch-idealisme of historisch-materialisme besprak in een artikeltje waarin verschillende Einstein-boeken de revue passeerden. Van Dieren had hij opgenomen als 'afschrikwekkend voorbeeld', om te laten zien hoe het niet moest. Op zijn eigen retorische vraag gaf hij ook antwoord: 'Van Dieren is een uitmuntend geneesheer die soms rake en leuke dingen weet te zeggen, maar in zijn blinde geloofsijver op een beeldenstormer lijkt uit de dagen van de hervorming, die alles aanvalt wat niet onder zijn eigen opvattingen valt te scharen. ${ }^{33}$

In een ingezonden brief gaf Van Dieren repliek: zelfs de bewonderaars van Einstein geven toe dat het verschil tussen Einstein en Newton maar heel gering is. "t Zou billijker zijn geweest indien de recensent had geschreven: "Volgens Van Dieren bracht Einstein ons geen nieuws onder de zon!" - zou de redactie van Het Vaderland dat niet in een 244 voetnoot aan het stuk willen toevoegen, vroeg hij. Nou vooruit, de redactie liet in een noot weten dat ze met genoegen aan zijn verzoek wilden voldoen: 'Volgens Van Dieren bracht Einstein ons geen nieuws onder de zon!.' Maar, vervolgde de redactie, dan hoort daar wel de toevoeging bij dat Van Dieren de theorie van Einstein niet juist begrepen heeft. ${ }^{44}$ - Gelijk hebben en gelijk krijgen hadden zich toen allang van elkaar vervreemd in de wereld van Van Dieren. Zes jaar later schamperde hij dat Einstein dan wel door de heren professoren in bescherming mocht worden genomen, maar dat dat hem er niet van kon weerhouden hun gebrek aan logica aan de kaak te stellen. ${ }^{45}$

\section{Gemiste kansen}

Een beeldenstormer dus, ja, maar dan wel een met een voorkeur voor de nobelste der grootheden onder de heiligen in de kerk. Hoe vaak verkeerde Van Dieren niet in de nabijheid van een Nobelprijswaardige gedachte, en hoe vaak werd niet hem onthouden wat wel aan een ander werd gegund? Driemaal sloeg het onrecht toe, en driemaal haalde hij zijn schouders op: in I905 (Koch), I920 (Einstein) en I925 (Wagner-Jauregg) ging de Nobelprijs naar een onwaardige opponent, een wetenschapper die met een oninteressant, onwaar of onbenullig idee in de openbaarheid was getreden. Maar toen hij voor de vierde maal werd gepasseerd kon hij niet anders dan zijn handen in wanhoop ten hemel heffen. Hoe was het mogelijk dat in I929 uitgerekend 
Christiaan Eijkman de Nobelprijs voor geneeskunde mocht ontvangen voor... zijn beriberiwerk? De klap was zo groot dat hij er niet éen woord aan heeft gewijd. Voor één keer was zijn zwijgen welluidender dan zijn spreken. Een onrecht zo enorm, zo onbevattelijk, dat er zelfs voor Van Dieren geen uitdrukking aan kon worden gegeven.

Zaterdag, 2 november 1929. Naar het Zweedsch tel.-agentschap uit Stockholm meldt, is de Nobelprijs voor geneeskunde 1929 verdeeld tussen prof. C. Eijkman te Utrecht en... ${ }^{46}$

Terwijl Van Dieren thuis de krant sprakeloos op de koffietafel legt, opent duizend kilometer verderop een oude vijand zijn dagboek en schrijft bedroefd: 'im Nobelpreis übergangen. ${ }^{47} \mathrm{Ja}$, ook Freud was teleurgesteld. Ook zijn ontdekkingen waren nog altijd niet op waarde geschat; zijn laatste kans op erkenning was voorbijgegaan, en hij wist het.

Welja! Het moest er nog maar bij komen dat deze bevorderaar van de ontucht bij een volgende gelegenheid een Nobelprijs waardig gekeurd zal worden, riep Van Dieren bitter uit. 'Ik acht dit lang niet onmogelijk; waarschijnlijk zelfs! Want het wordt er stelselmatig op aangelegd!'48

Maar dat was dan in elk geval rechtvaardig verdeeld: het onrecht.

\section{Ken $u$ zelf}

Hoe zou Van Dieren zichzelf hebben gekenschetst? Dat hij vond dat hij werd buitengesloten, ja, moedwillig tegengewerkt door de goegemeente staat vast, maar hoe zou hij zijn eigen werk hebben gezien, zijn onmatige polemieken en zijn eindeloze strijd met iedereen? Hoe zou hij zijn eigen persoon hebben gekarakteriseerd?

Dit is wat hij op een bijeenkomst van de Vereniging voor de Geschiedenis der Genees-, Natuur- en Wiskunde in I92I, op 60-jarige leeftijd zei: Buitengewoon zelfingenomen en verbijsterend luchthartig als het gaat om het beoordelen van complexe maatschappelijke vraagstukken; doet allerlei voorspellingen en spreekt daarbij met de zekerheid van een profeet; bezit niet het vermogen fantasie en werkelijkheid uit elkaar te houden; doet uitspraken over huwelijk en seksualiteit die niet van een in evenwicht zijnde geest getuigen; bepaalt zijn belangstelling in de wetenschap voornamelijk hiertoe dat hij met allerlei mannen van naam in persoonlijke aanraking tracht te komen om hen voor zijn plannen te gebruiken; is behept met een ziekelijke fantasie; beschikt over een overstelpende woordenrijkdom van een overwegend lyrisch 
karakter; heeft een neiging tot wereldverbetering en een overdreven belangstelling voor allerlei vraagstukken die hem niet aangaan. Als klinische diagnose dacht Van Dieren aan de toen gangbare term 'dementia preacox'.

Een griezelig trefzekere zelfbeschrijving, met als enige tekortkoming dat Van Dieren er niet zijn eigen naam boven schreef, maar die van twee 'beroemd geworden krankzinnigen', Charles Fourier en Graaf St. Simon..$^{49}$ Waarom koos hij deze twee figuren als façade voor zijn zelfkarakterisering in een notendop? Niet alleen lijken ze in geen enkele opzicht op de beschrijving die Van Dieren van hen gaf, ook lijken ze niets te delen. De een was een recalcitrante aristocraat die aan het hof van de koning werd veracht, de ander een onsuccesvolle koopman die over wereldharmonie schreef, maar daar volstrekt alleen in stond. Beiden echter gaven gestalte aan het onoplosbare dilemma dat ook Van Dieren zelf leek te belichamen: de eeuwige drang om erbij te horen maar niet te weten hoe. Beiden schreven veel maar vonden geen navolging; hun succes kwam postuum. In Fourier en Graaf St. Simon 246 herkende hij de persoon in zichzelf die overwonnen moest worden, de geest die hem in zijn angstdromen kwam bezoeken en nooit ophield vragen te stellen zonder ooit naar antwoord te luisteren, de twijfel die aan hem knaagde - 'de Ander', in termen van de filosoof Emmanuel Levinas, die onderworpen en beheerst moet worden, maar ongrijpbaar blijft.

Als zodanig, als representatie van het niet-gekende dat zich als een raadsel aan de lezer opdringt en schreeuwt om ingelijfd te worden, maar steeds weer ontsnapt aan iedere poging tot domesticatie, kan de figuur van Van Dieren zelf ook worden opgevat als de belichaming van de 'Ander'. Hij is dat wat door het 'ik' niet wordt begrepen: de twijfel van Eijkman, de mislukkingen van Van Eeden, Troelstra's eenzaamheid te midden al die kameraden.

\section{Exit Van Dieren}

Van Dieren ging met de schimmen van zijn broedervijanden een eeuwigdurend gevecht op leven en dood aan, dat ook na zijn dood moest worden voortgezet, ja, dat eigenlijk pas na zijn dood zou beginnen net als bij Semmelweis. Voor eeuwig en altijd aan zijn opponenten vastgeklonken in een eindeloze polemiek: de geschiedenis was werkelijk lankmoedig toen ze Van Dieren op 22 mei I940 naar zijn laatste rustplaats bracht, want de Nieuwe Oosterbegraafplaats, waar hij werd begraven, ligt midden in Watergraafsmeer, recht tegenover een wijk 
waar Eijkman, Pekelharing, Hugo de Vries, Darwin, Wibaut en al de rest van zijn vijanden worden geëerd met een naar hun vernoemde straat.

En daar, voor altijd tegenover zijn tegenstanders ingegraven, ligt Van Dieren op het kerkhof van de geschiedenis. Hij is mislukt, maar in zijn mislukking geslaagd; hij is miskend, maar in zijn miskenning uniek. En in zijn uniciteit is hij in zekere zin onaantastbaar; er is niets wat hem raakt of zal raken, er is geen geschiedenis waarin hij past, geen verhaal dat vat op hem krijgt.

Ook dit verhaal niet.

Maar waarom dan, vraagt de lezer misschien, deze geschiedenis toch opgeschreven? Met welk recht werd hij in zijn eeuwige onrustige slaap gestoord?

En toch - en toch - had dit boek niet ooit moeten worden geschreven? Door iemand? 


\section{I}

\section{Slotbeschouwing. Over marginaliteit als bestaanswijze}

De loop van de geschiedenis van de buitenkant bezien door de ogen van iemand die erin is verwikkeld, maar er toch niet aan deelneemt: de positie van de buitenstaander is tragisch en komisch tegelijk, maar bevat ook een dwingende logica. De buitenstaander past niet binnen de politieke, culturele en wetenschappelijke orde en valt het establishment 248 juist daarop aan. Anders gezegd: hij gebruikt zijn marginale positie in het verwerven van aanzien. Zijn publieke optreden is opzettelijk controversieel, en hij buit de tegenstand die die controverse oproept uit door de nadruk te leggen op zijn rol als slachtoffer.

Marginaliteit is daarmee zowel de voorwaarde voor als de consequentie van de positie van buitenstaander, die gecreëerd wordt met instemming van de gemarginaliseerde zelf. Marginaliteit verschaft de buitenstaander een podium van waar af hij zich steeds opnieuw kan ontplooien; hij is dus in werkelijkheid allesbehalve het slachtoffer van marginalisatie, maar integendeel het belangrijkste product daarvan. Dat wil zeggen dat de positie van buitenstaander een positie op zichzelf is en aan haar eigen 'wetten' gehoorzaamt, een eigen taal kent, een eigen 'systeem'. Ik wil dit laatste hoofdstuk gebruiken om dat systeem in grote trekken in kaart te brengen.

\section{Twee overzijden}

De tegenspraak is de eerste en meest principiële grootheid die de positie van de buitenstaander kenmerkt. Het is in de ontkenning waar hij ruimte vindt voor zijn eigen bestaan, de oorzaak sui generis van zijn zijn. Dit zou je het generieke of constituerende uitgangspunt kunnen noemen, het principe van waaruit alle verdere activiteit voortvloeit.

Ik heb in dit boek willen laten zien hoe de marginaal zich in een antiwereld beweegt die als het ware parallel loopt aan de realiteit en 
haar imiteert, maar die tegelijk volkomen onzichtbaar blijft. Die wereld onder de oppervlakte heeft de pretenties meer 'waar' te zijn dan de oppervlakkige realiteit waarin de doorsneeburger leeft. De bovengrondse realiteit wordt door het establishment in stand gehouden en is in de ogen van de buitenstaander corrupt. Zijn werkelijkheid is ver daarboven verheven, vooral in moreel opzicht, maar kan toch nooit deel van de geaccepteerde realiteit worden, juist omdat de ideologische repressie de aanspraak op waarheid garandeert. De wereld van de buitenstaander bestaat bij de gratie van het feit dat de ander hem verwerpt. Hoe groter de tegenwerking die hij ondervindt, des te meer bestaansrecht hij ziet voor zichzelf, des te meer waar zijn zijn observaties.

De verdediging van marginaliteit veronderstelt het bestaan van een totalitair centrum, zegt Bruno Latour, maar dat centrum is een illusie. ${ }^{1}$ Marginaliteit is een zelfgeconstrueerde relatie met de instituties die het kwaad representeren. Dat die instituties misschien wel daarom alle mogelijke moeite doen om de buitenstaander buiten de deur te houden (en de insider binnen) is daarbij ook waar, maar omgekeerd is het voor de buitenstaander zelf niet minder belangrijk dat die twee werelden gescheiden blijven. Men denkt zich eens in wat er gebeurt als de wereld haar poorten opent en de buitenstaander binnenhaalt als de nieuwe messias...

De ondergrondse en bovengrondse wereld zijn dus aan elkaar gespiegeld, maar het zijn geen symmetrische werelden. De bovengrondse wereld is enorm divers en vol met tegenstrijdigheden, de ondergrondse wereld daarentegen is merkwaardig coherent. Alles hangt samen, overal bestaat verband, en niets blijft onverklaard. Het is verleidelijk, en gedeeltelijk ook wel terecht, om daarin een paranoïde grootheidswaan te zien, zoals bijvoorbeeld Freud deed ten aanzien van de 'querulantenwaan'. Maar omdat ik in dit boek de nadruk op de ontkenning als een instrument van betekenisgeving heb gelegd, wil ik hier een andere dimensie uitlichten, namelijk de vraag hoe vanuit het perspectief van de buitenstaander gezien onderscheid gemaakt kan worden tussen ware en onware kennis, of tussen legitieme aanspraken en niet-legitieme aanspraken op de werkelijkheid.

\section{Het geheim van het mysterie}

Voor de buitenstaander is het wetenschappelijke bedrijf, als gezegd, een onneembaar bolwerk. Alles wat zich daarbinnen afspeelt blijft buiten zijn bereik. Wetenschappelijke ontwikkelingen gaan langs hem heen en 
alle vernieuwing die niet binnen bekende en gevestigde kaders valt moet hij daarom wel afwijzen. Legitieme of ware uitspraken zijn uitspraken die hij kan vertrouwen, omdat ze altijd al waar waren. Maar geldt iets dergelijks eigenlijk ook niet voor de 'insiders doctrine'? Leidt ook de benadering van de binnenstaander niet tot een soort 'conceptueel chauvinisme', om Robert Mertons term te gebruiken - een blind vertrouwen in het eigen kunnen van de ingroup ?2 Waar insider en outsider tegenover elkaar staan als het gaat om wat 'echte kennis' is, staan ze merkwaardig genoeg zij aan zij als het gaat om het behoud van kennis.

$\mathrm{Nu}$ is het niet mijn bedoeling hier een wetenschapstheoretische discussie te openen over de aard van wetenschappelijke kennis, maar wel wil ik een bijzondere omstandigheid onderstrepen van het tijdperk waarin Van Dieren leefde. Het eind van negentiende en het begin van de twintigste eeuw zagen dramatische omwentelingen op wetenschappelijk, cultureel, maatschappelijk en politiek terrein. Dit is, zoals bekend, het tijdperk waarop het 'modernisme' zijn intree doet in het Westen. In de tijd van één generatie - die van Van Dieren - veranderde het leven in ontelbaar vele subtiele en soms ook schokkende opzichten. Van de opkomst van de sociaal-democratie en het vrouwenkiesrecht in de politiek tot de enorme verbeteringen op sociaal-hygiënisch vlak die de levensverwachting deed toenemen en de kindersterfte deed afnemen, tot de ontkerkelijking en het algemeen verlies aan geloof in de hogere machten - de moderne tijd drong in alle aspecten van het leven door. Maar wat een afschuwelijke ironie dat Van Dieren in meer dan één opzicht de uitzondering representeerde. Ik noem twee opvallende aspecten. In de eerste plaats zou zijn generatie voor het eerst worden toegestaan door de sociale barrières heen te breken. Hij maakte daarvan dankbaar gebruik door als hbs'er van lagere komaf te gaan studeren - maar toch zou hij het gevoel hebben er nooit bij te horen. Ten tweede maakte Van Dieren als huisarts in de grote stad de enorme verbeteringen op het sociaal-hygiënische vlak van nabij mee - en toch stierven vijf van zijn acht kinderen.

Industrialisatie, mechanisatie en technologische vooruitgang gaven het moderne leven een immense opstoot, maar tegelijk zetten snel verschuivende inzichten in de wetenschap en radicaal veranderde politieke verhoudingen de zekerheden van gisteren op losse schroeven. Geen wonder dat die periode zowel de meest utopische alsook de meest pessimistische boeken heeft opgeleverd, waarin het heil der mensheid en haar ondergang in een vrijwel gelijkluidende toonsoort zijn bezongen. Dat alles greep de krantenlezer naar de keel - ook daar was geen ontkomen aan. 
In sommige opzichten beïnvloedden die parallelle ontwikkelingen elkaar. Toen Einstein de speciale relativiteitstheorie opstelde en tijd en ruimte aan een verdere abstractie onderwierp, opende hij een nieuw wetenschappelijk paradigma, maar hij creëerde tegelijk een probleem voor de buitenstaander. De abstracties van de relativiteitstheorie hielden voor de leek een grotere distantiëring in ten opzichte van zijn onmiddellijke belevingswereld. Einstein verbrak de intuïtieve betrekking waarin de mens zich ten opzichte van de dimensies tijd en ruimte had gesitueerd, ongeveer zoals Freud de mens van de veilige illusie beroofde dat hij een soeverein wezen is dat beschikt over een vrije wil en rationeel handelt. En zoals Marx de geruststellende zekerheid ondergroef dat er zoiets is als een 'natuurlijke orde' in de maatschappij waarin klassen en standen hun onveranderlijke plek innemen. Geen wonder dat Freud, Marx en Einstein Van Dierens voornaamste doelwitten vormden: het waren wetenschappers die zonder het te beseffen zijn wereld op de kop zetten.

We zijn die omwenteling van perspectieven in navolging van de wetenschapssocioloog Thomas Kuhn 'paradigmawisselingen' gaan noemen - fundamentele veranderingen van perspectief die doorgaans als een soort staatsgreep worden ervaren. Paradigmawisselingen worden begroet met weerstand die niet is gegrondvest in rationele argumentatie, maar in de onwil om een praktijk op te geven die tot dan toe prima had gefunctioneerd en nu opeens 'problematisch' of 'achterhaald' zou blijken te zijn. Een wetenschappelijke crisis kan een gevoel van onbehagen, misschien zelfs wanhoop, oproepen, schrijft Kuhn, en hij citeert Einstein die, toen hij ontdekte dat de gangbare natuurkundige opvattingen niet langer voldeden, het gevoel kreeg alsof 'de grond onder mijn voeten wegzakte en er nergens een fundering te bekennen was waarop we konden bouwen'. ${ }^{3}$

Dat aan de basis van die onzekerheid de rede, het verstand, heeft gestaan, is een vreemde paradox. De uitholling van rationaliteit door de ratio, zoals dat proces weleens is genoemd, leverde de 'moderne mens' uit aan door zichzelf geconstrueerde onzekerheden. Dat wat hem enorm heeft geëmancipeerd heeft hem tegelijk volkomen ontregeld. Modernisering hield een bevrijding, maar ook een diepe emotionele ontgoocheling in, ja, zelfs bijna een traumatische schok. ${ }^{4}$ Ze dwong de insider zowel als de outsider de wereld opnieuw uit te vinden, opnieuw betekenis te geven. En al gaven beiden verschillende antwoorden, de opgave om een nieuw evenwicht te vinden bleef voor hen hetzelfde.

Laten we eerst het perspectief van de insider beschouwen. In zijn opstel Problemen van betrokkenheid en distantie laat Norbert Elias 


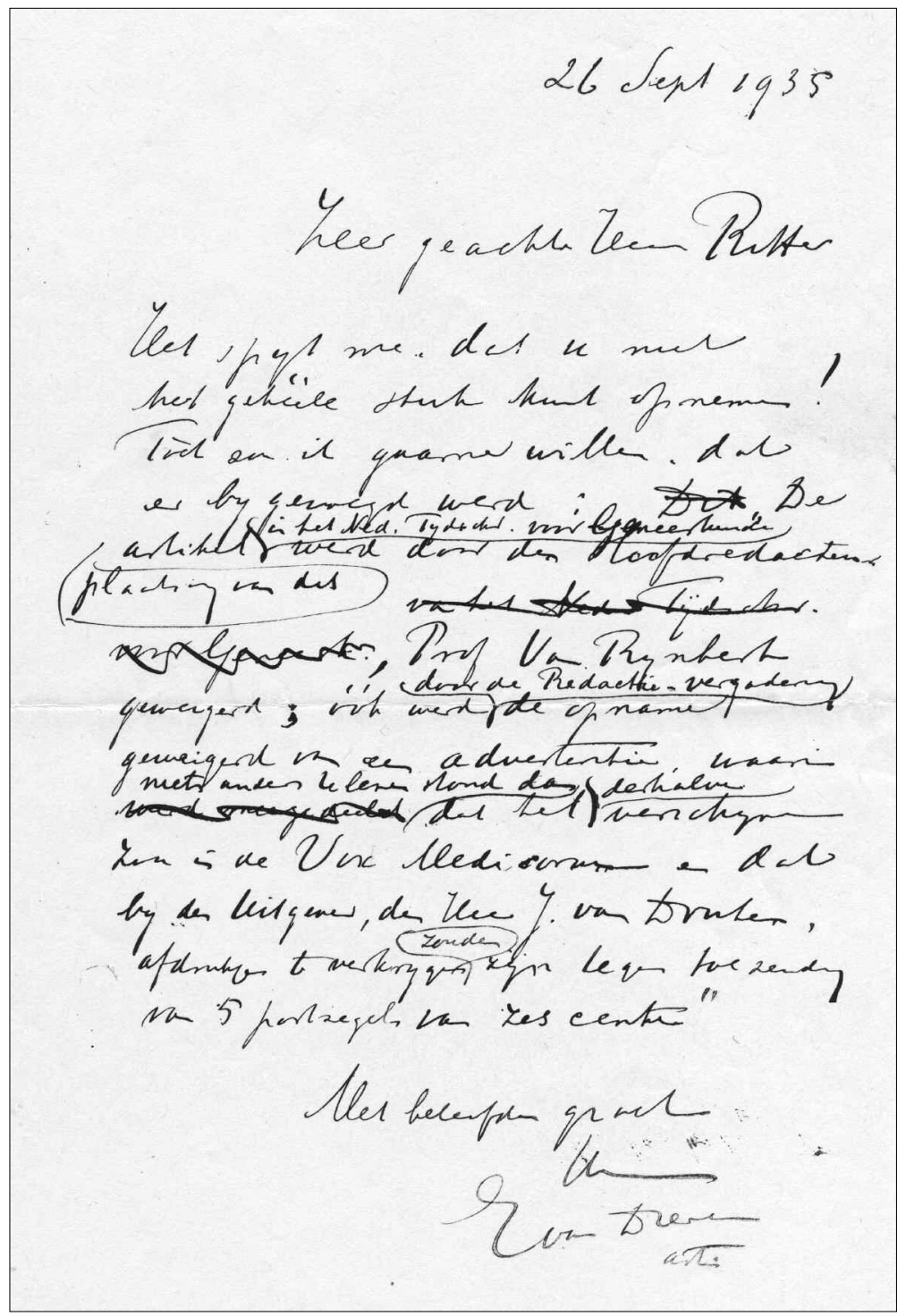

Laatste levensteken. Van Dieren aan P.H. Ritter.

zien dat iedere poging om met behulp van wetenschappelijke modellen vat te krijgen op veranderingen, vervat is in een dynamiek van zelfbeheersing en afstand nemen, zonder dat de wetenschapper daarbij overigens de betrokkenheid bij de dwingende logica van het alledaagse opgeeft. Met andere woorden, de wetenschapper gebruikt de weten- 
schap om afstand te scheppen en tegelijk om die afstand te overbruggen. Hij illustreert dit aan de hand van een parabel, ontleend aan Edgar Allen Poe. Twee vissers, broers van elkaar, worden met hun boot in een draaikolk gezogen. De jongste van de twee blijft verlamd van angst zitten en wordt verzwolgen; de oudste kijkt om zich heen en ziet dat sommige objecten sneller dan andere in de maalstroom naar beneden worden gezogen, handelt overeenkomstig de gevormde theorie en weet zich te redden. Elias schrijft dat de oudste broer had ontdekt dat hij de elementen in een onbeheersbaar proces kon gebruiken om de toestand voldoende te beheersen om zelf te kunnen overleven. ${ }^{5}$

In tijden van crisis is het volgens Elias voor de insider, de wetenschapper, bij uitstek van belang om distantie te ontwikkelen, maar ook om tegelijk voldoende tegenwoordigheid van geest te behouden om het onverklaarbare op te eisen en in te lijven in het wetenschappelijke keurslijf.

Hoe anders reageert de buitenstaander! Van Dieren was, zoals al zijn tijdgenoten, getuige van die reeks sociale, maatschappelijke en wetenschappelijke crises, en ze grepen hem hevig aan. Maar hij was niet bij machte er enige invloed op uit te oefenen, omdat hij in geen enkele ontwikkeling partij was; hij was onderzoeker noch revolutionair. Hij kon dus ook niet, zoals de echte wetenschappers met wie hij tevergeefs in debat trachtte te raken, conceptuele distantie ontwikkelen om greep te krijgen op de situatie. Toch liet hij de stortvloed van chaos en verwarring ook niet passief over zich heen komen. Hij was niet de jongere broer uit het bootje van Poe.

Als buitenstaander bevond Van Dieren zich op het snijvlak van verschillende sociale en maatschappelijke klassen, maar in geen ervan hoorde hij thuis. Het middenstandsmilieu waar hij van afstamde was hij ontgroeid, maar tot de gegoede burgerij behoorde hij net niet; als afgestudeerd dokter was hij ingewijd in de wetenschappen, maar wetenschapper was hij evenmin. Als auteur van een groot aantal boeken kon hij zich 'schrijver' noemen, maar onder de schrijvers telde hij niet mee. Als anti-freudiaan had hij de pennen in beweging gebracht van vooraanstaande psychiaters, maar in het debat telde zijn stem niet mee.

Doordat hij overal net buiten de boot viel was zijn positie in veel opzichten uniek. De strategie die hij ontwikkelde om greep te krijgen op de ontwikkelingen en veranderingen die zich in zijn tijd voltrokken ligt in het verlengde van de logica die hoort bij zijn positie. In plaats van wetenschappelijke distantie zette hij in op een strategie die lijkt op het tegenovergestelde, maar dat niet is, zoals we zullen zien. Door zich- 
zelf als centrum te kiezen van aandacht, het centrale punt van waaruit de wereld wordt begrepen, wist hij zich heel die verandering toe te eigenen, alsof hij aan de basis van alles stond.

Abstracte wetenschappelijke vraagstukken werden voor hem persoonlijke, identiteitsrelevante problemen. Met Einstein hield hij zich bezig alsof hij werkelijk met hem in gesprek was, met Eijkman was hij dat zelfs, althans eventjes. En verder probeerde hij met allerlei mannen van naam in persoonlijke aanraking te komen om hen voor zijn eigen plannen te gebruiken, zoals hij dat zelf zo treffend uitdrukte. Hij trok zich terug in zekerheden die hij onmiddellijk kon waarnemen met zijn eigen ogen. Ziekte en gezondheid, opstootjes in vergaderingen, letterkundigen die de taal, zijn taal, probeerden te hervormen, socialisten die tot in de gemeenteraad waren doorgedrongen, hun boeken en artikelen en alle andere fenomenen die zich aan hem persoonlijk presenteerden groeiden uit tot metafysische grootheden van absolute proporties, waarin hij zelf steeds als spil fungeerde. De buitenstaander verklaart de wereld door zichzelf als oorzaak van alle beweging aan te wijzen.

We hebben die strategie van toe-eigening 'mystificatie' genoemd, en gezien dat die een ondermijnende functie heeft. Via mystificatie eist de buitenstaander de wereld op en poogt hij ieder ander eruit te verdrijven. Vandaar dat de socioloog Erving Goffman zegt dat mystificatie als strategie een vorm van sociale distantie inhoudt. De mystificerende voorstelling schuift tussen het publiek en de gebruiker als een vreemde, onverklaarbare grootheid. Mystificatie houdt het publiek op afstand en verschaft de gebruiker manoeuvreerruimte om een indruk naar eigen keuze op te bouwen, ook als de keerzijde daarvan is dat achter de mystificerende voorstelling een leegte gaapt die met alle macht aan het zicht moet worden onttrokken. Want het geheim van het mysterie is dat er geen geheim is - het werkelijke probleem ligt dan ook in de vraag hoe men kan verhinderen dat het publiek dit te weten komt. ${ }^{6}$

\section{Hommes seule}

In de loop van zijn leven is Van Dieren de werkelijkheid in al haar details gaan zien als in toenemende mate kenbaar, en weigerde hij te accepteren dat er iets was wat zijn bevattingsvermogen te boven ging. De waarheid beschouwde hij a priori als 'eenvoudig', omdat die in hem zelf besloten lag. Er was in zijn perceptie een rechtstreeks verband tussen wat hij zag, dacht en deed. Hij was als subject een ondeelbare eenheid, volmaakt en onvergelijkelijk, volslagen doorzichtig als het ware, ook voor zichzelf. Een god aan de oppervlakte van zijn gedachten. 
Van die solipsistische perfectie is ieder ander uitgesloten die zich niet zijn zienswijze volkomen heeft eigengemaakt. Van Dieren was zich daarvan bewust en probeerde met grote precisie de persoon bloot te leggen die achter de buitenstaander schuilging. Hij stopte zijn werk vol met verwijzingen naar zijn eigen leven, iedere gebeurtenis fungeerde als een vingerwijzing, een hulpmiddel om tot de waarheid te komen. Toch zou het voor de ander juist daardoor steeds moeilijker worden om hem te volgen.

Wat begon als een eenvoudige, bijna niet te missen observatie van de naakte waarheid raakte bedolven onder de meest uiteenlopende schijnbaar volslagen ongerelateerde details, waardoor het zicht op de waarheid steeds verder werd belemmerd. Dit was voor de buitenstaander Van Dieren een onoplosbaar probleem. Alles wat de waarheid dichterbij zou moeten brengen had het omgekeerde effect. Zo hij al ooit eens gelijk zou hebben gehad, dan was het uit de warboel van opgestapelde bewijzen niet meer op te maken, en ten slotte kwam hij helemaal alleen te staan in zijn volstrekte en absolute gelijk.

\section{Don Quichottes droom}

Buitenstaanderschap is dat wat de positie van buitenstaander voortbrengt en tegelijk dat wat overwonnen moet worden, en dit verklaart misschien de continue beweging tussen afstoten en aantrekken die we in dit boek hebben gezien, waarbij de buitenstaander als het ware heen en weer wordt geslingerd tussen wel en niet meedoen aan het publieke debat. Hij is veroordeeld om eeuwig de dialoog met de ander te blijven zoeken zonder ooit in gesprek te raken.

Vanuit het perspectief van de buitenstaander lijkt het wel of hij altijd achtergesteld is, en vanuit die achtergestelde positie voorwaarts moet zien te snellen, als de haas in de fabel van Zeno, en nooit aankomt. Hij blijft eeuwig achtergesteld. Maar de achterstand die hij zichzelf oplegt mag helemaal niet worden overbrugd; het is juist een middel om de ander op afstand te houden. In feite is de achterstelling een metafoor voor de twee werelden die elkaar steeds net niet raken: de ondergrondse wereld van de schrijver die in zijn eigen teksten leeft en de bovengrondse wereld 'daar buiten', die onbereikbaar ver weg lijkt en toch zo dichtbij is. Daartussen liggen bruggen die nooit de overkant zullen halen.

Daarmee is de vergelijking tussen de buitenstaander en de tegen windmolens vechtende Don Quichotte waarmee Van Dieren vaak is vergeleken, treffender dan aanvankelijk wellicht is gedacht, want Don 
Quichotte is meer dan alleen maar een komische figuur. Laten we daarom nog één keer terugkomen op de figuur van de dolende ridder.

Michel Foucault heeft in De woorden en de dingen een paragraaf gewijd aan deze figuur wiens taak het is de wereld te ontcijferen. Of liever gezegd is hij veroordeeld om de onmogelijke relatie aan te tonen tussen de wereld en de taal over de wereld. Het is een hopeloze taak, want de woorden keren zich steeds tegen hem. Don Quichotte is, in de woorden van Foucault, in het diepst van zijn wezen 'geschreven tekst die in de wereld, tussen de op-elkaar-gelijkende-dingen in, ronddoolt'. Hij is 'betekenis' die ontsnapt is aan de wereld en nu voortdurend, maar tevergeefs, naar manieren zoekt om daarin terug te keren. Dat is de kern van de positie van de buitenstaander. Maar volkomen mislukt is hij niet; Don Quichotte heeft een eigen realiteit aangenomen die hij aan de taal zelf te danken heeft, en aan niets anders. Hij heeft een identiteit gevonden die geheel binnen die woorden gevangen blijft maar blijft bestaan zolang hij spreekt. ${ }^{7}$

Vergelijk het werk van Van Dieren, dat als een enorme barricade 256 tegen de oprukkende modernisering werd opgeworpen, met de uitspraak van iemand die in zijn droom zegt 'Ik droom'. Wittgenstein heeft die situatie eens onder de loep genomen en geconcludeerd dat die uitspraak onwaar is, omdat de conditie waarbinnen ze wordt gedaan niet overeenkomt met die waarbinnen taal normaal gesproken wordt geproduceerd en begrepen. ${ }^{8}$ Iets soortgelijks kan over het werk van Van Dieren worden gezegd: het hele oeuvre is beschouwd vanuit het perspectief van degene die niet droomt 'onwaar' - dat wil zeggen: niet relevant. Maar dat geldt niet voor Van Dieren zelf, die opgesloten zat in zijn eigen buitenstaanderschap en daarbinnen betekenis moest zien te geven aan wat hem overkwam.

\section{Don Quichottes aller landen...}

Zoals Van Dieren zijn er velen geweest, en ze zijn er nog. De buitenstaander ontleent op een geuzenachtige manier kracht uit de afwijzing van de ander, maar kan anderzijds ook inhoudelijk uit het repertoire van normen, waarden en gedragingen van de dominante partij putten om zijn eigen identiteit vorm te geven. Van een simpele omkering van gedragingen (precies doen wat zij niet zouden doen) tot een krachtig als 'anders' gedefinieerde waarde (waar zij dit doen, doe ik nu juist dat): de zelfmarginaliseringstechnieken schurken dicht tegen de marginaliseringstechnieken van de dominante partij aan en maken de marginaal tot een herkenbare, makkelijk te identificeren figuur. 


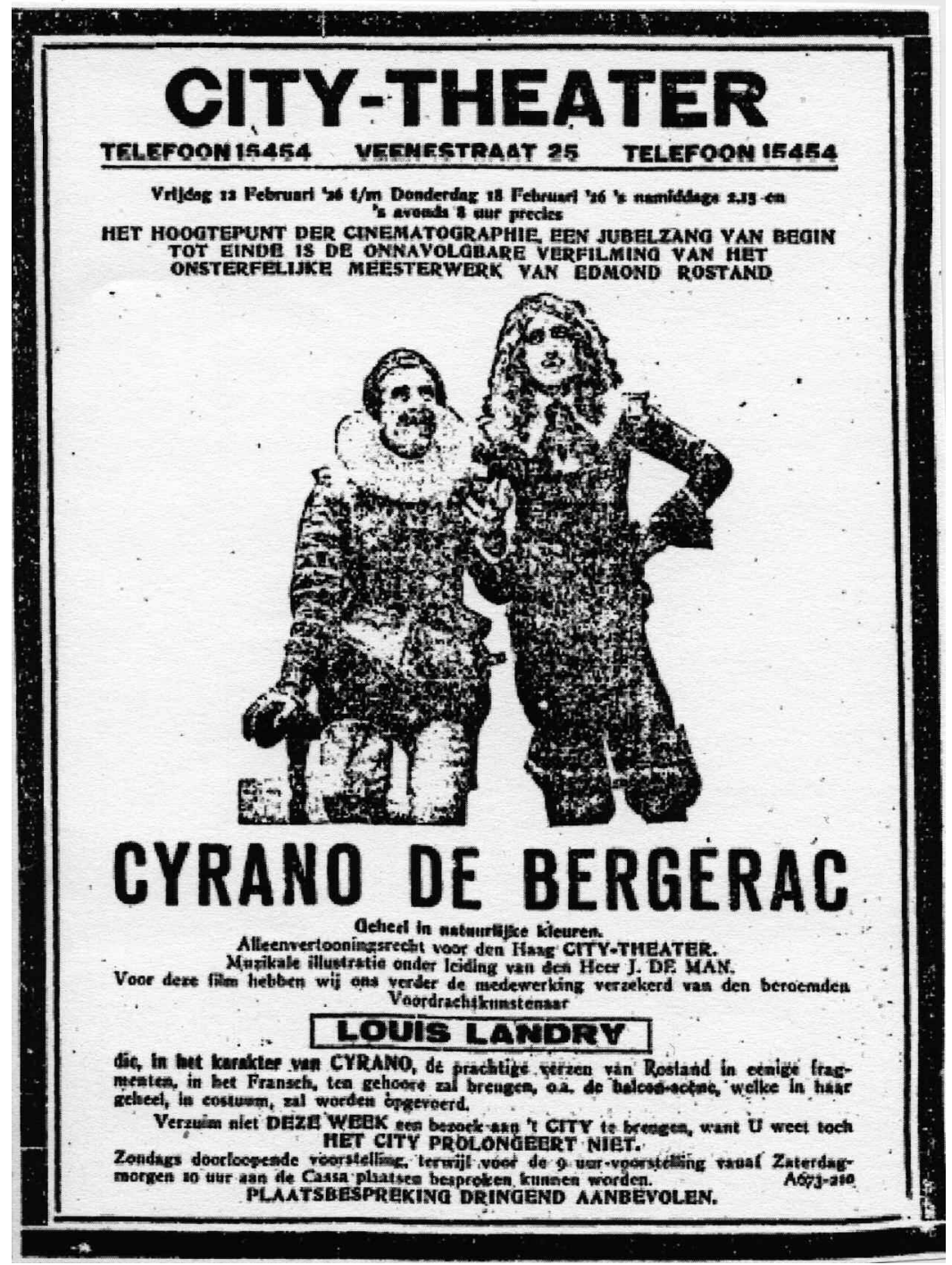

Cyrano de Bergerac: 'Ik heb gevochten tegen dombeid, oppervlakkigheid, halfheid, karakterloosheid en gebrek aan ridderlijkheid.'

Sommige buitenstaanders hebben een plaatsje in de geschiedenis weten af te dwingen door zich met een fantastische hardnekkigheid vast te bijten in hun eigen mislukking en via het vliegwiel van een of ander idee-fixe, een waanopvatting of misschien alleen maar een niet erkende ingeving, waarmee ze een eigen in zichzelf gedefinieerd parallel univer- 
sum konden oprichten, waarin ze zelf de finale autoriteit konden zijn. Enkelen stichtten eigen instituten, scholen, tijdschriften en opleidingen (de voorwaarde om volgelingen te kweken), en bereikten zodoende zelfs een publiek, waardoor ze boven zichzelf wisten uit te groeien en aanzien wisten te verwerven met weinig meer dan hun buitenstaanderschap.

Maar tegenover iedere succesvolle mislukkeling staat een leger van onsuccesvolle mislukkelingen die er niet in slagen voldoende momentum voort te brengen om de aandacht van het publiek ook maar een ogenblik vast te houden. Zonder de mogelijkheid om werk op eigen kosten te laten drukken en binnen eigen kring te verspreiden, zonder een netwerk van sympathisanten, zonder de steun van een groepje 'volgelingen' is de onsuccesvolle mislukkeling gedoemd een in alle opzichten marginale positie te moeten innemen. Zijn werk zal nooit in het publieke domein doordringen, zijn ideeën zullen geen enkele weerklank vinden, zelfs geen tegenspraak. De outcast belichaamt de ramp die permanent op de loer ligt en ons ieder moment kan overkomen, 258 zoals de geslaagde buitenstaander de oneindige verten belichaamt van wat mogelijk is in een ander, imaginair leven.

Tussen die twee extremen, van geslaagde en mislukte mislukking, bevind zich het gros van de mensen; zij zijn erin geslaagd de mislukking op afstand te houden en hebben hun leven binnen de smalle paden van het normale weten te loodsen. Maar ongevoelig voor de dynamiek van het marginale zijn zij niet. Huiverend voor het volkomen falen dat nooit ver verwijderd is enerzijds, en dromend van de gezagsondermijnende vrijheid die op steenworp afstand in het verschiet ligt anderzijds, legt de mens de wereld zijn zekerheden op in de vorm van zelfgeconstrueerde wetten - niet eens in de veronderstelling dat de wereld zich daaraan zal houden, maar eerder in de hoop dat ze hem houvast zal bieden hem overeind te houden en helpt te behoeden voor het ongeluk. Maar hij weet ook dat de buitenissige stelsels, vreemdsoortige opvattingen en zelfingenomen fantasieën van de mislukkeling met een verbazend gemak dwars door die zorgvuldig opgebouwde, hecht doortimmerde systemen prikken, waarop hij zijn kennis heeft gebouwd en die hij in de grond van de zaak niet kan beschermen anders dan door een krampachtig volgehouden stilzwijgen dat misschien alleen maar verhult dat ook hij het niet weet. 


\section{Overzicht publicaties van Van Dieren}

Dieren, E. van (г 887) Critiek op de beweringen van Prof. Pekelharing omtrent de beri-beri. Arnhem: K. van der Zande.

Dieren, E. van (I2.I 2.I 887) [Ingezonden brief]. Arnhemsche Courant.

Dieren, E. van (I 888) Nogmaals: De beri-beri questie. Arnhem: K. van der Zande.

Dieren, E. van (I 888) [Ingezonden brief]. Nederlandsch Militair Geneeskundig Archief, p. $575-584$.

Dieren, E. van (I 888) 'Dupliek aan C.L. van der Burg'. Nederlandsch Militair Geneeskundig Archief, p. 585-586.

Dieren, E. van (22.9.I 888) [Ingezonden brief]. NTvG, p. 288-292.

Dieren, E. van ( 1890 ) Voor artsen en Leeken: indien ik aan tuberculosis leed, liet ik mij niet inspuiten met het middel van Koch. Amsterdam, brochure in eigen beheer.

Dieren, E. van (I89I) Für Aerzte und Laien: wenn ich tuberculos wäre, ich wurde mich nicht mit dem Koch'schen Mittel einspritzen lassen. Amsterdam.

Dieren, E. van (I89I) Het middel van Koch veroorzaakt tuberculosis in plaats van deze te genezen. Amsterdam, brochure in eigen beheer: H.C. Delsman.

Dieren, E. van (29.9.I 894) 'Open brief aan Z. Exc. den Minister van Koloniën'. Medisch Weekblad, 26, p. 337-342.

Dieren, E. van (I897) Kantteekeningen op Dr. Vorderman's Beri-beri-Rapport en nog iets. Amsterdam: Scheltema \& Holkema's Boekhandel.

Dieren, E. van ( I 897) Beri-Beri eene rijstvergiftiging: critisch-historische bijdrage tot de kennis der meelvergiften. Amsterdam: Scheltema \& Holkema's Boekhandel.

Dieren, E. van (I 897) Beri-Beri eene rijstvergiftiging. Verweerschrift contra Dr. C.L. van der Burg's aankondiging van Beri-beri eene rijstvergiftiging: critisch-historische bijdrage tot de kennis der meelvergiften. Amsterdam, brochure in eigen beheer: De Roever Kröber \& Bakels.

Dieren, E. van (I3.3.I 897) 'Beri-beri een rijstvergiftiging' NTvG, 437-439.

Dieren, E. van (I 897) 'Beri-Beri eene rijstvergiftiging. Verweerschrift tegen Dr. Gelpke's aanval: "Gelpke contra van Dieren".' Geneeskundig Tijdschrift voor NederlandschIndië, p. 545-563.

Dieren, E. van (8.I.I 898) 'De bestrijding der Beri-Beri, eerst maatregelen daarna een congres.' Medisch Weekblad, p. 634-639.

Dieren, E. van (I 4.2.I898) 'Kantteekeningen op de Medische Kroniek van 9 Jan. Aan de lezers van het Handelsblad.' Algemeen Handelsblad, ochtendblad.

Dieren, E. van (feb. I 898) 't Kan verkeeren.' Indische Gids, p. I 8 5-1 86.

Dieren, E. van (I 898) Begripsverwarring of erger? Een antwoord op prof. Dr. C. Eykman's artikelen over "Beri-beri en voeding". Amsterdam, brochure in eigen beheer (meegezonden met $N T v G$ van 3I.I2.I I 898).

Dieren, E. van (I4.9.I90I) 'Door verkeerde wets-interpretatie tot bemoeilijking van het verzekeringsbedrijf.' $N T v G$, p. 6I I-6I6.

Dieren, E. van (I.I I.1902) 'Wat ik werkelijk denk over het verstrekken van schoolpantoffels enz. van gemeentewege; met een aanhangsel over gewichtige medisch-sociale onderwerpen (voor elck wat wils).' De Telegraaf, ochtendblad.

Dieren, E. van ( 1903$)$ Ter overname aangeboden: drie voorstellen voor de algemeene vergadering. Amsterdam, brochure in eigen beheer. 
Dieren, E. van (I4.3.I903) 'Dr. Schouten. Zal hij bij dreigend pokkengevaar zijne nietgevaccineerde kinderen inenten, ja of neen?' $N T v G$, p. 583-59I.

Dieren, E. van (I6.5.1903) 'Urgent of niet-urgent?’ $N T v G$, p. I I70-I I72.

Halbertsma, S.J., E. van Dieren, J.A. Lodewijks, A.C. van Bruggen en H.J.M. Schoo (23.5.1903) 'Rapport der commissie voor de herziening van de "wet op de besmettelijke ziekten”.' NTvG, p. I I97-I237.

Dieren, E. van (I3.6.I903) 'Bespreking van eenige oude en nieuwe geschriften over de oorzaak van beri-beri en aanverwante zaken'[Opgenomen in: verslag Genootschap ter bevordering der Natuur-, Genees-, en Heelkunde te Amsterdam] NTvG, p. I432I440.

Dieren, E. van (20.6.1903) 'Het rapport der commissie voor de herziening der wet op de besmettelijke ziekten $=$ "dilettantenwerk van inferieure kwaliteit?"' $N T v G$, p. I48II489.

Dieren, E. van (4.7.1903) 'Weerlegging van eenige bezwaren tegen het rapport der commissie voor de herziening van de wet op de besmettelijke ziekten.' NTvG, p. 5I-52.

Dieren, E. van (II.7.I903) 'Dr. Oosterbaan en het rapport der commissie voor de herziening van de wet op de besmettelijke ziekten.' $N T v G$, p. IOI-IO9.

Dieren, E. van (26.8.1903) 'Hoe de "Algemeene Vergadering” zich gedroeg ten opzichte van het "Rapport der Commissie voor de besmettelijke Ziekten".' Vox Medicorum, p. I32-I 42 .

Dieren, E. van (1903) Aan den leden van den Amsterdamschen Geneeskundigen Kring. Ter rechtvaardiging van mijzelf, ter kenschetsing mijner bestrijders, ter vergemakkelijking van mijn taak voor het vervolg. [Open brief aan de leden van de Amsterdamsche Geneeskundige Kring.] Amsterdam, brochure in eigen beheer: De Roever Kroeber en Bakels.

Dieren. E. van (5-6.5.1904) 'De mazelen hebben in Nederland vrij spel! Hoe lang nog?' Feuilleton in 2 afleveringen. De Telegraaf, avondblad.

Dieren, E. van (I4.5.I905) 'Over geschiktheid voor huwelijk en moederschap.' Algemeen Handelsblad.

Dieren, E. van (1905) Over vaccinatie en hare bestrijders. Baarn: Hollandia Drukkerij.

Dieren, E. van (I906) Over schoolartsen. Aan het Bestuur en de Leden van de Plaatselijke Commissie van Toezicht op het lager Onderwijs. Amsterdam: Scheltema \& Holkema.

Dieren, E. van (I.I 2.1906) ““Geen schoolartsen! Wat dan wel?”” NTvG, p. I 573-I 577.

Dieren. E, van (8.I2.I906) 'Voor het laatst: “Geen schoolartsen! Wat dan wel?”'NTvG, p. I656-I657.

Dieren, E. van (1907) Meelvergiftigingen: beri-beri, pelagra, kriebelziekte, erwtenziekte, polaranaemie, enz. Amsterdam: Scheltema en Holkema's Boekhandel.

Dieren, E. van (I908) 'De kring als Vakvereeniging op den verkeerden weg! Een voorstel tot intrekking van het bindend besluit tegenover de Foresters.' [Feuilleton in 3 afleveringen]. Vox Medicorum, 7.7.1908, p. IIO-III; 22.7.1908, p. II6-II7; 5.8.1908, p. I22-I23. Ook als aparte brochure verschenen onder dezelfde titel.

Dieren, E. van (I3.I0.1908) 'Een Psychische besmetting'. De Telegraaf, avondblad.

Dieren, E. van (24-27.I0.1908) 'Gevaarlijke onderwijzers'. [Feuilleton in 2 afleveringen]. De Telegraaf.

Dieren, E. van (1908) Geboycot en vogelvrij verklaard? Amsterdam, brochure in eigen beheer: Drukkerij 't Kasteel van Aemstel.

Dieren, E. van (1909) Het socialistisch gevaar. Eene bijdrage tot de kennis der besmettelijke zielsziekten. Tevens een waarschuwing aan autoriteiten, ouders en onderwijzers, enz. Amsterdam: Vivat. 
Dieren, E. van (22.5.1909) [Ingezonden brief] 'Het Socialistische Gevaar'. Algemeen Dagblad, ochtendblad.

Dieren, E. van (29.6.1909) [Ingezonden brief] 'Socialistische taktiek'. Het Volk.

Dieren, E. van (I7.4.1909) 'Beri-beri en rijstvoeding'. NTvG, p. I256-I 262.

Dieren, E. van (22.I.I9IO) 'De beri-beri geen infectie-ziekte'. NTvG, p. 258-259.

Dieren, E. van (I910) Kleine Nederlanders! Amsterdam: Holkema \& Warendorf.

Dieren, E. van (II.2.I9II) 'Het wetsontwerp tot wijziging der bepalingen omtrent de koepokinenting'. Nederlandsch Tijdschrift voor Geneeskunde, p. 589-590.

Dieren, E. van (I I.7.I9I I) 'Het rapport inzake de bestrijding van geslachtsziekten.' NTvG, p. 50.

Dieren, E. van (8.7-I 2.9.I9I I) 'Het Kamerlid Jhr. Mr. A. F. de Savornin Lohman als vaccinehater op weg van bekeering.' Moleschott. Opgenomen in Van Dieren, I9I2: het Kamerlid Jhr. Mr. A.F. de Savornin Lohman (enz.).

Dieren, E. van (I9I2) Bijgeloof en misbruik op medisch en hygiënisch gebied. Populaire voordracht (gehouden op 28 maart I9I2, in het Nederlandsch Hygiënisch genootschap). Amsterdam: Scheltema \& Holkema's Boekhandel.

Dieren, E. van (I9I 2) Het Kamerlid Jhr. Mr. A. F. de Savornin Lohman als vaccinehater op weg van bekeering. Amsterdam: Scheltema \& Holkema's Boekhandel.

Dieren, E. van (1913) Darwinisme en ongeloof. Een bijdrage tot de kennis der Schijnwetenschap. Baarn: Hollandia Drukkerij.

Dieren, E. van (I9I4) Op dwaalwegen: spel van den woeligen tijd in vier bedrijven. Amsterdam [zonder drukker]

Dieren, E. van (I 5.6.191 5) 'De ziel van het "Duitsche volk" of... de zwarte ziel van een leugenachtigen Franschen Journalist?' De Telegraaf.

Dieren. E. van (I9I 5) Is de Telegraaf een... Engelsche krant? Wie veroorzaakten den oorlog? Van welke kant dreigt voor Nederland het meeste gevaar? Wat is de taak en de plicht van iederen Nederlander? Is de Schrijver van "J'accure" een waarheidslievend Duitscher of een... minderwaardigheids-type? Amsterdam: W. ten Have.

Dieren, E. van (I9I5) Meelvergiftiging of gebrek? ("Mixed-pickles voor rijst- en andere meeleters"). Rede gehouden in den Amsterdamschen en den Rotterdamschen geneeskundigen Kring. Baarn: Hollandia.

Dieren, E. van (I9I6) 'Over sport.' Moleschott. Opgenomen in: Van Dieren (I9I7) De nadeelige invloed van fel zonlicht (enz.).

Dieren, E. van (I9I6) Gedanken eines Hollanders über den Weltkrieg. Berlijn: Concordia Verlag (Duitse vertaling van Is de Telegraaf een... Engelsche krant?)

Dieren, E. van (I9I7) De nadeelige invloed van fel zonlicht en sport op lichaam en geest. Amsterdam: W. ten Have.

Dieren, E. van (I8.I0.I9I8) [Ingezonden brief]. Medisch Weekblad. Opgenomen in: Van Dieren (I9I9) De waanzinnige waereld, p. 245-247.

Dieren, E. van (1919) De waanzinnige waereld. Een zielkundige ontleding van de huidige socialisten en hunne voorgangers. Amsterdam: Van Rossem.

Dieren, E. van (I919) De averechtse geestesrichting der zoogenaamde "nieuwlichters" op allerlei gebied; in het bizonder die der Kollewijners en hun verderfelijke invloed op onderwijs, taal en volk. Amsterdam: Swets \& Zeitlinger.

Dieren, E. van (1920) De anti-these. Spel van den woeligen tijd in drie bedrijven. Amsterdam: Van Rossem.

Dieren, E. van (1920) De gemeentelijke melkvoorziening: 'n financiëele ramp en 'n hygiënische schijnvertooning, waaraan enkel socialistische bedoelingen ten grondslag liggen. Amsterdam: Uitgeverij 'De Belastingbetaler'. 
Dieren, E. van (ca. I920) 'Waarom vaccinatiedwang?' Vox Medicorum. Ook verschenen als aparte brochure. Zonder imprimatur.

Dieren, E. van (6.I I.I920) 'Salon des refusés'. NTvG, p. I947-I949.

Dieren, E. van. (25.2.1922) 'De strijd tegen de diphtherie'.NTvG, p. 80I-802.

Dieren, E. van. (22.3.I922) 'De strijd tegen de diphtherie'. NTvG, p. I I 29-I I 30.

Dieren, E. van (I.4.1922) 'Ongevaarlijke homosexueelen? “Wat beslist niet mag!”Wat mij al lang op het hart lag, en wat o zoo nodig eens ongezouten, in rond Nederlandsch gezegd moet worden!'” NTvG, p. I 270-I 274.

Dieren, E. van (I922) Historisch-idealisme of historisch-materialisme? Opbouwen of ondermijnen? (2 delen) Amsterdam: Van Rossem.

Dieren, E. van (2I.IO.1922) 'Een in casu onbelangrijke vraag: socialist of niet?' $N T v G$, p. I 873 -I 874 .

Dieren, E. van (4.II.I922) 'Een kleine rectificatie'. NTvG, p. 2 I08.

Dieren, E. van (II.II.I922) 'Grieksche of andere cultuur?’ NTvG, p. 2204-2205.

Dieren, E. van (1923) 'Voor den beoefenaar der geneeskunst is kennis der geschiedenis noodzakelijk! Linnaeus, Henle en Pasteur'. NTvG, p. I645-I650.

Dieren, E. van (22.6.1923) [Ingezonden brief] 'De theorie van Einstein'. Het Vaderland, avondblad.

Dieren, E. van (1924) Toelichtingen behoorende bij de voordracht van den Arts E. van Dieren over: de nieuwe opvattingen omtrent "Beri-beri en anderen avitaminosen"in het licht der geschiedenis. In eigen beheer gedrukte brochure. Zonder imprimatur.

262 Dieren, E. van (I7.6.1925) [Boekaankondiging van] 'Psycho-Analyse en Godsdienst' [en] 'Ideeën van Freud'. Vox Medicorum, (I 2), p. I I 5 .

Dieren, E. van (26.8.1925) 'Freud'sche Psychoanalyse is niets anders dan Dadaïstische zwijnerij'. Vox Medicorum, I 59-I6I.

Dieren, E. van (3.7.1926) 'Dankbaarheid in advertenties'. NTvG, p. Iоo.

Dieren, E. van (I 2-26.I.I927) 'De Psycho-Analyse en hare verfilming'. [Feuilleton in 2 afleveringen.] Vox Medicorum, p. I-4; I3-I6.

Dieren. E. (19.7.1927) 'Prof. Freud en diens verderfelijke oud-Grieksche opvattingen op sexueel gebied'. Het Vaderland, avondblad.

Dieren, E. van (5.IO.1927) “'On ne peut pas contenter tout le monde et van Dieren”'. Vox Medicorum, p. 200-205.

Dieren. E. van (1927) Futuristische behandeling van Zielszieken. (Freudsche psychoanalyse; zoogenaamde "Zielsontleding") Wetenschap of waanzin? Weldaad of misdaad? Haarlem: Amicitia Drukkerij.

Dieren, E. van (27-29.6.1927) 'De psychoanalyse'. Het Vaderland.

Dieren, E. van (I4-28.I2.I927) “"Klein, onredelijk, onzedelijk en oneerlijk. Zoo zijn hunnen manieren, manieren, zoo zijn hunnen manieren!”' [Feuilleton in 2 afleveringen]. Vox Medicorum, p. 25 I-255; 259-264.

Dieren, E. van (I I-2 5.I.I928) 'Dr. Cox en Prof. V. Rijnberk als propagandisten van den alte-woordenrijke, bijgeloovigen, onwetenschappelijken en pervers-denkenden Graaf Hermann Keyserling' [Feuilleton in 2 afleveringen]. Vox Medicorum, p. 2-6; I I-I7.

Dieren, E. van (2I.3.I928) 'Graaf Hermann Keyserling gevoelt een grenzelooze minachting voor àlle Psycho-analysanten; en tòch verwacht hij alle heil van de Psycho-Analyse! Hoe rijmt men zoo iets ongerijmds te samen?' Vox Medicorum, p. 5 I-57.

Dieren, E. van (3.IO.I928) “"Roodvonk of angina?" "Wat doet het er toe?" Wat wel ter zake doet!' Vox Medicorum, p. I9I-I98.

Dieren, E. van (1929) Het Beri-beri en vitamine-treurspel. Ongeloofelijke bizonderheden uit mijn 40-jarige strijd tegen laboratoriumgeleerdheid-op-haar-smalst, enz., enz. 
In eigen beheer gedrukte brochure. Amsterdam: De Amsterdamsche drukkerij Th. Bakker.

Dieren, E. van (I8.5.I929) 'Geen schoolartsen! Wat dan wel?’ NTvG, p. 24I4-24I 5.

Dieren, E.van (I930) 'Het verband tusschen de "Futuristische behandeling van zielsziekten volgens Freud" en "de Bolsjewistische geestesgesteldheid". Vox Medicorum. Verscheen ook als aparte brochure onder dezelfde titel. Utrecht: J. van Druten.

Dieren, E. van (193I) Besmettelijke zielsziekten voorheen en thans. De danszucht, de naaktlooperij, de geeselaarsvertooningen en de hand-over-hand-toenemende sportepidemie en hare bevorderaars (sportartsen enz.) met een naschrift gericht tegen een artikel van Prof. Snapper over "Het sporthart". Baarn: Hollandia Drukkerij.

Dieren, E. van (I93 I) Aan de bestuurders en leden van de Nederlandsche Maatschappij ter Bevordering der Geneeskunde. Amsterdam, open brief in eigen beheer: zonder imprimatur.

Dieren, E. van (1932) Prof. Freud. De uitvinder van de z.g. psychoanalyse of te wel "diepte"-zielkunde en het door velen onderschatte perverse gevaar. Baarn: Hollandia Drukkerij.

Dieren, E. van en A. Querido (8.7-4.8.1932) 'Dokter Van Dieren en Professor Freud' [Feuilleton in 3 afleveringen]. Vox Medicorum, (I 2-I 4), p. 93-95; I48-I49; I 52-I60). Verscheen ook als aparte brochure onder de titel: Verbreiding van Freudiaansche Wetenschap (?) door den Radioomroep! Antwoord op de Vara-Voordracht van den zenuwdokter A. Querido (Psychiater bij den Gemeentelijken Gezondheidsdienst te Amsterdam) over: "Dokter Van Dieren en Professor Freud". Utrecht: J. van Druten.

Dieren, E. van (29.7.I932) 'De massa-vergiftiging te Tjilatjap. Proeven op dieren en... op menschen'. Vox Medicorum, (I3), p. I49.

Dieren, E. van (9.8.1932) 'Een anti-Freudprijs van E. van Dieren'. Het Vaderland, avondblad.

Dieren, E. van (26.8.1932) 'Twee prijsvragen; de eene op Freudiaansch gebied; de andere op Vitamine-gebied'. Het Vaderland, avondblad.

Dieren, E. van (1932) Toelichting behoordende bij de voordracht die den I $8^{\text {den }}$ november door E. van Dieren, arts, gehouden zal worden over Het Beri-Beri-treurspel en het Vitamine-fiasco, ongelooflijke bijzonderheden uit mijn 45-jarigen strijd tegen laboratoriumgeleerdheid (?) en klasse-hygiënisten, enz. Amsterdam: de Amsterdamse drukkerij Th. Bakker.

Dieren, E. van (I933-I934) 'Juristerij op haar smalst.' [Feuilleton in I I afleveringen]. Vox Medicorum. 


\section{Overzicht publicaties over Van Dieren}

In dit overzicht zijn alleen boekbesprekingen en artikelen over Van Dieren opgenomen.

Titels tussen vierkante haken zijn door de auteur toegevoegd.

Amerongen, M. van (5.9.1970) 'Dokter van Dieren en de besmettelijke zielsziekte die "socialisme" heet.' Vrij Nederland, p. I9.

Anoniem (I4.IO.I 888) [Boekaankondiging van] 'Kritiek op Prof. Pekelharing.' Arhemsche Courant.

Anoniem (mei I 897) 'Koloniale literatuur. Een nieuwe bijdrage tot de beri-beri-literatuur.' Indische Gids, p. $683-687$.

Anoniem (7.6.1905) 'Voor ons nageslacht' [bespreking van artikel Van Dieren in het Algemeen Handelsblad dd. I4.5.I905.] Evolutie. Veertiendaagsch blad voor de vrouw, I 5 (5), p. 38-39

Anoniem (22.I.I908) [Boekaankondiging van] 'Meelvergiftigingen.' Vox Medicorum, p. I4.

Anoniem (II.5.I909) [Boekbespreking van] 'Het socialistisch gevaar.' Algemeen Dagblad, avondblad.

Anoniem (22.5.I909) [Boekbespreking van] 'Het socialistisch gevaar.' Algemeen Handelsblad, ochtendblad.

Anoniem (I4.7.I909) [Boekbespreking van] 'Het socialistisch gevaar.' Oprechte Haarlemmer Courant.

Anoniem (24.6.1919) 'Notities van een schoolmeester.' Het Volk.

Anoniem (4.7.1919) 'Een rumoerige lezing over bolsjewisme.' Het Volk.

Anoniem (17.7.1919) [Boekbespreking van] 'De waanzinnige waereld.' De Standaard, $2^{\mathrm{c}}$ blad.

Anoniem (17.2.1923) [Boekbespreking van] 'Historisch idealisme of historisch materialisme.' De Amsterdammer.

Anoniem (2.6.1927) 'Tegen Freud en de Freudsche theorie.' Het Vaderland, avondblad.

Anoniem (2.9.1932), 'Van Dieren overdrijft!' Het Vaderland.

Bles, Ch. (4.I I.I9I6) 'Dr. van Dieren en de Beri-beri-bestrijding.' De Amsterdammer.

Bos, J. (200I) 'De man die Freud haatte, ofwel Evart van Dieren contra het Perverse Gevaar. Een voetnoot bij een voetnoot'. Psychologie en Maatschappij, 25, p. 199-209.

Bos, J. (2003) 'De querulant en zijn prooi. Evart van Dieren versus Christiaan Eijkman en de beriberi-controverse (I897-I898).' Gewina, 26, p. I27-I47.

Bos, J. (2005) “'Weg met de spellingshervormers”.' De Groene Amsterdammer, 4.I I.2005, p. $44-47$.

Bos, J. (in druk) Dieren, Evart van (I86I-I940). Biografisch Woordenboek van Nederland, deel 6.

Braak, M. ter (I932) 'Moralisten als Don Quichottes' [boekbespreking van 'Besmettelijke zielsziekten.] Forum, p. 264.

Brinkgreve, C. en M. Pam (17.2.1979) 'Dokter van Dieren en het Freudsche gevaar.' Vrij Nederland, p. 26-27.

Brenkman, C. J. (23.9.1922) 'Het voorwoord van Van Dieren's Historisch-Idealisme of Historisch-Materialisme? Opbouwen of ondermijnen?’ NTvG, p. I450. 
Büch, B. ( 1983 ) 'Excentriek. E. van Dieren, arts, en de kritiek tegen àlle beweringen.' NRCHandelsblad, 25.6.1983, p. 20.

Burg, C.L. van der (I 887) [Boekaankondiging van] 'Kritiek op de beweringen van Prof. Pekelharing omtrent de Beri-Beri.' Nederlandsch Militair Geneeskundig Archief, p. 470-474.

Burg, C.L. van der (I 888a) 'Een paar opmerkingen naar aanleiding der brochure van E. van Dieren: Nogmaals de beri-beri-kwestie.' Nederlandsch Militair Geneeskundig Archief, p. $254^{-2} 28$.

Burg, C.L. van der (г 888b) [Ingezonden brief]. Nederlandsch Militair Geneeskundig Archief, p. 584-585.

Burg, C.L. van der (27.2.I897) [Boekaankondiging van] 'Beri-beri eene rijstvergiftiging.' $N T v G$, p. $355-360$.

Burg, C.L. van der (20.3.I 898) 'Beri-beri.' NTvG, p. 480.

Chouillet, A. (24.6.I9I 5) 'L'âme de l'Allemagne.' De Telegraaf.

Delprat, C.C. (29.IO.I 887) [Boekaankondiging van] 'Critiek op de beweringen van Prof. Pekelharing.' NTvG, p. 485-487.

Delprat, C.C. (I.9.I 888) [Boekaankondiging van] 'Nogmaals de beri-beri-kwestie'. NTvG, p. 226-228.

Det, E.J. van (maart-april I907) “'Sophistiek en onkunde”. Naar aanleiding van de artikelen van den heer E. van Dieren'. De Bode.

Eijkman, C. (20.II.I 897) [Ingezonden mededeling] 'Beri-beri en rijstvoeding.' NTvG, p. $897-900$.

Eijkman, C. (23.4.I898) [Ingezonden mededeling]. NTvG, p. 682-684.

Eijkman, C. (5.2.-I 9.2.I 898) 'Beri-beri en voeding. Een kritisch-historische studie.' NTvG, p. I $85-209 ; 233-247 ; 275-303$.

Eizenga, J.A. van (20.10.1908) 'Dokter van Dieren op de jacht naar rood wild.' De Telegraaf.

Feltkamp, T.E.W. (30.4.I932) [Boekaankondiging van] 'Besmettelijke zielsziekten.' NTvG, p. $2 \mathrm{I} 2 \mathrm{I}$.

Fokker, A.P. (I3.I I.I 897) [Boekaankondiging van] 'E. van Dieren: Kantteekeningen op dr. Vorderman's Beri-Beri rapporten nog iets.' $N T v G$, p. 843-846.

Fokker, A.P. (I6.4.I 898) [Boekaankondiging van] 'Vorderman's verweerschrift.' NTvG, p. $629-630$.

Fokker, A.P. (7.5.I 898) [Ingezonden brief]. NTvG, p. 773.

Giltay, H. (2.7.1927) [Ingezonden stuk]. Het Vaderland, avondblad

Gelpke, O.G. (г897) 'Ueber die Aetiologie der Beri-Beri. Gelpke contra van Dieren.' Geneeskundig Tijdschrift voor Nederlandsch-Indië, p. Iо8-I I 4.

Gorkom, W. J. van (nov./dec. I 897) 'De Beri-Beri Questie. Vergiftiging of infectie?' De Indische Gids, p. I470-I495; I 595-I623.

Hoeven, H. van der (3 I.5.1927) 'Wetenschap of waanzin?' Het Vaderland, avondblad.

Kessler, H. J. ( ( 897) 'Beri-beri geen rijstvergiftiging.' Geneeskundig Tijdschrift voor Nederlandsch-Indië, p. 339-358.

Lindeboom, G.A. (1984) 'Dieren, Evert van.' Dutch Medical Biography (1475-1975). Amsterdam: Rodopi, p. 442-443.

Leyds, W.J. (30.6.1927) 'Dr. van Dieren en de psychoanalyse.' Het Vaderland, avondblad.

Mot, Jan de (27.I2.I924) 'Dagboek van een Amsterdammer. Aan dr. E. van Dieren, jubilaris.' De Amsterdammer.

Muntendam, P. (2I.4.I906) [Boekaankondiging van] 'Over vaccinatie en hare bestrijders.' $N T v G$, p. I2I3-I2I 5 . 
Muntendam, P. (2I.4.I906) [Boekaankondiging van] 'Het Kamerlid Jhr. Mr. A.P. de Savornin Lohman als vaccinehater op weg van bekering.' $N T \nu G$, p. I008-I009.

Muntendam, P. (4.9.I9I5) [Boekaankondiging van] 'Is de Telegraaf een... Engelsche krant?' NTvG, p. I363.

Ophuijsen, J. van (I 6.6.1927) 'Voor de psychoanalyse.' Het Vaderland, avondblad.

Persenaire, J.B.C. (3I.7.I9I5) [Boekaankondiging van] 'Meelvergiftiging of gebrek? Mixed Pickles voor rijst en ander meeleters.' $N T \nu G$, p. 763-765.

Pinkhof, H. (5.7.I9I9) [Boekaankondiging van] 'De waanzinnige waereld.' NTvG, p. 5052.

Pinkhof, H. (23.4.I92I) [Boekaankondiging van] 'De Anti-these.' NTvG, p. 2329-233I.

Pijnappel, M.W. (9.I.I898) 'Medische kroniek.' Algemeen Handelsblad.

Postmus, S. (I960) 'Evart van Dieren en de aetiologie der beriberi.' Voeding (I8.4.I960), p. I39-I 46 .

Querido, A (I6.4.I932) 'Dokter van Dieren en Prof. Freud.' Voordracht voor de VARAradio, uitgezonden op I6.4.I932. Tevens gepubliceerd als feuilleton in 2 afleveringen in Vox Medicorum.

Rijnberk, G. van (I 5.IO.I932) 'Dr. van Dieren's jongste brochure.' NTvG, p. 4890-489I.

'S' (8.8.19r 8) [Boekbeoordeling] 'De nadeelige invloed van zonlicht en sport op lichaam en geest.' Het Volk.

Scheer, A. van der (7.3.1908) [Boekaankondiging van] 'Meelvergiftigingen.' NTvG, p. 777779.

Schnepper, L. (23.6.I9I 5 ) 'De heer E. van Dieren en de Duitsche keizer.' De Telegraaf.

Sleeswijck, J.G. (I I.7.I9I4) [Boekaankondiging van] 'Bijgeloof en misbruik op medisch en hygiënisch gebied.' $N T v G$, p. I 57-I 59 .

Swaab, B. (7.9.19ı 8) [Boekaankondiging van] 'De nadeelige invloed van fel zonlicht en sport op lichaam en geest.' $N T v G$, p. 808-8 Io.

'V' (22.4.1903) 'De voorstellen van Dr. van Dieren.' Vox Medicorum, p. 59-60.

Valkenburg, C.T. (30.4.I932) [Boekaankondiging van] 'Prof. Freud.' NTvG, p. 2 I I9-2 I 20.

Vorderman, A.G. (I 897) Onderzoek naar het verband tusschen den aard der rijstvoeding in de gevangenissen op Java en Madoera en het voorkomen van beri-beri onder geïnterneerden. Batavia: Landsdrukkerij.

Vorderman, A. G. (I 898) 'Toelichting op mijn beri-beri-verslag.' Geneeskundig Tijdschrift voor Nederlandsch-Indië.

Voorthuis, J.A. (8.I.I 898) 'Mededeeling over beri-beri.' NTvG, p. 4I-49.

Vorrink, C. (3.7.I909) 'De psychiater 'par excellence.' Het Volk.

Westerman Holstijn, A. J. (30.4.I927) [Boekaankondiging van] 'Futuristische behandeling van zielszieken.' NTvG, p. $2358-2359$.

Wilde, P.A. de (22.I2.I934) 'Gouden artsjubileum E. van Dieren.' NTvG, p. 5755.

Wilde, P.A. de (ז.6.I940) 'In memoriam Evart van Dieren.' NTvG, p. 2073-2075. 


\section{Geraadpleegde archieven}

Gemeentearchief Amsterdam

Instituut voor Sociale Geschiedenis, Amsterdam; Archief H.C. Muller

Koninklijke Bibliotheek, Den Haag, afdeling bijzondere collecties; archief Te Winkel.

Koninklijk Huisarchief, Den Haag, brievenboek Koningin Regentes Emma; brievenboek koningin Wilhelmina

Letterkundig Museum, Den Haag, archief J.H. Been

Rijksarchief Utrecht, archief Westerman Holstijn

Stadsarchief Zutphen

Universiteitsbibliotheek Amsterdam, archief handschriften (Van Eeden; Lanz; Verwey)

Universiteitsbibliotheek Leiden, archief Bolland

Universiteitsbibliotheek Utrecht, afdeling handschriften (Eijkman; Pijnappel; Voorthuis Van der Burg)

\section{Fotoverantwoording}

Omslag: Digitaal bewerkte foto van het portret van Van Dieren door G. Ruter.

p. 6: De Prins, december 1924 .

p. I4, I9, 32, I48 en I60: Uit het familiearchief van Hille van Dieren.

p. 22, I76, I 85, 204 en 2I I: boekomslagen van Averechtse geestesrichting (I9I7), Besmet-

telijke zielsziekten (1932), Prof. Freud en het perverse gevaar (1932), Op dwaalwegen

(1917) en Futuristische behandeling van zielszieken (1927).

p. 65: Het amusante boek, spotprent van Jan Rotgans uit De Notenkraker van 4 juli I 909.

p. 72: Bernard Eilers: Keizersgracht nabij nr. 700. Copyright Stadsarchief Amsterdam.

p. 75: Reclame voor De waanzinnige waereld, uit Het Centrum, I I december I9I9.

p. 84: Reclame voor Is de Telegraaf een...Engelsche krant? Uit: Het Centrum, 25 juli I9 5.

p. 94: Portret Cornelis Pekelharing door J. Merkelbach, overgenomen uit: J.M. Baart de la

Faille et al Leven en werken van Cornelis Adrianus Pekelharing, 1848-1922. Utrecht:

Oosthoek, I948.

p. I I I: Portret Eijkman door Jan Veth.

p. I29: Briefkaartje Eijkman een Pijnappel: bibliotheek Universiteit Utrecht, handschriften.

p. I44: Reclame voor De antithese, uit Het Vaderland, 23 oktober 1923.

p. I 89: Reclame voor De macht van het onbewuste, uit Het Vaderland, I 5 december 1926.

p. 2 I 5: Ingezonden brief. Het Vaderland, 2 juli 1927.

p. 23 I: Ongedateerde brief van Van Dieren aan Westerman Holstijn en reactie van Wester-

man Holstijn op Van Dieren, uit het Rijksarchief Utrecht.

p. 237: Briefkaartje Van Dieren aan Bolland: bibliotheek van de universiteit van Leiden, archief Bolland.

p. 252: Brief van Van Dieren aan P.H.Ritter, bibliotheek Universiteit Utrecht.

p. 257: Reclame voor Cyrano de Bergerac, uit Het Vaderland, i I februari 1926. 


\section{Noten}

De geciteerde titels zijn in het notenapparaat als volgt verkort weergegeven.

$\mathrm{AT}=$ De antithese (1920)

$\mathrm{AG}=$ Averechtse geestesrichting der zoogenaamde 'nieuwlichters' op allerlei gebied (I9I7)

BBVT = Het Beri-Beri en Vitamine Treurspel (1929)

$\mathrm{BE}=$ Begripsverwarring of erger? ( 1898 )

$\mathrm{BM}=$ Bijgeloof en misbruik op medisch en hygiënisch gebied (I9I2)

$\mathrm{BZ}=$ Besmettelijke Zielsziekten (I93I)

$\mathrm{CP}=$ Critiek op Prof. Pekelharing (I887)

DO = Darwinisme en ongeloof (19I3)

FBZ = Futuristische behandeling van zielszieken. Freudiaansche psycho-analyse (I 927)

GSA = Geen schoolartsen (I906)

GVV = Geboycot en vogelvrij verklaard? (I908)

HIHM = Historisch-idealisme of historisch-materialisme? (I922)

ITEK = Is De Telegraaf een... Engelsche krant? (I9I 5)

$\mathrm{KN}=$ Kleine Nederlanders! (I9IO)

$\mathrm{KV}=$ Kantteekeningen op Dr. Vorderman's rapport en nog iets (I 898)

MV = Meelvergiftigingen: Beri-Beri, Pellagra, Ergotismus, Erwtenziekte, Polaranaemie, enz. (1907)

MG = Meelvergiftiging of gebrek? (I9I5)

$\mathrm{NB}=$ Nogmaals: de beri-beri-kwestie (I888)

NTvG $=$ Nederlands Tijdschrift voor Geneeskunde (tijdschrift)

$\mathrm{OD}=$ Op dwaalwegen (I9I7)

$\mathrm{PF}=$ Professor Freud en het perverse gevaar (1932)

$\mathrm{SG}=$ Het socialistisch gevaar (I909)

$\mathrm{SLVH}=$ Het kamerlid Jhr. Mr. A.F. de Savornin Lohman als vaccinehater op weg van bekeering (I9I2)

$\mathrm{VB}=$ Vaccinatie en hare bestrijders (1903)

$\mathrm{VM}=$ Vox Medicorum (tijdschrift)

VFW = Verbreiding van Freudiaansche wetenschap (I932)

WW = De waanzinnige waereld (I919)

Zonlicht $=$ De nadeelige invloed van fel zonlicht en sport op lichaam en geest (I9I7).

\section{Voorwoord}

I Sam Dresden, Over de biografie. Amsterdam: Meulenhoff, 1987.

\section{Hoofdstuk I}

I Vgl. Arien Mack en Irvin Rock, Inattentional Blindness. An Overview. Cambridge: MIT Press, I998.

2 Zie bijv. WW, p. II, waar nog meer 'eretitels' staan vermeld. 
3 Zonlicht, p. 36-37.

4 “Grinniken als de naam Van Dieren wordt uitgesproken', Zonlicht, p. 37; 'De schrijver brengt ons aan het lachen", Plemp van Duiveland over Averechtse Geestesrichtingen, geciteerd in ongepubliceerde brief van Van Dieren aan J. Been.

5 W.J. van Gorkom, 'De Beri-Beri Quastie', Indische Gids, I897, p. I490; vgl. ook BBVT, p. I.

6 WW, p. 224.

7 Zie PF, p. 25, WW, p. II.

8 "Krankzinnige ruziemaker": WW, p. II.

9 Sigmund Freud, 'Een kind wordt geslagen', in: Sigmund Freud Nederlandse editie, Klinische beschouwingen 3. Amsterdam: Boom, I985, p. 43.

Iо M. Zeegers, De ziekten van de geest. Baarn: Bosch en Keuning, zonder jaartal, p. 256.

I I Schüle geciteerd in J. Raecke, Der Querulantenwahn. Ein Beitrag zur sozialen Psychiatrie, I926, p. I2. Grenzfragen des Nerven- und Seelenlebens, dl. I27. München: F.J. Bergmann.

I2 Henri van der Hoeven, Psychiatrie. Een handleiding voor juristen, geciteerd in een anonieme bespreking in Het Centrum, 24.9.1913.

I3 David Hume, 'Essays Moral, Political, and Literary (I742-I754). Of Superstition and Enthusiasm'. The Writings of David Hume, James Fieser (red.) Internet Release, 1995.

I4 Peter van Rooden, 'Heeft de Verlichting de secularisatie bevorderd?', in G. Dekker en K.U. Gäbler (red.), Secularisatie in theologisch perspectief, Kampen: Kok, I988, p. 97II 5 .

I 5 Anoniem overlijdensbericht Van Dieren in De Telegraaf, 20.5.I940, avondblad.

I6 "Heilige taak": $M V$, p. VIII.

I7 Martin van Amerongen (5.9.I970), Dokter van Dieren en de besmettelijke zielsziekte die 'socialisme' heet, Vrij Nederland, p. I9; Christien Brinkgreve en Max Pam (17.2.1979), Dokter van Dieren en het Freud'sche gevaaar, Vrij Nederland; Boudewijn Büch (25.6.1983), NRC Handelsblad, p. 20.

I8 Matthijs van Boxel, Morosofie. De encyclopedie van de dombeid, Amsterdam: Querido, $200 \mathrm{I}$.

I9 Briefje Polak aan Van Dieren in WW, p. I90.

20 Ter illustratie: boven een berichtje in de krant over een Engels arts die zich over Freuds onzedelijke opvattingen beklaagde, schreef de redactie: 'Een Engelse Van Dieren'.

2I Anoniem (I7.7.I919), boekbespreking van WW in De Standaard.

22 Anoniem (2.9.1932), "Van Dieren overdrijft!", Het Vaderland.

23 "Socialistenvreter", WW, p. II.; "psychoanalysten-doder-bij-uitnemendheid”, Hendrik Giltay (2.7.1927), ingezonden stuk, Het Vaderland, avondblad.

24 Karl Marx/Friedrich Engels, 'Der achtzehnte Brumaire des Louis Bonaparte', Werke, Bd 8, p. I I 5. Berlijn: Dietz Verlag, i960.

\section{Hoofdstuk 2}

I Voor de Zutphense tongval, zie Johan Winkler, Algemeen Nederduitsch en Friesch Dialecticon (dl. I). Den Haag: Martinus Nijhoff, I874, p. 346.

2 Stamkaart Derk-Johan van Dieren (г 822-г 890), gemeentearchief Zutphen, kaart nr. I 882 .

3 In $B Z$, p. 6o, schrijft Van Dieren dat er ıo kinderen waren en in een brief 'we waren met z'n achten', terwijl de stamkaart van zijn vader vermeldt dat er 9 kinderen waren. Ik kan deze tegenstrijdigheid niet verklaren. 
4 BZ, p. 6I.

5 "Geluiden, even schoon en indrukwekkend als de klokken van de St. Walburgskerk te Zutphen": AT, p. IX.; "Toen ik kind was speelde ik als kind", $M V$, p. 22, randbemerking.

6 Ongepubliceerde brief van Van Dieren aan H.C. Muller, ongedateerd (ca. I9I9), Internationaal Instituut voor Sociale Geschiedenis, archief H.C. Muller, nr. 6.27.

7 Ongepubliceerde brief Van Dieren aan Van Eeden, ongedateerd, ca. jan. I9I4.

8 Vgl. WW, p. I.

9 Anekdote verteld in BZ, p. I I 5 .

Io "Eenvoud is het kenmerk van het ware", $M G$, omslag.

I I Zie Annet Mooij, De polsslag van de stad, Amsterdam: Querido, I999, voor een bespreking van de veranderingen in het medisch onderwijs in die periode.

I2 "Beroerd behandeld": zie ongepubliceerde brief van Van Dieren aan H.C. Muller, ongedateerd (ca. I9I9), IISG. Toneelopvoering met rol voor Van Dieren: BZ, p. I07, voetnoot.

I3 Zie $P F$, p. 3 I.

I4 WW, p. 225-226.

I5 Handelingen van de Tweede Kamer, verslag van I3.8.I886. De bewuste opmerking werd door het Kamerlid H.J. Kist uit Amsterdam gemaakt.

I6 NTv $G$, I 888 , p. 495-496.

I7 Zie PF, p. 24I-2, voetnoot. Het verhaal van de bunzing wordt in Willemstad gesitueerd, en omdat Van Dieren rond die periode in Paramaribo vertoefde, zou men gemakkelijk geneigd zijn te denken dat hij dus ook de hoofdstad van Curaçao moet hebben aangedaan, maar aangezien de bunzing niet in het Caribisch gebied voorkomt, zou hij het ook over de gelijknamige vestingstad in Noord-Brabant kunnen hebben gehad. Een andere mogelijkheid is dat het niet om een bunzing ging, maar een ander knaagdier.

I $8 \mathrm{VB}, \mathrm{p} .44$.

I9 HIHM, dl. 2, p. 397, voetnoot.

20 Anoniem, prof dr. A.J. Korteweg †, VM, 30.4.1930, p. 64.

2 I WW, p. I74.

$22 A G$, p. 232, voetnoot.

23 Behalve uit het elders in dit boek gedocumenteerde briefcontact tussen Van Dieren en Van Eeden en Verwey, blijkt uit enkele briefjes van Van Dieren uit de periode I9I9I 920 in het H.C. Muller-archief van het IISG te Amsterdam, dat er sprake moet zijn geweest van een betrekking met nog twee leden van het Flanorgezelschap, namelijk Muller en Paap. Hendrik Clemens Muller (I 855 -I927) behoorde tot een van de oorspronkelijke leden van het gezelschap, maar was al in I 882 met ruzie vertrokken. Willem Paap (I 85 6-I923) was behalve lid van de Flanor-vereniging ook redacteur van de latere Nieuwe Gids. Hoever de betrekkingen tussen deze twee 'flanorianen' en Van Dieren ging is niet helemaal precies in te schatten. Van Dieren schrijft in een brief aan Muller dat hij hoopt hem 'eens persoonlijk te leren kennen', waaruit volgt dat hij in zijn studententijd in elk geval nog geen contact met hem had. Wel blijkt uit een opmerking in Averechtse geestesrichting dat Van Dieren verwantschap bespeurde tussen zijn en Mullers standpunt ten aanzien van de spellingsvereenvoudiging. Over de relatie met Paap is nog minder bekend.

24 Klikspaan, Studentenleven, Den Haag, Kruseman, I97 I, p. 69.

25 Naar een vertaling van B.C. van Brabant.

26 Ongepubliceerde brief van Van Dieren aan Bolland, 20.3.1920, Universiteitsbibliotheek Leiden, afdeling handschriften, signatuur Bol B I920/I9. 
27 NRC, 3.6.1920, vgl. ook 'Dr van Dieren en de geneeskundige kring', Het Vaderland, 4.6.1920.

28 HIHM, dl. I, p. VIII.

29 Van Dieren aan Lanz, ongepubliceerde brief, ca. 1930. Universiteitsbibliotheek Amsterdam, afdeling handschriften, signatuur: bij Eh 69b.

30 "De kliek is vanouds goed georganiseerd": Van Dieren aan Lanz, circa I930.

3 I Vgl. Otto Lanz, 'De oorlogswinst der heelkunde', I925, p. I9I, en de ongepubliceerde brief van Van Dieren aan Lanz, ca. I930.

32 Biografische informatie over Diepenbrock, o.a. ontleend aan J. van der Veen, 'Diepenbrock, Alphonsus Joannes Maria (I862-I92 I)', Biografisch Woordenboek van Nederland, dl. I.

33 "De 'socies'...grijnzen": Cato Loman in haar dagboek, 29.8.I920, in E. Reeser Alphons Diepenbrock, Brieven en documenten. Amsterdam: Vereniging voor Nederlandse Muziekgeschiedenis, I98I, dl. I0, p. 253.

34 "Daar komt van Dieren met zijn H.B.S. argumenten": Alphons Diepenbrock aan zijn zuster Marie, I7.9.I914, in Reeser, Alphons Diepenbrock, dl. 8, p. 363.

35 Cato Loman in haar dagboek, 29.8.1920, in Reeser, Alphons Diepenbrock, dl. Io, p. 253.

36 Zie Bert Altena, 'en al beschouwen alle broeders mij als verloren broer'. De familiecorrespondentie van en over Ferdinand Domela Nieuwenhuis I846-1932. Amsterdam: Boom, I997, p. 452. Daar schrijft Domela Nieuwenhuis aan zijn vrouw dat 'dr. v. Dieren zijn moeder geregeld masseert'.

37 Fiets: $S G$, p. I9I; auto met chauffeur: $B Z$, p. I23.

38 Van Dieren, 'dankbaarheid in advertenties', $N T v G$, 3.7.1926, p. Io0.

39 Een greep uit de voorzitterschappen, lidmaatschappen en erebaantjes. Vanaf I902 lid van de Schoolcommissie; tweemaal voorzitter van de Amsterdamse afdeling van de Maatschappij ter bevordering van Verlos- en Heelkunde; voorzitter van de enquêtecommissie inzake ziekenfondsen (zelf behandelde hij alleen particulier verzekerden); lid van de bond tegen vivisectie; lid van Het Leesmuseum, lid van de commissie tot nazien van de bibliotheek van de Maatschappij ter bevordering der geneeskunde, rapporteur van de commissie voor de herziening der wet op besmettelijke ziekten.

$40 W W$, p. 22.

4 I Zie $S G$, p. 9.

42 A.H. Gerhard, 'De pantoffel-voordracht', De Telegraaf, 30.10.1902.

43 Cornelis Winkler, ingezonden brief, De Telegraaf, 30.10.1902.

44 Uit een opmerking van Van Dieren van later datum zou blijken dat de pantoffels er wel zijn gekomen, maar dat zij spoedig in onbruik zouden zijn geraakt; vgl. WW, p. 23 I.

45 Van Dieren, Rapport in zake de keuring van vleesch te Amsterdam, sept. I89I, p. I4. Pamflet, Gemeentearchief Amsterdam.

46 Zie Van Dieren, 'De kring als Vakvereeniging op de verkeerden weg! Een voorstel tot intrekking van het bindend besluit tegenover de Foresters'. VM, 7.7.1908; 22.7.1908; 5.8.1908.

47 J.A. van den Broeck, 'Het terrorisme van Van Dieren', VM, 5.8.1908, p. I23-I24.

48 Ibidem.

49 Van Dieren, ingezonden brief 'Terrorisme in de Amsterd. Genees. Kring', VM, 22.8.1908.

$50 \mathrm{Vgl}$. het overzicht van zijn belangrijkste verdiensten in WW.

${ }_{5}$ I 'Als ik raadslid was... dan zou ik bij de behandeling van de Ontwerp-Verordening, regelende den gemeentelijken Geneeskundigen Dienst de volgende rede gehouden heb- 
ben', open brief aan de raadsleden van de Amsterdamse gemeenteraad, ongedateerd, anoniem, 9 pag. In: Gemeentearchief Amsterdam, onder nr. R. I 5 I6.I 2.

52 Zie voor een bespreking van de discussie tussen Van Dieren en Van Det: A. Dijkstra, (ongepubliceerde doctoraalscriptie) 'Het gezonde lichaam. Een historisch onderzoek naar de opkomst en groei van de medicalisering op lagere scholen in de periode I $857^{-}$ I904', Universiteit Nijmegen, p. 68-69. Het standpunt van Van Dieren is uitgewerkt in GSA.

53 WW, p. 242.

54 Zie voor een verslag van de stemming in de Kamer NRC, 22.3.I9I 8, ochtendblad.

55 BZ, p. 8I voetnoot.

56 Brief van Van Dieren aan De Vlugt dd. I4.9.1926 (archief De Vlugt, Gemeentearchief Amsterdam).

57 Anonieme recensie van 'De gevangene' in NRC, 25.IO.I926. Ik dank Harm Kaal voor informatie betreffende de reactie van De Vlugt op Van Dierens bezwaar tegen de opvoering van het toneelstuk.

58 De scheldwoorden "dierenarts" en "farizeeër" worden door Van Dieren zelf met geuzentrots geciteerd in WW, p. III. Zie ook zijn stuk 'Juristerij-op-haar-smalst', VM, 29.8.1934, p. 425 .

59 P.A. de Wilde, 'Gouden artsjubileum E. van Dieren', NTvG, 22.I2.I934, p. 5756.

60 WW, p. 176.

6I NRC, 4.7.I9I9, avondblad.

62 Het Volk, 4.7.1919.

63 AT, p. 92-93, cursivering in het origineel.

64 "Jan Klaassen in de vaderlandse poppenkast": Jan de Mot, Dagboek van een Amsterdammer, Amsterdamsche Courant, 27.I2.I924.

65 De Tijd, 24.I2.1924.

66 Portret in bezit van Wouter van Dieren.

67 "Vijanden ten gronde gericht...": uit het Iovivat.

68 Bron onbekend. Uit de knipselmap 'Dr. E. van Dieren', gemeentearchief Amsterdam.

69 NRC, II.IO.I92I.

70 HIHM, dl. 2, p. 372, voetnoot.

7I KV, p. I35.

72 Christiaan Eijkman, "Beri-beri en voeding”, $N T v G$, I898, p. 275-303.

$73 M V$, titelpagina.

74 “Alles, alles, alles": MV, p. 306.

75 A. van der Scheer, boekaankondiging van 'Meelvergiftiging', NTvG, 7.3.1908, p. 778.

$76 \mathrm{MV}$, p. I.

77 WW, p. II-III, voetnoot.

78 Van Dieren, 'Een in casu niet onbelangrijke vraag; socialist of niet?', $N T v G$, 2I.IO.I922.

79 Van Dieren aan Eijkman, I8.5.1913, geciteerd in MG, p. 72-76.

80 Eijkman aan Van Dieren, 20.5.19I3, geciteerd in $M G$, p. 77.

8I Geciteerd in BBVT, p. 5 .

82 S. Postmus, 'Evart van Dieren en de aetiologie der beri-beri', Voeding, I 5.4.1940, p. I 45 .

83 Zie $D O$, p. I7.

84 De ironie wil dat 'creationisten' in de jaren tachtig van de twintigste eeuw opnieuw een verband tussen Marx en Darwin probeerden te leggen om de verdorvenheid van de evolutietheorie aan te tonen. Een brief van de eerste aan de laatste zou dat aantonen. 
Van inhoudelijke verwantschap tussen Darwin en Marx is echter vanuit het standpunt van Darwin gezien althans geen sprake, en de vermeende correspondentie bleek gebaseerd op een misinterpretatie. Zie Ralph Colp Jr., The myth of the Darwin-Marx letter, History of Political Economy, I982, p. 46I-482.

85 Het Centrum, I7.I2.I909.

86 Het Centrum, 24.3.19I0.

87 NRC, IO.II.I9I3, avondblad.

88 Jaris Baers (red.), Lectuur-Repertorium. Auteurslijst bevattende 23.000 bio-bibliografische nota's en 3000 portretten van auteurs behorende tot de Nederlandse en de algemene literatuur, met waarde en vakaanduiding van 90.000 literaire en vulgariserende werken, samengesteld door het Algemeen Secretariaat voor Katholieke Boekerijen. Antwerpen en Tilburg: Vlaamsche Boekcentrale / Nederland's Boekhuis, I954.

89 Het Centrum, 2I.I0.1909.

90 "Brochuromaan": geciteerd in Van Dieren, 'Juristerij-op-haar-smalst', VM, 29.8.1934, p. 425 .

9I Van Dieren aan Been, ongepubliceerde brief d.d. I2.I.I9I 8.

92 "Stapel drukwerk van onbehoorlijke lengte en breedte": Het Centrum, 24.9.I909.

93 "Blauw aangelopen sprakeloze woede": Arie Querido, Doorgaand verkeer. Lochum: Tijdstroom, 1980, p. 20

94 Het Volk, 2I.I.I920.

95 HIHM, dl. I, p. 53.

96 Het Volk, 2I.I.I920.

97 Discussie tussen Wijnkoop en Van Dieren geciteerd in PF, p. I74-I75.

98 "Een titel om van te rillen": boekaankondiging geciteerd in $A G, \mathrm{p}$. V.

99 Sleeswijk, boekaankondiging van 'Bijgeloof en misbuik op medisch en hygiënisch gebied', $N T v G$, I I.7.I9I4, p. I 58.

Io० Coos Vorrink, 'De psychiater "par excellence", Het Volk, 3.7.1909.

IOI Spotprent in de Notenkraker, zondagsblad van Het Volk, 4.7.I909, p. 6.

IO2 $S G$, p. 280.

I03 Gerard van Rijnberk, 'Tijdschriftlegenden', NTvG, 30.I0.I920.

IO4 Tegenstander vrijheid van drukpers: zie BZ, p. 64 voetnoot.

I05 Anoniem, dokter Van Dieren 50 jaar arts, Algemeen Handelsblad, 23.I2.I934, ochtendblad.

I06 Zeegers, Ziekten van de geest, p. 256.

I07 De Wilde, NTvG, I.7.I940, p. 2075.

I08 Het Vaderland, 24.5.I940; zie verder ook De Telegraaf, 22.5.1940; NRC, 23.5.1940.

ıо9 P.A. de Wilde, 'In memoriam Evart van Dieren', $N T v G$, I.7.1940, p. 2075.

\section{Hoofdstuk 3}

I Ook zijn correspondentie moet fenomenaal zijn geweest, maar die is voor zover mij bekend, niet gearchiveerd. Wat rest is een losse verzameling fragmenten, her en der verspreid over de universiteitsbibliotheken in Nederland. De totale omvang overgeleverde correspondentie bedraagt circa vijftig stukken (inclusief de door Van Dieren zelf gepubliceerde brieven); daarnaast is er de ongepubliceerde correspondentie tussen Eijkman en Pijnappel bewaard gebleven over Van Dieren uit de periode I 897-I898. De belangrijkste stukken daaruit komen in hoofdstuk 3 aan de orde.

2 Om een vergelijk met de huidige situatie te kunnen maken zou men de prijzen met 7 of 8 moeten vermenigvuldigen, en komen we uit op 5 à 6 euro voor een brochure, circa 
20 euro voor de gebonden boeken en tot 60 euro voor het dure HIHM. Wie zijn werk tweedehands wil aanschaffen betaalt nog steeds ongeveer dergelijke prijzen.

3 Van Dieren, 'De psychanalyse' (ingezonden artikel), Het Vaderland, 27.7.1927.

4 HIHM, dl. I, p. 36, voetnoot.

5 HIHM, dl. I, p. XV.

6 HIHM, dl. I, p. 37, voetnoot.

7 HIHM, dl. I, p. XV.

8 GVV, p. 5 .

9 P.C. Flu geciteerd in $B B V T$, p. I.

Io Ibidem, p. I9

II $G V V$, p. 22.

I2 $B E$, p. 43 .

I3 BZ, p. 2 en 4.

I4 $P F$, omslag.

I5 Van Dieren aan Eijkman, in $M G$, p. 76 .

I6 M.W. Pijnappel, Algemeen Handelsblad, avondblad, 9.I.I 898.

I7 K.F. Wenckebach aan Van Dieren, ongedateerd, geciteerd in BBVT, p. 5.

I8 A.J. Westerman Holstijn aan Van Dieren, circa augustus 1927, geciteerd in 'Klein, onredelijk, onzedelijk en oneerlijk!', VM, I4.I2.I927, p. 254-255.

I9 W.A. Bonger aan Van Dieren, geciteerd in $P F$, p. I90.

$27420 \quad M V$, p. IV

2I Ongepubliceerde brief van Van Dieren aan O. Lanz, ongedateerd, circa I930.

22 BE, p. 43.

23 Van Dieren geciteerd in De Telegraaf, avondblad, 22.5.1940.

24 P.K. Pel, 'Een kwart eeuw geneeskunde. Rede voor de Nederlandsche Maatschappij tot bevordering der Geneeskunst', NTvG, I0.7.191 5, p. 487.

25 HIHM, dl. I, p. XV.

26 Geciteerd in FBZ, p. IO-I I, voetnoot.

27 Edward Shorter, Een geschiedenis van de psychiatrie. Amsterdam: Ambo, 1998.

28 Paul Moeyen, Buiten Schot. Nederland tijdens de Eerste Wereldoorlog. Amsterdam: Querido, 200I.

29 De Telegraaf, I5.6.1915.

30 ITEK, p. 4 voetnoot.

3 I $M V$, p. 427 voetnoot.

32 Diepenbrock aan zijn zuster Marie, I7.9.I9I4. In E. Reeser, Alphons Diepenbrock, dl. 8, p. 394; de brief van Van Dieren aan Diepenbrock is niet bewaard gebleven.

33 Diepenbrock aan Van Dieren, I0.9.I9I 5. In: E. Reeser, Alphons Diepenbrock, dl. 9, p. 5.

34 C. Smit, Bescheiden betreffende de buitenlandse politiek van Nederland I 849-1919. $3^{\mathrm{C}}$ Periode I899-I9I9, dl. 7. Rijks Geschiedkundige Publicatien. Den Haag: Martinus Nijhoff, I97I.

35 Zie Moeyen, p. 4I6, noot 73.

36 Vgl. Huub Wijfjes, Journalistiek in Nederland I650-2000. Amsterdam: Boom, 2004, p. 524, noot 47: 'onduidelijk is of "Is de Telegraaf... enz" door de Duitsers werd betaald'.

37 Diepenbrock aan W.G. Hondius van der Broeck, 4.3.909. In: E. Reeser, Alphons Diepenbrock, dl. 6, p. 88 .

38 WW, p. I70-I72.

39 A. Gielen in de Boekenschouw, geciteerd in Het Vaderland, 8.7.1910.

40 Ongepubliceerde brief van Van Dieren aan Bolland, 20.3.I920. 
4I Zie: HIHM, dl. 2, p. 290.

42 Vgl. HIHM, dl. 2, p. 269 e.v.

43 Vgl. G.J.P.J. Bolland, De Teekenen des Tijds. Academische les Leiden, 's Gravenhage, Rotterdam en Amsterdam. Leiden: Adriani, I92 I, p. 7 e.v. en HIHM, dl. I, p. 270.

44 WW, p. II 8.

45 FBZ, p. 218 e.v.

46 BZ, p. 20.

47 Handgeschreven notitie van Van Dieren aan prof. Bouman op pagina I van 'Verbreiding van Freudiaansche Wetenschap (?) door den Radio-omroep! Antwoord op de Vara-Voordracht van den zenuwdokter A. Querido', exemplaar in bezit van de Universiteit Utrecht.

48 FBZ, p. 79 en 218 ; BZ, p. 7.

49 Van de oudste zoon, ir. Evart van Dieren, is bekend dat hij lid was van de NSB en als president-curator van de Technische Hogeschool Delft in I 944 de arrestatie van prof. Muyskens gelastte uit wraak voor een onwelgevallig besluit (vgl. Lou de Jong, Het Koninkrijk der Nederlanden in de Tweede Wereldoorlog, dl. 7, p. 557). Zijn collaboratie lijkt met terugwerkende kracht ook de naam van Van Dieren sr. aan te hebben getast. Althans, uit een briefje dat op 18.6.1999 door het Amsterdams Geneeskundig Genootschap werd geschreven aan de huidige bewoners van de Keizersgracht 622 (Amnesty International), het pand waar Van Dieren 20 jaar heeft gewoond, zou dat kunnen worden afgeleid. Het genootschap was voornemens later dat jaar een gedenkplaat ter nagedachtenis aan hun eerste voorzitter te onthullen en antwoordde op een kennelijke vraag van Amnesty: 'Van Dieren overleed op I8 mei I940; de kans dat hij fout was in de oorlog is dus niet zo heel groot.' Stellig werden de twee E. van Dierens door iemand met elkaar verwisseld.

50 Felix Ortt geciteerd in Van Boxsel, Morosofie, p. ıо०.

5I Mattheüs I3: 3I-32.

52 Kanttekening in rood potlood in de marge op een uit Meelvergiftigingen gescheurde bladzijde in een ongepubliceerde brief aan Lanz, ca. I930 (Universiteitsbibliotheek Amsterdam, afdeling handschriften, archief Lanz).

\section{Hoofdstuk 4}

I Bontius geciteerd in Von Romer, 'Dr. Jacob Bontius', Bijblad op het Geneeskundig Tijdschrift voor Nederlandsch-Indië, 77 (1932), p. I6.

2 Roy Porter, Blood and Guts. A Short History of Medicine. New York: W.W. Norton, 2002, p. 90.

3 W. van Itallie-Van Embden, 'Prof. Dr. C. Eykman', NRC, I I.I6.I928, avondblad.

4 Ibidem.

5 Zie over de ontmoeting tussen Pekelharing en Winkler met Eijkman verder: B.C.P. Jansen, Het levenswerk van Christiaan Eijkman. Haarlem: Erven F. Bohn, I959, p. I I; C. Winkler, Herinneringen. Utrecht/Amsterdam: Bohn, Scheltema \& Holkema, I982, p. 55.

6 Baart de la Faille, J.M., H. G. K. Westenbrink en P. Nieuwenhuijse, Leven en werken van Cornelis Adrianus Pekelharing, I848-1922. Utrecht: Oosthoek, I948.

7 Van Dieren, Critiek op de beweringen van Prof. Pekelharing omtrent de Beri-Beri, I 887, p. 3 .

8 C. C. Delprat, Boekaankondiging, NTvG, 29.I0.1887, p. 485-486.

9 C.L. van der Burg, Boekaankondiging, Nederlandsch Militair Geneeskundig Archief, I 887 , p. 473 . 
Io $N B$, p. I I.

I I $N B$, p. 8 I.

I2 $N B$, p. 55 .

I3 $C P, \mathrm{p} . \mathrm{I}_{3}$.

I4 $C P, \mathrm{p} . \mathrm{I}_{3}$.

I5 $M G$, p. 22-23.

I6 August Hirsch, Handbuch der Historisch-Geografischen Pathologie, dl. 2 (2de editie), I 883 , p. $420-42$ I.

I7 Ibidem, p. 422 .

I $8 M G$, p. I2.

I9 De belangrijkste gegevens omtrent de levensloop zijn ontleend aan B.C.P. Jansen, Eijkman.

20 Ibidem, p. 8.

2I Hoewel beriberi al sinds mensenheugenis slachtoffers vergde, werd het probleem pas met het uitbreken van de Atjeh-oorlog acuut, want nu vielen er ook grote aantallen Nederlandse soldaten aan ten prooi.

$22 K V$, p. 67.

$23 K V$, p. II5.

$24 K V$, p. I35.

25 Voor een geschiedenis van de strijd tegen beriberi en van de ontdekking van vitamine B zie: Kenneth J. Carpenter, Beriberi, white rice and vitamine B. A disease, a cause, and a cure. Berkeley: University of California Press, 2000.

26 Harmke Kamminga, 'Credit and resistance: Eijkman and the transformation of beriberi into a vitamine deficiency disease', in: K. Bayert en R. Porter (red.), From physicotechnology to bio-technology: essays in the social and cultural history of biosciences: a festschrift for Mikulas Teich. Amsterdam, 1989, p. 232-254.

27 Christiaan Eijkman, Antineuritisches vitamin und beriberi (Nobel-Vortrag), Stockholm, I930, p. 6.

28 "Eenvoud is niet het kenmerk van het ware": Eijkman, Simplex non veri sigillum. Utrecht, I9I3.

$29 W W$, p. I26, voetnoot.

30 HIHM, dl. 2, p. 446.

3 I Eijkman, Simplex non veri sigillum, p. I 2.

\section{Hoofdstuk 5}

I Van Dieren, 'Open brief', Medisch Weekblad, 29.8. I 894, p. 337.

2 Ibidem, p. 34I.

3 Ibidem, p. 342.

4 Ibidem, p. 342.

$5 \quad N R C$, II.I6.I928.

6 Eijkman, Simplex non veri sigillum, p. I 2.

$7 K V$, p. 136.

$8 K V$, p. II.

9 A.G. Vorderman, 'Toelichting op mijn beri-beri-verslag', in: Geneeskundig Tijdschrift voor Nederlandsch-Indie, I898, p. 47-68. Een latere criticus zou echter betogen dat het rapport van Vorderman wel degelijk mank ging aan allerlei typen statistische fouten; zie W.J. van Gorkom, 'Beri-Beri in de gevangenissen op Java. Critiek op Vorderman's enquêteverslag', in: Geneeskundig Tijdschrift voor Nederlandsch-Indië, ı 898, p. 709-774. 
Io Christiaan Eijkman, 'Boekaankondiging van A.G. Vorderman: Onderzoek naar het verband tusschen den aard der rijstvoeding en de gevangenissen op Java en Madoera en het voorkomen van beri-beri onder geïnterneerden', in: NTvG, 21.8.1897, p. 302-306.

I I Porter, Blood and Guts, p. 94.

I 2 C.L. van der Burg, boekaankondiging van 'Beri-Beri eene rijstvergiftiging', $N T v G$, 6.3.I 897 , p. 360 .

I3 Anonieme bespreking van 'Beri-beri eene rijstvergiftiging', Indische Gids, mei I 897, p. 683-687.

I4 C.A.H. Westhoff, boekbespreking van Van Dieren's 'Kantteekeningen', Medisch weekblad, 23.10.1898, p. 470.

I 5 C.O. Gelpke, 'Ueber die Aetiologie der Beri-Beri. Gelpke contra Van Dieren'; H.J. Kessler, 'Beri-Beri geen rijstvergiftiging' en E. van Dieren, 'Beri-Beri eene rijstvergiftiging. Verweerschrift tegen dr. Gelpke's aanval', in: Geneeskundig Tijdschrift voor Nederlandsch-Indie, I 897, p. IO8-I I 4; 339-358; 545-563. Bespreking van deze kritieken en de repliek van Van Dieren in: Algemeen Handelsblad, I7, I9 en 20 augustus I897.

I6 W.J. van Gorkom, 'De beri-beri questie. Vergiftiging of infectie?', in: Indische Gids. I 897, p. I623.

I7 Ongepubliceerde brief van Van Dieren aan koningin-regentes Emma, januari I 897. Archief Koninklijk Huis, brief A47-X-I 50.

I $8 \quad M V$, p. III.

I9 Facsimile van de brief van Van Gorkom aan Van Dieren, 27.II.I897 in Van Dieren, Brief aan de leden van den geneeskundigen kring, 1903.

20 Van Dieren, Brief aan de leden van den geneeskundigen kring, I903, p. I3-I4.

2 I Van Dieren, Brief aan de leden van den geneeskundigen kring, I903, p. I4.

22 Van Dieren, 't Kan verkeeren', Indische Gids, feb. I898, p. I86.

23 Eijkman geciteerd in Jansen, Eijkman, I959, p. I02.

24 C.C. Delprat, De geschiedenis van de eerste 50 jaren van het Nederlandsch Tijdschrift voor Geneeskunde I857-1907. Haarlem, I932, p. 228.

25 A.P. Fokker, boekaankondiging van 'Kantteekeningen op Dr. Vorderman's Beri-BeriRapport en nog iets', NTvG, I3.II.I897, p. 845.

26 Dat Fokker zich wel wat erg makkelijk voor het karretje van Van Dieren had laten spannen bevreemdt zeker. De verdenking dat het referaat van Van Dierens 'Kantteekeningen' dus in eerste instantie tegen de bacterioloog Eijkman was gericht lijkt niet onaannemelijk en Eijkman was zich daarvan ook wel bewust zoals blijkt uit zijn brief aan Pijnappel d.d. I I.5.I898: '[Fokker] heeft zich door Van Dieren even goed laten gebruiken als zooveel anderen en wilde dien kant te liever uit, omdat hij daar gelegenheid had om zijn antibacteriologische stokpaardje te berijden.'

27 Christiaan Eijkman, 'Beri-beri en rijstvoeding' (ingezonden brief), NTvG, 20.I I.I 897.

28 Anoniem, 'Beri-beri en rijstvoeding', Algemeen Handelsblad, 27.I I.I897, avondblad.

29 Zie bijv. de repliek op Van Gorkom in het Algemeen Handelsblad van I9 en 20 augustus I 897, 'Beri-beri eene rijstvergiftiging. Verweerschrift tegen Dr. Gelpke's aanval', in: Geneeskundig Tijdschrift van Nederlandsch-Indië (I 897), p. 545-563, de ingezonden brief over de 'beri-beri-questie' in het Algemeen Handelsblad d.d. 30.I I.I 897 en de ingezonden brief in antwoord op Eijkman in NTvG, 4.I2.I897.

30 Eijkman aan Pijnappel, ongepubliceerde brief d.d. 6.I2.I897, archief Universiteitsbibliotheek Utrecht, afdeling handschriften.

3 I Eijkman aan Pijnappel, 6.I 2.I897.

32 Zie Candace Fleming en Robert Andrew Parker, The Hatmake's Sign: A Story by Benjamin Franklin. New York: Orchard Books, 1998. 
33 Stokvis aan Van Dieren, 3 I.I0.I897, geciteerd in Algemeen Handelsblad, 9.2.I898.

34 Christiaan Eijkman, 'Beri-beri en voeding', p. 275-276.

35 BE, p. 3.

36 BE, p. 42.

$37 N T v G$, 3I.I2.I898, p. II 20.

38 Van der Scheer, 'Meelvergiftigingen', NTvG, 7.3.1907.

39 Van Dieren, 'Toelichting bij den voordracht van den arts E. van Dieren, over de nieuwe opvattingen omtrent beri-beri, 25.IO.1924', brochure in eigen beheer.

\section{Hoofdstuk 6}

I Jansen, Eijkman,p roo.

2 De correspondentie tussen Eijkman met Pijnappel is afkomstig uit de nalatenschap van Pijnappel en wordt bewaard in de bibliotheek van de Universiteit Utrecht, afdeling handschriften (Hs. $8 *$ F26). De collectie bevat $5 \mathrm{I}$ items waaronder 19 brieven en briefkaartjes van Eijkman en twee brieven van Van Dieren. De brieven van Pijnappel zelf zijn niet bewaard gebleven. Verder bevat de collectie 9 brieven van Voorthuis aan Pijnappel, 2 brieven van Van Dieren aan Voorthuis en 2 van Voorthuis aan van Dieren. De hele collectie brieven werd door de weduwe van Pijnappel aan dr. J.A. Putto geschonken; diens dochter, dr. Johanna Kossmann-Putto schonk ze tenstotte na de dood van haar vader in I966 aan de Utrechtse bibliotheek, waar ze onopgemerkt zijn blijven liggen.

3 Eijkman aan Pijnappel, I9.I.I898.

4 Hulshoff Pol, 'In memoriam M.W. Pijnappel', NTvG, I8.3.I92 I, p. 82 I.

5 Eijkman aan Pijnappel, 6.I2.I897.

6 Eijkman aan Pijnappel, 6.I2.I897.

7 Eijkman aan Pijnappel, I8.r.I 898.

8 Eijkman aan Pijnappel, 6.I2.I 897.

9 Pijnappel, 'Het beri-beri-debat', Algemeen Handelsblad, 8.I 2.I897.

Io Eijkman aan Pijnappel, I4.I2.I897.

I I Voorthuis aan Pijnappel, I8.I2.I897.

I2 Van Dieren aan Voorthuis, 8.I.I 898, in de collectie van brieven van Eijkman.

I3 Voorthuis aan Van Dieren, 9.I.I 898, afschrift door Voorthuis toegestuurd aan Pijnappel.

I4 Van Dieren, 'Kantteekening op de medische kroniek van 9 jan.', Algemeen Handelsblad, I4.2.I 898 .

I5 Voorthuis aan Pijnappel, 22.I.I898 en II.2.1989.

i6 C.L. van der Burg aan Pijnappel, 2I.I.I898, ongepubliceerde briefkaart uit de collectie Pijnappel.

I7 M.W. Pijnappel, 'Medische Kroniek', Algemeen Handelsblad, 9.I.I 898.

I8 Eijkman aan Pijnappel, I9.r.ı898.

I9 Zie behalve de 'Medische kroniek' van Pijnappel in het Algemeen Handelsblad de discussie onder de titel 'Beri-Beri' in dezelfde krant op I4.I.I 898 (Van Dieren), 9.2.I 898 (Pijnappel); 20.2.I 898 (Van Dieren) 20.2.I 898 (Pijnappel), 25.2.I 898 (Van Dieren) en 25.2.I 898 (Pijnappel).

20 MVG, p. 76.

2 I A.P. Fokker, boekaankondiging van 'Toelichting op mijn beri-beri-verslag' door A.G. Vorderman, in: NTvG, I6.4.I 898, p. 630.

22 Eijkman aan Pijnappel, I7.4.I 898. 
23 Christiaan Eijkman, 'ingezonden brief', $N T v G$, 23.4.I898, p. 684.

24 A.P. Fokker, 'ingezonden brief', NTvG, 7.5.I898, p. 773.

25 Eijkman aan Pijnappel, I I.5.I898.

26 Eijkman aan Pijnappel, 2.5.I 898.

27 Eijkman aan Pijnappel, 2.5.I898.

28 Eijkman aan Pijnappel, 2.5.I898.

29 Eijkman aan Pijnappel, I2.6.I898.

30 Eijkman aan Pijnappel, I I.5.I898.

3 I Eijkman aan Pijnappel, I2.6.I898.

32 Een voorbeeld ter illustratie. In het populariserende werkje Amsterdam, stad der wijsheid (Bussum, Kroonder I947) van A.C.W van der Vet wordt op het 'zeer merkwaardige feit' gewezen dat de 'Amsterdamsche huisarts Van Dieren, die nooit in Indië was geweest, nog voor de onderzoekingen van Eijkman ... zuiver op grond van lectuur en wetenschappelijke intuïtie, reeds geschreven had, dat de oorzaak van beri-beri niet in een bacterie, doch in de voeding zat. Overigens meenden zowel Eijkman als Van Dieren dat de van het zilvervliesje ontdane rijst gemakkelijk verrotte, waardoor de beri-beri zou ontstaan' (cursief toegevoegd).

33 Anoniem, 'De stofwisseling van den mensch. Vitaminen', NRC, 29.5.I929, avondblad.

34 NRC, 8.5.1929.

35 Dr. P. van Andel, 'De Beri-Beri', Het Vaderland, 28.6. I923.

36 Christiaan Eijkman, 'Aetiologie en prophylaxis der beri-beri', in: C. Jansen, Eijkman, I 48 .

37 Christiaan Eijkman, 'Simplex non veri sigillum', p. 37.

38 Christiaan Eijkman, Antineuritisches Vitamin und Berbiberi, p. 3, cursief toegevoegd.

39 Michael White, Rivals. Conclict as the fuel of science. Londen: Vintage, 2002, p. I 5.

40 Zie Rebecca Collins, 'Concealing the poverty of traditional historiography: myth as mystification in historical discourse', Rethinking History 7 (3) 2003, p. 34 I-365, voor een bespreking van myhe en mystificaties in geschiedschrijjving.

\section{Hoofdstuk 7}

I Vgl. OD, p. 3;AT.

2 Deze samenvatting bestaat uit een verdichting van enkele scènes uit het toneelstuk.

3 Ongepubliceerde brief van Van Dieren aan Van Eeden, zonder datering, vermoedelijk januari I9I4.

4 Frederik van Eeden, IJsbrand, eene tragi-komedie. Amsterdam: W. Versluys, I908, p. 48.

5 SG, p. 225-226.

6 Van Dieren aan Van Eeden, circa januari I9I4.

7 Jan de Mot, 'Van een Amsterdammer', De Amsterdammer, 24.I 2.I909.

8 OD, p. 63.

$9 A T$, p. IX.

Io $A T$, p. IX. In december I924, ter gelegenheid van het 40-jarig artsjubileum van Van Dieren, werden enige fragmenten uit De antithese opgevoerd door de toneelvereniging Het Schouwtoneel. De geschiedenis vermeldt niet welke fragmenten, maar de veronderstelling dat het om het bedrijf gaat waarin dr. Mol een belangrijke rol speelt lijkt niet al te vergezocht. Zie de berichtgeving over het 40 -jarig jubileum in De Tijd, 24.I2.I924.

I I H. Pinkhof, boekbespreking van 'De Antithese', NTvG, 23.4.I92 I, p. 2330. 
I2 Jean-Paul Sartre geciteerd in Richard Holmes: De biografie en de dood. Huizingalezing I997, p. 34 .

I3 Bron: Het Vaderland, 9.II.I942.

I4 $O D$, p. 53 , cursivering in het origineel.

I 5 Foto in 'Terschelling tussen Boschplaat en Behouden Huys. Een eerbetoon aan Wouter van Dieren (I902-1935)', Rinkelbollen. Geluiden uit de K.N.N.V. afd. Terschelling, nr. I en 2 , I985, p. I7.

I6 Ir. Evart van Dieren was door een benoeming van Seyss-Inquart secretaris-generaal van het nieuwe departement voor Verkeer en Energie geworden, in welke hoedanigheid hij allerlei ambitieuze plannen bedacht die niet zijn gerealiseerd; zie verder ook noot 49 bij hoofdstuk 3. Over de wat dubieuze rol van Gustaaf van Dieren gedurende de bezetting zie: Jan van der Wal, 'We vieren het pas als iedereen terug is.' Terschelling in de oorlog. Groningen, dissertatie, 2007. Gustaaf van Dieren werd geen lid van de NSB, maar sympathiseerde wel met de Duitsers; hij werd na de oorlog niet veroordeeld, omdat zijn 'geval' min of meer als 'pathologisch' werd gekarakteriseerd; hij werd beschouwd als iemand wiens doen en laten hem niet kan worden aangerekend.

I7 $A T$, p. I3.

I8 Elisabeth Diepenbrock geciteerd in: Reeser, Alphons Diepenbrock, dl. 5, p. 407.

I9 Alphons Diepenbrock aan J. Jongkurdt, 24.5.1908 in: Reeser, Alphons Diepenbrock, dl. 5 , p. 548 .

20 Van Dieren aan Bolland, ongepubliceerde brief d.d. 20.3.1920.

2 I BZ, p. 85, voetnoot.

$22 M V$, aanhangsel, p. 449.

$23 A G$, p. IV.

24 Het Volk, 3.Io.r916.

25 Het Vaderland, 6.8.1920.

26 Het Vaderland, iा.8.1920.

27 Het Volk, 2.6.19I9.

28 Het Nieuws van den Dag, avondblad, 5.8.1920.

29 Eveline Jas aan Alphons Diepenbrock, I.9.I920. In: Reeser, Alphons Diepenbrock, dl. Io, p. 254.

30 Algemeen Handelsblad, ochtendblad, I7.3.192 I; enkele details en de filosofische analyse over toeval in HIHM, dl. 2, p. 360.

3 I Van Dieren aan Been, d.d. I2.I.I9r 8.

32 De uitspraak komt uit een fabel van De la Fontaine, over een molenaar en zijn zoon die hun ezel naar de markt brengen; onderweg krijgen ze van iedereen commentaar, wat de molenaar ten slotte doet uitroepen: 'Parbleu - qui prétend contenter tout le monde et son père.' De moraal van het verhaal is dat je je niet te veel moet laten leiden door wat anderen te zeggen hebben over jou. Vooral niet als die anderen Van Dieren heten, luidt de toevoeging.

33 De rede werd uitgesproken door $\mathrm{H}$. Burgerhout ter gelegenheid van de $80^{\text {ste }}$ verjaardag van dr. Klinkert en verscheen in de NRC van 3 september 1927. Dr. Klinker had kort tevoren de wens uitgesproken dat schrijvers zich meer op het Frans richtten, uit stilistisch oogpunt; Van Dieren had hem toen 'op de vingers getikt' in een stukje in Vox Medicorum en kreeg nu dus de bal weet teruggekaatst.

34 Van Dieren, 'On ne peut pas contenter tout le monde et van Dieren', VM, 5.IO.I927, p. 205. Van Dieren zag waarschijnlijk de film Cyrano de Bergerac van de Italiaanse regisseur Augusto Genina uit 1925. De film rouleerde medio februari 1926 in Nederland. Cyrano was een geliefd thema in deze periode; ongeveer gelijktijdig met de film 
vond een theateropvoering van het oorspronkelijke toneelstuk van Edmond Rostand plaats en een muziekuitvoering van de Cyrano-ouverture van Johan Wagenaar.

$35 W W$, p. I.

36 Zie bijv. Arent van Santhorst, 'Een halve eeuw strijd I896-1946', Vriendschap, februari 1963 , p. I6.

37 Van Dieren, 'Ongevaarlijke homosexueelen?', NTvG, I.4.I922, p. I27I.

38 Ibidem, p. I274.

$39 P F$, p. I99. Jacob Israël de Haan was in 1924 in Palestina inderdaad vermoord, zij het niet vanwege zijn homoseksualiteit, maar vanwege zijn antizionistische opvattingen.

40 "Prachtige lijdens-hoogte", NRC, 25.IO.I926.

4I PF, p. 206.

42 Brief van anonieme jongeman aan Van Dieren: PF, p. 202, voetnoot.

43 HIHM, dl. 2, p. 502, voetnoot.

$44 V B$, p. I26.

45 DO, p. 55.

46 Overbeek de Meyer aan Van Dieren, 25 mei.r9I 2, geciteerd in SLVH, p. I I9-I 20.

47 De Savornin Lohman aan Van Dieren, 28 mei 1905, geciteerd in $S L V H$, p. 3.

48 SLVH, p. 8.

49 SLVH, p. 6.

50 Brochure De Savornin Lohman opgenomen in SLVH, p. I 5 I-I 75.

5 I De Savornin Lohman geciteerd in $S L V D$, p. I 54 .

52 P. Muntendam, $N T v G$, I4.9.I9I 4, p. I008.

53 Rede van De Savornin Lohman voor de Tweede Kamer, d.d. I9.5.I9I I, geciteerd in $K V$, p. 145 .

54 PF, p. I09.

55 "Hol platzakkig kliekje": Heijermans geciteerd in Salvador Bloemgarten: Henri Polak. Sociaal democraat I 869-I 943. Den Haag: Sdu Uitgevers, I996, p. 504. Vgl. verder P.J. Troelstra: Gedenkschriften (4 delen). Amsterdam: Querido, I927-I929; H. Roland Holst: Herman Gorter. Nijmegen: SUN, 1975.

$56 S G$, p. 64 e.v.

57 Van Dieren, 'Het verband tusschen de "Futuristische behandeling van zielsziekten volgens Freud" en de "Bolsjewistische geestesgesteldheid", brochure in eigen beheer, Utrecht: J. van Druten, I930, p. I2.

58 HIHM, dl. I, p. 76.

59 Geciteerd in Ernst Freud et al., Sigmund Freud. Sein Leben in Bildern und Texten. Frankfurt: Insel Taschenbuch, 1989, p. 258.

60 Jan en Annie Romein, Erflaters van onze beschaving, dl. 2. Amsterdam, Querido, 1947, p. 319-320. Vgl. ook Siebe Thissen, De spinozisten. Wijsgerige beweging in Nederland (I850-1907). Den Haag: Sdu Uitgevers, 2000.

6I “Een stumperige maniak": Polak aan Van Dieren, I8.6.I9I9, in: WW, p. I90-I9I.

62 Pinkhof, boekaankondiging, NTvG, 5.7.1919, p. 5 I.

63 Anoniem: Bespreking van 'Historisch-Idealisme of Historisch-materialisme?', De Amsterdammer, 17.2.1923.

64 Zonlicht, p. 52, voetnoot (cursief in het origineel). Zijn positie inzake het feminisme had hij eerder al (in 1905) in een stuk in Algemeen Handelsblad uiteengezet, waarin hij verklaarde dat meisjes beter niet konden doorleren, omdat dat hun 'plichten voor het moederschap' in allerlei opzichten in de weg zou staan. Daarop verscheen een verontwaardigde reactie in het feministische tijdschrift Evolutie (I7.6.1905), waarin 'des 
Scheppers bevoorrechte positie van de man' aan de kaak werd gesteld. Vgl. Francisca de Haan: Sekse op kantoor. Rotterdam: Uitgeverij Verloren, I992.

65 Anoniem, 'Arts E. van Dieren. Gouden artsjubileum I 884 - 24 december - I934' VM, I7.I2.I934, p. 64I-643.

66 BZ, p. 43.

67 Boudewijn Büch, NRC Handelsblad, 25.6.1983.

68 Boekbespreking van Besmettelijke zielsziekte door 'Dr. Marbuse', geciteerd in PF, p. 2 I 4.

69 Heijermans, geciteerd in $P F$, p. 30.

70 Geciteerd in $P F$, p. 190.

7I Donkersloot over Bonger geciteerd in Bart van Heerikhuizen, W.A. Bonger socioloog en socialist. Groningen: Wolters Noordhoff/Forsten, I987, p. I 53.

72 Menno ter Braak, 'Moralisten als Don Quichottes', Forum, I932, p. 264.

73 BZ, voorblad.

74 Zie voor de polemiek met Paul Scholten: PF, p. 219-228

75 Anoniem, boekbespreking van 'Het socialistisch gevaar', Oprechte Haarlemmer Courant, I4.6.1909.

76 Eijkman aan Pijnappel, ongepubliceerde brief d.d. 6.I2.I897.

77 Eijkman aan Pijnappel, ongepubliceerde brief d.d. 24.I2.I 897 .

\section{Hoofdstuk 8}

I Simon Schama, De ogen van Rembrandt. Amsterdam: Contact, I999, p. 353.

2 Het Nieuws van den Dag, 24.I2.I909.

$3 \mathrm{WW}, \mathrm{p} \cdot 32$.voetnoot

4 WW, p. 4I.

5 WW, p. VIII.

6 Zie Han van Ruler, 'Descartes en de onttovering van het wereldbeeld', Rekenschap. Tijdschrift voor wetenschap en cultuur I998, (2), p. 78-93.

7 De waanzinnige waereld draagt de opdracht: 'aan haar met wie ik veel liefs en leed gedeeld heb' en bevat een verwijzing naar Spreuken 3 I: 0-3 I (De lof der degelijke huisvrouw) onder vermelding van de data I7 mei I894 - I7 mei I9I9.

$8 W W$, voorwoord bij de tweede druk, p. XII.

9 WW, p. 2I-22.

Io F. v. W., 'Notities van een schoolmeester. VI. "Socialistische onderwijzers”, Het Volk, 24.6.19I9.

I I WW, p. 22-23.

I2 Dirk Struik, 'Mijn socialistiese jaren in Nederland', in: Jaarboek voor de geschiedenis van socialisme en arbeidersbeweging in Nederland. Nijmegen: SUN, I977, p. 2 I7.

I3 P.J. Troelstra, Gedenkschriften, deel 3: Branding. Amsterdam: Querido, I929, p. 20$2 \mathrm{I}$.

I4 Aldous Huxley, Heerlijke nienwe wereld. Amsterdam: Rainbow, I999, p. 262.

I 5 WW, p. 26. Inderdaad was rijwielbezit in die periode fors toegenomen. Schuursma meldt in Jaren van opgang, p. 26, een toename van II 3.000 fietsen in Nederland in I909, tot 600.000 in I9I3.

I6 WW, p.I55.

I7 WW, p. I22 e.v.

I 8 Wilhelm Weygandt, Beitrag zur Lehre von den psychischen Epidemien. Halle: Verlag Carl Marhold, I905. 
I9 WW, p. I Iо. Dat Henriette Roland Holst een boek over Rousseau had geschreven zal ook wel hebben geholpen Van Dieren afkerig van deze figuur te maken.

$20 \mathrm{WW}, \mathrm{p} \cdot 33-34$.

2 I Henriëtte Roland Holst, geciteerd in WW, p. 89.

22 WW, p. 89.

23 Van Breemen, geciteerd in WW, p. 37.

24 Henriëtte Roland Holst, Levensherinneringen. Het vuur brandde voort. Amsterdam: Arbeiderspers, I949, p. I79-180.

25 Zie HIHM, dl. I, p. 176.

26 WW, p. 25 , voetnoot.

27 Brief Polak aan Van Dieren, opgenomen in WW, p. 190.

28 WW, p. XII.

29 De Wilde, NTvG, I.7.1940, p. 2073.

30 Antwoord Polak aan Van Dieren op diens advertentie, WW, p. I9I.

3 I WW, p. I9I.

32 Zie HIHM, dl. I, p. I 82.

33 Melis Stoke, 'Renaissance?', De Amsterdammer, 28.6.I9I9, p. Io. Boekbespreking van 'De waanzinnige waereld'.

34 Correspondentie met mevr. Wibaut, juli I9ı9, geciteerd in WW, p. V.

35 FBZ, p. I73.

36 C.L. van der Burg, NMGA, I888, 257.

\section{Hoofdstuk 9}

I Het Volk, 6.7.I9Iо.

2 Het Volk, 7.5.I9I2.

3 Het Klassekarakter der Volksschool. Brochure van de S.D.O.V. aan de Nederlandsche Arbeiders. Amsterdam: Drukkerij van den A.N.D.B, zonder jaartal, p. 33.

4 Van Dieren, 'Een psychische besmetting', De Telegraaf, avondblad, I3.I0.I908.

$5 \mathrm{~J}$. van Eizenga, De Telegraaf, avondblad, 20.10.1908.

6 SDOV-brochure, p. 24-25, geciteerd door Van Dieren, 'Gevaarlijke onderwijzers', De Telegraaf, 24.I0.1908, voetnoot.

7 Jan de Bruijn, Het boetekleed ontsiert de man niet. Abraham Kuyper en de Lintjesaffaire (1909-I9IO). Amsterdam: Bert Bakker, 2005.

8 KN, p. I7.

9 KN, p. I7.

Iо 'Dr. Kuyper's pleitbezorger', Het Volk, 2I.I 2.1909.

I I KN, p. 40.

I2 Het Volk, I9.2.I9Io; NRC, I2.I.I9Io; Het Centrum, 22.I 2.I909.

I3 $A G$, p. I06, voetnoot.

I4 $A G$, p. I48.

I 5 De Vooys, geciteerd in $A G$, p. 295.

I6 $A G$, p. I28, voetnoot.

I7 $A G$, p. 26I, voetnoot.

I8 Het Volk, 3.Io.I9I6.

I9 Het Volk, 26.2.1917.

$20 A G$, p. 26I, voetnoot.

2 I Jaap Spanjaard, 'Tussen de wereldoorlogen', in: H. Stroeken, Freud in Nederland. Een eeuw psychoanalyse. Amsterdam: Boom, 1997, p. 42. 
22 Ilse Bulhof, Freud in Nederland. Baarn: Ambo, I984; Christien Brinkgreve, Psychoanalyse in Nederland. Amsterdam: De Arbeiderspers, I984.

23 V.W.D. Schenk, 'Nico van Suchtelen en de psychoanalyse'. In: Victor E. van Friesland, Het werk en de mens Nico van Suchtelen. Amsterdam: Wereldbibliotheek, I948, p. I03.

24 Nico van Suchtelen, Uit de diepten der ziel. Samenspraak over droom en geweten. Amsterdam: Maatschappij voor goede en goedkoope lectuur, I92I, p. 354.

25 Ibidem, p. IX.

26 Bulhof, Freud en Nederland, p. 3 I I.

27 WW, p. X.

28 'Geen modern psychiater', C. Winkler, Herinneringen, I982, p. I 50.

29 Verslag van afscheidsrede van Cornelis Winkler, 'De toekomst der psychiatrie', Het Vaderland, 20.6.1925.

30 Cornelis Winkler, Het stelsel van Prof. Sigmund Freud. Haarlem: Bohn,1917.

3 I Winkler, geciteerd in Van Dieren, FBZ, p. I 3 I.

32 Zie bijv. Adolf Grünbaum, The Foundations of Psychoanalysis. A Philosophical Critique. Berkeley: University of California Press, I984.

33 Zie voor een overzicht van kritieken bijv. Patrick J. Mahony, Freud's Dora: A Psychoanalytic, Historical and Textual Analysis. New Haven: Yale University Press, I996.

34 Sigmund Freud, Fragment van de analyse van een geval van hysterie ('Dora'). Sigmund Freud Nederlandse Editie, Ziektegeschiedenissen 2. Amsterdam: Boom, I980.

35 FBZ, p. I34-I35.

36 FBZ, p. I3I.

37 "Hartelijk dank zeg ik u", fragmenten uit brief Winkler aan Van Dieren, geciteerd in Van Dieren, VM, 18.7.1934, p. 353.

38 Vgl. Ilse Bulhof, Freud in Nederland, p. 3 I 2.

39 Zie mijn Een eeuw Freud. Met het oog op de geschiedenis. Amsterdam: Boom, 200I, voor een bespreking van de ontstaansgeschiedenis en receptie van deze film; vgl. verder ook Menno ter Braak, 'Cinema Militans', in: Verzameld werk, dl. 2, Amsterdam: Van Oorschot, I950, p. 5II-5I6.

40 Johan van Ophuijsen, 'Verborgen diepten eener ziel', Het Vaderland, 27.3.I926.

4I Van Dieren publiceerde zijn niet-gehouden voordracht tenslotte in de immer barmhartige Vox onder de titel 'De psychoanalyse en hare verfilming', VM, 2I.I.I927, p. I-4; 26.I.I927, p. I3-I6. De recensie van De macht van het onbewuste verscheen in de $N R C$ van 9.I2.1926, ochtendblad.

42 Van Itallie-Van Embden, NRC, I9.9.1924.

43 Vgl. E.A.D.E. Carp, Jelgersma, leven en werken van een verdienstelijk Nederlander. Lochem: De Tijdstroom, zonder jaartal, p. 20; Christien Brinkgreve, Psychoanalyse in Nederland. Amsterdam: De Arbeiderspers, 1984, p. 6r e.v. Bulhof, Freud in Nederland, p. I 20 e.v.

44 Jelgersma, geciteerd in FBZ, p. 4.

45 Vgl. Willem Otterspeer, Bolland, een biografie. Amsterdam: Bert Bakker, I996, p. 239.

46 FBZ, p. I-2.

47 Jelgersma, geciteerd in Carp, Jelgersma, p. 2 I.

48 A.J.Westerman Holstijn, boekaankondiging van E. van Dieren: Futuristische behandeling van zielszieken, $N T v G, 23 \cdot 7 \cdot 1927$, p. $2358-2359$.

49 Henri van der Hoeven, 'Wetenschap of waanzin?', Het Vaderland, 3 I.5.I927, avondblad.

50 Anoniem, 'Tegen Freud en de Freudsche theorie', Het Vaderland, 2.6.1927, avondblad.

5 I E.A. Keuchenius, 'Nogmaals tegen S. Freud en de Freudsche theorie', Het Vaderland, I I.6.I927, avondblad. 
52 Hendrik Giltay, 'Dr. Keuchenius contra Freud', Het Vaderland, I 5.6.1927, avondblad.

53 Johan van Ophuijsen, 'Voor de psychoanalyse', Het Vaderland, I6.6.1927, avondblad.

54 Van Dieren, 'De psychoanalyse', Het Vaderland, 27, 28 en 29 juni 1927.

55 W.J.Leyds, 'Dr. van Dieren en de psychoanalyse', Het Vaderland, 30.6.1927, avondblad.

56 Hendrik Giltay, 'Dr. van Dieren en de psychoanalyse', Het Vaderland, 2.7.I927, avondblad.

57 E.A.Keuchenius, 'Mijn samengevat antwoord aan drie bewonderaars van Freud', Het Vaderland, I3 en I4 juli I927, avondblad.

58 Van Dieren, 'Prof. Freud en diens verderfelijk oud-griekse opvattingen op sexueel gebied', Het Vaderland, 19.7.1927, avondblad.

59 Zie Bulhof, Freud in Nederland, p. 246.

60 F.J. Soesman, 'Freud en de psychoanalyse', Het Vaderland, 23.7.1927, avondblad.

6I "werkelijk vrije tribune": PF, p. 6.

62 A.J. Westerman Holstijn, ingezonden brief, VM, I4.I 2.I927, p. $250-25$ I.

63 Van Dieren aan A.J. Westerman Holstijn, ongedateerde brief, Westerman Holstijn archief.

64 P.A. Dietz, 'De eeuw der psychologie', Het Vaderland, 28.IO.I930, ochtendblad.

65 't Kwaje kreng' was de spotnaam waarmee Van Dieren op redacties werd aangeduid, zie PF, p. 25.

66 C.P. van Rossem, 'Een nieuw boek van Dr. E. van Dieren', Haagsche Post, 2.4.I932, p. 8.

67 C.T. van Valkenburg, boekbespreking 'Prof. Freud', NTvG, 30.I.I932, p. 2 I I9.

68 Menno ter Braak, 'Moralisten als Don Quichottes', Forum, I, I932, p. 264-266; ibidem; Carnaval der burgers. Amsterdam: Van Oorschot, I934 (2de druk). Vgl. ook de biografie van Ter Braak van Léon Hanssen: Menno ter Braak I902-1940. Leven en werk van een polemist, Amsterdam: Meulenhoff, 2003.

69 Zie verder de discussie in Het Vaderland van augustus I932. Een anonieme bespreking van 'Prof. Freud' verscheen op 2 augustus in die krant onder de veelzeggende titel 'Van Dieren overdrijft!', gevolgd door een ingezonden brief van Van Dieren op 9 augustus, een 'Open brief aan dr. E. van Dieren' van Van der Hoog van I 3 augustus, een 'Open brief aan dr. Van der Hoog' van Van Dieren d.d. 26 augustus en het aansluitende antwoord van Van der Hoog, eveneens op 26 augustus, waarna de redactie de discussie voor gesloten verklaarde.

70 Arie Querido, 'Dokter van Dieren en Prof. Freud', radiovoordracht voor de VARA radio, I6.4.1932. Opgenomen in VFW, p. 6-7.

7I Querido aan Van Dieren, 2I.4.I932, geciteerd in VFW, p. I I.

72 Van Dieren aan Querido, 2I.4.1932, geciteerd in VFW, p. I2.

73 PF, p. 73.

74 Querido, geciteerd in: VFW, p. 34.

75 Ibidem, p. 35 .

76 Querido zag er de aardigheid wel van in om zowel het Nederlandsch Tijdschrift voor Geneeskunde als Vox Medicorum van dat feit op de hoogte te brengen. Zie: NTvG, I5.IO.I932, p. 4890-489I en VM, 26.I0.1932, p. 203. Vox kon de verleiding niet weerstaan om boven het berichtje waarin de mededeling van Querido verscheen 'Machtswellust?' te drukken.

77 Anoniem, 'Verslag vergadering Genootschap ter Bevordering der Natuur-, Genees- en Heelkunde, I902', NTvG, I6.6.1903, p. I440.

78 Ongepubliceerde brief van Van Dieren naar aanleiding van de commotie over zijn voordracht 'Domheden, dwaasheden en dwalingen', vermoedelijke datering februari of maart 1927, bibliotheek Universiteit van Amsterdam. 
79 Van Dieren aan Wenckebach, ongedateerd, in: BBVT, p. 5 .

80 Wenckebach aan Van Dieren, in BBVT, p. 5.

8 I Vgl. HIHM, dl. I, p. I43.

\section{Hoofdstuk Io}

I Van Dieren aan koningin-regentes Emma, ongedateerd (januari I 897). Archief Koninklijk Huis, brief A47-X-I 50.

2 Van Dieren aan koningin-regentes Emma, ongedateerd (oktober I 897). Archief Koninklijk Huis, brief A47-X-ı60.

3 Schriftelijke mededeling van C.J.M. Eymael, hoofdarchivist van het Archief Koninklijk Huis, Den Haag, d.d. 25.2.2004.

4 Van Dieren aan koningin Wilhelmina, I2.07.I9I 8 [brief niet aanwezig]; brievenboek van het particulier secretariaat, nr. I333, datum I2 juli I9I8, korte inhoud: Aanbieding geschrift: 'De nadeelige invloed van fel zonlicht en sport op lichaam en geest'. Antwoord, nr. I333, d.d. I6 juli I9I8. 'Goede ontvangst bericht. / Politiek antiEngelsch geschrift.' Mogelijk werd het verward met zijn brochure Is 'De Telegraaf' een... Engelsche krant? Wie veroorzaakten den oorlog? enz. uit I9I 5

5 WW, p. 237.

6 Van Dieren aan koningin-regentes Emma d.d. I9.I0.I 897. Geen antwoord bekend.

7 MV, p. VI-VII.

8 De droom wordt vrijwel woordelijk zo verteld in FBZ, p. I I I-I I 2.

9 BM, p. 8-9.

Iо $B M$, p. 6 en 17.

I I Van Dieren aan Van Eeden, ongedateerd, waarschijnlijk januari I9 I4, afkomstig uit de collectie Frederik van Eeden van de Universiteitsbibliotheek van Amsterdam, nr. Hs. XXIV C I7.

I2 Alphons Diepenbrock aan zijn zuster Marie, I7.9.I9I4. In: Reeser, Alphons Diepenbrock, dl. 8, p. 394 .

I3 Van Dieren aan Verwey, ongepubliceerde brief d.d. 2I.2.I930, Universiteitsbibliotheek Amsterdam, afdeling handschriften; signatuur Hs. XLI B 292 I.

I4 $A G$, p. 4I e.v.

I 5 Jan en Annie Romein, Erflaters van onze beschaving, dl. 2. Amsterdam: Querido, I 947.

I6 MV, p. 306, voetnoot.

I7 Van Dieren aan Lanz, ongepubliceerde brief, circa I930.

I8 Annet Mooij, De polsslag van de stad, p. 203.

I9 $B M$, p. 50-5I.

20 Ongepubliceerde brief aan H.C. Muller, ongedateerd (ca. I919). 'Mevrouw Douwes Dekker' was Mimi Hamminck Schepel (г889-1930), de tweede vrouw van Multatuli, die ook de brieven van Multatuli bezorgde.

2I $A G$, p. I69.

22 Bolland aan Van Dieren, 28.I 2.I9I4, geciteerd in HIHM, dl. I, p. 289.

23 Vgl. Otterspeer, Bolland.

24 "Aan de voeten van de meester", en "van dien man houd ik": HIHM, dl. I, p. 290.

25 Ongepubliceerde briefkaart van Van Dieren aan Bolland, poststempel 29.3.I9I9. Bollandarchief, Universiteit Leiden, handschriftenafdeling, signatuur Boll B I919/23.

26 A. Klaver, De vrijmetselarij en Prof. Bolland. Baarn: Hollandia drukkerij, I9I4.

27 Ongepubliceerde brief van Van Dieren aan Bolland, 20.3.1920.

28 HIHM, dl. I, p. 252. 
29 HIHM, dl. I, p. 257-258.

30 Zie bijv. Cynthia Saltzman, Portrait of Dr Gachet: The story of a Van Gogh Masterpiece. Harmindsworth: Viking, 1998, waarin het belang van deze tentoonstelling wordt onderstreept.

3I $S G$, p. I33.

32 Frederik van Eeden, 'Kunst. Vincent van Gogh', De Nieuwe Gids, I891, p. 263.

33 BZ, p. 30.

34 PF, p. 156.

35 PF, p. I57.

36 Vgl. NRC, 20.5.1920; Het Vaderland, 27.I0.1920.

37 Vgl. NRC, 20.4.I92 I; Het Vaderland, I 5.6.I92I.

38 Thomas Kuhn, The Structure of Scientific Revolutions, 1962. Chicago: The University of Chicago Press.

39 HIHM, dl. 2, p. 487

40 HIHM, dl. 2, p. 457.

4I HIHM, dl. 2, p. 508.

42 Gefantaseerd gesprek tussen Van Dieren en Einstein in HIHM, dl. 2, p. 432-434.

43 Anonieme bespreking van Historisch-idealisme of historisch-materialisme, in Het Vaderland, 9.6.1923, avondblad.

44 Ingezonden brief van Van Dieren getiteld 'De theorie van Einstein', en redactioneel commentaar, Het Vaderland, 22.6.1923.

45 PF, p. 242.

46 Het Centrum, 2.I I.I920.

47 Michael Molnar (red.), The Diary of Sigmund Freud 1929-1939. Londen: The Hogarth Press, 1992, p. 266.

48 PF, p. Io.

49 Verslag van een voordracht van Van Dieren d.d. I8.I2.I92 I te Den Bosch, in NTvG, 4.2.1922, p. 503-504.

\section{Hoofdstuk I I}

I Bruno Latour, Wij zijn nooit modern geweest. Amsterdam: Van Gennep, I993, p. I75.

2 Robert Merton, 'Insiders and Outsiders; A Chapter in Sociology of Knowledge', American Journal of Sociology, 77 (1972), p. 9-47.

3 Kuhn, The structure of Scientific Revolutions, p. 83.

4 Vgl. Ulrich Beck, Anthony Giddens en Schott Lash, Reflexive Modernization. Politics, Tradition and Aesthetics in the Modern Social Order. Cambridge: Polity Press, 1994.

5 Norbert Elias, Problemen van betrokkenheid en distantie. Amsterdam: Meulenhoff, I982.

6 Erving Goffman, De dramaturgie van het dagelijks leven. Utrecht: Bijleveld, I993, p. 68-69.

7 Michel Foucault, De woorden en de dingen. Baarn: Ambo, 1987, p. 68-70.

8 Ludwig Wittgenstein, Over zekerheid. Meppel/Amsterdam: Boom, I977. 


\section{Register}

Aalders, Gerhard Charles 53

Abraham, Karl 207

Adler, Alfred I 63

Algemeen Handelsblad I3, 4I, II4, II 8, I20, I23, I27-I28, I30, I35-I36, I 86

Amerongen, Martin van 2I, 269

Amsterdams Geneeskundig Genootschap 42

Amsterdamse Geneeskundige Kring 45, I I 6

Ancient Order of Foresters 45

antisemitisme 2I, 86-88

Arnhemsche Courant 34

ARP (Anti-Revolutionaire Partij) 43, 6I, I 59

Atjeh-oorlog 92, 276

autosuggestie 55, I2I

Averechtse geestesrichting, de 64, 7I, 200

Baart de la Faille, I.M., 267, 275

Baers, Saris 273

Bakker, Cornelis I45

Bayert, K. 276

Beck, Ulrich 287

Been, Johan 62, I 53, 200, 269, 273, 280

Bekker, Balthasar 178

Belastingbetaler, de 43

Bellaar Spruyt, C. 69

Berdenis van Berlekom, Mathilde I 88

beriberi 54, 56-58, 68, 79, 9I-92, 95-99, IOI, IO3-IO7, IO9-IIO, II2, II4-II 5, II7, I 20, I22, I25, I27-I28, I30, I34, I36, I38, I63-I64, I 82, I9I, 200, 203, 228, 276 beriberibacil $93, \mathrm{I} 36$

beriberibacterie 95 , 109

beriberibemoeienis 60

beriberiboeken 102

beribericonflict 74

beribericongres $\mathrm{I} 34-\mathrm{I} 35$

beriberikwestie 54

beriberilijder 79

beriberimisvatting 55

beriberionderzoeker 55

beriberioorlog $\mathrm{I} 22$

beriberiopvatting 99

beriberipatiënt 93

beriberiprobleem 94

beriberiraadsel 57,93 , 106

beriberistrijd $58, \mathrm{I} 24, \mathrm{I} 34$

beriberivraagstuk $80, \mathrm{IO}_{3}, \mathrm{IO} 7, \mathrm{II} 3, \mathrm{I} 37-\mathrm{I} 38$

beriberiwerk I0, 73, 9I, 245

Beri-Beri eene rijstvergiftiging II 3-I I 5, 277

Berns, Anthonius Wilhelm Cornelis 35

Besmettelijke zielsziekten 7I, 88, I67, I7I-I72

Bezem, de 88-89

bipolaire stoornis I7, I49 
Bloemgarten, Salvador 28I

Boerhaave, Herman $3 \mathrm{I}$

Bolland, Gerardus 38, 70, 74, 82, 86-88, I49, I 55, 2I3, 235-236, 238-239, 242-243, $270,274-275,280,284,286$

Bolsius, H. 59

Bonger, Willem Adriaan I 5 I, I62, I70-I7I, 274, 282

Bontius, Jacob 92, 275

Bouman, K.H. I 57

Bouman, L. 74

Bourdet, Eduard 48

Boxel, Matthijs van 23, 269

Braak, Menno ter 24, I7I, I77, 222, 282, 284-285

Bredero, Gerbrand Adriaensz. 36-37

Breemen, Jan van 185,283

Brinkgreve, Christien I I, 2I, 200, 284

Bruijn, Jan de I94, 196, 283

Büch, Boudewijn 21, 89, I67, 282

Buitendijk, prof. I 69

buitenstaander IO, I 2, 23-26, 32, I 22, I 38, I 58, I62-I63, I70-I7I, I88, I96, 22 I-222, $234,248-249,25$ I, $253-258$

buitenstaanderschap I0, 70, 256, 258

Bulhof, Ilse 200-20I, 203, 284-285

Burg, C.L. van der 96-97, II 4, I29, 275, 277-278, 283

Burgerhout, H. 280

Carnaval der burgers. Zie Menno ter Braak

Carp, E.A.D.A. 284

Carpenter, Kenneth 276

Chijs, Arie van der 2I4

Colijn, Hendrik I9, 72, 74, 79

Collins, Rebecca 279

Colp, Ralph 273

Coward, Noel 48

critisch-historische methode $98, \mathrm{I} 20$

Cyrano de Bergerac (film) I 54

Dante Alighieri 202

Darwin, Charles 26, 58-60, 62, I45-I46, I64, 242, 247, 272

darwinisme 58-60, I43, I45-I46, I77, I9I, 235

evolutieleer 59

Darwinisme en ongeloof 26, 60, 235

De Jonge 30,170

De waanzinnige waereld 24, 26, 49, 56, 6I, 73-74, 86, I40, I65-I66, I7 I, I77-I78, I80-I 8 I, I83-I84, I86-I87, 234, 236, 238, 282-283

Delprat, Constant Charles 33, 96, I I 7, 275, 277

Det, Eldert Johannes van 46, 272

Diepenbrock, Alphons 39-40, 5I, 70, 82-87, I47-I49, I62, I64, I74, I77, 232, 27I, $274,280,286$

Dieren, Assiena van (zuster) 29

Dieren, Catharina van (dochter) 53, I46

Dieren, Catharina van, geboren Bakker (vrouw) 42, 70, I45-I 47, I 49

Dieren, Cornelis van (zoon) I46

Dieren, Derk-Johan van (vader) 28-29, 269

Dieren, Derk-Johan van (zoon) 53, I46, I 50 overlijden I99

Dieren, Evart van $25^{\mathrm{C}}$ artsjubileum $37, \mathrm{I} 75$, I94-I95

$40^{\circ}$ artsjubileum $39,5 \mathrm{I}, 53$ 
$50^{\circ}$ artsjubileum 68, I 66

aangereden I5I-I 52

als raadsman-geneesheer 36

als student $\mathrm{I} 7,3 \mathrm{I}$

artsexamen 32

assistent bij Korteweg 35, 4I

assistent in het Burgerziekenhuis 35

assistent in het Ned. Isr. Ziekenhuis 99

bewondert Klikspaan 37

bewondert Mussolini 89

bezoekt tentoonstelling Van Gogh 239

breuk met Diepenbrock 85

briefwisseling met Been I 53,200

briefwisseling met Bolland 38, 87, 235-236, 238

briefwisseling met Bonger I70

briefwisseling met De Savornin Lohman 160

briefwisseling met De Vooys 199

briefwisseling met Diepenbrock 85

briefwisseling met Eijkman 57

briefwisseling met Holdert 83

briefwisseling met Koningin I9, I I 5, 227-228

briefwisseling met Lanz 38-39, 79, 233

briefwisseling met Polak I 86

briefwisseling met Querido 223-224

briefwisseling met Scholten $\mathrm{I} 73$

briefwisseling met Stokvis I 20

briefwisseling met Van Eeden I4O, 232

briefwisseling met Verwey 232-233

briefwisseling met Voorthuis I 28

briefwisseling met Wagner-Jauregg 80

briefwisseling met Wenckebach 226

briefwisseling met Westerman Holstijn 2 I9

denkbeeldig gesprek met Einstein 243

Dr. Mol (pseudoniem) I39, I43, I45, 279

droom van Koningin 230

geneesheer aan de kweekschool voor de zeevaart 42

geschatte inkomsten 72

gesprek met belastinginspecteur 73

gesprek met bootwerkers I 79

gesprek met student over relativiteit 242

huisartspraktijk 36

huwelijk 42

in Arnhem 34

in Paramaribo 34

in Wenen 35

jeugd 30

loopt Nobelprijs mis 245

officier van gezondheid 33

ontmoeting met Bolland 87, 236

optreden in de Nutszaal loopt uit de hand 49

overlijden en begrafenis 68

pantoffelincident $43,27 \mathrm{I}$

patiënten 40

poogt opvoering van 'De gevangene' te verhinderen 48

verhuist naar de Keizersgracht 42

verkoopsucces 73 
verzoek aan Koningin 229

vestigt zich in Amsterdam 35

voordracht over de proletarische revolutie en het onverstand 178

voorzitter Amsterdamse afdeling Bond van belastingbetalers 43

voorzitter Amsterdamse Geneeskundige Kring 38

woont lezing bij van De Ligt I 87

woont lezing bij van Roland Holst 177

woont lezing bij van Wibaut 63

woont lezing bij van Wijnkoop 63

wordt toegang tot lezing van Eijkman ontzegd I37

Dieren, Evart van (zoon) 79, I46, 275, 280

Dieren, Gerhard van (zoon) 54

Dieren, Gustaaf van (zoon) 54, I 47, 280

Dieren, Jacobus Wouterus van (broer) 29

Dieren, Jan van (zoon) 53, I46, I69

Dieren, Jentien van (geboren Uiterwijk) (moeder) 28

Dieren, Maria Elisabeth van (zuster) 29

Dieren, Wouter van (zoon) 54, I46

Dieren, Wouterus van (grootvader) 28

Dietz, P.A. 220, 285

Dijkstra, A. 272

'dokter X' 209

Domela Nieuwenhuis, Ferdinand 40, 27I

Don Quichotte I3, 222, 255

don quichottesk 222

Donath, W.F. 57-58, 105

Dongen, Kees van 240

Dreesmann, Willem 240

Dresden, Sam 9

Dumas, Alexandre I75

Eeden, Frederik van 37, 40, 70, 72, 74, 86, I40-I43, I62, I74, 200-202, 2 I I, 227, 230232, 239-240, 246, 270, 279, 286-287

IJsbrandt I4 I-I 43, 202, 279

Eijkman, Christiaan Io, 39, 52-53, 55-57, 70, 72, 77, 91-93, 95, 98-99, IO2-I I 5, I I7-

I 2I, I 23-I 25, I27, I29-I38, I46, I63, I73-I74, I77, I90, I99, 220, 227, 234, 245-

$247,254,272,274-279,282$

expeditie naar Java 93

mengt zich in publiek debat met Van Dieren II7

Nobelprijsrede I06, I37

ontmoeting met Pekelharing en Winkler in Berlijn 93

ontvangt Nobelprijs I03, I05, I36, 244

Einstein, Albert 69, I07, I 57, I64, I66, 24I-244, 25 I, 254, 287

ontvangt Nobelprijs 24I, 244

Eizenga, J. van I92-I93, 203, 283

Elias, Norbert 25I, 253, 287

Emants, Marcellus I62, I98

Engels, Friedrich 197, 269

Enklaar, dr. 169

Feith, Jan 167

Fleming, Candice 277

Flu, P.C. 274

Fokker, A.P. II7, I23-I 26, I3 I-I35, 277-279

Fontaine, Jean de la 280

Foucault, Michel 256, 287

Fourier, Charles 246

Franklin, Benjamin II9, 277 
Freud, Ernst 28I

Freud, Sigmund 7, I 5, 2I, 24, 26, 6I-62, 70, 88, I 5I, I 56, I62-I65, I69, I7I-I73, I 89, 200-207, 209-2IO, 2I 2-2I 4, 2I 6-225, 230, 240, 242, 245, 249, 25I, 269, 28I, $284-285,287$

Dora (gevalsstudie) 205-206

freudiaan 2I2, 2I $8,222,224,253$

freudiaans I 56, 207

kleine Hans (gevalsstudie) 205-206

loopt Nobelprijs mis 245

Funk, Casimir I05

Futuristische behandeling van zielszieken $\mathrm{I} 3,26,6 \mathrm{I}, 73,2 \mathrm{IO}, 2 \mathrm{I} 3,220$

Geelkerken, J.G. 53

geestdrijverij I6-I 8, 200

Gelpke, O.G. I I 4, I3 I, 277

Geneeskundig Tijdschrift voor Nederlandsch-Indië II 4-I I 5, I 25, I3 I-I32

Geneeskundige Courant 33

Geneeskundige Kring 32, 24I

Genestet, Petrus Augustus de 36-37

Genina, Augusto 280

Gerhard, Adrien Henri 44, 27 I

Giddens, Anthony 287

Gielen, A. 274

Giltay, Hendrik 6I, 2I 5-2I6, 269, 285

292

Goethe, Johann Wolfgang von 39, 202

Goffman, Erving 254, 287

Gogh, Vincent van 239, 287

Golkom, kapelaan van 59

Gorkom, W.J. van II 5-II7, I3 I, 269, 276-277

Gorter, Herman 40, 6I, 70, 72, I62-I64, I74, I77, I84, 20I, 2II, 227, 28 I

Grijns, Gerrit 70, I05, I63

Groddeck, Carl Theodor 182

Groene Amsterdammer, de IO-I I, 85

Grünbaum, Adolf 284

Haan, Francisca de 282

Haan, Jacob Israel de $155^{-1} 5^{6}$

Hahn, Albert I4I

Hamminck Schepel, Mimi 286

Handelingen van de Tweede Kamer 47, I6I, 270

Hanssen, Léon 222, 285

Hartog, A.H. de 53

Heerikhuizen, Bart van 282

Hegel, Georg Wilhelm Friedrich 26, 197, 238-239, 242-243

Heije, Jan Pieter 210, 234-235

Heijermans, Louis 6I, I40, I43, I62-I63, I67-I69, 28I-282

Helder, hr. I69

Hermans, E. H. I36

Hermans, Willem Frederik 24

Hirsch, August 100-102, 276

Historisch-idealisme of historisch-materialisme 38, 71, 77, I65, 238, 242, 244, 284, 287

Hoeven, Henri van der I 5, 6I, 2I4-2I 5, 269

Holdert, Hendrikus Marinus Cornelis 83

homoseksualiteit 48-49, I55-I 57, I66, 28 I

Hondius van der Broeck, W.G. 40, 274

Hoog, P.H. van der 285

Hoogendijk, C.J. 49-50

Hopkins, Frederik 106 
Hubrecht, Ambrosius 59, 226, 242

Hulshoff-Pol, D.J. I05

Hume, David I6, 269

Huxley, Aldous I $80-\mathrm{I} 82,282$

idee fixe IO, 9I, I00, 102, 257

Indische Gids I I4-I I 6

Is de Telegraaf ...een Engelsche krant? 85

Israël de Haan, Jacob I 55, 28 I

Itallie-Van Embden, W. van 275, 284

Jacobs, Aletta I66

Jansen, Barend Coenraad Petrus 57-58, I05, I23, 275-279

Jas, Eveline 280

Javabode 97

Jefferson, Thomas ing

Jelgersma, Gerbrandus 33, I62, 2 I0-2 I 5, 284

Jong, Lou de 275

Jongkurdt, J. 280

Jung, Carl Gustav I63

Kaal, Harm 272

Kamminga, Harmke 105,276

Kant, Immanuel 175

Kantteekeningen op Dr. Vordermans rapport en nog iets II 3, II7, I26, I3 I, 228

Kappers, Ariëns 183

Kautsky, Karl 87, I84

Kessler, H.J. I I 4, I 26, I3 I, 277

Keuchenius, E.A. 6I, 2I 4-2I 5, 2I7, 284-285

Keyserling, Graaf Hermann I 5 I, 22 I

Kindt, Aris 174

Klaver, A. 238,286

Klinkert, H. I 53,280

Knapper, Nico 69

Kneppelhout, Johannes 37, I44, 233

Koch, Robert 20, 92-93, IOI, I03, I09, 244 ontvangt Nobelprijs 20, 244

Kollewijn, Roeland 22, 69, I62, I96-199

kollewijns (schrijfwijze) I 50, I62, I96, I99

Koningin Emma 227-228, 277

Koningin Wilhelmina 229

Korteweg, J.A. 35, 4I-42, 270

Kühlmann, Richard von 86

Kuhn, Thomas 25I, 287

Kuyper, Abraham 43, 59, 6I, 74, 86, I 59, I94-I96, 283

Lafargue, Paul I 5 I

Lamberts Hurrelbrinck, mr. I $5 \mathrm{I}$

Lanz, Otto 38-40, 70, 72, 74, 79, 82-83, I69, 233, 27I, 274-275, 286

Lasch, Scott 287

Latour, Bruno 249, 287

Leffertstra, G. I99

Lehmann, R. I94

Lely, Cornelis 47

Lenin, Vladimir Iljietsj I 80

Lévinas, Emmanuel 246

Leyds, W.J. 285

Ligt, Bart de $\quad$ 87

Lincoln, Abraham 69

Linnaeus, Carolus 58, 235 
lintjesaffaire I 59, I94-I96

Lutkie, Wouter 88-89

Maatschappij ter Bevordering van Verlos- en Heelkunde, 27I

Macht van het onbewuste, de (film) 207-208, 216, 284

Mahler, Gustav 39

marginaliteit 239, 248-249

Marx, Karl 2I, 26, 62, 69, 87, I07, I62-I63, I97, 242, 25I, 269, 272 marxisme 59, I07, I 82, 238

marxistisch I 85

Medisch Weekblad 33, I09, II4, I85

Meijer, Arnold 88-89

Mengelberg, Willem 40

Merton, Robert 250, 287

Molnar, Michael 287

Mooij, Annet I I , 234, 270, 286

Moszkowski, Alexander 243

Mot, Jan de 272, 279

Muller, H.C. 270,286

Multatuli (ps. van Eduard Douwes Dekker) I I 4, 234-235, 286

Mussolini, Benito 89

mystificatie I0, 80, 82, I23, I37-I38, I64, I93, 254

Nederlandsch Militair Geneeskundig Archief 33, 96

Nederlandsch Tijdschrift voor Geneeskunde 32, 4I, 49, 6I, 66-68, 96, I04, II4, II7-I I8, I 20-I23, I25-I27, I29-I33, I 55-I 56, I6I, I65, 2I3-2I4, 22 I, 265, 270, 278-279

Nederlandsche Maatschappij ter Bevordering van de Geneeskunde 4I

Netscher, Frans I98

Nietzsche, Friedrich Wilhelm 39, I64, I69, 242

Nieuwe Gids, de 37, I63

Nieuwenhuijse, P. 267,275

Nieuws van den Dag 40

NRC 38, 49-50, 53, 60, I 29, I36, I 53-I 54, I96, 2I4-2I 5, 24I, 269, 27 I-272, 283

Oeser, Prof. 35

Op dwaalwegen I39, I44-I45, 26I

Ophuijsen, Johan van 6I, 208-209, 2I 6-2I7, 284-285

Ortt, Felix 89, 275

Otterspeer, Willem 236, 284, 286

Overbeek de Meyer, Gilles IOI, I35, I 59, 28 I

Paap, Willem I75, 234, 270

Pabst, Georg Wilhelm 207

Pam, Max 2I, 269

Parker, Robert Andrew 277

Pasteur, Louis 234

Paulus, apostel 29

Pekelharing, Cornelis 92-99, IO2-IO5, I07, IO9-IIO, II 5, I36-I37, 232, 247, 275

Pel, Pieter Klazes 79, 274

Philips, Anton 240

Pijnappel, Mari Willem 33, I I8, I20, I23-I25, I27, I29-I32, I34-I35, I73, 220, 273$274,277-279,282$

Pinkhof, H. 33, I44, I65, 279, 28I

Place, Thomas 102

Poe, Edgar Allen 253

Polak, Henri 23, 49, 6I, 74, I62, I64, I84, I86-I87, I92, 207, 269, 28 I, 283

Porter, Roy 92, 275-277

Postmus, S. 58, 272

Propria Cures I68, I73

psychische epidemie 39, I $82-$ I 83 
psychoanalyse 7, I3, 58, 6I, 77, I62-I63, I66, I92, 200-209, 2I 2-2I 5, 2I7-2I9, 22I-223, 225,284

Querido, Arie 6I-63, 22 I, 223-224, 269, 273, 28I, 285

querulant I 5-I7, 23, 62, 68, 89, II 8, I20, I23, I46, I73, 235, 275

Radek, Karl (ps. van Karl Sobelsohn) 27

Rembrandt van Rijn I74-I75, 282

Renterghem, Albert Willem van 200, 2I0, 2I 4

Rijn, prof. van 242

Rijnberk, Gerard van 66-67, 262, 273

rijstvergiftigingshypothese II4, II 7 , I3O, I36-I 38

Ritter, Pierre Henri jr. 40, I62

Ritter, Pierre Henri sr. 40

Roland Holst, Henriëtte 40, 50, 6I, 74, I62-I64, I77, I80, I84-I86, 20I, 227, 239, $28 \mathrm{I}, 283$

Romein, Annie 233, 286

Romein, Jan 233, 286

Rooden, Peter van 16,269

Rossem, C.P. van 22I-222, 285

Rossum, Kardinaal van 240

Rostand, Edmond 28I

Rousseau, Jean Jacques I 84

Ruler, Han van 282

Rüter, Georg 52-53

Sachs, Hanns 207

Salomonson, Herman 187

Saltet, Rudolph Hendrik 83

Saltzmann, Cynthia 287

Sankhorst, Arent van 28I

Savornin Lohman, A.F. de I58-162, I65, I94, I99, 28 I

Schama, Simon I74, 282

Scheer, A. van der 76, I 22, 266, 272, 278

Schenk, V.W.D. 284

Scholten, Paul I72-I73, 282

schoolartsen 46, 268

Schoolcommissie 43, 27I

Schüle, Heinrich I 5,269

Semmelweis, Ignaz 234-235, 246

Shelley, Percy Bysshe 202

Shorter, Edward 8I, 274

Sinclair, Upton 187

Sleef, J.W. I92

Sluijters, Jan 52, I69, 240

Snapper, Isidore 168,170

socialisme 43, 45, 58-60, 62, 87, 89, 99, I62, I64, I66, I77, I80-I84, I87, 200, 203, 282

Socialistisch gevaar, het I3, 64, I63, I65, I75, I92, I94-I95, 235, 282

Soesman, F.J. 2I 8,285

Solkes, S.H. $5 \mathrm{I}-53$

Spanjaard, Jaap 283

Spinoza, Baruch de 87, 164, 233, 242

St. Simon, Graaf 246

Standaard, de 24, 6I-62

Stärcke, August 20I

Stekel, Wilhelm I63, 202-203

Stoke, Melis (zie Salomson)

Stokvis, B.J. I 20, I 34-I 35, 278

Straub, Manuel 33, 70, I22 
Stroeken, Harry 283

Struik, Dirk I 80,282

Suchtelen, Nico van I64, 20I-203, 284

Telegraaf, de 44, 60-61, 73, 83, 85, I86, I92, I94-196, 2 I 2

Terschelling 67, 70, I46-I 47

Thissen, Siebe $28 \mathrm{I}$

Tideman, mr. I94-I95

Toorop, Jan 40, I48, I62

Treub, Manuel 70, 83, I97

Troelstra, Pieter Jelles 24, 26, 6I, 70, 72, 74, I62-I63, I78, I80, I94-I95, 201, 246, $28 \mathrm{I}-282$

Trotsky, Leon I 5 I

tuberculine $20,8 \mathrm{I}$

Tulp, Nicolaes I74-I75

Vaccinatie en hare bestrijders 158,268

Vaderland, het 6I, 69, 87, I 5 I, I 86, 208, 2I4-2I 5, 2I 8, 220, 225, 244

Verkade, Willem 40, I48

Verne, Jules I75

Verschuur, W. 27

Verwey, Albert 40, 72, I62-I64, 227, 232-233, 286

Vet, A.C.W. van der 279

Vlugt, Willem de 48, 272

Volk, het 49-50, 6I, 63-64, I4I, I68-I69, I79-I80, I86, I9I-I92, I94-I96, I99, 239, 282

Voorthuis, J.A. I27-I3 I, 278

Vooys, Cornelis Gerrit Nicolaas de I62, I98-I99, 283

Vorderman, Adolphe Guillaume II2-I I3, II 5-II7, I23, I26, I3 I-I32, I35, 276-278

Vorrink, Coos 64, 273

Vox Medicorum 35, 40, I 54, I66, 219, 224

Vries, Hugo de 59-60, 70, I45, 242, 247

Waerden, Theo van der 192

Wagenaar, Johan 28I

Wagner-Jauregg, Julius von 80-82, 244 ontvangt Nobelprijs $8 \mathrm{I}-82,244$

Wal, Jan van der 280

Wansleven, Guus I69

Wenckebach, Karel Frederik 58, 274, 286

Wereldoorlog I 73, 82, I66, 2I 2, 240

Wereldoorlog II 197,275

Westenbrink, H.G.K. 267, 275

Westerman Holstijn, A.J. 6I, I 56, I99, 2I4, 2I9-220, 23I, 274, 284-28 5

Westhoff, C.A.H. 277

Westmeijer, Mathilde 194

Weygandt, Wilhelm I 83,282

White, Michael 279

Wibaut, Florentinus Marinus 49, 52, 62-63, 70, 72, 74, I 5 I, I 84, I 88, 240, 247, 283

Wijfjes, Huub 274

Wijnkoop, David 63-64, 87, I63, 273

Wilde, Oscar I $55,272-273$

Wilde, P.A. de 266, 272-273, 283

Winkler, Cornelis 44, 74, 92-93, 95-96, I03, I05, II 5, I67, 204-207, 216, 223, 27I, 275,284

Yandell, D.W. I 82

Zeegers, M. I 5, 269, 273

Zuiderzee $47, \mathrm{I} 66$ 